\title{
Государственный доклад
}

«О состоянии

санитарно-эПидемиологического

благополучия населения

в Российской Федерации

в 2020 году» 
ББК 5.1.1(Poc)1

$\mathrm{O} 11$

O11 О состоянии санитарно-эпидемиологического благополучия населения в Российской Федерации в 2020 году: Государственный доклад. М.: Федеральная служба по надзору в сфере защиты прав потребителей и благополучия человека, 2021. 256 с.

ISBN 978-5-7508-1849-5

Подписано в печать 27.05.2021

Формат $60 \times 90 / 8$

Печ. л. 32,0

Заказ 53

Тираж 300 экз.

() Федеральная служба по надзору в сфере защиты прав потребителей и благополучия человека, 2021 


\section{Содержание}

Введение ....

Раздел 1. Результаты социально-гигиенического мониторинга за отчетный год и

в многолетней динамике.

1.1. Состояние среды обитания и ее влияние на здоровье населения

1.1.1. Состояние атмосферного воздуха и его влияние на здоровье населения ........................ 16

1.1.2. Состояние питьевой воды, воды водоемов, используемых для водоснабжения населения и рекреационных целей, и ее влияние на здоровье населения ........................22

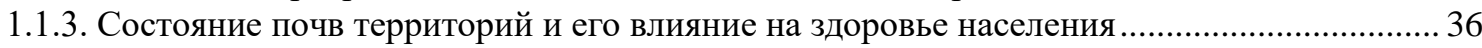

1.1.4. Мониторинг безопасности продовольственного сырья и пищевых продуктов................ 44

1.1.5. Влияние потребления алкоголя и табакокурения на здоровье населения.......................5 51

1.1.6. Мониторинг условий обучения и воспитания, отдыха детей и их оздоровления ...........57

1.1.7. Мониторинг физических факторов среды обитания...................................................... 73

1.1.8. Мониторинг радиационной обстановки .................................................................. 84

1.2. Анализ состояния здоровья в связи с вредным воздействием факторов среды обитания

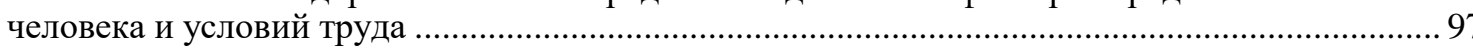

1.2.1. Анализ состояния здоровья населения в связи с вредным воздействием факторов среды обитания на человека.

1.2.2. Анализ состояния здоровья работающего населения и профессиональной заболеваемости.

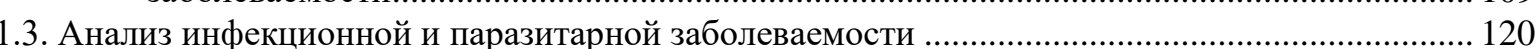

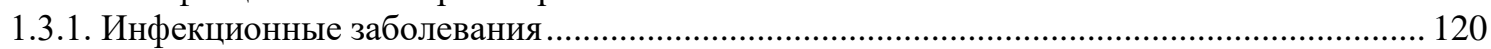

1.3.2 Санитарная охрана территории Российской Федерации ................................................ 173

1.3.3. Инфекции, связанные с оказанием медицинской помощи (ИСМП).............................. 175

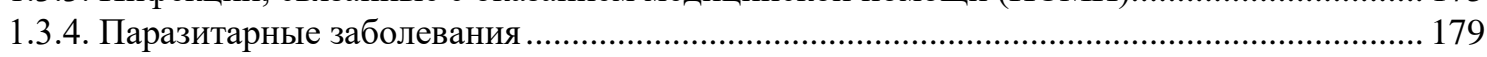

Раздел 2. Основные результаты научных исследований в области гигиены, эпидемиологии,

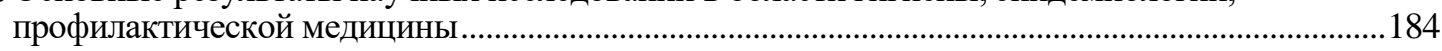

2.1. Основные результаты научных исследований в области гигиены ........................................ 184

2.2. Основные результаты научных исследований в области эпидемиологии и профилактической медицины .....

Раздел 3. Результаты деятельности органов и учреждений Российской Федерации, входящих в систему федерального государственного санитарно-эпидемиологического надзора ..............221

3.1. Основные результаты деятельности структурных подразделений Федерального медико-биологического агентства Российской Федерации.

3.2. Основные результаты деятельности структурных подразделений Управления делами Президента Российской Федерации .

3.3. Основные результаты деятельности структурных подразделений Министерства внутренних дел Российской Федерации.

3.4. Основные результаты деятельности структурных подразделений Федеральной службы безопасности Российской Федерации ....

3.5. Основные результаты деятельности структурных подразделений учреждений Федеральной службы исполнения наказаний Российской Федерации

3.6. Основные результаты деятельности структурных подразделений Федеральной службы войск национальной гвардии Российской Федерации.

3.7. Основные результаты деятельности структурных подразделений Министерства обороны Российской Федерации.

Раздел 4. Достигнутые результаты улучшения санитарно-эпидемиологической обстановки, имеющиеся проблемные вопросы при обеспечении санитарно-эпидемиологического благополучия и намечаемые меры по их решению

4.1. Достигнутые результаты и прогноз улучшения качества среды обитания и состояния здоровья населения, оценка предотвращенных экономических потерь валового внутреннего продукта, связанных с неблагоприятным воздействием факторов среды обитания......

4.2. Выполнение мер по реализации международных актов и нормативных правовых актов Российской Федерации, принятых в целях обеспечения санитарно-эпидемиологического благополучия населения Российской Федерации......

4.3. Приоритетные задачи обеспечения санитарно-эпидемиологического благополучия населения. 


\section{Введение}

В 2020 году Российская Федерация, как и весь мир, столкнулась с глобальным вызовом, связанным с новой коронавирусной инфекцией, распространившейся вне зависимости от границ государств. Санитарно-эпидемиологическая обстановка в Российской Федерации характеризовалась как напряженная, вместе с тем управляемая, позволившая с минимальными потерями пройти сложный период пиковых нагрузок в связи с распространением новой коронавирусной инфекции (COVID-19).

В 2020 году пандемия новой коронавирусной инфекции (COVID-19) оказала огромное воздействие на социальную, экономическую, политическую и культурную сферы в стране, это воздействие продолжается по настоящее время. В Российской Федерации в 2020 году выявлено 3159297 случаев заболевания (2152,63 на 100 тыс. населения) в 85 регионах страны.

В связи с неблагополучной эпидемиологической ситуацией в мире, возникновением угроз санитарно-эпидемиологическому благополучию потребовалось принятие дополнительных мер по санитарной охране территории, в том числе по усилению санитарно-карантинного контроля в пунктах пропуска через государственную границу Российской Федерации. Правительство Российской Федерации приняло Национальный план по предупреждению завоза и распространения новой коронавирусной инфекции на территории Российской Федерации. С марта 2020 года было прекращено транспортное сообщение с иностранными государствами, ограничены въезд в Российскую Федерацию для иностранных граждан и движение через наземные пункты пропуска через государственную границу Российской Федерации. Роспотребнадзором был разработан и проводился комплекс противоэпидемических и профилактических мероприятий по недопущению ввоза и распространения на территории Российской Федерации новой коронавирусной инфекции (COVID-19). Постановлением Главного государственного санитарного врача Российской Федерации № 15 от 22 мая 2020 г. утверждены новые санитарно-эпидемиологические правила CП 3.1.3597-20 «Профилактика новой коронавирусной инфекции (COVID-19)».

Научными организациями Роспотребнадзора разработаны и зарегистрированы в установленном порядке тест-системы для диагностики COVID-19, вакцина против новой коронавирусной инфекции (COVID-19) «ЭпиВакКорона», разработанная ГНЦ ВБ «Вектор» Роспотребнадзора. Организовано и проводится молекулярно-генетическое исследование вирусов SARS-CoV-2, циркулирующих на территории России. В субъектах Российской Федерации реализован пилотный проект по проведению сероэпидемиологического исследования для определения антител класса $\mathrm{IgG}$ к вирусу SARS-CoV-2 у населения Российской Федерации в динамике в течение года.

Важным аспектом работы по борьбе с новой коронавирусной инфекцией (COVID-19) стало укрепление и расширение международного взаимодействия по реагированию на пандемию, прежде всего со странами Евразийского экономического союза (ЕАЭС) и Содружества Независимых Государств (СНГ), а также Китаем, государствами Юго-Восточной Азии и Африки. Всего зарубежным партнерам было передано более 1,5 млн тестов и реагентов для диагностики.

На фоне противоэпидемических мер в отношении новой коронавирусной инфекции (COVID-19) в 2020 году по большинству инфекций наблюдалось снижение показателей заболеваемости по сравнению с 2019 годом и среднемноголетними показателями. Уменьшилось число очагов групповой заболеваемости, в том числе в детских организованных коллективах. В условиях осложнённой эпидемической ситуации, направляя все основные усилия на борьбу с распространением новой коронавирусной инфекции, в 2020 году удалось достигнуть утвержденных уровней по целевым индикаторам: заболеваемость дифтерией регистрируется на уровне менее 0,01 
на 100 тыс. населения, эпидемическим паротитом, гепатитом В - на уровне менее 1 на 100 тыс. населения, не регистрируются случаи полиомиелита, вызванного диким полиовирусом. С 2017 года Российская Федерация сохраняет статус страны, свободной от эндемичной краснухи. Индикатор заболеваемости краснухой по итогам 2020 года соответствует уровню, утвержденному Всемирной организацией здравоохранения. Обеспечено поддержание статуса Российской Федерации как территории, свободной от полиомиелита. В результате подготовки к эпидемическому сезону 2020-2021 гг. привито против гриппа более 85,89 млн человек, что составило 59 \% от численности населения страны, в том числе привито более 19,62 млн детей. Результативность вакцинации подтверждается положительной динамикой снижения заболеваемости гриппом, уровень которой с 1997 года снизился почти в 147 раз - с 5 173,8 на 100 тыс. населения (при охвате вакцинацией 4,9 млн человек в 1996 г.) до 35,07 в 2020 г. (при охвате вакцинацией 72 млн человек в 2019 г.). Ежегодно регистрируются только единичные случаи дифтерии. В целом по стране достигнут охват прививками выше регламентированного 95\%-го уровня в отношении всех инфекций, управляемых средствами иммунопрофилактики, за исключением туберкулеза $(94,69$ \%).

В напряженной эпидемической ситуации проведены запланированные мероприятия по обеспечению санитарно-эпидемиологического благополучия населения, реализации национальных и федеральных проектов, предусмотренных к выполнению в соответствии с указами Президента Российской Федерации от 7 мая 2018 г. № 204 «О национальных целях и стратегических задачах развития Российской Федерации на период до 2024 года» и от 21 июня 2020 г. № 474 «О национальных целях развития Российской Федерации на период до 2030 года».

Для оценки санитарно-эпидемиологического благополучия населения Федеральной службой по надзору в сфере защиты прав потребителей и благополучия человека проведено более 68920328 исследований атмосферного воздуха населенных мест, питьевой воды и источников водоснабжения, почв селитебных территорий, продовольственного сырья и пищевых продуктов, условий обучения и воспитания детей, физических факторов среды обитания и радиационной обстановки.

Мониторинг качества среды обитания, контрольно-надзорная деятельность, оценка состояния санитарно-эпидемиологического благополучия населения и его прогноз обеспечили разработку, обоснование и принятие результативных и эффективных решений по управлению риском для здоровья населения, адекватных возникающим в 2020 году угрозам.

Разработаны и реализованы на практике методические рекомендации для организации питания детей, в том числе с различными хроническими заболеваниями (сахарным диабетом, целиакией, фенилкетонурией, муковисцидозом), в которых представлены примерные меню, разработанные научными организациями и учитывающие нормы физиологических потребностей детей. Проведена оценка около 37 тыс. меню школьных завтраков и обедов, которые откорректированы с учетом принципов здорового питания, сокращено количество выдаваемых кондитерских и колбасных изделий более чем в 2 раза, увеличено количество выдаваемых фруктов и овощей более чем на $30 \%$, что позволило обеспечить должную пищевую и биологическую ценность рациона питания.

Система осуществляемых в течение ряда лет в Российской Федерации мероприятий по улучшению качества среды обитания позволила снизить обусловленную влиянием загрязнения среды обитания дополнительную заболеваемость и смертность населения. Снижение уровня загрязнения атмосферного воздуха, химического и микробиологического загрязнения питьевой воды, доли проб почв городских и сельских поселений, не соответствующих гигиеническим нормативам по микробиологическим и паразитологическим показателям, а также уменьшение воздействия физических факторов как результат деятельности органов и учреждений Роспотребнадзора 
позволили в 2020 году вероятностно предотвратить возникновение более 0,23 дополнительных случая смерти на 1000 населения (33,8 тыс. случаев) и более 3,603 тыс. дополнительных случаев заболеваний на 100 тыс. населения $(5,29$ млн случаев) в Российской Федерации.

В 2020 году сумма предотвращенных в результате деятельности Роспотребнадзора экономических потерь валового внутреннего продукта (далее - ВВП) составила более 161,3 млрд рублей.

Экономическая эффективность деятельности Федеральной службы в сфере защиты прав потребителей и благополучия человека составила, по критерию предотвращенных потерь ВВП, в Российской Федерации в 2020 году около 20,23 руб. на 1 руб. затрат.

Научно-исследовательские работы, выполненные в рамках отраслевых программ на 2016-2020 гг. «Проблемно-ориентированные научные исследования в области эпидемиологического надзора за инфекционными и паразитарными болезнями» и «Гигиеническое научное обоснование минимизации рисков здоровью населения России», создали и обеспечили практическое применение научного потенциала, позволившего решить сложные санитарно-эпидемиологические проблемы 2020 года.

Необходимую поддержку в обеспечении санитарно-эпидемиологического благополучия населения оказали структурные подразделения федеральных органов исполнительной власти, входящие в систему федерального государственного санитарноэпидемиологического надзора.

В 2020 году продолжена работа по оптимизации обязательных санитарноэпидемиологических требований, позволяющих концентрировать возможности и потенциал Роспотребнадзора на приоритетных проблемах обеспечения санитарноэпидемиологического благополучия населения. $\mathrm{C}$ привлечением научного и практического звена проведена работа по систематизации, кодифицикации и сокращению количества санитарных правил и гигиенических нормативов с более чем 400 документов до 10. Это позволило уйти от фрагментарности разрозненных актов по узким вопросам, а также сформировать научно обоснованные, гармонизированные с международным опытом санитарно-эпидемиологические требования, разработать к ним методические рекомендации и иллюстрированные пособия.

В 2020 году получило развитие и укрепление двустороннее и многостороннее международное сотрудничество в области санитарно-эпидемиологического благополучия населения, реализации обязательств Российской Федерации в рамках членства в международных организациях по вопросам борьбы с инфекционными, неинфекционными и паразитарными болезнями, обеспечения безопасности продукции и среды обитания человека с учетом ограничительных мер, связанных с коронавирусной инфекцией.

Государственный доклад «О состоянии санитарно-эпидемиологического благополучия населения в Российской Федерации» подготовлен на основе данных и информации социально-гигиенического и эпидемиологического мониторинга, осуществляемого в субъектах Российской Федерации, материалов научноисследовательских институтов Роспотребнадзора гигиенического и эпидемиологического профиля, органов и учреждений Российской Федерации, входящих в систему федерального государственного санитарно-эпидемиологического надзора.

Государственный доклад направлен на обеспечение открытости информации о состоянии санитарно-эпидемиологического благополучия населения Российской Федерации и деятельности по его обеспечению для заинтересованных пользователей.

Главный государственный санитарный врач Российской Федерации

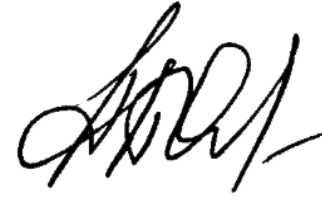


Государственный доклад «О состоянии санитарно-эпидемиологического благополучия населения в Российской Федерации в 2020 году»

\section{Раздел 1. Результаты социально-гигиенического мониторинга} за отчетный год и в многолетней динамике

В 2020 году Российская Федерация, как и весь мир, столкнулись с глобальным вызовом, связанным с новой коронавирусной инфекцией (COVID-19), распространившейся вне зависимости от границ государств. Жесткие карантинные ограничения, как и сама пандемия, привели к усилению влияния различных факторов среды обитания и их совокупности на состояние санитарно-эпидемиологического благополучия населения.

Комплекс факторов среды обитания, оказывающих влияние на состояние здоровья населения в субъектах Российской Федерации, включает группы социальноэкономических и санитарно-гигиенических факторов, а также факторов, характеризующих образ жизни населения.

В соответствии с Федеральным законом от 30 марта 1999 года № 52-Ф3 «О санитарно-эпидемиологическом благополучии населения» факторы среды - это биологические (вирусные, бактериальные, паразитарные и иные), химические, физические (шум, вибрация, ультразвук, инфразвук, тепловые, ионизирующие, неионизирующие и иные излучения), социальные (питание, водоснабжение, условия быта, труда, отдыха) и иные факторы среды обитания, которые оказывают или могут оказывать воздействие на человека и (или) на состояние здоровья будущих поколений. Оценка уровня влияния различных факторов среды обитания на состояние здоровья населения осуществляется в рамках ведения социально-гигиенического мониторинга в субъектах Российской Федерации.

Анализ данных социально-гигиенического мониторинга проводился с использованием методологии оценки и управления рисками, статистических методов математического анализа, ранжирования и прогнозирования вероятностной оценки влияния факторов среды обитания на показатели состояния здоровья населения на основе утвержденных методических подходов и технологий с применением информационно-аналитических инструментов.

Наиболее значимыми (в порядке приоритетности) факторами среды обитания, формирующими состояние санитарно-эпидемиологического благополучия и здоровья населения Российской Федерации, в 2020 году являлись (табл. 1):

- социальные и экономические факторы, наиболее выраженному влиянию которых на состояние здоровья подвержено около 94,3 млн человек в 53 субъектах Российской Федерации (64,6 \% населения Российской Федерации);

- санитарно-гигиенические факторы (химические, биологические, физические), которые оказывают выраженное влияние на состояние здоровья более чем 93,7 млн человек в 50 субъектах Российской Федерации (64,2 \% населения);

- факторы образа жизни (табакокурение, употребление алкоголя, несбалансированное питание), оказывающие выраженное влияние на состояние здоровья около 64,9 млн человек в 46 субъектах Российской Федерации $(44,5 \%$ населения). 


\section{Факторы среды обитания, формирующие состояние здоровья населения в субъектах Российской Федерации, 2020 год}

\begin{tabular}{|c|c|c|}
\hline $\begin{array}{c}\text { Группы факторов } \\
\text { среды обитания }\end{array}$ & Факторы, входящие в состав группы & $\begin{array}{c}\text { Численность } \\
\text { населения, } \\
\text { подверженного } \\
\text { влиянию факторов } \\
\text { среды обитания } \\
\end{array}$ \\
\hline $\begin{array}{l}\text { Социальные и } \\
\text { экономические } \\
\text { факторы }\end{array}$ & $\begin{array}{c}\text { Промышленно-экономическое развитие территории } \\
\text { Социальная напряженность } \\
\text { Социальное благополучие. Обеспеченность } \\
\text { медицинской помощью } \\
\text { Условия обучения и воспитания детей } \\
\text { Условия труда } \\
\end{array}$ & $\begin{array}{l}\text { 94,3 млн человек, } \\
53 \text { субъекта } \\
\text { Российской } \\
\text { Федерации }\end{array}$ \\
\hline $\begin{array}{c}\text { Санитарно- } \\
\text { гигиенические } \\
\text { факторы }\end{array}$ & $\begin{array}{c}\text { Химическое и биологическое загрязнение продуктов } \\
\text { питания, питьевой воды, атмосферного воздуха и почвы } \\
\text { Физические факторы }\end{array}$ & $\begin{array}{l}\text { 93,7 млн человек, } \\
50 \text { субъектов } \\
\text { Российской } \\
\text { Федерации }\end{array}$ \\
\hline $\begin{array}{c}\text { Факторы образа } \\
\text { жизни }\end{array}$ & $\begin{array}{c}\text { Потребление алкогольных напитков } \\
\text { Потребление табака } \\
\text { Отклонение от норм потребления продуктов питания }\end{array}$ & $\begin{array}{l}\text { 64,9 млн человек, } \\
46 \text { субъектов } \\
\text { Российской } \\
\text { Федерации }\end{array}$ \\
\hline
\end{tabular}

Санитарно-эпидемиологическая обстановка по всем субъектам и в целом по Российской Федерации в 2020 году характеризовалась как напряженная, вместе с тем управляемая, позволившая с минимальными потерями пройти сложный период пиковых нагрузок в распространении коронавирусной инфекции (COVID-19).

Динамика изменения численности населения Российской Федерации, подверженного влиянию комплекса факторов среды обитания за период с 2011 по 2020 год, приведена на рис. 1.

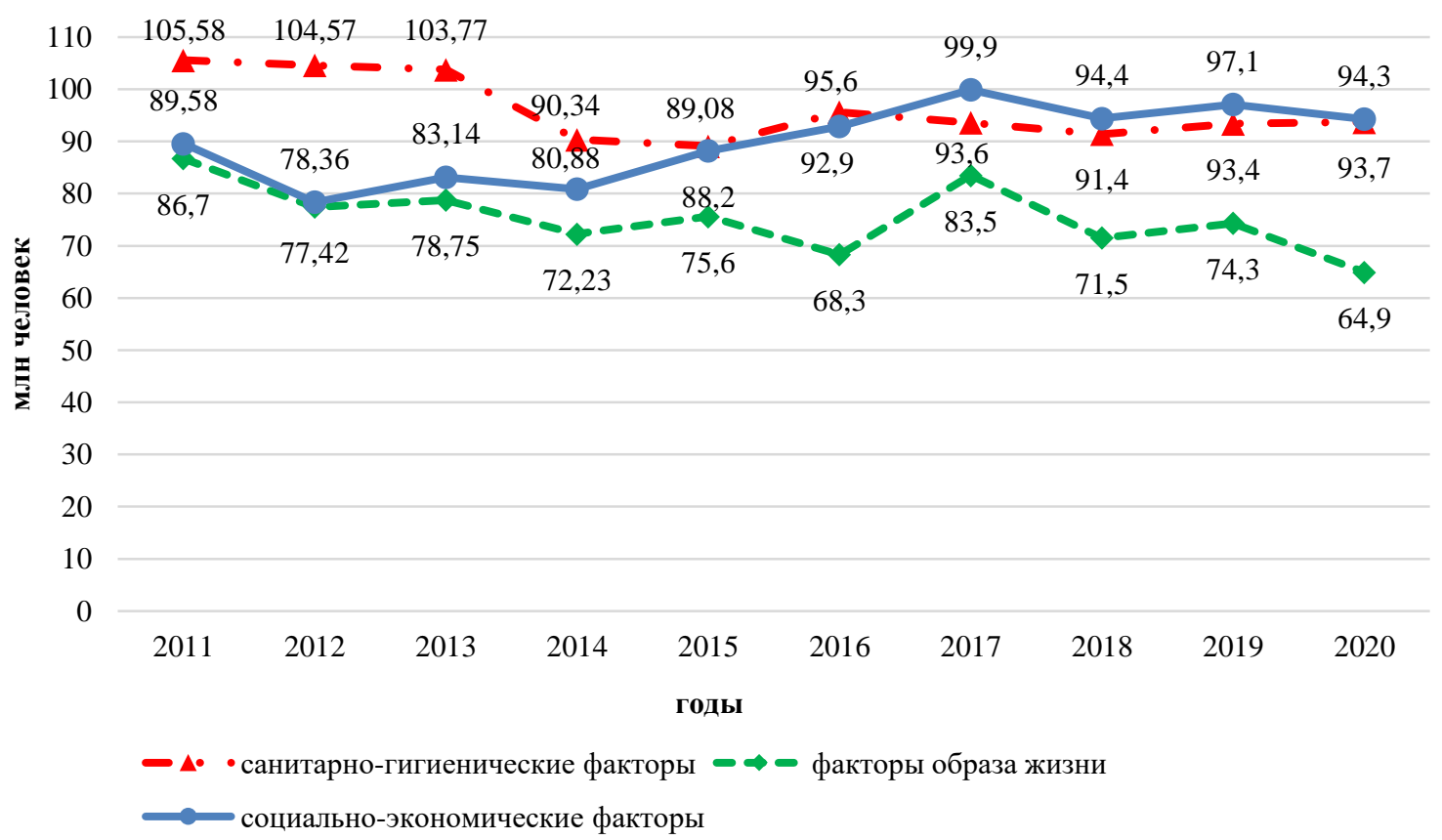

Рис. 1. Численность населения Российской Федерации, подверженного воздействию факторов среды обитания, за период 2011-2020 гг.

Влияние социальных и экономических факторов на состояние здоровья населения, начиная с 2011 года, все в большей степени определяет состояние здоровья 
населения, опережая уровень влияния санитарно-гигиенических факторов. При этом реализация специальных антикризисных мер поддержки экономики и бизнеса в 2020 году позволила смягчить негативные последствия влияния социально-экономических факторов на состояние здоровья населения в субъектах Российской Федерации. Удалось сохранить уровень численности населения, подверженного влиянию социальноэкономических факторов, на уровне 94-95 млн человек, а влиянию санитарногигиенических факторов - на уровне 93-94 млн человек (в целом на уровне не более 65 \% населения). Большое влияние на формирование здоровья населения продолжают оказывать связанные с образом жизни населения факторы, которым подвержено почти $45 \%$ населения Российской Федерации, имеющие положительную тенденцию к снижению.

Приоритетные проблемы, формирующие санитарно-эпидемиологическую обстановку, распространение новой коронавирусной инфекции (COVID-19), характерные особенности влияния факторов среды обитания на состояние здоровья населения определили те меры и действия по управлению риском для здоровья, которые были предприняты в 2020 году органами и учреждениями Роспотребнадзора для обеспечения стабильности и управления санитарно-эпидемиологическим благополучием населения в субъектах Российской Федерации.

Последовательное и системное улучшение качества среды обитания населения и эпидемической ситуации в субъектах Российской Федерации, реализуемые адресные, учитывающие особенности санитарно-эпидемиологической обстановки, меры и действия по управлению риском для здоровья, связанным с факторами среды обитания, повышение эффективности и целенаправленности надзорной деятельности в сфере обеспечения санитарно-эпидемиологического благополучия населения влекут за собой улучшение состояния здоровья населения как ключевого социально значимого результата деятельности по обеспечению его санитарно-эпидемиологического благополучия.

Эти действия и меры имеют тем больший эффект, чем в большей степени учитывают приоритеты влияния санитарно-гигиенических факторов и факторов образа жизни населения на фоне воздействия на состояние здоровья социально-экономических факторов, и прежде всего при их комплексном воздействии в различных кластерах субъектов Российской Федерации.

Кластеры субъектов Российской Федерации в зависимости от преимущественного влияния этих групп факторов среды обитания приведены на рис. 2 .

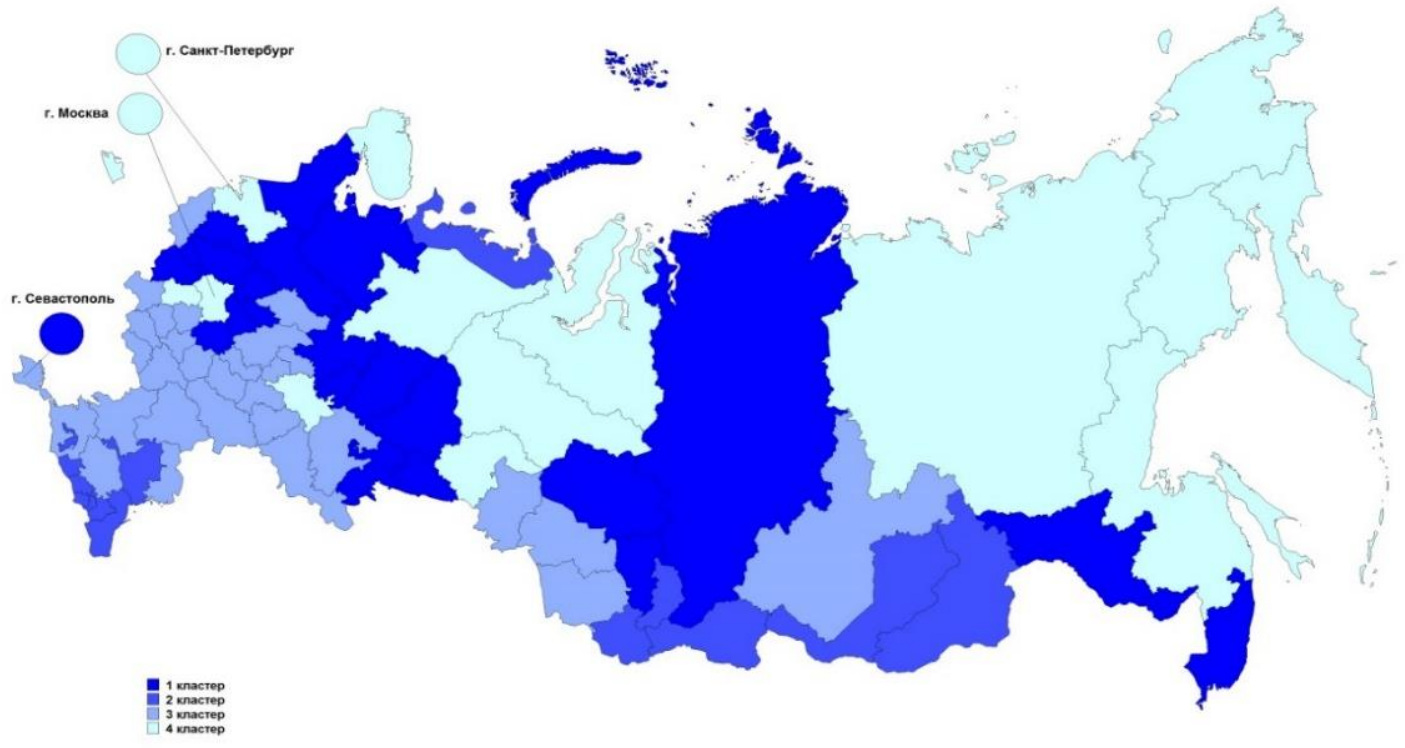

Рис. 2. Кластеры субъектов Российской Федерации, объединенные по группам преимущественного влияния факторов среды обитания, 2020 год 
Санитарно-гигиенические факторы, формирующие состояние здоровья населения в субъектах Российской Федерации, 2020 год

\begin{tabular}{|c|c|c|}
\hline $\begin{array}{c}\text { Виды нагрузки } \\
\text { на население }\end{array}$ & $\begin{array}{c}\text { Основные показатели состояния здоровья } \\
\text { населения, на которые влияют } \\
\text { санитарно-гигиенические факторы }\end{array}$ & \begin{tabular}{|} 
Численность \\
населения, \\
подверженного \\
воздействию \\
факторов
\end{tabular} \\
\hline $\begin{array}{l}\text { Комплексная химическая } \\
\text { нагрузка: } \\
\text { - процент } \\
\text { неудовлетворительных проб } \\
\text { по санитарно-химическим } \\
\text { показателям: питьевой воды } \\
\text { разводящей сети; } \\
\text { атмосферного воздуха } \\
\text { (городская и сельская } \\
\text { местность); почвы (всего), в } \\
\text { том числе селитебных зон; } \\
\text { продуктов питания; } \\
\text { - плотность загрязнения } \\
\text { атмосферного воздуха и др. }\end{array}$ & $\begin{array}{c}\text { Заболеваемость всего населения, в том числе } \\
\text { детей и взрослых. Распространенность болезней } \\
\text { органов дыхания, в том числе у детей. } \\
\text { Распространенность болезней органов } \\
\text { пищеварения, в том числе у детей, болезней } \\
\text { системы кровообращения, в том числе у детей, } \\
\text { болезней эндокринной системы, в том числе у } \\
\text { детей, мочеполовой системы у детей, } \\
\text { злокачественных новообразований, болезней } \\
\text { костно-мышечной системы. Заболеваемость с } \\
\text { временной утратой трудоспособности у мужчин } \\
\text { и женщин. Врожденные аномалии у детей. } \\
\text { Травмы и отравления. Рождаемость, } \\
\text { естественная убыль населения. Смертность } \\
\text { всего населения, в том числе от болезней } \\
\text { системы кровообращения, внешних причин, } \\
\text { злокачественных новообразований }\end{array}$ & $\begin{array}{c}78,6 \text { млн } \\
\text { человек, } \\
44 \text { субъекта } \\
\text { Российской } \\
\text { Федерации } \\
\text { (53,85\% } \\
\text { населения) }\end{array}$ \\
\hline $\begin{array}{l}\text { Комплексная биологическая } \\
\text { нагрузка: } \\
\text { - процент } \\
\text { неудовлетворительных проб } \\
\text { по микробиологическому } \\
\text { показателю: питьевой воды } \\
\text { из развод сети; почвы; } \\
\text { почвы селитебных зон; } \\
\text { почвы на территории ДОУ; } \\
\text { продуктов питания и др. }\end{array}$ & $\begin{array}{c}\text { Заболеваемость всего населения, в том числе } \\
\text { детей, взрослых. Распространенность } \\
\text { инфекционных и паразитарных заболеваний } \\
\text { всего населения, в том числе детского } \\
\text { населения. Распространенность } \\
\text { злокачественных новообразований, болезней } \\
\text { органов пищеварения. Заболеваемость с } \\
\text { временной утратой трудоспособности у мужчин } \\
\text { и женщин. Смертность всего населения, } \\
\text { смертность от злокачественных } \\
\text { новообразований, от внешних причин. } \\
\text { Младенческая смертность }\end{array}$ & $\begin{array}{c}\text { 61,8 млн } \\
\text { человек, } \\
37 \text { субъектов } \\
\text { Российской } \\
\text { Федерации } \\
\text { (42,3\% } \\
\text { населения) }\end{array}$ \\
\hline $\begin{array}{l}\text { Комплексная нагрузка, } \\
\text { связанная физическими } \\
\text { факторами: } \\
\text { - средняя индивидуальная } \\
\text { доза на } 1 \text { жителя мЗв/год; } \\
\text { - процент } \\
\text { неудовлетворительных проб } \\
\text { по шуму, вибрации, ЭМИ } \\
\text { на рабочих местах, } \\
\text { автомагистралях и др. }\end{array}$ & $\begin{array}{c}\text { Заболеваемость всего населения, в том числе } \\
\text { взрослых, детей. Распространенность болезней } \\
\text { системы кровообращения, в том числе у детей, } \\
\text { болезней эндокринной системы, болезней } \\
\text { нервной системы. Заболеваемость с временной } \\
\text { утратой трудоспособности у мужчин и женщин. } \\
\text { Распространенность злокачественных } \\
\text { новообразований, врожденных пороков } \\
\text { развития у детей. Смертность всего населения, } \\
\text { в том числе от злокачественных } \\
\text { новообразований. Младенческая смертность, } \\
\text { рождаемость, естественная убыль населения }\end{array}$ & $\begin{array}{c}\text { 62,2 млн } \\
\text { человек, } \\
29 \text { субъектов } \\
\text { Российской } \\
\text { Федерации } \\
\text { (42,6\% } \\
\text { населения) }\end{array}$ \\
\hline
\end{tabular}

Наиболее значимыми факторами из этой группы, определяющими уровень нагрузки и формирующими основные риски для здоровья населения, в 2020 г. являлись: - комплексная химическая нагрузка (за счет химического загрязнения продуктов питания, питьевой воды, атмосферного воздуха и почвы);

- комплексная биологическая нагрузка (за счет микробиологического загрязнения продуктов питания, питьевой воды и почвы);

- комплексная нагрузка, связанная с физическими факторами среды обитания (шум, электромагнитное излучение, вибрация, ультразвук и иные). 
На рис. 3 приведена динамика изменения численности населения в субъектах Российской Федерации, подверженного воздействию санитарно-гигиенических факторов, за период 2011-2020 гг.

При стабильной положительной тенденции снижения комплексной химической нагрузки на населения (снижение численности подверженного населения за последнее десятилетие почти в 1,3 раза при среднем ежегодном снижении на 3,5\%) в 2020 г. остаются стабильным и высоким уровень воздействия комплекса биологических факторов (ежегодно около 60 млн человек подверженного населения) и развитие с 2014 года негативной тенденции увеличения воздействия физических факторов (в основном за счет увеличения шумового воздействия от автотранспорта и электромагнитного излучения (от мобильных средств телефонной связи), радиационной нагрузки от медицинских диагностических исследований (лучевой диагностики, в основном за счет увеличения КТ-исследований).

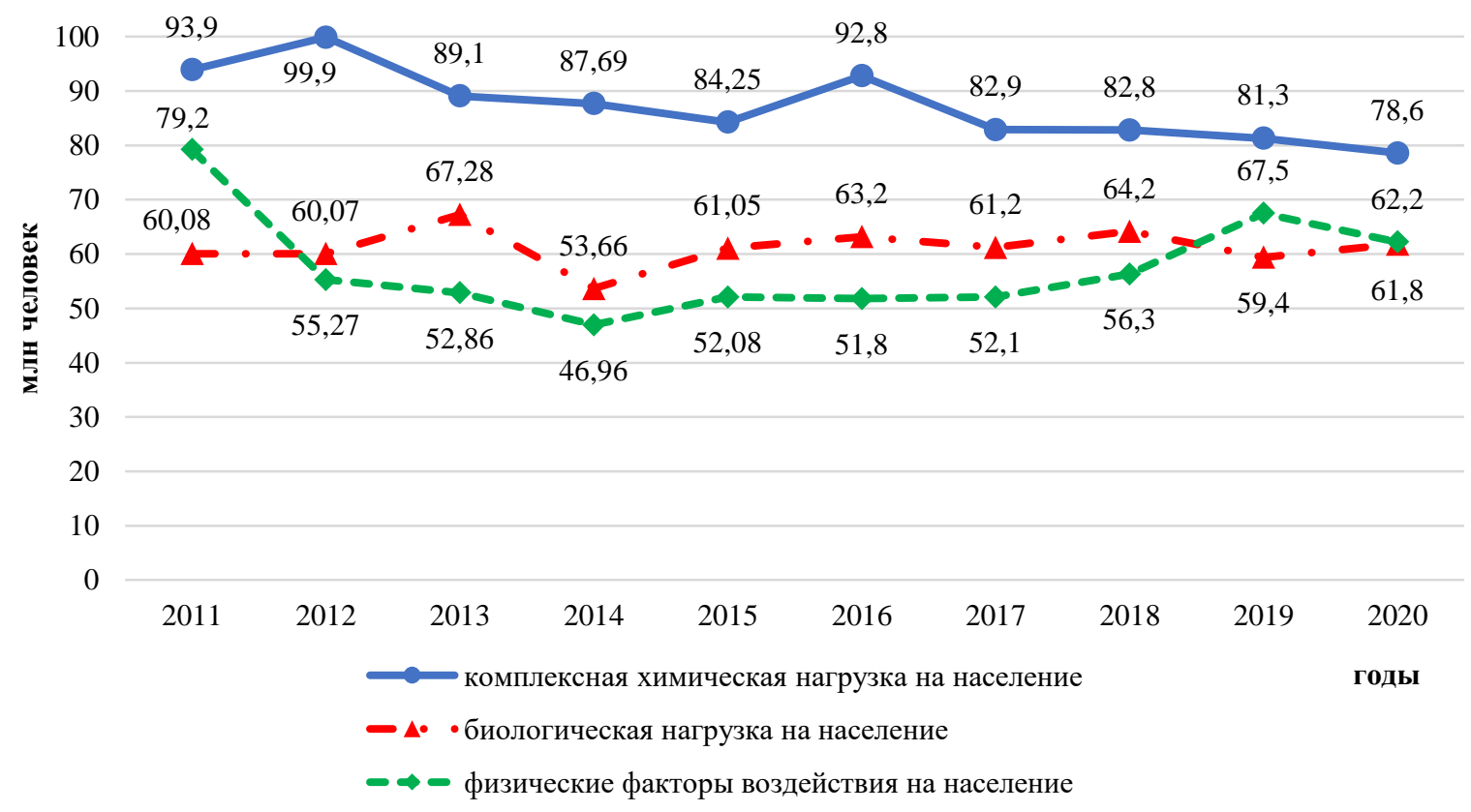

Рис. 3. Численность населения Российской Федерации, подверженного воздействию комплекса санитарно-гигиенических факторов за период 2011-2020 гг.

К группе субъектов Российской Федерации с наибольшим уровнем влияния комплекса санитарно-гигиенических факторов на состояние здоровья населения в 2020 г. относились Республика Карелия, Республика Коми, Архангельская область, Новгородская область, Республика Дагестан, Пермский край, Курганская область, Приморский край, Хабаровский край, Еврейская автономная область. В группу субъектов Российской Федерации с наименьшим уровнем влияния санитарногигиенических факторов на состояние здоровья населения входят Орловская область, Республика Адыгея, Краснодарский край, Астраханская область, Кабардино-Балкарская Республика, Ставропольский край, Республика Марий Эл, Оренбургская область, Республика Алтай, Камчатский край.

Ранжирование субъектов Российской Федерации по уровню воздействия санитарно-гигиенических факторов на состояние здоровья населения приведено на рис. 4. Максимальный ранг присвоен субъектам Российской Федерации с наибольшим влиянием интегрального показателя, характеризующего санитарно-гигиеническую обстановку, на показатели состояния здоровья населения, соответственно, минимальный ранг - с наименьшим влиянием. 
Основные показатели состояния здоровья работающего населения, на которые оказывают влияние условия труда, а также количество субъектов Российской Федерации, для которых характерно значительное влияние этих факторов на здоровье, приведены в табл. 3. Проблемы негативного влияния факторов условий труда на состояние здоровья работающего населения характерны для 33 субъектов Российской Федерации.

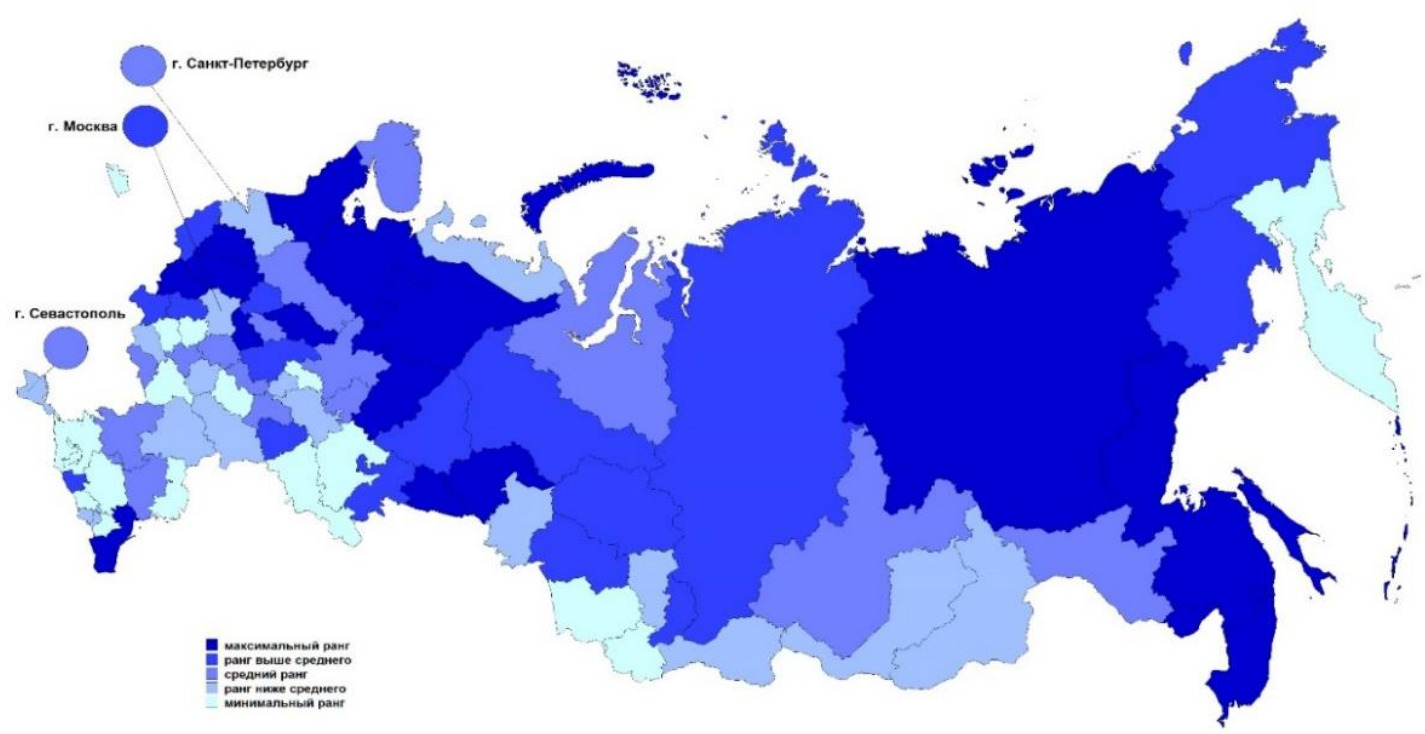

Рис. 4. Распределение субъектов Российской Федерации по интегральному показателю санитарно-гигиенической обстановки, 2020 год

Наибольшее влияние факторов, характеризующих условия труда, на состояние здоровья работающего населения в 2020 г. отмечается в Брянской области, Калужской области, Республике Карелия, Республике Коми, Новгородской области, Республике Мордовия, Пермском крае, Ханты-Мансийском автономном округе, Томской области, Магаданской области. В меньшей степени влияние условий труда на состояние здоровья работающего населения характерно для Ивановской области, Астраханской области, Республики Ингушетия, Кабардино-Балкарской Республики, Ставропольского края, Пензенской области, Тюменской области, Республики Алтай, Республики Хакасия, Камчатского края.

Таблица 3

\section{Факторы условий труда, формирующие негативные тенденции в состоянии} здоровья населения в субъектах Российской Федерации, 2020 год

\begin{tabular}{|c|c|c|}
\hline Группа факторов & $\begin{array}{c}\text { Основные медико-демографические показатели и } \\
\text { показатели заболеваемости, на которые влияют } \\
\text { факторы условий труда }\end{array}$ & $\begin{array}{c}\text { Количество } \\
\text { субъектов РФ, } \\
\text { подверженных } \\
\text { воздействию } \\
\text { факторов }\end{array}$ \\
\hline $\begin{array}{l}\text { Условия труда (процент } \\
\text { неудовлетворительных } \\
\text { проб на рабочих местах по } \\
\text { шуму, вибрации, пыли и } \\
\text { аэрозолям, парам и газам, } \\
\text { ЭМИ, ионизирующему } \\
\text { излучению и др.) }\end{array}$ & $\begin{array}{c}\text { Заболеваемость всего населения, в том числе взрослых. } \\
\text { Заболеваемость с временной утратой трудоспособности } \\
\text { мужчин и женщин. Заболевания органов дыхания, } \\
\text { злокачественные новообразования. Распространенность } \\
\text { травм и отравлений. Инфекционные и паразитарные } \\
\text { болезни. Смертность общая, в том числе смертность от } \\
\text { болезней системы кровообращения, от злокачественных } \\
\text { новообразований, от внешних причин }\end{array}$ & $\begin{array}{l}33 \text { субъекта } \\
\text { Российской } \\
\text { Федерации }\end{array}$ \\
\hline
\end{tabular}


Распределение субъектов Российской Федерации по степени влияния комплекса факторов условий труда на состояние здоровья работающего населения приведено на рис. 5.

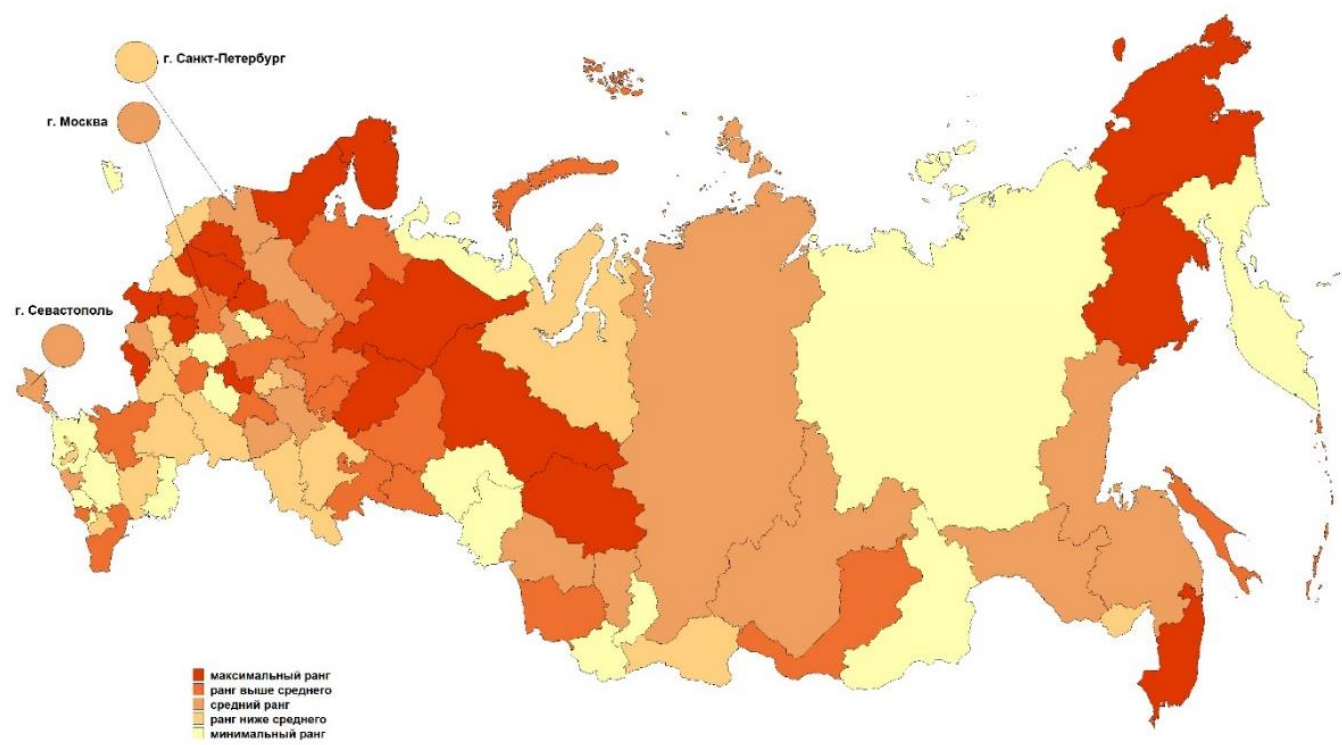

Рис. 5. Распределение субъектов Российской Федерации по степени влияния условий труда на состояние здоровья работающего населения, 2020 год

Максимальный ранг присвоен субъектам Российской Федерации, для которых характерна наибольшая степень такого влияния, соответственно, минимальный наименьшая степень.

Основные показатели состояния здоровья детского населения, на которые оказывают влияние условия обучения и воспитания, а также число субъектов Российской Федерации, для которых характерно значительное влияние этих факторов на здоровье, приведены в табл. 4.

Таблица 4

\section{Факторы условий обучения и воспитания детей, формирующие негативные тенденции в состоянии их здоровья в субъектах Российской Федерации, 2020 год}

\begin{tabular}{|c|c|c|}
\hline Группа факторов & $\begin{array}{c}\text { Основные медико-демографические } \\
\text { показатели и показатели заболеваемости, } \\
\text { на которые влияют факторы обучения и } \\
\text { воспитания }\end{array}$ & $\begin{array}{c}\text { Количество } \\
\text { субъектов РФ, } \\
\text { подверженных } \\
\text { воздействию } \\
\text { факторов }\end{array}$ \\
\hline $\begin{array}{l}\text { Условия обучения и воспитания } \\
\text { - процент охвата школьников } \\
\text { горячим питанием; } \\
\text { - процент неудовлетворительных } \\
\text { проб: блюд на калорийность, } \\
\text { химический состав; почвы на } \\
\text { территории ОУ по } \\
\text { микробиологическим и санитарно- } \\
\text { химическим показателям; в ОУ по } \\
\text { микроклимату, освещенности, шуму } \\
\text { и др. }\end{array}$ & $\begin{array}{c}\text { Общая заболеваемость детей. } \\
\text { Распространенность болезней органов } \\
\text { дыхания у детей, травм и отравлений. } \\
\text { Инфекционные и паразитарные } \\
\text { заболевания среди детей. Болезни } \\
\text { органов пищеварения, костно-мышечной } \\
\text { системы }\end{array}$ & $\begin{array}{l}23 \text { субъекта } \\
\text { Российской } \\
\text { Федерации }\end{array}$ \\
\hline
\end{tabular}


В 23 субъектах Российской Федерации отмечено существенное влияние факторов риска, связанных с условиями обучения и воспитания, на показатели состояния здоровья детей. В 2020 году в наибольшей степени это было характерно для следующих субъектов Российской Федерации: Новгородская область, Свердловская область, ХантыМансийский автономный округ, Республика Тыва, Республика Хакасия, Приморский край, Магаданская область, Еврейская автономная область, Чукотский автономный округ.

В наименьшей степени влияние факторов риска, связанных с условиями обучения и воспитания, на состояние здоровья детей отмечается в Орловской области, г. СанктПетербурге, Республике Адыгея, Волгоградской области, Республике Ингушетия, Республике Марий Эл, Чувашской Республике, Пензенской области, Новосибирской области, г. Севастополе.

Распределение субъектов Российской Федерации по степени влияния на состояние здоровья детского населения комплекса факторов условий обучения и воспитания детей и подростков по интегральной оценке приведено на рис. 6.

На карте максимальный ранг присвоен субъектам Российской Федерации с наибольшим влиянием этих факторов на здоровье детей, минимальный ранг - с наименьшим влиянием.

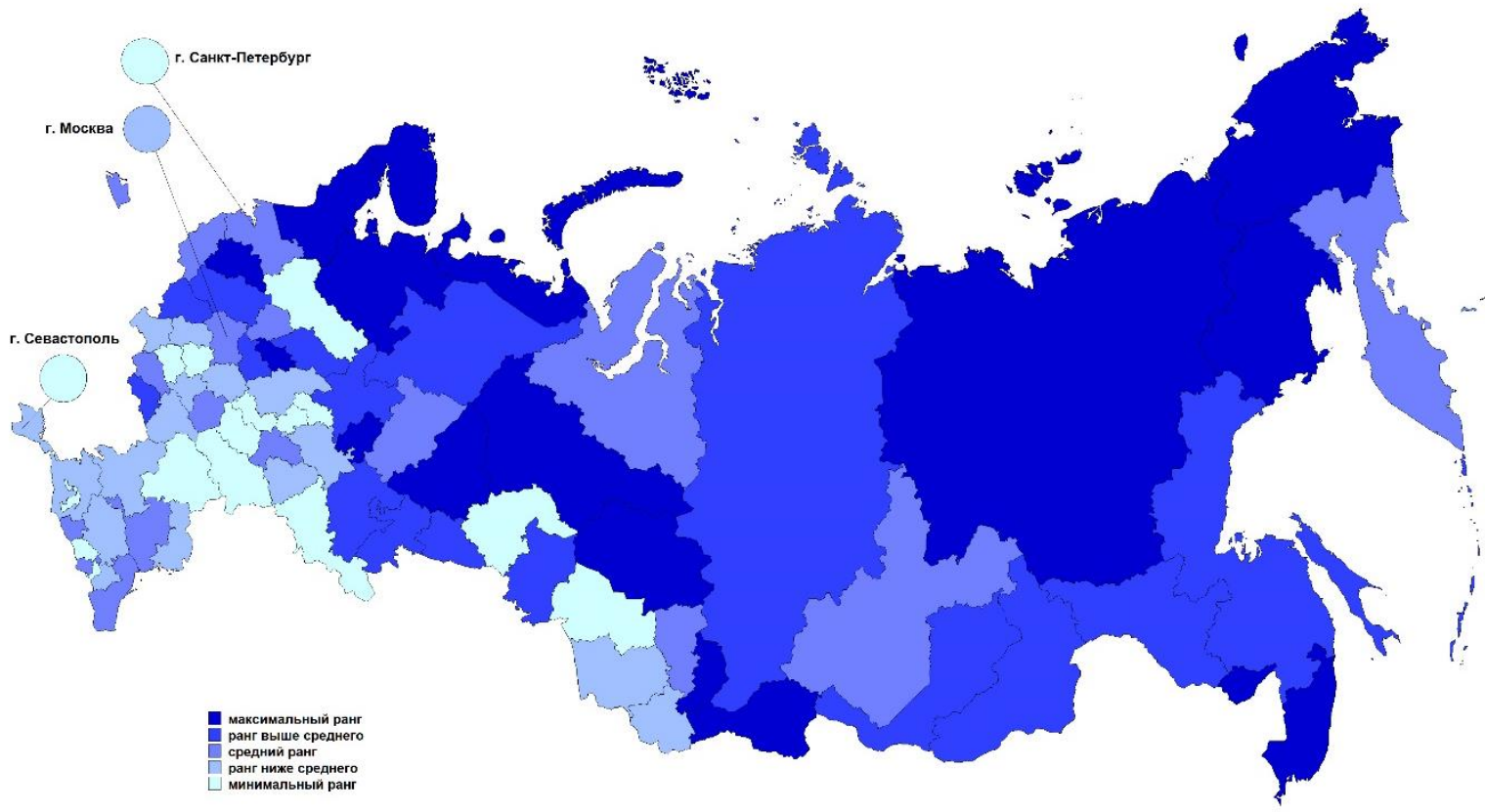

Рис. 6. Распределение субъектов Российской Федерации по степени влияния условий образования и воспитания на состояние здоровья детского населения, 2020 год

Основные факторы, характеризующие образ жизни населения (по показателям отклонения от норм потребления продуктов питания, расходов на табак на одного члена домохозяйства в месяц, объема продаж алкогольных напитков на одного человека в год), показатели состояния здоровья населения, на которые они оказывают влияние, доля населения, подвергающегося воздействию, по субъектам Российской Федерации приведены в табл. 5. 
Факторы образа жизни, формирующие негативные тенденции в состоянии здоровья населения, 2020 год

\begin{tabular}{|c|c|c|}
\hline Группы факторов & $\begin{array}{c}\text { Основные медико-демографические показатели и } \\
\text { показатели заболеваемости, на которые влияют } \\
\text { факторы образа жизни }\end{array}$ & $\begin{array}{c}\text { Количество } \\
\text { субъектов РФ и } \\
\text { численность } \\
\text { населения, } \\
\text { подверженного } \\
\text { воздействию } \\
\text { факторов }\end{array}$ \\
\hline $\begin{array}{c}\text { Отклонение от норм } \\
\text { питания }\end{array}$ & \multirow{3}{*}{$\begin{array}{c}\text { Заболеваемость всего населения, в том числе детей, } \\
\text { взрослых. Распространенность болезней органов } \\
\text { дыхания среди всего населения и среди детей, болезней } \\
\text { системы кровообращения, пищеварения, в том числе у } \\
\text { детей, эндокринной системы, в том числе у детей, травм } \\
\text { и отравлений, инфекционных и паразитарных } \\
\text { заболеваний среди всего населения и среди детей. } \\
\text { Заболеваемость с временной утратой трудоспособности } \\
\text { (мужчин и женщин). Заболеваемость злокачественными } \\
\text { новообразованиями, врожденными аномалиями. } \\
\text { Рождаемость, естественная убыль. Смертность всего } \\
\text { населения, в том числе от болезней систем } \\
\text { кровообращения, от злокачественных новообразований, } \\
\text { от внешних причин, включая употребление алкоголя }\end{array}$} & \multirow[b]{3}{*}{$\begin{array}{c}46 \text { субъектов РФ, } \\
64,9 \text { млн человек } \\
\text { (45,5 \% } \\
\text { населения) }\end{array}$} \\
\hline $\begin{array}{c}\text { Объем продажи } \\
\text { алкогольных напитков }\end{array}$ & & \\
\hline $\begin{array}{c}\text { Денежные траты на } \\
\text { табачные изделия } \\
\text { (расходы на табак на } \\
1 \text { члена домохозяйства } \\
\text { в месяц, \%) }\end{array}$ & & \\
\hline
\end{tabular}

Около 64,9 млн человек, или 45,5\% населения, в субъектах Российской Федерации подвержено воздействию факторов нездорового образа жизни. По степени влияния на показатели состояния здоровья населения факторы образа жизни в субъектах Российской Федерации в 2020 году располагаются следующим образом: несбалансированное питание, употребление алкоголя и табакокурение.

На рис. 7 приведена интегральная оценка влияния факторов образа жизни на состояние здоровья населения в субъектах Российской Федерации. Максимальный ранг присвоен субъектам Российской Федерации с наибольшим влиянием этой группы факторов.

К группе субъектов Российской Федерации, в которых отмечается наибольшее влияние факторов образа жизни на состояние здоровья населения, относятся Воронежская область, Ненецкий автономный округ, Ленинградская область, Удмуртская Республика, Свердловская область, Ямало-Ненецкий автономный округ, Республика Хакасия, Амурская область, Еврейская автономная область, Республика Крым.

К субъектам Российской Федерации с наименьшим влиянием комплекса факторов образа жизни на состояние здоровья населения относятся Тамбовская область, Республика Калмыкия, Республика Дагестан, Республика Ингушетия, КабардиноБалкарская Республика, Карачаево-Черкесская Республика, Республика Северная Осетия - Алания, Чеченская Республика, Республика Тыва, Чукотский автономный округ. 


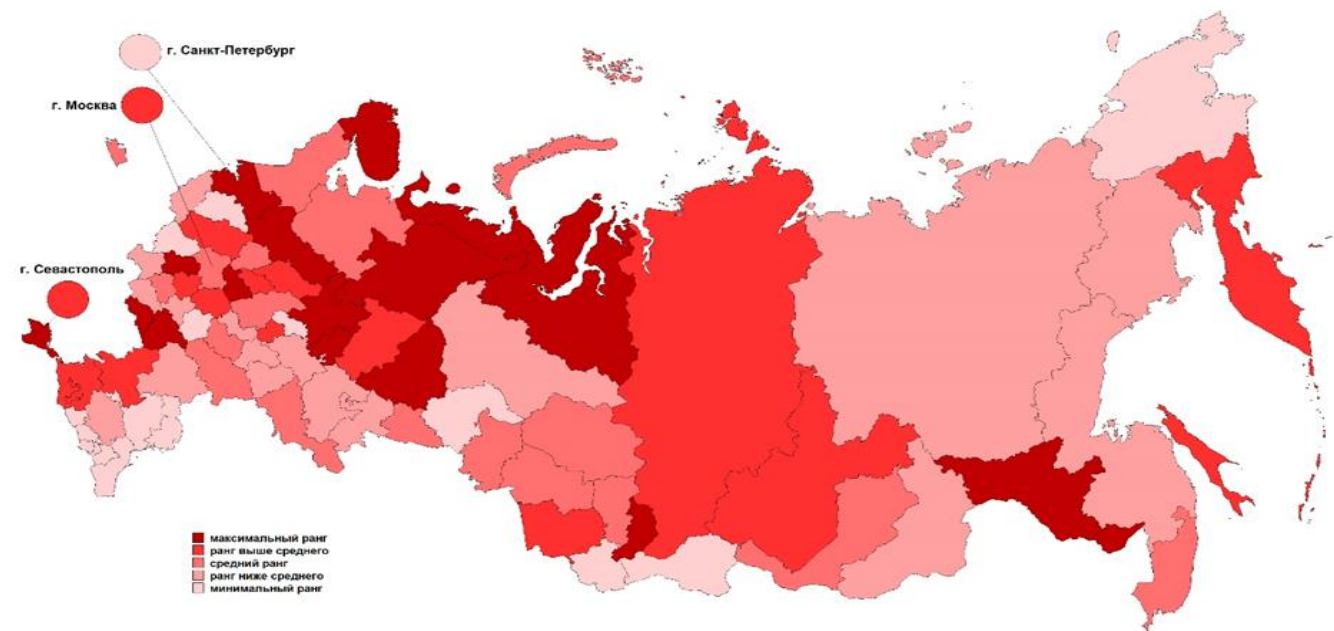

Рис. 7. Распределение субъектов Российской Федерации по интегральному показателю, характеризующему факторы образа жизни, 2020 год

\section{1. Состояние среды обитания и ее влияние на здоровье населения}

\subsection{1. Состояние атмосферного воздуха и его влияние на здоровье населения}

\section{Качество атмосферного воздуха поселений}

В 2020 году в результате деятельности органов и организаций Роспотребнадзора на территории Российской Федерации исследовано более 1,416 млн проб атмосферного воздуха, что на 197,6 тыс. проб больше, чем в 2019 году.

На территории сельских поселений в 2020 году исследовано более 195,8 тыс. проб воздуха, городских - свыше 1,220 млн проб, в том числе:

- при маршрутных и подфакельных исследованиях в зоне влияния промышленных предприятий - более 856,5 тыс. проб;

- на автомагистралях в зоне жилой застройки - более 289,0 тыс. проб;

- на стационарных постах наблюдения - более 75,2 тыс. проб.

Динамика общего количества проб атмосферного воздуха населенных мест, исследованных в 2011-2020 гг., представлена на рис. 8.

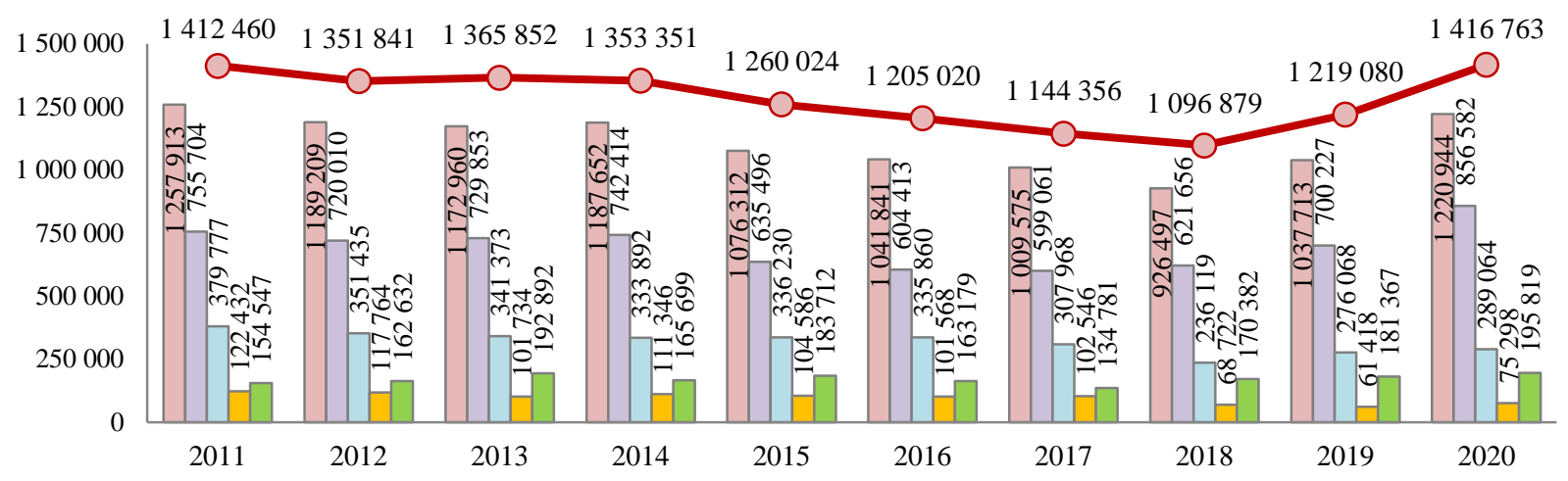

$\square$ в городских поселениях (всего)

$\square$ маршрутные и подфакельные исследования в зоне влияния промышленных предприятий в городских поселениях

$\square$ на автомагистралях в зоне жилой застройки в городских поселениях

$\square$ на стационарных постах в городских поселениях

$\square$ в сельских поселениях (всего)

- Всего исследовано проб атмосферного воздуха

Рис. 8. Динамика количества проб атмосферного воздуха населенных мест, исследованных в 2011-2020 гг. 


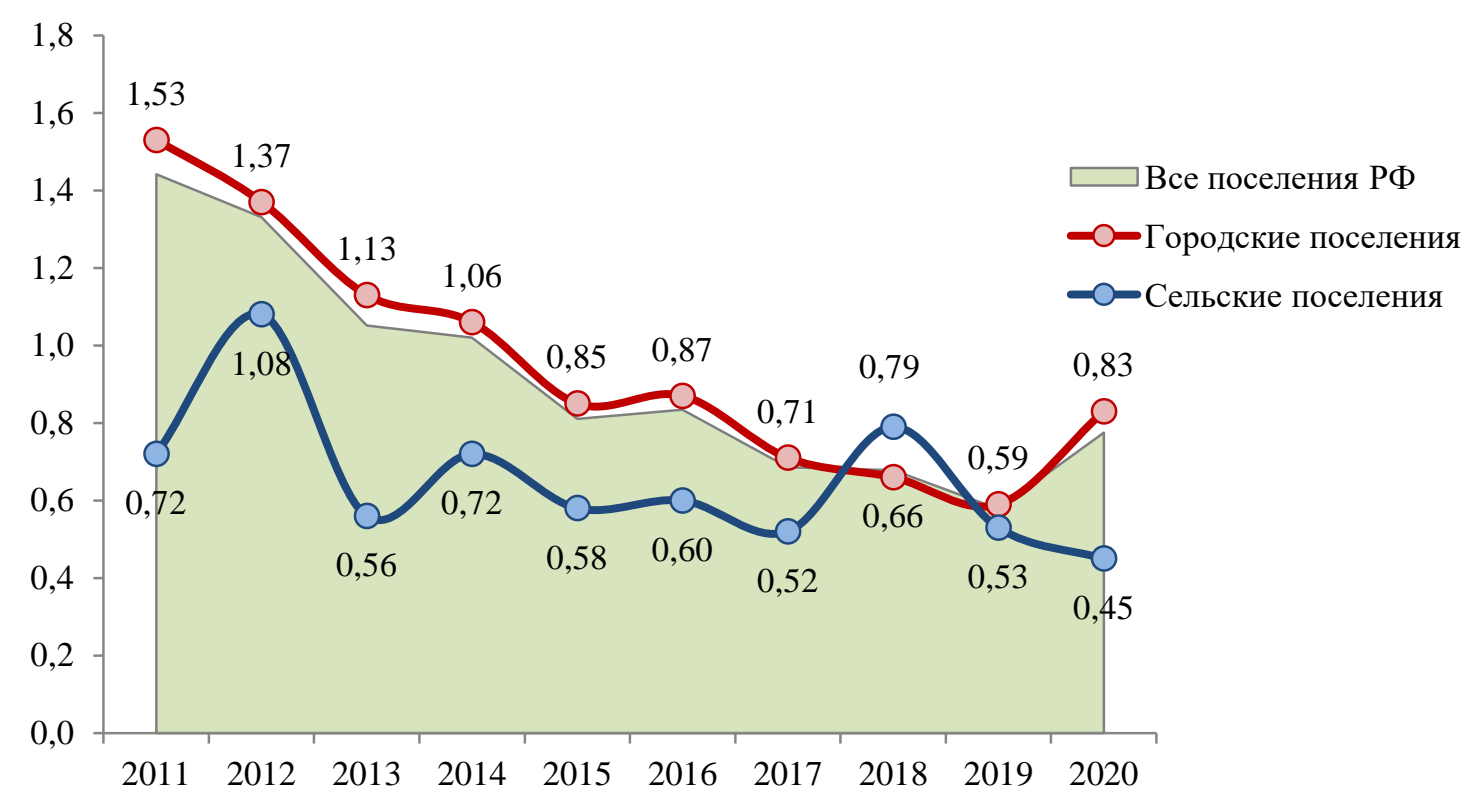

Рис. 9. Доля (\%) проб атмосферного воздуха с превышением ПДК, отобранных на территории городских и сельских поселений в 2011-2020 гг.

За последние десять лет (2011-2020 гг.) отмечалось стабильное снижение в 1,86 раза по сравнению с уровнем 2011 года доли неудовлетворительных проб с превышением ПДК атмосферного воздуха населенных мест в Российской Федерации (рис. 9). На городских территориях за тот же период данный показатель уменьшился в 1,84 раза (с $1,53 \%$ до $0,83 \%$ ), на сельских - в 1,6 раза (с 0,72 \% до 0,45\%). В 2020 году установлен рост процента неудовлетворительных проб, исследованных на территориях городских поселений, за счет увеличения приоритетного перечня контролируемых показателей и количества исследований в 5,9 раз в 12 городах - участниках федерального проекта «Чистый воздух». На территориях эксперимента по результатам оценки риска определено 73 приоритетных загрязняющих вещества, из которых 28 веществ относятся к 1 и 2 классам опасности.

Пробы атмосферного воздуха, в которых превышен уровень 5 ПДК, в 2020 году выявлены на территории городских поселений, расположенных в 20 субъектах Российской Федерации: Воронежская область, Ивановская область, Рязанская область, Тульская область, Республика Карелия, Калининградская область, Мурманская область, Краснодарский край, Волгоградская область, г. Севастополь, Чеченская Республика, Самарская область, Свердловская область, Челябинская область, Красноярский край, Иркутская область, Кемеровская область - Кузбасс, Омская область, Республика Бурятия, Забайкальский край.

За последние десять лет в атмосферном воздухе поселений Российской Федерации (городских и сельских) отмечено значительное снижение доли проб атмосферного воздуха с превышением ПДК по содержанию алифатических непредельных углеводородов, ртути, кадмия, мышьяка, аминов (алифатических и ароматических, диметилформальдегида и др.) и прочих химических веществ (табл. 6). 
Таблица 6

Динамика доли проб приоритетных загрязняющих веществ с превышением ПДК в атмосферном воздухе поселений Российской Федерации (городских и сельских), 2011-2020 гг., \%

\begin{tabular}{|l|c|c|c|c|c|c|c|c|c|c|}
\hline Загрязняющее вещество & 2011 & 2012 & 2013 & 2014 & 2015 & 2016 & 2017 & 2018 & 2019 & 2020 \\
\hline \multicolumn{10}{|c|}{ Вещества 1 класса опасности } \\
\hline Свинец & 0,76 & 0,36 & 0,26 & 0,39 & 0,54 & 0,37 & 0,31 & 0,05 & 0,03 & 0,09 \\
\hline \multicolumn{10}{|c|}{ Вещества 2 класса опасности } \\
\hline Сероуглерод & 2,66 & 1,03 & 0,03 & 0,00 & 0,50 & 0,61 & 0,26 & 0,23 & 0,00 & 0,17 \\
\hline Хлор & 0,32 & 0,30 & 0,43 & 0,00 & 0,20 & 0,16 & 0,28 & 0,12 & 0,00 & 0,13 \\
\hline $\begin{array}{l}\text { Гидроксибензол (фенол) и } \\
\text { иго производные }\end{array}$ & 2,11 & 1,60 & 2,11 & 2,20 & 0,86 & 0,85 & 1,20 & 0,56 & 0,72 & 1,25 \\
\hline Хлористый водород & 1,43 & 0,72 & 0,90 & 0,88 & 0,61 & 0,86 & 0,32 & 2,02 & 0,57 & 1,00 \\
\hline Серная кислота & 0,07 & 0,12 & 0,50 & 0,10 & 0,12 & 0,02 & 0,16 & 0,37 & 0,00 & 0,06 \\
\hline \multicolumn{10}{|c|}{ Вещества 3 класса опасности } \\
\hline Взвешенные вещества & 2,87 & 2,35 & 1,88 & 1,87 & 1,65 & 1,62 & 1,10 & 1,11 & 1,0 & 1,0 \\
\hline Азота диоксид & 0,87 & 0,84 & 0,65 & 0,75 & 0,56 & 0,58 & 0,43 & 0,36 & 0,32 & 0,42 \\
\hline Азота оксид & 0,48 & 0,34 & 0,36 & 0,31 & 0,08 & 0,40 & 0,17 & 0,11 & 0,14 & 0,24 \\
\hline & 0,92 & 0,89 & 0,82 & 0,49 & 0,54 & 0,81 & 0,50 & 0,66 & 0,44 & 0,58 \\
\hline Аммиак
\end{tabular}

В 2020 году на территориях городов - участников федерального проекта «Чистый воздух» по результатам исследований разовых концентраций, выполненных по полной программе наблюдений, получено 31,745 тыс. результатов расчетных среднесуточных концентраций, в 2,6 тыс. полученных результатов (8,2 \%) зарегистрированы превышения ПДКсс:

- Братск (превышения ПДК по 19 из 33 исследованных веществ - 57,6 \%): азота диоксид, алюминий и его соединения, бенз(а)пирен, бензол, взвешенные вещества, взвешенные частицы РМ2,5, гидроксибензол, диметилбензол, метилбензол, пропан-1тиол, серы диоксид, серная кислота, сероводород, углерод, формальдегид, фториды неорганические плохо растворимые, фтористые газообразные соединения (в пересчете на фтор), хлор, этилбензол;

- Красноярск (18 из 36 исследованных веществ - 50,0 \%): азот (II) оксид, азота диоксид, аммиак, бенз(а)пирен, бензол, взвешенные вещества, взвешенные частицы PM10 и РМ2,5, гидроксибензол, фтористые газообразные соединения, диметилбензол, дихлорметан, метилбензол, проп-2-еннитрил, тетрахлорэтилен, углерод оксид, формальдегид, этилбензол;

- Липецк (7 из 28 исследованных веществ - 25 \%): азота диоксид, азота оксид, аммиак, озон, взвешенные вещества, взвешенные частицы РМ2,5, бенз(а)пирен;

- Магнитогорск (18 из 44 исследованных веществ - 40,9\%): азот (II) оксид, азота диоксид, аммиак, бенз(а)пирен, взвешенные вещества, взвешенные частицы PM10 и PM2,5, гидрохлорид (по молекуле НС1), дигидросульфид, диметилбензол, метилбензол, пыль неорганическая с содержанием $\mathrm{SiO}_{2}$ более $70 \%$, пыль неорганическая с содержанием $\mathrm{SiO}_{2} 20-70 \%$, свинец и его неорганические соединения, серы диоксид, углерод, углерод оксид, этилбензол;

- Медногорск (7 из 22 исследованных веществ - 31,8 \%): углерода оксид, азота оксид, азота диоксид, серы диоксид, взвешенные частицы РМ2,5 и РМ10, свинец и его неорганические соединения; 
- Нижний Тагил (26 из 33 исследованных веществ - 78,8 \%): азота (II) оксид, азота диоксид, акролеин, аммиак, бенз(а)пирен, бензин (нефтяной, малосернистый, в пересчете на углерод), бензол, взвешенные вещества, взвешенные частицы РМ10 и PM2,5, диванадий пентоксид (пыль), железа (II, III) оксиды (в пересчете на железо), кадмия дихлорид (в пересчете на кадмий), ксилол, марганец и его соединения (в пересчете на марганца (IV) оксид), нафталин, пыль неорганическая с содержанием $\mathrm{SiO}_{2}$ менее $20 \%$, пыль неорганическая с содержанием $\mathrm{SiO}_{2} 20-70 \%$, свинец и его неорганические соединения (в пересчете на свинец), серы диоксид, сероводород, стирол, углерода оксид, фенол, формальдегид, этилбензол;

- Новокузнецк (6 из 18 исследованных веществ - 33,3 \%): взвешенные вещества, взвешенные частицы РМ2,5 и РМ10, сероводород, углерод, углерода оксид;

- Норильск (9 из 19 исследованных веществ - 47,4 \%): азота диоксид, бензол, взвешенные вещества, взвешенные частицы РМ10 и РМ2,5, дигидросульфид, меди оксид (в пересчете на медь), свинец и его неорганические соединения, серы диоксид;

- Омск (17 из 18 исследованных веществ - 94,4%): бенз(а)пирен, азота диоксид, аммиак, бензол, взвешенные вещества, взвешенные частицы PM10 и PM2.5, диметилбензол, углерод, дигидросульфид, серы диоксид, метилбензол, углерода оксид, гидроксибензол, формальдегид, хром шестивалентный, этилбензол;

- Челябинск (32 из 53 исследованных веществ - 60,4 \%): 1,2-дихлорэтан, азота (II) оксид, азота диоксид, аммиак, бенз(а)пирен, бензин (нефтяной, малосернистый), бензол, взвешенные вещества, взвешенные частицы PM10 и PM2,5, гидроксибензол, гидрохлорид (по молекуле $\mathrm{HC1}$ ), дигидросульфид, железа оксид, диметилбензол, керосин, марганец и его соединения, метилбензол, нафталин, проп-2-ен-1-аль, пыль неорганическая с содержанием $\mathrm{SiO}_{2}$ более 70 \%, пыль неорганическая с содержанием $\mathrm{SiO}_{2}$ 20-70\%, свинец и его неорганические соединения, серы диоксид, сероуглерод, смесь предельных углеводородов С6-С10, углерод, формальдегид, фтористые газообразные соединения, хлор, эпоксиэтан, этенилбензол;

- Череповец (4 из 19 исследованных веществ - 21,1 \%): взвешенные частицы РМ 10 и РМ 2,5, углерод, этилбензол;

- Чита (11 из 13 исследованных веществ - 84,6 \%): азота диоксид, углерода оксид, бенз(а)пирен, взвешенные вещества, взвешенные частицы размером PM10 и PM2,5, дигидросульфид, серы диоксид, аммиак, диметилбензол, гидроксибензол.

По данным расчетов рассеивания с использованием сводных баз данных об источниках выбросов выполнена оценка аэрогенного риска для здоровья населения всех 12 приоритетных городов (Нижний Тагил, Челябинск, Магнитогорск, Медногорск, Красноярск, Чита, Омск, Липецк, Братск, Липецк, Норильск, Новокузнецк), вошедших в федеральный проект «Чистый воздух». Неприемлемый неканцерогенный риск установлен для всех исследованных городов. Кратность превышения допустимых уровней риска в отдельных зонах городов составила до 10 и более раз.

Прогнозируется 10170 дополнительных случаев смерти ежегодно от воздействия взвешенных частиц размером РМ2.5 на территориях городов - участников федерального проекта «Чистый воздух» (или 13,7\% от фактических уровней общей смертности населения).

Установлено, что критическими поражаемыми органами и системами являются органы дыхания, иммунная система, кровь, процессы развития и пр.

Неприемлемый канцерогенный риск (выше $1 \times 10^{-4}$ ) зафиксирован в городах Нижний Тагил, Челябинск, Магнитогорск, Медногорск, Красноярск, Чита, Омск, Липецк. При этом канцерогенные риски рассматриваются как недооцененные - по данным расчетов рассеивания концентрации ряда канцерогенных примесей были в ряде случаев ниже инструментально измеряемых. 
Для каждого города по уточненным оценкам риска определены приоритетные химические примеси, которые вносят более 95 \% в неприемлемые риски для здоровья населения и подлежат первоочередному мониторингу и включению в системы квотирования выбросов и планы природоохранных мероприятий.

Результаты оценки риска по приоритетным примесям легли в основу оптимизации программ мониторинга за качеством атмосферного воздуха в рамках социально-гигиенического мониторинга и установления первоочередного перечня квотируемых веществ, а также корректировки программ воздухоохранных мероприятий.

Результаты представляются в информационной системе по информированию о качестве атмосферного воздуха, результатах оценки риска здоровью населения (АИС «КАВ_риски») (рис. 10).

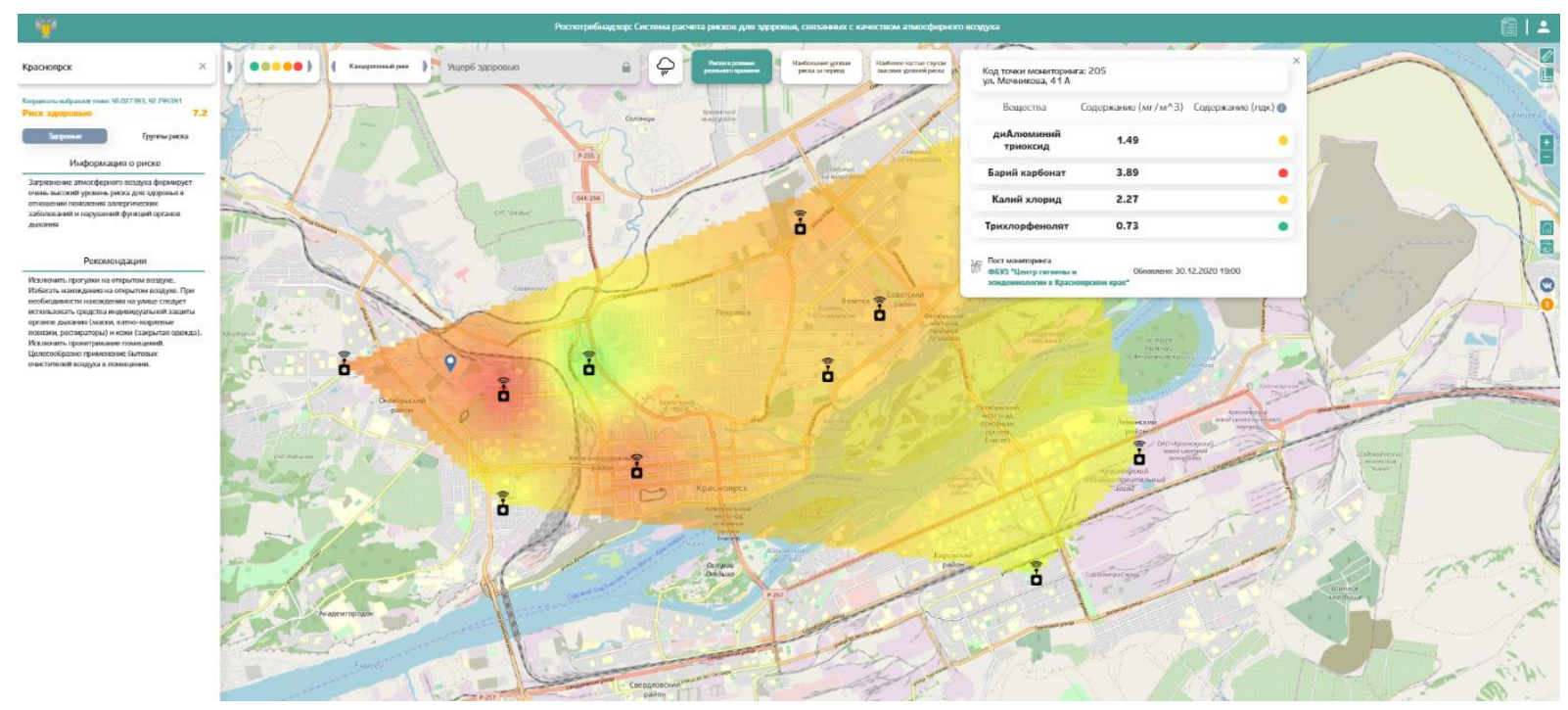

Рис. 10. Ранжирование рисков для здоровья населения (в реальном режиме времени) от влияния приоритетных загрязнителей атмосферного воздуха на примере одного из 12 городов - участников федерального проекта «Чистый воздух»

\section{Влияние атмосферного воздуха на здоровье населения}

Выявленные причинно-следственные связи между показателями качества атмосферного воздуха и рядом медико-демографических показателей в субъектах Российской Федерации показали, что в среднем число дополнительных случаев смерти от всех причин, вероятностно обусловленных загрязнением атмосферного воздуха селитебных территорий, составило в 2020 г. 5,1 случая на 100 тыс. населения, что в 1,9 раза меньше показателя 2012 года. В динамике с 2012 г. регистрируется положительная тенденция снижения как уровня вероятностно обусловленной смертности, так и уровня общей смертности (на 7,5 \%) всего населения страны.

В Российской Федерации в 2020 г. смертность по четырем причинам (болезни органов дыхания, органов пищеварения, системы кровообращения, злокачественных новообразований) вероятностно обусловлена воздействием загрязнений атмосферного воздуха, и основную долю дополнительных случаев смерти всего населения формировали болезни системы кровообращения (показатель 2,14 на 100 тыс.), что составляет 0,37 \% от фактической смертности населения по данной причине. Смертность населения от болезней системы кровообращения вероятностно обусловлена (имеет устойчивую связь с загрязнением гидроксибензолом и его производными, оксидом углерода, бензолом атмосферного воздуха в 26 субъектах Российской Федерации.

Смертность населения от болезней органов дыхания вероятностно обусловлена загрязнением атмосферного воздуха диоксидом азота, оксидом азота, аммиаком, 
взвешенными веществами, гидроксибензолом и его производными, ароматическими углеводородами, ксилолом, формальдегидом, фтором и его соединениями в 62 субъектах Российской Федерации, число дополнительных случаев - 1,72 на 100 тыс., что составляет 4,26 \% от фактической смертности всего населения по данной причине.

Смертность от злокачественных новообразований вероятностно обусловлена загрязнением атмосферного воздуха бенз(а)пиреном, формальдегидом, свинцом в 19 субъектах Российской Федерации, число дополнительных случаев составило в 2020 г. 1,05 случая на 100 тыс.

Число дополнительных случаев заболеваний от всех причин, вероятностно обусловленных загрязнением атмосферного воздуха селитебных территорий, в целом по Российской Федерации составило в 2020 г. 1032,0 случаев на 100 тыс. всего населения, или $1,32 \%$ от первичной заболеваемости всего населения. Для взрослого населения трудоспособного возраста аналогичный показатель составил 519,9 дополнительных случаев на 100 тыс. населения. Заболеваемость детского населения, вероятностно обусловленная загрязнением атмосферного воздуха, составила 2994,3 дополнительных случаев на 100 тыс. детского населения, или $1,74 \%$ от первичной заболеваемости детского населения.

Основную долю дополнительных случаев заболеваний всего населения формировали болезни органов дыхания $(76,7 \%$ в структуре), на втором месте находились болезни органов пищеварения - 9,8\%, на третьем - болезни системы кровообращения - 4,6\%, на четвертом - болезни нервной системы - 3,1 \%, остальные классы болезней вносили менее $3 \%$ в структуру ассоциированных случаев заболеваний.

Заболеваемость всего населения болезнями органов дыхания вероятностно связана с загрязнением атмосферного воздуха азота оксидом, азота диоксидом, аммиаком, гидроксибензолом и его производными, марганцем, серной кислотой, хлором и его соединениями, хлористым водородом, диоксидом серы, фтором и его соединениями, фтористым водородом, взвешенными веществами, ароматическими углеводородами, ксилолом, толуолом, формальдегидом в 47 субъектах Российской Федерации и в среднем по РФ составила в 2020 г. 792,0 случаев на 100 тыс. человек (2,22\% от первичной заболеваемости всего населения).

Число дополнительных случаев заболеваний детского населения болезнями органов дыхания, вероятностно обусловленных загрязнением атмосферного воздуха селитебных территорий, в целом по Российской Федерации составило в 2020 г. 2705,6 на 100 тыс. детей (2,33\% от первичной заболеваемости детского населения).

Заболеваемость бронхиальной астмой детского населения, согласно данным ВОЗ, относится к индикаторам качества среды обитания. Показатель заболеваемости астмой и астматическим статусом среди детей в возрасте от 0 до 14 лет с диагнозом, установленным впервые в жизни, составил в 2019 г. 111,7 на 100 тыс. детского населения, в 2012 г. 154,1\%000). В 2019 г. на территориях 28 субъектов Российской Федерации показатель первичной заболеваемости детского населения бронхиальной астмой и астматическим статусом превышал среднероссийский в 1,1-2,9 раза, на территориях 40 субъектов показатель был ниже в 1,0-18,6 раза.

Заболеваемость детей (0-14 лет) бронхиальной астмой и астматическим статусом, вероятностно обусловленная качеством атмосферного воздуха, в 2020 году зарегистрирована на территориях 36 субъектов Российской Федерации и составила 4,1 дополнительных случая на 100 тыс. детей соответствующего возраста, или 3,7 \% от первичной заболеваемости детского населения по данной причине.

Заболеваемость детей (0-14 лет) бронхитом хроническим и неуточненным, эмфиземой, вероятностно обусловленная качеством атмосферного воздуха, в 2020 году зарегистрирована на территориях 50 субъектов Российской Федерации и составила 16,6 дополнительных случаев на 100 тыс. детей соответствующего возраста. 
Государственный доклад «О состоянии санитарно-эпидемиологического благополучия населения в Российской Федерации в 2020 году»

\subsection{2. Состояние питьевой воды, воды водоемов, используемых для водоснабжения населения и рекреационных целей, и ее влияние на здоровье населения}

Качество питьевой воды, воды водоемов, используемых для водоснабжения и рекреационных ичелей

В 2020 году на территории Российской Федерации органами и организациями Роспотребнадзора было отобрано и исследовано более 1,802 млн проб воды, включая воду источников питьевого централизованного водоснабжения (более 351,4 тыс. проб), водопроводов (свыше 181,4 тыс. проб), распределительной сети (более 1,2 млн проб), источников нецентрализованного водоснабжения (колодцы, каптажи родников) (более 66,4 тыс. проб). Динамика количества исследованных проб с 2011 по 2020 г. представлена на рис. 11.

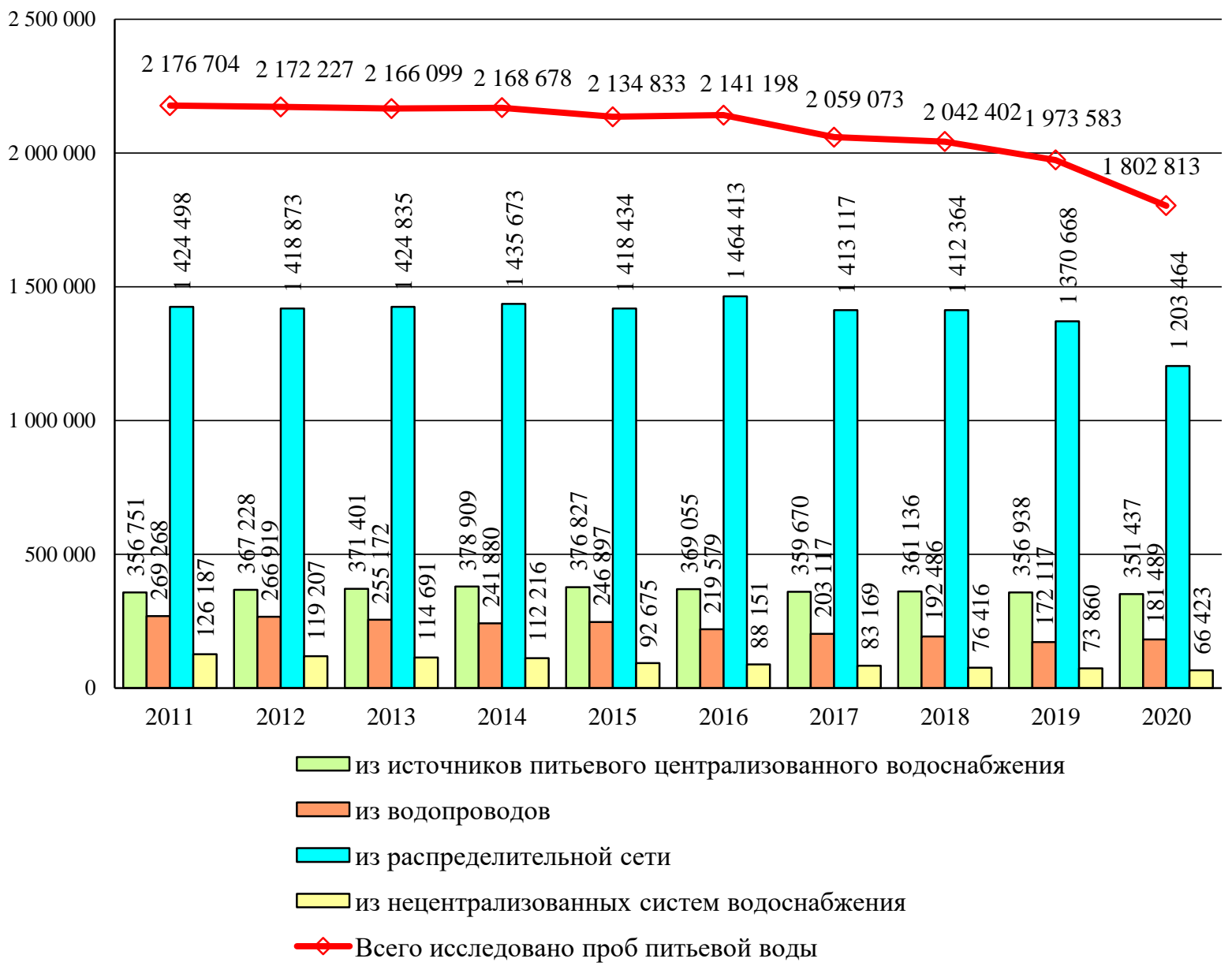

Рис. 11. Динамика числа исследованных проб питьевой воды в 2011-2020 гг., абс.

В 2020 году общее число источников централизованного питьевого водоснабжения уменьшилось по сравнению с 2011 годом на 7,77 \% и составило 94299 (рис. 12) за счет подземных и поверхностных водоисточников. Число поверхностных источников питьевого централизованного водоснабжения незначительно увеличилось по сравнению с 2019 годом и составило 1782 в 2020 году. 
Государственный доклад «О состоянии санитарно-эпидемиологического благополучия населения в Российской Федерации в 2020 году»

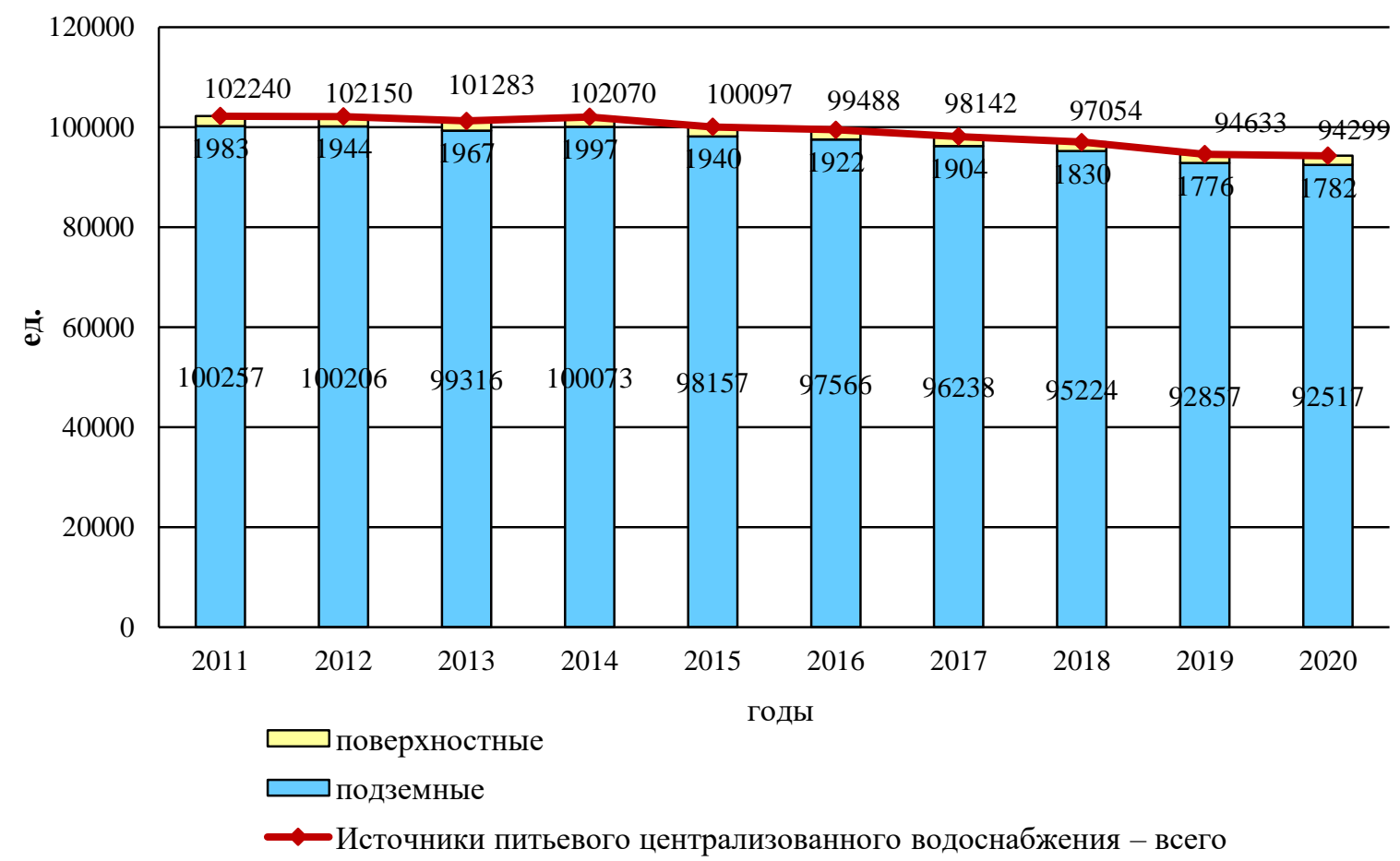

Рис. 12. Число источников питьевого централизованного водоснабжения в 2011-2020 гг., абс.

Удельный вес источников централизованного питьевого водоснабжения, не соответствующих санитарно-эпидемиологическим требованиям, стабилен в последние годы и составил $14,46 \%$, в том числе по поверхностным источникам $35,07 \%$ и по подземным 14,06 \% (табл. 7).

Таблица 7

Доля источников централизованного питьевого водоснабжения, не отвечавших санитарно-эпидемиологическим требованиям, 2011-2020 гг., \%

\begin{tabular}{|l|c|c|c|c|c|c|c|c|c|c|}
\hline $\begin{array}{c}\text { Источники } \\
\text { водоснабжения }\end{array}$ & 2011 & 2012 & 2013 & 2014 & 2015 & 2016 & 2017 & 2018 & 2019 & 2020 \\
\hline $\begin{array}{l}\text { Все источники, } \\
\text { в том числе: }\end{array}$ & 16,22 & 15,76 & 15,82 & 15,67 & 15,66 & 15,28 & 15,17 & 14,58 & 14,93 & 14,46 \\
\hline - поверхностные & 35,65 & 34,98 & 34,98 & 35,20 & 33,92 & 33,14 & 32,72 & 32,73 & 35,08 & 35,07 \\
\hline - подземные & 15,84 & 15,39 & 15,44 & 15,28 & 15,30 & 14,93 & 14,82 & 14,23 & 14,54 & 14,06 \\
\hline
\end{tabular}

Неблагоприятное санитарное состояние источников централизованного питьевого водоснабжения в 2020 году отмечено в Республике Дагестан $(96,65 \%$ источников не отвечают санитарно-эпидемиологическим требованиям), Республике Карелия (83,01 \%), Чеченской Республике (82,90\%).

Основной причиной несоответствия источников централизованного питьевого водоснабжения населения санитарно-эпидемиологическим требованиям, как и в предыдущие годы, является отсутствие зон санитарной охраны (рис. 13). 


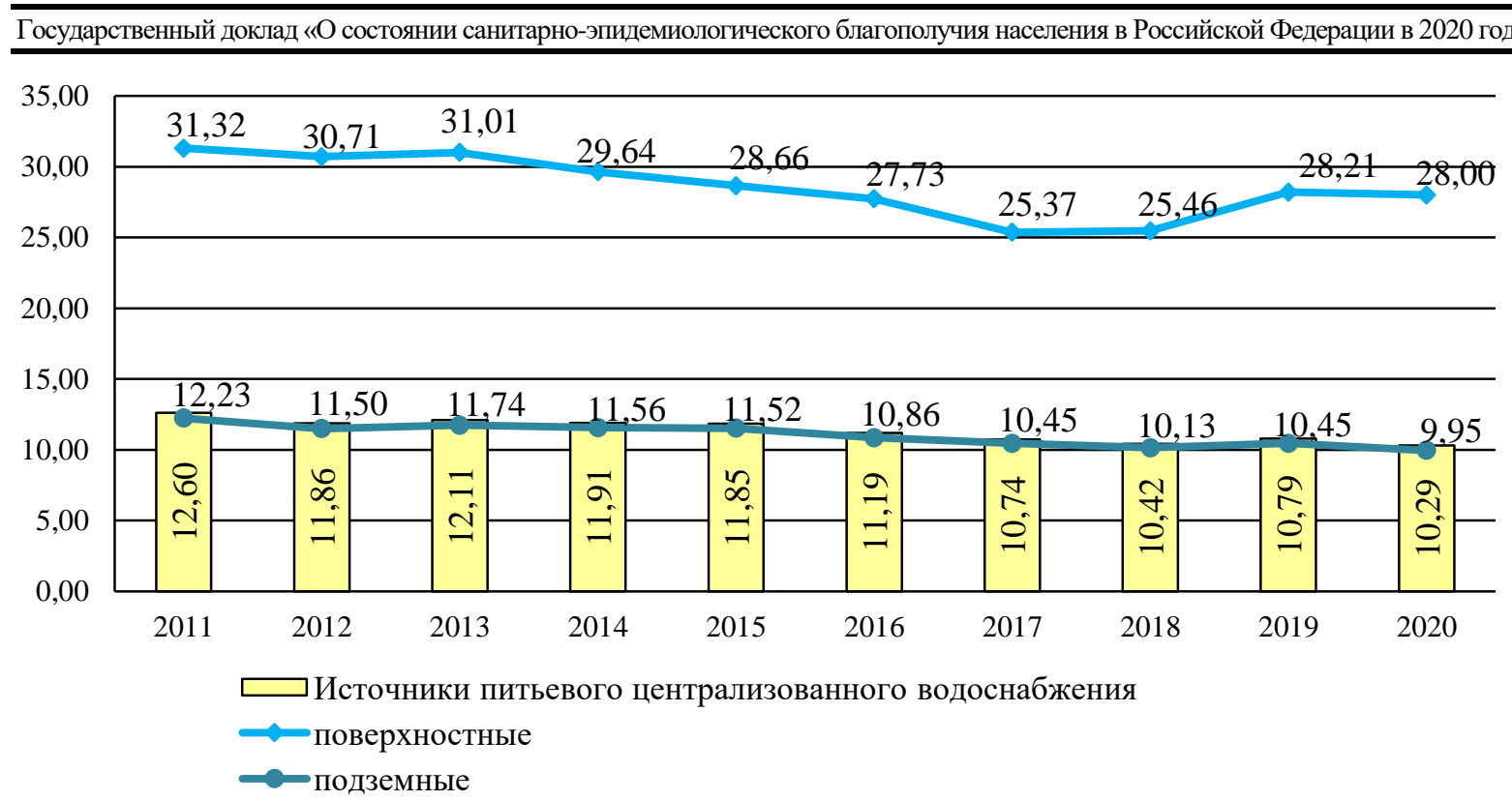

Рис. 13. Доля источников централизованного питьевого водоснабжения, не отвечавших санитарно-эпидемиологическим требованиям из-за отсутствия зон санитарной охраны,

$$
\text { в 2011-2020 гг., \% }
$$

За период 2011-2020 гг. доля источников централизованного водоснабжения, у которых отсутствуют зоны санитарной охраны, уменьшилась на 8,32\%, в том числе поверхностных на 10,58 \%, подземных 18,64\%.

В течение 2011-2020 гг. стабильными остаются показатели превышения доли проб воды источников централизованного водоснабжения, не соответствующих гигиеническим нормативам по санитарно-химическим показателям: в 2020 году показатель составил 26,06 \%, по микробиологическим - 3,86\%, паразитологическим $0,43 \%$ (рис. 14).

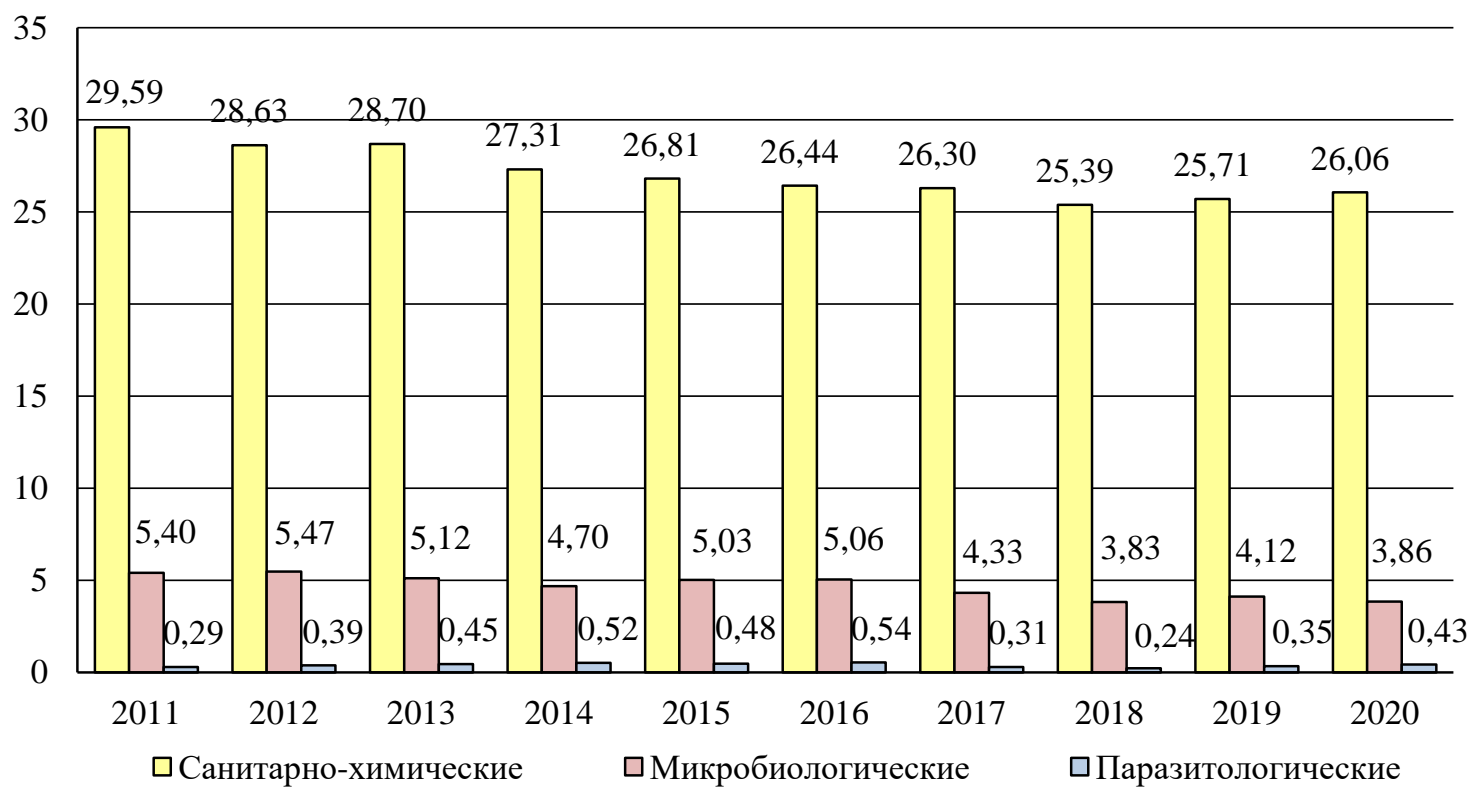

Рис. 14. Доля проб воды в источниках централизованного водоснабжения, не соответствовавших гигиеническим нормативам, в 2011-2020 гг., \%

Сравнительный анализ показателей загрязнения воды поверхностных и подземных источников централизованного водоснабжения за 2011-2020 гг. показал, что доля проб воды поверхностных источников, не соответствующих гигиеническим 
Государственный доклад «О состоянии санитарно-эпидемиологического благополучия населения в Российской Федерации в 2020 году»

нормативам по санитарно-химическим показателям, находится на одном уровне с долей не соответствующих нормативам проб из подземных источников, а по микробиологическим показателям более чем в 5 раз превышает уровень загрязнения подземных источников (рис. 15).

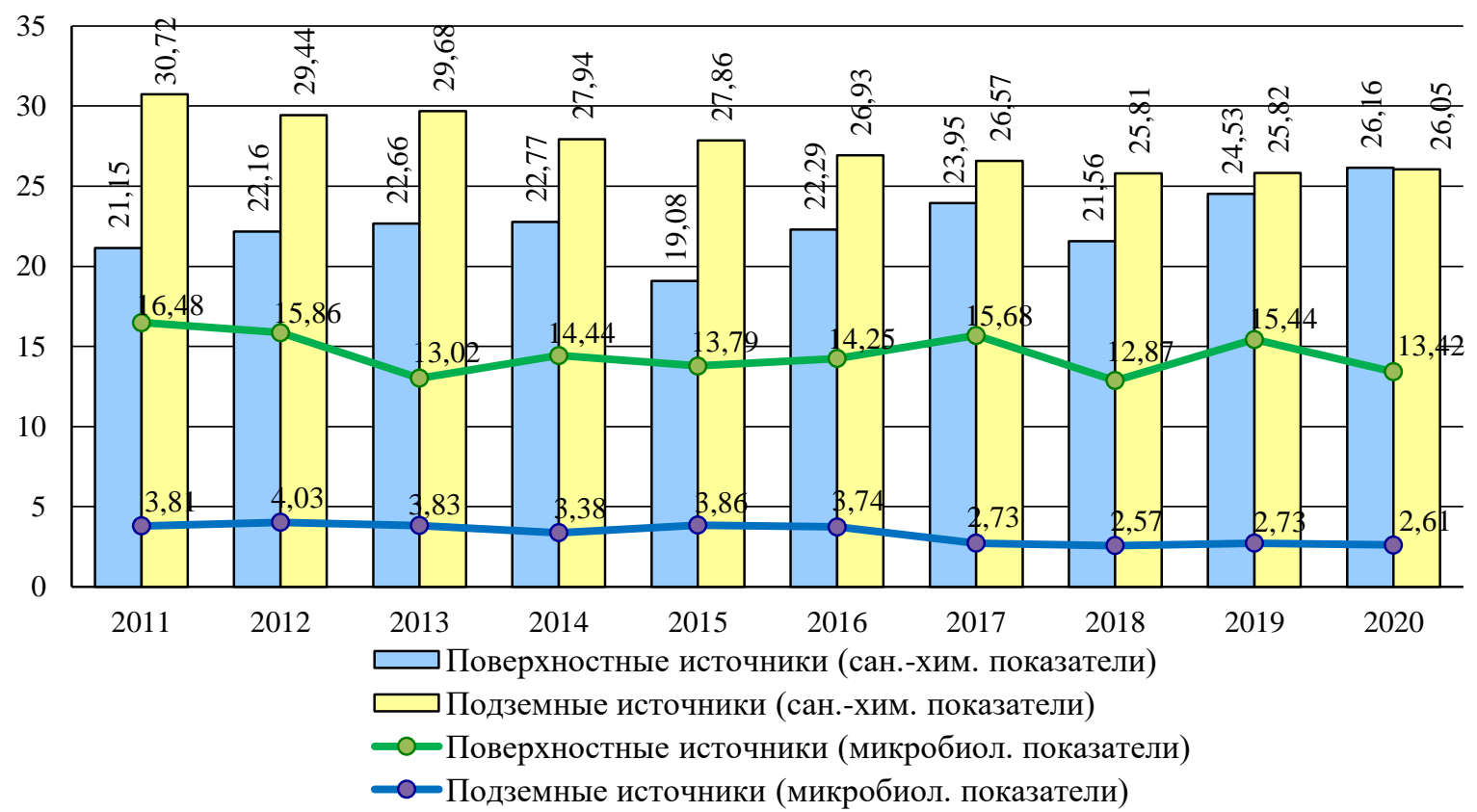

Рис. 15. Доля проб воды поверхностных и подземных источников, не соответствовавших санитарно-эпидемиологическим требованиям по санитарно-химическим и микробиологическим показателям, в 2011-2020 гг., \%

За период 2011-2020 гг. в Российской Федерации качество воды водоемов I категории, используемых в качестве источников питьевого и хозяйственно-питьевого водоснабжения, а также используемых для водоснабжения предприятий пищевой промышленности, ухудшилось по санитарно-химическим показателям. Доля проб воды, не соответствующих гигиеническим нормативам по санитарно-химическим показателям, увеличилась на 8,27 \% и составила в 2020 году 30,34 \% (рис. 16).

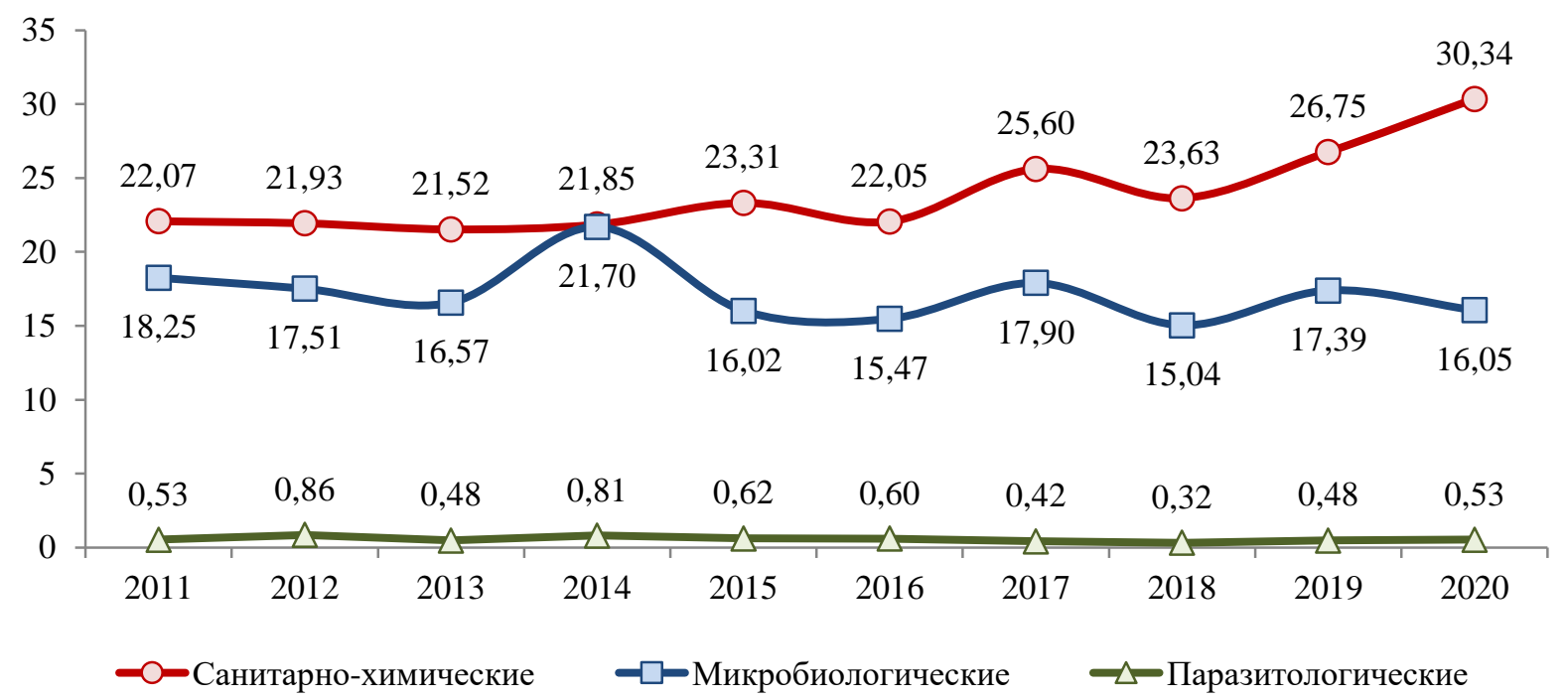

Рис. 16. Доля проб воды водоемов I категории, не соответствующих санитарным требованиям по санитарно-химическим, микробиологическим и паразитологическим показателям,

$$
\text { в 2011-2020 гг., \% }
$$


В отношении микробиологических показателей качество воды водных объектов I категории в местах водопользования населения улучшилось. Доля проб воды с превышением гигиенических нормативов по микробиологическим показателям снизилась за период 2011-2020 гг. на 2,2\%. В отношении паразитологического загрязнения воды водоемов I категории ситуация за последнее десятилетие стабильна.

В 2020 году наиболее высокий уровень загрязнения воды водоемов I категории химическими веществами был зафиксирован на территории Еврейской автономной области $(95,8$ \% проб, не соответствующих санитарным требованиям по санитарнохимическим показателям), Республики Калмыкия (83,3 \%), г. Москвы (82,7 \%) и Красноярского края (81,8 \%). Территории риска по доле проб воды водоемов I категории, не соответствующих санитарным требованиям по микробиологическим показателям: г. Санкт-Петербург (92,0 \%), Еврейская автономная область $(75,0 \%)$, Пензенская область $(58,3 \%)$ и г. Севастополь $(53,3 \%)$.

Доля проб воды водоемов II категории, используемых для рекреационных целей, не соответствующих санитарным требованиям по санитарно-химическим показателям, снизилась за последнее десятилетие на $6,07 \%$, по микробиологическим - на 4,29 \%, по паразитологическим показателям - на 0,49 \% (рис. 17).

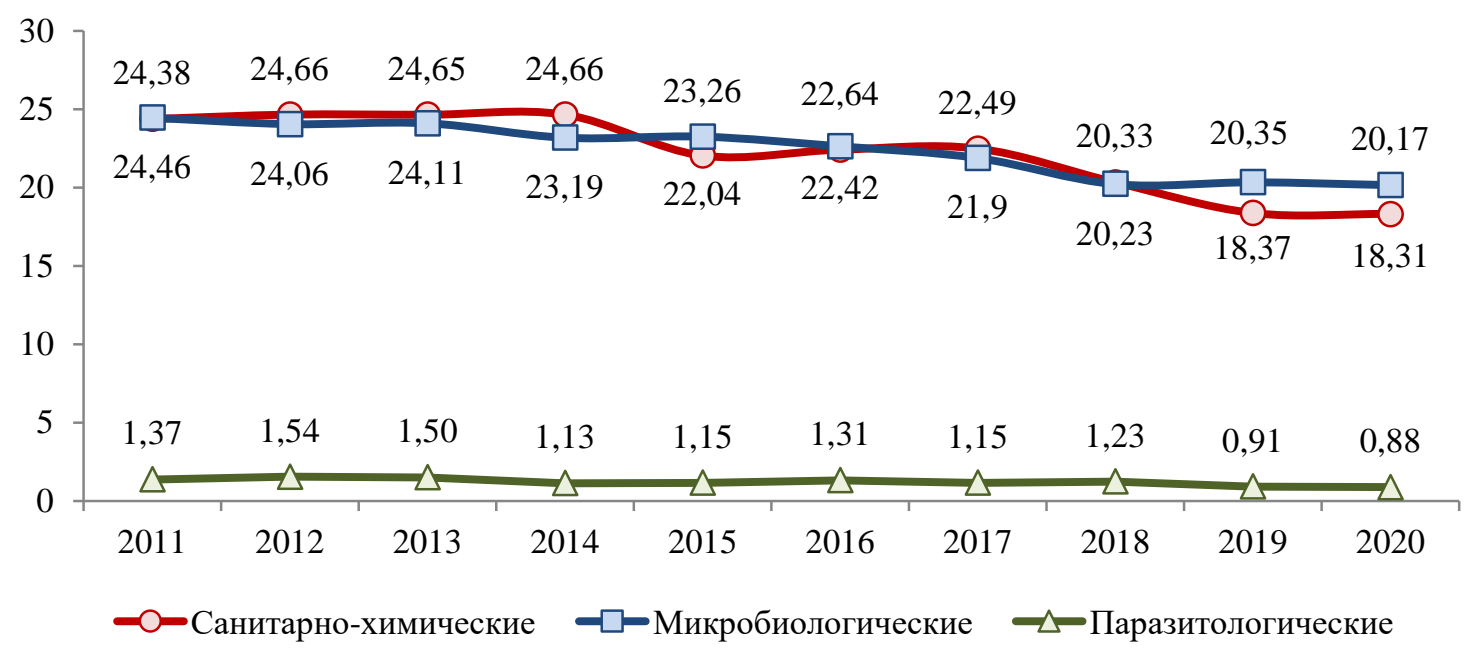

Рис. 17. Доля проб воды водоемов II категории, не соответствующих санитарным требованиям по санитарно-химическим, микробиологическим и паразитологическим показателям, в 2011-2020 гг., \%

Более 50 \% проб воды не соответствовало санитарным требованиям по санитарнохимическим показателям в водоемах II категории пяти субъектов Российской Федерации: г. Санкт-Петербурга (83,5 \%), Ханты-Мансийского автономного округа $(67,8 \%)$, Республики Калмыкия (51,7\%), Новгородской $(51,4 \%)$ и Омской $(50,4 \%)$ областей.

Наиболее высокий уровень микробиологического загрязнения был зафиксирован в г. Санкт-Петербурге (75,2 \%), Карачаево-Черкесской Республике $(53,0$ \%), г. Москве $(52,8 \%)$ и Омской области $(52,6 \%)$.

К неблагополучным территориям по доле проб воды водоемов II категории, не соответствующих санитарно-эпидемиологическим требованиям по паразитологическим показателям, в 2020 году можно отнести Республику Северная Осетия - Алания (10,3 \% проб воды с превышениями гигиенических нормативов), Республику Калмыкия (6,67 \%), Свердловскую $(6,39 \%)$ и Тамбовскую $(6,25 \%)$ области.

За последние десять лет отмечается значительное улучшение качества воды морей. В 2020 году, по сравнению с 2011 годом, снизилась доля проб воды, не 
отвечающих санитарным требованиям по всем показателям: санитарно-химическим (на 2,76 \%), микробиологическим (на 8,54 \%) и паразитологическим (на 0,06 \%) (рис. 18).

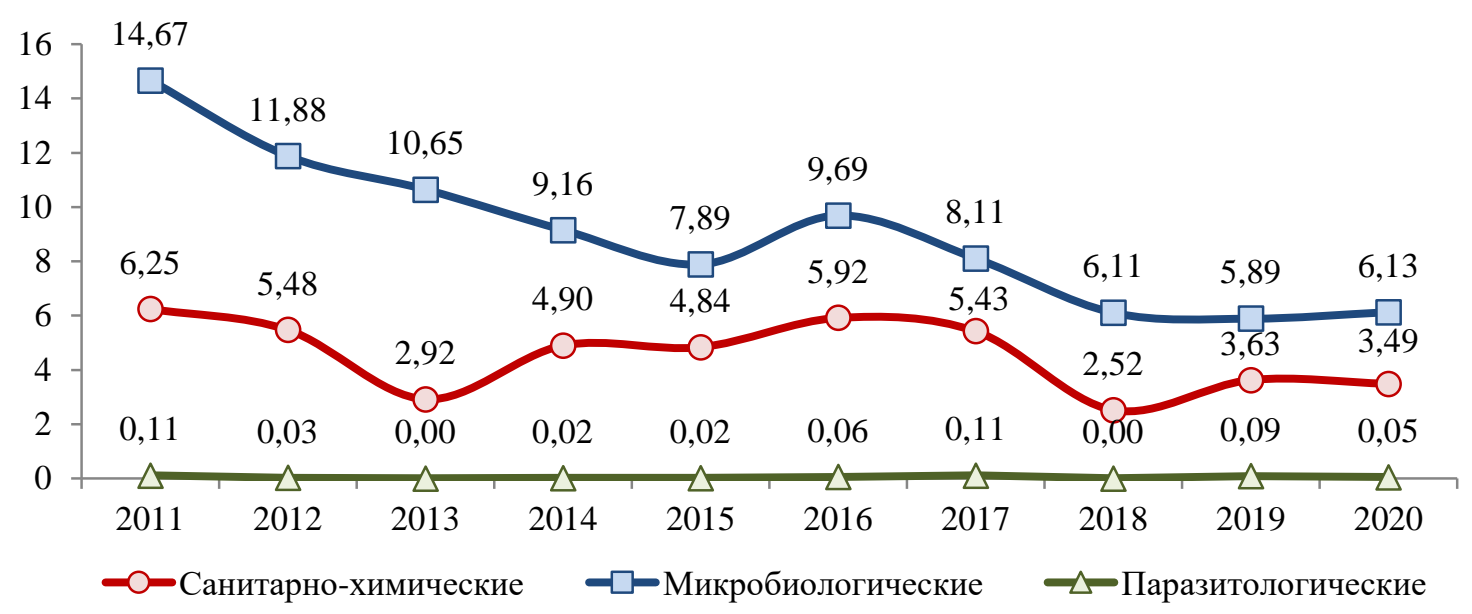

Рис. 18. Доля проб воды морей, не соответствующих санитарным требованиям по санитарнохимическим, микробиологическим и паразитологическим показателям, в 2011-2020 гг., \%

Территории риска по качеству воды морей по санитарно-химическим показателям: г. Санкт-Петербург (97,3 \%), Ростовская область (70,9\%), Архангельская область (41,7 \%), Сахалинская область (10,4\%).

Все пробы воды морей, омывающих территории Калининградской и Мурманской областей, Чукотского и Ямало-Ненецкого автономных округов, в 2020 году соответствовали санитарно-эпидемиологическим требованиям по микробиологическим показателям. Более 91,6 \% проб воды морей, отобранных в г. Санкт-Петербурге, не соответствовали гигиеническим нормативам по микробиологическим показателям, в Хабаровском крае этот показатель составил 45,1%, в Приморском крае - 40,2 \% .

Наиболее загрязнена вода морей паразитами на территории Республики Дагестан $(1,82 \%$ проб воды морей не соответствуют санитарным требованиям по паразитологическим показателям) и Калининградской области $(1,41 \%)$.

На состояние воды источников водоснабжения, воды водных объектов в местах водопользования населения и питьевой воды систем централизованного водоснабжения оказывали влияние следующие факторы:

- сброс в водные объекты загрязненных, недостаточно очищенных сточных вод предприятий металлургической, горнодобывающей, нефтяной и целлюлозно-бумажной промышленности, а также объектов жилищно-коммунального хозяйства и животноводческих комплексов;

- разливы нефтепродуктов, в том числе на грунт: при переливе дизельного топлива из одной цистерны в другую в Мотыгинском районе Красноярского края на территории нефтебазы АО «Красноярскнефтепродукт» произошел разлив нефтепродуктов площадью $8000 \mathrm{~m}^{2}$; вследствие разгерметизации резервуара объемом 21163 м $^{3}$ с дизельным топливом, расположенного на территории ТЭЦ-3 «Надеждиного металлургического завода» в городе Норильске Красноярского края, произошло попадание нефтепродуктов в акваторию реки Амбарной; в результате утечки 9 тонн нефтепродуктов из нефтепровода «Оха - Комсомольск-на-Амуре»; разлив дизельного топлива при затоплении буксира на реке Москве, разлив нефтепродуктов на р. Селемдже в районе населенного пункта Экимчан Селемджинского района Амурской области; при перекачке дизельного топлива с грузовой баржи на берег в реку Ангару попали нефтепродукты в объеме порядка 0,5 тонн; в результате разлива дизельного топлива в объеме 40 л на территории автотранспортного предприятия в г. Красноярске; утечка 
нефтепродуктов от пришвартованного в черте г. Красноярска теплохода «Литва»; разлив мазута в результате схода цистерн грузового поезда на 238-м километре Горьковской железной дороги во Владимирской области и пр.;

- смыв (вследствие интенсивных ливневых дождей) медьсодержащих пестицидов (агрохимикатов) с обработанных весной территорий под лесными насаждениями (сельскохозяйственными культурами);

- аварийный сброс загрязненных вод из прудов-накопителей (поступление в реку Ангара сточных вод, загрязненных ионами ртути, вследствие разрушения дамбы иловой карты недействующего предприятия АО «Усольехимпром», загрязнение воды реки Баргадонки (Амурская область) взвешенными веществами в результате сброса предприятием, осуществляющим добычу ОРПИ, неочищенных сточных вод из-за промыва дамбы фильтрационного отстойника) и др.

Помимо исходного состояния источника централизованного водоснабжения на качество и безопасность питьевой воды оказывают влияние используемые технологии очистки и водоподготовки, обеззараживания, доведения воды до заданных параметров качества, состояние водопроводных и распределительных сетей.

В целом за период 2011-2020 гг. доля водопроводов, не отвечающих санитарноэпидемиологическим требованиям, снизилась на 17,77\% от 2011 года и составила $15,61 \%$ (рис. 19).

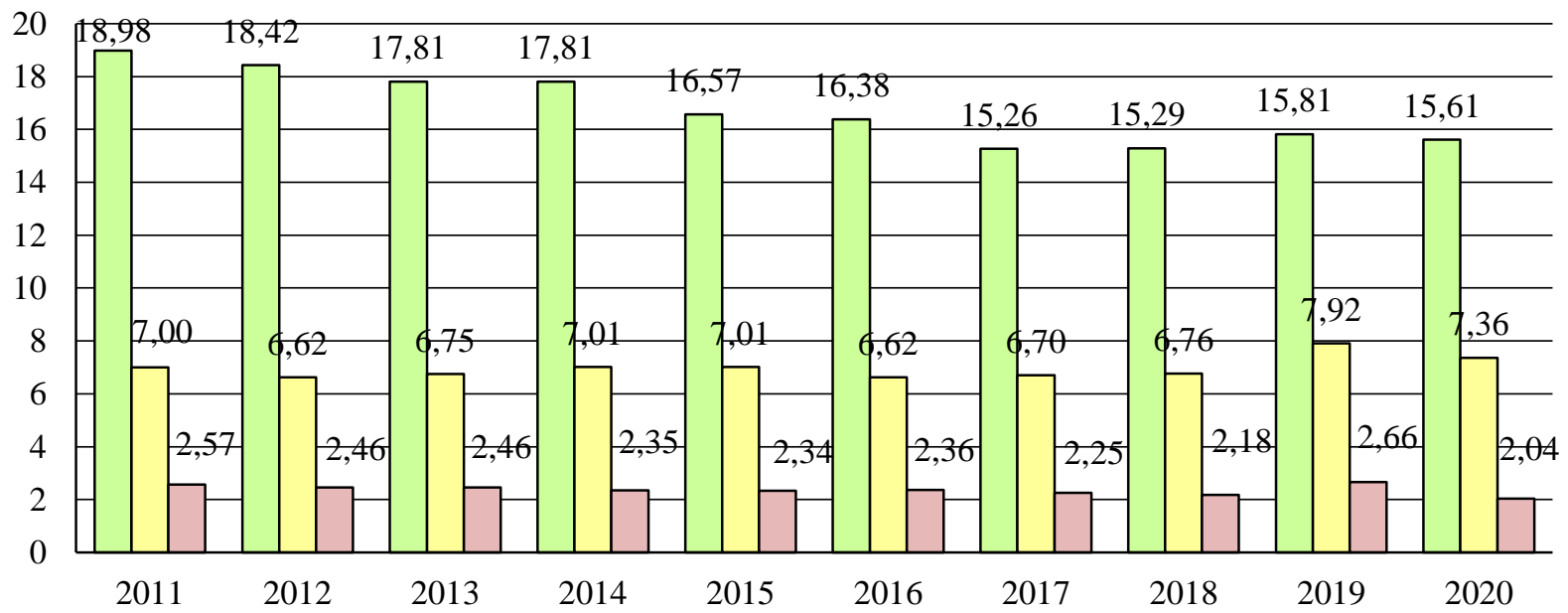

$\square$ Всего, в том числе

口отсутствует необходимый комплекс очистных сооружений

口отсутствуют обеззараживающие установки

Рис. 19. Доля водопроводов, не отвечающих санитарно-эпидемиологическим требованиям, в 2011-2020 гг., \%

В 2020 году более $50 \%$ водопроводов не соответствовало требованиям санитарного законодательства на территории Томской области $(71,3 \%)$, Республики Дагестан (65,64 \%), Республики Хакасия (64,82 \%), Чеченской Республики $(57,42$ \%), Республики Карелия $(56,94 \%)$.

По данным контроля качества питьевой воды водопроводов (вода перед поступлением в распределительную сеть) в 2020 г. по сравнению с 2011 г. наблюдается достоверное снижение удельного веса проб воды, не соответствующих гигиеническим нормативам, по санитарно-химическим показателям на 5,07 \%, по микробиологическим - на 50,54 \%, паразитологическим показателям на 17,63 \% (рис. 20). При этом произошло увеличение доли неудовлетворительных по санитарно-химическим показателям проб воды до 17,11 \% в 2020 году. 
Государственный доклад «О состоянии санитарно-эпидемиологического благополучия населения в Российской Федерации в 2020 году»

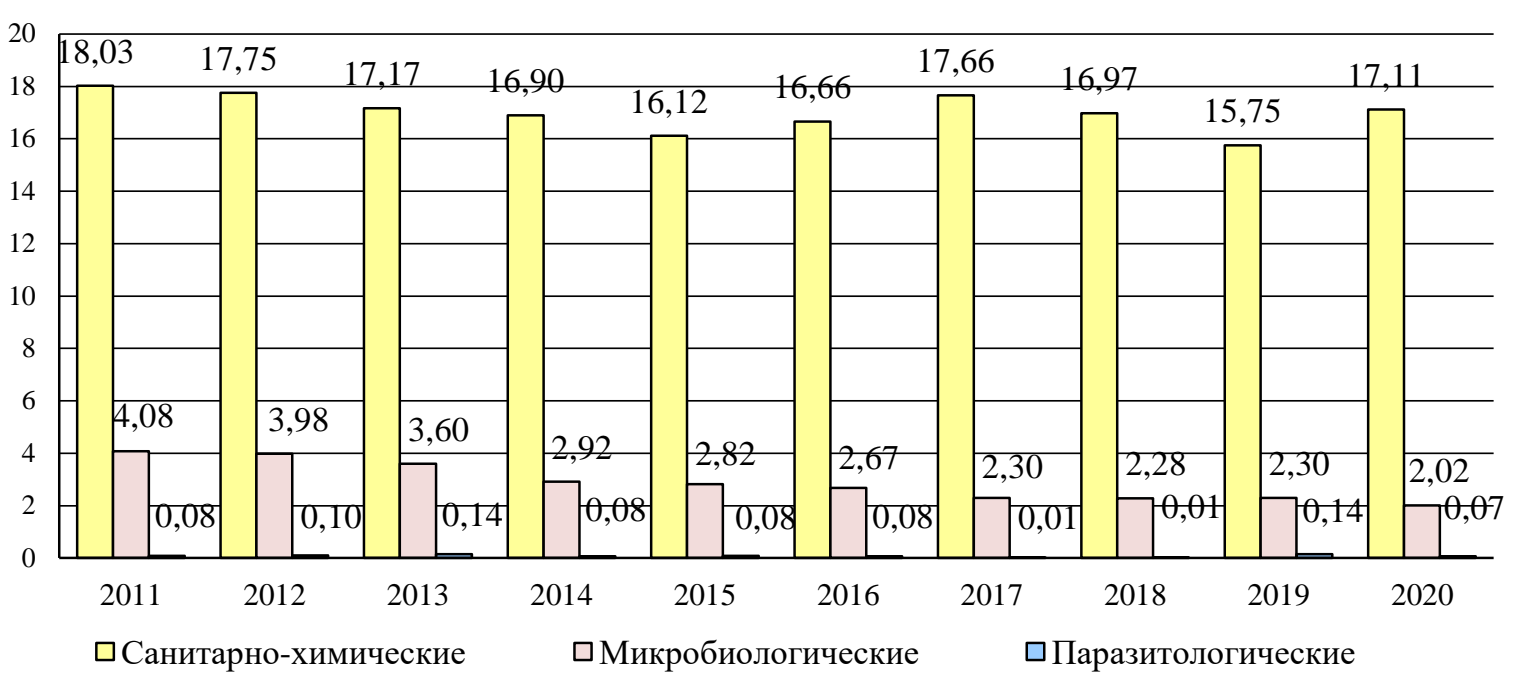

Рис. 20. Доля проб воды водопроводов, не соответствующих гигиеническим нормативам, в 2011-2020 гг., \%

Вместе с тем низкий уровень качества питьевой воды водопроводов по санитарнохимическим показателям был отмечен в 2020 г. в Республике Калмыкия $(95,3 \%)$, Еврейской автономной области $(63,6 \%)$, Смоленской $(60,0 \%)$ и Тамбовской $(54,9 \%)$ областях, Ханты-Мансийском автономном округе (53,0\%), Ростовской $(48,43 \%)$ и Новгородской $(41,58 \%)$ областях.

В 2020 г. в число регионов с наиболее низкими показателями качества воды водопроводов по микробиологическим показателям вошли Республика Тыва (19,35 \% отобранных проб не соответствовало гигиеническим нормативам), Республика Ингушетия (15,3 \%) и Кабардино-Балкарская Республика (12,12 \%).

В течение 2011-2020 гг. наблюдался достоверный тренд к снижению доли проб питьевой воды, отобранных из распределительной сети, не соответствующих гигиеническим нормативам по санитарно-химическим (на 3,68 \%), микробиологическим (на $1,97 \%$ ) и паразитологическим (на $0,06 \%$ ) показателям (рис. 21).

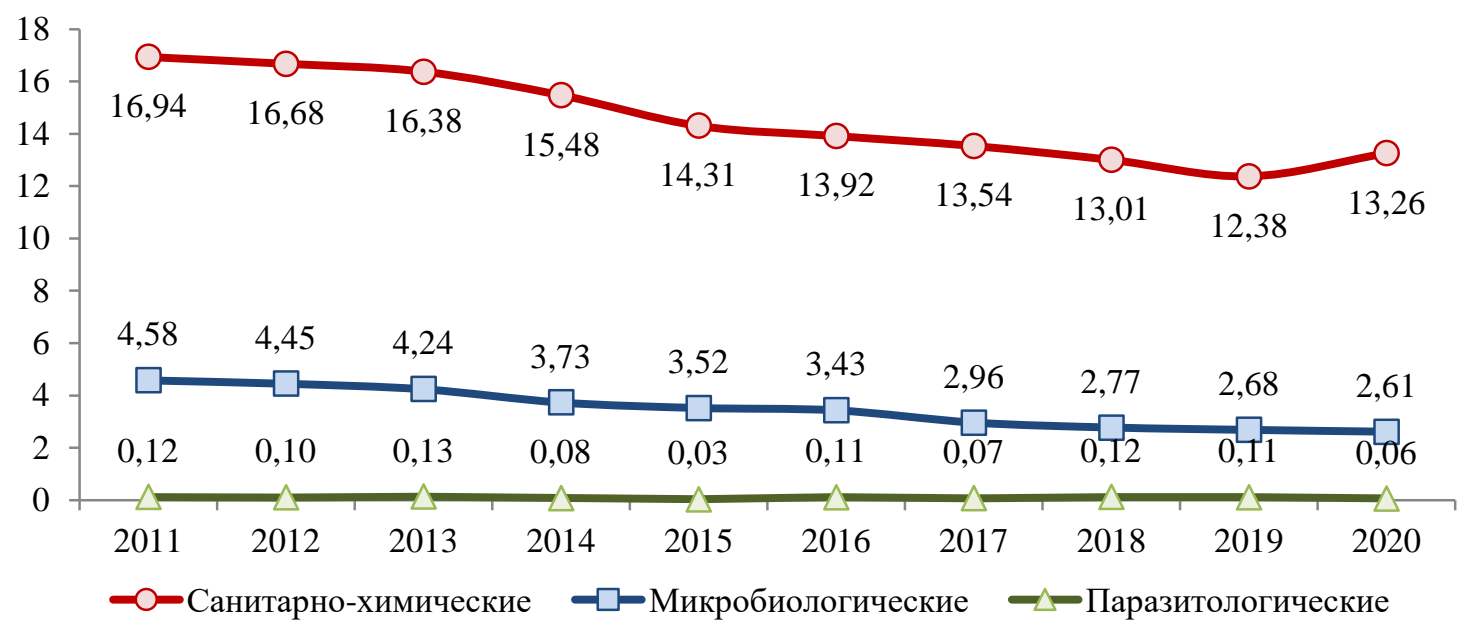

Рис. 21. Доля проб воды из распределительной сети централизованного водоснабжения, не соответствующих санитарным требованиям, в 2011-2020 гг., \%

В 2020 г. территориями риска по качеству питьевой воды являлись Республика Калмыкия (69,0\% отобранных проб не соответствовало гигиеническим нормативам) и Карелия (40,0 \%), Новгородская область (36,4 \%), Республика Дагестан $(35,8$ \%), Ростовская область $(35,2 \%)$, Чукотский автономный округ $(33,5 \%)$ и Курганская область $(33,4$ \%). Распределение субъектов Российской Федерации по доле проб питьевой воды 
из распределительной сети централизованного питьевого водоснабжения с превышением гигиенических нормативов по санитарно-химическим показателям в 2020 году представлено на рис. 22.

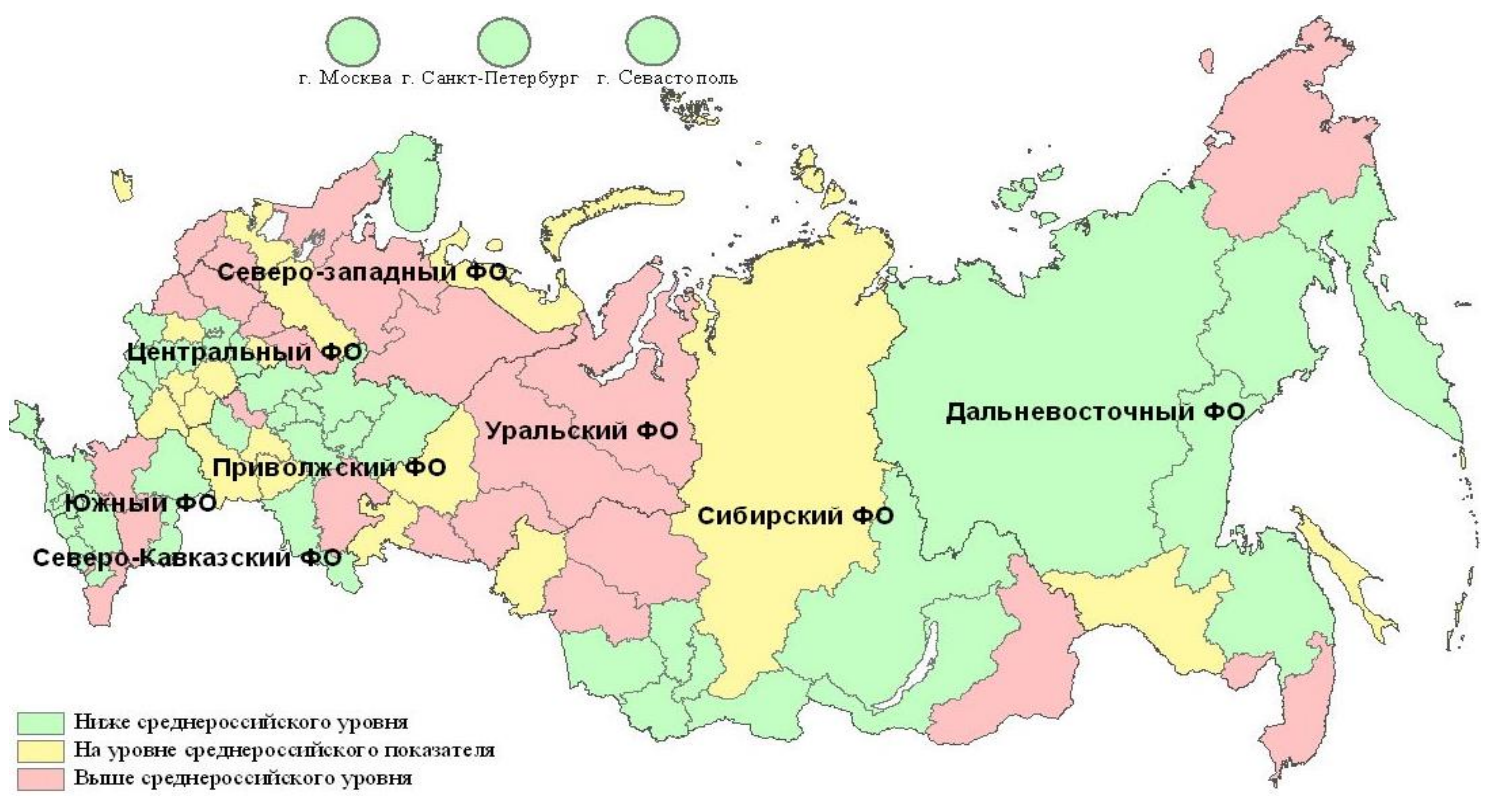

Рис. 22. Распределение субъектов Российской Федерации по доле проб питьевой воды из распределительной сети централизованного питьевого водоснабжения с превышением гигиенических нормативов по санитарно-химическим показателям, 2020 год

Доли проб воды из распределительной сети, не соответствующих гигиеническим нормативам по микробиологическим показателям, в 2020 году, были следующими: в Республике Ингушетия (27,9\% проб с превышениями гигиенических нормативов), Карачаево-Черкесской Республике (21,6 \%), Республике Калмыкия (13,7 \%), Республике Дагестан (11,8 \%) и Чеченской Республике (11,3\%) (рис. 23$).$

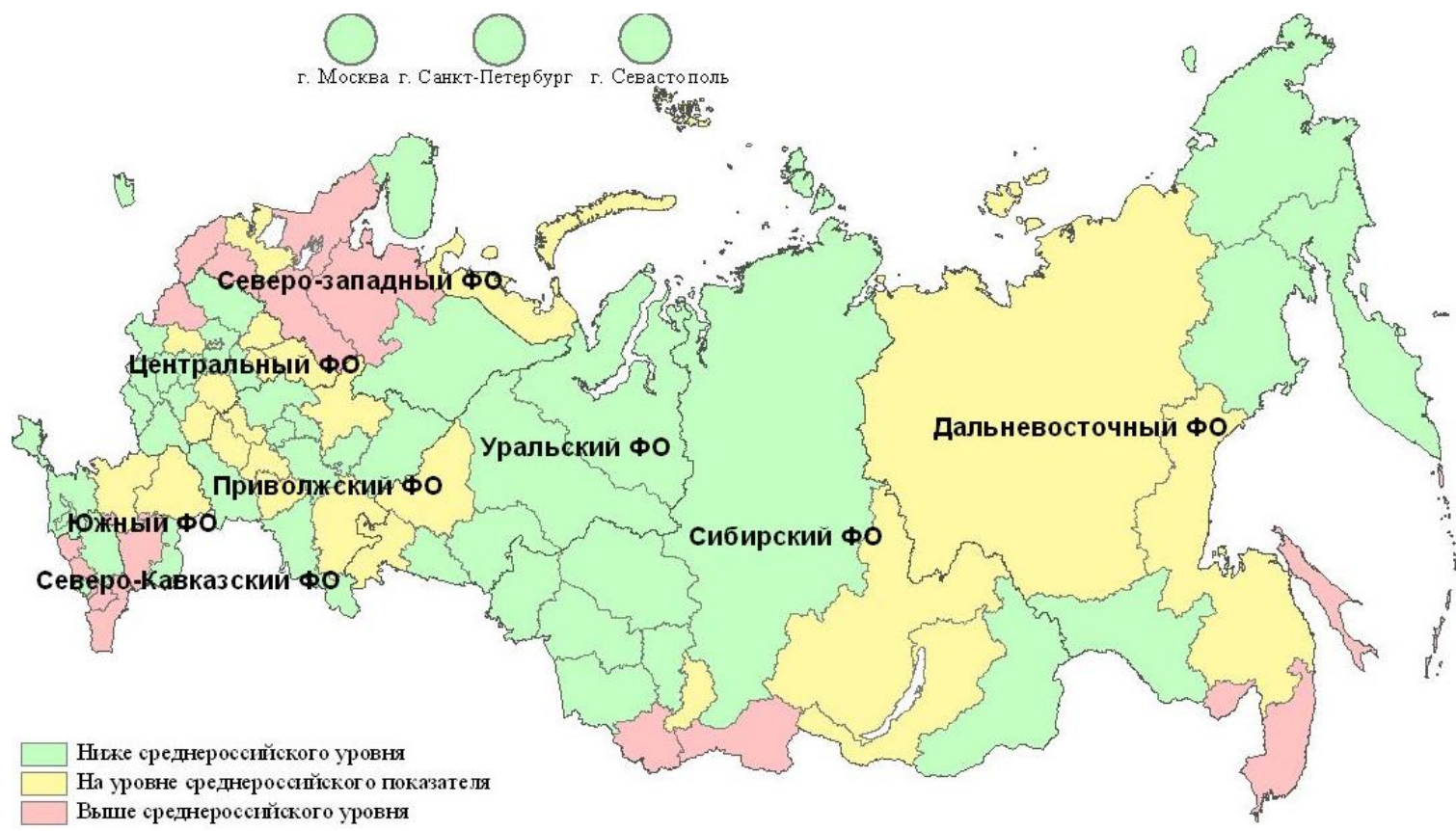

Рис. 23. Распределение субъектов Российской Федерации по доле проб питьевой воды из распределительной сети централизованного питьевого водоснабжения с превышением гигиенических нормативов по микробиологическим показателям, 2020 год 
Государственный доклад «О состоянии санитарно-эпидемиологического благополучия населения в Российской Федерации в 2020 году»

Питьевую воду из нецентрализованных источников водоснабжения в 2020 г. использовали более 7,743 млн жителей Российской Федерации, в том числе проживающих в сельской местности 6,107 млн чел., в городских поселениях 1,635 млн чел.

Доля источников нецентрализованного водоснабжения, не отвечающих санитарно-эпидемиологическим требованиям, за последнее десятилетие стабильна, при незначительном снижении от 2011 года на 3,6 \%, в том числе в сельских поселениях - на $3,14 \%$, в городских - на $6,42 \%$ (рис. 24$)$.

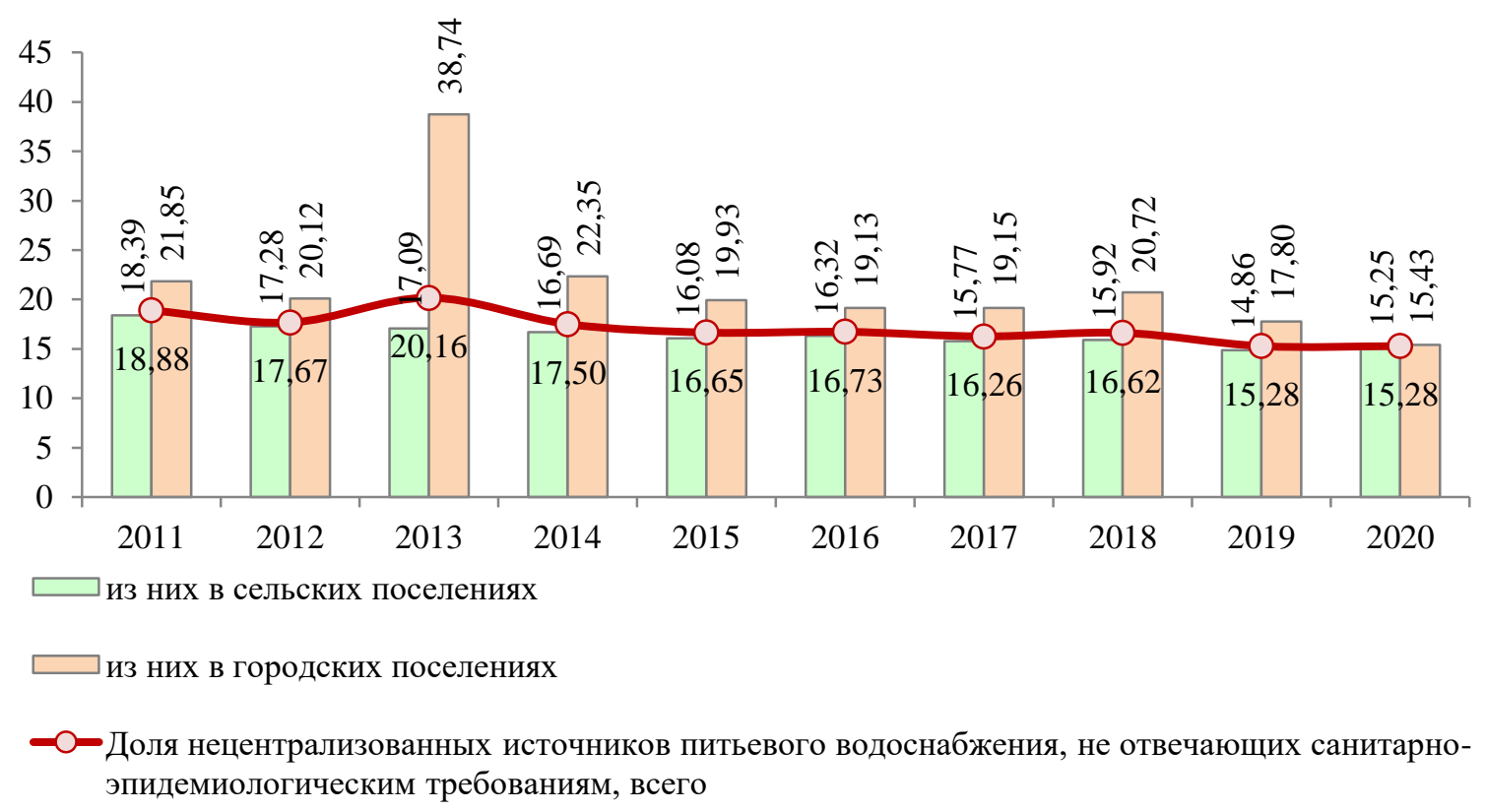

Рис. 24. Доля источников нецентрализованного водоснабжения, не отвечающих санитарно-эпидемиологическим требованиям, 2011-2020 гг., \%

Качество воды нецентрализованного водоснабжения за период с 2011 по 2020 г. улучшилось только по микробиологическим показателям. Доля проб воды нецентрализованного питьевого водоснабжения с превышением гигиенических нормативов по микробиологическим показателям снизилась на 1,94 \%, а по санитарнохимическим и паразитологическим показателям увеличилась на 3,9\% и 0,18\%, соответственно (рис. 25).

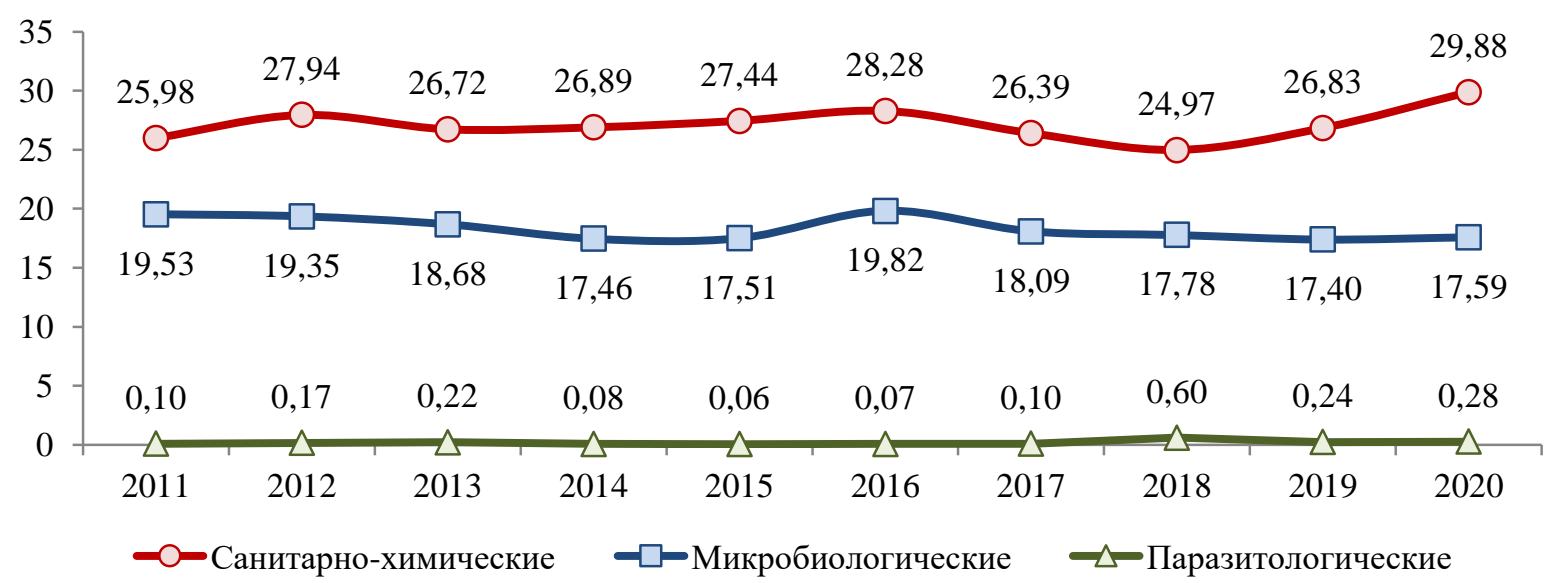

Рис. 25. Доля проб питьевой воды систем нецентрализованного водоснабжения, не соответствующих санитарным требованиям по санитарно-химическим, микробиологическим и паразитологическим показателям, в 2011-2020 гг., \% 
Территориями риска по качеству воды нецентрализованного водоснабжения по показателю доли проб питьевой воды, не соответствующих санитарным требованиям по санитарно-химическим показателям, являлись Новосибирская область $(88,9 \%)$, г. Москва (86,3\%), Самарская область $(75 \%)$ и Чеченская Республика $(75 \%)$; по микробиологическим показателям - Еврейская автономная область (76,1\% проб питьевой воды нецентрализованного водоснабжения не соответствовали санитарноэпидемиологическим требованиям), Тверская (51,9\%), Новгородская $(50,9 \%)$, Нижегородская $(50,6 \%)$ области.

В 2020 г. приоритетными веществами, применительно к которым наиболее часто регистрируются нарушения гигиенических нормативов, были бром, кремний (по $\mathrm{Si}$ ), хлор, железо (по Fe), натрий, литий, магний, марганец, хлороформ, бор, стронций, сероводород (по $\left.\mathrm{H}_{2} \mathrm{~S}\right)$.

Территориальные органы Роспотребнадзора участвовали в проведении субъектами Российской Федерации оценки состояния объектов централизованных систем водоснабжения, в том числе на предмет соответствия установленным показателям качества и безопасности, в подготовке и согласовании региональных программ повышения качества водоснабжения в рамках федерального проекта «Чистая вода», а также в оценке достижения целевых показателей федерального проекта.

В 2020 году доля населения Российской Федерации, обеспеченного качественной питьевой водой из систем централизованного водоснабжения, составила $86,5 \%$, что выше уровня 2019 года на 1,03\%. Целевой показатель на 2020 г. (87,8\%) не был достигнут. Оценка уровня достижения целевого показателя регионами показала, что в 2020 г. в 53 субъектах Российской Федерации достигнуты значения уточненного базового показателя «Доля населения Российской Федерации, обеспеченного качественной питьевой водой из систем централизованного водоснабжения, \%», определенные на 2020 г. для каждого субъекта.

В 30 субъектах Российской Федерации уточненные базовые значения показателя, запланированные федеральным проектом «Чистая вода» на 2020 год, не достигнуты: Республика Калмыкия (на 65,5 \%), Курганская область (на 22,7 \%), Свердловская область (на 15,7 \%), Республика Дагестан (на 15,2 \%), Республика Северная Осетия - Алания (на 13,7 \%), Кабардино-Балкарская Республика (на 11,1\%), Архангельская область (на $9,7 \%$ ), Пензенская область (на 8,8\%), Ростовская область (на 8,6\%), Республика Ингушетия (на 8,6\%), Республика Карелия (на 8,6 \%), Республика Крым (на 7,0 \%), Томская область (на 6,5 \%), Республика Саха (Якутия) (на 5,3 \%), Забайкальский край (на 5,2\%), Ставропольский край (на 4,4 \%), Саратовская область (на 4,1 \%), Рязанская область (на 3,5 \%), Республика Татарстан (на 3,3 \%), Ульяновская область (на 3,0 \%), Республика Коми (на 2,3 \%), Магаданская область (на 2,2 \%), Челябинская область (на $1,1 \%$ ), Белгородская область (на 0,8 \%), Ямало-Ненецкий автономный округ (на $0,5 \%$ ), Амурская область (на $0,5 \%$ ), г. Севастополь (на 0,4 \%), Мурманская область (на 0,4 \%), Кировская область (на 0,2 \%), Оренбургская область (на 0,1%) (рис. 26).

Качественной питьевой водой из систем централизованного водоснабжения в 2020 г. было обеспечено 93,5 \% городского населения Российской Федерации, что ниже уровня целевого показателя, предусмотренного федеральной программой «Чистая вода» на этот год $(94,9$ \%). Анализ регионального распределения данного показателя выявил 37 регионов Российской Федерации (кроме того, 2 города федерального значения Москва и Санкт-Петербург, не участвующих в ФП «Чистая вода»), на территориях которых в 2020 г. доля городского населения, обеспеченного качественной питьевой водой из систем централизованного водоснабжения, была на уровне или превысила целевой показатель 2020 г. (94,9 \%), и один субъект Российской Федерации, достигший уровня целевого показателя 2024 г. $(99,9 \%)$ - Камчатский край. 


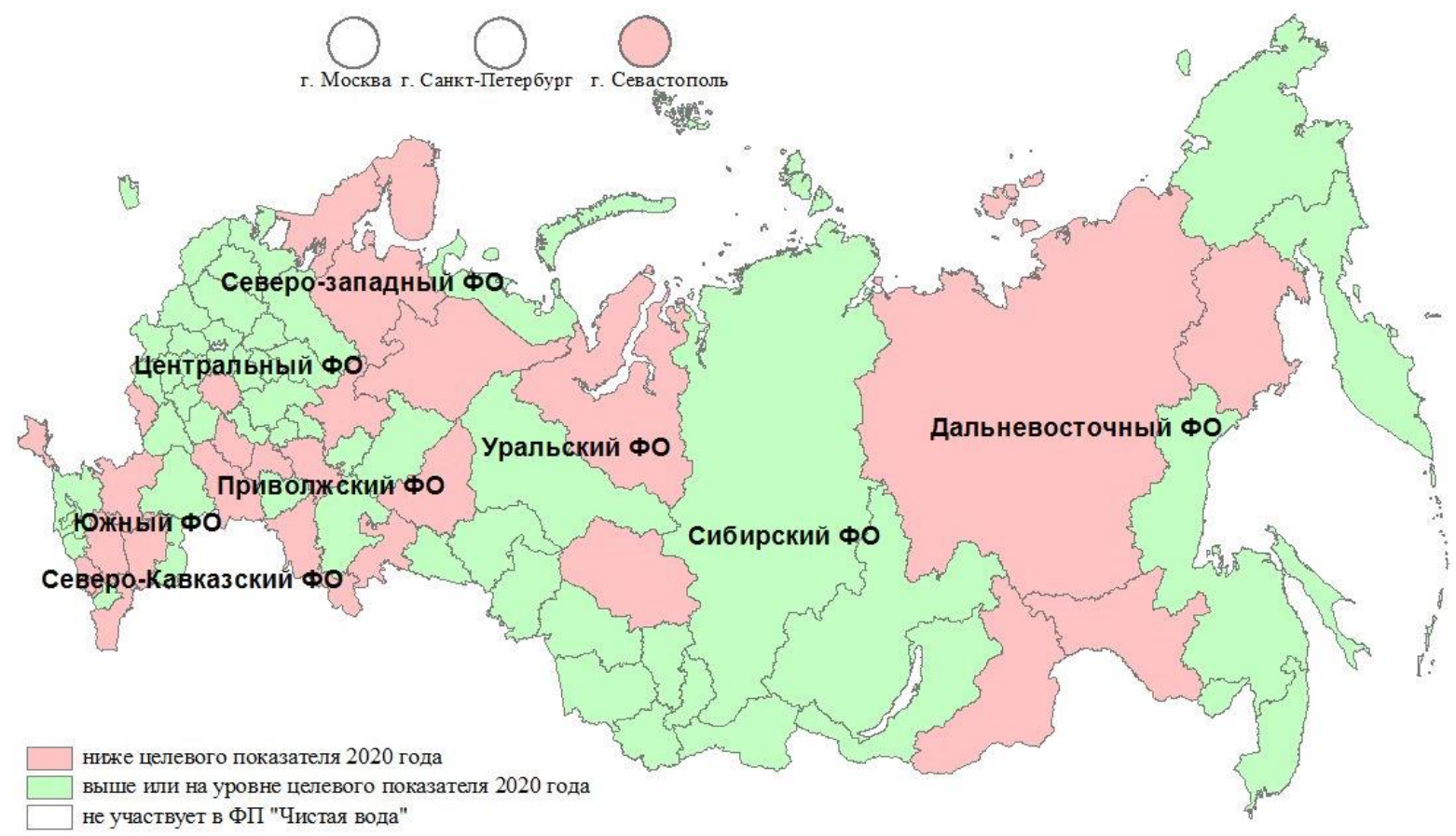

Рис. 26. Достижение целевого показателя «Обеспеченность населения качественной питьевой водой из централизованных систем водоснабжения» по субъектам Российской Федерации в 2020 году

На территории 46 субъектов Российской Федерации целевой уровень 2020 г. $(94,9 \%)$ не был достигнут. В 2020 г. наиболее низкая доля городского населения, обеспеченного качественной питьевой водой из систем централизованного водоснабжения, наблюдалась на территории Республики Тыва $(43,5$ \%), Забайкальского края $(60,0 \%)$, Вологодской области $(63,5 \%)$, Курганской области $(66,7 \%)$ и Ненецкого автономного округа $(68,8 \%)$.

\section{Влияние питьевой воды на здоровье населения}

Качество питьевой воды системы централизованного питьевого водоснабжения и присутствие в ней различных химических веществ (мышьяка, никеля, меди, марганца, железа, аммиака, хлора, хлороформа и хлорорганических соединений, бора, стронция, фтора, брома и других соединений), микробиологических и паразитологических агентов вероятностно способствовало формированию 9,24 случаев смерти на 100 тыс. всего населения, что составляет $0,75 \%$ от показателя общей смертности и ниже на $16,93 \%$ показателя 2012 г. Число дополнительных случаев смерти всего населения от злокачественных новообразований, вероятностно обусловленных загрязнением питьевой воды, составило 0,93 случая на 100 тыс. населения, или $10,06 \%$ от всей смертности, вероятностно обусловленной качеством питьевой воды, и $0,46 \%$ от всей смертности населения от злокачественных новообразований. Количество дополнительных случаев смерти, вероятностно обусловленных качеством питьевой воды, от болезней органов пищеварения составило 2,98 на 100 тыс. населения и отмечено на территориях 32 субъектов Российской Федерации.

В Российской Федерации число дополнительных случаев заболеваний, вероятностно обусловленных качеством питьевой воды в 2020 г., составило 938,07 случаев на 100 тыс. всего населения и 1 898,17 случаев на 100 тыс. детского населения, что составляет соответственно $1,2 \%$ и $1,1 \%$ от всей первичной заболеваемости соответствующей группы населения. В динамике заболеваемость, вероятностно 
обусловленная качеством питьевой воды, снизилась на 20,8 \% у всего населения и на 16,82 \% - у детского населения от уровня 2012 года.

Распределение субъектов Российской Федерации по уровню дополнительных случаев заболеваемости всего населения, ассоциированной с неудовлетворительным качеством питьевой воды, и по уровню дополнительных случаев заболеваемости детского населения, ассоциированной с неудовлетворительным качеством питьевой воды, представлено на рис. 27 и 28.

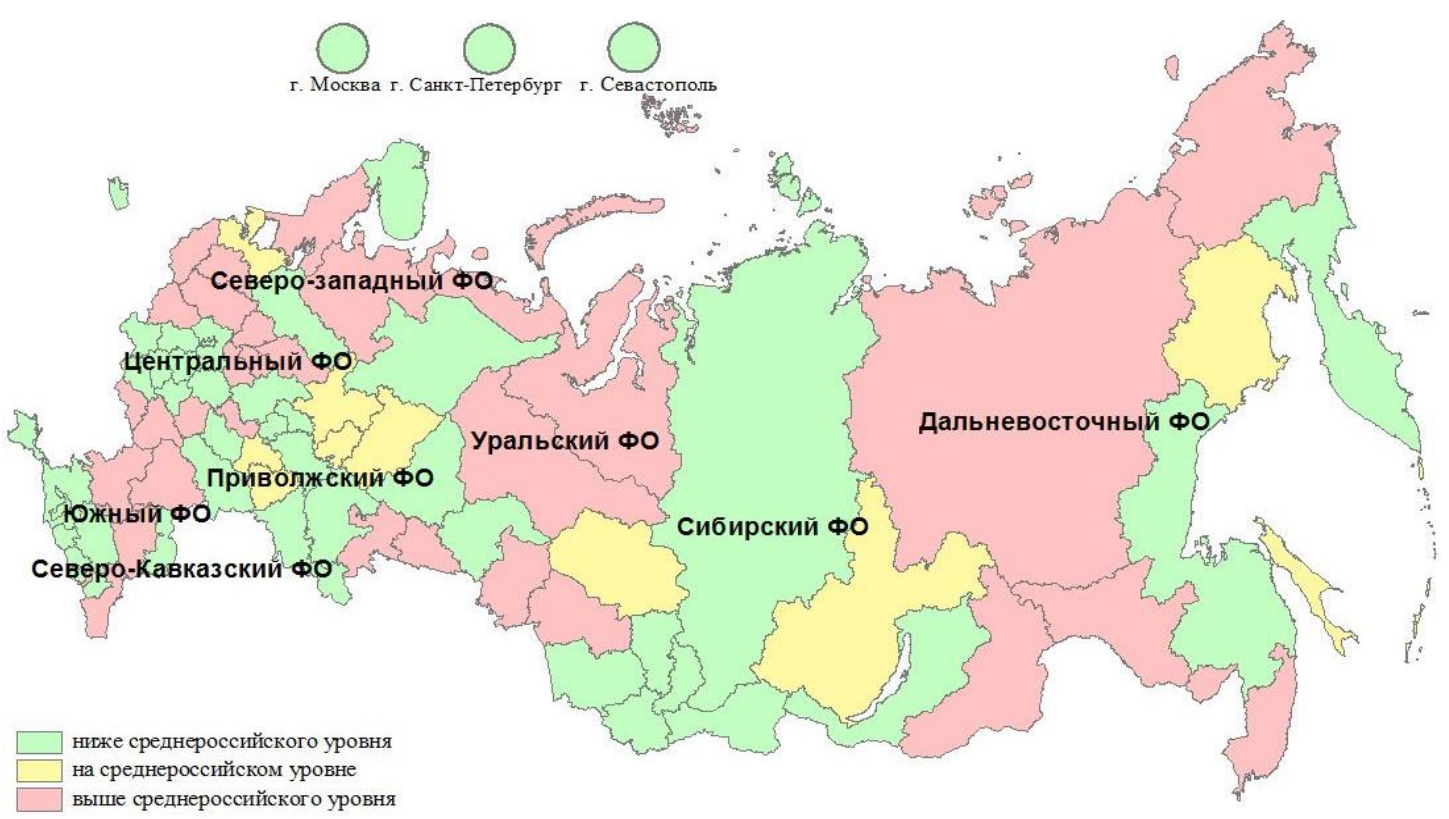

Рис. 27. Распределение субъектов Российской Федерации по уровню дополнительных случаев заболеваемости всего населения, ассоциированной с неудовлетворительным качеством питьевой воды, 2020 год

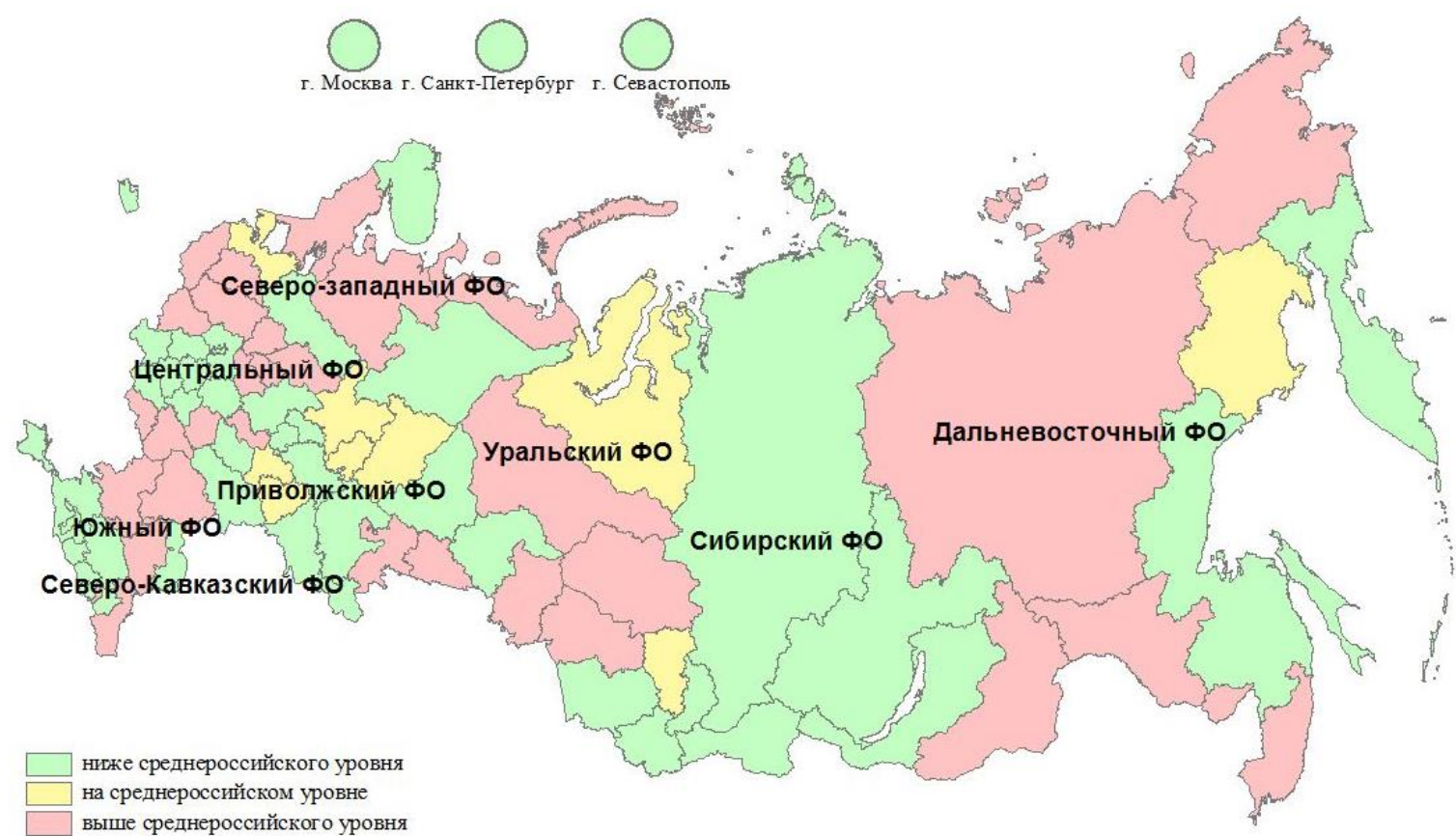

Рис. 28. Распределение субъектов Российской Федерации по уровню дополнительных случаев заболеваемости детского населения, ассоциированной с неудовлетворительным качеством питьевой воды, 2020 год 
В 2020 г. в Российской Федерации в структуре заболеваемости всего населения, вероятностно обусловленной водным пероральным фактором, приоритетные позиции по абсолютному числу дополнительных случаев занимали болезни мочеполовой системы $31,71 \%$ (436 478 абс. сл.), болезни органов пищеварения - 25,41\% (349 739 абс. сл.), болезни кожи и подкожной клетчатки - 16,7 \% (229 945 абс. сл.), болезни эндокринной системы, расстройства питания и нарушения обмена веществ - 6,95 \% (95 623 абс. сл.), болезни костно-мышечной системы - 5,03\% (69238 абс. сл.). Структура дополнительных случаев заболеваемости представлена на рис. 29.
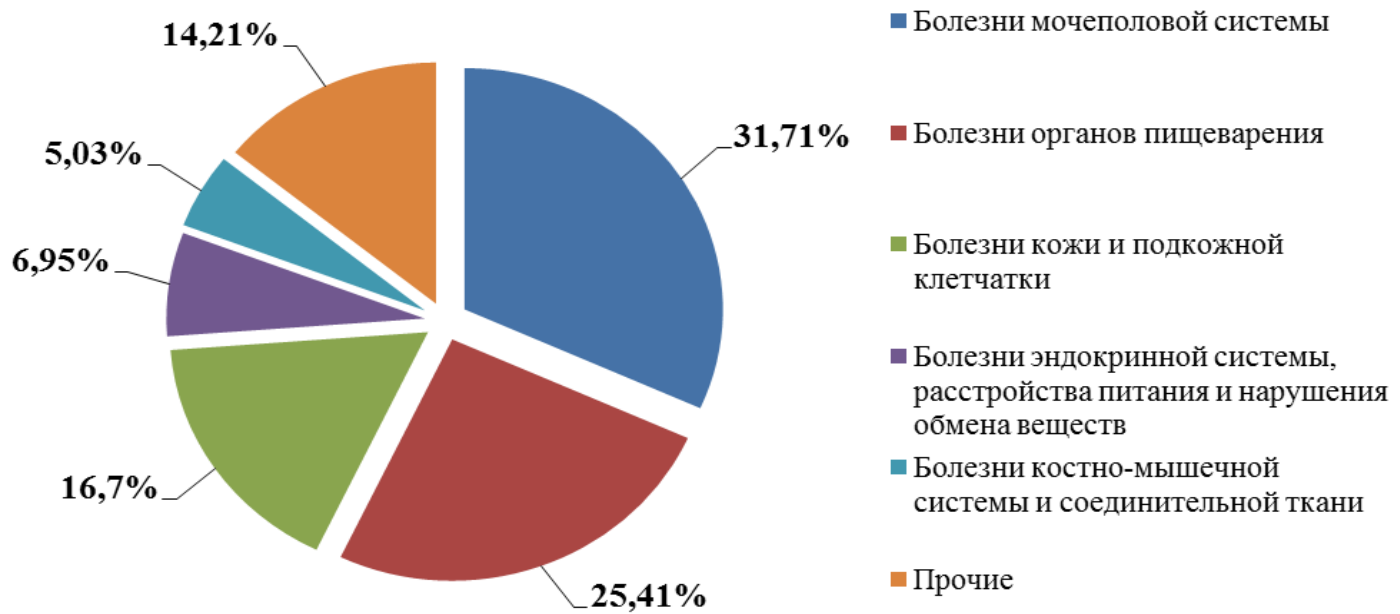

- Болезни эндокринной системы, расстройства питания и нарушения обмена веществ

- Болезни костно-мышечной системы и соединительной ткани

Прочие

Рис. 29. Структура дополнительных случаев заболеваемости всего населения Российской Федерации, ассоциированной с неудовлетворительным качеством воды системы централизованного хозяйственно-питьевого водоснабжения, 2020 год

В структуре заболеваемости детского населения, вероятностно обусловленной водным пероральным фактором, приоритетные позиции в 2020 г. по числу абсолютных случаев занимали болезни органов пищеварения - 30,77 \% (160 261 абс. сл.), болезни кожи и подкожной клетчатки - 21,35 \% (111218 абс. сл.), болезни костно-мышечной системы и соединительной ткани - 13,29\% (69 238 абс. сл.), болезни мочеполовой системы - 12,64 \% (65 846 абс. сл.), болезни крови, кроветворных органов и отдельные нарушения, вовлекающие иммунный механизм - 11,54 \% (60 117 абс. сл.) (рис. 30).
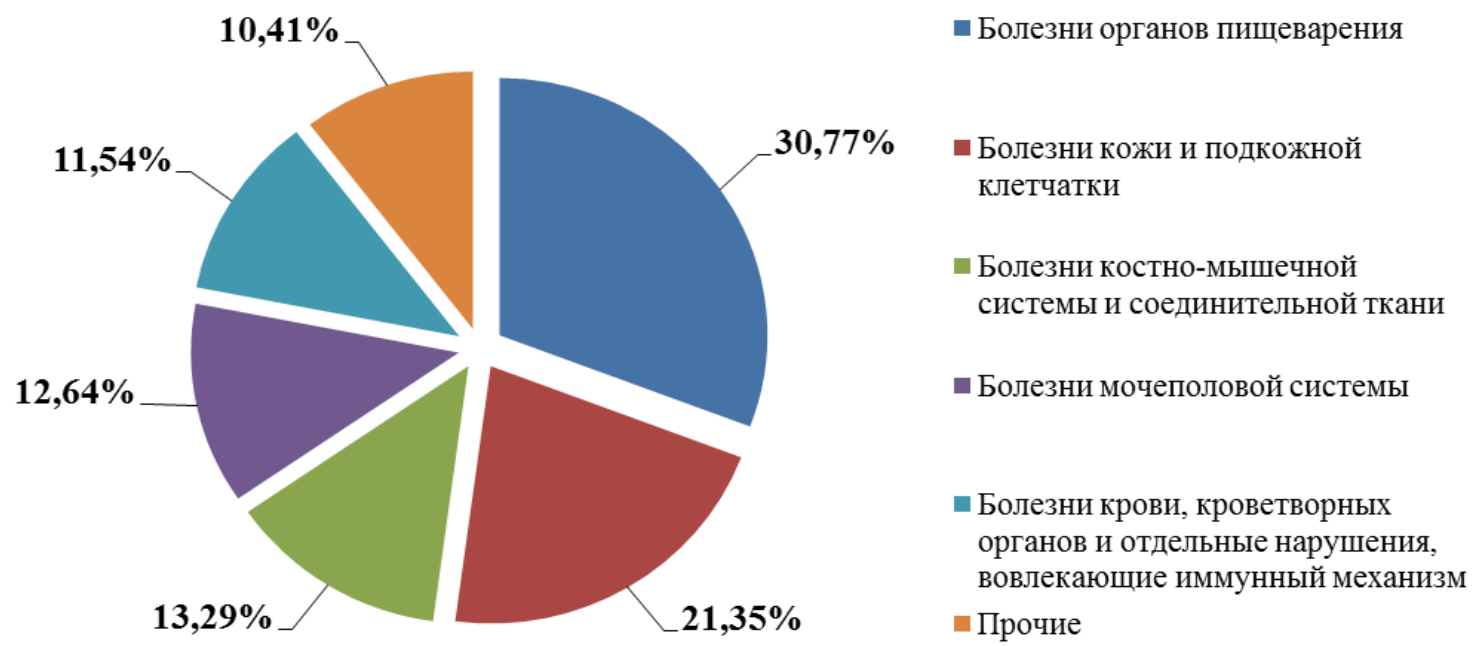

— Болезни мочеполовой системы

Ш Болезни крови, кроветворных органов и отдельные нарушения, вовлекающие иммунный механизм прочие

Рис. 30. Структура дополнительных случаев заболеваемости детского населения РФ, ассоциированной с неудовлетворительным качеством воды системы централизованного хозяйственно-питьевого водоснабжения, 2020 год 
В рамках реализации мероприятий федерального проекта «Чистая вода» Роспотребнадзором начиная с 2019 года создается информационная система «Интерактивная карта контроля качества питьевой воды в Российской Федерации» (ИС ИКК), целью которой является информирование населения, органов государственной и исполнительной власти Российской Федерации, органов местного самоуправления, водоснабжающих организаций о качестве воды систем централизованного питьевого водоснабжения.

В ИС ИКК сформированы модули информирования населения о качестве питьевой воды по запрашиваемому адресу, визуализация информации о качестве питьевой воды в точке контроля (рис. 31), в т. ч. с помощью цветовой шкалы, справочная информация о ходе выполнения мероприятий по повышению качества воды, возможность направления при неудовлетворительном качестве воды обращения в управляющую компанию и Роспотребнадзор, информация об аварийных ситуациях.

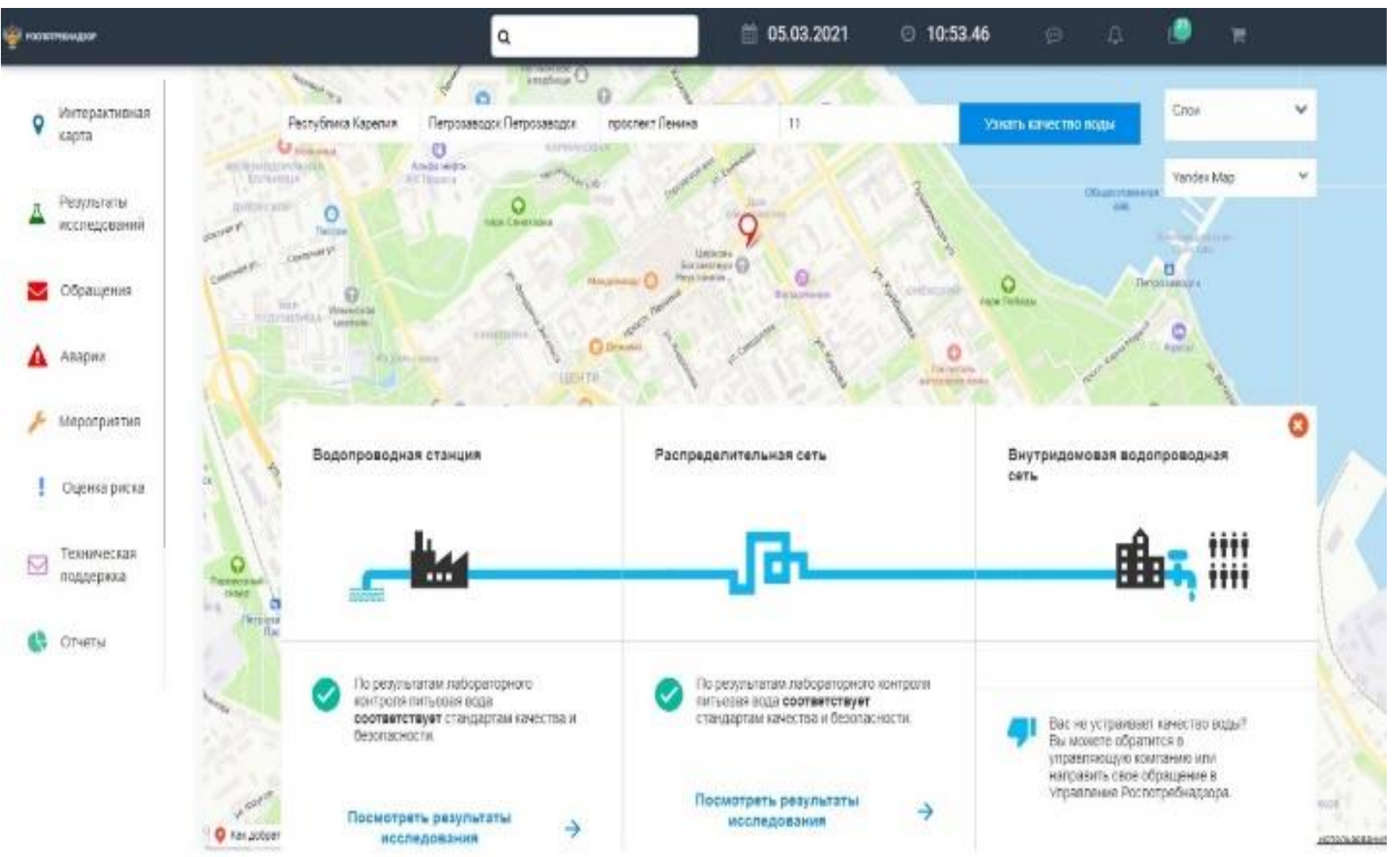

Рис. 31. Визуализация информации о качестве воды централизованных систем водоснабжения по конкретному адресу

В 2020 г. проведена апробация ИС ИКК с участием органов и организаций Роспотребнадзора 20 субъектов Российской Федерации.

\subsection{3. Состояние почв территорий и его влияние на здоровье населения}

Качество почв территорий населенных мест

В течение 2020 года на территории Российской Федерации органами и организациями Роспотребнадзора отобрано и исследовано более 262 тыс. проб почвы, в том числе:

- в селитебной зоне - более 170,1 тыс. проб (64,8 \% от общего количества отобранных проб), в том числе на территории детских организаций и детских площадок - свыше 99,2 тыс. проб (37,8 \% от общего количества отобранных проб почвы на территории Российской Федерации); 
- в зонах влияния промышленных предприятий, транспортных магистралей, в местах применения пестицидов и минеральных удобрений - более 18,4 тыс. проб $(7,0$ \%);

- в зонах санитарной охраны источников водоснабжения - более 10,1 тыс. проб $(3,9 \%)$

- на территориях животноводческих комплексов и ферм - более 4,9 тыс. проб $(1,9 \%)$;

- на территориях курортов - более 4,1 тыс. проб (1,6 \%);

- в местах производства растениеводческой продукции - более 5,1 тыс. проб $(2,0 \%)$

- на прочих территориях - более 43,7 тыс. проб (18,9\%).

Динамика исследований проб почвы с 2011 по 2020 г. представлена на рис. 32.

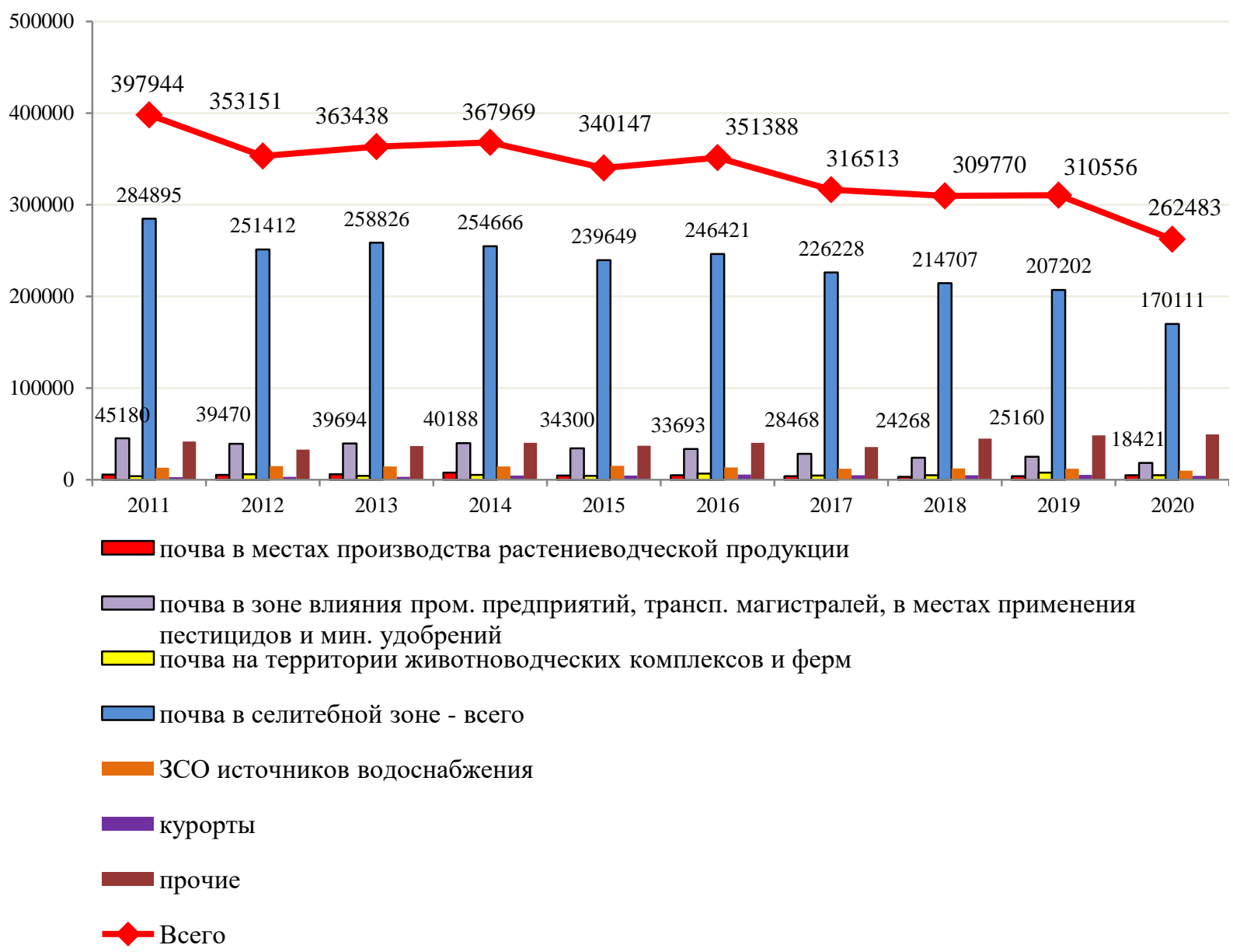

Рис. 32. Общее количество исследованных проб почвы, 2011-2020 гг., абс.

На соответствие гигиеническим нормативам по санитарно-химическим показателям в 2020 г. отобрано и исследовано более 54,1 тыс. проб (более 20,6 \% всех проб почвы), по микробиологическим - более 80,3 тыс. проб (30,6\%), по паразитологическим - более 99,6 тыс. проб (37,9 \%), по содержанию преимагинальных стадий мух - более 15,4 тыс. проб (5,9\%), радиоактивных веществ - 12,8 тыс. проб $(4,9 \%)$.

В 2020 г. относительно 2011 г. наблюдается снижение доли проб с превышением гигиенических нормативов на $1,97 \%$. Наибольший вклад в долю проб, не соответствующих гигиеническим нормативам (по всем видам исследований), вносит почва в зонах влияния промышленных предприятий, транспортных магистралей, в местах применения пестицидов и минеральных удобрений (рис. 33). 


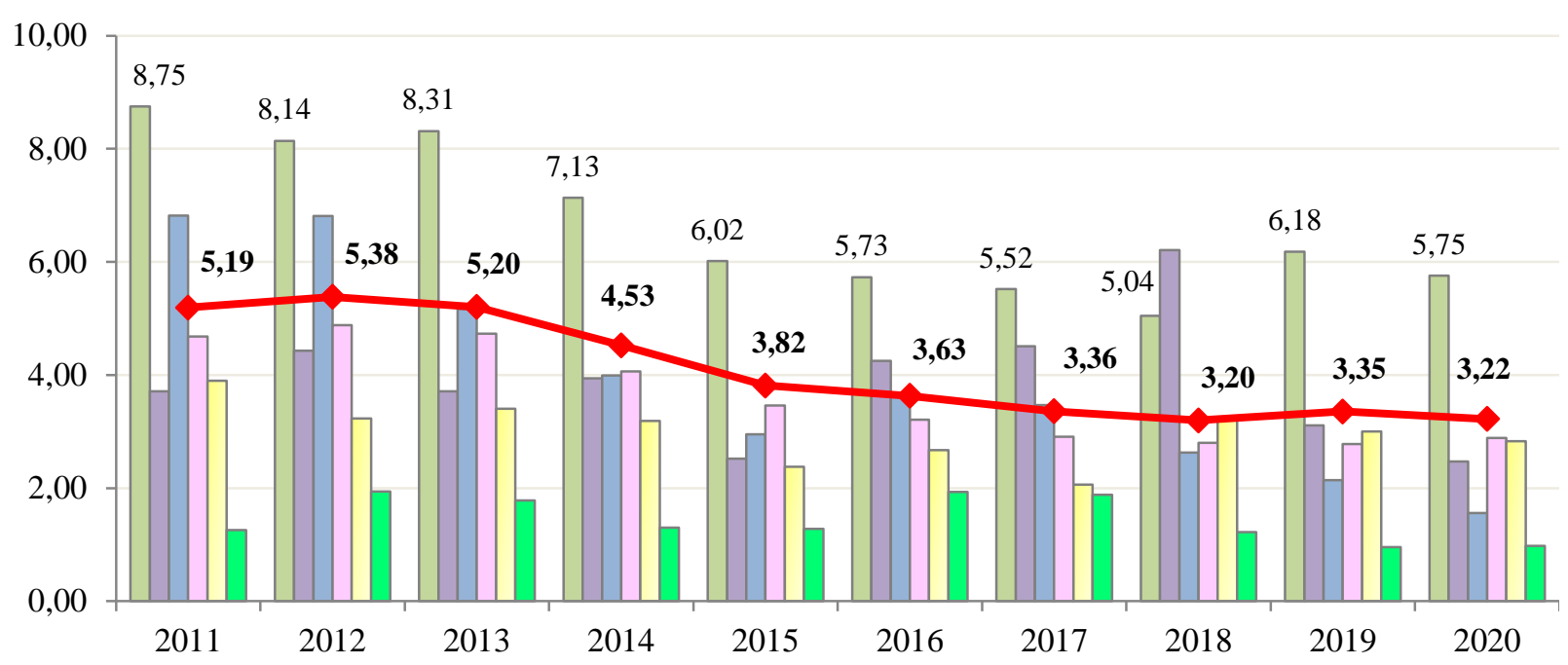

$\square$ почва в зоне влияния пром. предприятий, трансп. магистралей, в местах применения пестицидов и мин. удобрений

$\square$ почва в местах производства растениеводческой продукции

$\square$ почва на территории животноводческих комплексов и ферм

$\square$ почва в селитебной зоне - всего

$\square 3 \mathrm{CO} \mathrm{источников} \mathrm{водоснабжения}$

$\square$ курорты

- Доля проб почвы, не соответствующих гигиенических нормативам (всего), \%

Рис. 33. Доля проб почвы, не соответствующих гигиеническим нормативам, в 2011-2020 гг.

Анализ результатов исследований показал, что за последние десять лет качество почв на территории Российской Федерации улучшилось, за период 2011-2020 гг. снизилась доля почв, не соответствующих гигиеническим нормативам как по санитарнохимическим, так и по микробиологическим (на $3,26 \%$ ) и паразитологическим (на $0,75 \%$ ) показателям (рис. 34). При этом по санитарно-химическим показателям с 2019 г. отмечается тенденция к ухудшению показателей.

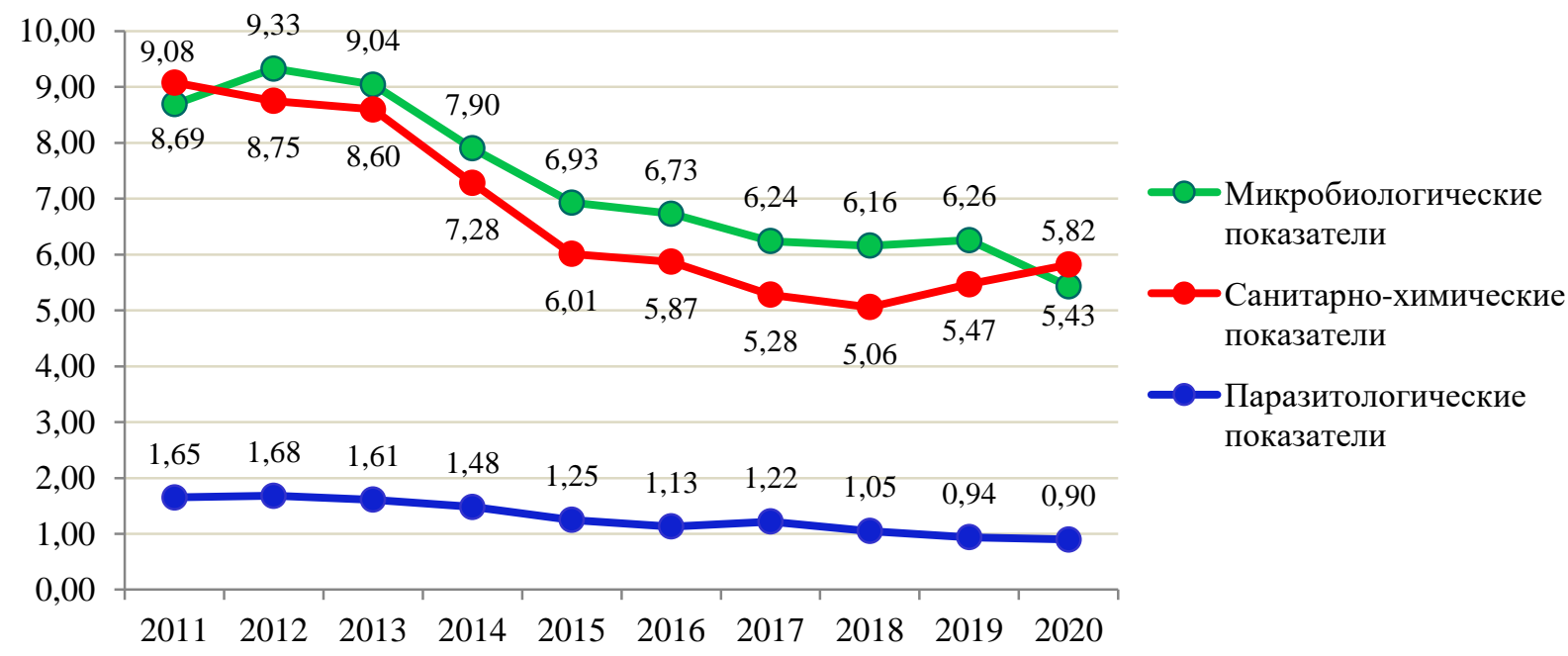

Рис. 34. Доля проб почвы, не соответствующих гигиеническим нормативам по санитарно-химическим, микробиологическим и паразитологическим показателям, 2011-2020 гг., \% 
По санитарно-химическим показателям наиболее высокая доля проб почвы, не соответствующих гигиеническим нормативам, зафиксирована в 2020 г. в Приморском крае (36,48 \% проб с превышениями гигиенических нормативов), Забайкальском крае $(33,49 \%)$, Новгородской области $(28,18 \%)$, Челябинской $(24,47 \%)$, Кировской $(24,14 \%)$, Мурманской $(22,58 \%)$ областях, Республике Башкортостан $(22,09 \%)$, Свердловской области (18,31\%) и Республике Мордовия $(18,21 \%)$.

Наиболее высокий уровень микробиологического загрязнения почв наблюдался в 2020 г. на территориях Новосибирской области $(30,88 \%$ проб с превышениями гигиенических нормативов), Еврейской автономной области (28,94 \%), Архангельской $(24,63 \%)$ области, Приморского края $(21,08 \%)$, Республики Карелия $(16,63 \%)$, Удмуртской Республики (16,54 \%), Республики Мордовия (14,63 \%), Свердловской $(14,34$ \%), Рязанской (12,25 \%) и Владимирской областей $(11,5 \%)$.

Средний по Российской Федерации уровень паразитологического загрязнения почв был значительно превышен в 2020 г. в Новосибирской области (7,42 \% проб почвы, не соответствующих гигиеническим нормативам), республиках Коми (5,04\%), Карачаево-Черкесской $(4,92 \%)$, Северная Осетия - Алания $(4,42 \%)$, Ингушетия $(4,04 \%)$, в Смоленской $(3,73 \%)$ и Архангельской $(3,69 \%)$ областях.

За период 2011-2020 гг. качество почв селитебных территорий Российской Федерации в целом улучшилось. Так, доля проб почвы в селитебной зоне, не соответствующих гигиеническим нормативам по микробиологическим показателям, снизилась в 2020 г. по сравнению с 2011 г. на 2,73\%, по санитарно-химическим - на 4,08 \%, по паразитологическим - на $0,68 \%$ (рис. 35 ).

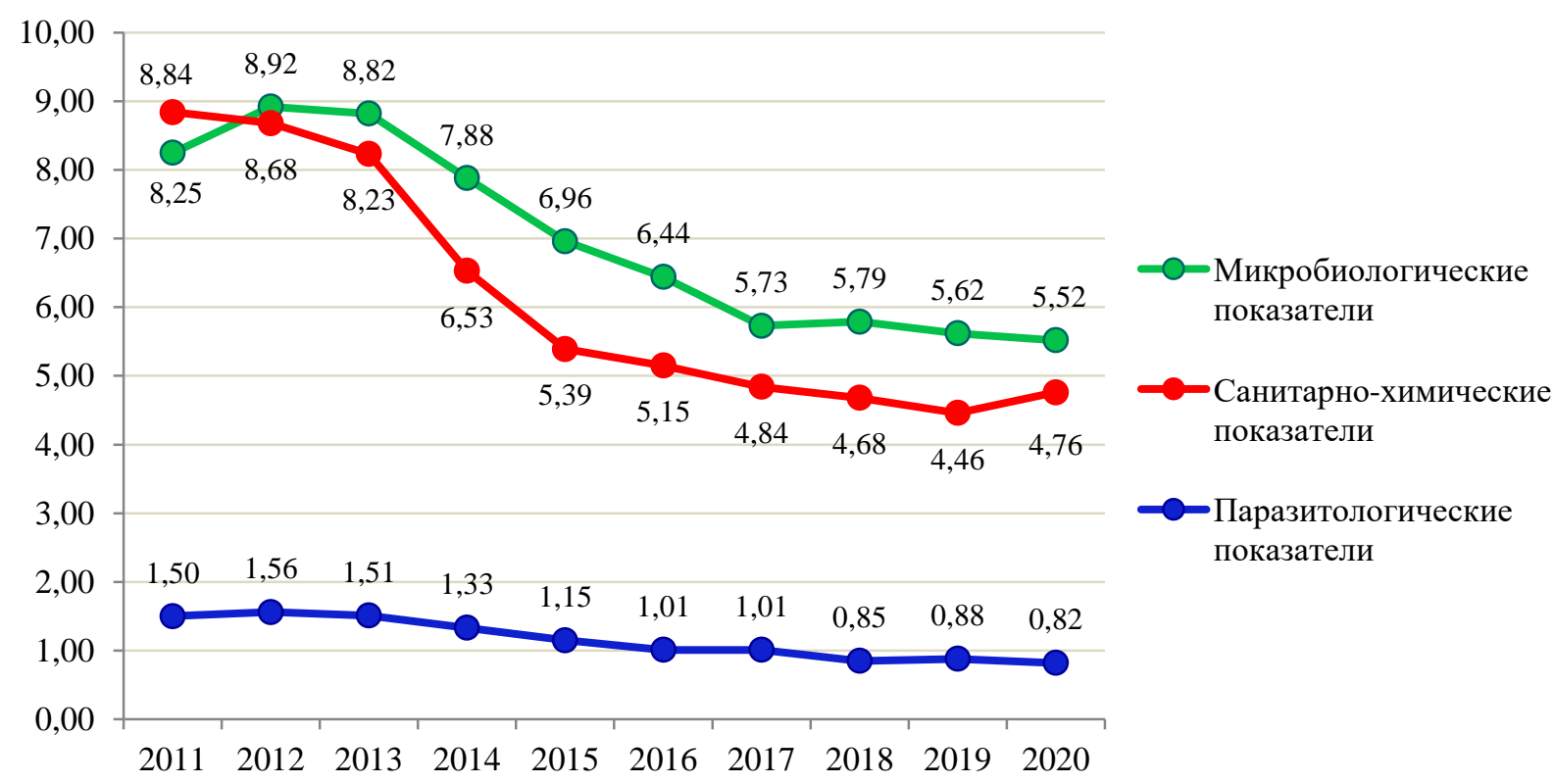

Рис. 35. Доля проб почвы селитебной зоны, не соответствующих гигиеническим нормативам, 2011-2020 гг., \%

Распределение субъектов Российской Федерации по доле проб почвы селитебной зоны с превышением гигиенических нормативов по санитарно-химическим показателям представлено на рис. 36. 


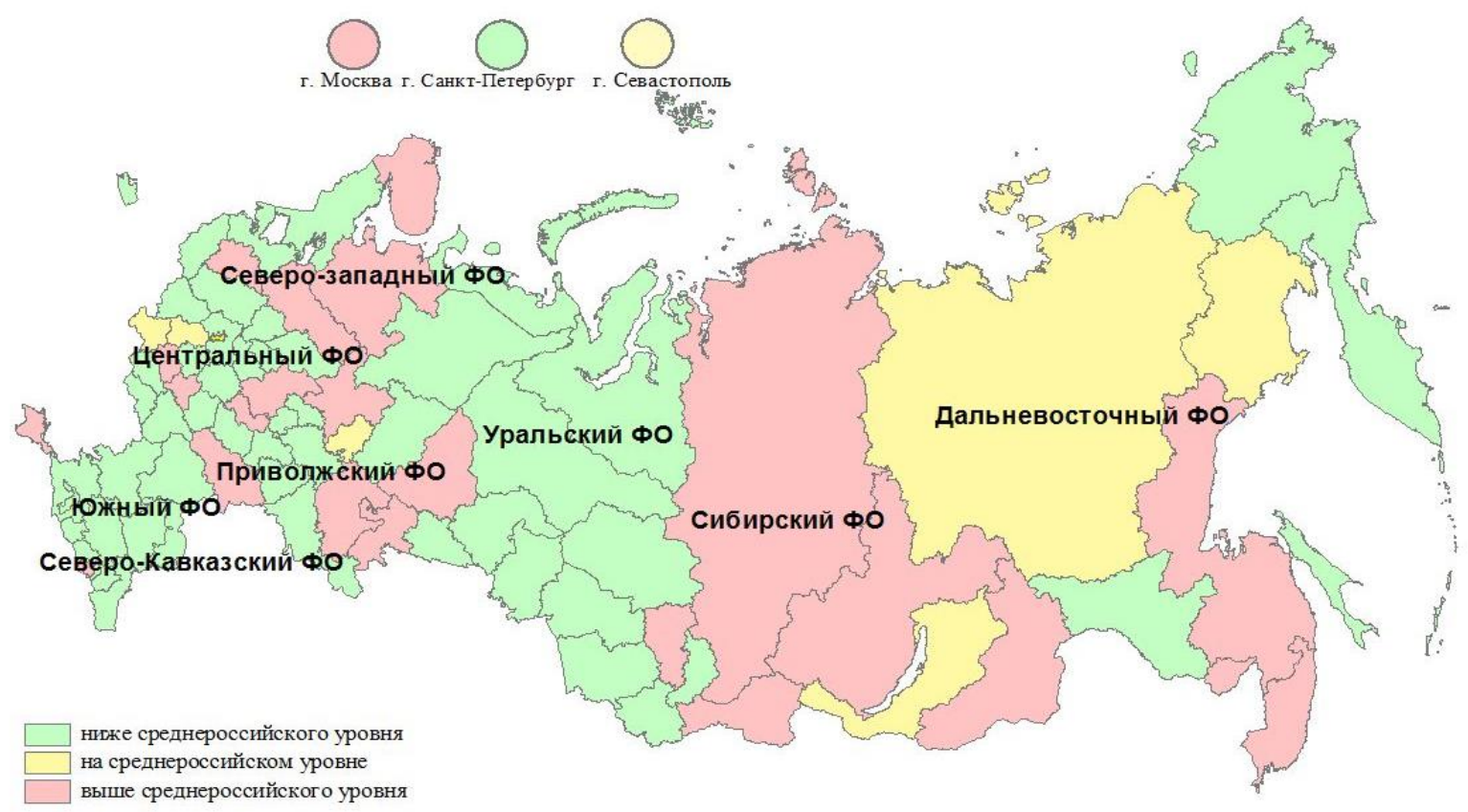

Рис. 36. Распределение субъектов Российской Федерации по доле проб почвы селитебной зоны с превышением гигиенических нормативов по санитарно-химическим показателям, 2020 год, \%

В 2020 г. более чем в 1,5 раза превышен среднероссийский уровень загрязнения почв селитебных зон химическими веществами на территории Новгородской, Кировской, Челябинской, Мурманской, Свердловской, Орловской, Иркутской, Вологодской, Липецкой, Архангельской, Нижегородской, Саратовской, Кемеровской областей, Забайкальского, Приморского, Хабаровского, Красноярского краев, Республик Мордовия, Северная Осетия - Алания, Крым, Тыва, Башкортостан, г. Москвы, Еврейской автономной области.

За период 2011-2020 гг. удельный вес проб почвы селитебных территорий, не соответствующих гигиеническим нормативам по содержанию тяжелых металлов, снизился с $6,56 \%$ в 2011 г. до 3,39\% в 2020 г., ртути - с 0,12\% до 0,05\%, свинца - с $2,64 \%$ до $1,13 \%$, кадмия - с 0,65 \% до 0,27 \%, пестицидов с $0,37 \%$ до 0,22 \% (рис. 37 ).

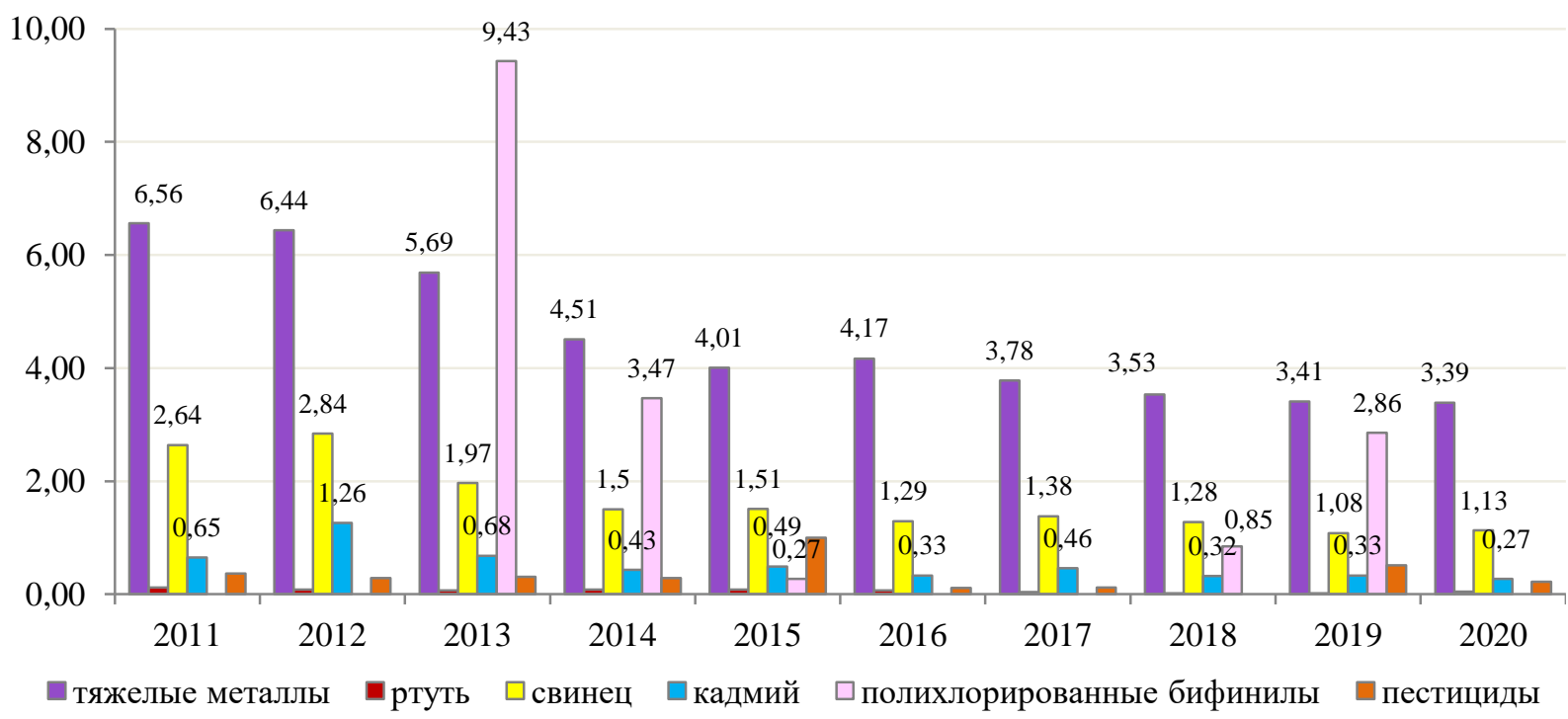

Рис. 37. Доля проб почвы селитебной зоны с превышением гигиенических нормативов по содержанию приоритетных веществ, 2011-2020 гг., \% 
Наиболее высокие значения доли проб почв селитебной зоны, не соответствующих гигиеническим нормативам по содержанию тяжелых металлов, зафиксированы в 2020 г. на территориях Кировской $(38,21 \%)$, Челябинской $(22,39 \%)$, Мурманской $(21,11 \%)$, Свердловской $(15,47 \%)$, Новгородской $(12,35 \%)$ областей, Приморского (36,79\%), Забайкальского $(27,19 \%)$, Хабаровского (12,42\%) краев, Республики Северная Осетия - Алания (27,5\%), Еврейской автономной области $(13,09 \%)$.

Ртутью наиболее загрязнены почвы Нижегородской $(1,54 \%$ проб почвы с превышением гигиенических нормативов), Челябинской $(0,59 \%)$, Магаданской $(0,76 \%)$ областей $(0,48$ \%) и Республики Саха (Якутия) (0,82 \%), свинцом - Республики Северная Осетия - Алания $(27,5$ \%), Забайкальского $(10,6 \%)$ и Приморского $(13,1 \%)$ краев.

Распределение субъектов Российской Федерации по доле проб почвы селитебной зоны с превышением гигиенических нормативов по микробиологическим показателям представлено на рис. 38.

В 2020 г. территориями риска по микробиологическому загрязнению почв были Новосибирская, Владимирская, Амурская, Тверская, Костромская, Новгородская, Волгоградская, Рязанская, Архангельская, Свердловская области, г. Москва, Приморский, Красноярский, Хабаровский края, Кабардино-Балкарская Республика, республики Карелия, Саха (Якутия), Удмуртская Республика, Еврейская автономная область.

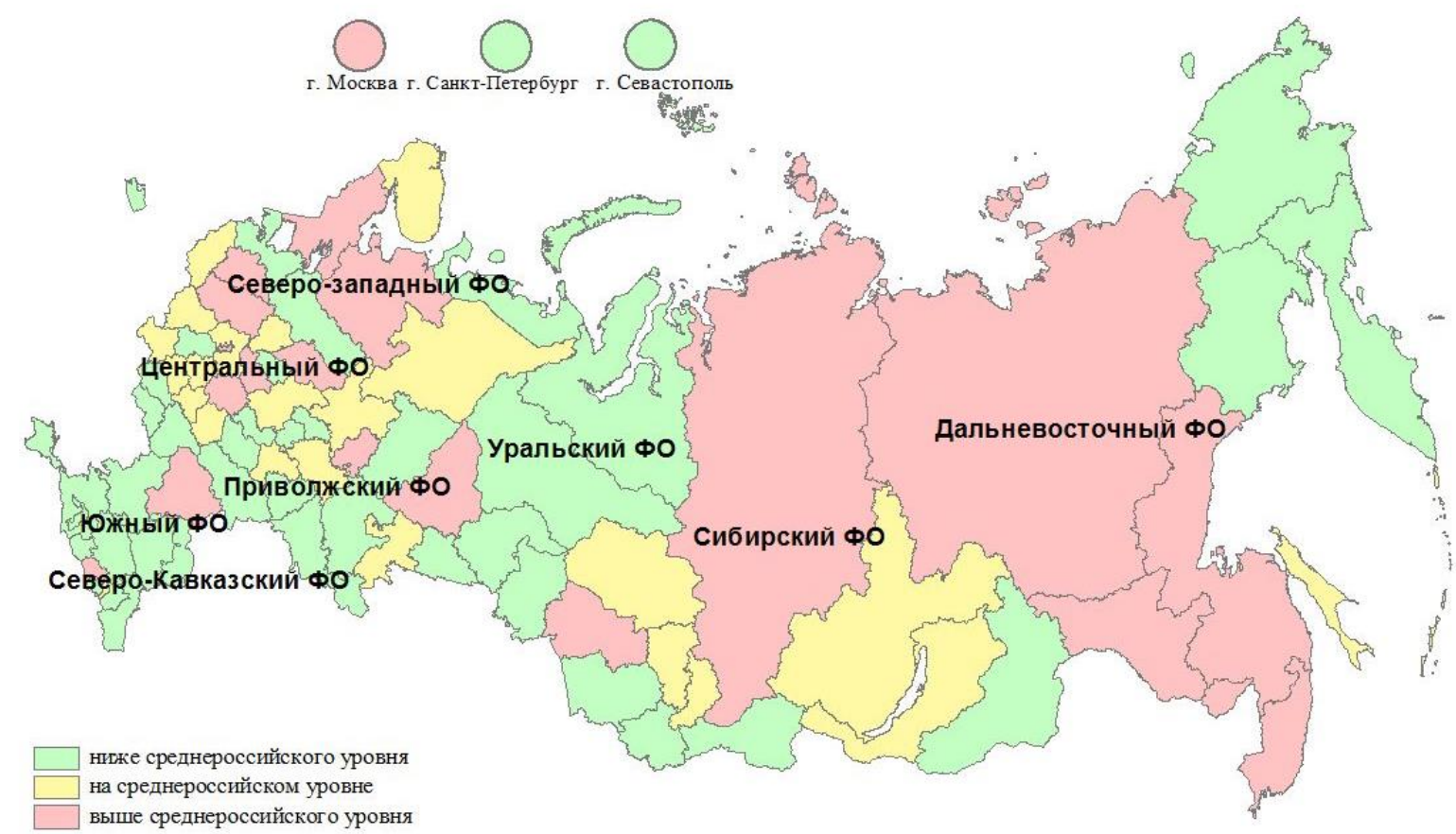

Рис. 38. Распределение субъектов Российской Федерации по доле проб почвы селитебной зоны с превышением гигиенических нормативов по микробиологическим показателям, 2020 год, \%

В 2020 г. территориями риска по паразитологическому загрязнению почв селитебных зон были Архангельская, Астраханская, Кемеровская, Новосибирская, Рязанская, Тамбовская, Ярославская, Кировская, Нижегородская, Омская, Курская, Смоленская, Новгородская, Свердловская области, республики Северная Осетия Алания, Ингушетии, Коми, Карачаево-Черкесская, Хабаровский край (рис. 39). 


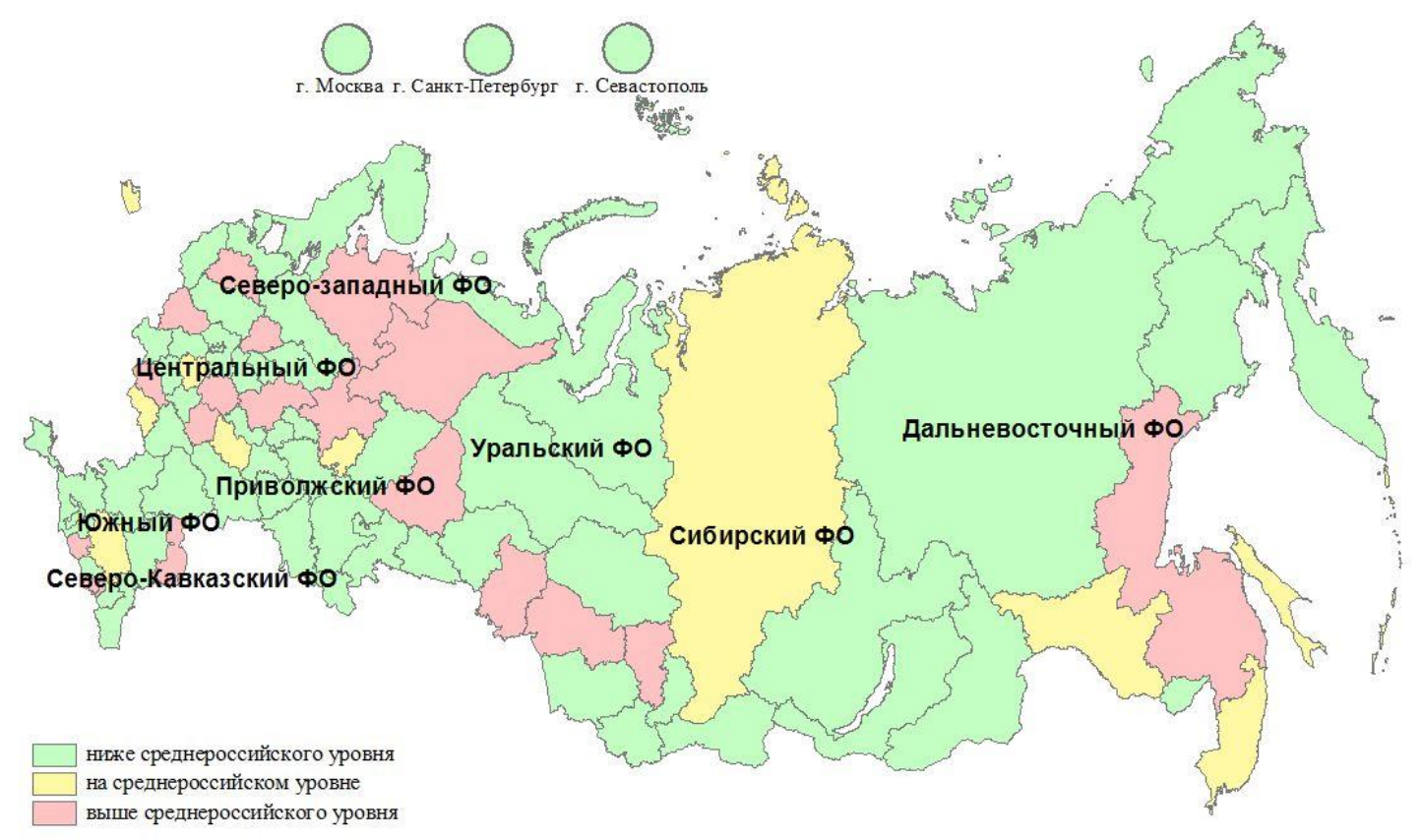

Рис. 39. Распределение субъектов Российской Федерации по доле проб почвы селитебной зоны с превышением гигиенических нормативов по паразитологическим показателям, 2020 год, \%

За период 2011-2020 гг. снизилась доля проб почвы, не соответствующих гигиеническим нормативам по санитарно-химическим показателям, с 4,15 \% в 2011 г. до $3,55 \%$ в 2020 г., по микробиологическим показателям - с 7,64\% до 4,17\%, по паразитологическим показателям - с 1,08 \% до 0,52 \% (рис. 40).

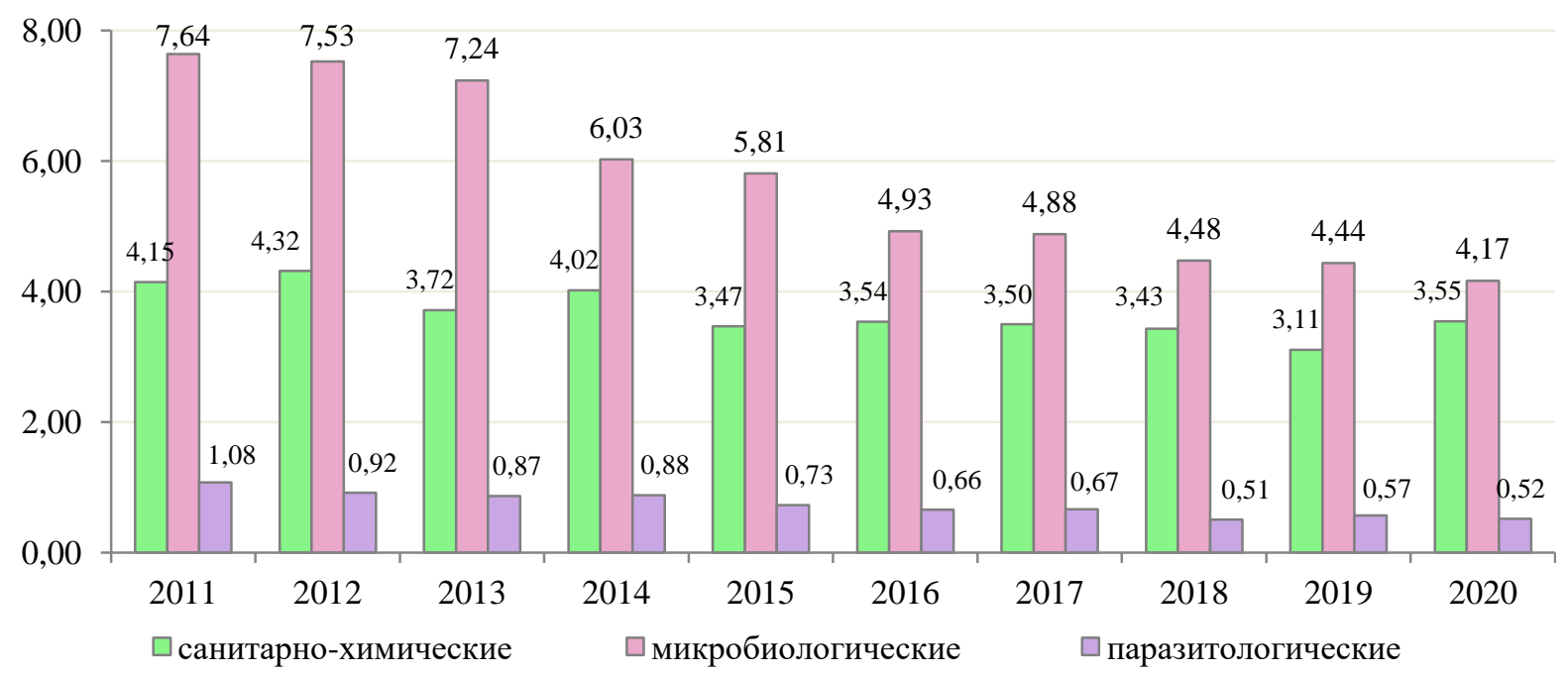

Рис. 40. Доля проб почвы, отобранных на территории детских организаций и детских площадок, не соответствующих санитарно-эпидемиологическим требованиям, 2011-2020 гг., \%

Более чем в три раза был превышен среднероссийский показатель загрязненности почв химическими веществами на территории детских учреждений и детских площадок Новгородской (30,18\% проб с превышениями гигиенических нормативов) области, Забайкальского $(26,22 \%)$, Хабаровского (16,15\%), Приморского (12,96 \%) краев, Кировской $(26,04 \%)$, Мурманской (14,89\%) областей, Республики Крым $(19,57 \%)$, Республики Мордовия (15,82 \%), Еврейская автономной области $(15,42 \%)$, Республики Северная Осетия - Алания $(29,79$ \%). 
В три и более раза был превышен в 2020 г. среднероссийский уровень микробиологической загрязненности почв на территории детских учреждений и детских площадок в Еврейской автономной области $(30,39 \%$ проб с превышениями гигиенических нормативов), Архангельской области (22,0\%), Удмуртской Республики $(19,21 \%)$, Приморского края (18,47 \%), Республики Карелия $(16,14$ \%), Новгородской области $(12,87 \%)$.

Наиболее высокий уровень паразитарного загрязнения почв был зафиксирован на территории детских организаций и детских площадок в Астраханской $(3,78$ \% проб с превышениями гигиенических нормативов), Архангельской $(3,2 \%)$, КарачаевоЧеркесской Республики (3,12 \%), Рязанской (1,93 \%), Свердловской $(1,38$ \%) областях, Республике Коми (1,49 \%), Хабаровском крае (1,48 \%).

На уровень загрязнения почв Российской Федерации в 2020 г. оказывали влияние следующие антропогенные и природные факторы:

- долговременное и непрерывное загрязнение почв селитебных территорий выбросами промышленных предприятий и автотранспорта;

- техногенные и природные аварии, пожары и катастрофы;

- загрязнение почв комплексом тяжелых металлов от предприятий черной и цветной металлургии, машиностроения и металлообработки, топливной, энергетической, химической, нефтехимической, строительной промышленности и производства стройматериалов.

\section{Влияние почвы селитебных территорий на здоровье населения}

Микробное и паразитарное загрязнение почвы селитебных территорий может формировать риски развития инфекционных и паразитарныых заболеваний. В среднем по Российской Федерации вероятностно обусловлено загрязнением почвы 577,97 дополнительных случаев заболеваний на 100 тыс. детского населения в классе «некоторые инфекционные и паразитарные заболевания», что составляет $7,02 \%$ от первичной заболеваемости по данной причине (рис. 41).

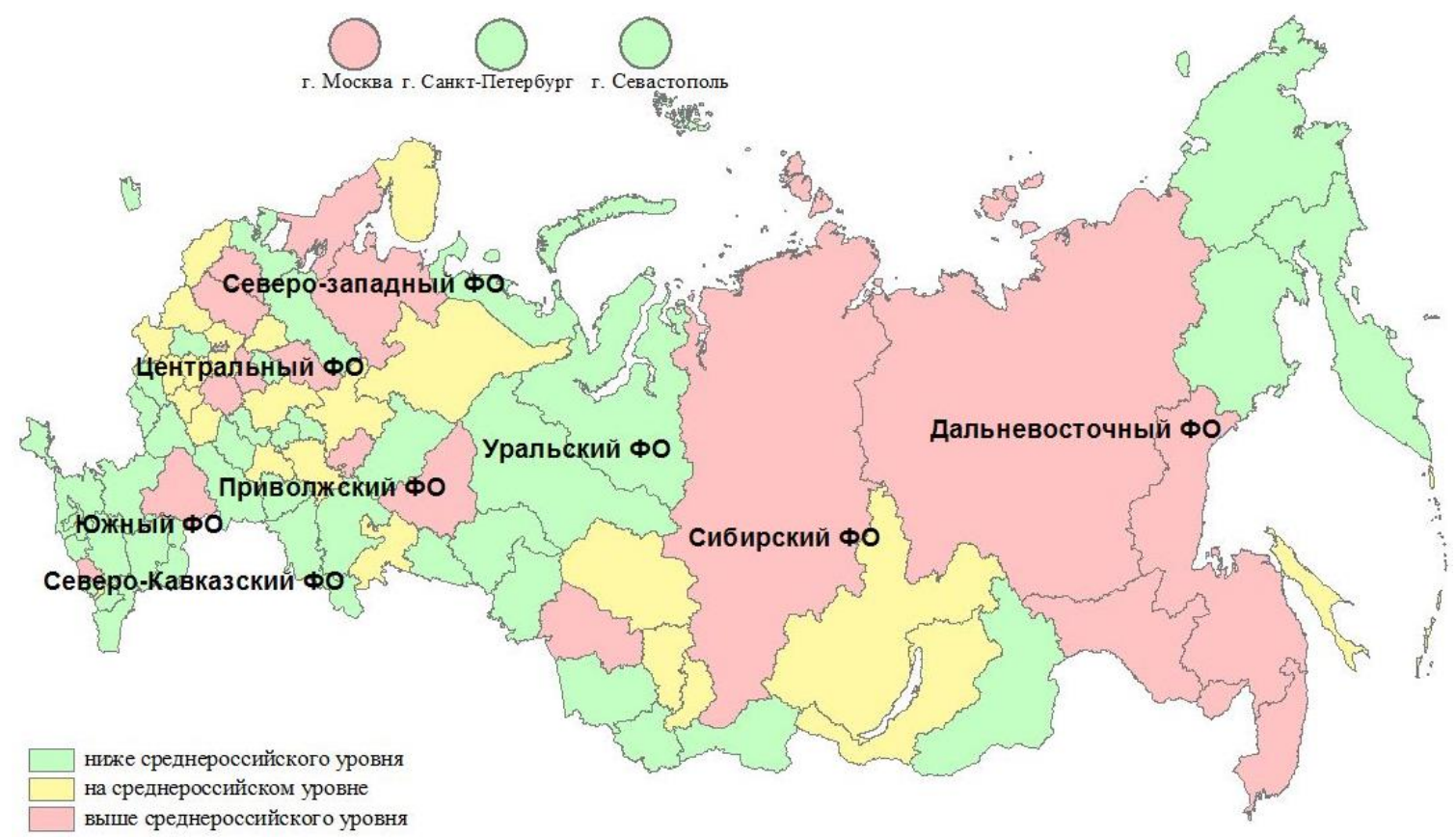

Рис. 41. Распределение субъектов Российской Федерации по уровню дополнительных случаев заболеваемости детского населения некоторыми инфекционными и паразитарными заболеваниями, обусловленных микробным и паразитарным загрязнением почв селитебных территорий, 2020 год 
Государственный доклад «О состоянии санитарно-эпидемиологического благополучия населения в Российской Федерации в 2020 году»

\subsection{4. Мониторинг безопасности продовольственного сырья и пищевых продуктов}

В 2020 году на территории Российской Федерации органами и организациями Роспотребнадзора было отобрано и исследовано 1,572 млн проб отечественной и импортной пищевой продукции. Динамика количества исследованных проб за период 2011-2020 гг. представлена на рис. 42.

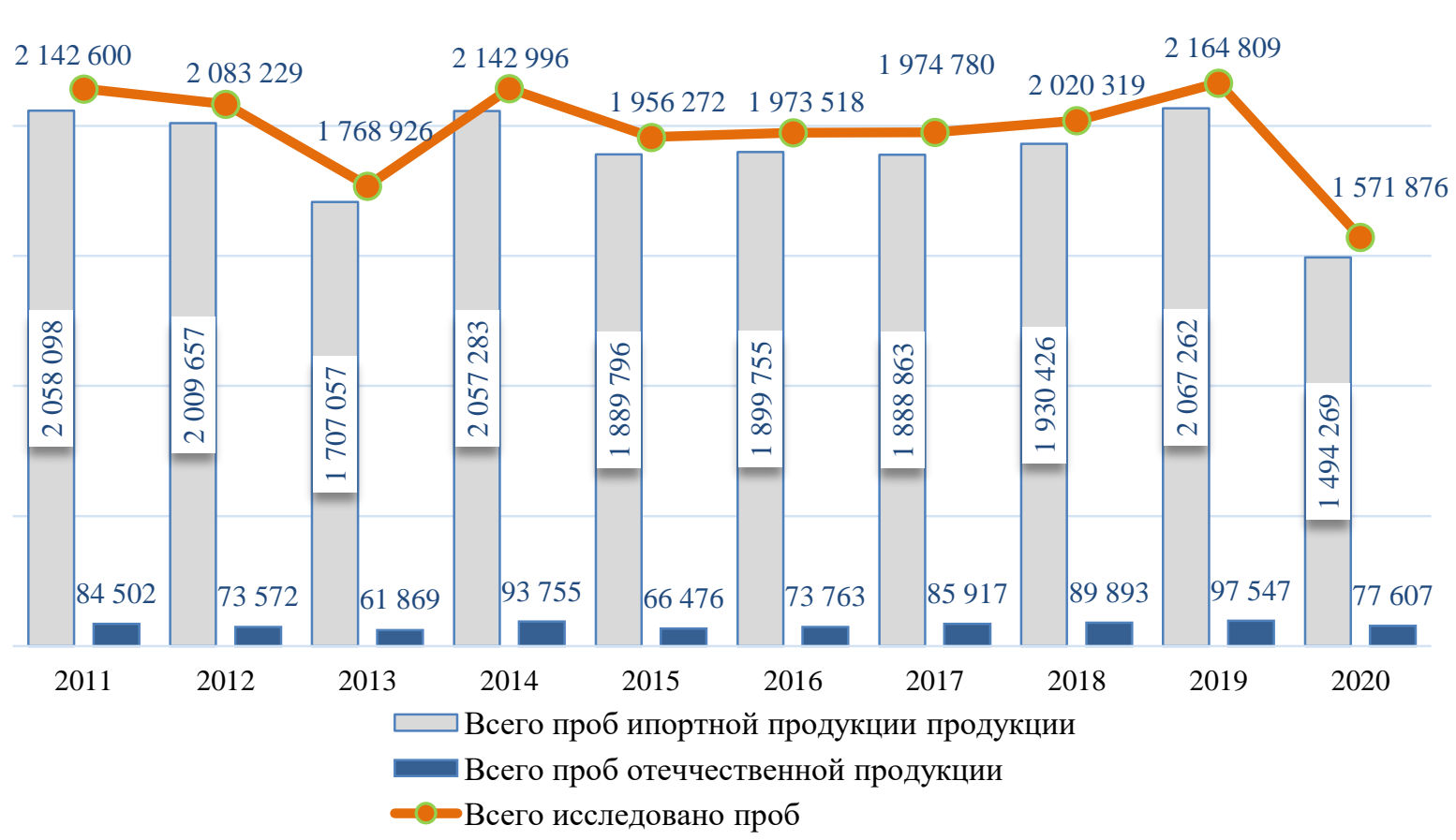

Рис. 42. Динамика количества исследованных проб пищевой продукции, 2011-2020 гг.

За период 2011-2020 гг. произошло снижение доли проб пищевой продукции, не соответствующих санитарно-эпидемиологическим требованиям как по санитарнохимическим (с 2,95\% в 2011 г. до 0,4\% в 2020 г.), так и по микробиологическим (с 4,84 \% в 2011 г. до 3,54 \% в 2020 г.) показателям (рис. 43).

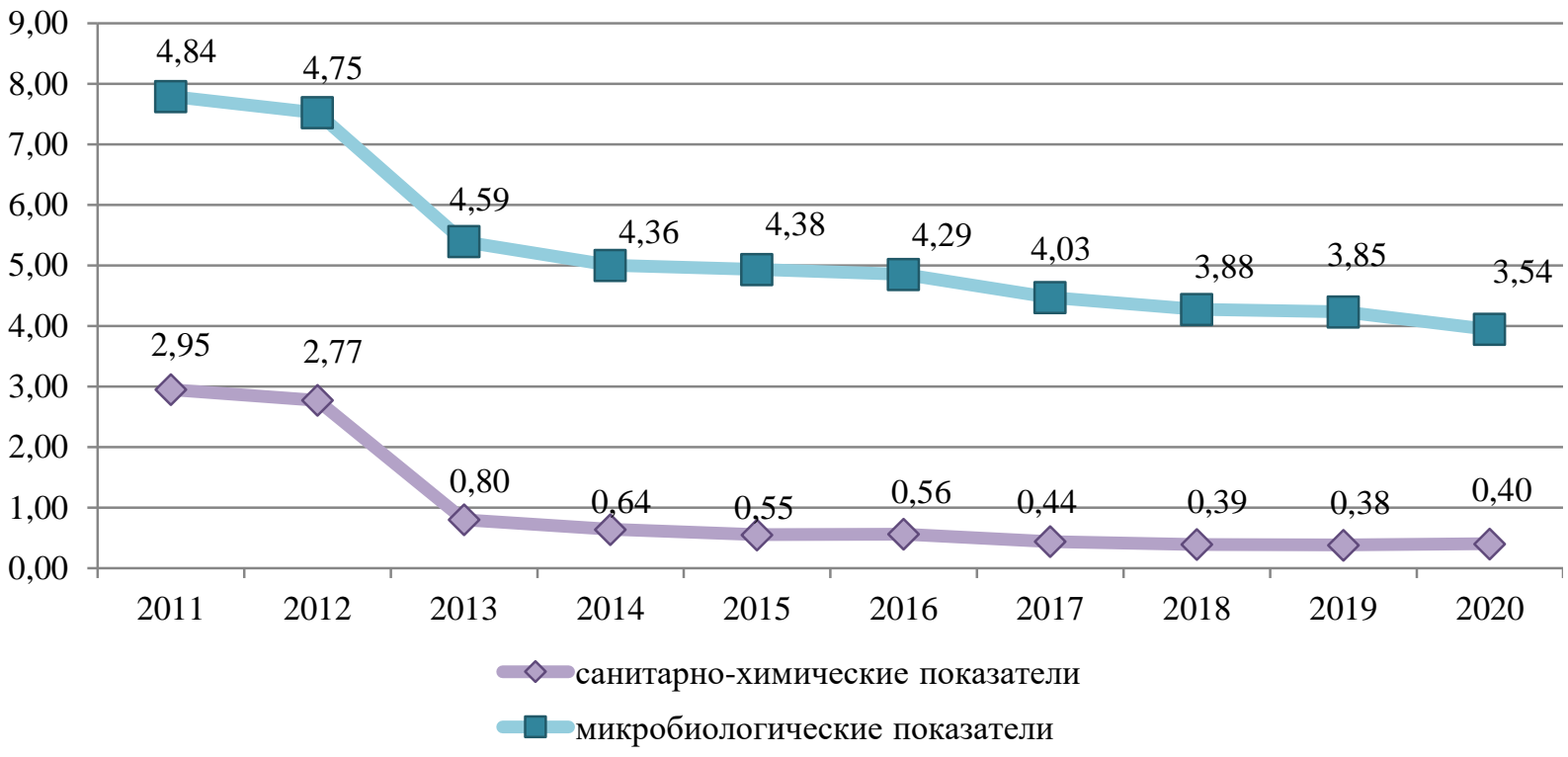

Рис. 43. Доля проб пищевой продукции, не соответствующих гигиеническим нормативам по микробиологическим и санитарно-химическим показателям, 2011-2020 гг., \%. 
Снизилась доля проб отечественной продукции, не соответствующих санитарноэпидемиологическим требованиям по санитарно-химическим показателям $(3,0 \%$ - в 2011 г., 0,42 \% - в 2020 г.) (рис. 44).

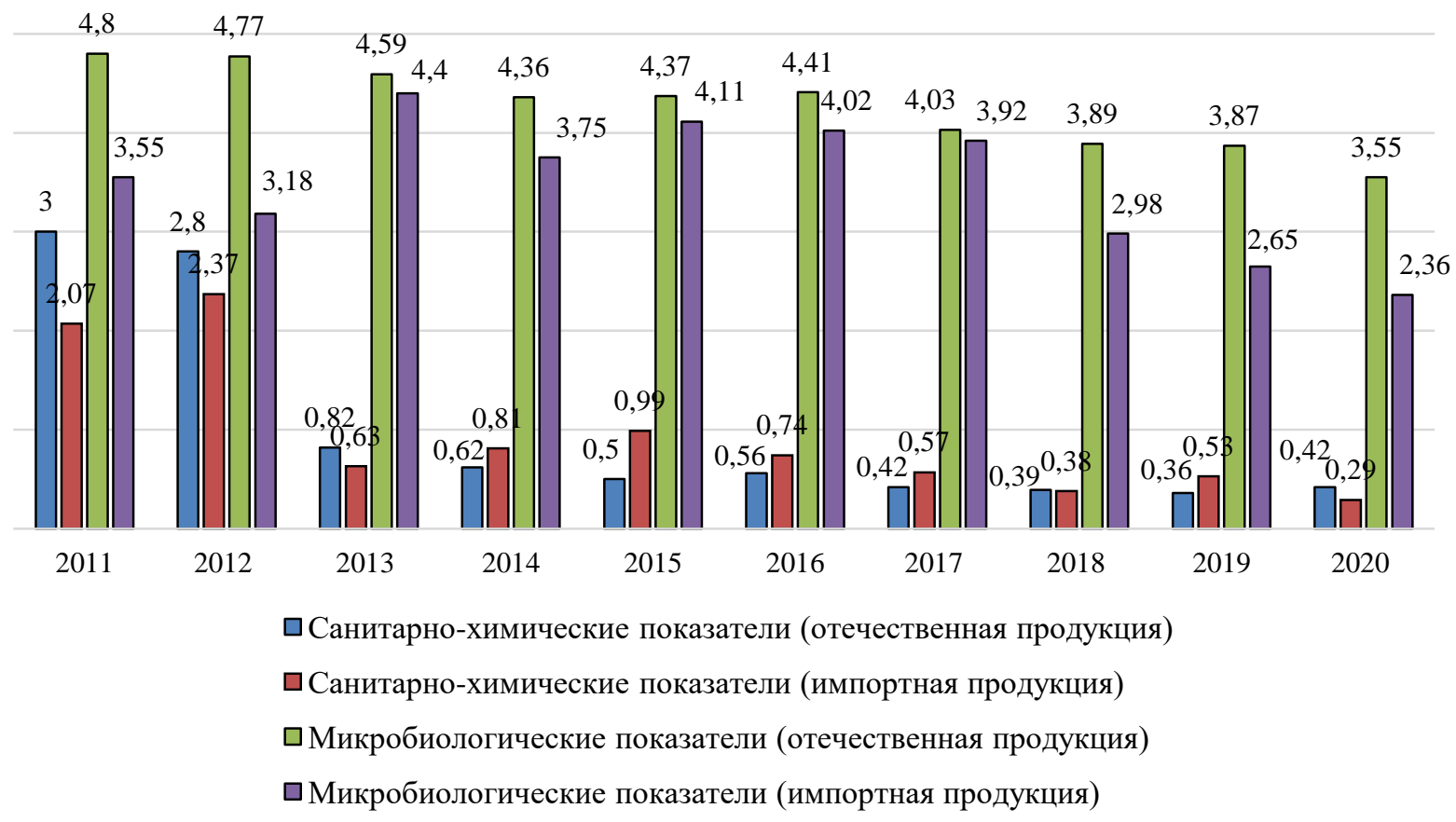

Рис. 44. Доля проб отечественной и импортируемой пищевой продукции, не соответствующих санитарно-эпидемиологическим требованиям по санитарно-химическим и микробиологическим показателям, 2011-2020 гг., \%

Доля проб импортируемой продукции, не соответствующих санитарноэпидемиологическим требованиям по санитарно-химическим показателям, в целом по России в 2020 г. составила $0,29 \%$ (2,07\% - в 2011 г.). Доля проб импортируемой продукции, не соответствующих нормативам по микробиологическим показателям, составила $2,36 \%(3,55 \%$ - в 2011 г.).

В 2020 г. по сравнению с 2019 г. снизилась доля проб продукции, не соответствующих санитарно-эпидемиологическим требованиям по микробиологическим показателям, в 28 группах из 47: «пресервы» - на 3,56\%, «продукция для детей 6 лет и старше» - на 2,74 \%, «консервы рыбные» - на 1,79\%, «кулинарные изделия, вырабатываемые по нетрадиционной технологии» - на 1,32 \%.

Вместе с тем отмечался рост доли проб, не соответствующих санитарноэпидемиологическим требованиям по микробиологическим показателям, в группах отечественной продукции: «пресервы»-с 0,21 \% в 2019 г. до 0,62 \% в 2020 г.; «консервы рыбные» - с 0,19\% до 0,56\%; «консервы молочные» - с 0,0\% до 0,24\%; в группах отечественной продукции: «зерно (семена)» - с 0,0 \% в 2019 г. до 14,3\% в 2020 г.; «птица, яйца и продукты их переработки» - с 4,9\% до 7,1\%; «молоко и молочные продукты»- с 2,5\% до 3,3\%.

Незначительно возросла доля проб продукции, не соответствующих санитарноэпидемиологическим требованиям по санитарно-химическим показателям, в группах «мясо и мясная продукция» (отечественная) - с 0,11\% в 2019 г. до 0,43 \% в 2020 г.; «пищевая продукция для детей с 6 лет и старше» (отечественная) - с 0,00 \% в 2019 г. до $0,28 \%$ в 2020 г. 
Государственный доклад «О состоянии санитарно-эпидемиологического благополучия населения в Российской Федерации в 2020 году»

Приоритетными контаминантами по доле проб, не соответствующих санитарноэпидемиологическим требованиям, остаются нитраты (табл. 8).

Таблица 8

Доля проб пищевой продукции, не соответствующих санитарноэпидемиологическим требованиям по содержанию химических веществ, в Российской Федерации, \%

\begin{tabular}{|c|c|c|c|c|c|c|c|c|c|c|c|}
\hline $\begin{array}{c}\text { Контаминанты } \\
\text { /годы }\end{array}$ & 2011 & 2012 & 2013 & 2014 & 2015 & 2016 & 2017 & 2018 & 2019 & 2020 & $\begin{array}{c}\text { Темп } \\
\text { прироста к } \\
2011 \text { г., \% }\end{array}$ \\
\hline Нитраты & 2,35 & 2,62 & 2,31 & 1,86 & 1,54 & 1,29 & 1,05 & 1,09 & 1,26 & 1,21 & $-48,51$ \\
\hline Пестициды & 0,03 & 0,02 & 0,01 & 0,03 & 0,01 & 0 & 0,03 & 0,01 & 0 & 0,04 & $+33,3$ \\
\hline Микотоксины & 0,13 & 0,05 & 0,02 & 0,03 & 0,02 & 0,03 & 0,04 & 0,03 & 0,02 & 0,04 & $-69,23$ \\
\hline Нитрозамины & 0 & 0,01 & 0 & 0,03 & 0 & 0 & 0,02 & 0 & 0 & 0 & - \\
\hline $\begin{array}{l}\text { Токсичные } \\
\text { элементы }\end{array}$ & 0,14 & 0,07 & 0,04 & 0,01 & 0,03 & 0,02 & 0,02 & 0,01 & 0,01 & 0,03 & $-78,57$ \\
\hline Гистамин & - & 0,12 & 0,29 & 0,8 & 0,26 & 0,11 & 0,12 & 0 & 0 & 0,1 & - \\
\hline
\end{tabular}

Доля проб продукции, не соответствующих установленным требованиям по показателям качества и идентификации (физико-химическим), в 2020 г. была ниже аналогичного показателя предыдущих лет и составила 3,3 \% (2019 г. - 3,78 \%; 2018 г. 3,86 \%; 2017 г. - 4,14 \%). Отмечался рост доли проб, не соответствующих санитарноэпидемиологическим требованиям по физико-химическим показателям, в следующих группах пищевой продукции: «бахчевые культуры» - с 4,26 \% в 2019 г. до 12,04 \% в 2020 г.; «консервы рыбные» - с 3,97 \% в 2019 г. до 10,88 \% в 2020 г.

По ассортименту импортируемой продукции ухудшилось качество хлебобулочных изделий с 0 \% в 2019 г. до 13,9\% в 2020 г. и мясных консервов с 0 \% в 2019 г. до $10,0 \%$ в 2020 г.

В разрезе субъектов Российской Федерации данные о несоответствии продукции по показателям санитарно-эпидемиологическим требований представлены на рис. 45.

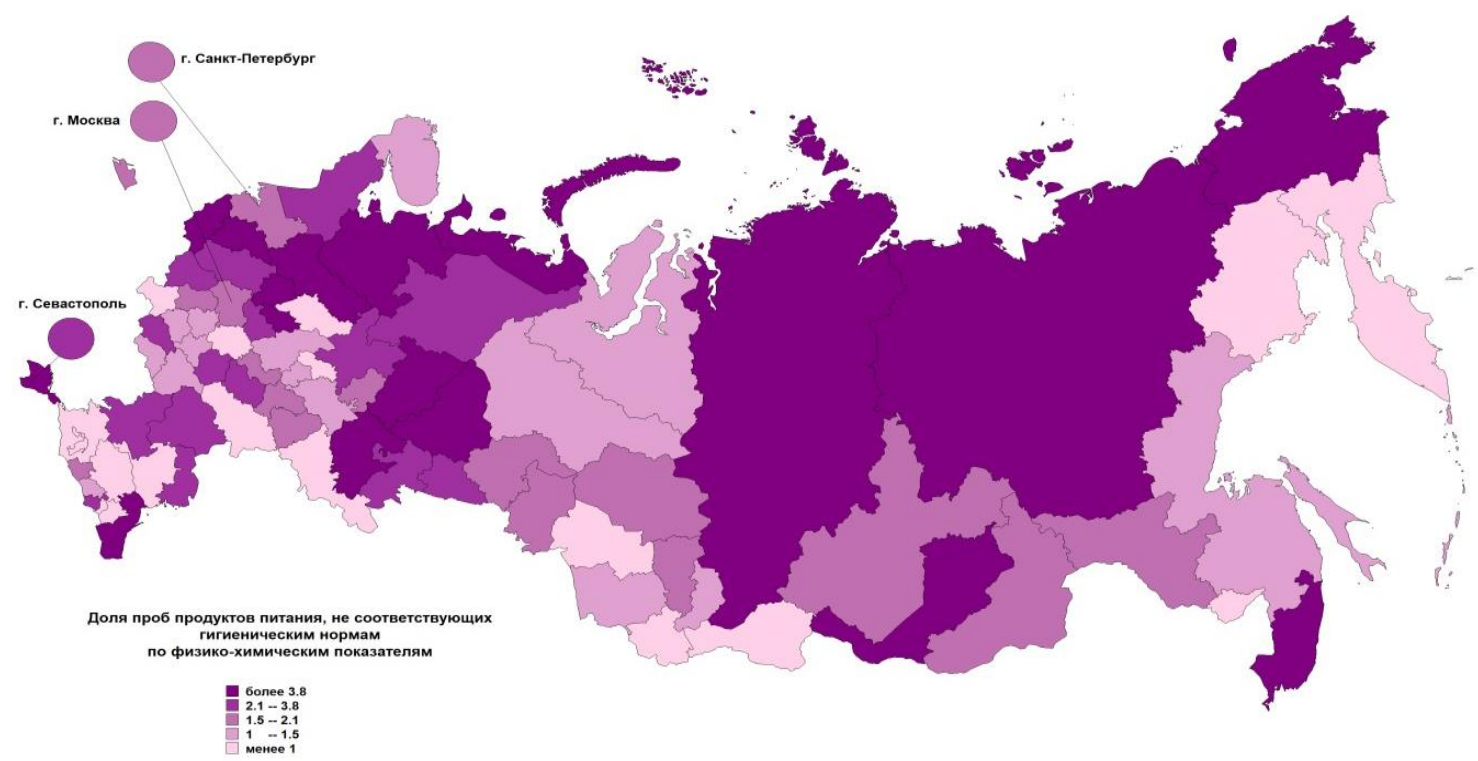

Рис. 45. Доля проб продукции, не соответствующих установленным требованиям по физико-химическим показателям, 2020 год, \% 
За 2020 г. опорными ИЛЦ ФБУЗ «Центр гигиены и эпидемиологии Роспотребнадзора» в субъектах Российской Федерации проведено 152507 исследований по определению незаявленных веществ, доля контаминированных образцов от общего количества исследованных составила 1,24 \%.

Наибольшее количество контаминированных образцов представлено по группам показателей: антибиотики; пестициды; глицидол. Также в образцах обнаружены консерванты, подсластители, красители, микотоксины, никотин, кокцидиостатики, антигельментики, ингибиторы фосфодиэстеразы-5.

Наибольшее количество контаминированных образцов выявлено в плодоовощной продукции (41,58 \%); масложировой продукции и масличном сырье (16,36 \%); молоке и продуктах его переработки (14,26 \%); мясе и мясопродуктах $(13,05 \%)$.

При проведении в 2020 г. мониторинговых исследований по идентификации пестицидов в пищевой продукции в 0,15 \% образцов плодоовощной продукции наряду с нормируемыми пестицидами (ДДТ, гамма-ГХЦГ, ДДД, ДДЭ) выявлены незаявленные пестициды (крезоксим-метил, малатион, металаксил, перметрин, пиридабен, пириметанил, пиримифос-метил, процимидон, триадимефон, фенвалерат I, II, фозалон, фталид, хлорпирифос, цигалотрин, циперметрин I, II, III, IV).

Доля проб пищевой продукции, не соответствующих санитарноэпидемиологическим требованиям по содержанию антибиотиков, паразитологическим показателям, представлена в табл. 9.

Таблица 9

Доля проб пищевой продукции, не соответствующих санитарно-эпидемиологическим требованиям по содержанию антибиотиков и паразитологическим показателям, в Российской Федерации, \%

\begin{tabular}{|l|c|c|c|c|c|c|c|c|c|c|c|}
\hline $\begin{array}{c}\text { Показатели/ } \\
\text { годы }\end{array}$ & 2011 & 2012 & 2013 & 2014 & 2015 & 2016 & 2017 & 2018 & 2019 & 2020 & $\begin{array}{c}\text { Темп } \\
\text { прироста } \\
\text { к 2011 г., } \\
\%\end{array}$ \\
\hline Антибиотики & 0,36 & 0,45 & 0,34 & 0,48 & 0,59 & 0,58 & 0,53 & 0,41 & 0,30 & 0,23 & $-36,11$ \\
\hline $\begin{array}{l}\text { Паразитологи- } \\
\text { ческие } \\
\text { показатели }\end{array}$ & 0,93 & 0,86 & 0,63 & 0,49 & 0,48 & 0,47 & 0,43 & 0,37 & 0,42 & 0,32 & $-65,59$ \\
\hline
\end{tabular}

Планомерное дооснащение с 2017 г. испытательных лабораторных центров высокотехнологичным оборудованием позволило увеличить количество исследований в четыре раза и увеличить номенклатуру показателей до 90 наименований антимикробных веществ, что в 1,7 раза больше, чем, в 2018-2019 гг. (51 наименование).

В 2020 г. исследовано на определение остаточных количеств антимикробных препаратов 31808 образцов пищевой продукции и продовольственного сырья (116 725 исследований), из них 73 не соответствовали санитарно-эпидемиологическим требованиям $(0,23 \%)$. Кроме того, установлена контаминация антимикробными препаратами 1303 образцов $(4,55 \%)$.

В структуре пищевой продукции наиболее контаминированы: молоко и молочные продукты $(39,6 \%)$, мясо и мясопродукты (36,0 \%). Превышение допустимого уровня содержания антимикробных препаратов преобладает в молоке и молочных продуктах (57,9 \%). В 2018-2019 гг. контаминирование, а также превышение допустимых уровней значительно преобладало в продукции из мяса и составляло $88,6 \%$ и $62,7 \%$ соответственно.

Данные по номенклатуре определяемых антимикробных препаратов (по группам) в пищевой продукции и продовольственном сырье представлены в таблице 10. 
Данные по определению антимикробных препаратов в пищевой продукции и продовольственном сырье, 2020 г.

\begin{tabular}{|c|l|c|c|}
\hline \multirow{2}{*}{ № } & \multirow{2}{*}{ П/п } & Наименование показателя & \multicolumn{2}{|c|}{ Количество исследований } \\
\cline { 3 - 4 } & & Всего исследований & из них контаминированных \\
\hline 1 & Тетрациклины & 33470 & 417 \\
\hline 2 & Пенициллины & 21953 & 302 \\
\hline 3 & Амфениколы & 21838 & 765 \\
\hline 4 & Аминогликозиды & 12249 & 76 \\
\hline 5 & Хинолоны & 8477 & 31 \\
\hline 6 & Полипептиды & 7630 & 90 \\
\hline 7 & Сульфаниламиды & 5297 & 16 \\
\hline 8 & Нитрофураны & 4045 & 2 \\
\hline 9 & Нитроимидазолы & 1063 & 5 \\
\hline 10 & Кокцидиостатики & 330 & 0 \\
\hline 11 & Линкозамиды & 201 & 0 \\
\hline 12 & Плевромутилины & 142 & 0 \\
\hline 13 & Макролиды & 30 & 1708 \\
\hline & ВСЕГО: & 116725 & \\
\hline
\end{tabular}

В 2020 г. в общем объеме контаминирования пищевой продукции преобладают амфениколы $(44,8 \%)$ и тетрациклины $(54,7 \%)$.

В рамках пострегистрационного мониторинга контролируется наличие ГМО в пищевой продукции, а также присутствие информации для потребителей о содержании ГМО в пищевом продукте. По отчетным данным управлений Роспотребнадзора по субъектам Российской Федерации, на наличие ГМО в 2020 г. исследовано 24198 проб пищевой продукции, из них в 3 обнаружены ГМО (более 0,9 \%). Доля проб продукции с обнаруженными ГМО в целом по России в 2020 г. составила 0,005 \% (2019 г. - 0,04 \%).

Доля проб импортируемой продукции с выявленными ГМО (более 0,9 \%) в 2020 г. составила $0,07 \%$ (2019 г. - 0,22 \%) (табл. 11).

Таблица 11

Результаты обнаружения зарегистрированных линий ГМО в пищевой продукции в Российской Федерации, 2011-2020 гг.

\begin{tabular}{|c|c|c|c|}
\hline Годы & & Всего & $\begin{array}{c}\text { В том числе } \\
\text { импортируемая }\end{array}$ \\
\hline 1 & 2 & 3 & 4 \\
\hline \multirow{3}{*}{2011} & исследовано проб на наличие ГМО & 27123 & 3192 \\
\cline { 2 - 4 } & количество проб с ГМО & 28 & 5 \\
\cline { 2 - 4 } & \% проб с ГМО & 0,1 & 0,15 \\
\hline \multirow{3}{*}{2012} & исследовано проб на наличие ГМО & 27593 & 2887 \\
\cline { 2 - 4 } & количество проб с ГМО & 22 & 8 \\
\cline { 2 - 4 } & \% проб с ГМО & 0,08 & 0,28 \\
\hline \multirow{3}{*}{2013} & исследовано проб на наличие ГМО & 27642 & 5133 \\
\cline { 2 - 4 } & количество проб с ГМО & 18 & 0,16 \\
\cline { 2 - 4 } & \% проб с ГМО & 0,07 & 5 \\
\hline
\end{tabular}


Государственный доклад «О состоянии санитарно-эпидемиологического благополучия населения в Российской Федерации в 2020 году»

Продолжение табл. 11

\begin{tabular}{|c|c|c|c|}
\hline 1 & 2 & 3 & 4 \\
\hline \multirow{3}{*}{2014} & исследовано проб на наличие ГМО & 26655 & 2612 \\
\hline & количество проб с ГМО & 37 & 18 \\
\hline & \% проб с ГМО & 0,14 & 0,69 \\
\hline \multirow{3}{*}{2015} & исследовано проб на наличие ГМО & 25729 & 1963 \\
\hline & количество проб с ГМО & 22 & 4 \\
\hline & \% проб с ГМО & 0,09 & 0,20 \\
\hline \multirow{3}{*}{2016} & исследовано проб на наличие ГМО & 24684 & 1744 \\
\hline & количество проб с ГМО & 12 & 1 \\
\hline & \% проб с ГМО & 0,05 & 0,06 \\
\hline \multirow{3}{*}{2017} & исследовано проб на наличие ГМО & 26019 & 1825 \\
\hline & количество проб с ГМО & 17 & 14 \\
\hline & \% проб с ГМО & 0,07 & 0,77 \\
\hline \multirow{3}{*}{2018} & исследовано проб на наличие ГМО & 27188 & 1713 \\
\hline & количество проб с ГМО & 21 & 4 \\
\hline & \% проб с ГМО & 0,08 & 0,23 \\
\hline \multirow{3}{*}{2019} & исследовано проб на наличие ГМО & 36921 & 2779 \\
\hline & количество проб с ГМО & 16 & 8 \\
\hline & \% проб с ГМО & 0,04 & 0,22 \\
\hline \multirow{3}{*}{2020} & исследовано проб на наличие ГМО & 24198 & 1362 \\
\hline & количество проб с ГМО & 3 & 1 \\
\hline & \% проб с ГМО & 0,012 & 0,07 \\
\hline
\end{tabular}

При этом отсутствовала информация для потребителя о наличии ГМО в 1 случае из 3 (2019 г. - в 8 случаях из 16, в 2018 г. - в 1 случае из 21, в 2017 г. - в 1 случае из 17, в 2016 г. - в 2 из 12, в 2015 г. - 2 из 22, в 2014 г. - 7 из 37, в 2013 г. - в 10 из 18, в 2012 г. - в 13 из 22, в 2011 г. - в 9 из 28).

В 2020 г. молекулярно-биологические исследования по определению видовой принадлежности сырьевого состава мясной и рыбной продукции осуществляли 38 ФБУЗ «Центр гигиены и эпидемиологии» в субъектах Российской Федерации. Выполнено 6126 исследований, из них 4,3 \% с выявлением незаявленных видов $(75,3 \%$ - видовая принадлежность мяса, птицы; 24,7 \% - видовая принадлежность рыбы).

В 2020 г. в структуре ПЦР-исследований пищевой продукции 71,9 \% составили исследования с целью выявления ГМО, 17,6 \% - индикация возбудителей инфекционных болезней, $10,5 \%$ - идентификации сырьевого состава мясной и рыбной продукции.

Проведение лабораторного контроля, наряду с привлечением экспертов и экспертных организаций при осуществлении контроля технических регламентов Таможенного союза (далее - ТР ТС) и технических регламентов Евразийского экономического союза (далее - ТР ЕАЭС), является одним из ведущих инструментов в обеспечении санитарно-эпидемиологического благополучия населения, установлении причинно-следственных связей и основным доказательством при выявлении, предупреждении и пресечении правонарушений санитарного законодательства.

Контрольно-надзорные мероприятия, осуществляемые территориальными органами Роспотребнадзора, сопровождались проведением лабораторных и инструментальных исследований, доля которых увеличилась с 61,9 \% в 2014 г. до 67,2 \% в 2020 г., а также привлечением экспертов и экспертных организаций, доля которых также увеличилась с 62,1\% в 2014 г. до 68,4\% в 2020 г., что позволило повысить объективность проверок. 
Государственный доклад «О состоянии санитарно-эпидемиологического благополучия населения в Российской Федерации в 2020 году»

Сведения о доле проб пищевой продукции, не соответствующих установленным требованиям, за период 2014-2020 гг. приведены в табл. 17.

Таблица 12

Доля проб пищевой продукции, не соответствующих установленным требованиям ТР ТС и ТР ЕАЭС, в Российской Федерации, \%

\begin{tabular}{|c|c|c|c|}
\hline \multirow{2}{*}{ Год } & \multirow{2}{*}{$\begin{array}{c}\text { Количество исследованных } \\
\text { проб продукции, всего }\end{array}$} & \multicolumn{2}{|c|}{ из них не отвечают установленным требованиям } \\
\cline { 3 - 4 } & 304880 & абс. & $\%$ \\
\hline 2014 & 372061 & 10383 & 3,4 \\
\hline 2015 & 422360 & 12712 & 3,4 \\
\hline 2016 & 449575 & 15795 & 3,7 \\
\hline 2017 & 487769 & 14322 & 3,2 \\
\hline 2018 & 567500 & 15891 & 3,3 \\
\hline 2019 & 235528 & 18826 & 3,32 \\
\hline 2020 & & 7793 & 3,31 \\
\hline
\end{tabular}

Общее количество отобранных и исследованных проб на соответствие требованиям технических регламентов Таможенного союза и Евразийского экономического союза в абсолютных числах в 2020 г. в 2,6 раза ниже данного показателя 2019 г., что объясняется эпидемиологической ситуацией, связанной с новой коронавирусной инфекцией (COVID-19), и, как следствие, со снижением количества проводимых контрольно-надзорных мероприятий.

В 2020 г. в 10 субъектах Российской Федерации доля проб пищевой продукции, не соответствующих установленным требованиям, превысила общероссийский показатель (2,58 \%) более чем в 2 раза (свыше 5,2 \%), данные приведены в табл. 13.

Таблица 13

\section{Субъекты Российской Федерации с удельным весом проб пищевой продукции, не соответствующих установленным требованиям, 2020 г., \%}

\begin{tabular}{|c|l|c|}
\hline $\begin{array}{c}\text { Место } \\
\text { по рангу }\end{array}$ & \multicolumn{1}{|c|}{ Субъекты Российской Федерации } & $\begin{array}{c}\text { Удельный вес проб, } \\
\text { не соответствующих требованиям, } \\
\text { \% от общего количества проб }\end{array}$ \\
\hline 1 & Республика Саха (Якутия) & 8,73 \\
\hline 2 & Новгородская область & 8,54 \\
\hline 3 & Псковская область & 8,48 \\
\hline 4 & Владимирская область & 6,93 \\
\hline 5 & Республика Карелия & 6,85 \\
\hline 6 & Сахалинская область & 6,34 \\
\hline 7 & Московская область & 6,09 \\
\hline 8 & Приморский край & 5,77 \\
\hline 9 & г. Москва & 5,65 \\
\hline 10 & Калужская область & 5,2 \\
\hline
\end{tabular}

По результатам мониторинга качества и безопасности пищевой продукции, находившейся в 2020 г. на потребительском рынке, в целом по Российской Федерации органами Роспотребнадзора забраковано 27980 партий продукции объемом 1210,4 т, в том числе продукции отечественного производства: «молоко и молочная продукция» 
(354,9 т против 192,6 т в 2019 г.), «соки, нектары, сокосодержащие напитки» (свыше 130,8 т против 10,9 т в 2019 г.), «консервы» (55,6 т против 20,9 т в 2019 г.), «картофель» (110,3 т против 94,2 т в 2019 г.), «грибы» (30,1 т против 0,6 т в 2019 г).

Увеличилось количество забракованной продукции импортного производства по сравнению с 2019 г. в группах продуктов «грибы» (6,3 т против 0,01 т в 2019 г.), «молоко и молочные продукты» $(10,8$ т против 5,0 т в 2019 г.), «консервы плодово-ягодные» $(2,8$ т против 0,05 т в 2019 г.).

При реализации федерального проекта «Укрепление общественного здоровья» национального проекта «Демография» (далее проект «Демография») в 24 пилотных регионах за 2019-2020 гг. было проведено более 590000 исследований пищевых продуктов (в 2020 г. отмечено увеличение числа исследований в 7,5 раза) в 15658 образцах, отобранных более чем в 2900 торговых точках.

Исследования проводились по 117 показателям качества и безопасности, исследованы 11 групп пищевой продукции (хлебные продукты, фрукты, овощи и продукты их переработки, овощи, мясо и мясные изделия, яйца и яйцепродукты, молочная продукция, рыба и продукты ее переработки, масложировая продукция, кондитерские изделия, биологически активные добавки к пище, йодированная соль) по 55 подгруппам.

Всего за 2020 г. отобрано 12578 проб продукции, по которым проведено 436186 исследований по показателям качества и 172578 исследований по показателям безопасности, из них в 12,0 \% выявлены несоответствия (2019 г. - 16,59 \%). Основные нарушениями являются: отклонение от данных этикетки по содержанию основных пищевых веществ и энергетической ценности более чем на $5 \%$; фальсификация молочной продукции немолочными жирами; выявление в мясных продуктах микробной трансглютаминазы (фермент, не разрешенный для использования в производстве пищевых продуктов на территории России и стран ЕАЭС); высокое содержание натрия в мясных переработанных и национальных мясных продуктах, рыбных консервах.

Оценка доступа населения в 2019-2020 гг. к отечественной пищевой продукции, способствующей ликвидации дефицита макро- и микронутриентов, проведена в 76844 торговых точек (в 2020 г. количество обследованных торговых точек было увеличено в 16,1 раза). Оценка обеспечения доступа населения к пищевой продукции, способствующей устранению дефицита макро- и микронутриентов, выявила, что данный показатель составляет 54,89 \% (44,74 \% в 2019 г., увеличение на 10,15 \%). К продукции, имеющей высокий уровень доступности по ассортименту, относятся: пшеничный хлеб, макароны, рис, сосиски (в 2019 г. - макароны, рис, сосиски, замороженные овощи, сыр). Отрицательный индекс доступности установлен для специализированной пищевой продукции для питания детей, мяса баранины, пресноводной рыбы, БАД к пище (в 2019 г. - говядина, соя).

Доступность по минимальным ценам в 2020 г. показана для следующих пищевых продуктов: курица, рыбные консервы, субпродукты, молоко, кефир, яйца, подсолнечное масло, макароны, овсяная крупа (в 2019 г. - курица, рыбные консервы, субпродукты, молоко, кефир, яйца, подсолнечное масло, макароны, овсяная крупа, капуста).

\subsection{5. Влияние потребления алкоголя и табакокурения на здоровье населения}

По данным Росстата (доступна информация по состоянию на 2019 г.) в структуре продаж алкогольных напитков в пересчете на душу населения по Российской Федерации в динамике количество потребляемой водки и ликероводочных изделий снизилось с 11,0 л/год в 2010 году до 5,7 л/год в 2019 году, шампанского - с 1,9 л/год до 1,2 л/год, пива с 70,3 л/год до 48,6 л/год (рис. 46). 


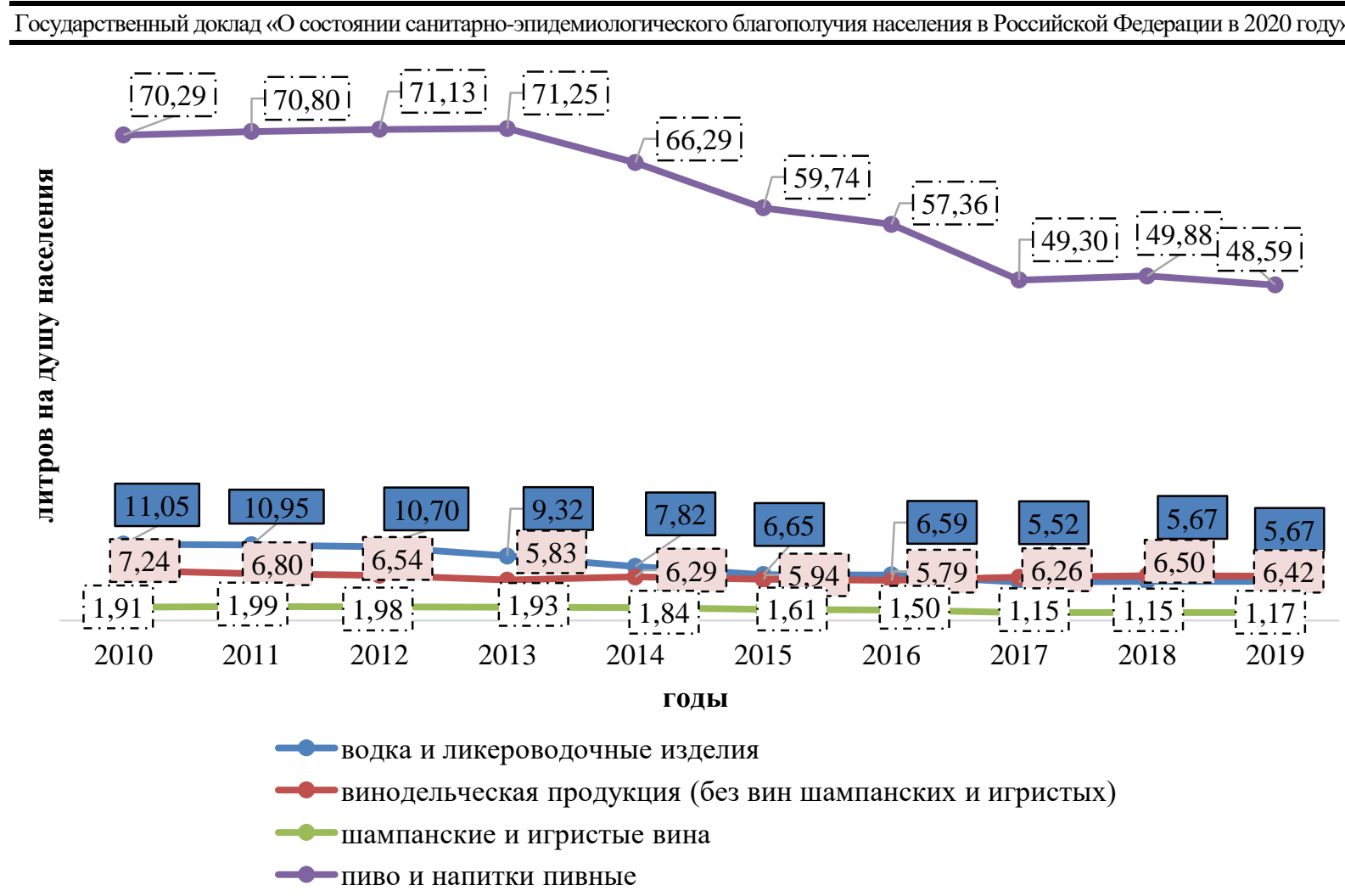

Рис. 46. Динамика продаж алкогольной продукции в Российской Федерации, литров на душу населения

Лидирующее место в продажах алкогольной продукции в 2019 году по-прежнему занимало пиво - 77,7 \% (в 2018 г. - 78,0 \%), виноградные и плодовые вина составляли 10,2 \% (в 2018 г. - 10,2 \%), водка и ликероводочные изделия - 9,0 \% (в 2018 г. - 8,9\%), шампанские и игристые вина - 1,8 \% (в 2018 г. - 1,8\%), коньяки - 1,3\% (в 2018 г. $1,2 \%)$.

Распределение объемов продаж населению водки и ликероводочных изделий, а также пива по субъектам Российской Федерации представлен на рис. 47 и 48.

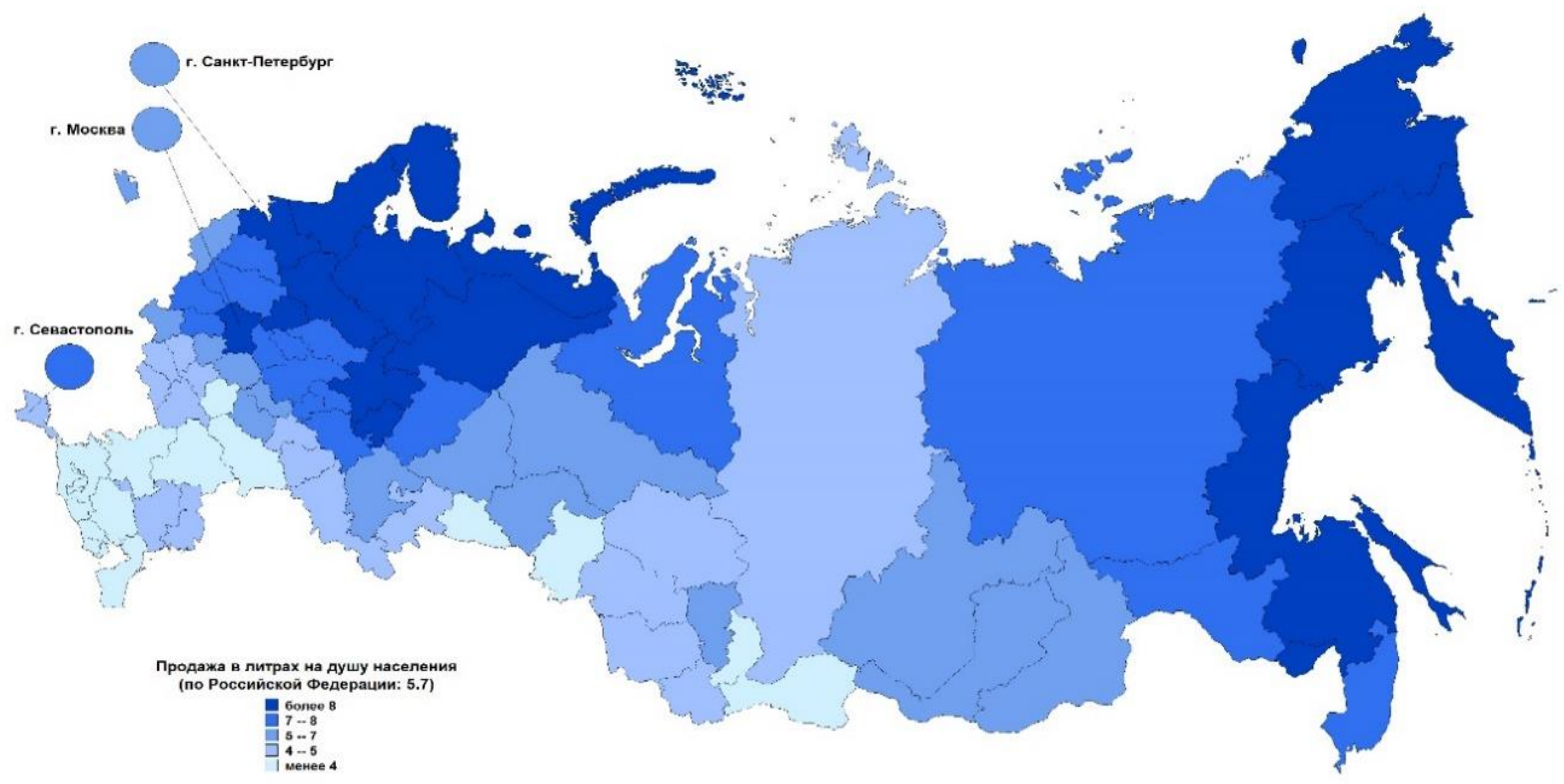

Рис. 47. Распределение объемов продаж населению водки и ликероводочных изделий по субъектам Российской Федерации, литров на душу населения 


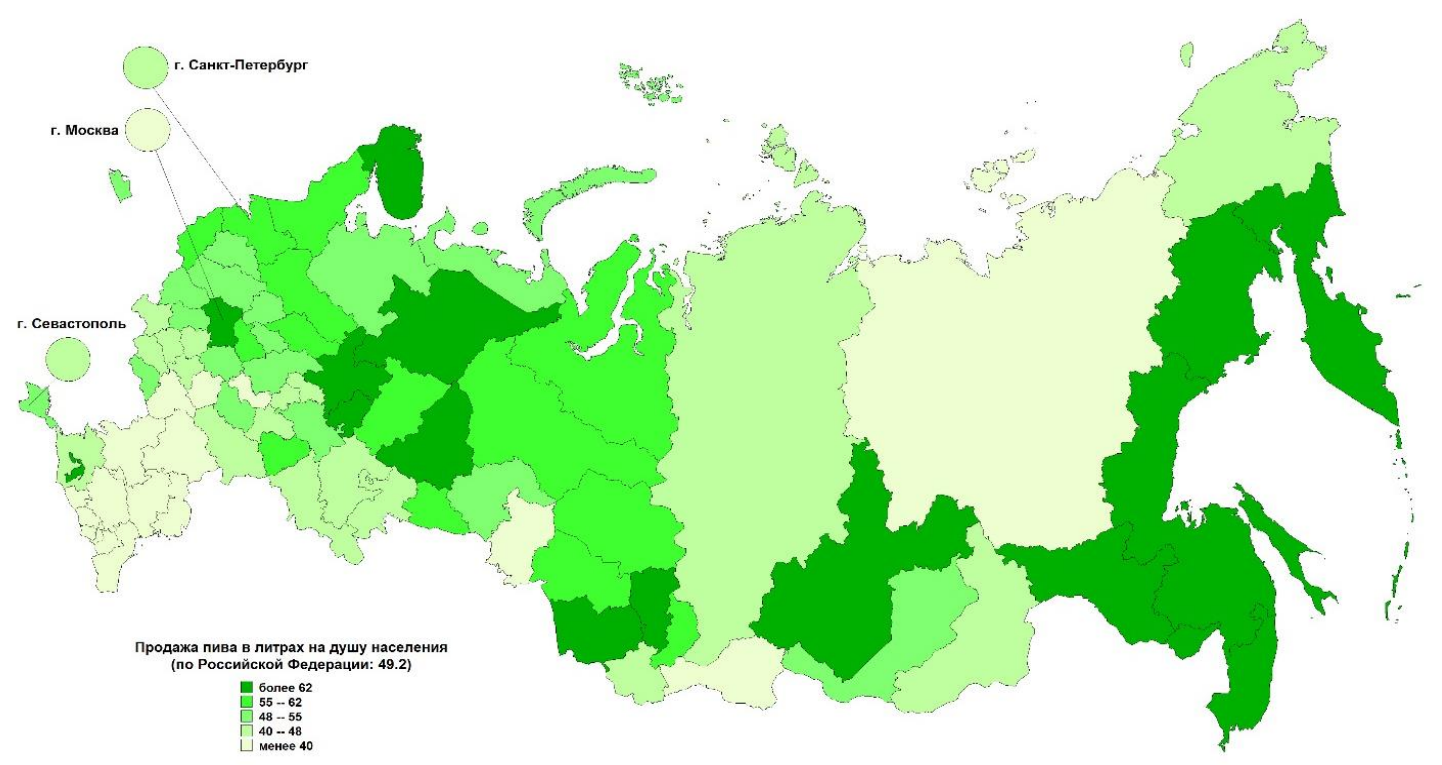

Рис. 48. Распределение объемов продаж населению пива по субъектам Российской Федерации, литров на душу населения

В Российской Федерации объем продаж населению алкогольной продукции по сравнению с 2018 г. (63,2 л/год на человека) в 2019 г. снизился и составил 61,8 л/год на человека.

Выявлена прямая зависимость распространенности психотических расстройств, связанных с употреблением алкоголя и синдром зависимости от алкоголя, алкогольными психозами, хроническим алкоголизмом с продажей в субъектах Российской Федерации населению водки и ликероводочных изделий, коньяка, винодельческой продукции, пива и пивных напитков.

\section{Оиенка динамики острых отравлений от спиртосодержащей продукции}

За период 2011-2020 гг. на территории Российской Федерации зарегистрировано 501892 случая острых отравлений спиртосодержащей продукцией, в том числе 130064 случая с летальным исходом $(25,9 \%)$.

В 2020 г. показатель острых отравлений от спиртосодержащей продукции составил 25,03 случая на 100 тыс. населения.

В 2020 г. по сравнению с 2019 г. отмечено снижение показателя острых отравлений спиртосодержащей продукцией в целом по Российской Федерации (на $27,4 \%$ ), и снижение показателя острых отравлений спиртосодержащей продукцией с летальным исходом (на 3,9 \%) (рис. 49, 50).

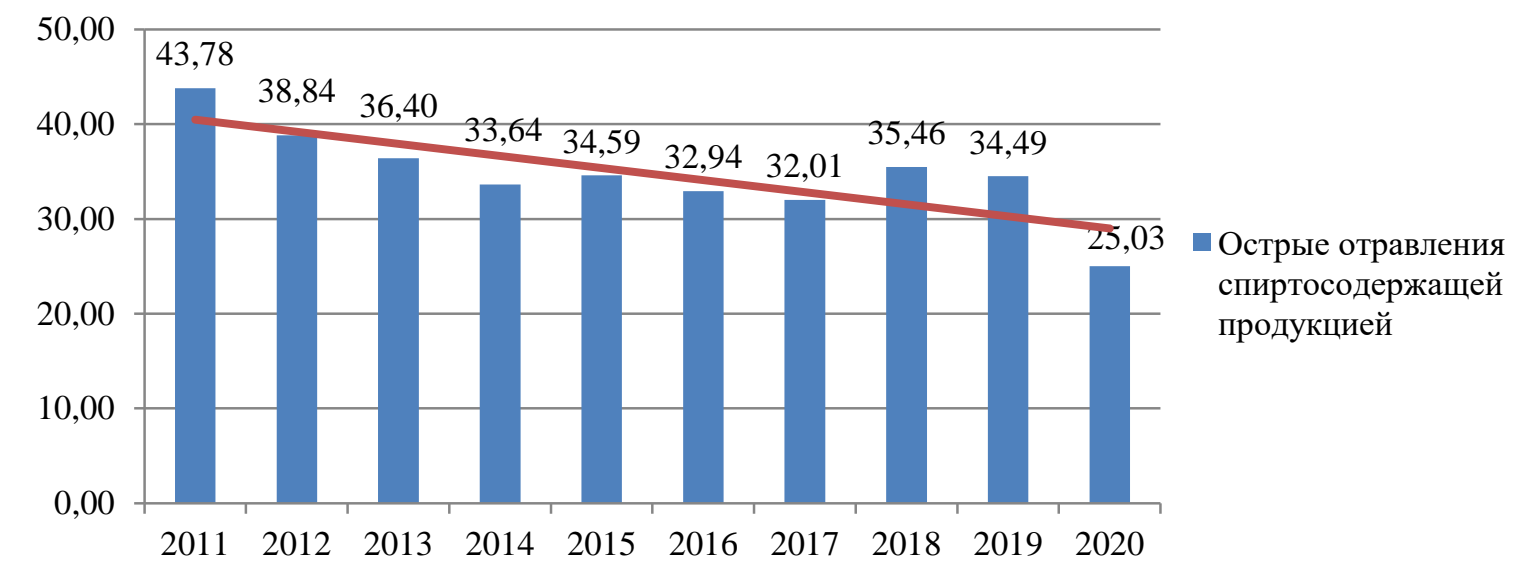

Рис. 49. Уровни острых отравлений спиртсодержащей продукцией среди всего населения Российской Федерации в динамике за 2011-2020 гг. (на 100000 человек) 
Государственный доклад «О состоянии санитарно-эпидемиологического благополучия населения в Российской Федерации в 2020 году»

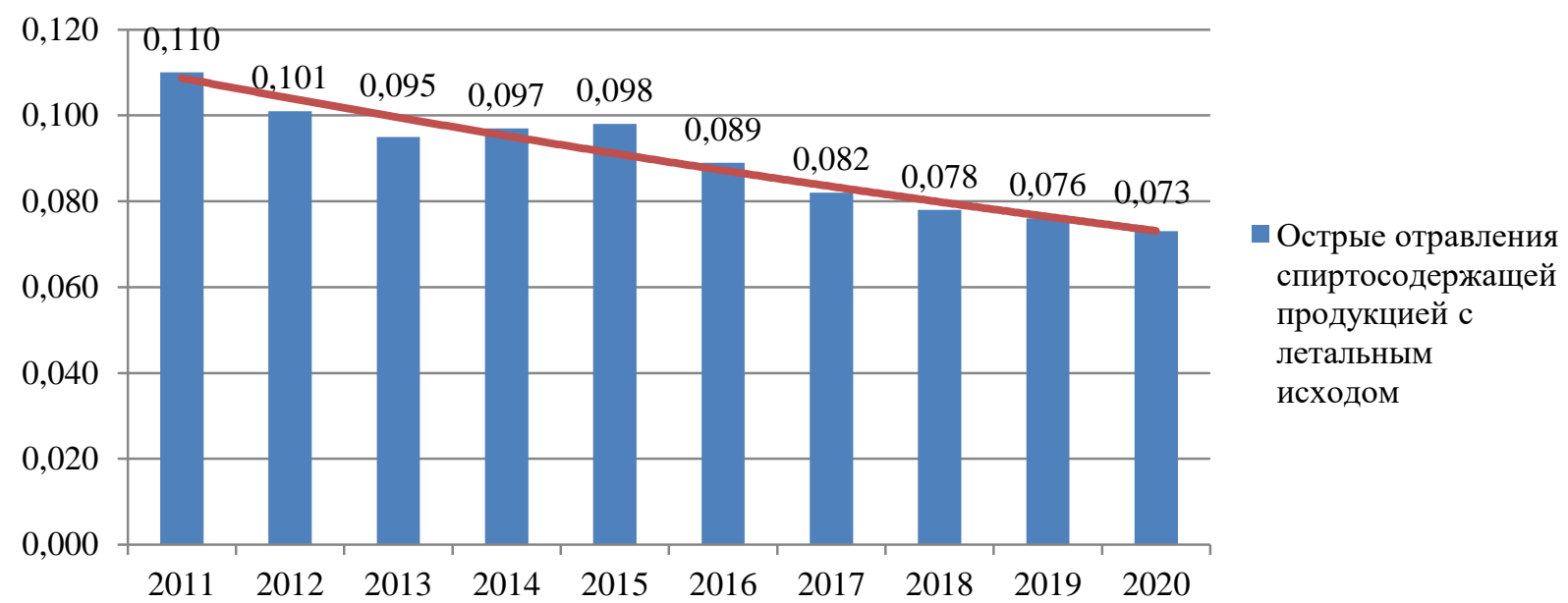

Рис. 50. Уровни острых отравлений спиртсодержащей продукцией с летальными исходам среди всего населения Российской Федерации в динамике за 2011-2020 гг. (на 1000 человек)

В 2020 г. по сравнению с 2019 г. наблюдается рост удельного веса случаев острых отравлений спиртосодержащей продукцией с летальным исходом к общему числу случаев острых отравлений спиртосодержащей продукцией на 7,2 \% (рис. 51).

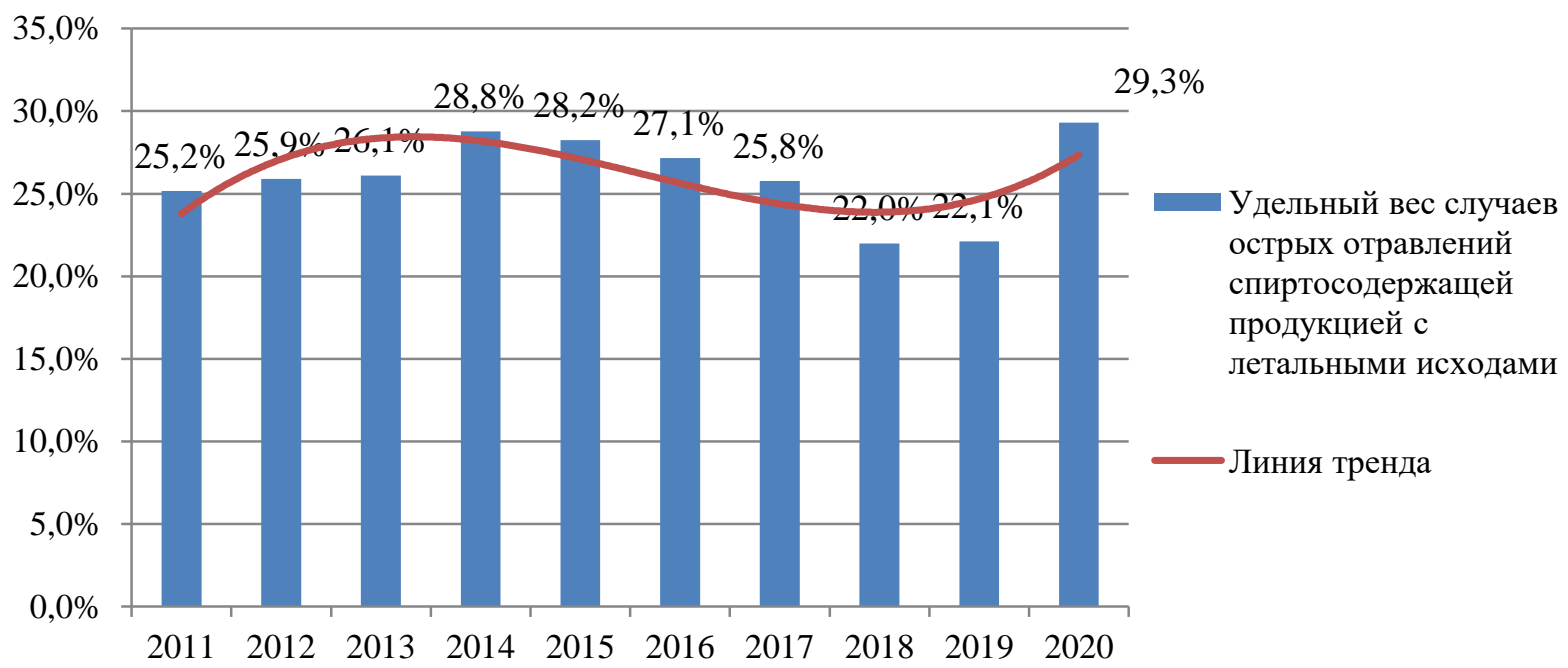

Рис. 51. Удельный вес случаев острых отравлений от спиртосодержащей продукции с летальным исходом среди всего населения Российской Федерации в динамике за 2011-2020 гг.

В структуре острых отравлений спиртосодержащей продукцией в 2020 г. 80,5 \% отравлений приходится на отравления среди мужчин (40 505 случая) и 19,5\% среди женщин (9813 случаев). На отравления среди взрослого населения (от 18 лет и старше) приходится 92,4\% (33 579 случаев), на отравления среди детей (от 0 до 14 лет включительно) 3,9 \% (1343 случая) и на отравления среди подростков (от 15 до 17 лет включительно) 3,7 \% (1422 случая).

За период 2011-2020 гг. структура отравлений спиртосодержащей продукцией по возрастному составу в Российской Федерации не изменилась.

В 2020 г. острые отравления спиртосодержащей продукцией выше среднероссийского уровня регистрировались в 27 субъектах Российской Федерации: г. Санкт-Петербурге - в 6,01 раза; от 2 до 3 раз: в Самарской области, Красноярском и Алтайском краях, Республике Тыва; от 1,5 до 2 раз: в Архангельской, Кемеровской, 
Курской, Новосибирской, Омской, Пензенской областях, Чувашской Республике, Республике Алтай; от 1,01 до 1,5 раз: в Астраханской, Воронежской, Иркутской, Калужской, Кировской, Курганской, Ленинградской, Липецкой, Рязанской, Саратовской, Томской, Тульской, республиках Бурятия и Марий Эл.

За период 2011-2020 гг. ежегодно острые отравления спиртосодержащей продукцией выше среднероссийского уровня регистрировались в 15 субъектах Российской Федерации: г. Санкт-Петербурге, Архангельской, Астраханской, Кемеровской, Курганской, Курской, Новосибирской, Омской, Пензенской, Рязанской, Самарской областях, Алтайском и Красноярском краях, Республике Тыва.

В 2020 г. показатель острых отравлений спиртосодержащей продукцией с летальными исходами выше среднероссийского уровня регистрировался в 45 субъектах Российской Федерации: от 3 до 4 раз - во Владимирской, Воронежской, Ивановской, Калужской областях; от 2 до 3 раз - в Архангельской, Костромской, Курской, Ленинградской, Мурманской, Липецкой, Московской, Орловской, Рязанской, Тверской, Тульской областях, республиках Карелия и Коми, Ненецком автономном округе; от 1,5 до 2 раз - в Астраханской, Кировской, Курганской, Новгородской, Пензенской, Саратовской, Тюменской, Ульяновской областях, республиках Крым, Марий Эл, Чувашской и Удмуртской республиках, Пермском крае; от 1,01 до 1,5 раз - в Иркутской, Кемеровской, Магаданской, Новосибирской, Омской, Томской областях, республиках Алтай, Бурятия, Хакасия, Забайкальском, Камчатском и Красноярском краях, Чукотском и Ханты-Мансийском автономных округах.

За период 2011-2020 гг. острые отравления спиртосодержащей продукцией с летальными исходами выше среднероссийского уровня регистрировались в 30 субъектах Российской Федерации: в Архангельской, Воронежской, Кемеровской, Кировской, Костромской, Курганской, Курской, Ленинградской, Липецкой, Магаданской, Московской, Новгородской, Омской, Пензенской, Рязанской, Саратовской, Тульской, Тюменской, Ульяновской областях, Забайкальском, Красноярском и Пермском краях, республиках Алтай, Бурятия, Карелия, Коми, Марий Эл, Хакасия, Удмуртской и Чувашской.

Основными причинами острых отравлений от спиртосодержащей продукции являются: острые отравления этанолом, спиртом неуточненным (денатуратом, одеколоном и парфюмерными изделиями, стеклоочистителями, суррогатами алкоголя, техническим спиртом, тормозной жидкостью, тосолом, этиленгликолем), другими спиртами, метанолом, 2-пропанолом, сивушным маслом. Ведущее место занимают отравления этанолом (рис. 52, 53).

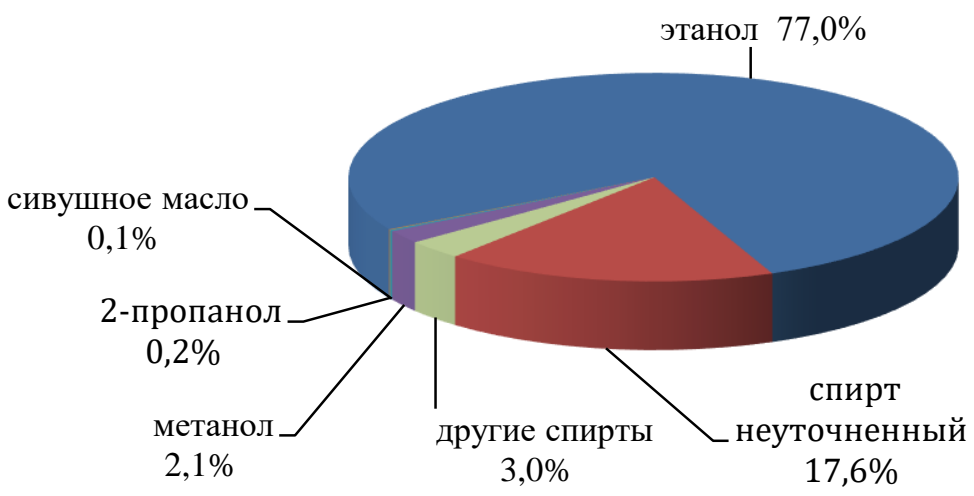

Рис. 52. Структура острых отравлений от спиртсодержащей продукции по видам отравлений среди всего населения Российской Федерации за 2011-2020 гг. 


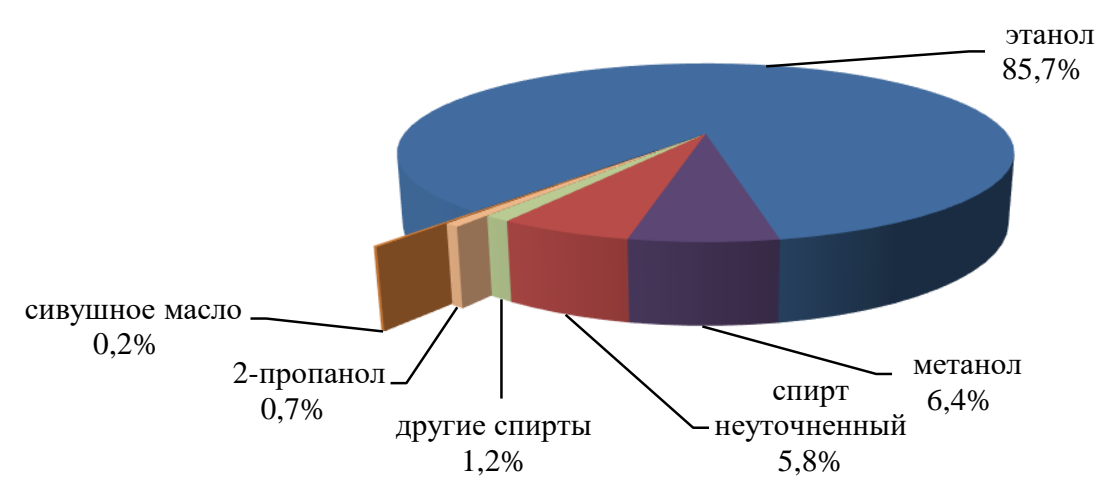

Рис. 53. Структура острых отравлений от спиртсодержащей продукции с летальными исходами по видам отравлений среди всего населения Российской Федерации за 2011-2020 гг.

Изменение доли потребительских расходов на табачную продукцию Российской Федерации в последние годы меняется незначительно - она составила 2,8 \% (рис. 54).

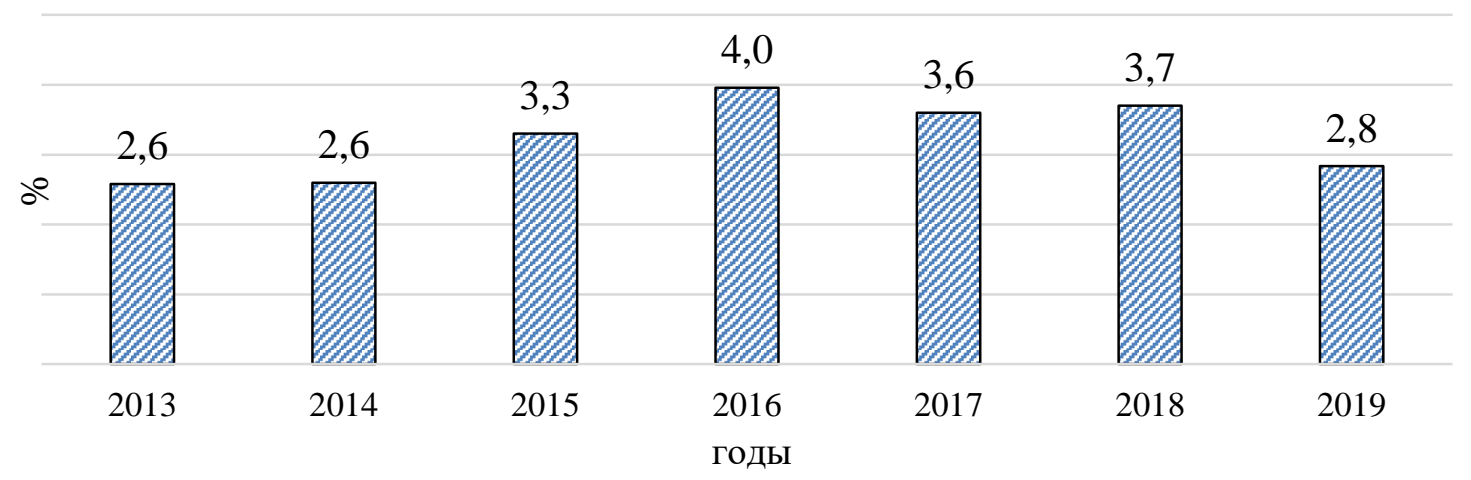

Рис. 54. Динамика потребительских расходов на табачную продукцию в Российской Федерации, 2013-2019 гг., \%

При этом доля лиц в возрасте 15 лет и старше, курящих ежедневно, в общей численности населения составила 21,6 \% для жителей городской местности и 22,9 \% в сельской местности. Каждый третий курящий в возрасте 35-44 года, в возрасте 2534 года - $27 \%$, и $22 \%$ в возрасте 15 лет и старше.

В 2020 г. зарегистрировано 502 случая отравлений курительными смесями (spice) среди всего населения, или 0,35 случая на 100 тыс. населения (рис. 55). Из них 16 случаев $(3,2 \%)$ составляют отравления с летальным исходом среди взрослого населения (1870 лет). За последние 3 года отравлений курительными смесями (spice) с летальным исходом среди детей и подростков не регистрировалось. В сравнении с 2019 г. отмечено снижение показателей острых отравлений курительными смесями (spice) среди всего населения на $25,5 \%$.

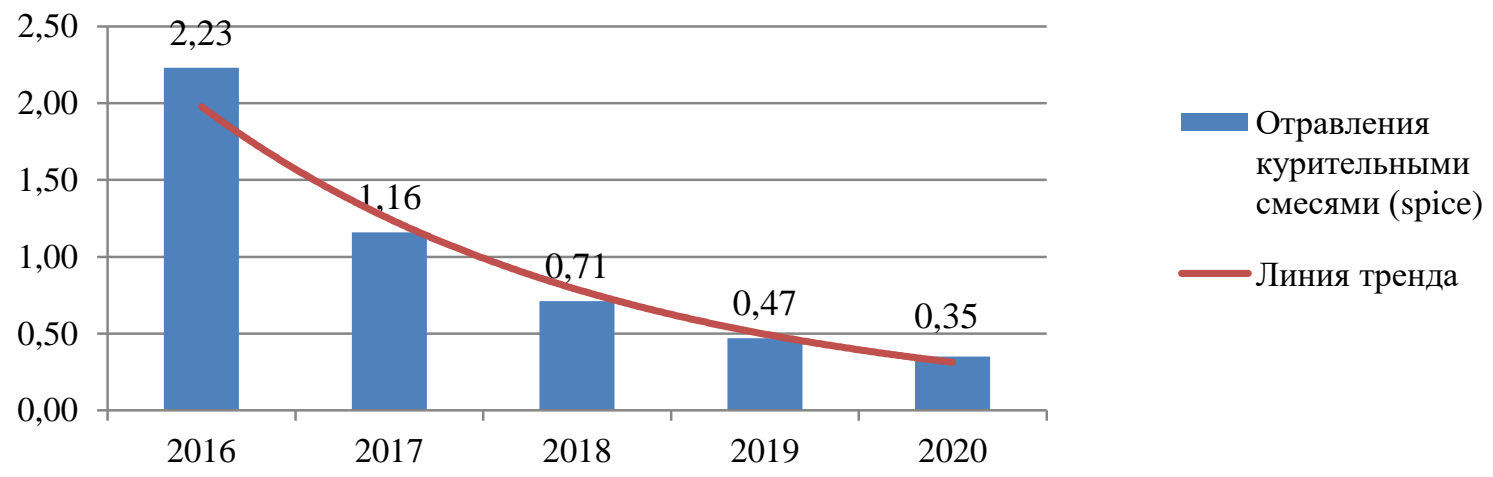

Рис. 55. Уровни отравления курительными смесями (spice) среди всего населения Российской Федерации в динамике за 2016-2020 гг. (на 100 тыс. населения) 
В структуре отравлений курительными смесями (spice) по возрастному составу в 2020 г. по сравнению с 2019 г. стоит отметить снижение показателей среди детского населения (0-14 лет) на 1,8 \%, а среди подростков (15-17 лет) на 3,8 \% (рис. 56).

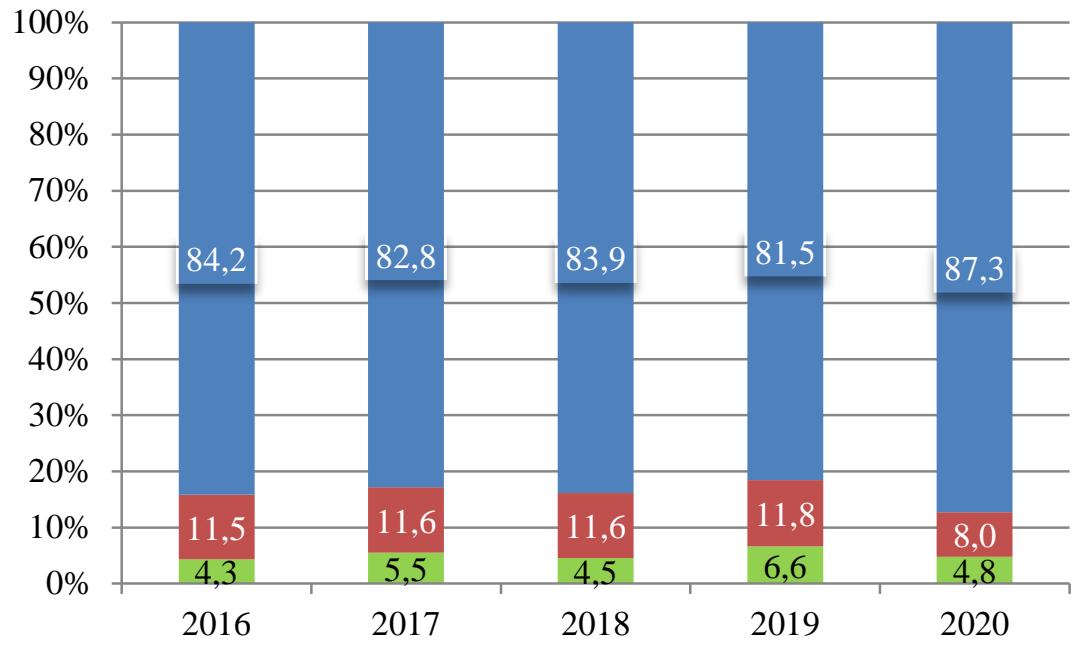

- Взрослое население (18-70 лет и старше)

Подростковое население (15-17 лет)

Детское население (014 лет)

Рис. 56. Структура отравления курительными смесями (spice) по возрастному составу в Российской Федерации в динамике за 2016-2020 гг.

В структуре отравлений курительными смесями (spice) среди всего населения 80,1 \% отравлений приходится на отравления с не определенным веществом и 19,9 \% с выявленным наркотическим веществом.

Следует отметить, что в 2020 г. среди всего населения острые отравления курительными смесями (spice) выше среднероссийского уровня регистрировались в 13 субъектах Российской Федерации: Архангельской, Вологодской, Ивановской, Кемеровской, Курской, Липецкой, Новосибирской, Оренбургской, Пензенской, Томской, Челябинской областях, Красноярском крае, Республике Тыва. Показатель острых отравлений курительными смесями (spice) с летальными исходами выше среднероссийского уровня регистрировался в 4 субъектах Российской Федерации: в Кемеровской, Новосибирской, Оренбургской областях, Красноярском крае.

Острые отравления детей курительными смесями (spice) выше среднероссийского уровня регистрировались в 15 субъектах Российской Федерации: Архангельской, Волгоградской, Вологодской, Иркутской, Калужской, Кемеровской, Новосибирской, Свердловской, Смоленской, Тамбовской областях, Красноярском, Пермском и Приморском краях, Республике Коми, Ненецком автономном округе.

Острые отравления подростков курительными смесями (spice) выше среднероссийского уровня регистрировались в 14 субъектах Российской Федерации: Архангельской, Волгоградской, Вологодской, Иркутской, Кемеровской, Нижегородской, Новосибирской, Оренбургской, Пензенской, Ростовской, Томской областях, Красноярском и Хабаровском краях, Ханты-Мансийском автономном округе.

\subsection{6. Мониторинг условий обучения и воспитания, отдыха детей и их оздоровления}

В 2020 г. на контроле территориальных органов Роспотребнадзора находилось 173052 организации для детей и подростков. Число организаций для детей и подростков в динамике с 2011 по 2020 г. снижается (табл. 14), в сравнении с 2011 годом оно сократилось на 7,6 \% (-14 292 объекта), в сравнении с 2019 - на 3,4 \% (-6019 объектов). 


\section{Число организаций для детей и подростков разного типа в Российской Федерации в 2011-2020 гг.}

\begin{tabular}{|l|c|c|c|c|c|c|c|c|c|c|}
\hline \multicolumn{1}{|c|}{ Типы организаций } & 2011 & 2012 & 2013 & 2014 & 2015 & 2016 & 2017 & 2018 & 2019 & 2020 \\
\hline Всего & 187344 & 184237 & 186379 & 186001 & 185266 & 183530 & 180481 & 179381 & 179071 & 173052 \\
\hline $\begin{array}{l}\text { Дошкольные } \\
\text { образовательные } \\
\text { организации }\end{array}$ & 46655 & 47309 & 46735 & 48794 & 49432 & 49740 & 50291 & 50710 & 50868 & 51449 \\
\hline $\begin{array}{l}\text { Общеобразовательные } \\
\text { организации }\end{array}$ & 48781 & 47651 & 45333 & 43810 & 43246 & 42143 & 50261 & 49773 & 49558 & 49181 \\
\hline $\begin{array}{l}\text { В том числе: школы- } \\
\text { интернаты, } \\
\text { специальные } \\
\text { (коррекционные) } \\
\text { общеобразовательные } \\
\text { организации }\end{array}$ & 1913 & 1886 & 2210 & 2187 & 2145 & 2125 & 2138 & 2168 & 2185 & 2166 \\
\hline $\begin{array}{l}\text { Организации для } \\
\text { детей-сирот и детей, } \\
\text { оставшихя без } \\
\text { попечения родителей }\end{array}$ & 1576 & 1520 & 3020 & 2897 & 2717 & 2591 & 2544 & 2481 & 2404 & 2377 \\
\hline $\begin{array}{l}\text { Организации } \\
\text { дополнительного } \\
\text { образования }\end{array}$ & 20251 & 20161 & 20269 & 20342 & 20971 & 20945 & 21635 & 21608 & 21856 & 22107 \\
\hline $\begin{array}{l}\text { Профессиональные } \\
\text { образовательные } \\
\text { организации }\end{array}$ & 6054 & 5797 & 6042 & 5718 & 5730 & 5636 & 5650 & 5623 & 5658 & 5641 \\
\hline $\begin{array}{l}\text { Организации отдыха } \\
\text { детей и их } \\
\text { оздоровления }\end{array}$ & 52789 & 50473 & 50030 & 48594 & 47426 & 46789 & 45213 & 43846 & 43352 & 36663 \\
\hline $\begin{array}{l}\text { в том числе: детские } \\
\text { оздоровительные } \\
\text { организации, } \\
\text { работающие } \\
\text { круглогодично }\end{array}$ & $\mathrm{X}$ & $\mathrm{X}$ & $\mathrm{X}$ & 529 & 525 & 520 & 541 & 567 & 553 & 444 \\
\hline $\begin{array}{l}\text { детские санаторин** } \\
\text { Прочие типы } \\
\text { организаций для детей } \\
\text { и подростков }\end{array}$ & 5984 & 6266 & 5456 & 5832 & 5145 & 4832 & 4565 & 5031 & 5070 & 5339 \\
\hline
\end{tabular}

* Учет показателей ведется с 2014 года

** Учет показателей ведется с 2013 года

Снижение общего числа организаций для детей и подростков, подлежащих надзору, относительно 2019 г. произошло в первую очередь за счет снижения числа детских санаториев, организаций отдыха детей и их оздоровления, что объясняется тем, что часть организаций этих типов не планировались к открытию в 2020 г. в связи с сохраняющимися рисками заболевания новой коронавирусной инфекции. Однако в период 2011-2019 гг. вклад организаций отдыха детей и их оздоровления в снижение общего числа детских и подростковых организаций также был наибольшим - с 2011 г. их число снизилось на 17,3\% (-9 132 организации), с 2019 по 2020 г. - на 15,3\% (-6 689 организаций). 
Вместе с тем за десятилетний период на 4794 (+10,3\%) увеличилось число дошкольных образовательных организаций, на 1856 (+9,2\%) - организаций дополнительного образования, на $400(+0,8 \%)$ - общеобразовательных организаций. Число профессиональных образовательных организаций и организаций для детей-сирот и детей, оставшихся без попечения родителей, продолжает снижаться: с 2011 г. их число уменьшилось на $413(-6,8 \%)$ организаций и $821(-25,0 \%)$ организацию соответственно.

В структуре организаций для детей и подростков на первом месте в 2020 г. находились дошкольные и общеобразовательные организации $(29,4 \%$ и $28,1 \%$ соответственно) (рис. 57), на втором месте - организации отдыха детей и их оздоровления и санатории $(20,9 \%)$, на третьем - организации дополнительного образования $(12,6 \%)$.

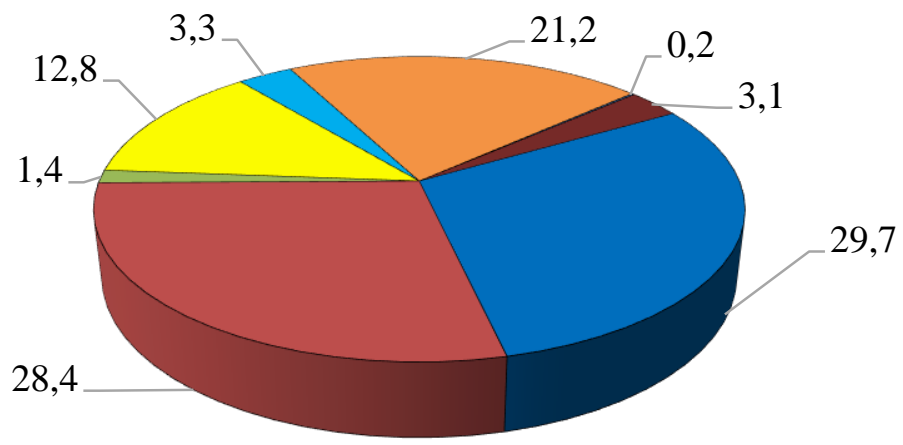

口Дошкольные образовательные организации

口Общеобразовательные организации

$\square$ Организации для детей-сирот и детей, оставшихся без попечения родителей

๑Организации дополнительного образования

$\square$ Профессиональные образовательные организации

$\square$ Организации отдыха детей и их оздоровления, в том числе с дневным пребыванием

口Детские санатории

口Прочие типы организаций для детей и подростков

Рис. 57. Структура организаций для детей и подростков в 2020 г., \%

За десятилетний период увеличилось общее число детей, посещающих организации разного типа. С 2011 по 2020 г. возросло число детей, посещающих дошкольные образовательные организации (на 21,8 \%), общеобразовательные организации (на 30,0\%), организации дополнительного образования (на 4,8\%), профессиональные образовательные организации (на 7,1 \%).

Основными показателями, характеризующими санитарно-техническое состояние организаций для детей и подростков, являются их обеспеченность централизованными системами водоснабжения, водоотведения и отопления, а также необходимость проведения в них ремонтных работ.

С 2011 г. число организаций, работающих без централизованного водоснабжения, снизилось более чем в 2 раза: на 7997 организаций (64,5\%), водоотведения - на 10001 организацию (71,9 \%), отопления - на 4502 организации (65,9 \%) (табл. 15).

Число предназначенных для детей и подростков организаций, функционирующих без централизованного водоснабжения, в 2020 г. составило 4385 организаций $(2,5 \%$ от общего числа организаций для детей и подростков), водоотведения - 3895 организаций (2,3\%), отопления - $2323(1,3 \%)$. 
Динамика числа предназначенных для детей и подростков организаций, не обеспеченных централизованными системами водоснабжения, водоотведения и отопления, в динамике 2011-2020 гг. и 2019-2020 гг., \%

\begin{tabular}{|c|c|c|c|c|c|c|c|c|c|c|c|c|}
\hline \multirow{3}{*}{ Типы организаций } & \multicolumn{4}{|c|}{$\begin{array}{c}\text { Центральное } \\
\text { водоснабжение }\end{array}$} & \multicolumn{4}{|c|}{$\begin{array}{c}\text { Центральное } \\
\text { водоотведение }\end{array}$} & \multicolumn{4}{|c|}{$\begin{array}{c}\text { Центральное } \\
\text { отопление }\end{array}$} \\
\hline & \multicolumn{2}{|c|}{$\begin{array}{l}\text { Динамика } \\
2011-2020 \\
\end{array}$} & \multicolumn{2}{|c|}{\begin{tabular}{|c|} 
Динамика \\
$2019-2020$ \\
\end{tabular}} & \multicolumn{2}{|c|}{\begin{tabular}{|l|} 
Динамика \\
$2011-2020$ \\
\end{tabular}} & \multicolumn{2}{|c|}{$\begin{array}{l}\text { Динамика } \\
2019-2020 \\
\end{array}$} & \multicolumn{2}{|c|}{$\begin{array}{c}\text { Динамика } \\
\text { 2011-2020 } \\
\end{array}$} & \multicolumn{2}{|c|}{\begin{tabular}{|l|} 
Динамика \\
2019-2020 \\
\end{tabular}} \\
\hline & абс. & $\% *$ & абс. & $\% * *$ & абс. & $\% *$ & абс. & $\% * *$ & абс. & $\% *$ & абс. & $\% * *$ \\
\hline \begin{tabular}{|l} 
Детские и \\
подростковые \\
учреждения - всего, \\
в том числе:
\end{tabular} & -7997 & $-64,6$ & -1140 & $-20,6$ & -10001 & $-72,0$ & -612 & $-13,6$ & -4502 & $-66,0$ & -965 & $-29,3$ \\
\hline \begin{tabular}{|l} 
Дошкольные \\
образовательные \\
организации
\end{tabular} & -1397 & $-55,4$ & -121 & $-9,7$ & -1442 & $\mid-55,9$ & -53 & $-4,5$ & -655 & $-55,2$ & -27 & $-4,8$ \\
\hline $\begin{array}{l}\text { Общеобразовательные } \\
\text { организации }\end{array}$ & -2974 & $-62,9$ & -389 & $-18,2$ & -4155 & $-72,6$ & +156 & $+11,0$ & -1649 & $-71,3$ & -109 & $-14,1$ \\
\hline $\begin{array}{l}\text { Организации для детей- } \\
\text { сирот и детей, } \\
\text { оставшихся без } \\
\text { попечения родителей }\end{array}$ & -2 & $-6,5$ & +2 & $+7,4$ & -4 & $-15,4$ & -1 & $-4,3$ & -6 & $-60,0$ & -14 & $-77,8$ \\
\hline \begin{tabular}{|l} 
Организации \\
дополнительного \\
образования \\
\end{tabular} & -537 & $-62,5$ & -80 & $-19,9$ & -710 & $-68,3$ & -62 & $-15,8$ & -122 & $-50,2$ & -63 & $-34,2$ \\
\hline $\begin{array}{l}\text { Профессиональные } \\
\text { образовательные } \\
\text { организации }\end{array}$ & -62 & $-70,5$ & -4 & $-13,3$ & -69 & $\mid-71,9$ & -3 & $-10,0$ & -29 & $-60,4$ & 0 & 0,0 \\
\hline
\end{tabular}

* указан темп прироста/снижения к 2011 году

** указан темп прироста/снижения к 2019 году

Большинство не имеющих централизованной системы водоснабжения организаций для детей и подростков работают на привозной воде (3360 организаций, 76,6 \%). Среди организаций, функционирующих без центрального отопления, используют печное отопление 298 организаций (12,8 \%).

По итогам 2020 г. наибольший удельный вес не имеющих централизованных систем водоснабжения, водоотведения и отопления организаций для детей и подростков отмечался в 8 субъектах Российской Федерации: Архангельской области, республиках Калмыкия, Дагестан, Тыва и Саха (Якутия), Забайкальском и Хабаровском краях, Чеченской Республике. На рис. 58 представлено распределение по субъектам Российской Федерации функционирующих без централизованного водоснабжения организаций для детей и подростков; на рис. 59 - без централизованного водоотведения.

Наибольшее число дошкольных организаций, функционирующих в условиях отсутствия централизованного водоснабжения, водоотведения и отопления $(10,0$ \% и более организаций) регистрируется в 8 субъектах Российской Федерации: Архангельская область, республики Калмыкия, Республика, Чеченская, Тыва, Саха (Якутия), Забайкальский и Хабаровский края; общеобразовательных организаций - в 12 субъектах Российской Федерации (Республика Карелия, Архангельская область, республики Калмыкия, Республика, Карачаево-Черкесская, Чеченская, Республика Хакасия, Иркутская область, Республики Бурятия и Саха (Якутия), Забайкальский и Хабаровский края. 


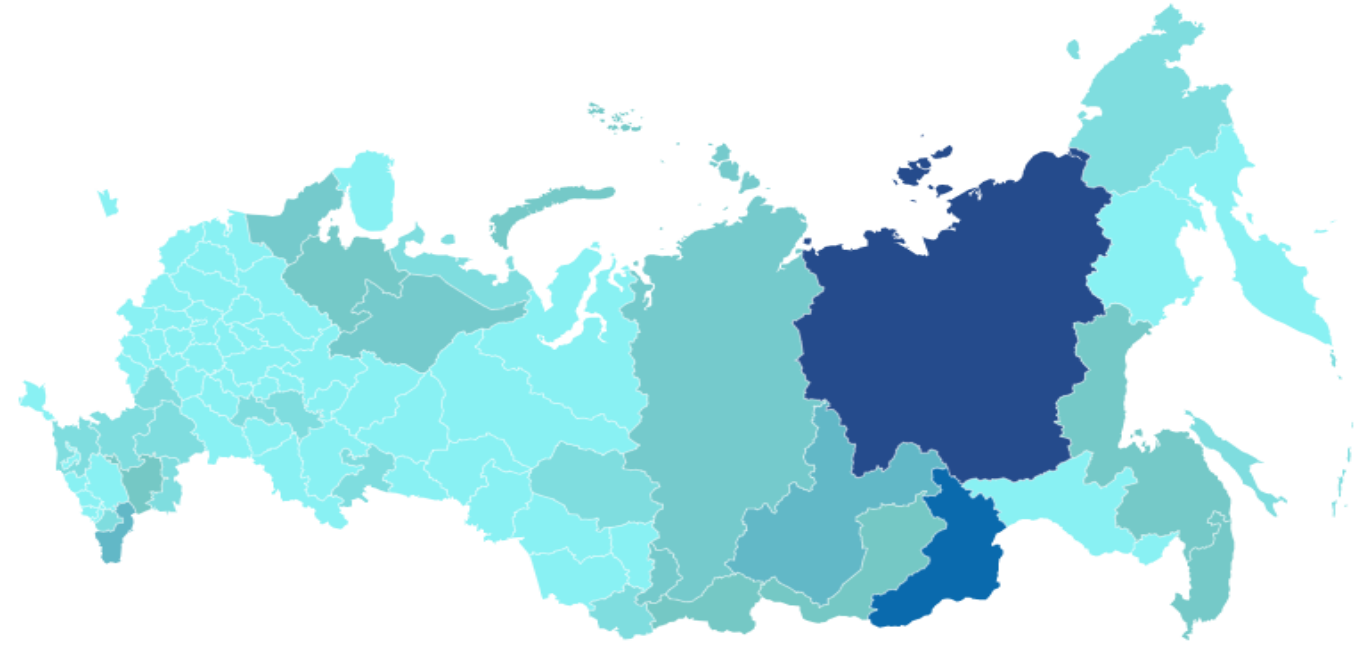

Рис. 58. Распределение по субъектам Российской Федерации организаций, функционирующих без централизованного водоснабжения в 2020 г.

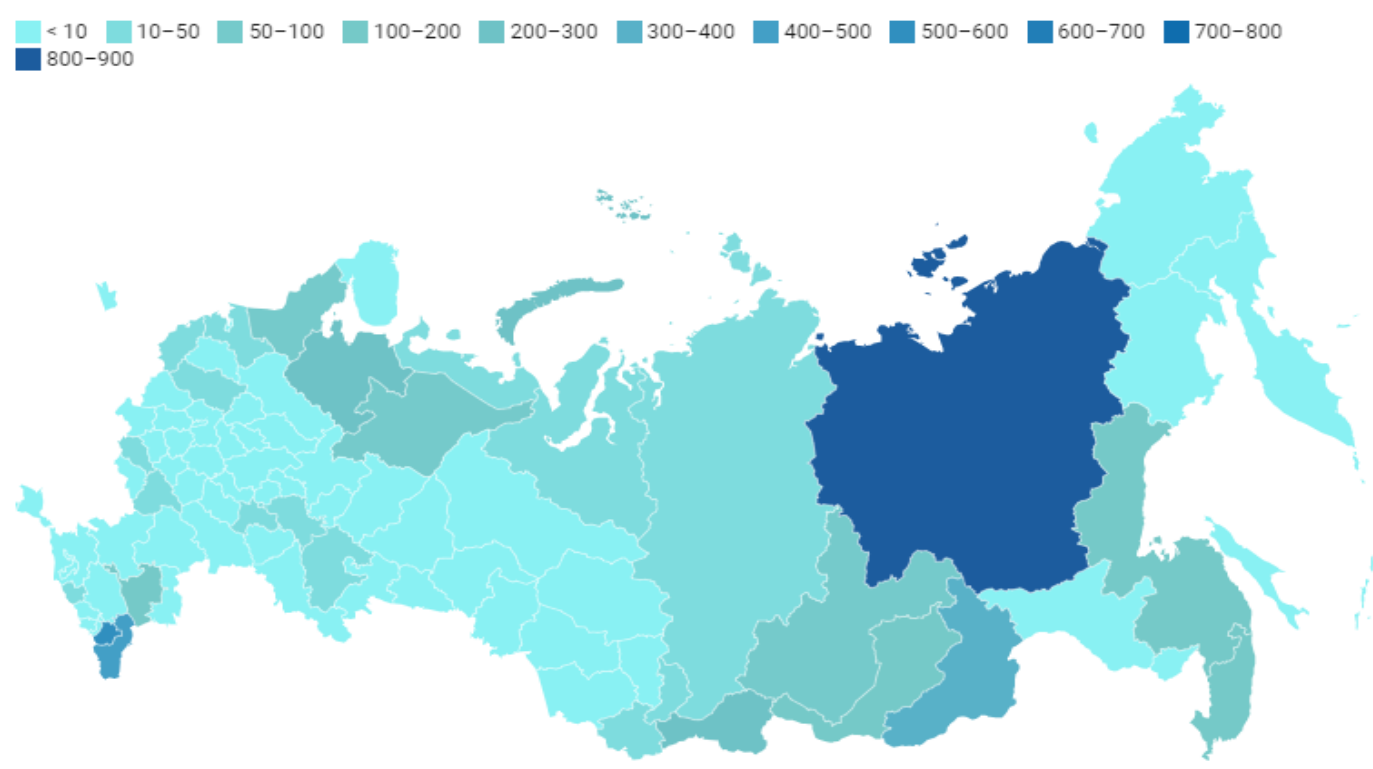

Рис. 59. Распределение по субъектам Российской Федерации организаций, функционирующих без централизованного водоотведения в 2020 г.

С 2011 г. сократилось число организаций (на 965), требующих капитального ремонта. По итогам 2020 г. капитальный ремонт необходим 4716 организациям $(2,7 \%$ от общего числа организаций для детей и подростков), частичный - 21545 организациям (12,5\%), косметический - $27883(16,1 \%)$.

Наибольший удельный вес предназначенных для детей и подростков организаций, которым необходим капитальный ремонт, отмечается в Республике Дагестан (737 организаций; 25,7 \% от всех организаций в данном субъекте РФ), Курганской области (238 организаций; 19,8 \%), Республике Саха (Якутия) (406 организаций; $16,4 \%$ ).

В 5 субъектах Российской Федерации в каждой десятой дошкольной образовательной организации необходимо проведение капитального ремонта, (Рязанская область, Республика Дагестан, Томская область, Республика Саха (Якутия), Забайкальский край). Аналогичный показатель для общеобразовательных организаций 
характерен для 9 субъектов (республики Дагестан, Марий Эл, Мордовия, Курганская и Томская области, Республики Бурятия и Саха (Якутия), Забайкальский край.

Увеличение численности детского населения в Российской Федерации, наряду с наличием организаций, требующих ремонта, функционирующих в условиях неблагоприятного санитарно-технического обеспечения, диктует необходимость строительства новых организаций для детей и подростков.

В период с 2013 по 2020 г. число вновь построенных и введенных в эксплуатацию организаций для детей и подростков составило 4 990, в том числе 3668 дошкольных организаций $(74 \%)$, и 1059 общеобразовательных организаций $(21 \%)$. Наибольшее число дошкольных организаций было построено в Московской области (317), Республике Татарстан (217), Свердловской области (138), Республике Саха (137), Чеченской Республике (131), Ростовской области (108), Санкт-Петербурге (101). Наибольшее число общеобразовательных организаций было построено в Чеченской Республике (83), Московской области (79), Республике Татарстан (65), Республике Дагестан (60), г. Москве (50). В 2020 г. было построено 722722 организации для детей и подростков, в том числе 525 дошкольных организаций (72 \% от всех построенных) и 182 общеобразовательные организации (25\%). В 29 субъектах Российской Федерации в 2020 г. было построено по 10 и более организаций. Наибольшее число организаций для детей и подростков было введено в эксплуатацию в Московской области (34), Удмуртской Республике (27), Ленинградской области (26), г. Москве (24), Республике Татарстан (24), Чеченской Республике (21) и Свердловской области (20).

Несмотря на ежегодное строительство новых организаций для детей и подростков, сохраняются организации, функционирующие с превышением проектной мощности. Работа организации в переуплотненном режиме приводит к невозможности обеспечить безопасные условия пребывания детей и подростков в организованных коллективах, что вызывало особую обеспокоенность в 2020 г. после объявления пандемии новой коронавирусной инфекции.

Всего в переуплотненном режиме в 2020 г. функционировало 12029 организаций. (59,6\% из них составляют дошкольные образовательные организации, 38,5 \% общеобразовательные организации и 1,9 \% - другие организации) (рис. 60).

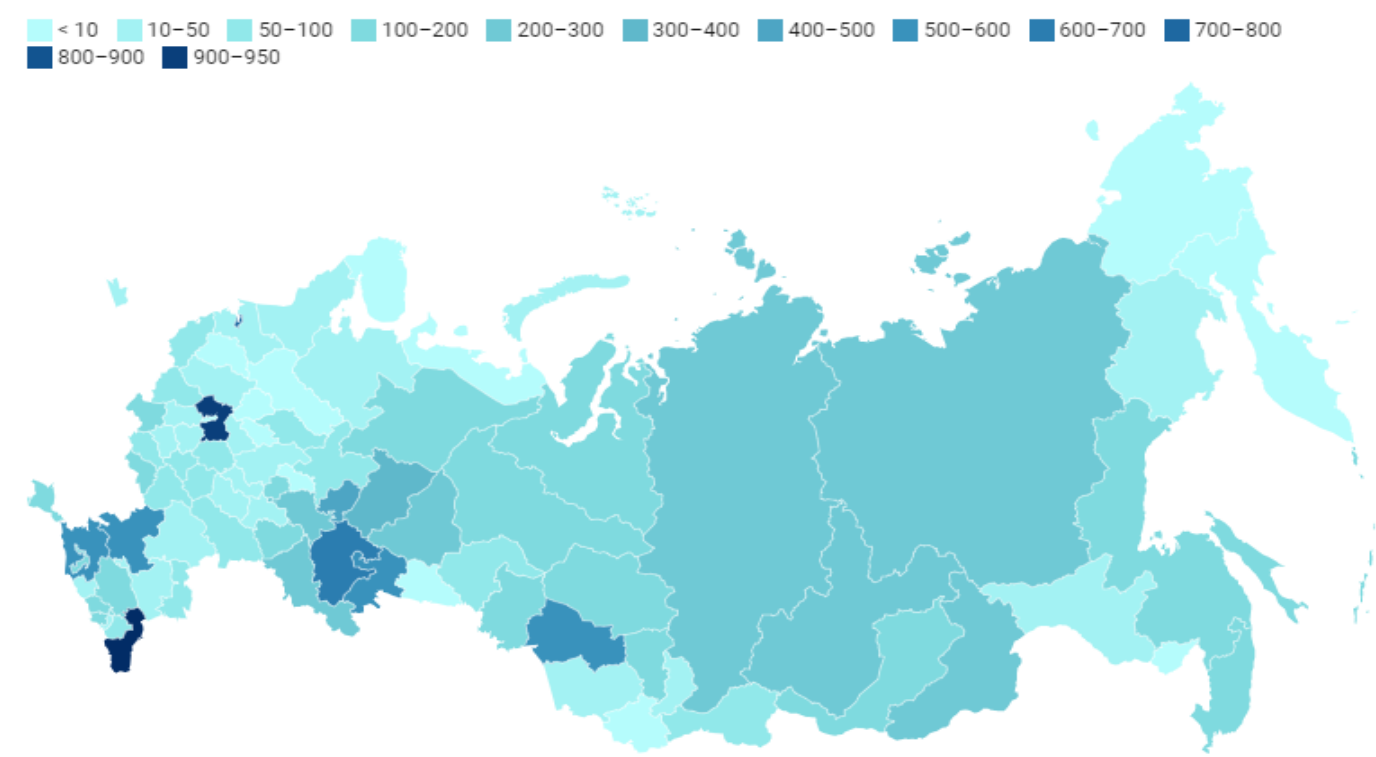

Рис. 60. Число организаций для детей и подростков, функционирующих в «переуплотненном» режиме, в Российской Федерации в 2020 г.

В Российской Федерации в 2020 г. в переуплотненном режиме работали 7177 дошкольных образовательных организаций, что составляет $14,0 \%$ от общего числа 
образовательных организаций этого типа. Наибольший удельный вес дошкольных образовательных организаций, которые работают с превышением проектной вместимости, отмечается в 9 субъектах Российской Федерации: Республике Дагестан $(88,3 \%$, от общего количества дошкольных образовательных организаций в данном субъекте РФ), Кабардино-Балкарской Республике $(42,8$ \%), Сахалинской области $(36,4 \%)$, Удмуртской Республике $(38,3 \%)$, Хабаровской крае $(38,4 \%)$, Республике Адыгея $(37,4 \%)$, г. Санкт-Петербурге $(38,3 \%)$, Республике Крым $(31,9 \%)$, Новосибирской области $(36,1 \%)$.

В условия превышения проектной вместимости работали 4636 общеобразовательных организаций, что составляет 9,4\% от общего числа образовательных организаций этого типа. Более $30 \%$ общеобразовательных организаций работают в переуплотненном режиме в 4 субъектах: Республике Адыгея $(33,8 \%)$, Московской области $(30,6 \%)$, Республике Северная Осетия - Алания $(30,1 \%)$, Ямало-Ненецком автономном округе $(37,4 \%)$.

Для снижения рисков нарушения здоровья, связанных с переуплотненным режимом работы, общеобразовательные организации функционируют в несколько смен. В 2020 г., как и в предыдущие годы, большинство организаций (39 747) работало в одну смену (80,8 \%), в две и три смены - 9326 (19,0\%) и 108 (0,2\%) организации соответственно (рис. 61).

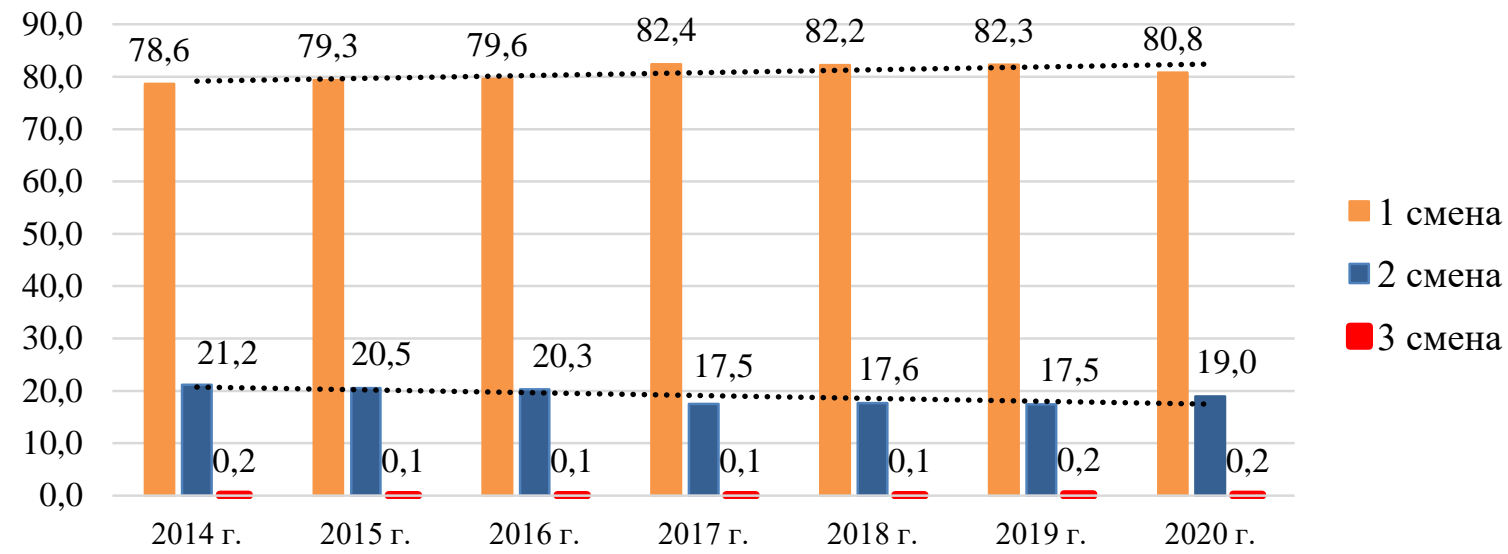

Рис. 61. Количество общеобразовательных организаций в Российской Федерации в 2020 году в зависимости от режима работы организации, \%

В 2020 г. удельный вес общеобразовательных организаций, работающих в одну смену, регистрировался ниже, а в две смены - выше, чем в последние три года. Это может объясняться временным переходом ряда общеобразовательных организаций на работу в двухсменном режиме с целью создания для обучающихся и сотрудников условий, способствующих снижению риска распространения новой коронавирусной инфекции.

Выше, чем в среднем по Российской Федерации, удельный вес общеобразовательных организаций, работающих в двухсменном режиме, в Чеченской Республике $(58,5$ \% от общего количества общеобразовательных организаций в данном субъекте РФ), Республике Тыва (50 \%), Ханты-Мансийском автономном округе (46,8 \%), Ямало-Ненецком автономном округе (44,3 \%) Республике Дагестан $(42,4$ \%), Чувашкой Республике (40\%), Пермском крае (40\%), Республике Ингушетия $(37,6 \%)$, Свердловской области (35,1\%), Саратовской области (35\%), Краснодарском крае $(34,7 \%)$, Астраханской области $(32,4 \%)$.

В трехсменном режиме в Российской Федерации в 2020 г. работали 108 общеобразовательных организаций: в Чеченской Республике (70), Республике Дагестан (28), Республике Бурятия (8) и Республике Тыва (2). В сравнении с 2019 г. в Чеченской Республике и Республике Бурятия отмечается положительная динамика в 
изменении числа общеобразовательных организаций, работающих в три смены: оно уменьшилось на 15 и 4 организации соответственно. Общее количество обучающихся в третью смену составило 19147 детей.

Обеспечение условий для реализации физической активности детей и подростков является важным фактором создания благоприятной профилактической среды в организациях, особенно в тех, где дети проводят наибольший период времени, образовательных и организациях с круглосуточным пребыванием. Оборудованную спортивную зону на территории организации имеют 76,6\% из этих организаций, спортивный зал - 75,4\%, бассейны - 3,9\%. В 12 субъектах Российской Федерации (Липецкая область, Тульская область, г. Москва, Ненецкий автономный округ, Калининградская область, г. Севастополь, Республика Северная Осетия - Алания, Кировская область, Ульяновская область, Курганская область, Еврейская автономная область) 9 из 10 дошкольных и общеобразовательных организаций имеют спортивный зал и оборудованную спортивную зону на территории организации.

Обязательным компонентом системы мероприятий по сохранению и укреплению здоровья детей является организация их питания. Здоровое питание детей и подростков - одно из базовых условий сохранения и укрепления их здоровья, а также обеспечения нормального роста, физического и умственного развития. В образовательных организациях дети проводят порядка 5-12 часов, поэтому организация их питания приобретает особую значимость. В Российской Федерации условия для организации питания созданы во всех организациях для детей-сирот и детей, оставшихся без попечения родителей, в дошкольных организациях, функционирующих в режиме более 4-часового пребывания воспитанников. В период 2013-2020 гг. отмечается уменьшение числа общеобразовательных и профессиональных организаций, в которых не созданы условия для организации учащихся. Удельный вес таких общеобразовательных организаций за 7 лет сократился в 6 раз (2020 г. - 0,2\%, 2013 г. - 1,2\%), а профессиональных образовательных организаций - в 2 раза $(2020$ г. - 3,8 \%, 2013 г. $7,0 \%)$.

Показатели охвата горячим питанием школьников имели за период 2011-2020 гг. позитивную динамику по всем возрастным группам. В 2020 г. в Российской Федерации средний показатель охвата школьников горячим питанием составил 91,8 \% (2011 г. $83,5 \% ; 2019$ г. - 90,6 \%). При этом охват горячим питанием школьников 1-4 классов составил 99,8 \%, а учащихся 5-11 классов - 85,5\% (рис. 62).

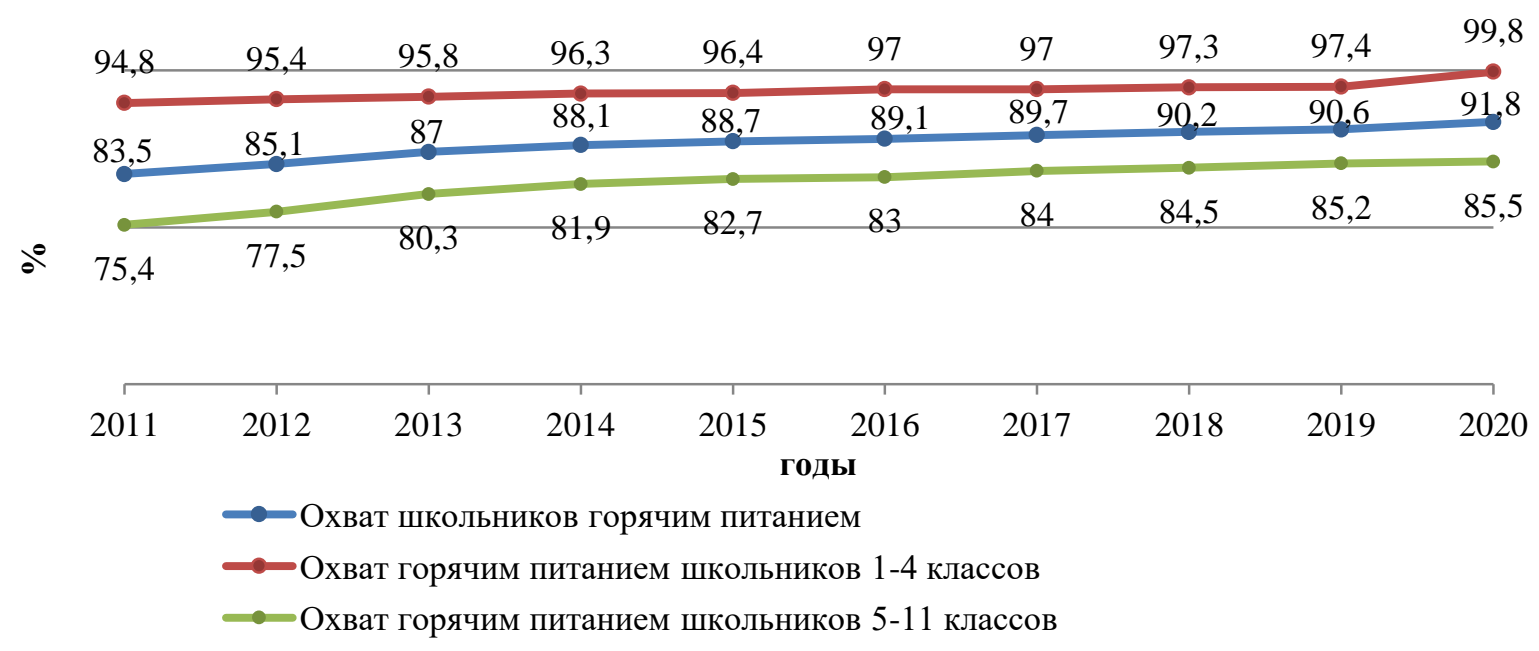

Рис. 62. Средний показатель охвата школьников горячим питанием в Российской Федерации за 2011-2020 гг., \% 
Всего по состоянию на 01.01.2021 было охвачено горячим питанием 15068095 школьников (2011 г. - 10878363 школьников, 2019 г. - 14625 476). Все школьники были охвачены горячим питанием в Республике Алтай, Ямало-Ненецком и Чукотском автономных округах.

Выше $95 \%$ отмечался показатель охвата школьников горячим питанием в 28 субъектах РФ, в т. ч. в Тюменской области (99,9\%), Республике Бурятия (99,9\%), г. Санкт-Петербурге (99,7\%), Ханты-Мансийском автономном округе $(99,3 \%)$, Новосибирской области $(99,3 \%)$, Брянской области $(99,2 \%)$. Вместе с тем остаются низкими показатели охвата горячим питанием школьников в республиках Северная Осетия - Алания (41,8 \%), Дагестан (49,7 \%), Ингушетия (61,7 \%).

Охват горячим питанием учащихся 1-4 классов составляет 99, 8 \%. В 49 субъектах Российской Федерации горячее питание получали 100 \% учащихся начальных классов (в 2019 году данный показатель на таком уровне регистрировался только в 19 субъектах Российской Федерации). В остальных субъектах Российской Федерации показатель охвата горячим питанием школьников 1-4 классов составил не менее $97 \%$.

Средний показатель охвата горячим питанием учащихся 5-11 классов ниже, он равнялся 85,5\%. Менее половины учащихся средней и старшей школы охвачено горячим питанием в республиках Ингушетия (27,8\%), Северная Осетия - Алания $(8,6$ \%), Карачаево-Черкесской $(46,8 \%)$, а также Астраханской области (43,5 \%).

Приоритетной формой организации горячего питания для школьников является завтрак, его получают 56,9 \% учащихся. В период 2011-2020 гг. увеличился показатель охвата школьников двухразовым горячим питанием. По состоянию на 01.01.2021 он составил $24,6 \%$ (2011 г. - 25,0 \%; 2019 г. - 31,5\%). Среди учащихся, получающих горячее питание, 2-разовое питание имеют более $70 \%$ учащихся в Белгородской $(84,1 \%)$ и Воронежской $(74,7$ \%) областях. Существенно ниже среднего показателя по Российской Федерации был охват школьников двухразовым горячим питанием в Брянской области (7,9\%), республиках Дагестан (3,4\%), Ингушетия (2,5\%) и Адыгея (5,2\%), Приморском крае $(7,9 \%)$.

Показатели охвата горячим питанием обучающихся в профессиональных образовательных организациях также характеризовались положительной динамикой. За период 2014-2020 гг. удельный вес учащихся, получающих горячее питание в образовательных организациях этого типа, увеличился на 5,4 \% (2014 г. - 66,3 \%; 2020 г. - 71,7\%). Расширение охвата горячим питанием учащихся образовательных организаций данного типа произошло за счет увеличения охвата обучающихся обедами. Обед является приоритетной формой организации горячего питания для учащихся профессиональных организаций. Среди получающих горячее питание учащихся профессиональных образовательных организаций обедают 61,8\%. Стопроцентного охвата горячим питанием обучающихся в профессиональных образовательных организациях удалось добиться в 7 субъектах Российской Федерации: Алтайском крае, Белгородской, Новгородской, Орловской и Тюменской областях, г. Москве, Чукотском автономном округе. Наименьший охват горячим питанием учащихся профессиональных образовательных организаций - в Карачаево-Черкесской Республике $(1,3 \%)$, республиках Дагестан (1,8 \%) и Ингушетия (13\%).

При реализации федерального проекта «Укрепление общественного здоровья» национального проекта «Демография» (далее - проект «Демография») в 24 пилотных регионах за 2019-2020 гг. проводилась оценка организации школьного питания в 2800 школах (2019 г. - 2283 ) с охватом 15 тыс. (2019 г. - 35 тыс.) учащихся начальной, средней и старшей школы.

Завтрак для начальной школы был организован на первой перемене в 61,6 \% школ, на второй перемене для учащихся 5-9 классов - в 39,9 \% школ, старшеклассники получали завтрак на третьей перемене в 44,6 \% школ. На завтрак отведено не более 15 минут в 20 \% школ. Оборудованное место для мытья и сушки рук имеется в 99,5\% школ. 
Буфеты имелись менее чем в половине обследованных школ. Наиболее часто реализуемой продукцией в школьных буфетах является выпечка, соки, шоколад и кондитерские изделия. Необходимые для здорового питания детей продукты, такие как овощи, фрукты и молочные продукты, чаще всего были в ассортименте школьных буфетов только в 29,9-36,3\% школ. В части школ через буфеты реализуются не рекомендованные для питания детей сладкие газированные напитки $(3,4 \%)$. На основании данных опросов детей о частоте потребления основных продуктов выявлены значительные нарушения в структуре питания школьников: низкое ежедневное потребление таких продуктов, как молоко, кисломолочные напитки, мясо, овощи и фрукты. В целом набор продуктов ежедневного потребления содержит недостаточное количество прежде всего высокобелковых продуктов (мяса, молочных продуктов), сложных углеводов (отмечается низкое потребление зерновых и блюд из них), недостаточное потребление овощей и фруктов. Наряду с этим выявлена достаточно высокая частота потребления продуктов с добавленным сахаром. Установлено, что большая часть детей не принимает витаминно-минеральные комплексы: только $38 \%$ опрошенных школьников сообщили об их использовании.

Правила здорового питания соблюдали $92 \%$ опрошенных: употребляли 2 овоща в день 76,2\%, по 250-300 г фруктов ежедневно 76,7\%, предпочитали хлеб из муки грубого помола - 46,9 \%, включали блюда из рыбы в недельный рацион 58,3 \% и 2-3 порции молочных продуктов в день $-68,2 \%$.

Нормальные показатели индекса массы тела характерны для большинства детей школьного возраста $(68,6 \%)$, недостаточность массы тела имеют только 5,0\% обследованных. При этом доля детей с нормальной массой тела и недостатком веса в большей степени выявлялась в группе девочек - 73,9 \% и 5,2 \%, аналогично у мальчиковшкольников эти показатели составили 62,9\% и 4,7 \%.

Избыточная масса тела и ожирение были установлены у 18,2\% и 8,4\% обследованных школьников соответственно (17,0\% и 7,8 \% в 2019 г.). Более высокая распространенность избыточной массы тела и ожирения наблюдалась у мальчиковшкольников - 21,2 \% и 11,5\% (что превышает показатели 2019 г. - 20,4 \% и 10,7 \% соответственно) по сравнению с девочками - 15,6 \% и 5,6 \% (в 2019 г. 14,0 \% и 5,6\% соответственно). Низкий уровень физической активности зафиксирован у 35,2\% школьников.

Достоверная оценка условий обучения и воспитания, созданных в организациях для детей и подростков, проводится с использованием методов лабораторноинструментального контроля. Структура всех исследований, проведенных в организациях для детей и подростков, отражена на рис. 63.

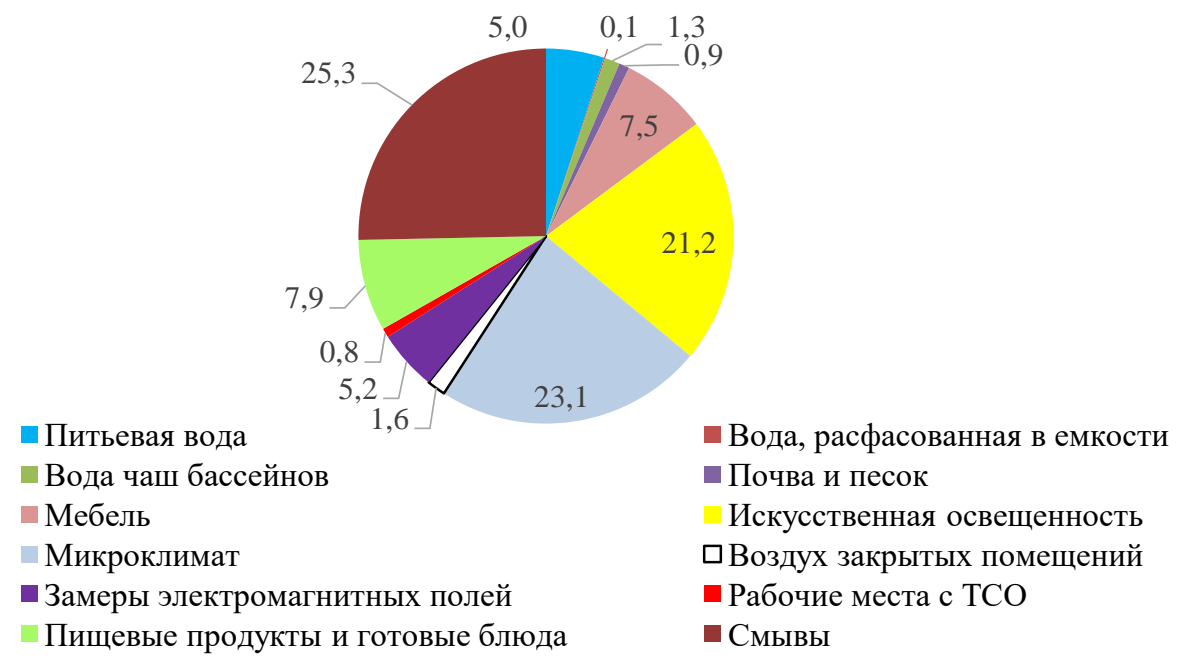

Рис. 63. Структура исследований, проведенных в Российской Федерации в организациях для детей и подростков в 2020 г., \% 
Основную долю исследований составили замеры искусственной освещенности $(21,2 \%$ всех исследований), микроклимата $(23,1 \%)$ и смывов с различных поверхностей $(25,3 \%)$. Исследования пищевых продуктов и готовых блюд составили 7,9 \%, замеры мебели на соответствие росту детей $-7,5 \%$, питьевой воды - 5,0 \%, электромагнитных полей $-5,2 \%$. Другие исследования (воды, расфасованной в емкости, воды чаш бассейнов, исследования почвы и песка, воздуха закрытых помещений, рабочих мест с техническими средствами обучения) составили 4,8 \%.

Результаты исследований проб воды и готовых блюд представлены в табл. 16. За период 2011-2020 гг. отмечается тенденция к снижению удельного веса проб, не соответствующих требованиям.

Особое внимание уделяется лабораторному контролю за качеством воды в субъектах Российской Федерации, где имеются организации, функционирующие без централизованного водоснабжения. Доля исследований качества питьевой воды в этих субъектах составила $1,1-10,8$ \% от всех исследований. Доля неудовлетворительных проб по санитарно-химическим показателям и (или) по микробиологическим показателям составила более 10,0 \% в 5 субъектах Российской Федерации: Архангельская область, республики Калмыкия, Дагестан, Республика, Саха (Якутия).

Таблица 16

Результаты лабораторно-инструментального контроля воды и готовых блюд в организациях для детей и подростков в Российской Федерации за 2011-2020 гг.

\begin{tabular}{|c|c|c|c|c|c|c|c|c|c|c|}
\hline \multirow{2}{*}{ Показатель } & \multicolumn{10}{|c|}{$\begin{array}{c}\text { Удельный вес проб и замеров, не соответствующих } \\
\text { санитарно-эпидемиологическим требованиям, \% }\end{array}$} \\
\hline & 2011 & 2012 & 2013 & 2014 & 2015 & 2016 & 2017 & 2018 & 2019 & 2020 \\
\hline \multicolumn{11}{|c|}{ Исследование питьевой воды } \\
\hline $\begin{array}{l}\text { по санитарно-химическим } \\
\text { показателям }\end{array}$ & 12,1 & 10,5 & 10,2 & 9,6 & 8,8 & 8,3 & 7,6 & 7,4 & 6,9 & 6,5 \\
\hline $\begin{array}{l}\text { по микробиологическим } \\
\text { показателям }\end{array}$ & 4,4 & 3,8 & 3,4 & 3,7 & 3,5 & 3,2 & 2,8 & 2,6 & 2,5 & 2,1 \\
\hline \multicolumn{11}{|c|}{ Исследование готовых блюд } \\
\hline $\begin{array}{l}\text { на калорийность и полноту } \\
\text { вложения }\end{array}$ & 8,8 & 7,7 & 7,3 & 9,2 & 6,9 & 5,7 & 4,7 & 4,5 & 4,0 & 4,6 \\
\hline на вложение витамина C & 8,1 & 7,8 & 8,0 & 9,2 & 8,8 & 8,4 & 6,9 & 7,9 & 7,6 & 7,4 \\
\hline $\begin{array}{l}\text { на качество термической } \\
\text { обработки }\end{array}$ & $\mathrm{X}$ & $X$ & 0,7 & 1,0 & 1,2 & 1,1 & 0,5 & 0,5 & 0,4 & 0,4 \\
\hline $\begin{array}{l}\text { по микробиологическим } \\
\text { показателям }\end{array}$ & 2,9 & 2,7 & 2,6 & 2,6 & 2,3 & 2,1 & 2,1 & 2,1 & 1,8 & 1,8 \\
\hline
\end{tabular}

*Учет показателя в формах статистического наблюдения ведется с 2013 г.

В 12 субъектах Российской Федерации (Смоленская область, Тамбовская область, Республика Карелия, Новгородская область, Республика Дагестан, Чеченская Республика, Удмуртская Республика, Ханты-Мансийский автономный округ, ЯмалоНенецкий автономный округ, Красноярский край, Республика Саха (Якутия), Чукотский автономный округ) качество воды было неудовлетворительным более чем в 10,0\% бассейнов.

Результаты замеров микроклимата, освещенности, мебели и электромагнитных полей, проведенных в организациях для детей и подростков, представлены на рис. 64. 
Государственный доклад «О состоянии санитарно-эпидемиологического благополучия населения в Российской Федерации в 2020 году»

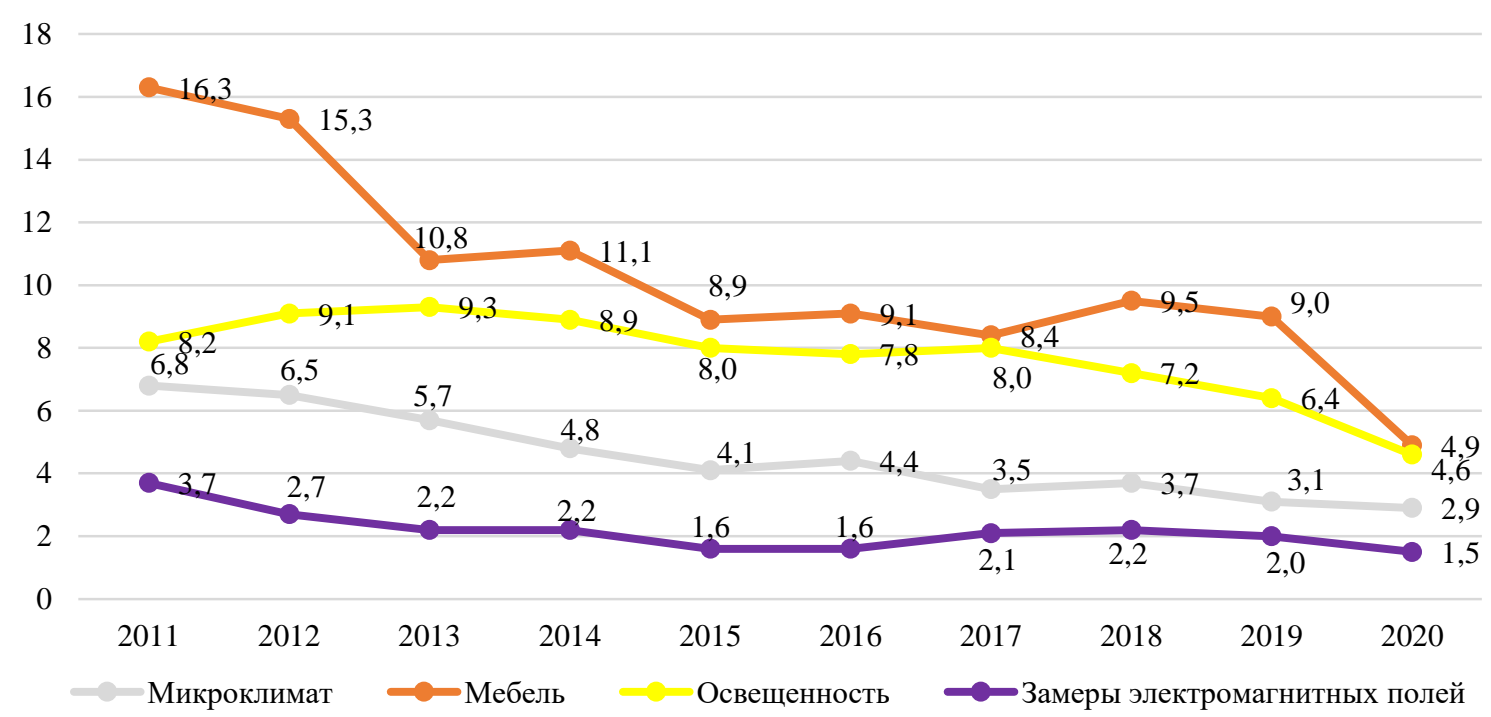

Рис. 64. Удельный вес замеров, не соответствующих нормативным требованиям, в организациях для детей и подростков, \%

В современном учебном процессе активно используются электронные средства обучения (ЭСО). В 2020 г. было проведено 33415 замеров рабочих мест с ЭСО в 2870 организациях. Удельный вес замеров, не соответствующих требованиям, составил 1,6 \%.

На формирование ведущей патологии детей школьного возраста (хронические болезни глаза и придаточного аппарата, органов пищеварения, костно-мышечной системы, нервной системы, травмы и отравления) оказывают заметное влияние условия обучения и воспитания: переуплотненность и многосменный режим работы образовательных организаций, превышение количества обучающихся в классах, режим учебно-воспитательного процесса (количество учебных занятий, нерационально составленное расписание занятий); несоответствие параметров микроклимата и освещенности в учебных помещениях гигиеническим нормативам; несоответствие учебной мебели ростовым особенностям обучающихся; отсутствие необходимого набора помещений для образовательной деятельности; развитие цифровой образовательной среды без достаточного научного обоснования и гигиенического обеспечения. Также на формирование заболеваемости у детей и подростков в 2020 г. повлияла дистанционная форма обучения в период пандемии COVID-19 с марта 2020 г.

Обеспечение санитарно-эпидемиологического благополучия детей в период летней оздоровительной кампании 2020 года было особенно актуальным на фоне сохраняющихся рисков распространения новой коронавирусной инфекции после нескольких месяцев вынужденной самоизоляции обучающихся всей страны и организации их обучения в дистанционном режиме с марта и до конца учебного года.

Летом 2020 г. к открытию планировались 30304 организации отдыха детей и их оздоровления, но ввиду сложившейся эпидемиологической обстановки функционировало 9205 организаций $(30,4$ \% от общего количества запланированных к открытию). Снижение составило 70 \% и более по сравнению с периодом 2011-2019 гг.

Возможность эксплуатации организаций отдыха детей и их оздоровления определялась в каждом регионе Российской Федерации в зависимости от сложившейся в нем эпидемиологической ситуации. В большинстве регионов она началась позднее обычного срока (после 1 июля), а в 25 субъектах РФ не проводилась вообще в связи с высоким риском распространения коронавирусной инфекции (Владимирская, Смоленская, Архангельская, Саратовская, Ульяновская, Тюменская, Новосибирская, Томская и Магаданская области, республики Адыгея, Калмыкия, Дагестан, Ингушетия, 
Мордовия, Алтай, Северная Осетия - Алания и Хакасия, Ненецкий, Ямало-Ненецкий и Ханты-Мансийский автономные округа, Камчатский и Ставропольский края, Кабардино-Балкарская и Чеченская республики, Еврейская автономная область).

В 61 субъекте Российской Федерации, где осуществлялся организованный отдых детей, были открыты только несколько типов оздоровительных организаций: стационарные загородные оздоровительные организации функционировали в 55 регионах, организации с дневным пребыванием - в 38 регионах. Число организаций отдыха детей и их оздоровления, функционирующих в период летней оздоровительной кампании в Российской Федерации в 2020 году, представлено на рис. 65.

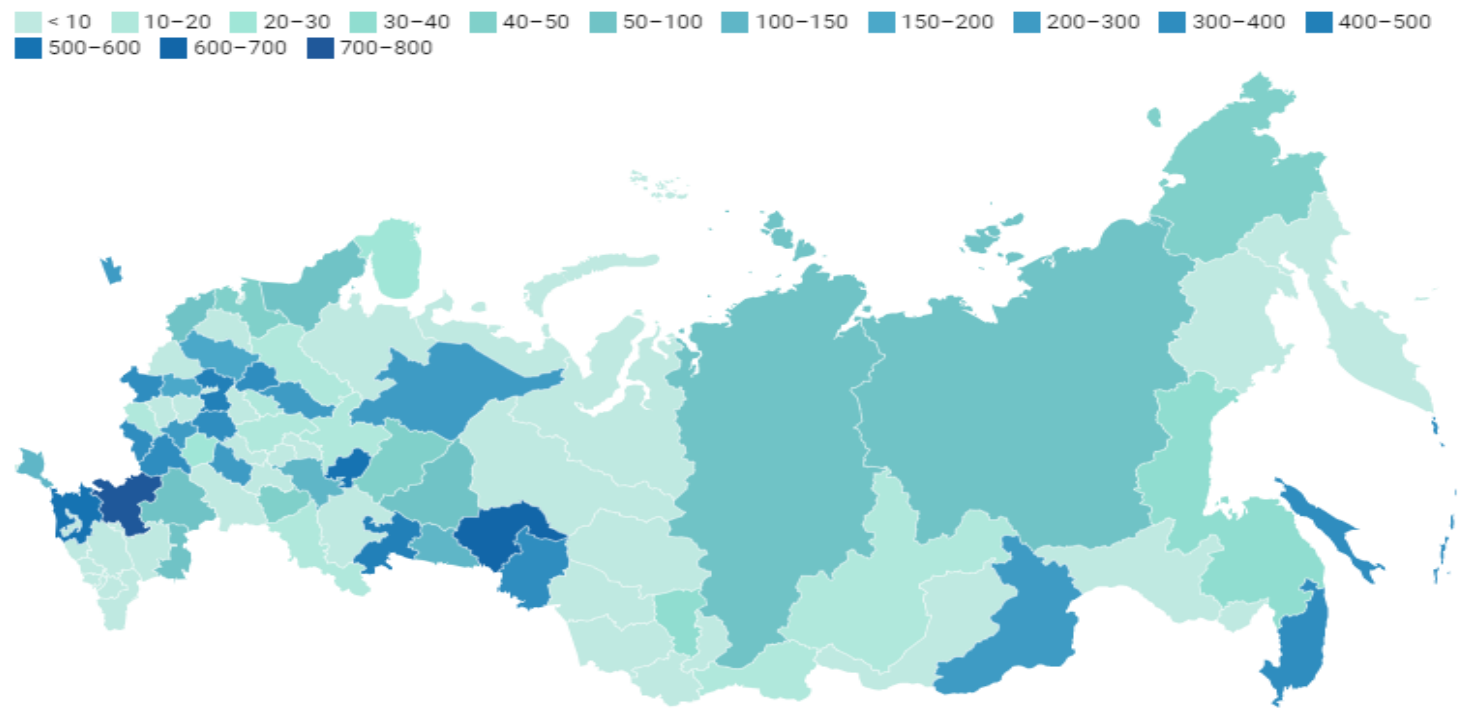

Рис. 65. Количество организаций отдыха детей и их оздоровления, функционирующих в период летней оздоровительной кампании в Российской Федерации в 2020 году

До 2020 года наблюдалось ежегодное снижение числа всех типов организаций отдыха детей, за исключением детских лагерей труда и отдыха. Значительно сократилось число загородных дошкольных организаций (детские дачи) - на 67,2 \% (в 3,1 раза), детских лагерей палаточного типа - на 47,6 \%, организаций с дневным пребыванием на $17,6 \%$. Соответственно в этих организациях снизилось и количество отдыхающих детей: в загородных дошкольных организациях - на 55,0 \%, лагерях палаточного типа на $21,3 \%$, организациях с дневным пребыванием - на $12,0 \%$. Число стационарных загородных оздоровительных организаций также продолжает снижаться, однако число отдохнувших в них детей возросло на 109534 чел. (на 7,1 \%).

В 2020 г. доля организаций отдыха детей и их оздоровления, не имеющих централизованного водоотведения, составила 0,37 \% (2011 г. - 7,4 \% и 2019 г. - 3,0 \%), не имеющих центрального водоснабжения - 0,47\% (2011 г. - 6,8\% и 2019 г. - 3,8\%), работающих на привозной воде $-0,41 \%$ (2011 г. - 4,4 \% и 2019 г. - 3,0 \%). В структуре этих учреждений преобладают организации дневного пребывания и детские лагеря палаточного типа.

За предыдущие девять лет в летний период в открывшихся детских оздоровительных организациях ежегодно отдыхали более 5 млн детей, а в 2020 г. летней оздоровительной кампанией было охвачено 1334904 детей (табл. 17). 
Количество детей, отдохнувших в организациях отдыха детей и их оздоровления, в период летней оздоровительной кампании в Российской Федерации, в динамике за 2011-2020 гг.

\begin{tabular}{|c|c|c|c|c|c|c|c|c|c|c|}
\hline Типы организаций & 2011 & 2012 & 2013 & 2014 & 2015 & 2016 & 2017 & 2018 & 2019 & 2020 \\
\hline Всего & 5244435 & 5193748 & 5573621 & 5627142 & 5823197 & 5943794 & 5671940 & 5659064 & 5615612 & 1334904 \\
\hline $\begin{array}{l}\text { Загородные } \\
\text { дошкольные } \\
\text { организации } \\
\text { (детские дачи) }\end{array}$ & 14452 & 13098 & 6918 & 8863 & 10410 & 9656 & 15677 & 15388 & 6505 & 140 \\
\hline \begin{tabular}{|l} 
Стационарные \\
загородные \\
оздоровительные \\
организации
\end{tabular} & 1538943 & 1544748 & 1553972 & 1623640 & 1561616 & 1696285 & 1590971 & 1659194 & 1648477 & 278122 \\
\hline $\begin{array}{l}\text { Организации с } \\
\text { дневным } \\
\text { пребыванием детей }\end{array}$ & 3102190 & 3105985 & 3004351 & 2942590 & 2860041 & 2763493 & 2678506 & 2693085 & 2729761 & 463552 \\
\hline $\begin{array}{l}\text { Детские лагеря } \\
\text { труда и отдыха* }\end{array}$ & $\mathrm{X}$ & X & 147693 & 143640 & 142778 & 138175 & 128987 & 125845 & 123241 & 6243 \\
\hline \begin{tabular}{|l} 
Детские лагеря \\
палаточного типа*
\end{tabular} & X & X & 243461 & 260703 & 256158 & 245231 & 169720 & 166140 & 143397 & 145 \\
\hline $\begin{array}{l}\text { Стационарные } \\
\text { загородные } \\
\text { оздоровительные } \\
\text { организации } \\
\text { санаторного типа }\end{array}$ & 385230 & 360403 & 349278 & 353650 & 377468 & 382395 & 356013 & 291700 & 270196 & 45546 \\
\hline Детские санатории & 203620 & 173114 & 113910 & 126320 & 124805 & 135487 & 132636 & 99380 & 89677 & 11670 \\
\hline Прочие** & $\mathrm{X}$ & $\mathrm{X}$ & 154038 & 167736 & 489921 & 573072 & 599430 & 608332 & 604358 & 529486 \\
\hline
\end{tabular}

* Учет показателей ведется с 2013 г.

Эффективность оздоровления детей в организациях отдыха и оздоровления оценивалась в 50 регионах (в 82,0 \% регионов, в которых функционировали организации отдыха детей и их оздоровления летом 2020 г.) у 1261921 ребенка (94,5\% от общего числа охваченных организованным отдыхом детей). В среднем по Российской Федерации данный показатель составил 96,5\%. В связи со сложившейся эпидемиологической ситуацией в ряде регионов продолжительность смен в отдельных организациях отдыха детей и их оздоровления была сокращена и составила менее 21 дня (республики Карелия и Башкортостан, Мурманская, Псковская, Калужская, Курганская, Свердловская и Омская области, Забайкальский и Хабаровский края, г. СанктПетербург). На протяжении 5 лет отмечался ежегодный рост данного показателя, за период с 2015 по 2020 г. он вырос на 3,4 \% (2015 г. - 93,1 \%; 2016 г. - 93,7 \%; 2017 г. 94,0\%; 2018 г. $-94,6 \% ; 2019$ г. $-95,0 \%)$.

В 2020 г. в рамках подготовки к работе и в период функционирования организаций отдыха детей и их оздоровления было проведено 83936 исследований, в том числе питьевой воды и воды открытых водоемов и бассейнов, используемых для купания, - по санитарно-химическим, микробиологическим и паразитологическим показателям; готовых блюд - по санитарно-химическим, микробиологическим показателям, на качество термической обработки, калорийность и химический состав, в том числе на вложение витамина $\mathrm{C}$; почвы и песка - по паразитологическим показателям. Удельный вес проб питьевой воды, не соответствующих требованиям по санитарнохимическим показателям, составил 4,5 \%, по микробиологическим показателям $-1,2 \%$. Удельный вес проб воды открытых водоемов и бассейнов, не соответствующих требованиям по санитарно-химическим и микробиологическим показателям, составил не 
Государственный доклад «О состоянии санитарно-эпидемиологического благополучия населения в Российской Федерации в 2020 году»

более $0,5 \%$; проб воды, не соответствующих требованиям по паразитологическим показателям, не было выявлено. Удельный вес проб готовых блюд, не соответствующих требованиям по химическому составу и калорийности, составил $2,8 \%$, по микробиологическим показателям $-1,1 \%$.

Комплекс мероприятий, введенных летом 2020 г. для уменьшения рисков распространения коронавирусной инфекции, позволил снизить заболеваемость относительно 2019 г. в 1,8 раза, число зарегистрированных вспышек инфекционных заболеваний снизилось в 3 раза.

В период 2011-2020 гг. заболеваемость детей, регистрируемая в организациях отдыха детей, снизилась с 730,7 (2011 г.) до 332,7 (2019 г.) и 181,0 (2020 г.) на 100000 чел. (рис. 66, табл. 18).

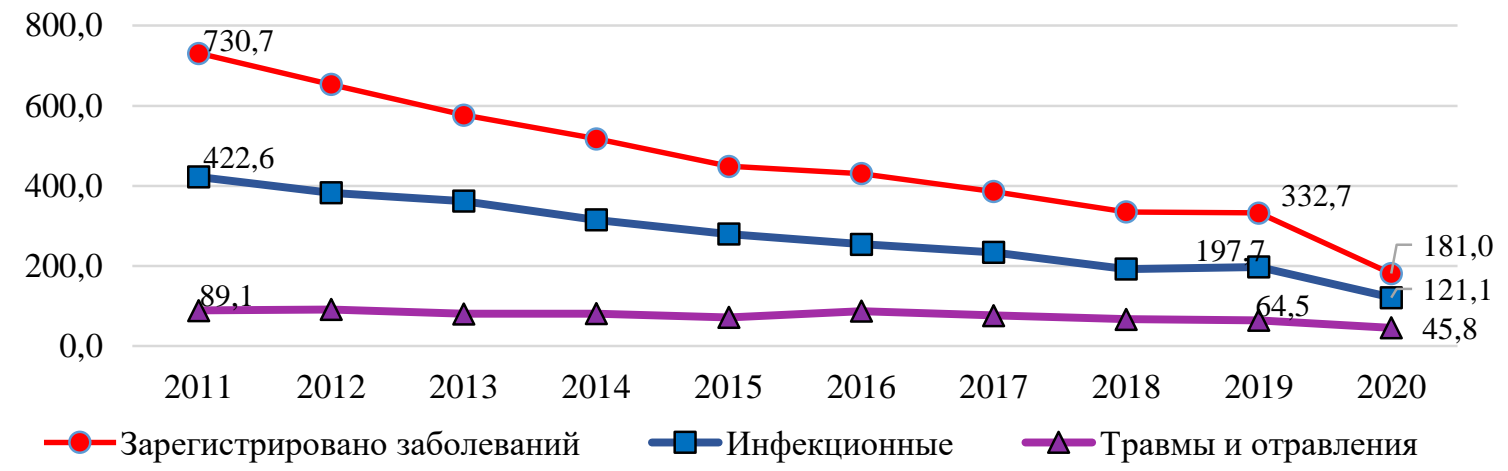

Рис. 66. Заболеваемость детей, находившихся в организациях отдыха детей и их оздоровления, в период оздоровительной кампании в Российской Федерации,

в динамике 2011-2020 гг. (на 100000 чел.)

Таблица 18

Заболеваемость детей, находившихся в организациях отдыха детей и их оздоровления, в период оздоровительной кампании в Российской Федерации, в динамике 2011-2020 гг. (на 100000 чел.)

\begin{tabular}{|c|c|c|c|c|c|c|c|c|c|c|}
\hline & 2011 & 2012 & 2013 & 2014 & 2015 & 2016 & 2017 & 2018 & 2019 & 2020 \\
\hline Зарегистрировано случаев & 730,7 & 653,4 & 576,9 & 517,6 & 449,2 & 430,8 & 386,1 & 334,9 & 332,7 & 181,0 \\
\hline $\begin{array}{l}\text { Инфекционные болезни } \\
\text { в том числе }\end{array}$ & 422,6 & 383,2 & 362,1 & 315,2 & 280,0 & 254,6 & 234,0 & 192,5 & 197,7 & 121,1 \\
\hline острые кишечные инфекции & 13,3 & 10,6 & 16,0 & 7,7 & 11,3 & 10,9 & 5,8 & 10,6 & 9,1 & 2,2 \\
\hline $\begin{array}{l}\text { инфекции с аэрозольным } \\
\text { путем передачи } \\
\text { в том числе }\end{array}$ & 400,9 & 368,2 & 339,2 & 299,6 & 259,0 & 235,6 & 221,5 & 175,2 & 181,9 & 112,8 \\
\hline $\begin{array}{l}\text { острые респираторные } \\
\text { заболевания }\end{array}$ & 381,3 & 355,5 & 324,1 & 288,4 & 233,2 & 220,5 & 197,4 & 169,7 & 171,3 & 105,6 \\
\hline грипп & 0,0 & 0,3 & 0,0 & 0,9 & 15,2 & 0,1 & 0,0 & 0,2 & 0,0 & 0,0 \\
\hline ветряная оспа & 14,1 & 11,1 & 9,9 & 9,1 & 8,2 & 8,0 & 7,0 & 4,5 & 5,9 & 0,4 \\
\hline корь & 0,0 & 0,0 & 0,0 & 0,0 & 0,0 & 0,0 & 15,4 & 0,0 & 0,0 & 0,0 \\
\hline Педикулез & 3,2 & 2,6 & 2,6 & 5,2 & 8,0 & 5,5 & 4,2 & 3,4 & 3,4 & 5,4 \\
\hline $\begin{array}{l}\text { Укусы насекомыми и } \\
\text { членистоногими* }\end{array}$ & $\mathrm{X}$ & $\mathrm{X}$ & 8,0 & 9,0 & 1,9 & 6,6 & 3,1 & 7,2 & 4,7 & 1,0 \\
\hline $\begin{array}{l}\text { Травмы и отравления } \\
\text { в том числе }\end{array}$ & 89,1 & 91,9 & 80,6 & 81,1 & 71,9 & 87,6 & 76,7 & 67,3 & 64,5 & 45,8 \\
\hline травмы & 77,7 & 91,8 & 66,5 & 73,7 & 71,5 & 84,5 & 76,3 & 66,0 & 64,0 & 45,8 \\
\hline $\begin{array}{l}\text { Число вспышек } \\
\text { инфекционных заболеваний } \\
\text { и пищевых отравлений, ед. }\end{array}$ & 16 & 14 & 19 & 8 & 13 & 22 & 13 & 18 & 18 & 6 \\
\hline
\end{tabular}

* Учет показателя ведется с 2013 г. 
В основном заболеваемость сократилась за счет снижения случаев инфекционных болезней на 100000 чел.: с 422,6 в 2011 г. до 332,7 в 2019 г. и 121,1 в 2020 г. В структуре заболеваемости, регистрируемой в организациях отдыха, преобладают инфекционные болезни (57,8-66,9\%), на втором месте находятся травмы и отравления $(12,2-25,3 \%)$. Основную долю инфекционных заболеваний составляют острые респираторные заболевания (91,0-96,1%), доля кишечных инфекционных заболеваний составляет 1,5$4,4 \%$.

Отмечено и снижение заболеваемости острыми респираторными заболеваниями - с 381,3 до 171,3 (2019 г.) и 105,6 (2020 г.) на 100000 чел.

Несмотря на невысокую заболеваемость педикулезом у детей в организациях отдыха, ежегодно регистрируется данное заболевание в 2,6-8,0 случаев на 100000 чел.

Для сохранения и укрепления здоровья детей большое значение имеет обеспечение их качественной и безопасной одеждой, обувью, игрушками и другими товарами детского ассортимента. По итогам 2020 г. Роспотребнадзором было проведено 2926 мероприятий по контролю за соблюдением требований технических регламентов Таможенного союза 007/2011 «О безопасности продукции, предназначенной для детей и подростков» и 008/2011 «О безопасности игрушек» в отношении субъектов надзора (юридический лиц и индивидуальных предпринимателей), деятельность которых связана с производством и оборотом продукции, предназначенной для детей и подростков. Выявлено 1433 нарушения требований ТР ТС 007/2011 и 766 нарушений требований ТР ТС 008/2011. Все выявленные нарушения касаются требований к продукции, в структуре наибольший удельный вес имеют нарушения требований к маркировке продукции в части порядка и объема сведений $(80 \%)$. По выявленным нарушениям приняты меры административного воздействия. Вынесены постановления о назначении административного наказания в виде штрафа на общую сумму 15 266,5 тыс. рублей, а также постановления о назначении административного наказания в виде штрафа на общую сумму 1532,5 тыс. рублей с конфискацией продукции на сумму 7577,8 тыс. рублей. Выдано 251 предписание об устранении нарушений обязательных требований ТР ТС, 102 предписания о разработке программ мероприятий по предотвращению причинения вреда и 115 предписаний о приостановлении реализации продукции. Исследовано 2540 проб продукции, предназначенной для детей и подростков, и 1675 проб игрушек. Удельный вес проб, не соответствующих требованиям ТР ТС 007/2011 и ТР ТС 008/2011, составил соответственно 15,3\% и 16,5\%.

За период 2013-2020 гг. удельный вес не соответствующих нормативным требованиям проб продукции, предназначенной для детей и подростков, увеличился в 3 раза $(2020$ г. - 15,3\%, 2019 г. - 10,3\%, 2013 г. - 5,2\%). При этом более $40 \%$ не соответствующих требованиям проб составляют пробы импортной продукции (2020 г. 50,1 \%, 2019 г. - 53,3 \%, 2013 г. - 64,2 \%). Наибольшее число нарушений установленных требований отмечается по следующим видам товаров: обувь для детей и подростков, трикотажные изделия, одежда и изделия из текстильных материалов и кожи. Удельный вес проб игрушек, не соответствующих нормативным требованиям, в указанный период увеличился в 2,5 раза (2020 г. - 16,5\%, 2019 г. - 7,3\%, 2013 г. - 6,8 \%). При этом более $60 \%$ от общего количества не соответствующих требованиям проб составляют пробы импортной продукции (2020 г. - 84,1 \%, 2019 г. - 61,0 \%, 2013 г. - 74,5 \%). Наибольший удельный вес проб, не соответствующих обязательным требованиям, отмечается по показателям маркировки.

В 2020 г. в ходе тематических горячих линий специалистами Роспотребнадзора было проведено 53651 консультация, в том числе 252 обратившимся оказана помощь в составлении претензии в адрес продавца. Наиболее частыми причинами для составления претензий являлись негативные свойства товаров, выявленные в процессе эксплуатации 
(потеря цвета и товарного вида изделия после стирки при соблюдении рекомендаций по уходу за изделием, неработающие электронные игрушки и книги), а также отказ продавца от обмена или возврата товара.

Структура поступивших в 2020 г. обращений в период проведения тематических горячих линий изменилась, что обусловлено сложившейся эпидемиологической ситуацией, связанной с риском распространения коронавирусной инфекции. Наряду с вопросами о качестве и безопасности детской одежды, обуви и игрушек высокую популярность приобрели вопросы о режиме работы образовательных организаций, проведении термометрии сотрудникам и детям, необходимости использования ими средств индивидуальной защиты (масок), о дезинфекционной обработке рук детей и рекомендуемых для этой цели средствах, медицинской документации, необходимой в случае выезда из региона, и необходимости соблюдения карантинных мероприятий по приезде.

\subsection{7. Мониторинг физических факторов среды обитания}

На учете территориальных органов Роспотребнадзора находится свыше 1,5 миллионов потенциально опасных для здоровья человека объектов, на которых зарегистрированы источники физических факторов неионизирующей природы. Из них абсолютное большинство являются сочетанными источниками разных физических факторов.

Основная часть объектов относится к промышленным предприятиям. Объектами, содержащими источники физических факторов неионизирующей природы, являются также жилые и общественные здания, в том числе медицинские организации, детские и образовательные учреждения и территория жилой застройки. В 2020 году обследовано 50308 объектов, что составило 3,2 \% от общего количества (в 2019 г. - 10,1\%).

Удельный вес объектов, обследованных в рамках проведения мероприятий по контролю (надзору) по отдельным физическим факторам, составляет от $0,5 \%$ до 2,2 \%, из них лабораторно от 39,8 до 91,5 \% (исключение составляют гипогеомагнитные поля $3,7 \%$ ) (рис. 67).

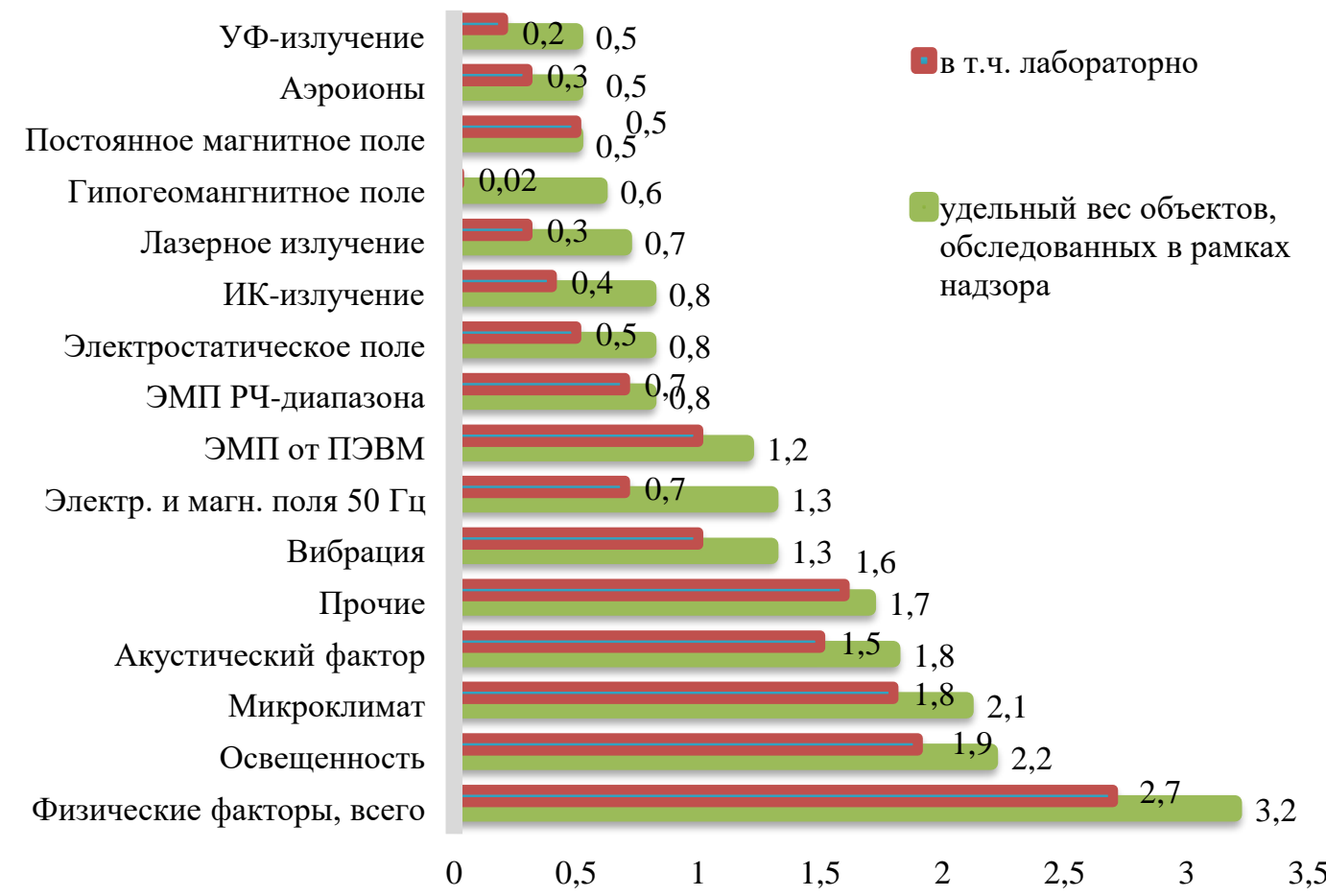

Рис. 67. Удельный вес объектов, обследованных в рамках надзора, в т.ч. лабораторно в 2020 г., \% 
Удельный вес объектов, на которых выявлено несоответствие уровней физических факторов требованиям санитарного законодательства, за последние 10 лет имеет тенденцию к снижению, однако остается высоким. Наибольшая доля объектов, не соответствующих санитарно-эпидемиологическим требованиям, отмечается по таким факторам, как шум (12,0 \%), освещенность $(9,9 \%)$ и ЭМП $(6,2 \%)$ (рис. 68).

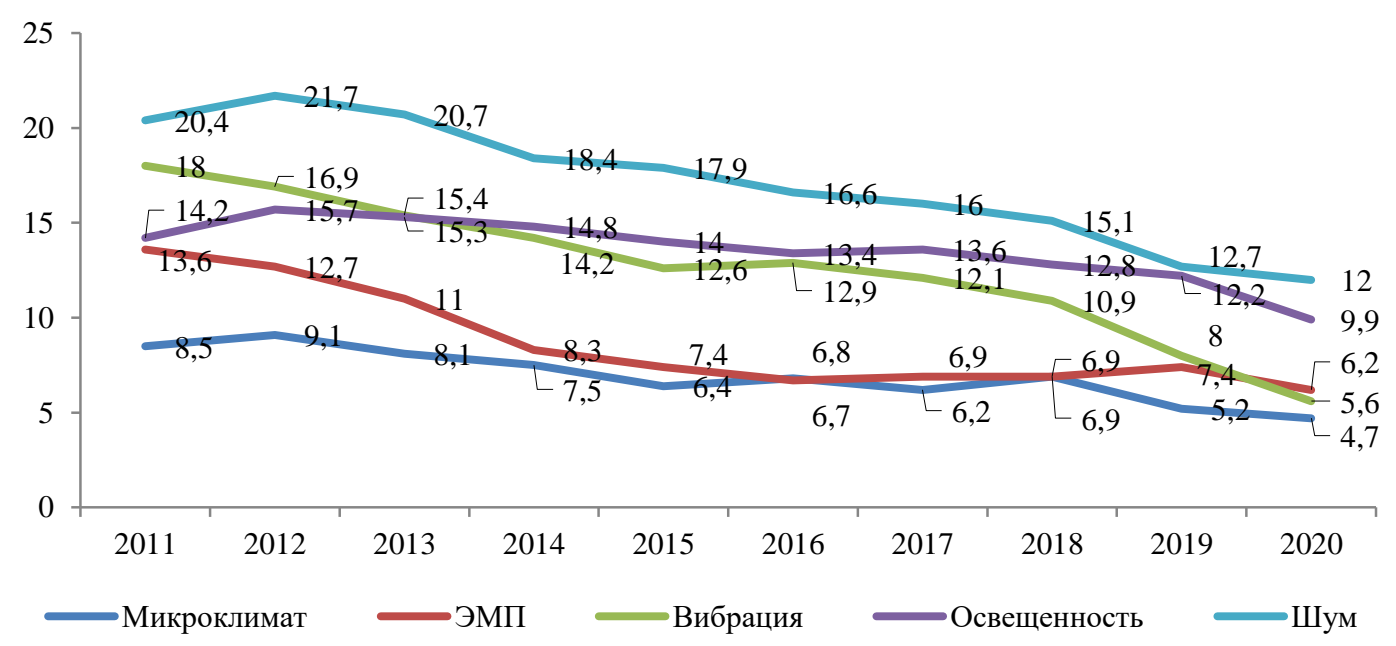

Рис. 68. Удельный вес объектов, не соответствующих санитарно-эпидемиологическим требованиям по физическим факторам, \%

В структуре исследований физических факторов неионизирующей природы в 2020 г., как и в прошлые годы, наибольший удельный вес приходится на измерения параметров микроклимата $(50,9 \%)$ и освещенности $(25,2 \%)$ (рис. 69$)$.

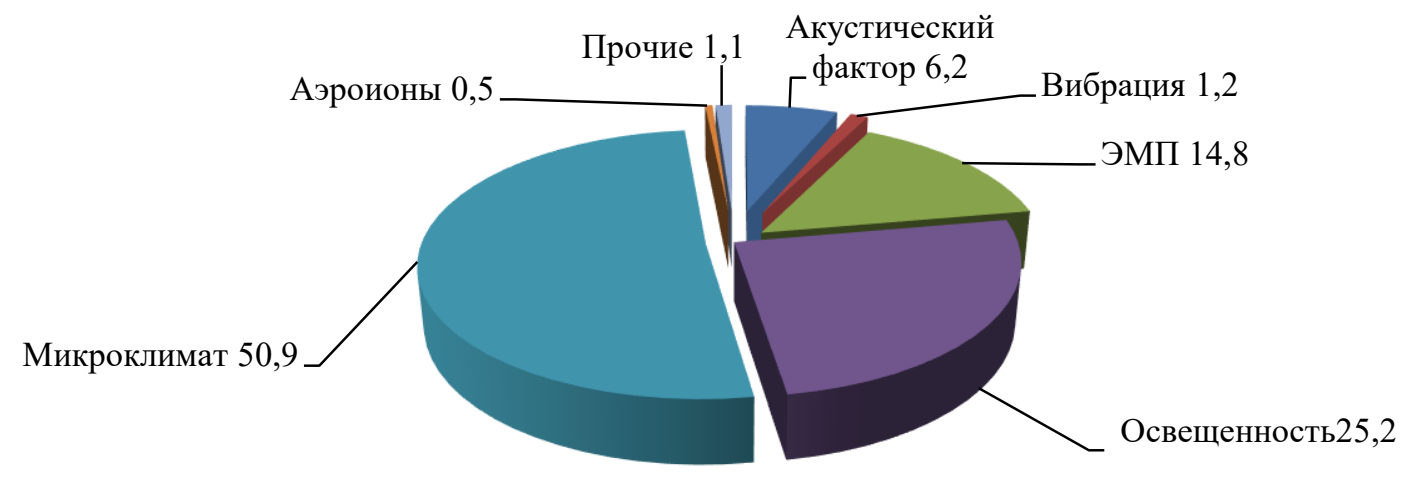

Рис. 69. Структура исследований физических факторов неионизирующей природы в 2020 году, \%

Количество измерений в 2020 году по сравнению с 2015 годом увеличилось в 1,1 раза и составило 6180429 измерений. В то же время удельный вес измерений, не соответствующих санитарно-эпидемиологическим требованиям, снизился с $6,9 \%$ в 2015 г. до 4,2\% в 2020 г. Наибольший удельный вес проб, не соответствующих гигиеническим нормативам, представлен аэроионами $(23,2 \%)$ и акустическим фактором $(11,9 \%)$.

Снижение удельного веса измерений, не соответствующих санитарным нормам, отмечено по всем физическим факторам (рис. 70). 


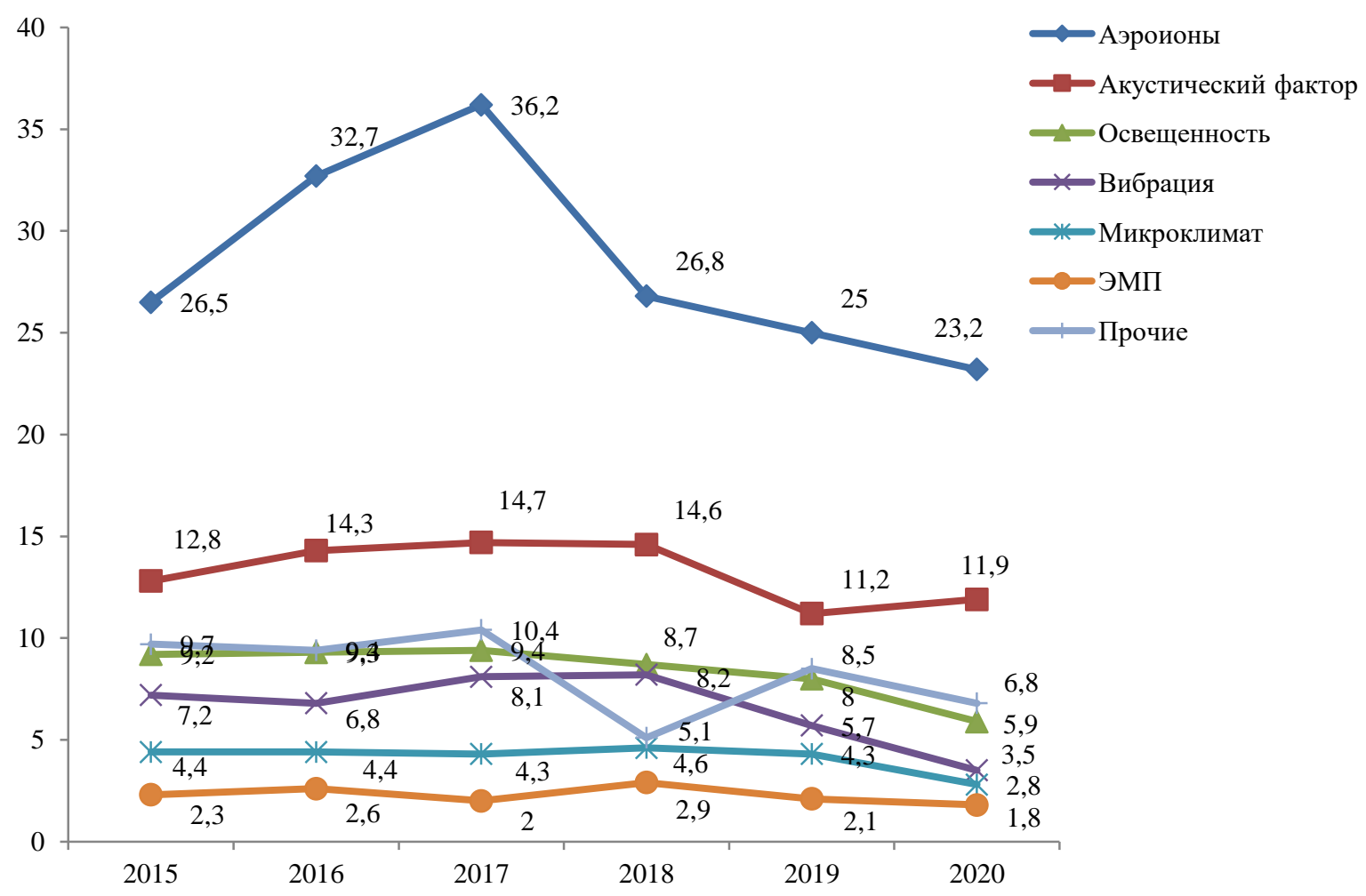

Рис. 70. Удельный вес измерений физических факторов, не соответствующих санитарным нормам, \%

Физические факторы являются одним из основных факторов риска условий труда, влияющих на состояние здоровья работающих. Доля неудовлетворительных проб в 2020 году составила по шуму на промышленных предприятиях 23,5 \% и освещенности 20,8 \%.

За период 2011-2020 гг. отмечается снижение удельного веса промышленных предприятий, не соответствующих санитарно-эпидемиологическим требованиям по всем физическим факторам, в том числе по вибрации на 56,7 \% и ЭМП на 43,3\% (табл. 19).

Таблица 19

Удельный вес промышленных предприятий, обследованных лабораторно по физическим факторам, не отвечающих гигиеническим нормативам, \%

\begin{tabular}{|c|c|c|c|c|c|}
\hline Годы & Шум & Вибрация & ЭМП & Освещенность & Микроклимат \\
\hline 2011 & 36,8 & 25,4 & 15,7 & 29,1 & 15,1 \\
\hline 2012 & 36,0 & 22,7 & 17,8 & 31,2 & 15,2 \\
\hline 2013 & 33,9 & 21,4 & 13,1 & 30,0 & 13,0 \\
\hline 2014 & 33,1 & 20,4 & 10,3 & 30,0 & 12,7 \\
\hline 2015 & 31,3 & 18,5 & 8,8 & 27,0 & 10,7 \\
\hline 2016 & 32,7 & 21,2 & 8,8 & 27,3 & 11,3 \\
\hline 2017 & 32,4 & 20,4 & 10,8 & 29,5 & 10,3 \\
\hline 2018 & 31,1 & 19,8 & 8,2 & 22,8 & 19,3 \\
\hline 2019 & 26,8 & 14,2 & 11 & 26,7 & 9,9 \\
\hline 2020 & 23,6 & 11,0 & 8,9 & 20,8 & 9,0 \\
\hline $\begin{array}{l}\text { Темп снижени } \\
\text { к 2011г., \% }\end{array}$ & $-35,9$ & $-56,7$ & $-43,3$ & $-28,5$ & $-40,4$ \\
\hline
\end{tabular}


В 2020 году наибольший удельный вес промышленных предприятий, не отвечающих санитарно-эпидемиологическим требованиям по уровню шума, отмечен в Нижегородской области $(61,8 \%)$, Брянской области $(58,8 \%)$, Республике Карелия $(57,1 \%)$, Республике Марий Эл $(54,6 \%)$, Тверской области $(51,2 \%)$, в Магаданской $(50,0 \%)$, Костромской $(50,0 \%)$ и Владимирской $(50,0 \%)$ областях, Республике Тыва $(50,0 \%)$, Томской области $(44,4 \%)$.

За последние 10 лет отмечается сокращение удельного веса рабочих мест промышленных предприятий, не соответствующих санитарно-эпидемиологическим требованиям по таким факторам, как микроклимат на 60,0 \%, вибрация на 59,7 \%, шум на 41,6\% и освещенность на 40,5\% (табл. 20).

Таблица 20

\section{Удельный вес обследованных рабочих мест промышленных предприятий, не соответствующих санитарно-эпидемиологическим требованиям по физическим факторам}

\begin{tabular}{|c|c|c|c|c|c|}
\hline Годы & Шум & Вибрация & ЭМП & Освещенность & Микроклимат \\
\hline 2011 & 25,5 & 15,4 & 6,2 & 16,3 & 8,5 \\
\hline 2012 & 25,4 & 14,0 & 7,0 & 16,6 & 7,6 \\
\hline 2013 & 24,6 & 14,8 & 6,0 & 16,7 & 6,6 \\
\hline 2014 & 21,8 & 12,5 & 4,5 & 16,0 & 5,9 \\
\hline 2015 & 19,9 & 10,8 & 4,1 & 14,7 & 5,1 \\
\hline 2016 & 19,6 & 10,0 & 3,8 & 13,7 & 5,2 \\
\hline 2017 & 19,5 & 10,4 & 5,7 & 13,9 & 4,4 \\
\hline 2018 & 17,4 & 10,0 & 6,8 & 13,0 & 4,9 \\
\hline 2019 & 15,3 & 7,5 & 6,4 & 12,4 & 4,0 \\
\hline 2020 & 14,9 & 6,2 & 5,9 & 9,7 & 3,4 \\
\hline $\begin{array}{l}\text { Темп снижения } \\
\text { к 2011 г., \% }\end{array}$ & $-41,6$ & $-59,7$ & $-4,8$ & $-40,5$ & $-60,0$ \\
\hline
\end{tabular}

В 2020 г. количество обследованных рабочих мест в целом на объектах надзора (промышленных, коммунальных, транспорта и др.) снизилось в 1,8 раза по сравнению с 2011 г., что связано с общим уменьшением количества надзорных мероприятий, обусловленным изменениями законодательства, сокращением числа рабочих мест в ряде субъектов Российской Федерации, пандемией COVID-19.

Доля обследованных рабочих мест промышленных предприятий, не соответствующих санитарно-эпидемиологическим требованиям, сократилась с 13,1 \% в 2011 г. до 7,7\% в 2020 г.

Доля обследованных рабочих мест промышленных предприятий, не соответствующих санитарно-эпидемиологическим требованиям по шуму, сократилась в 2020 году в 1,7 раза (рис. 71). 
Государственный доклад «О состоянии санитарно-эпидемиологического благополучия населения в Российской Федерации в 2020 году»

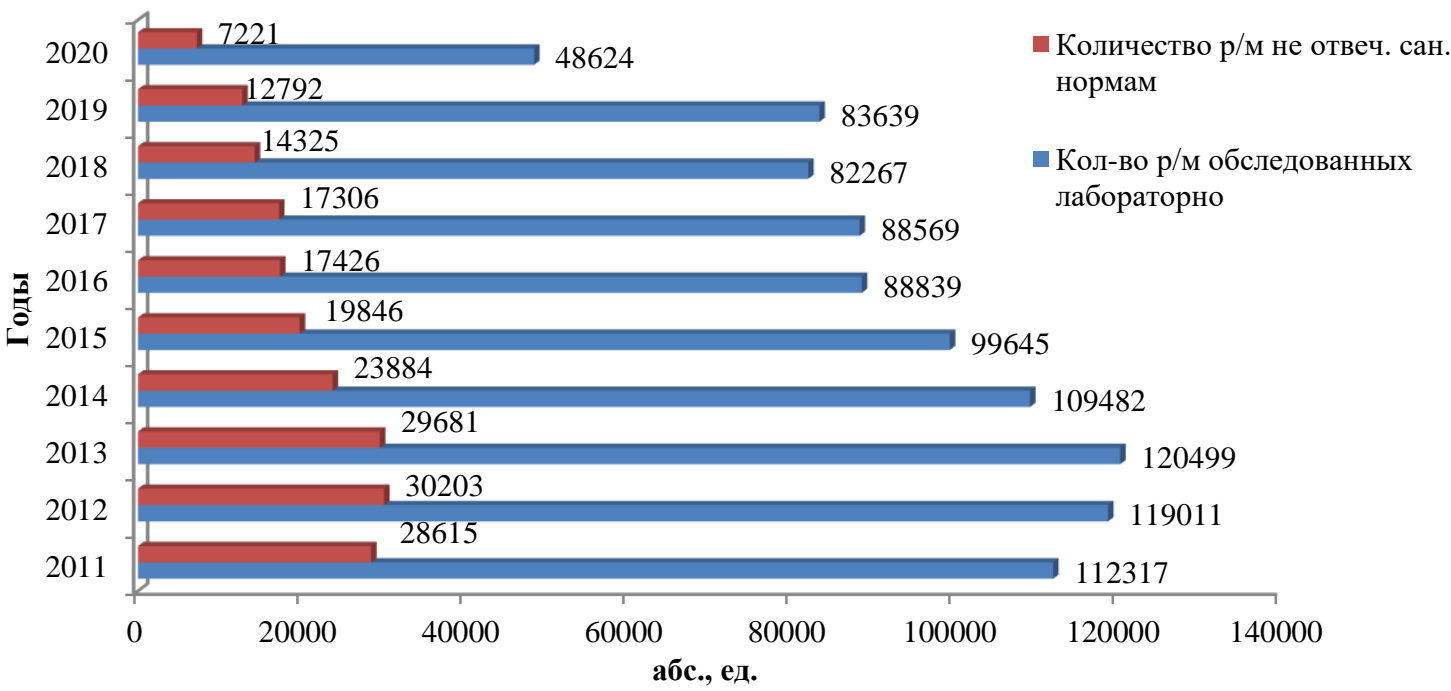

Рис. 71. Количество рабочих мест промышленных предприятий, не соответствующих санитарным нормам по уровням шума, 2011-2020 гг.

Основными причинами превышения безопасных уровней физических факторов на рабочих местах остаются несовершенство технологических процессов, конструктивные недостатки технологического оборудования и инструментов, их физический износ, несоблюдение сроков проведения планово-предупредительных ремонтов, неудовлетворительная организация производственного контроля, а также недостаточная ответственность работодателей и руководителей производств за состояние условий и охраны труда.

На транспортных средствах в 2020 г. приоритетное гигиеническое значение сохраняют шум, вибрация и микроклимат: доля объектов, не соответствующих санитарно-эпидемиологическим требованиям, составила соответственно 6,6 \%, 5,9\% и $5,9 \%$. Отмечается положительная динамика этих показателей относительно 2011 г. (табл. 21), за исключением микроклимата (темп прироста +15,7%).

Таблица 21

Удельный вес обследованных транспортных средств, не соответствующих санитарно-эпидемиологическим требованиям по физическим факторам

\begin{tabular}{|c|c|c|c|c|c|}
\hline Годы & Шум & Вибрация & ЭМП & Освещенность & Микроклимат \\
\hline 2011 & 26,9 & 21,3 & 1,7 & 5,0 & 5,1 \\
\hline 2012 & 24,9 & 18,5 & 1,0 & 9,0 & 7,3 \\
\hline 2013 & 23,8 & 16,2 & 0,3 & 5,4 & 4,7 \\
\hline 2014 & 21,8 & 15,6 & 1,4 & 5,2 & 5,0 \\
\hline 2015 & 19,3 & 14,5 & 0,5 & 2,4 & 2,6 \\
\hline 2016 & 20,5 & 13,9 & 0,5 & 3,7 & 4,1 \\
\hline 2017 & 15,8 & 12,3 & 0,3 & 3,4 & 3,2 \\
\hline 2018 & 10,8 & 10,9 & 0,5 & 9,0 & 7,1 \\
\hline 2019 & 8,8 & 9,4 & 0,2 & 6,3 & 11,8 \\
\hline 2020 & 6,6 & 5,9 & 0,6 & 3,4 & 5,9 \\
\hline $\begin{array}{l}\text { Темп прироста/ } \\
\text { снижения к 2011 г., } \%\end{array}$ & $-75,5$ & $-72,3$ & $-64,7$ & $-32,0$ & $+15,7$ \\
\hline
\end{tabular}

Отмечается достаточно низкая доля транспортных средств, не соответствующих санитарно-эпидемиологическим требованиям по уровню электромагнитных полей.

Для коммунальных объектов приоритетными физическими факторами являются шум и освещённость. В 2020 г. наблюдается тенденция снижения удельного веса 
Государственный доклад «О состоянии санитарно-эпидемиологического благополучия населения в Российской Федерации в 2020 году»

организаций коммунального и социального назначения, не соответствующих санитарноэпидемиологическим требованиям по всем физическим факторам (табл. 22).

Таблица 22

Удельный вес обследованных организаций коммунального и социального назначения, не соответствующих санитарно-эпидемиологическим требованиям по физическим факторам

\begin{tabular}{|c|c|c|c|c|c|}
\hline Годы & Шум & Вибрация & ЭМП & Освещенность & Микроклимат \\
\hline 2011 & 17,8 & 8,4 & 12,8 & 11,9 & 8,4 \\
\hline 2012 & 18,7 & 8,2 & 10,9 & 12,5 & 8,9 \\
\hline 2013 & 17,1 & 8,5 & 11,6 & 11,7 & 7,6 \\
\hline 2014 & 14,9 & 6,5 & 7,4 & 11,1 & 6,8 \\
\hline 2015 & 15,8 & 5,4 & 7,1 & 11,0 & 5,4 \\
\hline 2016 & 13,1 & 4,4 & 6,2 & 10,9 & 5,8 \\
\hline 2017 & 14,1 & 4,6 & 5,8 & 10,5 & 5,2 \\
\hline 2018 & 15,1 & 6,2 & 6,5 & 10,3 & 5,0 \\
\hline 2019 & 14,0 & 4,2 & 7,1 & 10,0 & 4,1 \\
\hline 2020 & 13,9 & 2,6 & 5,3 & 7,3 & 3,2 \\
\hline $\begin{array}{l}\text { Темп снижения } \\
\text { к 2011 г., \% }\end{array}$ & $-21,9$ & $-69,0$ & $-58,6$ & $-38,6$ & $-62,0$ \\
\hline
\end{tabular}

В 2020 году наибольший удельный вес организаций коммунального и социального назначения, не отвечающих санитарно-эпидемиологическим требованиям по уровню шума, отмечен в Республике Северная Осетия - Алания $(48,6 \%)$, Новосибирской области $(47,1 \%)$, Нижегородской области $(44,8 \%)$, Республике Дагестан $(41,8 \%)$, Иркутской области $(39,9 \%)$, Калужской области $(35,9 \%)$, Магаданской области $(33,3$ \%), Ивановской области (31,2 \%), Республике Башкортастан $(29,7$ \%).

В детских и подростковых организациях, как и в прошлые годы, основными факторами являются освещенность, микроклимат и электромагнитные поля.

В 2020 г. по сравнению с 2011 г. наблюдается тенденция снижения удельного веса детских и подростковых организаций, не соответствующих санитарноэпидемиологическим требованиям по всем физическим факторам (табл. 23).

Таблица 23

Удельный вес объектов в детских и подростковых учреждениях, обследованных лабораторно по физическим факторам, не отвечающих гигиеническим нормативам, \%

\begin{tabular}{|c|c|c|c|c|c|}
\hline Годы & Шум & Вибрация & ЭМП & Освещенность & Микроклимат \\
\hline 2011 & 4,6 & 2,1 & 12,8 & 16,3 & 11,2 \\
\hline 2012 & 4,2 & 2,6 & 10,4 & 17,3 & 11,9 \\
\hline 2013 & 4,4 & 2,4 & 8,6 & 15,5 & 10 \\
\hline 2014 & 4,1 & 1,0 & 7,4 & 15,3 & 9,3 \\
\hline 2015 & 3 & 0,5 & 6,3 & 14,4 & 8,4 \\
\hline 2016 & 3,5 & 0,5 & 6,3 & 14,1 & 8,5 \\
\hline 2017 & 2,6 & 0,7 & 5,8 & 14,6 & 8,0 \\
\hline 2018 & 3,9 & 0,8 & 6,9 & 13,4 & 7,8 \\
\hline 2019 & 2,1 & 0,0 & 5,9 & 11,9 & 6,9 \\
\hline 2020 & 2,1 & 0,6 & 5,8 & 10,3 & 6,6 \\
\hline $\begin{array}{l}\text { Темп снижения } \\
\text { к 2011 г., \% }\end{array}$ & $-54,3$ & $-71,3$ & $-54,7$ & $-36,8$ & $-41,1$ \\
\hline
\end{tabular}


В 2020 году наибольший удельный вес обследованных детских и подростковых организаций, не отвечающих санитарно-эпидемиологическим требованиям по уровню освещенности, отмечен в Амурской области (41,3\%), Тверской области $(34,5 \%)$, Новгородской области $(32,6 \%)$, Смоленской области $(31,3 \%)$, Калужской области $(31,2 \%)$, Чукотском автономном округе $(30,0 \%)$, Республике Карелия $(28,5 \%)$, Республике Хакасия $(26,7 \%)$, Архангельской области $(25,8 \%)$, Республике Тыва $(22,8 \%)$.

Продолжается рост числа источников физических факторов неионизирующей природы, неблагоприятно влияющих на условия проживания и здоровье населения на территории жилой застройки и в жилых помещениях. За последние 6 лет число измерений физических факторов на территории жилой застройки выросло в 1,4 раза (табл. 24).

Таблица 24

Результаты инструментальных измерений физических факторов на территории жилой застройки

\begin{tabular}{|c|c|c|c|c|c|c|c|c|c|c|c|c|}
\hline \multirow[b]{2}{*}{ Факторы } & \multicolumn{2}{|c|}{2015} & \multicolumn{2}{|c|}{2016} & \multicolumn{2}{|c|}{2017} & \multicolumn{2}{|c|}{2018} & \multicolumn{2}{|c|}{2019} & \multicolumn{2}{|c|}{2020} \\
\hline & $\mid \begin{array}{c}\text { Кол-во } \\
\text { изме- } \\
\text { рений, } \\
\text { абс. ед. }\end{array}$ & $\begin{array}{c}\text { из них } \\
\text { не } \\
\text { соотв. } \\
\text { гигие- } \\
\text { ничес- } \\
\text { ким } \\
\text { норма- } \\
\text { тивам, } \\
\%\end{array}$ & $\begin{array}{c}\text { Кол-во } \\
\text { изме- } \\
\text { рений, } \\
\text { абс. ед. }\end{array}$ & $\begin{array}{c}\text { из них } \\
\text { не } \\
\text { соотв. } \\
\text { гигие- } \\
\text { ничес- } \\
\text { ким } \\
\text { норма- } \\
\text { тивам, } \\
\%\end{array}$ & $\begin{array}{c}\text { Кол-во } \\
\text { изме- } \\
\text { рений, } \\
\text { абс. ед. }\end{array}$ & $\begin{array}{c}\text { из них } \\
\text { не } \\
\text { соотв. } \\
\text { гигие- } \\
\text { ничес- } \\
\text { ким } \\
\text { норма- } \\
\text { тивам, } \\
\%\end{array}$ & $\begin{array}{c}\text { Кол-во } \\
\text { изме- } \\
\text { рений, } \\
\text { абс. ед. }\end{array}$ & $\begin{array}{c}\text { из них } \\
\text { не } \\
\text { соотв. } \\
\text { гигие- } \\
\text { ничес- } \\
\text { ким } \\
\text { норма- } \\
\text { тивам, } \\
\%\end{array}$ & $\begin{array}{c}\text { Кол-во } \\
\text { изме- } \\
\text { рений, } \\
\text { абс. ед. }\end{array}$ & $\begin{array}{c}\text { из них } \\
\text { не } \\
\text { соотв. } \\
\text { гигие- } \\
\text { ничес- } \\
\text { ким } \\
\text { норма- } \\
\text { тивам, } \\
\%\end{array}$ & $\begin{array}{c}\text { Кол-во } \\
\text { изме- } \\
\text { рений, } \\
\text { абс. ед. }\end{array}$ & $\begin{array}{c}\text { из них } \\
\text { не } \\
\text { соотв. } \\
\text { гигие- } \\
\text { ничес- } \\
\text { ким } \\
\text { норма- } \\
\text { тивам, } \\
\%\end{array}$ \\
\hline $\begin{array}{l}\text { Всего, } \\
\text { в т.ч. }\end{array}$ & 268221 & 3,5 & 270632 & 3,0 & 345596 & 3,6 & 376603 & 4,7 & 423556 & 3,9 & 384004 & 5,1 \\
\hline Шум & 42216 & 17,4 & 39615 & 16,6 & 57553 & 19,2 & 75156 & 19,8 & 115361 & 13,4 & 118690 & 15,7 \\
\hline $\begin{array}{l}\text { Инфра- } \\
\text { Звук }\end{array}$ & 785 & 2,2 & 1786 & 8,8 & 1696 & 1,2 & 1204 & 1,1 & 1094 & 0,2 & 655 & 1,8 \\
\hline $\mid \begin{array}{l}Э М П ~ \\
50 \text { Гц }\end{array}$ & 7523 & 0,4 & 5737 & 0,5 & 5893 & 0,4 & 8133 & 0,2 & 11181 & 0,3 & 12146 & 0,4 \\
\hline \begin{tabular}{|l|} 
ЭМП \\
радиочас \\
тот. диа- \\
пазона \\
(включая \\
ПРТО)
\end{tabular} & 209942 & 0,8 & 215129 & 0,5 & 264964 & 0,2 & 282459 & 0,7 & 288106 & 0,1 & 245008 & 0,1 \\
\hline
\end{tabular}

Наиболее значимым из физических факторов, оказывающих влияние на среду обитания человека, является шум, воздействие которого на людей в условии плотной застройки населенных пунктов продолжает возрастать. Доля измерений шума на территории жилой застройки, не соответствующих санитарным нормам, в 2020 г. составила $15,7 \%$ (в 2019 г. - 13,4\%, в 2015 г. - 17,4\%,).

В 2020 году наибольший удельный вес инструментальных измерений шума на территории жилой застройки, не отвечающих санитарно-эпидемиологическим требованиям, отмечен в Вологодской области $(62,5 \%)$, Тамбовской области $(50,0 \%)$, Республике Коми $(44,4 \%)$, Владимирской области $(43,2 \%)$, Челябинской области $(42,4 \%)$, Новгородской области $(40,0 \%)$, Республике Татарстан $(38,0 \%)$, г. Москве $(33,7$ \%), Республике Крым (33,3 \%), Краснодарском крае $(31,4$ \%). 
Государственный доклад «О состоянии санитарно-эпидемиологического благополучия населения в Российской Федерации в 2020 году»

За период 2011-2020 гг. снизился удельный вес измерений в эксплуатируемых жилых и общественных зданиях, не отвечающих гигиеническим нормативам по всем показателям: темп снижения по шуму составил 25,5 \%, по вибрации - 35,7 \%, по ЭМИ $34,8 \%$ (табл. 25).

Таблица 25

Удельный вес общего числа измерений в эксплуатируемых жилых и
общественных зданиях по физическим факторам, не отвечающих
гигиеническим нормативам, \%

\begin{tabular}{|c|c|c|c|}
\hline Годы & Шум & Вибрация & ЭМИ \\
\hline 2011 & 20,0 & 5,6 & 2,3 \\
\hline 2012 & 21,1 & 7,1 & 2,7 \\
\hline 2013 & 19,3 & 7,4 & 2,4 \\
\hline 2014 & 20,5 & 6,5 & 2,9 \\
\hline 2015 & 16,6 & 5,3 & 2,2 \\
\hline 2016 & 17,3 & 4,3 & 3,1 \\
\hline 2017 & 16,1 & 7,23 & 1,86 \\
\hline 2018 & 17,5 & 6,61 & 2,39 \\
\hline 2019 & 15,1 & 3,5 & 3,1 \\
\hline 2020 & 14,9 & 3,6 & $-34,8$ \\
\hline Темп снижения & $-25,5$ & $-35,7$ & \\
к 2011 г., \% & & & \\
\hline
\end{tabular}

Ведущим источником шума в населенных пунктах по-прежнему является транспорт. В связи с увеличением количества автотранспорта на дорогах за последние годы вырос удельных вес измерений шума на автомагистралях и улицах с интенсивным движениям автотранспорта, не отвечающих гигиеническим нормативам, с $35,3 \%$ в 2011 г. до 42,2\% в 2020 г. (рис. 72).

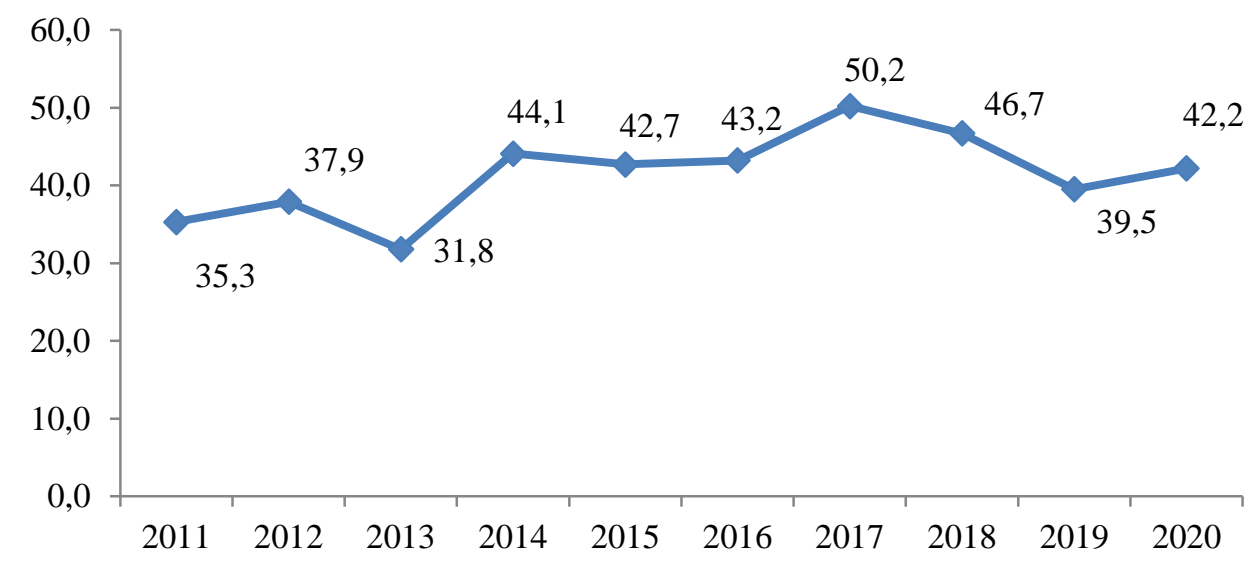

Рис. 72. Динамика измерений шума, не соответствующих гигиеническим нормативам на автомагистралях в 2011-2020 гг., \%

Кроме того, значимыми причинами повышенного уровня шума на селитебной территории и в жилых помещениях являются функционирование встроеннопристроенных объектов и инженерно-технологического оборудования зданий, 
Государственный доклад «О состоянии санитарно-эпидемиологического благополучия населения в Российской Федерации в 2020 году»

проведение строительных работ и эксплуатация строительной техники. По-прежнему актуальной остается проблема авиационного шума.

Удельный вес измерений шума в жилых помещениях от встроеннопристроенных объектов 1-2-х этажей жилых домов, не соответствующих санитарным нормам, в 2020 году снизился по сравнению с 2011 годом с 13,3 \% до 11,9\% (темп снижения 10,5\%) (табл. 26).

Таблица 26

Доля измерений в жилых помещениях, не соответствующих санитарно-эпидемиологическим требованиям по шуму от встроенно-пристроенных объектов 1-2-х этажей жилых домов

\begin{tabular}{|c|c|c|}
\hline Год & $\begin{array}{c}\text { Количество измерений } \\
\text { по шуму, всего }\end{array}$ & из них не соответствуют СН, \% \\
\hline 2011 & 5826 & 13,3 \\
\hline 2012 & 6785 & 17,5 \\
\hline 2013 & 6350 & 15,5 \\
\hline 2014 & 6353 & 13,8 \\
\hline 2015 & 7341 & 14,9 \\
\hline 2016 & 6278 & 9,9 \\
\hline 2017 & 5711 & 16,5 \\
\hline 2018 & 4359 & 13,2 \\
\hline 2019 & 4944 & 11,9 \\
\hline 2020 & 3626 & \\
\hline
\end{tabular}

Основными источниками электромагнитных полей радиочастотных диапазонов, воздействующих на население, являются мобильные телефоны сотовой связи, а также различные передающие радиотехнические объекты (далее - ПРТО) связи, радио и телевещания, радионавигации, генерирующие электромагнитные поля в радиочастотном диапазоне.

Базовые станции сотовой связи являются относительно маломощными объектами (излучаемая мощность до 50 Вт), однако они располагаются в черте жилой застройки, рядом с жилыми и общественными помещениями, имеют в связи с этим большую гигиеническую значимость. В 2020 году по сравнению с 2015 годом отмечается снижение удельного веса объектов ПРТО, не соответствующих санитарноэпидемиологическим требованиям, по таким видам ПРТО, как базовые станции сотовой связи (БССС) и прочие ПРТО. По остальным видам ПРТО отмечается увеличение удельного веса объектов, не соответствующих санитарно-эпидемиологическим требованиям (рис. 73).

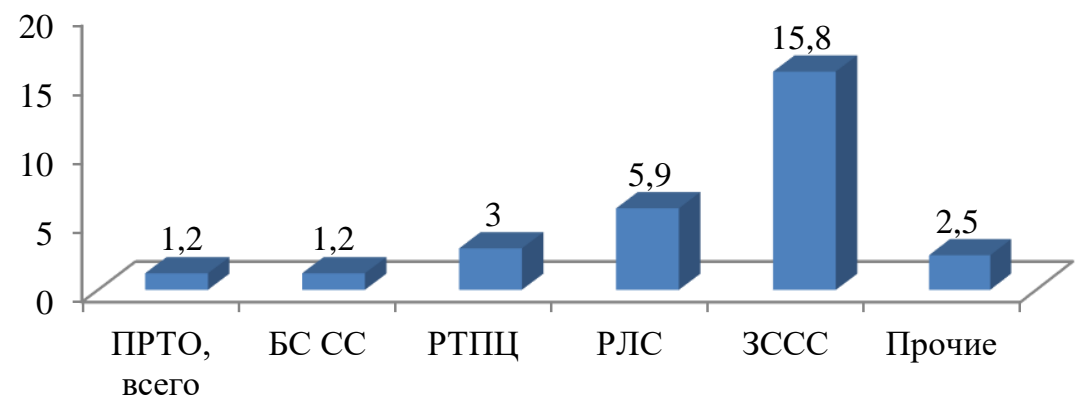

Рис. 73. Удельный вес экспертиз ПРТО, не соответствующих санитарным нормам, в 2020 г., \% 
Анализ жалоб населения на условия проживания, связанных с воздействием физических факторов, показал их увеличение в сравнении с 2015 годом и уменьшение в сравнении с 2018 и 2019 годами (рис. 74).

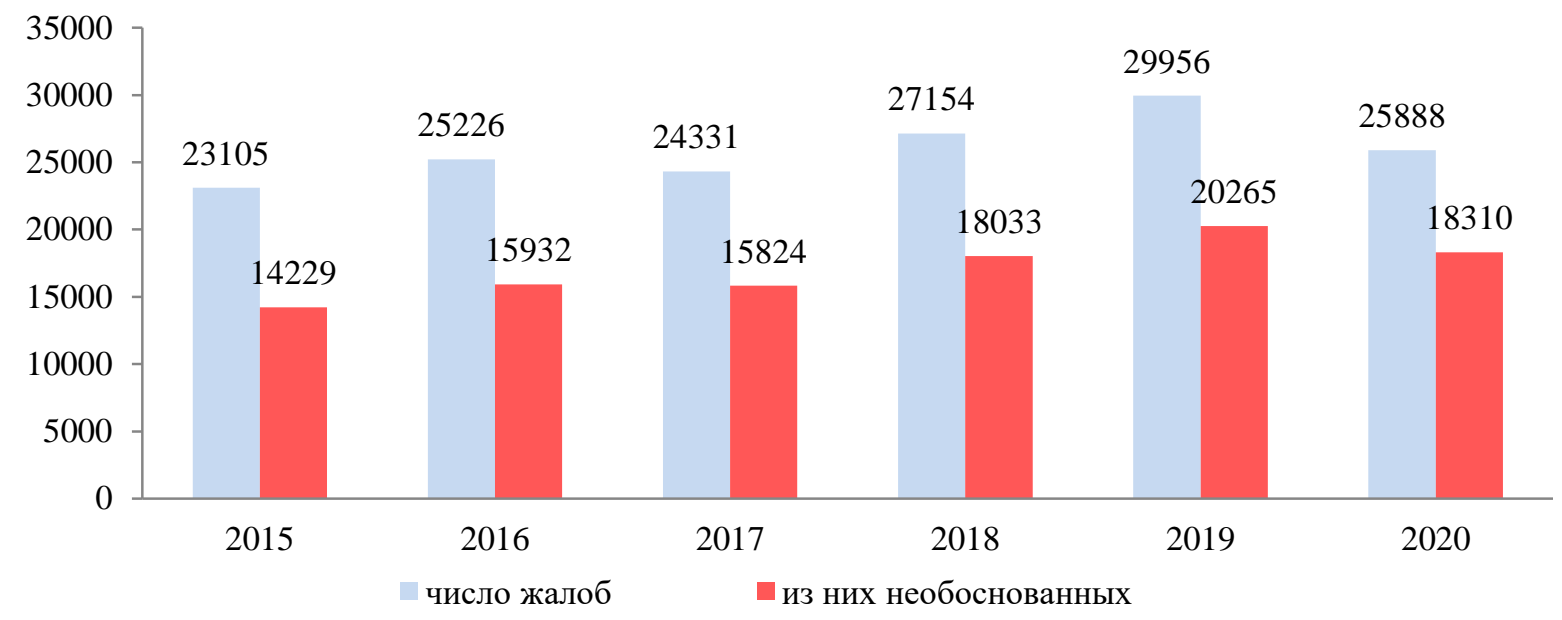

Рис. 74. Количество жалоб населения на условия проживания, связанные с воздействием физических факторов

Так, в 2020 году было зарегистрировано более 25 тыс. жалоб на неблагоприятное воздействие физических факторов.

В структуре жалоб населения, связанных с воздействием физических факторов, наиболее значимое место по-прежнему сохраняют жалобы на уровни шума (рис. 75).

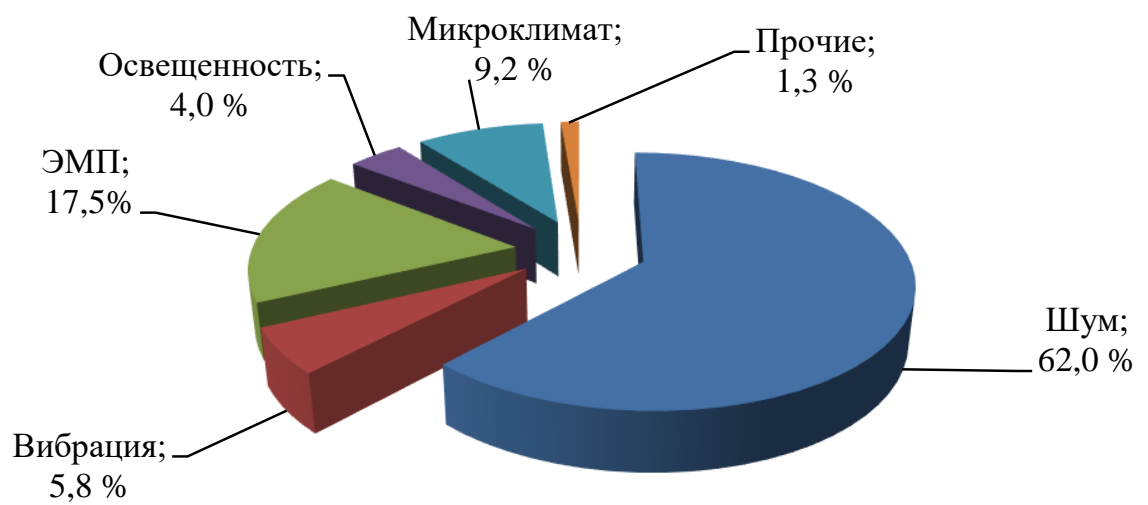

Рис. 75. Структура жалоб населения, связанных с воздействием физических факторов, в 2020 г., \%

В 2020 году было расследовано 17246 жалоб на повышенные уровни шума, из которых в 27,2 \% были выявлены превышения гигиенических нормативов (в 2019 г. $35,3 \%)$.

Среди объектов - источников шума, являющихся основанием для жалоб, лидирующее значение, как и в предыдущие годы, занимают предприятия общественного питания и торговли, имеющие значительное количество вентиляционного и холодильного оборудования, наружные блоки системы кондиционирования и охлаждения, встроенные (пристроенные) к жилым домам спортивно-оздоровительные учреждения, предприятия отдыха и развлечения (бильярдные, дискотеки, клубы и т. д.).

Жалобы на микроклимат обусловлены в основном обращениями граждан по поводу соблюдения температурного режима в квартирах. 
Общее число обращений и жалоб населения на размещение и эксплуатацию ПРТО в 2020 г. увеличилось в 1,4 раза относительно 2019 г., что обусловлено ежегодным увеличением количества БССС, которые монтируются на жилых зданиях и опорах двойного назначения.

Характерные нарушения, выявляемые в ходе рассмотрения жалоб: отсутствие согласований размещения и эксплуатации ПРТО, размещение с отступлением от согласованного проекта, работа в несогласованном диапазоне частот, несоответствие фактической градостроительной ситуации согласованному проекту, несоответствие количества, расположения, направления излучения антенн согласованным условиям. Расстояние от места размещения БССС до жилых зданий и других социально значимых объектов, в т. ч. школ, детских садов, санитарными правилами не регламентируется, что также вызывает жалобы со стороны населения.

В целом по результатам мониторинга физических факторов отмечается:

- за период 2011-2020 гг. отмечается снижение удельного веса промышленных предприятий, не соответствующих санитарно-эпидемиологическим требованиям по всем физическим факторам; наиболее выраженное снижение наблюдается по вибрации (темп снижения 56,7 \%) и по ЭМП (темп снижения 43,3 \%);

- за последние 10 лет отмечается сокращение удельного веса рабочих мест промышленных предприятий, не соответствующих санитарно-эпидемиологическим требованиям по таким факторам, как микроклимат (темп снижения 60,0 \%), вибрация (темп снижения 59,7 \%), шум (темп снижения 41,6 \%) и освещенность (темп снижения $40,5 \%)$;

- на транспортных средствах в 2020 г. приоритетное гигиеническое значение сохраняют шум, вибрация и микроклимат: доля объектов, не соответствующих санитарно-эпидемиологическим требованиям, составила по этим факторам соответственно $6,6 \%, 5,9 \%$ и 5,9\%. Отмечается положительная динамика этих показателей относительно 2011 г., за исключением микроклимата (темп прироста $15,7 \%)$

- в 2020 г. наблюдается тенденция снижения удельного веса организаций коммунального и социального назначения, не соответствующих санитарноэпидемиологическим требованиям по всем физическим факторам, по отношению к 2011 г.;

- в 2020 г. наблюдается тенденция снижения удельного веса детских и подростковых организаций, не соответствующих санитарно-эпидемиологическим требованиям по всем физическим факторам;

- наиболее значимым из физических факторов, оказывающих влияние на среду обитания человека, является шум, воздействие которого на людей в условиях плотной застройки населенных пунктов продолжает оставаться приоритетным; доля измерений шума на территории жилой застройки, не соответствующих санитарным нормам, в 2020 г. составила $15,7 \%$ (в 2019 г. - 13,4\%);

- актуальной остается проблема авиационного шума: в 2020 году удельный вес измерений уровней звука, не соответствующих санитарным нормам, от аэропортов значительно увеличился и составил 54,3 \% (в 2019 году - 9,5 \%, в 2018 году - 37,1 \%);

- снижение удельного веса объектов ПРТО, не соответствующих санитарноэпидемиологическим требованиям, отмечается по таким видам ПРТО, как базовые станции сотовой связи (БССС) и прочие ПРТО. По остальным видам ПРТО отмечается увеличение удельного веса объектов, не соответствующих санитарноэпидемиологическим требованиям. 
Государственный доклад «О состоянии санитарно-эпидемиологического благополучия населения в Российской Федерации в 2020 году»

\subsection{8. Мониторинг радиационной обстановки}

Радиационный фактор не являлся ведущим фактором вредного воздействия на здоровье населения ни в одном из субъектов Российской Федерации. Радиационная обстановка за последние годы существенно не изменялась и в целом оставалась удовлетворительной.

Результаты радиационно-гигиенической паспортизации показывают, что в структуре коллективных доз облучения повсеместно ведущее место занимают дозы от природных и медицинских источников (рис. 76, данные по состоянию на 2019 год).

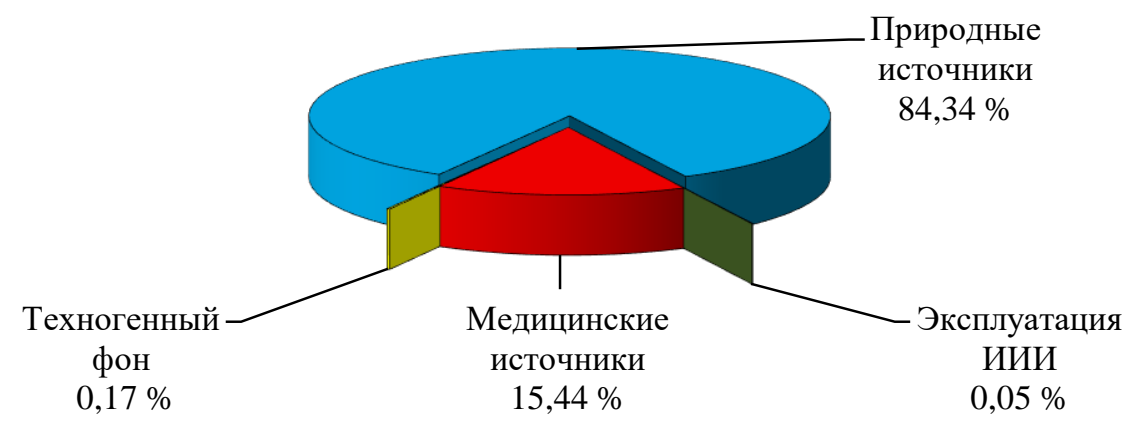

Рис. 76. Структура годовых коллективных эффективных доз облучения населения Российской Федерации в 2019 г., \%

Изменение соотношения основных компонентов дозы облучения населения Российской Федерации за период с 2010 по 2019 г. приведено в табл. 27.

Таблица 27

\section{Средние годовые эффективные дозы облучения населения Российской Федерации за период 2010-2019 гг.}

\begin{tabular}{|c|c|c|c|c|c|c|c|c|}
\hline \multirow{2}{*}{ Год } & \multicolumn{2}{|c|}{ Природные } & \multicolumn{2}{c|}{ Медицинские ИИИ } & \multicolumn{2}{c|}{ Техногенный фон } & \multicolumn{2}{c|}{ Эксплуатация ИИи } \\
\cline { 2 - 10 } & мЗв/год & $\%$ & м3в/год & $\%$ & м3в/год & $\%$ & мЗв/год & $\%$ \\
\hline 2010 & 3,24 & 84,56 & 0,58 & 15,18 & 0,008 & 0,20 & 0,0018 & 0,04 \\
\hline 2011 & 3,21 & 84,19 & 0,59 & 15,53 & 0,009 & 0,24 & 0,0017 & 0,04 \\
\hline 2012 & 3,34 & 85,30 & 0,57 & 14,44 & 0,009 & 0,22 & 0,0017 & 0,04 \\
\hline 2013 & 3,28 & 86,81 & 0,48 & 12,91 & 0,008 & 0,22 & 0,0017 & 0,04 \\
\hline 2014 & 3,22 & 86,92 & 0,47 & 12,81 & 0,008 & 0,22 & 0,0017 & 0,05 \\
\hline 2015 & 3,31 & 86,87 & 0,49 & 12,84 & 0,009 & 0,23 & 0,0020 & 0,05 \\
\hline 2016 & 3,24 & 86,08 & 0,51 & 13,63 & 0,009 & 0,24 & 0,0019 & 0,05 \\
\hline 2017 & 3,31 & 85,58 & 0,55 & 14,13 & 0,009 & 0,24 & 0,0020 & 0,05 \\
\hline 2018 & 3,26 & 84,87 & 0,57 & 14,90 & 0,007 & 0,18 & 0,0019 & 0,05 \\
\hline 2019 & 3,28 & 84,34 & 0,60 & 15,44 & 0,007 & 0,17 & 0,0021 & 0,05 \\
\hline Среднее & 3,27 & 85,55 & 0,54 & 14,18 & 0,008 & 0,22 & 0,0019 & 0,05 \\
\hline
\end{tabular}

До настоящего времени остаются территории с зонами радиоактивного загрязнения, образовавшимися в результате прошлых радиационных аварий, где в отношении отдельных групп населения не полностью обеспечивается выполнение нормативных требований радиационной безопасности.

К зонам радиоактивного загрязнения в результате аварии на Чернобыльской АЭС относятся 3855 населенных пунктов (НП), расположенных в 14 субъектах Российской Федерации, с численностью населения более 1,5 млн человек. Радиационная обстановка на этих территориях до настоящего времени определяется наличием долгоживущего продукта аварии - цезия-137. Наибольшие площади загрязнения расположены в Брянской, Калужской и Тульской областях. 
Государственный доклад «О состоянии санитарно-эпидемиологического благополучия населения в Российской Федерации в 2020 году»

Выполненные расчеты показали, что численные значения СГЭД90 в радиоактивно загрязненных областях России варьируют в диапазоне от сотых долей мЗв/год до 5,7 мЗв/год. Максимальное расчетное значение отмечено в пос. Барсуки Красногорского района Брянской области. При этом количество населенных пунктов, в которых СГЭД90 равна или превышает 1,0 мЗв/год, составляет 121 НП. Все они находятся в Брянской области. Из них в 2 НП эта величина оказалась выше 5,0 мЗв/год (табл. 28, рис. 77).

Таблица 28

\section{Распределение населенных пунктов субъектов Российской Федерации, отнесенных к зонам радиоактивного загрязнения, по величине средней годовой эффективной дозы облучения жителей в 2019 году}

\begin{tabular}{|c|c|c|c|c|c|}
\hline \multirow{2}{*}{$\begin{array}{c}\text { Субъект Российской } \\
\text { Федерации }\end{array}$} & \multirow{2}{*}{$\begin{array}{c}\text { Количество } \\
\text { населенных } \\
\text { пунктов }\end{array}$} & \multicolumn{4}{|c|}{ В том числе в интервалах СГЭД, мЗв/год } \\
\hline & & $<1,0$ & $\geq 1,0$ & $\geq 5,0$ & Максимум \\
\hline Белгородская область & 78 & 78 & - & - & 0,07 \\
\hline Брянская область & 749 & 628 & 121 & 2 & 5,7 \\
\hline Воронежская область & 74 & 74 & - & - & 0,09 \\
\hline Калужская область & 300 & 300 & - & - & 0,71 \\
\hline Курская область & 156 & 156 & - & - & 0,16 \\
\hline Ленинградская область & 29 & 29 & - & - & 0,08 \\
\hline Липецкая & 69 & 69 & - & - & 0,10 \\
\hline Орловская область & 843 & 843 & - & - & 0,36 \\
\hline Пензенская область & 31 & 31 & - & - & 0,10 \\
\hline Республика Мордовия & 15 & 15 & - & - & 0,12 \\
\hline Рязанская область & 285 & 285 & - & - & 0,24 \\
\hline Тамбовская область & 6 & 6 & - & - & 0,04 \\
\hline Тульская область & 1215 & 1215 & - & - & 0,44 \\
\hline Ульяновская область & 5 & 5 & - & - & 0,08 \\
\hline Итого: & 3855 & 3734 & 121 & 2 & 5,7 \\
\hline
\end{tabular}

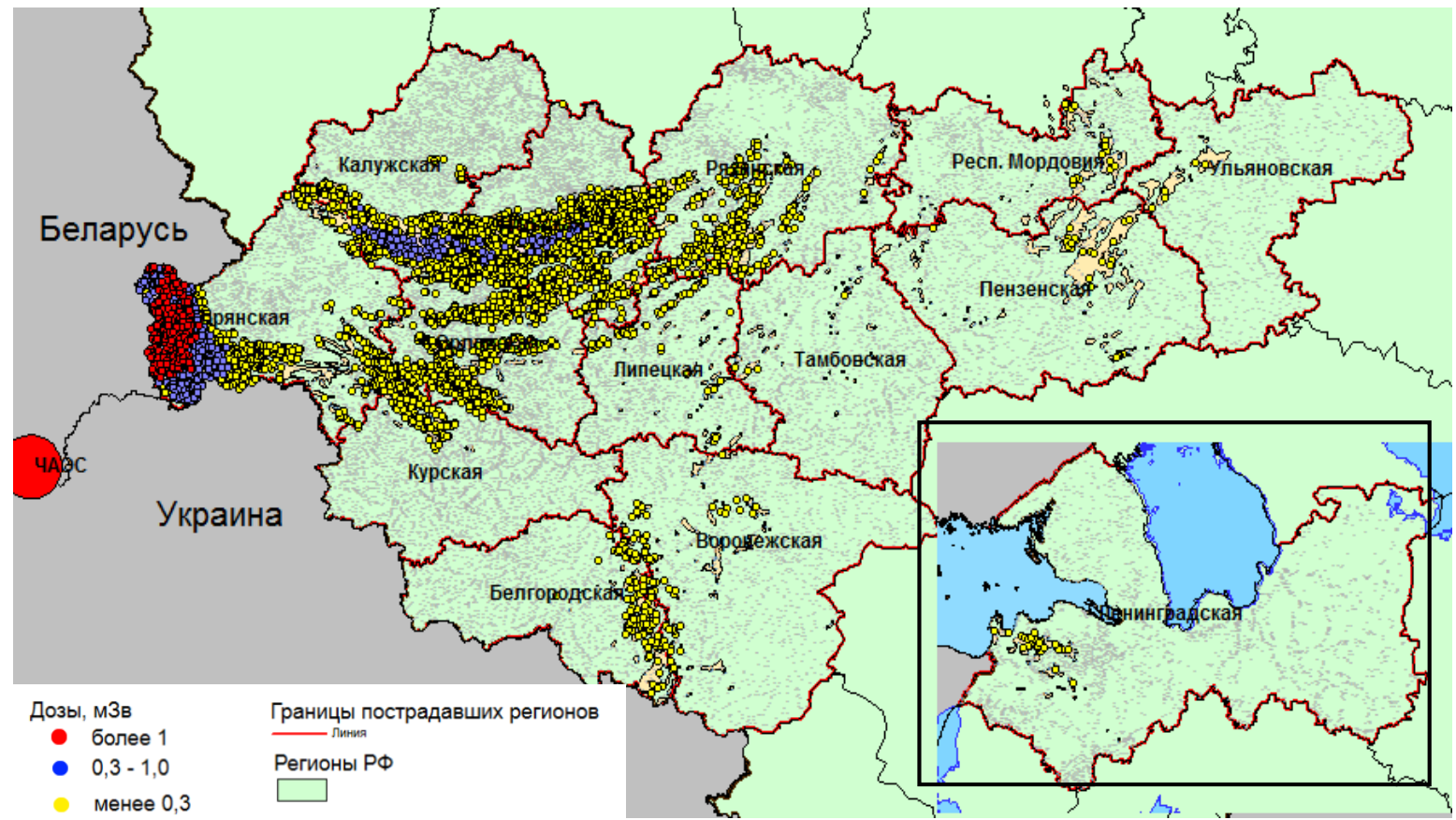

Рис. 77. Средние годовые дозы облучения населения вследствие аварии на ЧАЭС 
Годовую дозу определяет как внешнее облучение, так и внутреннее. Вклад дозы внутреннего облучения в суммарную дозу варьирует в широких пределах. Так, в Брянской и Калужской областях, характеризующихся преимущественным преобладанием дерново-подзолистых песчаных и супесчаных почв, вклад внутреннего облучения в суммарную дозу достигает $50 \%$ и более. Напротив, в субъектах Российской Федерации, где высока доля плодородных почв (черноземов), вклад внутреннего облучения в суммарную дозу в подавляющем большинстве НП составляет не более $15 \%$.

В силу специфики радиоактивного загрязнения территорий вследствие аварии на Чернобыльской АЭС именно цезий-137 практически полностью обуславливает в настоящее время облучение населения загрязненных регионов Российской Федерации. Вклад стронция-90 в суммарную дозу не превышает нескольких процентов.

Согласно расчетным данным, в 58 населенных пунктах Брянской области, отнесенных к зонам радиоактивного загрязнения постановлением Правительства Российской Федерации от 08.10.2015 № 1074, средняя накопленная за период 19862019 гг. эффективная доза облучения жителей равна или превышает 70 мЗв (при максимальном значении 309 м3в).

Для населенных пунктов всех других регионов России, подвергшихся радиоактивному загрязнению в результате аварии на Чернобыльской АЭС, средние накопленные эффективные дозы не превышают и не превысят в дальнейшем 70 мЗв.

В настоящее время в результате прошлых радиационных аварий и прошлой производственной деятельности ПО «Маяк» имеются радиоактивно загрязненные техногенными радионуклидами ${ }^{137} \mathrm{Cs}$ и ${ }^{90} \mathrm{Sr}$ территории в Курганской, Свердловской и Челябинской областях. Радиационная обстановка, обусловленная деятельностью ПО «Маяк», остается в целом удовлетворительной. Средняя годовая эффективная доза населения и его критических (наиболее облучаемых) групп за счет радиоактивного загрязнения местности ни в одном из населенных пунктов, расположенных на этих территориях, не превышает 1 мЗв.

Радиационный мониторинг содержания радионуклидов в воде открытых водоемов и пищевой продукции, включая питьевую воду, осуществляется в рамках радиационно-гигиенической паспортизации и социально-гигиенического мониторинга.

Результаты исследований показали, что концентрации радионуклидов в последние годы сохраняются примерно на одном уровне. В большей части поверхностных водоемов России удельная активность ${ }^{137} \mathrm{Cs}$ и ${ }^{90} \mathrm{Sr}$ в воде значительно ниже уровней вмешательства (УВ) для этих радионуклидов в питьевой воде по НРБ99/2009. Среднегодовая удельная активность ${ }^{90} \mathrm{Sr}$ в р. Теча (п. Муслюмово, Челябинская область) на 3 порядка превышает фоновый уровень для рек Российской Федерации.

Превышения гигиенических нормативов (уровней вмешательства) по удельной активности ${ }^{137} \mathrm{Cs}$ и ${ }^{90} \mathrm{Sr}$ в воде источников питьевого водоснабжения ни в одном из субъектов Российской Федерации не зарегистрированы.

Превышения гигиенических нормативов (уровней вмешательства) по удельной активности ${ }^{137} \mathrm{Cs}$ и ${ }^{90} \mathrm{Sr}$ в воде источников питьевого водоснабжения ни в одном из субъектов Российской Федерации не зарегистрированы.

К 2020 году из общего количества источников централизованного водоснабжения (более 94 тыс.) центрами гигиены и эпидемиологии Роспотребнадзора было обследовано $31 \%$ источников по показателям суммарной альфа- и бета-активности (2011 г. - $28 \%$, 2018 г. - 30 \%, 2019 г. - 32 \%). В 40 субъектах Российской Федерации (2011 г. - 33, 2018 г. - 37, 2019 г. - 35) выявлены случаи превышения контрольных уровней (КУ) первичной оценки содержания радионуклидов в питьевой воде (табл. 29). 


\section{Результаты исследований проб воды из источников централизованного питьевого водоснабжения по показателям радиационной безопасности}

\begin{tabular}{|c|c|c|c|c|c|c|}
\hline \multirow[b]{3}{*}{ Годы } & \multicolumn{6}{|c|}{ Исследовано проб воды } \\
\hline & \multicolumn{2}{|c|}{$\begin{array}{c}\text { суммарная альфа-, } \\
\text { бета-активность }\end{array}$} & \multicolumn{2}{|c|}{$\begin{array}{c}\text { природные } \\
\text { радионуклиды }\end{array}$} & \multicolumn{2}{|c|}{$\begin{array}{c}\text { техногенные } \\
\text { радионуклиды }\end{array}$} \\
\hline & всего, абс. & $\begin{array}{c}\text { с превышением КУ } \\
\text { по суммарной } \\
\text { альфа-активности, } \\
\text { абс. }(\%)\end{array}$ & всего, абс. & $\begin{array}{c}\text { с превышением УВ, } \\
\text { абс. (\%) }\end{array}$ & $\begin{array}{l}\text { всего, } \\
\text { абс. }\end{array}$ & $\begin{array}{c}\text { с превышением УВ, } \\
\text { абс. }(\%)\end{array}$ \\
\hline 2011 & 28476 & $1221(4,3)$ & 12186 & $281(2,3)$ & 2323 & 0 \\
\hline 2012 & 30257 & $1175(3,9)$ & 14042 & $471(3,4)$ & 1510 & 0 \\
\hline 2013 & 29873 & $1144(3,8)$ & 14654 & $363(2,5)$ & 1297 & 0 \\
\hline 2014 & 29106 & $1249(4,2)$ & 14861 & $474(3,2)$ & 1457 & 0 \\
\hline 2015 & 29094 & $1271(4,4)$ & 16247 & $543(3,3)$ & 1276 & 0 \\
\hline 2016 & 29926 & $1295(4,3)$ & 16949 & $412(2,4)$ & 1095 & 0 \\
\hline 2017 & 30796 & $1269(4,1)$ & 18113 & $418(2,3)$ & 1109 & 0 \\
\hline 2018 & 29725 & $1189(4,0)$ & 18371 & $481(2,6)$ & 913 & 0 \\
\hline 2019 & 32257 & $1313(4,1)$ & 19412 & $565(2,9)$ & 868 & 0 \\
\hline 2020 & 28931 & $1137(3,9)$ & 18756 & $461(2,5)$ & 846 & 0 \\
\hline
\end{tabular}

В 3 субъектах Российской Федерации доля проб с превышением контрольного уровня (КУ) по суммарной альфа-активности составляет более $20 \%$ (Республика Хакасия, Ленинградская область, г. Санкт-Петербург). В основном, это пробы воды подземных источников водоснабжения, для которых необходимы дальнейшие исследования в части контроля показателей радиационной безопасности.

Превышения суммарной бета-активности в пробах воды из централизованных источников питьевого водоснабжения населения выявлены в 127 случаях $(0,44 \%$ от общего числа отобранных проб).

Превышения УВ в питьевой воде отмечены в 23 субъектах Российской Федерации (2011 г. - 19, 2012 г. - 19, 2013 г. - 23, 2014 г. - 22, 2015 г. - 19, 2016 г. - 25, 2017 г. - 38, 2018 г. - 18, 2019 г. - 24), из них наибольшая доля проб с превышением УВ отмечена в Республике Саха (Якутия) (24,8 \%), Республике Тыва (19,2 \%), Ленинградской области $(37,7 \%)$, Магаданской области $(24,8 \%)$, Забайкальском крае $(16,6 \%)$. В большинстве случаев превышения уровней вмешательства связаны с повышенным содержанием радона в воде подземных источников, в некоторых случаях превышены УВ по радию226 и радию-228, а также по изотопам урана. В единичных источниках питьевой воды обнаружены превышения УВ по полонию-210 и свинцу-210.

Источники питьевой воды с содержанием природных радионуклидов, создающих эффективную дозу более 1 мЗв/год и требующих проведения защитных мероприятий в безотлагательном порядке, не зарегистрированы.

В 2020 г. центрами гигиены и эпидемиологии исследованы 39258 проб пищевых продуктов на содержание техногенных радионуклидов, из которых 157 проб (0,4 \%) не соответствовали гигиеническим нормативам по содержанию ${ }^{137} \mathrm{Cs}$. По содержанию ${ }^{90} \mathrm{Sr}$ превышения гигиенических нормативов ни в одном из субъектов Российской Федерации не зарегистрировано (табл. 30). 


\section{Динамика результатов исследований проб продовольственного сырья и пищевых продуктов на содержание радиоактивных веществ}

\begin{tabular}{|c|c|c|c|c|c|c|c|c|}
\hline \multirow{4}{*}{ Годы } & \multicolumn{8}{|c|}{ Исследовано проб продовольственного сырья и пищевых продуктов } \\
\hline & \multirow[b]{3}{*}{$\begin{array}{c}\text { всего, } \\
\text { абс. }\end{array}$} & \multirow{3}{*}{\begin{tabular}{|c|} 
из них с \\
превышением \\
гигиенических \\
нормативов, \\
абс. (\%)
\end{tabular}} & \multicolumn{6}{|c|}{ в том числе } \\
\hline & & & \multicolumn{2}{|c|}{$\begin{array}{c}\text { мясо и мясные } \\
\text { продукты }\end{array}$} & \multicolumn{2}{|c|}{$\begin{array}{c}\text { молоко и } \\
\text { молокопродукты }\end{array}$} & \multicolumn{2}{|c|}{$\begin{array}{c}\text { дикорастущие } \\
\text { пищевые продукты }\end{array}$} \\
\hline & & & $\begin{array}{c}\text { всего, } \\
\text { абс. }\end{array}$ & $\begin{array}{c}\text { из них с } \\
\text { превышением } \\
\text { гигиенических } \\
\text { нормативов, } \\
\text { абс. (\%) }\end{array}$ & $\begin{array}{l}\text { всего, } \\
\text { абс. }\end{array}$ & \begin{tabular}{|c|} 
из них с \\
превышением \\
гигиенических \\
нормативов, \\
абс. $(\%)$
\end{tabular} & $\begin{array}{l}\text { всего, } \\
\text { абс. }\end{array}$ & \begin{tabular}{|c} 
из них с \\
превышением \\
гигиенических \\
нормативов, \\
абс. (\%)
\end{tabular} \\
\hline 2011 & 56001 & $356(0,6)$ & 5415 & $11(0,2)$ & 8962 & $48(0,5)$ & 3710 & $291(7,8)$ \\
\hline 2012 & 49152 & $342(0,7)$ & 5226 & $9(0,8)$ & 8774 & $53(0,6)$ & 3767 & $264(7,0)$ \\
\hline 2013 & 50908 & $399(0,8)$ & 5112 & $8(0,6)$ & 8534 & $45(0,5)$ & 4287 & $333(7,8)$ \\
\hline 2014 & 53307 & $269(0,5)$ & 5152 & $19(0,4)$ & 10349 & $22(0,2)$ & 1930 & $162(8,4)$ \\
\hline 2015 & 45643 & $277(0,6)$ & 4856 & $6(0,1)$ & 8223 & $19(0,2)$ & 3495 & $240(6,9)$ \\
\hline 2016 & 45782 & $265(0,6)$ & 4393 & $6(0,1)$ & 9438 & $17(0,2)$ & 3151 & $236(7,5)$ \\
\hline 2017 & 43192 & $229(0,5)$ & 4523 & $9(0,2)$ & 7839 & $13(0,2)$ & 2681 & $201(7,5)$ \\
\hline 2018 & 47440 & $152(0,3)$ & 5205 & $5(0,1)$ & 8947 & $6(0,1)$ & 2817 & $138(4,9)$ \\
\hline 2019 & 50296 & $189(0,4)$ & 5819 & $5(0,1)$ & 9206 & $7(0,1)$ & 3071 & $146(4,8)$ \\
\hline 2020 & 39258 & $157(0,4)$ & 4051 & $2(0,05)$ & 7369 & $3(0,04)$ & 3234 & $140(4,3)$ \\
\hline
\end{tabular}

Случаи превышения допустимого содержания радионуклидов в продуктах питания местного производства отмечены в Брянской области: в продуктах леса (грибы, ягоды) и в продуктах, производимых в частном секторе (молоко и мясо).

Единичные случаи превышения допустимого содержания радионуклидов могут регистрироваться в лесных продуктах питания, ввозимых в субъекты Российской Федерации с загрязненных территорий (ягоды, грибы) (рис. 78).

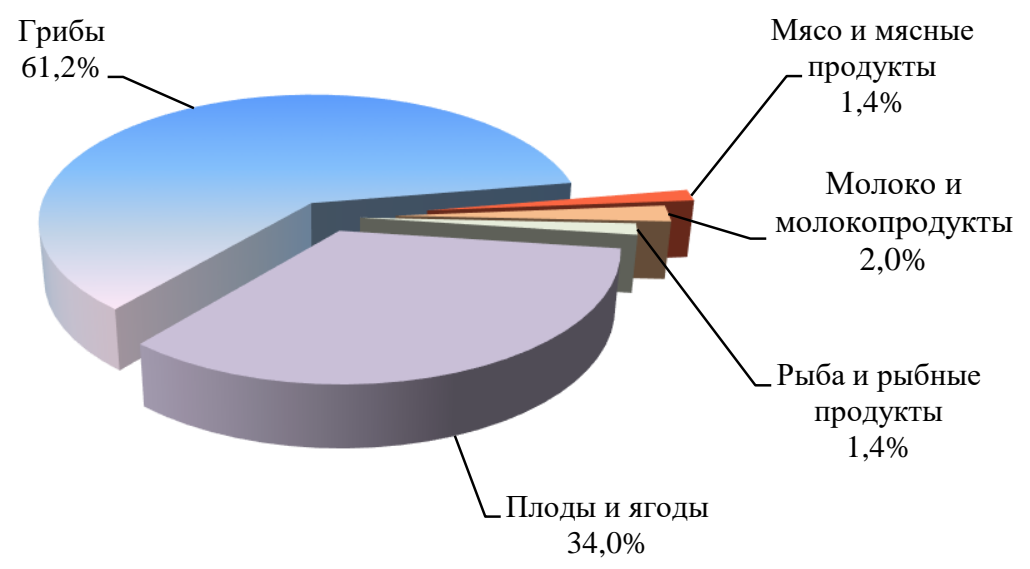

Рис. 78. Структура проб продовольственного сырья и пищевых продуктов, не соответствующих гигиеническим нормативам по содержанию ${ }^{137} \mathrm{Cs}$ в 2020 году, \%

Ведущим фактором облучения населения, как и ранее, являются природные источники ионизирующего излучения. Среднее по Российской Федерации значение 
Государственный доклад «О состоянии санитарно-эпидемиологического благополучия населения в Российской Федерации в 2020 году»

вклада в коллективную дозу облучения населения природными источниками ионизирующего излучения в 2019 г. составляет 84,3\%.

Средняя по Российской Федерации суммарная доза облучения населения за счет всех природных источников излучения составляет 3,36 мЗв/год, наибольшая часть ее формируется за счет ингаляции изотопов радона и их короткоживущих дочерних продуктов распада в воздухе помещений - в среднем около 59,6\%. Внешнее облучение гамма-излучением природных радионуклидов обуславливает $20 \%$ дозы природного облучения, космическое излучение - $10,1 \%$. На долю всех остальных природных источников приходится чуть более 10 \% дозы природного облучения (табл. 31).

Таблица 31

\section{Структура средней индивидуальной годовой эффективной дозы природного облучения населения Российской Федерации по данным исследований за период 2001-2019 гг.}

\begin{tabular}{|c|c|c|c|c|c|c|c|c|}
\hline $\begin{array}{c}\text { Вклад } \\
\text { в дозу }\end{array}$ & ${ }^{40} \mathrm{~K}$ & $\begin{array}{c}\text { Космическое } \\
\text { излучение }\end{array}$ & $\begin{array}{c}\text { Внешнее } \\
\text { терригенное } \\
\text { облучение }\end{array}$ & $\begin{array}{c}{ }^{222} \mathrm{Rn}, \\
\text { их ДПП } \mathrm{Rn} \text { и }\end{array}$ & $\begin{array}{c}\text { Пищевые } \\
\text { продукты }\end{array}$ & $\begin{array}{c}\text { Питьевая } \\
\text { вода }\end{array}$ & $\begin{array}{c}\text { Атмосфер- } \\
\text { ный воздух }\end{array}$ & $\begin{array}{c}\text { Суммарная } \\
\text { доза }\end{array}$ \\
\hline мЗв/год & 0,17 & 0,339 & 0,67 & 2,00 & 0,133 & 0,038 & 0,006 & 3,36 \\
\hline$\%$ & 5,06 & 10,13 & 19,96 & 59,59 & 3,96 & 1,13 & 0,17 & 100 \\
\hline
\end{tabular}

По данным исследований 2001-2019 гг., наибольшая интегральная оценка средней годовой эффективной дозы облучения природными источниками ионизирующего излучения на одного жителя зарегистрирована в Республике Алтай (8,74 мЗв/год) (рис. 79).

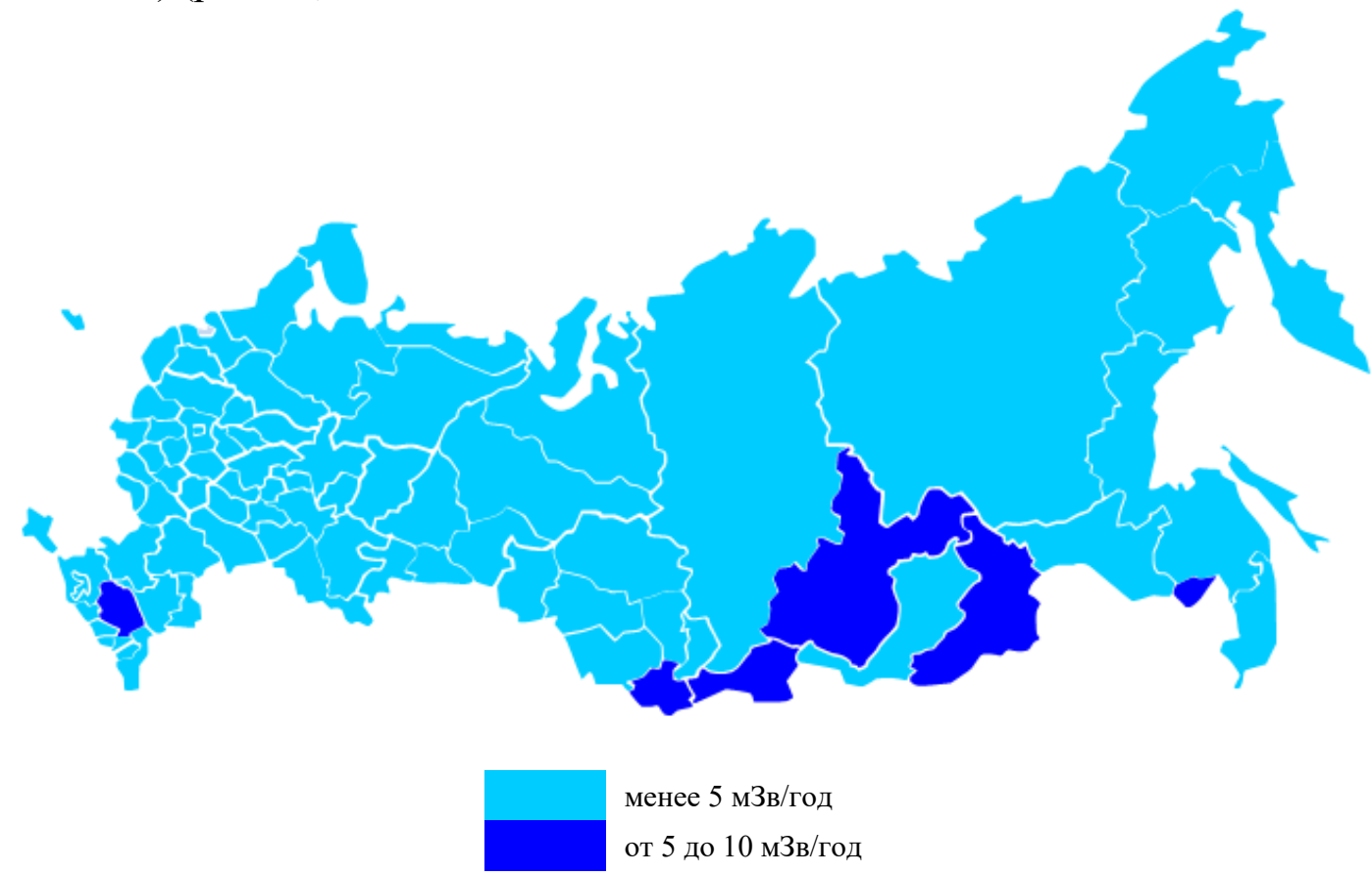

Рис. 79. Средние годовые индивидуальные дозы облучения населения Российской Федерации за счет природных источников ионизирующего излучения по данным 2001-2019 гг.

Повышенные (в интервале от 5,0 до 10,0 м3в/год) средние дозы облучения населения природными источниками ионизирующего облучения также характерны для жителей Республики Тыва (5,62 мЗв/год), Ставропольского (5,76 м3в/год) и 
Забайкальского (7,56 мЗв/год) краев, Еврейской автономной области (6,44 мЗв/год) и Иркутской области (5,30 мЗв/год).

По данным объединенных измерений, за период 2001-2019 гг. средняя годовая эффективная доза облучения населения природными источниками ионизирующего излучения ни для одного субъекта Российской Федерации не превысила 10,0 мЗв/год.

Динамика за 10 лет (с 2010 по 2019 г.) средних годовых индивидуальных доз облучения населения Российской Федерации за счет природных источников ионизирующего излучения, а также динамика минимальных и максимальных среднегодовых по субъектам Российской Федерации индивидуальных доз облучения населения за счет природных источников ионизирующего излучения, полученных по данным объединенных измерений за период с 2001 г. по отчетный год, представлена на рис. 80.

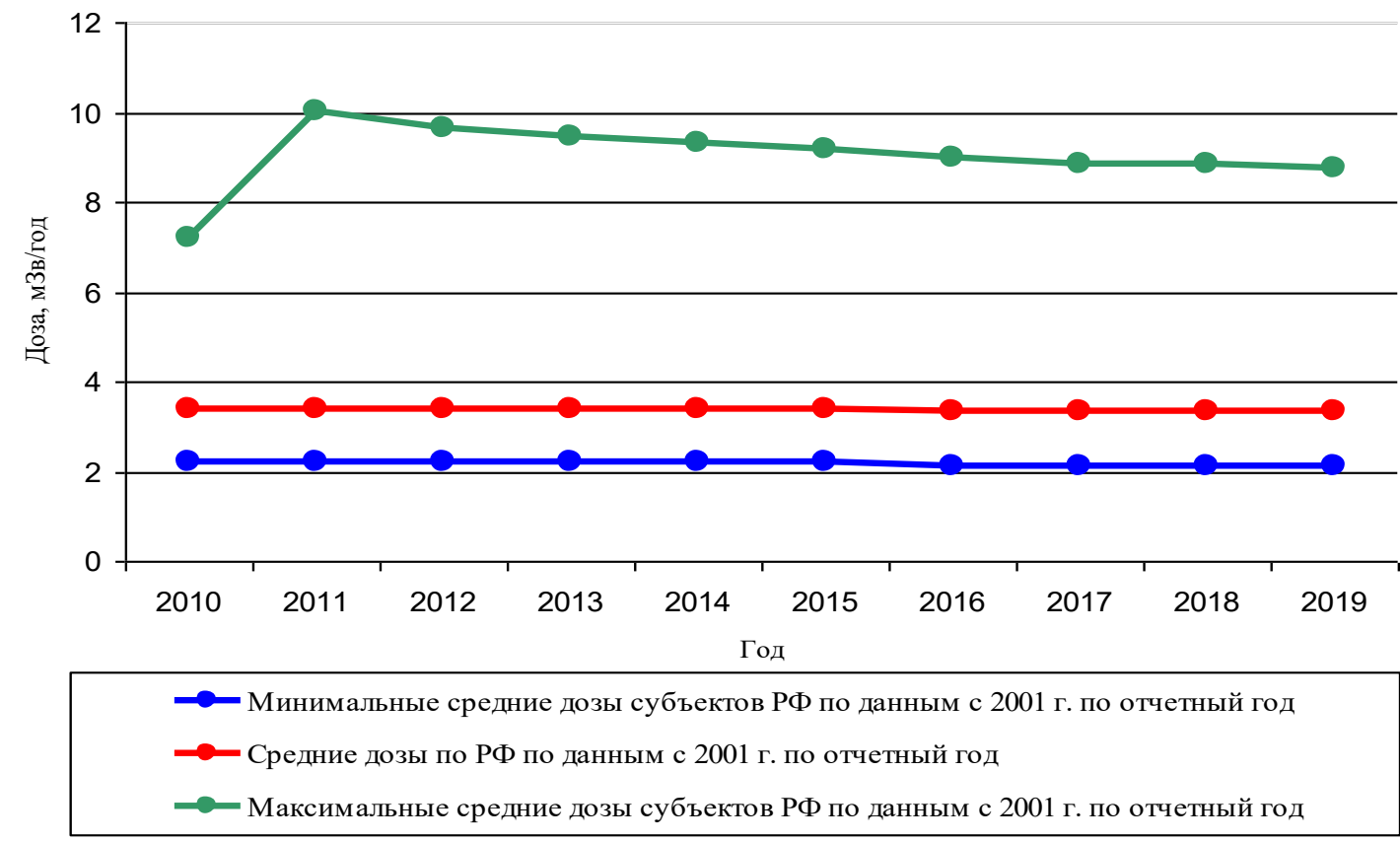

Рис. 80. Динамика годовых индивидуальных доз облучения населения Российской Федерации за счет природных источников ионизирующего излучения в 2010-2019 гг.

Содержание радона в воздухе более $98 \%$ обследованных помещений жилых, общественных и производственных зданий соответствовало гигиеническим нормативам (табл. 32).

В 12 субъектах Российской Федерации (республики Тыва, Удмуртская; Белгородская, Ивановская, Кемеровская, Ленинградская, Мурманская, Новосибирская, Тамбовская, Тульская области; Ставропольский край; Еврейская автономная область) отмечено превышение гигиенического норматива среднегодовой ЭРОА радона для строящихся жилых и общественных зданий (более 100 Бк/ $\mathrm{m}^{3}$ ). 
Динамика числа помещений жилых, общественных и производственных зданий, обследованных на содержание радона в воздухе

\begin{tabular}{|c|c|c|c|c|c|c|}
\hline \multirow[b]{4}{*}{ Годы } & \multicolumn{6}{|c|}{ Количество обследованных помещений } \\
\hline & \multicolumn{4}{|c|}{ жилые и общественные здания } & \multirow{2}{*}{\multicolumn{2}{|c|}{ производственные здания }} \\
\hline & \multicolumn{2}{|c|}{ эксплуатируемые } & \multicolumn{2}{|c|}{ строящиеся } & & \\
\hline & $\begin{array}{c}\text { всего, } \\
\text { абс. }\end{array}$ & $\begin{array}{c}\text { из них } \\
\text { с превышением } \\
\text { гигиенического } \\
\text { норматива, } \\
\text { абс. }(\%)\end{array}$ & $\begin{array}{c}\text { всего, } \\
\text { абс. }\end{array}$ & $\begin{array}{c}\text { из них } \\
\text { с превышением } \\
\text { гигиенического } \\
\text { норматива, } \\
\text { абс. }(\%)\end{array}$ & $\begin{array}{c}\text { всего, } \\
\text { абс. }\end{array}$ & $\begin{array}{c}\text { из них } \\
\text { с превышением } \\
\text { гигиенического } \\
\text { норматива, } \\
\text { абс. }(\%)\end{array}$ \\
\hline 2011 & 39791 & $447(1,1)$ & 85894 & $523(0,6)$ & - & - \\
\hline 2012 & 48849 & $506(1,0)$ & 85068 & $357(0,4)$ & - & - \\
\hline 2013 & 48646 & $509(1,0)$ & 84541 & $177(0,2)$ & 6196 & $44(0,7)$ \\
\hline 2014 & 32368 & $334(1,0)$ & 77615 & $131(0,2)$ & 6595 & $13(0,2)$ \\
\hline 2015 & 42991 & $626(1,5)$ & 81360 & $388(0,5)$ & 7723 & $60(0,8)$ \\
\hline 2016 & 51399 & $344(0,7)$ & 67656 & $238(0,4)$ & 5670 & $73(1,3)$ \\
\hline 2017 & 39687 & $390(0,9)$ & 53813 & $232(0,4)$ & 6079 & $10(0,2)$ \\
\hline 2018 & 41465 & $626(1,5)$ & 43625 & $619(1,4)$ & 5593 & $14(0,3)$ \\
\hline 2019 & 33553 & $414(1,2)$ & 49895 & $409(0,8)$ & 7655 & $9(0,1)$ \\
\hline 2020 & 37350 & $507(1,4)$ & 52688 & $332(0,6)$ & 4917 & $16(0,3)$ \\
\hline
\end{tabular}

В 15 субъектах Российской Федерации (республики Алтай, Башкортостан и Саха (Якутия); Белгородская, Ивановская, Иркутская, Кемеровская, Новгородская, Новосибирская, Свердловская, Сахалинская, Тульская, области; Ставропольский и Забайкальский края; Еврейская автономная область) зарегистрированы превышения гигиенического норматива по среднегодовой ЭРОА радона в помещениях эксплуатируемых жилых и общественных зданий (более 200 Бк/м3). Большинство эксплуатируемых жилых и общественных зданий с превышением гигиенического норматива среднегодовой ЭРОА изотопов радона в воздухе помещений является зданиями старой постройки. Доля превышений гигиенического норматива для производственных зданий сократилась в 2,3 раза - с 0,7 \% в 2013 г. до 0,3 \% в 2020 г.

За последние годы не менее 97 \% исследуемых образцов строительных изделий и сырья местного производства относились к I классу и могли использоваться без ограничения в строительстве. Строительные изделия и материалы с повышенным содержанием природных радионуклидов (II класса и выше) регистрируются в привозных из других субъектов Российской Федерации и ввозимых в страну материалах (керамогранит, гранит, керамическая плитка, алюминатный и глиноземистый цемент и др.) (табл. 33). 


\section{Распределение строительных материалов по классам}

\begin{tabular}{|c|c|c|c|c|c|c|c|c|c|c|c|c|}
\hline \multirow{4}{*}{ Годы } & \multicolumn{12}{|c|}{ Число исследованных проб } \\
\hline & \multicolumn{4}{|c|}{ местного производства } & \multicolumn{4}{|c|}{$\begin{array}{c}\text { привозные из других субъектов } \\
\text { Российской Федерации }\end{array}$} & \multicolumn{4}{|c|}{ импортируемые } \\
\hline & \multirow{2}{*}{ всего } & \multicolumn{3}{|c|}{ из них класса, \% } & \multirow{2}{*}{ всего } & \multicolumn{3}{|c|}{ из них класса, \% } & \multirow{2}{*}{ всего } & \multicolumn{3}{|c|}{ из них класса, \% } \\
\hline & & I & II & III и IV & & I & II & III и IV & & I & II & III и IV \\
\hline 2011 & 12272 & 998,3 & 1,7 & - & $330^{\prime}$ & 99,4 & 0,6 & - & 1473 & 97,8 & 2,1 & 0,1 \\
\hline 2012 & 429 & 99,4 & 0,5 & 0 & 300 & 99,8 & 0,1 & 0,1 & 1130 & 95,5 & 4,2 & 0,3 \\
\hline 2013 & 10649 & 99,5 & 0,4 & 0,1 & 299 & 99,6 & 0,4 & 0,0 & 862 & 97,9 & 1,9 & 0,2 \\
\hline 2014 & 10998 & 99,5 & 0,5 & 0,0 & 2573 & 99,7 & 0,3 & 0,0 & 728 & 97,7 & 1,6 & 0,7 \\
\hline 2015 & 11928 & 99,6 & 0,3 & 0,1 & 396 & 98,2 & 0,1 & 1,7 & 1998 & 98,8 & 1,1 & 0,1 \\
\hline 2016 & 11019 & 99,3 & $\overline{0,6}$ & 0,1 & 298 & 99,9 & 0,1 & 0,0 & 4816 & 87,4 & 12,58 & 0,02 \\
\hline 2017 & 10770 & 99,2 & 0,7 & 0,1 & 3678 & 98,1 & 1,9 & 0,0 & 3861 & 80,2 & 19,8 & 0,0 \\
\hline 2018 & 10226 & 98,5 & 1,4 & 0,1 & 1696 & 96,0 & 3,9 & 0,1 & 3363 & 74,0 & 26,0 & 0,0 \\
\hline 2019 & 9760 & 98,2 & 1,5 & 0,3 & 240 & 96,4 & 3,5 & 0,1 & 2931 & 77,5 & 22,4 & 0,1 \\
\hline 2020 & 7381 & 97,6 & 0,6 & 1,8 & 150 & 99,8 & 0,2 & - & 2822 & 99,3 & 0,7 & - \\
\hline
\end{tabular}

Основная часть минерального сырья и материалов с повышенным содержанием природных радионуклидов относится к I классу и может использоваться без ограничения в производственных условиях (табл. 34).

Таблица 34

\section{Распределение минерального сырья и материалов с повышенным содержанием природных радионуклидов по классам}

\begin{tabular}{|c|c|c|c|c|c|c|c|c|c|c|c|c|}
\hline \multirow{4}{*}{ Годы } & \multicolumn{12}{|c|}{ Число исследованных проб } \\
\hline & \multicolumn{4}{|c|}{ местного производства } & \multicolumn{4}{|c|}{$\begin{array}{c}\text { привозные из других } \\
\text { субъектов Российской } \\
\text { Федерации }\end{array}$} & \multicolumn{4}{|c|}{ импортируемые } \\
\hline & \multirow{2}{*}{ всего } & \multicolumn{3}{|c|}{ из них класса, \% } & \multirow{2}{*}{ всего } & \multicolumn{3}{|c|}{ из них класса, \% } & \multirow{2}{*}{ всего } & \multicolumn{3}{|c|}{ из них класса, \% } \\
\hline & & $\mathrm{I}$ & II & III и IV & & I & II & III и IV & & I & II & III и ІV \\
\hline 2011 & 587 & 91,1 & 3,8 & 5,1 & 119 & 84,8 & 7,6 & 7,6 & 510 & 83,5 & 6,9 & 9,6 \\
\hline 2012 & 775 & 91,1 & 4,1 & 4,8 & 44 & 88,6 & 11,4 & - & 275 & 81,8 & 16,0 & 2,2 \\
\hline 2013 & 839 & 93,7 & 1,9 & 4,4 & 86 & 76,7 & 10,5 & 12,8 & 456 & 79,8 & 9,9 & 10,3 \\
\hline 2014 & 725 & 89,8 & 1,1 & 9,1 & 69 & 78,3 & 5,8 & 15,9 & 242 & 89,7 & 5,0 & 5,3 \\
\hline 2015 & 768 & 79,8 & 0,3 & 19,9 & 297 & 56,2 & 8,4 & 35,4 & 885 & 53,9 & 38,0 & 8,1 \\
\hline 2016 & 742 & 95,7 & 1,9 & 2,4 & 842 & 91,9 & 1,5 & 6,5 & 1094 & 41,6 & 32,1 & 26,3 \\
\hline 2017 & 635 & 94,8 & 3,3 & 1,9 & 635 & 86,8 & 10,2 & 3,0 & 1969 & 86,1 & 3,9 & 10,0 \\
\hline 2018 & 1163 & 94,5 & 1,9 & 3,6 & 398 & 62,1 & 30,4 & 7,5 & 1576 & 74,6 & 7,9 & 17,5 \\
\hline 2019 & 821 & 79,9 & 13,6 & 6,5 & 953 & 72,2 & 19,2 & 8,6 & 1272 & 58,6 & 14,4 & 27,0 \\
\hline 2020 & 702 & 92,5 & 4,1 & 3,4 & 610 & 46,4 & 12,0 & 41,6 & 1605 & 60,2 & 7,7 & 32,1 \\
\hline
\end{tabular}

По результатам измерений, проведенных в 2019 году, наиболее значительный вклад в величину среднего индивидуального пожизненного радиационного риска для населения внесло облучение радоном и дочерними продуктами его распада. На всей территории России (за исключением Орловской области) средний по субъектам РФ индивидуальный пожизненный радиационный риск за счет облучения радоном составил 
не менее $1 \times 10^{-4}$. При этом максимальное значение данного показателя, равное $1,02 \times 10^{-3}$, что соответствует диапазону De manifestis risk, имело место для Республики Алтай. На рис. 81 представлено ранжирование субъектов Российской Федерации по величине среднего индивидуального пожизненного радиационного риска для населения за счет воздействия радона в 2019 г.

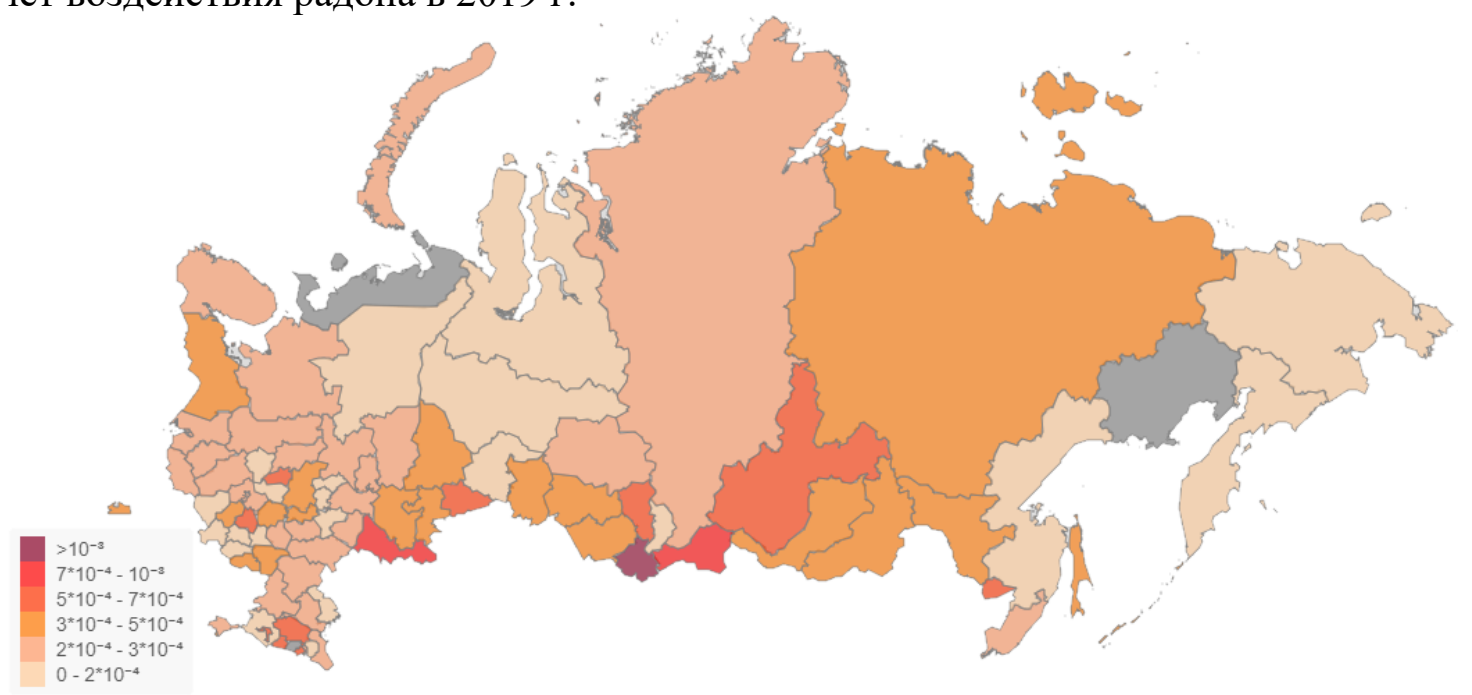

Рис. 81. Ранжирование субъектов Российской Федерации по величине среднего индивидуального пожизненного радиационного риска для населения за счет воздействия радона в 2019 г.

Уровни медицинского облучения зависят от потребности в медицинских услугах и от переоснащения российской рентгенологии современным оборудованием.

Первое место по величине вклада в коллективную дозу занимает компьютерная томография (КТ) - 56,1 \%. Динамика вклада основных видов рентгенорадиологических исследований в коллективную дозу медицинского облучения в период 2010-2019 гг. представлена на рис. 82.

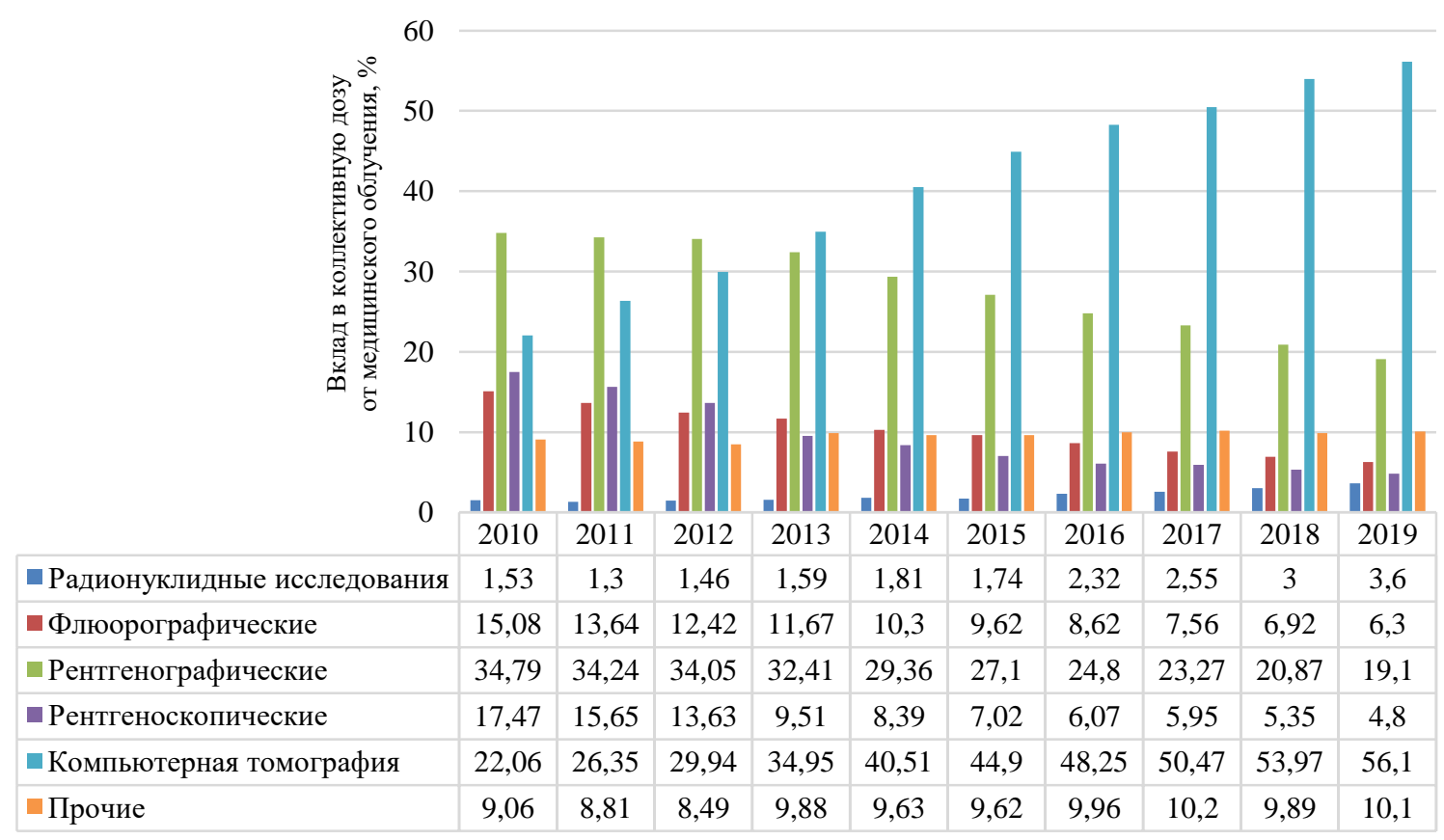

Рис. 82. Динамика вклада различных видов лучевой диагностики в коллективную дозу медицинского облучения за период 2010-2019 гг., \% 
В Российской Федерации после некоторой стабилизации средней годовой эффективной дозы медицинского облучения в расчете на одного жителя на уровне $0,45-$ 0,48 м3в в 2013-2015 гг. с 2016 г. отмечен ее медленный рост до 0,6 мЗв в 2019 г. Колебания средней по Российской Федерации годовой эффективной дозы медицинского облучения в расчете на одного жителя за период 2010-2019 гг. не превышают 20 \%, но при этом разброс средних по субъектам Российской Федерации доз медицинского облучения составляет до 10 раз.

Похожая картина наблюдается и для средних по Российской Федерации доз на одну процедуру. За период с 2015 по 2019 г. данная величина медленно увеличивалась с 0,26 мЗв до 0,3 мЗв при разбросе средних величин по субъектам Российской Федерации в $3-5$ раз.

В 2019 году в Российской Федерации 22086 организаций использовали в своей деятельности техногенные источники ионизирующего излучения (ИИИ), в том числе 47 организаций, относящихся к I категории потенциальной радиационной опасности, при аварии на которых возможно аварийное радиационное воздействие на население зоны наблюдения. Использовалось около 161,7 тыс. установок с техногенными ИИИ, из них более 68,1 тыс. установок с генерирующими ИИИ.

Численность персонала радиационных объектов составила 295707 человек, из них 213243 - персонал группы А и 82464 - персонал группы Б. На рис. 83 представлены данные по динамике численности персонала группы А и группы Б в Российской Федерации.

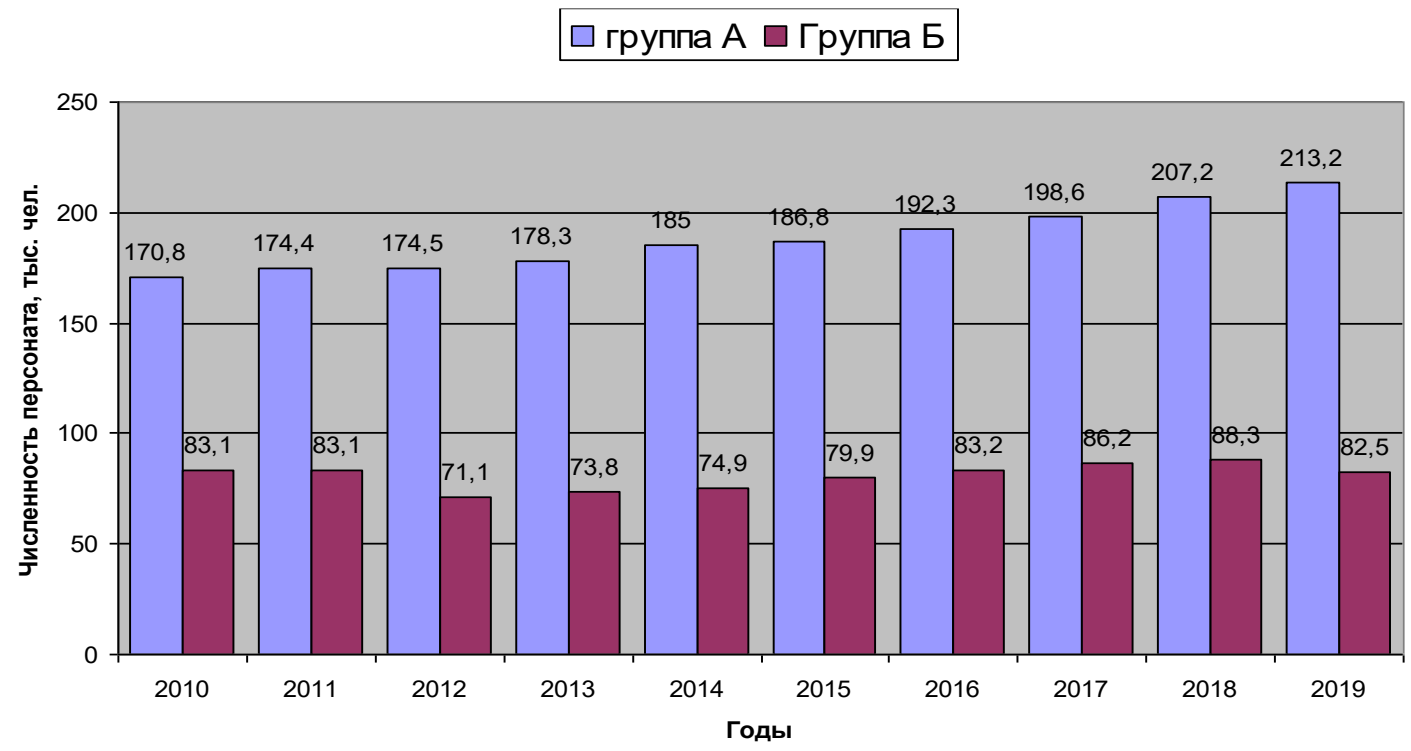

Рис. 83. Динамика численности персонала, работающего с техногенными источниками ионизирующего излучения, 2010-2019 гг.

По данным за 2019 г. средняя годовая эффективная доза персонала группы А составила 1,27 м3в/год, а персонала группы Б - 0,21 мЗв/год. Зарегистрировано 7 случаев превышения среднегодового предела дозы для персонала группы А (20 мЗв/год) и 17 случаев превышения среднегодового предела дозы для персонала группы Б (5 м3в/год).

На рис. 84 представлена динамика средних по Российской Федерации доз персонала группы А в сравнении с максимальными и минимальными значениями средних по субъектам Российской Федерации доз персонала группы А. Как видно из представленного рисунка, несмотря на значительные колебания максимальных и минимальных значений средних по субъектам Российской Федерации доз персонала группы А (в 2 и более раза), колебания средних значений этих величин по Российской Федерации в целом не превышают $3,3 \%$. 
Государственный доклад «О состоянии санитарно-эпидемиологического благополучия населения в Российской Федерации в 2020 году»

\section{Средние дозы персонала группы А}

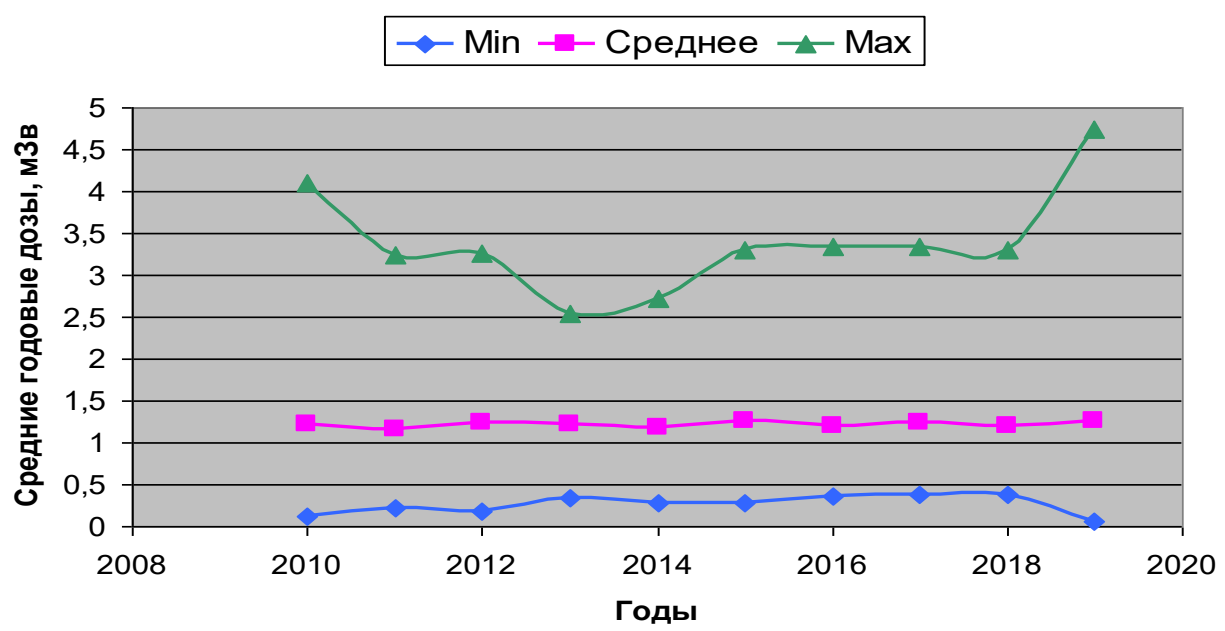

Рис. 84. Динамика средних по Российской Федерации, максимальных и минимальных средних по субъектам Российской Федерации доз облучения персонала группы А

Обобщенные данные (по количеству организаций, численности персонала, величине средних и максимальных доз облучения персонала) организаций, подотчетных Роспотребнадзору, представлены согласно ведомственной принадлежности в табл. 35.

Таблица 35

\section{Численность и средние дозы облучения персонала групп А и Б} для различных видов деятельности в 2019 году

\begin{tabular}{|c|c|c|c|c|c|}
\hline Виды организаций & $\begin{array}{c}\text { Число } \\
\text { организаций }\end{array}$ & Группа & Численность, чел. & $\begin{array}{c}\text { Средняя доза, } \\
\text { мЗв/год }\end{array}$ & $\begin{array}{l}\text { Макс. доза, } \\
\text { м3в/год }\end{array}$ \\
\hline \multirow{2}{*}{ медучреждения } & \multirow{2}{*}{16743} & A & 90922 & 0,97 & 48,3 \\
\hline & & Б & 10414 & 0,92 & 18,5 \\
\hline \multirow{2}{*}{ промышленные } & \multirow{2}{*}{2611} & A & 31931 & 1,46 & 36,2 \\
\hline & & Б & 10688 & 0,36 & 6,2 \\
\hline \multirow{2}{*}{ прочие } & \multirow{2}{*}{1998} & A & 29554 & 1,21 & 20,51 \\
\hline & & Б & 3210 & 0,34 & 3,3 \\
\hline \multirow{2}{*}{ научные и учебные } & \multirow{2}{*}{363} & A & 7646 & 0,97 & 19,5 \\
\hline & & Б & 2928 & 0,34 & 4,6 \\
\hline \multirow{2}{*}{$\begin{array}{c}\text { геологоразведочные и } \\
\text { добывающие }\end{array}$} & \multirow{2}{*}{183} & A & 6003 & 2,22 & 18,4 \\
\hline & & Б & 584 & 0,73 & 6,4 \\
\hline \multirow{2}{*}{ таможенные } & \multirow{2}{*}{117} & A & 5561 & 0,79 & 13,4 \\
\hline & & $\overline{5}$ & 65 & 0,72 & 2,0 \\
\hline \multirow{2}{*}{ пункты захоронения РАО } & \multirow{2}{*}{17} & A & 463 & 1,42 & 20,0 \\
\hline & & 5 & 106 & 0,46 & 2,8 \\
\hline \multirow{2}{*}{$\begin{array}{c}\text { прочие особо } \\
\text { радиационноопасные }\end{array}$} & \multirow{2}{*}{43} & A & 20438 & 1,43 & 20,1 \\
\hline & & 5 & 40937 & 0,10 & 0,99 \\
\hline \multirow{2}{*}{ атомные электростанции } & \multirow{2}{*}{11} & A & 20725 & 1,30 & 17,6 \\
\hline & & Б & 13532 & 0,02 & 0,2 \\
\hline \multirow{3}{*}{ Всего } & \multirow{3}{*}{22086} & $\mathbf{A}$ & 213243 & 1,19 & 48,3 \\
\hline & & Б & 82464 & 0,64 & 18,5 \\
\hline & & $(A+B)$ & 295707 & 1,15 & 48,3 \\
\hline
\end{tabular}


Наибольшие средние дозы облучения в 2019 г. зарегистрированы у персонала геологоразведочных и добывающих (2,22 м3в/год), промышленных (1,46 мЗв/год) и прочих особо радиационно-опасных (1,43 м3в/год) предприятий.

В 2020 г. зарегистрировано 152 случая радиационных аварий (РА) и ситуаций санитарно-эпидемиологического характера, связанных с потерей контроля над источниками ионизирующего излучения. Наибольшее число случаев РА приходится на следующие субъекты Российской Федерации: г. Москва (26), Московская область (20), г. Санкт-Петербург (12), Ямало-Ненецкий автономный округ (12), Свердловская область (11) (табл. 36).

Таблица 36

Распределение радиационных аварий и инцидентов, имевших место в 2020 году

\begin{tabular}{|l|c|l|c|}
\hline \multicolumn{1}{|c|}{ Наименование } & $\begin{array}{c}\text { Количество } \\
\text { инцидентов }\end{array}$ & \multicolumn{1}{|c|}{ Наименование } & инцидентов \\
\hline Архангельская область & 3 & Оренбургская область & 5 \\
\hline Астраханская область & 1 & Пермский край & 5 \\
\hline Белгородская область & 1 & Приморский край & 2 \\
\hline Вологодская область & 2 & Республика Башкортостан & 3 \\
\hline г. Москва & 26 & $\begin{array}{l}\text { Республика Крым и } \\
\text { Г. Севастополь }\end{array}$ & 1 \\
\hline г. Санкт-Петербург & 12 & Республика Хакасия & 1 \\
\hline Иркутская область & 2 & Ростовская область & 1 \\
\hline Калининградская область & 6 & Самарская область & 1 \\
\hline Калужская область & 1 & Саратовская область & 1 \\
\hline Кемеровская область & 2 & Свердловская область & 1 \\
\hline Краснодарский край & 5 & Томская область & 10 \\
\hline Красноярский край & 3 & Тюменская область & 4 \\
\hline Ленинградская область & 2 & Хабаровский край & 2 \\
\hline Липецкая область & 20 & $\begin{array}{l}\text { Ханты-Мансийский автономный } \\
\text { округ - Югра }\end{array}$ \\
\hline Московская область & Челябинская область & Ямало-Ненецкий автономный \\
\hline Мурманская область & округ & 12 \\
\hline Нижегородская область & 1 & & 1 \\
\hline
\end{tabular}

Наиболее распространенными причинами аварий являются: обнаружение, выявление неконтролируемых ИИИ или радиоактивных загрязнений (29 \%), нарушение правил сбора и оборота металлолома (26\%), прихват или обрыв ИИИ в скважине в результате проведения геофизических исследований $(18 \%)$, нарушение правил транспортирования радиоактивный веществ (12\%).

В 40 случаях (2019 г. - 39 случаев) источники были обнаружены при радиационном контроле партий металлолома в 15 субъектах Российской Федерации. Наибольшее число партий металлолома, не соответствующих требованиям по обеспечению радиационной безопасности, выявлено в Хабаровском крае (9) и Свердловской области (8). Основными причинами повышенного уровня гаммаизлучения от металлолома является присутствие в составе металлолома фрагментов различной радиационной техники или загрязненных природными радионуклидами в процессе эксплуатации металлических труб (в основном Ra-226 и его соли). 
Все случаи аварий, связанные с нарушением правил транспортирования радиоактивных веществ (18 случаев), были выявлены при таможенном досмотре. При идентификации определены природные радионуклиды (Ra-226, Th-232).

В 2020 году зарегистрировано 27 случаев прихвата или обрыва геофизического оборудования с ИИИ при каротажных работах на буровых скважинах. Аварийного радиационного воздействия на персонал и окружающую среду ни в одном случае не зарегистрировано. При ликвидации аварийной ситуации проводился радиационный контроль.

\section{2. Анализ состояния здоровья в связи с вредным воздействием факторов среды обитания человека и условий труда}

Важнейшим индикатором качества жизни и состояния санитарноэпидемиологического благополучия населения Российской Федерации является ожидаемая продолжительность жизни. Целевые значения этого ключевого показателя на десятилетний период определены Указом Президента Российской Федерации от 21 июля 2020 г. № 474 «О национальных целях развития Российской Федерации на период до 2030 года» (рис. 85). Проект целевых показателей, предложенных Правительством Российской Федерации, учитывает то, что распространение коронавирусной инфекции объективно отклонило развитие страны от планируемой траектории (данные по проекту Единого плана по достижению национальных целей развития Российской Федерации на период до 2024 года и на плановый период до 2030 года, Правительство Российской Федерации, 1 марта 2021 года).

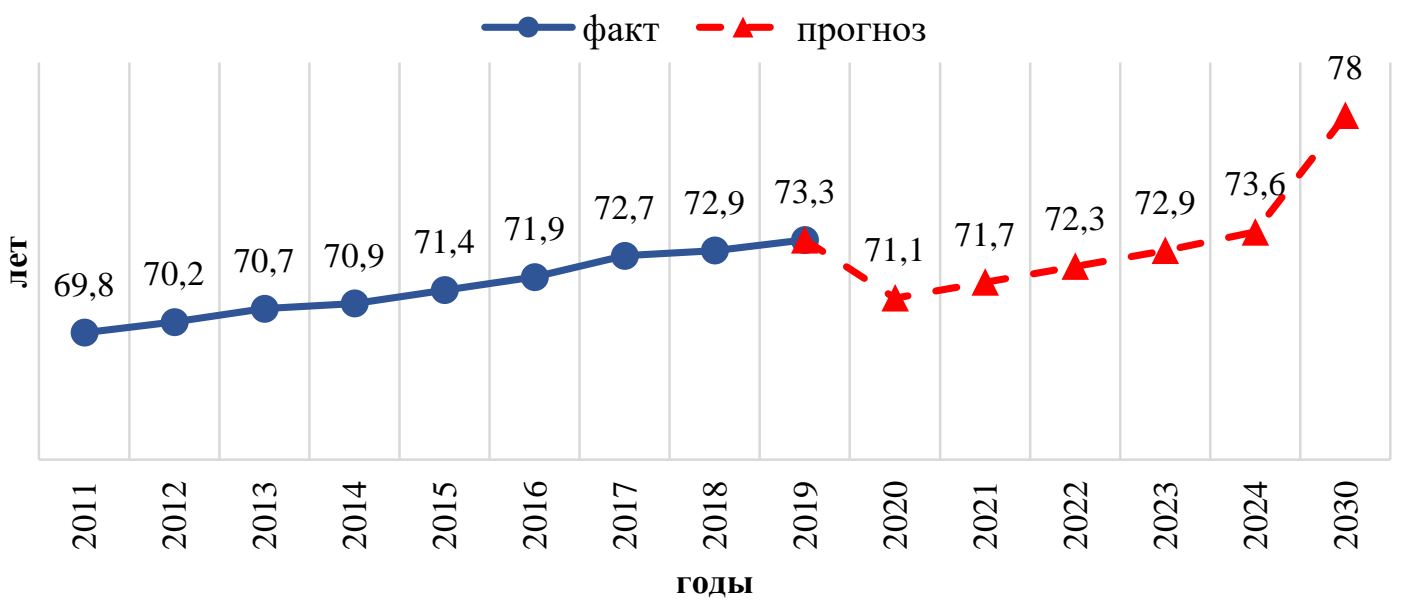

Рис. 85. Прогнозная оценка изменения ожидаемой продолжительности жизни населения в Российской Федерации в период до 2024 года и плановый период до 2030 года, лет

Основной вклад в формирование демографических процессов, дополнительную заболеваемость и смертность населения в субъектах Российской Федерации в связи с вредным воздействием среды обитания вносят факторы, обусловленные долговременным, непрерывным и многокомпонентным загрязнением, которое определяет комплексную химическую, биологическую, физическую нагрузку, и их комбинация на население.

Эти группы факторов продолжают в значительной степени определять показатели смертности (рис. 86) населения в субъектах Российской Федерации. 


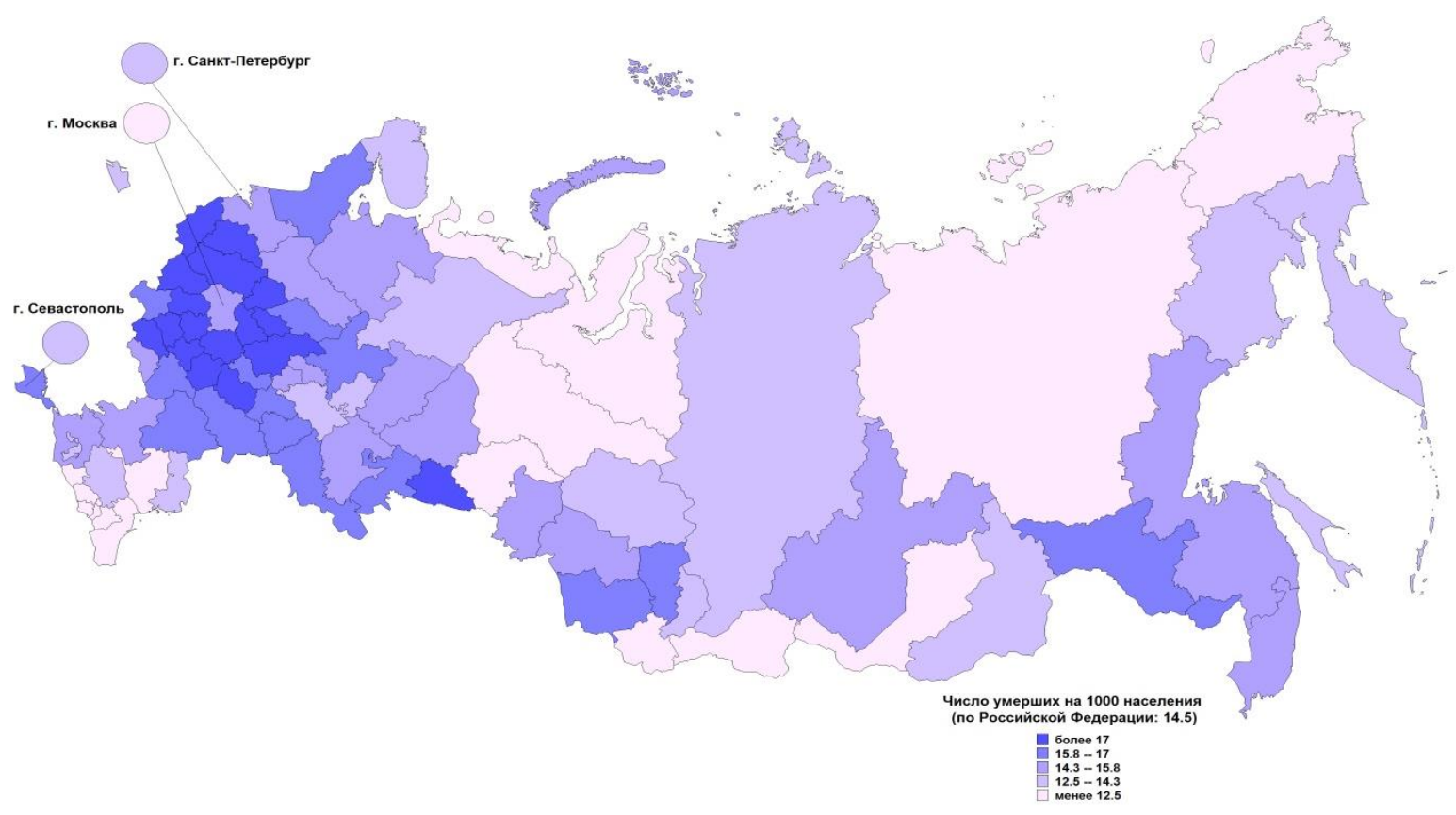

Рис. 86. Общая смертность населения в субъектах Российской Федерации, 2020 год

Основными причинами смертности на фоне повышенного уровня, обусловленного коронавирусной инфекцией, остаются в последнее десятилетие: болезни системы кровообращения, новообразования, внешние причины, болезни органов пищеварения, болезни органов дыхания, некоторые инфекционные и паразитарные болезни. Динамика изменения показателя общей смертности всего населения в субъектах Российской Федерации за последние годы приведена на рис. 87.

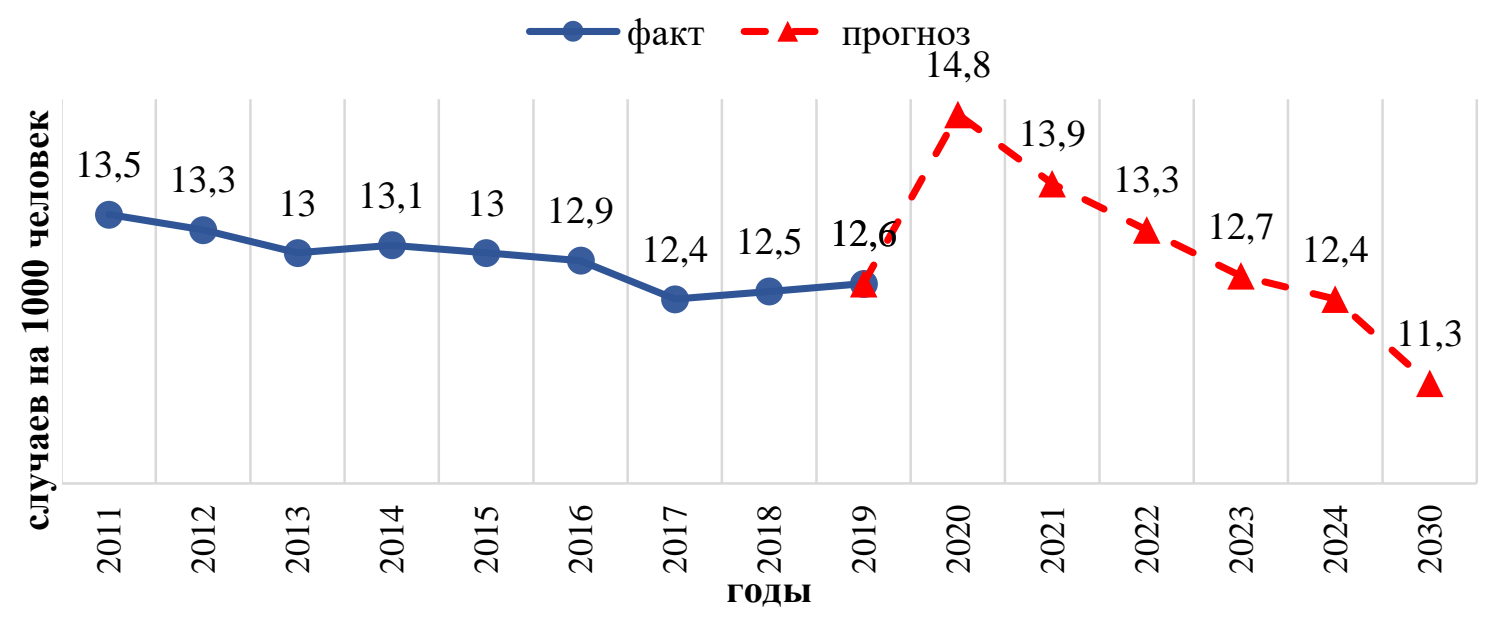

Рис. 87. Прогнозная целевая оценка изменения уровня общей смертности населения Российской Федерации на период до 2030 года, случаев на 1000 человек

Целевые прогнозные показатели приведены по данным проекта Единого плана по достижению национальных целей развития Российской Федерации на период до 2024 года и на плановый период до 2030 года.

Прогнозная оценка снижения показателя смертности на период до 2024 года и до 2030 года предполагает реализацию оптимистического сценария пресечения распространения новой коронавирусной инфекции и возврат к целенаправленному улучшению санитарно-эпидемиологической обстановки в Российской Федерации, включая эпидемическую ситуацию. 
На рис. 88 приведено ранжирование субъектов Российской Федерации по показателю смертности населения в трудоспособном возрасте, на рис. 89 динамика изменения этого показателя и прогноз его значения на период до 2030 года.

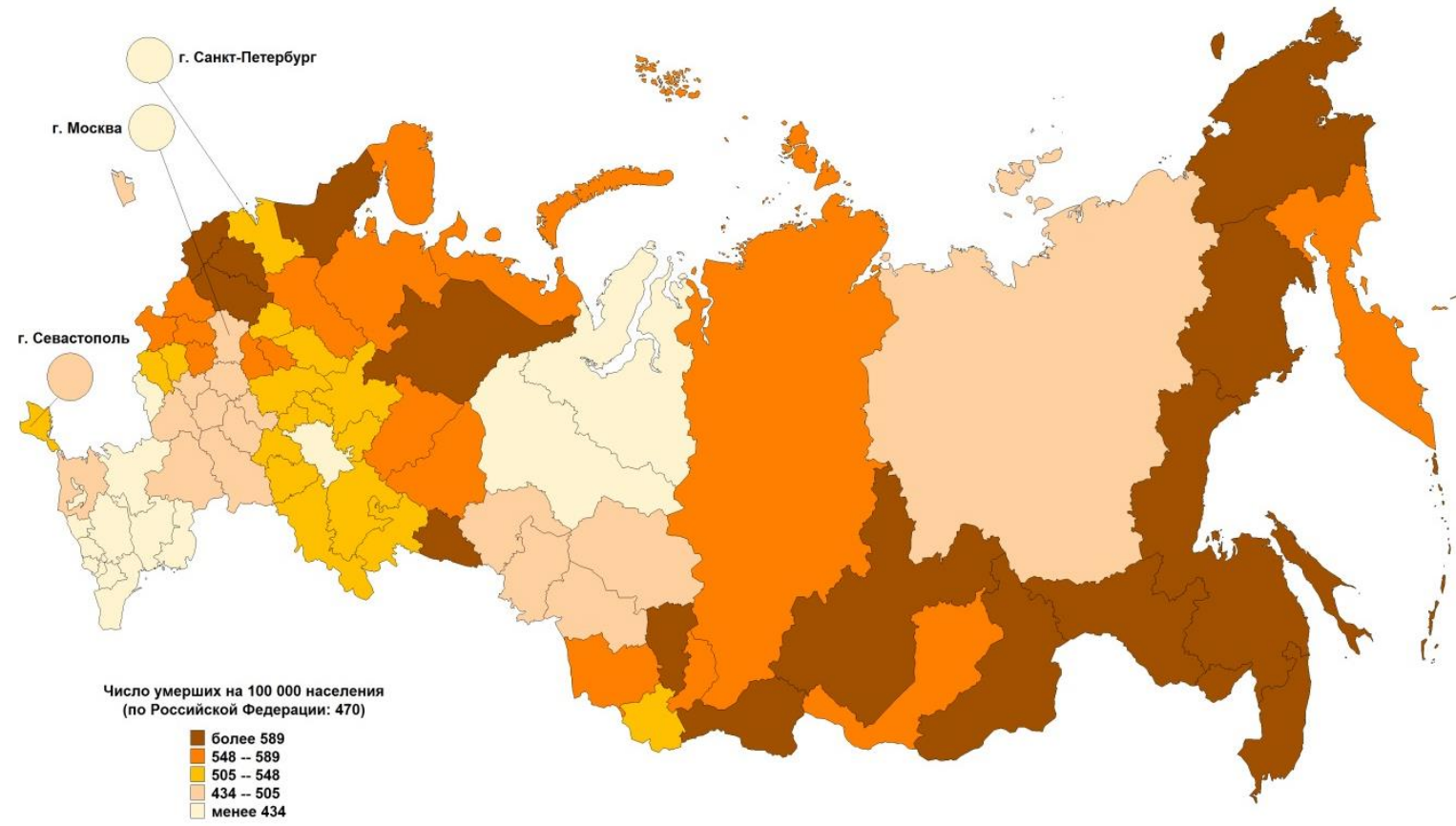

Рис. 88. Смертность населения в трудоспособном возрасте в субъектах Российской Федерации, 2020 год

Распространение коронавирусной инфекции повлияло на динамику изменения показателя смертности населения в трудоспособном возрасте и людей старшего возраста. Прогнозируется, что к 2024 году показатель достигнет уровня 410,0 случая смерти на 100000 человек.

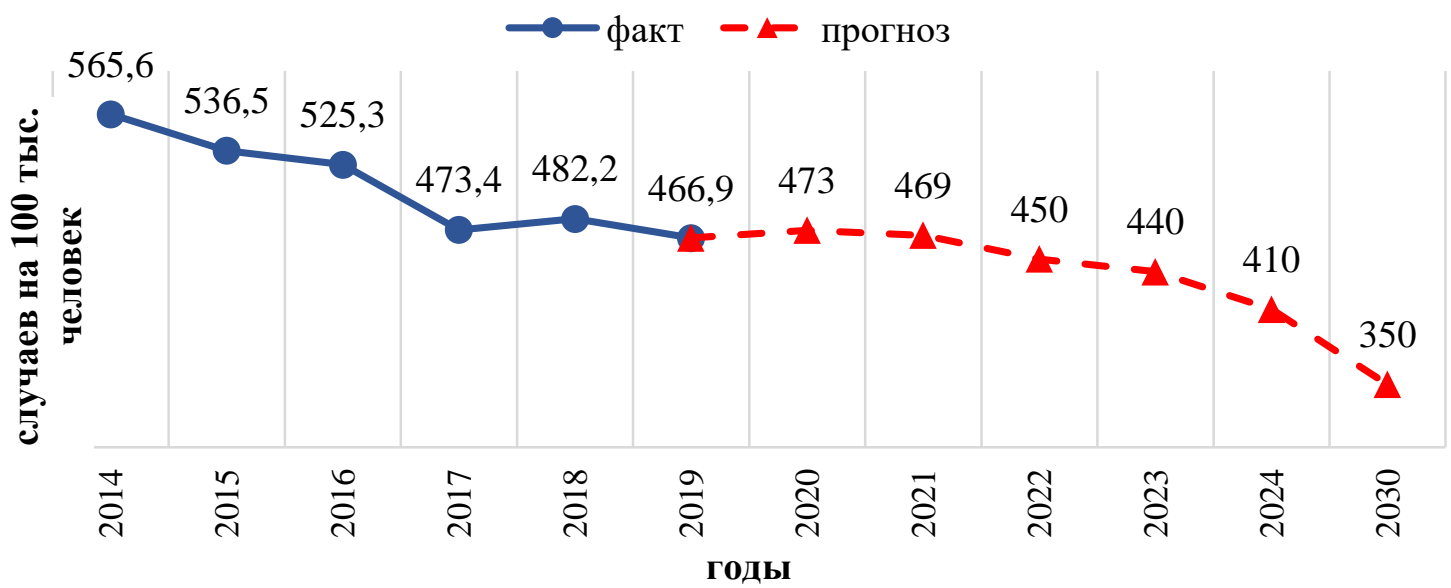

Рис. 89. Прогнозная оценка изменения уровня смертности населения в трудоспособном возрасте в Российской Федерации на период до 2030 года, случаев на 100000 человек

Проблемы повышенной смертности населения, обусловленной факторами среды обитания, рассматриваются на фоне и во взаимообусловленности с эпидемической ситуацией, сложившейся в субъектах Российской Федерации в 2020 году.

На рис. 90 приведена информация об уровне общей заболеваемости населения и структуре причин заболеваемости в субъектах Российской Федерации. 


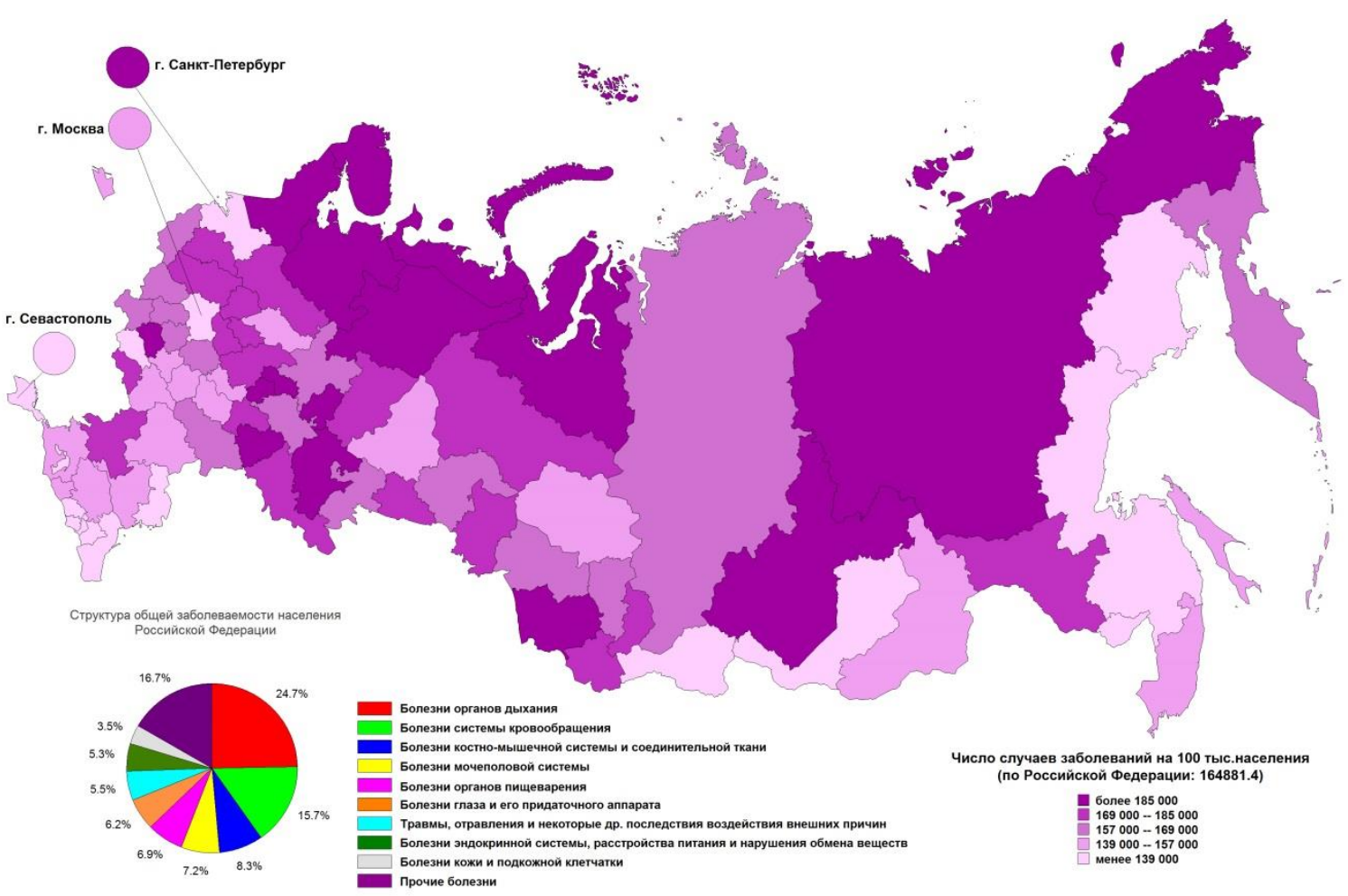

Рис. 90. Общая заболеваемость всего населения и структура причин заболеваемости в субъектах Российской Федерации, 2020 год

Основными причинами высокого уровня заболеваемости всего населения в субъектах Российской Федерации остаются: болезни органов дыхания, системы кровообращения, болезни костно-мышечной системы, болезни мочеполовой системы, а также болезни органов пищеварения. При значении среднероссийского показателя на уровне 164881,4 случая заболеваний на 100000 человек значение показателя различается в субъектах Российской Федерации от менее 135000 до более 185000 случаев без учета коронавирусной пандемии.

Результаты анализа качества среды обитания и его влияния на состояние здоровья населения (смертность и заболеваемость) показали различный уровень обусловленности этого влияния в различных субъектах Российской Федерации в зависимости от установленных приоритетов при разработке и реализации адресного управления риском для здоровья населения. Прежде всего, качество среды обитания для большинства населения субъектов Российской Федерации определяется уровнем загрязнения атмосферного воздуха поселений, питьевых вод, продуктов питания и почв селитебных территорий. Специфика и соотношение уровня воздействия различных факторов среды обитания на состояние здоровья населения определяют демографические потери в субъектах Российской Федерации.

\subsection{1. Анализ состояния здоровья населения в связи с вредным воздействием факторов среды обитания на человека}

По данным ВОЗ, качество среды обитания обуславливает около 15-25\% глобального бремени болезней. К приоритетным факторам риска, вносящим основной вклад в дополнительную, ассоциированную с факторами среды обитания, заболеваемость и смертность населения, относятся: постоянное и многокомпонентное загрязнение атмосферного воздуха, питьевых вод, почв селитебных территорий. 
Всемирная организация здравоохранения относит к индикаторным в отношении качества среды обитания такие показатели состояния здоровья населения, как общая смертность населения, младенческая смертность, ожидаемая продолжительность предстоящей жизни, заболеваемость, в том числе частота врожденных пороков развития, бронхиальная астма у детей, онкологическая заболеваемость и ряд других.

Уровень и динамика вышеуказанных показателей могут быть использованы для оценки социально-гигиенической ситуации на территории страны и отдельных ее субъектов и планирования эффективных профилактических мероприятий и системы действий по обеспечению санитарно-эпидемиологического благополучия населения.

Региональная специфика загрязнения объектов среды обитания и особенности социально-экономической ситуации, климатической дифференциации определяют ассоциированные медико-демографические потери.

Системное и последовательное улучшение качества объектов среды обитания регионов Российской Федерации, в том числе путем внедрения риск-ориентированного подхода к осуществлению контрольно-надзорных мероприятий, влечет за собой и общее снижение числа ассоциированных с санитарно-эпидемиологическими факторами нарушений здоровья. Анализ данных ведомственной статистики и федерального информационного фонда социально-гигиенического мониторинга за 2020 г. свидетельствует о том, что в целом по стране с загрязнением атмосферного воздуха (без учета физических факторов), питьевых вод, почв городских и сельских поселений вероятностно связано порядка 17,5 дополнительных случая смертей на 100 тыс. всего населения (или 64,3\% от уровня 2012 г.) и около 21,9 дополнительных случая заболеваний детского и взрослого населения на 1 тыс. всего населения (или 60,0 \% от уровня 2012 г.). В целом доля нарушений здоровья населения страны, достоверно ассоциированных с негативными факторами среды обитания - качеством атмосферного воздуха, питьевых вод, почв - в динамике постепенно снижается, что является, в том числе, следствием реализации комплексных мер при осуществлении надзорной и профилактической деятельности Роспотребнадзора (рис. 91, 92).

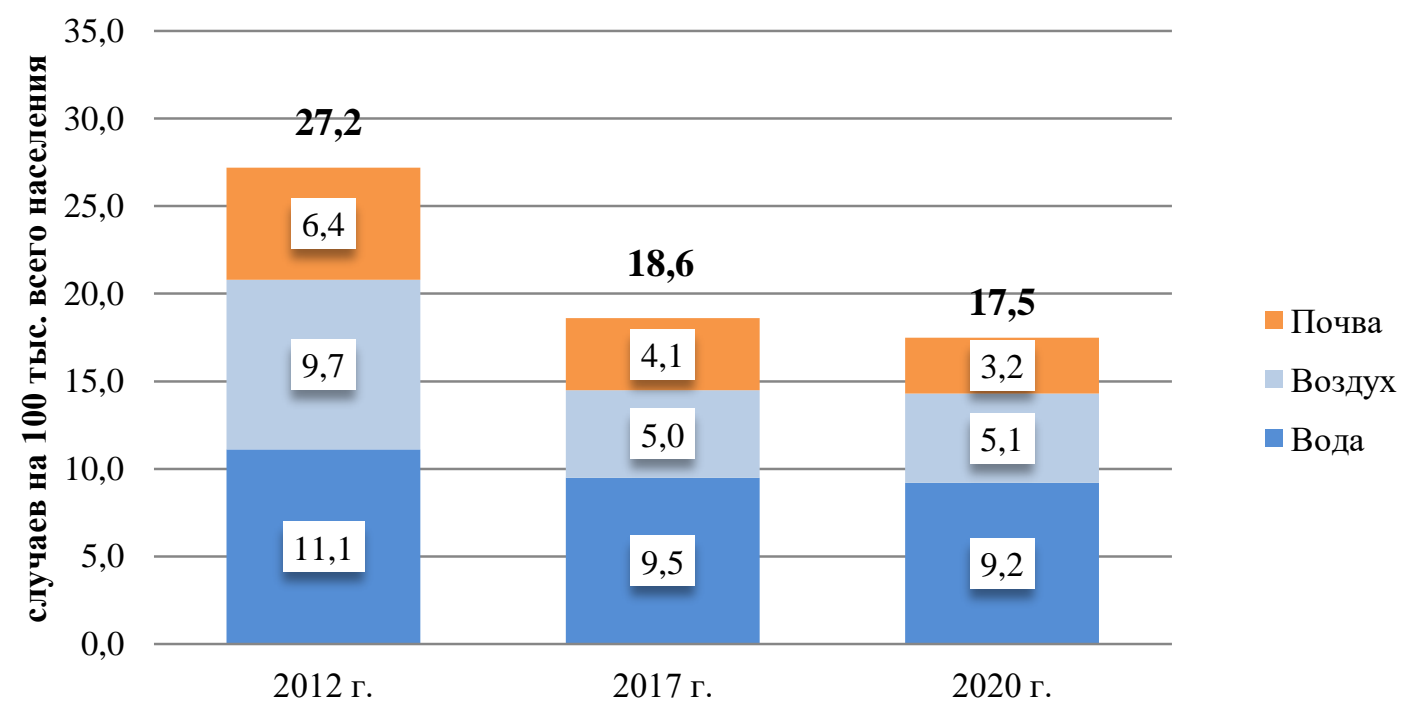

Рис. 91. Динамика дополнительной смертности населения Российской Федерации, ассоциированной с негативным воздействием приоритетных факторов среды обитания 


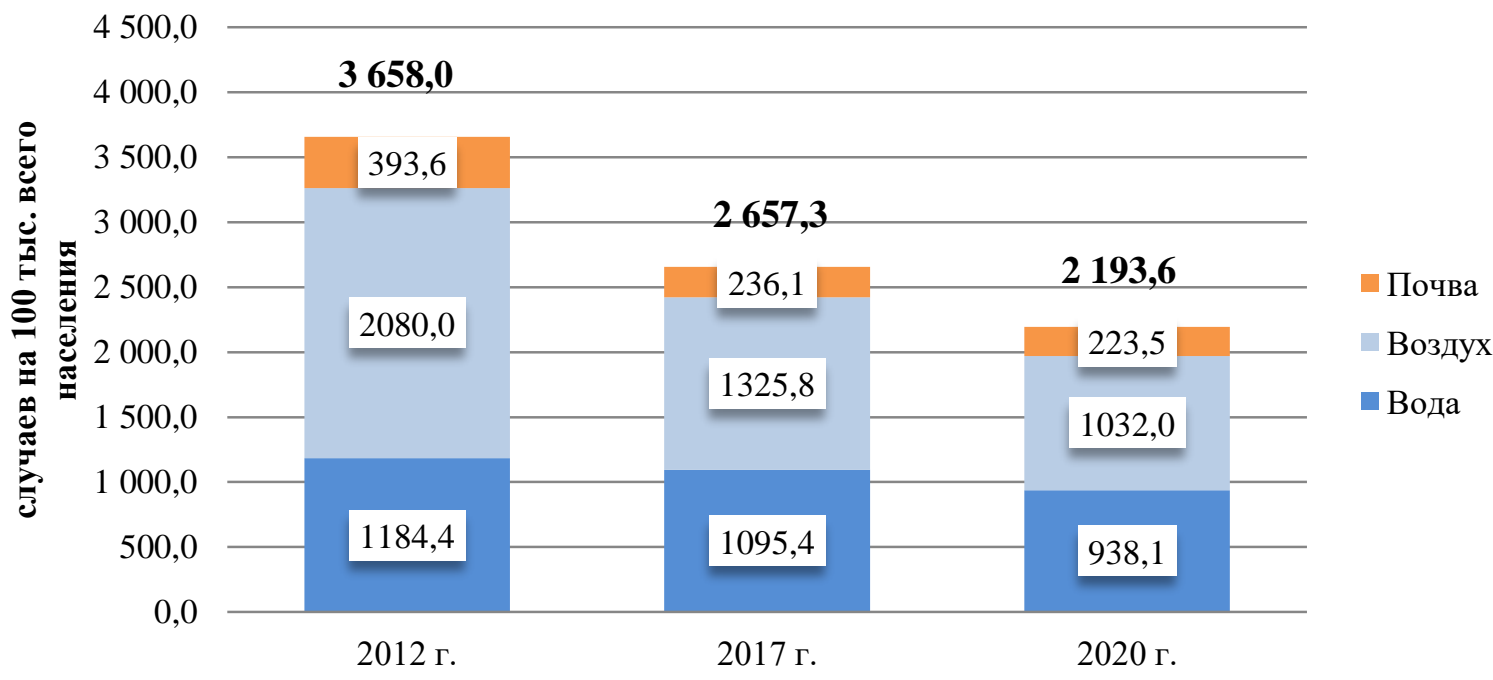

Рис. 92. Динамика дополнительной заболеваемости населения Российской Федерации, ассоциированной с негативным воздействием приоритетных факторов среды обитания

Приоритетными санитарно-эпидемиологическими факторами, формирующими медико-демографические потери, продолжают оставаться химическое и биологическое загрязнение среды обитания, воздействие физических факторов (табл. 37).

В силу постепенного снижения загрязнения атмосферного воздуха поселений, улучшения качества питьевых вод и почв общее число смертей и заболеваний населения, ассоциированных с факторами внешней среды, постепенно сокращается. В относительных показателях наиболее существенным является снижение числа смертей и заболеваний, ассоциированных с качеством атмосферного воздуха городских и сельских поселений.

Таблица 37

\section{Приоритетные факторы среды обитания, формирующие медико-демографические потери}

\begin{tabular}{|c|c|c|c|c|}
\hline \multirow[t]{2}{*}{$\begin{array}{c}\text { Приоритетные } \\
\text { факторы среды обитания }\end{array}$} & \multirow[t]{2}{*}{$\begin{array}{l}\text { Ассоциированные с фактором } \\
\text { основные показатели здоровья }\end{array}$} & \multicolumn{2}{|c|}{$\begin{array}{c}\text { Число дополнительных } \\
\text { случаев на } 100 \text { тыс. всего } \\
\text { населения }\end{array}$} & \multirow{2}{*}{\begin{tabular}{|c|} 
Темп \\
изменения \\
относительно \\
2012 г., \%
\end{tabular}} \\
\hline & & 2012 г. & 2020 г. & \\
\hline 1 & 2 & 3 & 4 & 5 \\
\hline $\begin{array}{c}\text { Загрязнение атмосферного } \\
\text { воздуха химическими } \\
\text { компонентами (азота оксид, } \\
\text { азота диоксид, бенз(а)пирен, } \\
\text { гидроксибензол, }\end{array}$ & $\begin{array}{c}\text { Смертность по причине болезней } \\
\text { органов дыхания, органов } \\
\text { пищеварения, системы } \\
\text { кровообращения, злокачественных } \\
\text { новообразований }\end{array}$ & 9,7 & 5,1 & $-47,4$ \\
\hline $\begin{array}{c}\text { формальдегид, аммиак, } \\
\text { дигидросульфид, хлор, } \\
\text { хлористый водород } \\
\text { взвешенные вещества, } \\
\text { углерод оксид, } \\
\text { ароматические } \\
\text { углеводороды, ксилол, } \\
\text { бензол, толуол, марганец, } \\
\text { серная кислота, свинец, } \\
\text { алифатические предельные } \\
\text { углеводороды, серы диоксид, } \\
\text { сероуглерод, фтор, } \\
\text { фтористый водород и др.) }\end{array}$ & $\begin{array}{c}\text { Заболеваемость в классах: } \\
\text { болезни глаза и его придаточного } \\
\text { аппарата; костно-мышечной } \\
\text { системы и соединительной ткани; } \\
\text { крови, кроветворных органов и } \\
\text { отдельные нарушения, } \\
\text { вовлекающие иммунный } \\
\text { механизм; нервной системы; } \\
\text { органов дыхания; органов } \\
\text { пищеварения; системы } \\
\text { кровообращения; эндокринной } \\
\text { системы; новообразования }\end{array}$ & 2080,0 & 1032,0 & $-50,4$ \\
\hline
\end{tabular}


Продолжение табл. 37

\begin{tabular}{|c|c|c|c|c|}
\hline 1 & 2 & 3 & 4 & 5 \\
\hline \multirow[b]{2}{*}{$\begin{array}{c}\text { Загрязнение питьевых вод } \\
\text { химическими компонентами } \\
\text { (хлор, хлороформ, кадмий, } \\
\text { свинец, нитриты, никель, } \\
\text { медь, железо, марганец, } \\
\text { аммиак, мышьяк, нитраты, } \\
\text { сульфаты, бор, стронций, } \\
\text { тетрахлорметан, фтор и др.) } \\
\text { и микробиологическими } \\
\text { агентами }\end{array}$} & $\begin{array}{c}\text { Смертность от некоторых } \\
\text { инфекционных и паразитарных } \\
\text { болезней; болезней органов } \\
\text { пищеварения; болезней системы } \\
\text { кровообращения; злокачественных } \\
\text { новообразований }\end{array}$ & 11,1 & 9,2 & $-17,1$ \\
\hline & $\begin{array}{c}\text { Заболеваемость в классах: болезни } \\
\text { кожи и подкожной клетчатки; костно- } \\
\text { мышечной системы и соединительной } \\
\text { ткани; крови, кроветворных органов и } \\
\text { отдельные нарушения, вовлекающие } \\
\text { иммунный механизм; болезни } \\
\text { мочеполовой системы; органов } \\
\text { пищеварения; системы } \\
\text { кровообращения; эндокринной } \\
\text { системы; некоторые инфекционные и } \\
\text { паразитарные болезни, } \\
\text { новообразованиями }\end{array}$ & 1184,4 & 938,1 & $-20,8$ \\
\hline \multirow{2}{*}{$\begin{array}{c}\text { Загрязнение почв тяжёлыми } \\
\text { металлами, в том числе } \\
\text { свинцом, кадмием, ртутью и } \\
\text { др., микробиологическими и } \\
\text { паразитарными агентами }\end{array}$} & $\begin{array}{c}\text { Смертность от некоторых } \\
\text { инфекционных и паразитарных } \\
\text { болезней, злокачественных } \\
\text { новообразований }\end{array}$ & 6,4 & 3,2 & $-50,0$ \\
\hline & $\begin{array}{c}\text { Заболеваемость в классах: болезни } \\
\text { мочеполовой системы; врождённые } \\
\text { аномалии и пороки развития, } \\
\text { некоторые инфекционные и } \\
\text { паразитарные болезни, } \\
\text { новообразования }\end{array}$ & 393,6 & 223,5 & $-43,2$ \\
\hline \multirow[b]{2}{*}{$\begin{array}{c}\text { Физические факторы (шум, } \\
\text { электромагнитное } \\
\text { излучение, вибрация, } \\
\text { освещённость, } \\
\text { ионизирующее излучение) }\end{array}$} & $\begin{array}{c}\text { Смертность от болезней системы } \\
\text { кровообращения, злокачественных } \\
\text { новообразований }\end{array}$ & $\begin{array}{c}18,98 \\
(2016 \text { г.) }\end{array}$ & 19,19 & $+1,16$ \\
\hline & $\begin{array}{c}\text { Заболеваемость в классах: болезни } \\
\text { системы кровообращения, болезни уха } \\
\text { и сосцевидного отростка, болезни } \\
\text { нервной системы, костно-мышечной } \\
\text { системы, болезни глаза и его } \\
\text { придаточного аппарата, последствия } \\
\text { воздействия внешних причин }\end{array}$ & $\begin{array}{c}217,4 \\
(2016 \text { г.) }\end{array}$ & 184,7 & $-15,1$ \\
\hline
\end{tabular}

Воздействием приоритетных химических примесей атмосферного воздуха селитебных территорий в 2020 г. вероятностно обусловлено около 5,1 сл. заболеваний на 100 тыс. всего населения (что более чем на $47 \%$ меньше, чем в 2012 г.) и около 1032 дополнительных случаев заболеваний на 100 тыс. всего населения (что в 2,0 раза ниже, чем в 2012 году). Положительная динамика показателей свидетельствует, что уровни загрязнения атмосферного воздуха, способные формировать дополнительные случаи нарушений здоровья, системно снижаются. К регионам с наиболее низкими значениями дополнительных вероятностно обусловленных с качеством атмосферного воздуха нарушений здоровья в 2020 г. относятся Архангельская область, г. Санкт-Петербург, Еврейская автономная область, Камчатский край, Карачаево-Черкесская Республика, Пермский край, Республика Алтай.

Приоритетными загрязняющими веществами являются окислы азота, алифатические предельные и ароматические углеводороды, в т. ч. бензол, гидроксибензол и его производные, ксилол, толуол, аммиак, бенз(а)пирен, взвешенные вещества, дигидросульфид, марганец, свинец, серы диоксид, серная кислота, сероуглерод, углерода оксид, формальдегид, фтор и его соединения, хлор и его соединения и др. 
Оценка связи нарушений здоровья населения с регистрируемым уровнем загрязнения атмосферного воздуха в приоритетных городах - участниках федерального проекта «Чистый воздух» национального проекта «Экология» на существующее положение показала, что наибольшее число вероятностно обусловленных случаев заболеваний всего населения формируется в Челябинске (276,50 тыс. случаев), Чите (104,83 тыс. случаев), Красноярске (28,10 тыс. случаев). В относительных случаях приоритетные позиции по количеству дополнительных случаев заболеваний всего населения занимают Чита (30 036,98 на 100 тыс. случаев), Челябинск $(23027,95$ на 100 тыс. случаев), Братск (8 031,56 на 100 тыс. случаев), Красноярск (2 563,27 на 100 тыс. случаев). Наибольший вклад в уровень этой заболеваемости вносят болезни органов дыхания, болезни системы кровообращения. Приоритетными загрязняющими веществами являются углерода оксид, ароматические и алифатические углеводороды, в том числе ксилол, толуол, бензол, гидроксибензол и его производные, марганец, свинец, окислы азота, хлор и его соединения, фтор и его соединения, аммиак, формальдегид, бенз(а)пирен, взвешенные вещества, серная кислота, дигидросульфид и др.

Взвешенные вещества и их фракционный состав определены как приоритет на большинстве территорий федерального проекта «Чистый воздух». Только мелкодисперсные фракции пыли формируют реальные медико-демографические потери, которые могут составлять до 0,3-3,5 случаев дополнительной смерти на 1000 человек (рис. 93).

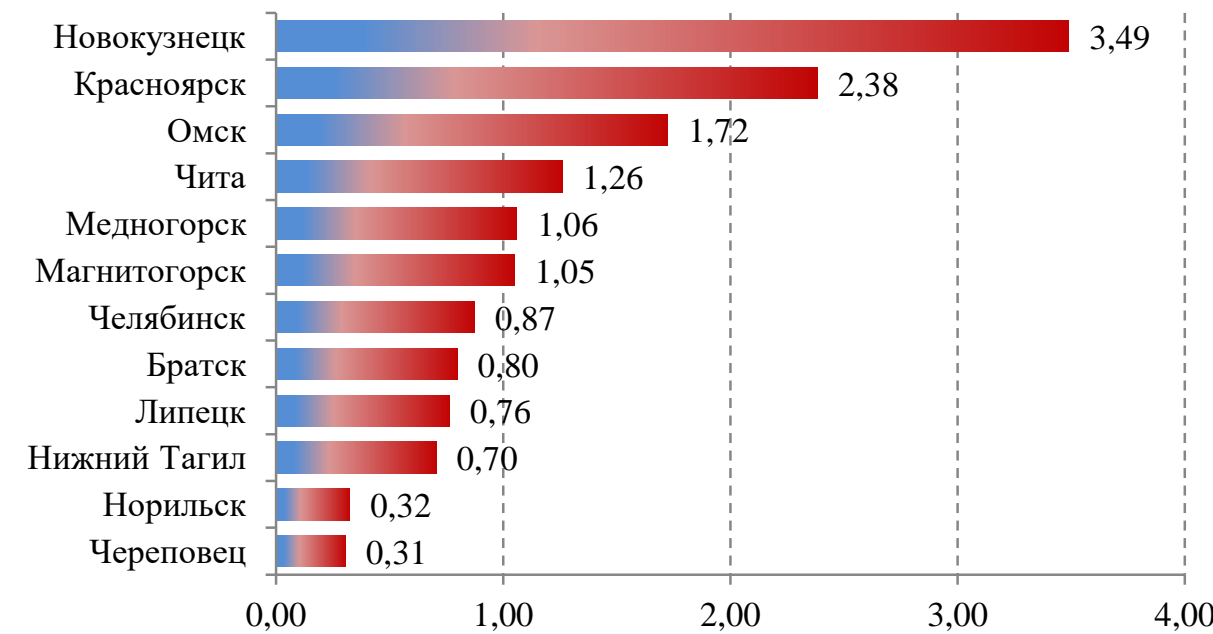

Рис. 93. Дополнительная смертность населения от воздействия мелкодисперсных фракций пыли РМ2.5 в городах - участниках федерального проекта «Чистый воздух», сл./1000 чел.

Наиболее существенными физическими факторами опасности, формирующими наибольшее количество заболеваний, обусловленных факторами среды обитания, являются шум и электромагнитное излучение. Постоянное акустическое загрязнение, в основном городских территорий, является причиной заболеваний сердечно-сосудистой, нервной систем и органов слуха. При этом дополнительная вероятностно обусловленная смертность населения от данного фактора в последние годы сохраняется на одном уровне - порядка 19 сл. на 100 тыс. населения. Заболеваемость постепенно снижается, темп убыли с 2016 г. составил $15,1 \%$. Вероятностно обусловленная заболеваемость, связанная с воздействием физических факторов, составила в 2020 г. 184,7 сл. на 100 тыс. населения.

Улучшение качества и безопасности питьевых вод, подаваемых населению, в том числе в результате реализации мероприятий федерального проекта «Чистая вода» национального проекта «Экология», имело следствием стабилизацию дополнительных случаев смерти и заболеваний, вероятностно обусловленных химическим и микробным загрязнением воды (6 и 7 регионов соответственно, в том числе Кировская область, Республика Саха и др.), а в ряде регионов и существенное их снижение: 52 и 53 региона 
соответственно, в диапазоне от $10,2 \%$ до $94,0 \%$ и от $10,4 \%$ до 96,2 \% соответственно. Наиболее значимое снижение заболеваемости, вероятностно обусловленной качеством питьевой воды, наблюдалось в г. Санкт-Петербурге, Республике Марий Эл, КарачаевоЧеркесской Республике, Республике Северная Осетия - Алания, Камчатском крае, Орловской области (темп убыли от 83,5\% до 96,2\%), смертности - в КарачаевоЧеркесской Республике, Республике Северная Осетия - Алания, Республике Марий Эл, Орловской области (темп убыли от 86,0 \% до 94,0 \%).

В целом по Российской Федерации в сравнении с 2012 г. количество дополнительных вероятностно обусловленных качеством питьевой воды случаев заболеваний всего населения снизилось на 20,8 \%, случаев смертности - на 17,1 \%.

Среди приоритетных опасных факторов питьевых вод продолжают оставаться несоответствие воды требованиям по санитарно-химическим (наличие в воде в концентрациях, превышающих гигиенические нормативы, хлора и хлорорганических соединений, железа, марганца, стронция, бора и других соединений) и микробиологическим показателям.

Количество вероятностно обусловленных загрязнением почв случаев нарушений здоровья продолжает снижаться - темп убыли дополнительных ассоциированных случаев заболеваний по сравнению с 2012 г. составил 50,0\%. При этом микробное и паразитарное загрязнение почв, а также присутствие в почвах селитебных зон тяжелых металлов, в том числе свинца, кадмия, ртути и др. соединений, продолжают оставаться приоритетными факторами опасности для здоровья населения.

Установленные приоритетные санитарно-эпидемиологические факторы окружающей среды оказывают свое воздействие на фоне совокупного модифицирующего (потенцирующего или сдерживающего) влияния комплекса социальноэкономических, демографических, погодно-климатических детерминант и показателей образа жизни населения. Уровень влияния данных показателей имеет региональную специфику, при этом в целом по Российской Федерации сохраняющиеся положительные тренды повышения качества и уровня жизни населения страны, в том числе в результате реализации федеральных и национальных проектов, могут привести к снижению вероятностно обусловленных качеством среды обитания потерь здоровья населения.

В 2020 году значительно возросло влияние на формирование здоровья населения группы факторов обеспеченности населения медицинской помощью (табл. 38), ключевых социально значимых факторов.

Таблица 38

Приоритетные факторы обеспеченности населения медицинской помощью, формирующие негативные тенденции в состоянии здоровья населения, 2020 год

\begin{tabular}{|c|c|c|}
\hline $\begin{array}{c}\text { Группа } \\
\text { факторов }\end{array}$ & $\begin{array}{c}\text { Основные медико-демографические показатели и показатели } \\
\text { заболеваемости, на которые влияют факторы обеспеченности } \\
\text { населения медицинской помощью }\end{array}$ & $\begin{array}{c}\text { Численность } \\
\text { населения, } \\
\text { подверженного } \\
\text { воздействию } \\
\text { факторов }\end{array}$ \\
\hline $\begin{array}{c}\text { Обеспеченность } \\
\text { медицинскими } \\
\text { кадрами }\end{array}$ & \multirow{3}{*}{$\begin{array}{c}\text { Заболеваемость всего населения, заболеваемость детей, взрослых. } \\
\text { Болезни органов дыхания (все население, дети). Болезни } \\
\text { эндокринной системы. Инфекционные и паразитарные болезни (все } \\
\text { население, дети), болезни органов пищеварения всего населения, в } \\
\text { том числе у детей, болезней мочеполовой системы, болезни системы } \\
\text { кровообращения. Заболеваемость с временной утратой } \\
\text { трудоспособности. Врожденные аномалии (дети). Травмы и } \\
\text { отравления (все население). Распространенность злокачественных } \\
\text { новообразований. Смертность всего населения, в том числе } \\
\text { смертность внешних причин, обусловленная алкоголем, смертность } \\
\text { от болезней системы кровообращения, злокачественных } \\
\text { новообразований, младенческая смертность }\end{array}$} & \multirow{3}{*}{$\begin{array}{c}81,4 \text { млн человек, } \\
43 \text { субъекта } \\
\text { Российской } \\
\text { Федерации }\end{array}$} \\
\hline $\begin{array}{c}\text { Расходы } \\
\text { здравоохранения }\end{array}$ & & \\
\hline $\begin{array}{c}\text { Обеспеченность } \\
\text { медицинскими } \\
\text { койками }\end{array}$ & & \\
\hline
\end{tabular}


У более 81,4 млн человек $(55,8 \%$ населения) на состояние здоровья влияют факторы обеспеченности медицинскими кадрами, коечным фондом и в целом расходов на здравоохранение. По степени влияния наибольшее значение имеют факторы, связанные с обеспеченностью медицинскими кадрами, далее - расходы на здравоохранение, затем - обеспеченность медицинскими койками.

На рис. 94 приведена карта, которая иллюстрирует уровень влияния интегрального показателя, характеризующего факторы обеспеченности медицинской помощью на состояние здоровья населения в субъектах Российской Федерации. Максимальный ранг соответствует большему влиянию, минимальный ранг - меньшему.

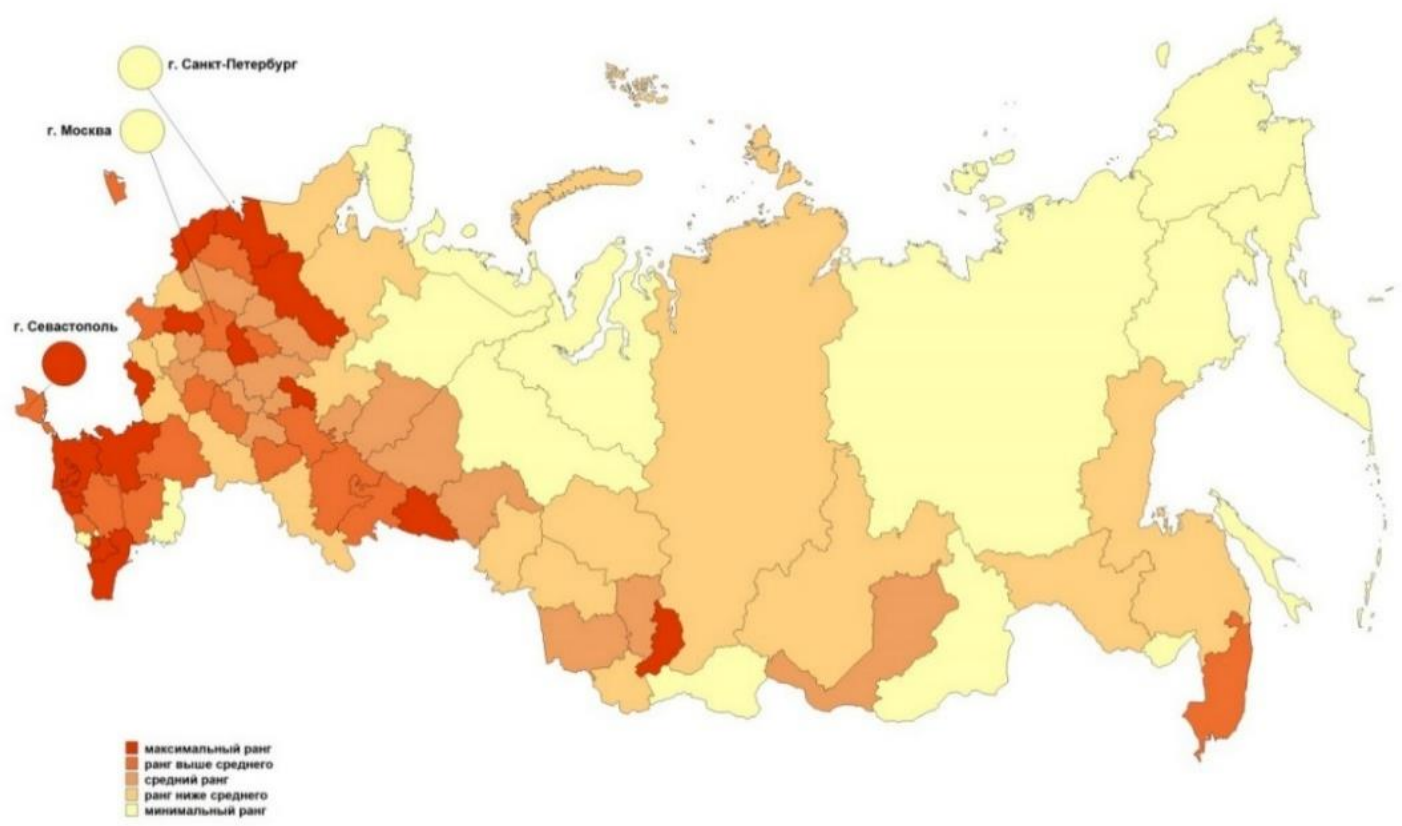

Рис. 94. Ранжирование субъектов Российской Федерации по степени влияния на состояние здоровья населения факторов медицинского обеспечения, 2020 год

По результатам анализа среднедушевого потребления пищевой продукции населением Российской Федерации с 2011 года отмечается положительная динамика в потреблении овощей и фруктов, молочных продуктов и рыбы, однако потребление пищевых продуктов основных групп остается на недостаточном уровне и не вполне соответствует современным принципам здорового питания (рекомендуемым рациональным нормам), особенно по картофелю (-41\%), фруктам и ягодам (-20\%), молоку и молочным продуктам (-26\%), а также овощам и бахчевым $(-17 \%)$. Потребление мяса и мясных продуктов, а также сахара и кондитерских изделий ежегодно растет, и в 2019 году потребление мяса превысило рекомендуемые нормы на 26 \% (рис. 95).

Продукты растительного происхождения (зерновые, бобовые, овощи и фрукты) составляют основу рациона и являются источниками усвояемых углеводов, белка, пищевых волокон, витаминов и микроэлементов. Использование в питании достаточного количества зерновых продуктов, овощей и фруктов ассоциируется со снижением риска смертности от сердечно-сосудистых заболеваний, ишемической болезни сердца и новообразований. В структуре питания населения Российской Федерации сохраняется дисбаланс в потреблении продуктов растительного и животного происхождения. Доля растительной пищи составляет 33,7\% против рекомендуемой $60 \%$ (рис. 96). 


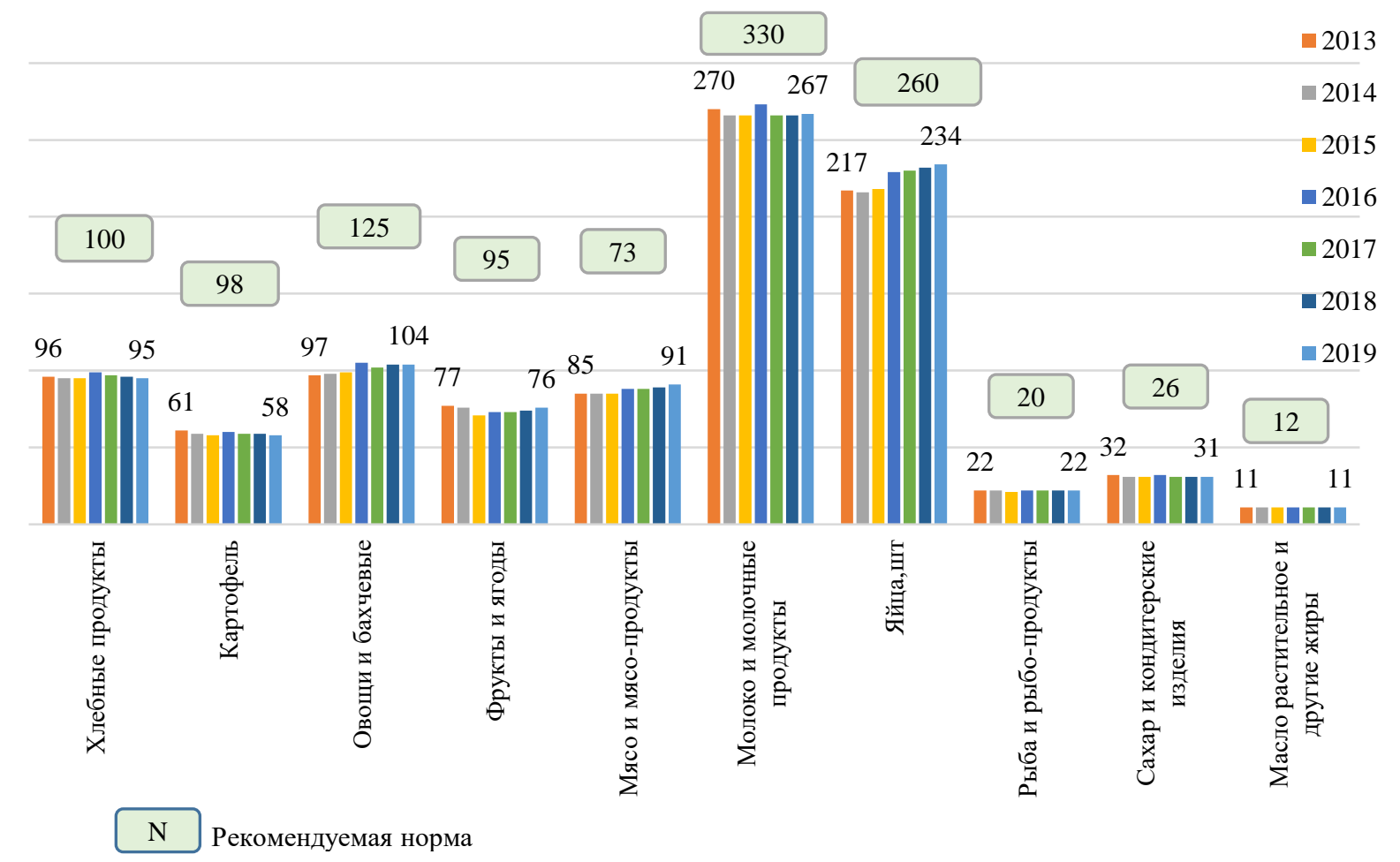

Рис. 95. Динамика среднедушевого потребления основных групп продуктов питания населением Российской Федерации, 2013-2019 гг., кг/год

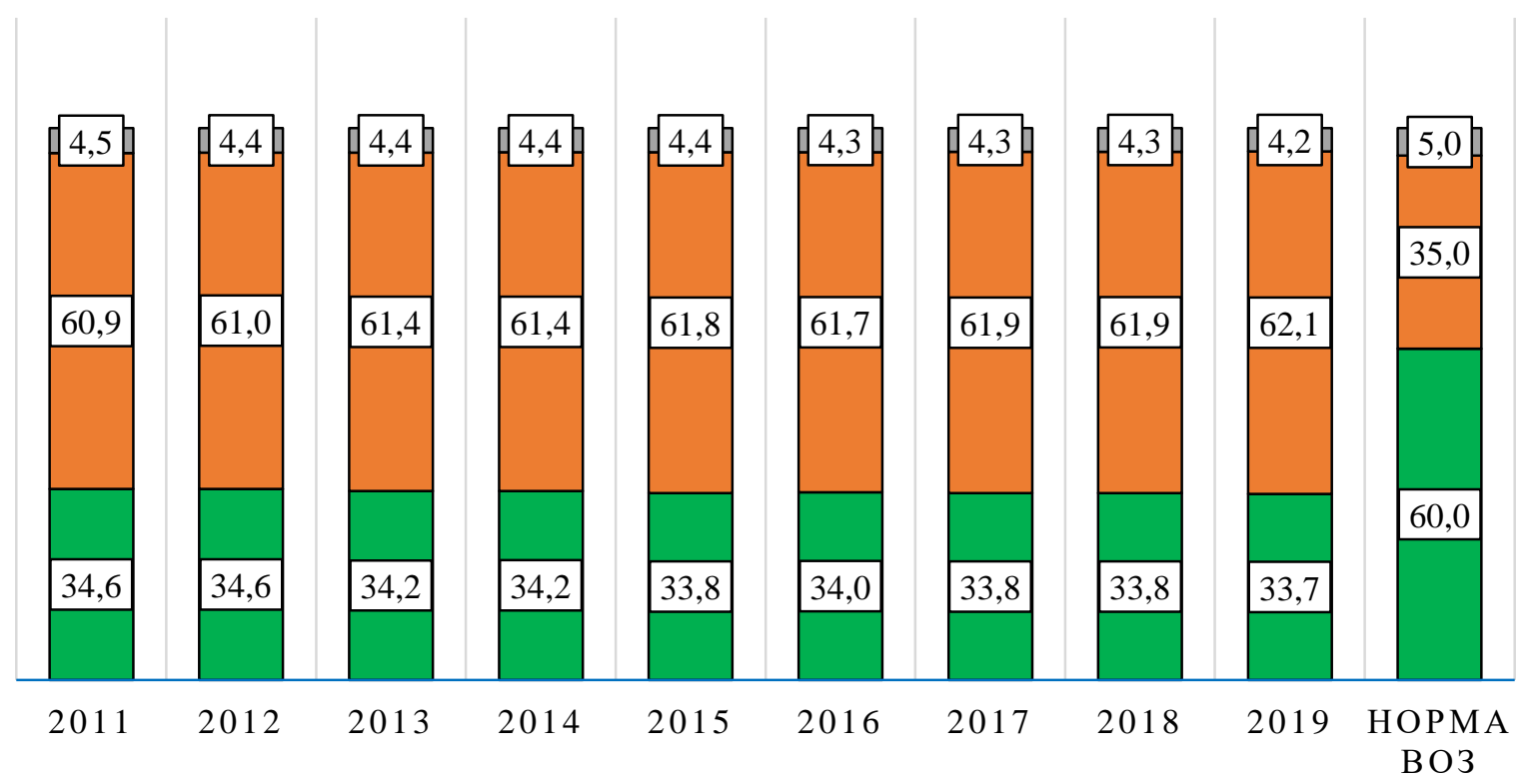

口Растительные продукты $\quad$ 口Животные продукты $\quad$ 口Жиры и сахара

Рис. 96. Структура потребления основных групп пищевых продуктов в динамике, 2011-2019 гг.

Дефицит потребления овощей и фруктов более выражен в субъектах РФ, находящихся в зоне холодного климата (среднее отклонение $-38,1 \%$ ). В то же время превышение норм потребления сахара и кондитерских изделий - в субъектах, расположенных в зоне с теплым климатом (среднее превышение 43,6\%), а мясной продукции - в зоне с умеренным климатом (среднее превышение 24,2 \%) Низкое потребление овощей отмечается в II географической зоне в таких субъектах, как 
Тамбовская $(-41,7 \%)$, Новгородская $(-38,1 \%)$, Псковская $(-38,4 \%)$ области, республиках Марий Эл $(-38,1$ \%), Саха (Якутия) $(-48,6$ \%).

Основной вклад в энергетическую ценность рациона питания населения РФ обуславливают хлеб и хлебобулочные изделия (35 \%), мясо и мясные продукты (18 \%), молоко и молочные продукты (12\%), сахар и кондитерские изделия (12\%), рис. 97.

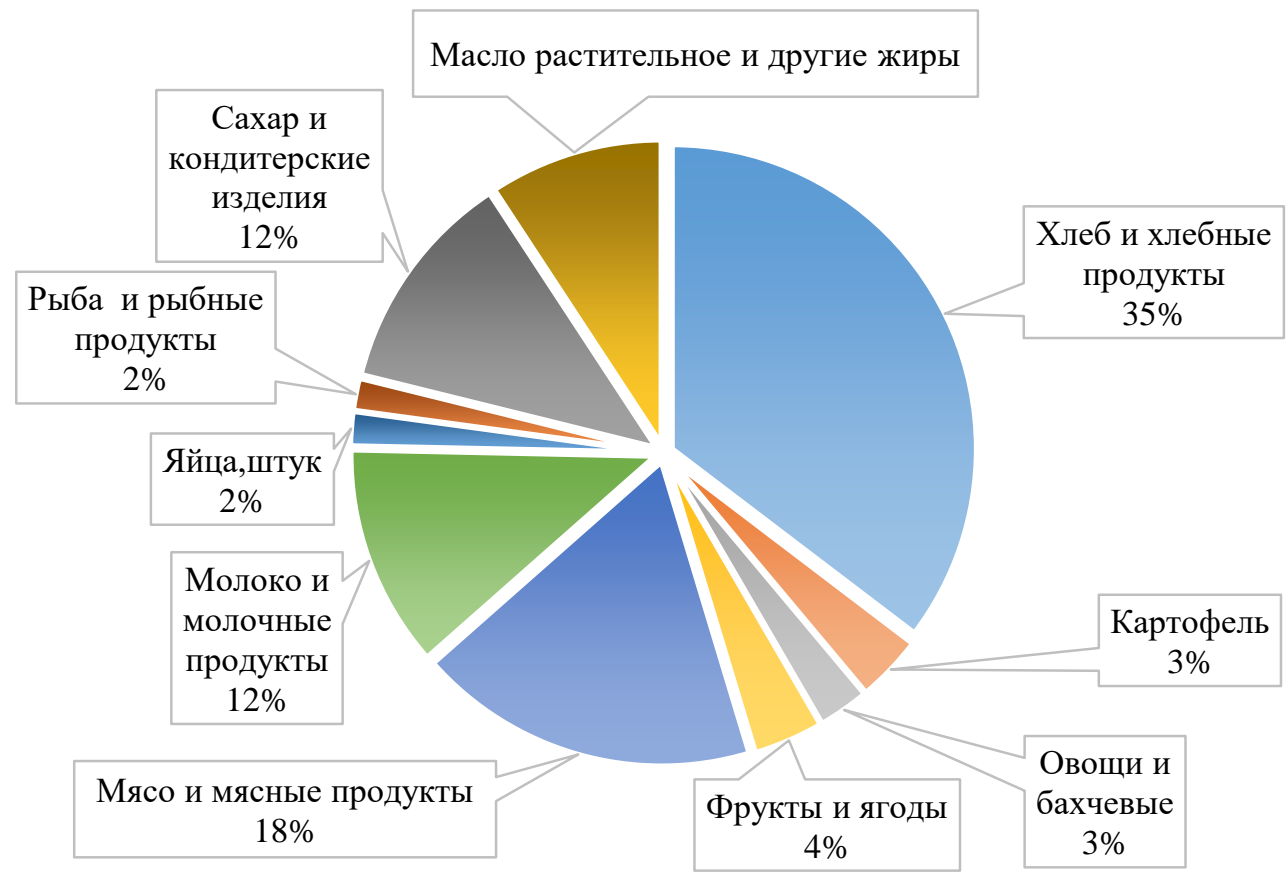

Рис. 97. Вклад в энергетическую ценность рациона питания пищевых продуктов, \%

Необходимо отметить, что потребление жира населением России сохраняется на высоком уровне и 2019 году превышает рекомендуемые нормы на 19,6 \% (в 2018 г. на $19,1 \%)$, при этом избыточное потребление жира наблюдается у 97,4\% населения субъектов Российской Федерации (в 2018 г. - 96,3 \%). Уровень потребления углеводов в рационах питания населения большинства субъектов Российской Федерации находится ниже среднего рекомендуемого значения у 97,0 \% населения (в 2018 г. - 93,3\%). Недостаток углеводов в питании обусловлен прежде всего низким потреблением картофеля, овощей и фруктов.

По оценкам ВО3, широкое распространение заболеваний, риски возникновения которых напрямую связаны с нарушением питания (заболевания сердечно-сосудистой системы, сахарный диабет, ожирение, некоторые злокачественные новообразования и др.), пониженный уровень физической активности населения и употребление табака представляют серьезную медико-социальную и экономическую проблему, обусловленную неуклонным ростом числа больных, высокой частотой, тяжестью и прогрессированием различных осложнений, снижением продолжительности жизни, что влечет за собой увеличение прямых и косвенных затрат на здравоохранение и рост потребности в дорогостоящей высокотехнологичной медицинской помощи, которая, как показывает мировая практика, не может в полной мере обеспечить оздоровление населения.

Одним из механизмов достижения увеличения ожидаемой продолжительности здоровой жизни, снижения смертности населения может являться оптимизация структуры питания, обеспечивающая ликвидацию микронутриентной недостаточности, снижение потребления критически значимых для здоровья населения пищевых веществ путем увеличения потребления овощей и фруктов. Значимый рост показателя ОПЖ 
может быть обусловлен сбалансированным питанием и нормализацией уровней потребления до рекомендуемых Министерством здравоохранения Российской Федерации таких групп продуктов, как овощи и фрукты (+65 дней), фрукты и ягоды (+23,3 дня) и др.

\subsection{2. Анализ состояния здоровья работающего населения и профессиональной заболеваемости}

Состояние условий труда - основная причина, оказывающая наиболее существенное влияние на состояние профессионального здоровья работников, которое, в свою очередь, является важным социальным индикатором, от которого зависит трудовой потенциал страны.

Оценка интенсивности и длительности воздействия на работников факторов трудового процесса и выработка механизмов управления для снижения их неблагоприятного воздействия до уровней приемлемых рисков позволяет сохранять профессиональное здоровье работающих, что приведет к экономическому подъему государства.

\section{Условия труда работающих}

В период с 2013 по 2020 г. произошло сокращение на промышленных предприятиях рабочих мест, не соответствующих санитарно-гигиеническим требованиям по уровню воздействия на организм работников шума, вибрации, освещенности, параметров микроклимата и электромагнитных полей (рис. 98).

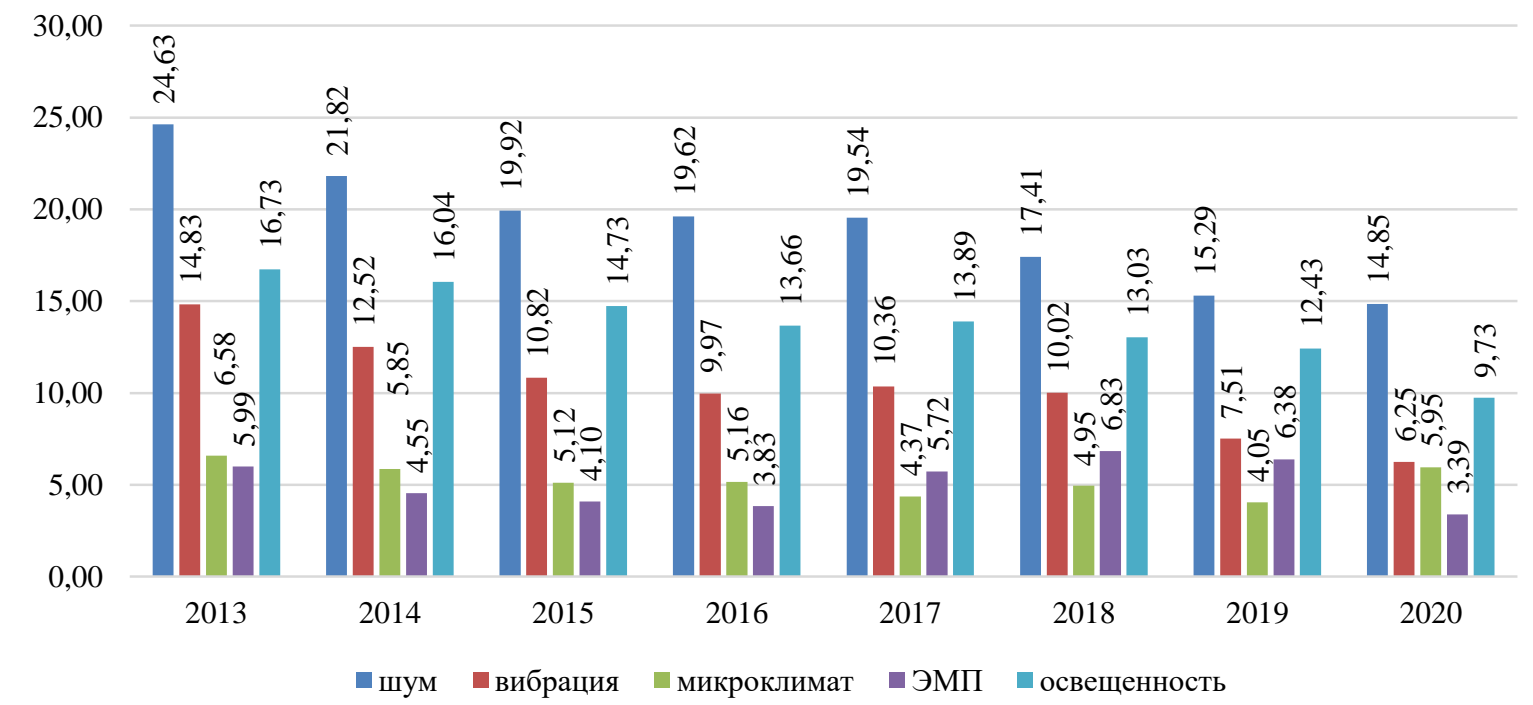

Рис. 98. Удельный вес на промышленных предприятиях рабочих мест, не соответствующих гигиеническим нормативам по отдельным физическим факторам, \%

За период с 2011 по 2020 год наблюдается устойчивая тенденция по снижению количества обследованных объектов (всего), по сравнению с 2011 годом снижение составило 83,83 \% (табл. 39). В то же время увеличилась доля обследований объектов с применением лабораторных и инструментальных методов исследований. Показатель удельного веса таких обследований в 2020 году составил 65,94 \%, темп прироста с 2011 года составил $29,09 \%$.

Удельный вес неудовлетворительных проб на пары и газы по веществам 1 и 2 класса опасности по сравнению с 2011 годом сократился на 62,64 \%. Показатель по пробам на пыль и аэрозоли по веществам 1 и 2 класса опасности за аналогичный период сократился на $88,11 \%$. 
Государственный доклад «О состоянии санитарно-эпидемиологического благополучия населения в Российской Федерации в 2020 году»

Таблица 39

Результаты контроля состояния воздушной среды рабочей зоны

\begin{tabular}{|c|c|c|c|c|c|c|c|c|c|c|c|c|}
\hline \multicolumn{2}{|c|}{ Показатели } & 2011 & 2012 & 2013 & 2014 & 2015 & 2016 & 2017 & 2018 & 2019 & 2020 & \begin{tabular}{|c|} 
Темп \\
прироста \\
к2011 г., \%
\end{tabular} \\
\hline \multicolumn{2}{|c|}{$\begin{array}{l}\text { Число обследован- } \\
\text { ных объектов, всего }\end{array}$} & 32200 & 35170 & 31665 & 27455 & 24303 & 17553 & 17952 & 17372 & 21982 & 5206 & $-83,83$ \\
\hline \multicolumn{2}{|c|}{\begin{tabular}{|l|} 
Удельный вес \\
обследований \\
объектов с примене- \\
нием лабораторных \\
и инструментальных \\
исследований, \% \\
\end{tabular}} & 51,08 & 59,9 & 60,5 & 61,6 & 63,4 & 60,9 & 62,8 & 62,54 & 67,3 & 65,94 & $+29,09$ \\
\hline \multicolumn{2}{|c|}{\begin{tabular}{|l|} 
Число \\
исследованных \\
проб на пары и газы \\
\end{tabular}} & 507041 & 531293 & 539666 & 496075 & 454784 & 453039 & 425447 & 422307 & 406452 & 237263 & $-53,21$ \\
\hline \multicolumn{2}{|c|}{$\begin{array}{l}\text { - их них превышает } \\
\text { ПДК, \% }\end{array}$} & 2,86 & 2,6 & 2,6 & 2,0 & 1,9 & 2,1 & 2,2 & 1,9 & 1,7 & 1,9 & $-33,57$ \\
\hline \multicolumn{2}{|c|}{$\begin{array}{l}\text { Число исследован- } \\
\text { ных проб на пыль и } \\
\text { аэрозоли }\end{array}$} & 383085 & 393186 & 370890 & 325678 & 300193 & 277016 & 262675 & 269007 & 249542 & 161714 & $-57,79$ \\
\hline \multicolumn{2}{|c|}{$\begin{array}{l}\text { - их них превышает } \\
\text { ПДК, \% }\end{array}$} & 8,84 & 7,4 & 7,1 & 6,5 & 6,6 & 6,5 & 5,8 & 4,8 & 3,6 & 3,45 & $-60,98$ \\
\hline \multirow{2}{*}{\begin{tabular}{|l|} 
Доля проб \\
веществ 1 и 2 \\
класса опаснос- \\
ти с превыше- \\
нием ПДК, \%
\end{tabular}} & \begin{tabular}{|l|} 
- пары и \\
газы \\
\end{tabular} & 3,8 & 3,5 & 2,9 & 2,8 & 2,96 & 3,7 & 3,7 & 3,3 & 1,1 & 1,42 & $-62,64$ \\
\hline & $\begin{array}{l}\text { - пыль и } \\
\text { аэрозо- } \\
\text { ли }\end{array}$ & 7,9 & 6,7 & 6,6 & 6,6 & 7,4 & 8,5 & 6,7 & 5,3 & 3,1 & 0,94 & $-88,11$ \\
\hline
\end{tabular}

Наиболее неблагоприятные условия труда, которые представляют самый высокий риск утраты профессиональной трудоспособности, характерны для предприятий по добыче полезных ископаемых, металлургии, машиностроения и судостроения, по производству строительных материалов, стройиндустрии, сельского хозяйства, транспорта.

\section{Профессиональная заболеваемость}

Уровень профессиональной заболеваемости в Российской Федерации в 2020 г. по сравнению с 2011 г. снизился и составил 0,78 на 10000 работников $(2019$ г. $-1,03,2011$ г. $-1,92)$ (рис. 99).

2,5

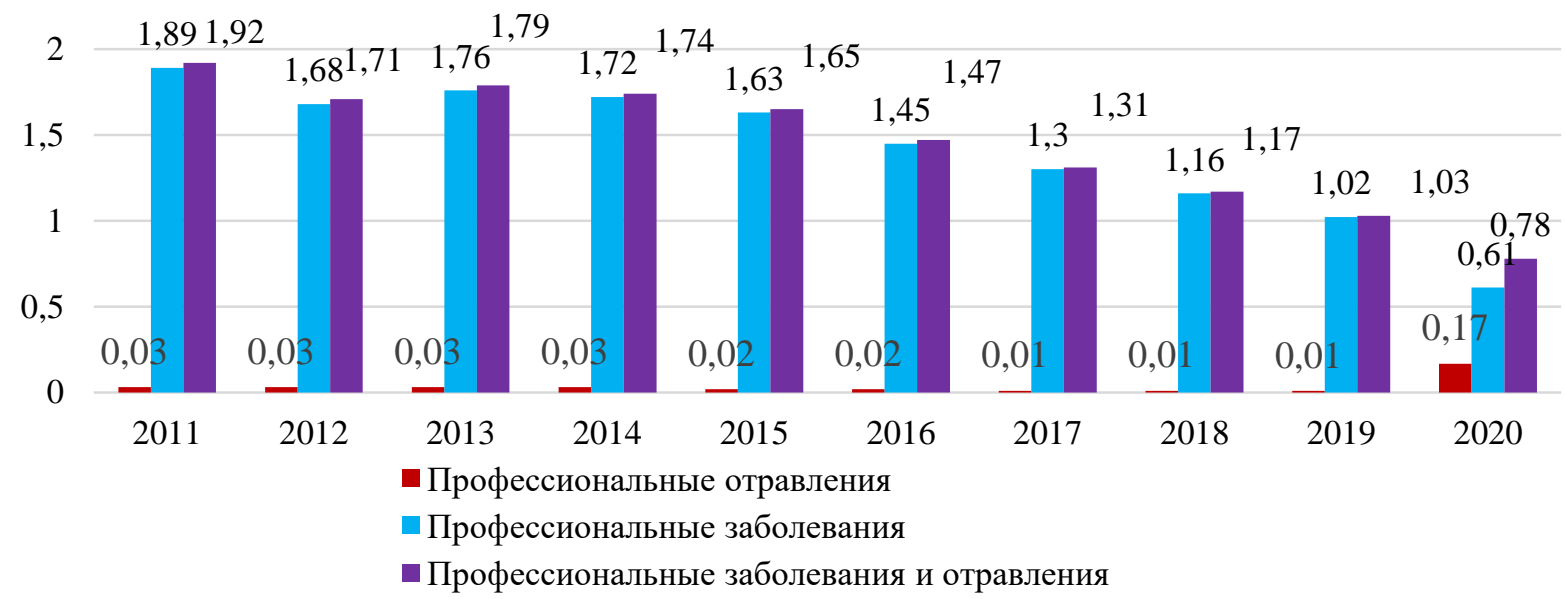

Рис. 99. Показатели профессиональной заболеваемости, 2011-2020 гг., случаев на 10 тыс. работников 
В 2020 году уровень хронической профессиональной патологии выше уровня острой патологии, при этом соотношение острой и хронической профессиональной заболеваемости изменилось из-за пандемии, связанной с COVID-19, удельный вес острых профессиональных заболеваний и отравлений в 2020 году составил 21,4 \% (729 случаев). Число смертельных случаев как исход острой профессиональной патологии в 2020 г. составило 606 случаев, что выше значения 2019 года (9 случаев) на 597 случаев за счет случаев преждевременной смети, связанных с COVID-19 (рис. 100).

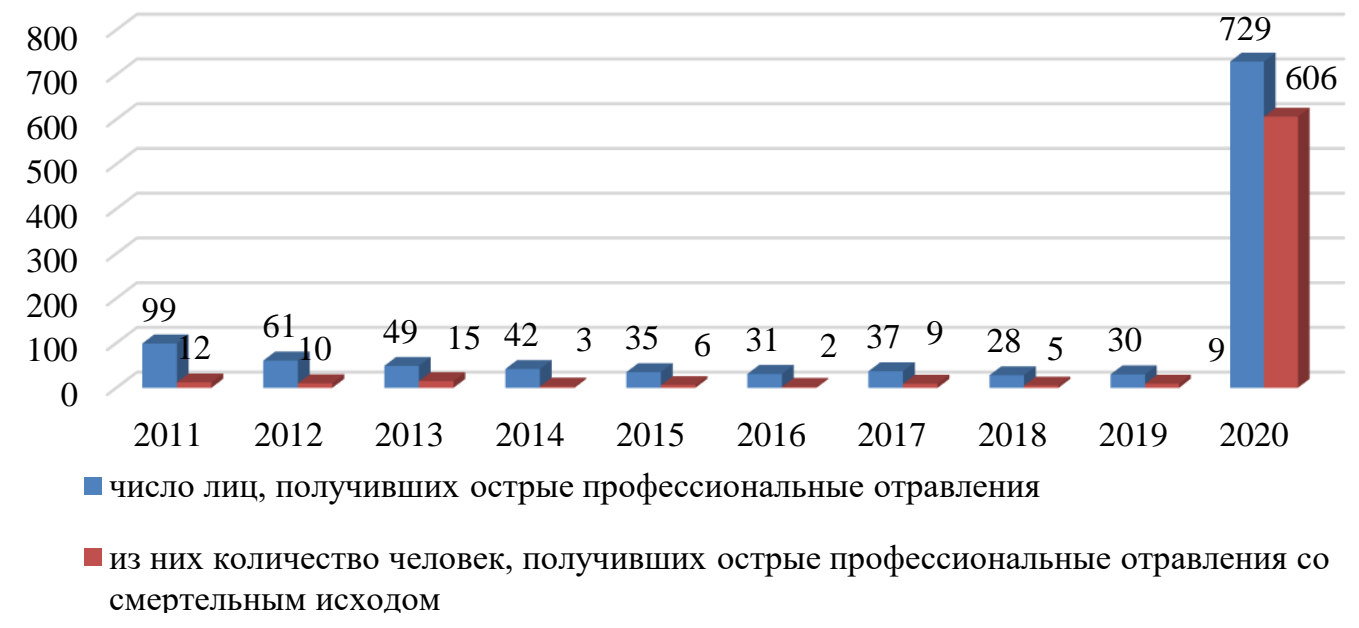

Рис. 100. Число смертельных случаев как исход острой профессиональной патологии, 2011-2020 гг.

В 2020 г. продолжилось снижение одного из показателей тяжести течения профессионального заболевания - удельного веса пострадавших с исходом в инвалидность вследствие приобретенного профессионального заболевания. Число больных с профессиональной патологией, получивших инвалидность в 2020 г., составило 209 случаев, что ниже 2011 года на 85,6 \% (2019 г. - 252 случая) (рис. 101).

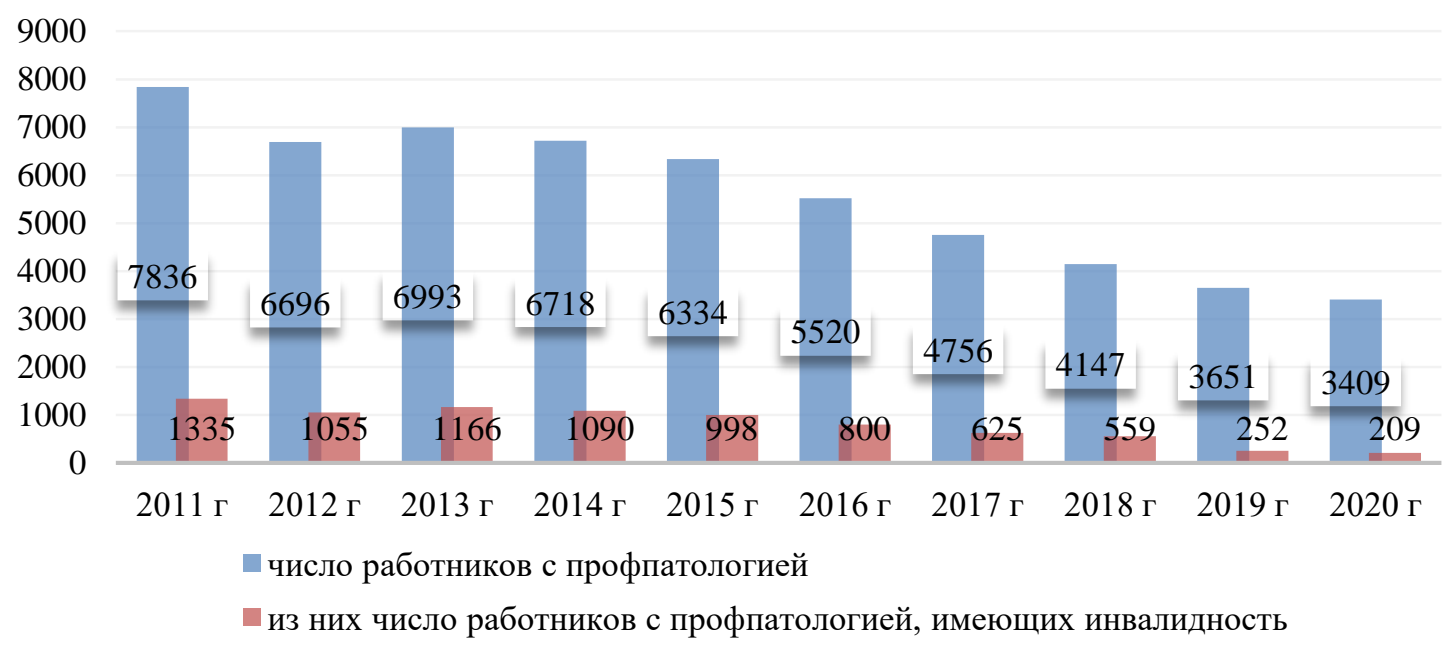

Рис. 101. Распределение работников с профессиональной патологией с исходом в инвалидность, 2010-2020 гг.

В 2020 г. из 3409 случаев профессиональных заболеваний 718 случаев впервые выявленных профессиональных заболеваний зарегистрировано у женщин, что составило 21,06 \% от общего числа всех профзаболеваний (отравлений). Хронические формы профессиональных заболеваний (отравлений) зарегистрированы у 287 работниц (40,0\% от всех впервые выявленных профзаболеваний у женщин в 2020 году), у 49 выявлено 
Государственный доклад «О состоянии санитарно-эпидемиологического благополучия населения в Российской Федерации в 2020 году»

2 и более профессиональных заболевания. Острые профессиональные заболевания (отравления) установлены у 431 женщины $(60,0 \%$ от всех впервые выявленных профзаболеваний у женщин в 2020 году), в 348 случаях - со смертельным исходом (80,7 \% от всех впервые выявленных острых профзаболеваний у женщин в 2020 году). У 32 женщин была установлена инвалидность вследствие профессионального заболевания или отравления, что составило 4,5 \% от общего числа женщин с впервые установленным диагнозом профессионального заболевания в 2020 году.

В структуре профессиональной патологии в зависимости от воздействующего вредного производственного фактора по-прежнему на первом месте остается профессиональная патология вследствие чрезмерного воздействия на организм работников физических факторов производственных процессов. При этом доля таких профзаболеваний в 2020 г. снизилась и составила 42,33\% всех впервые выявленных профессиональных заболеваний.

Учитывая ситуацию с пандемией, связанной с COVID-19, впервые за 10 лет второе ранговое место в структуре профессиональной патологии в зависимости от воздействующего вредного производственного фактора заняли заболевания, связанные с действием биологических факторов, - 20,19\%. Третье - профессиональные заболевания, связанные с воздействием физических перегрузок и перенапряжения отдельных органов и систем, $-20,17 \%$. Четвертое и пятое места соответственно - за профессиональными заболеваниями от воздействия промышленных аэрозолей $(10,91 \%)$ и заболеваниями (интоксикациями), вызванными химическими веществами $(4,7 \%)$. Доля прочих вредных производственных факторов составила 1,7 \% (рис. 102).

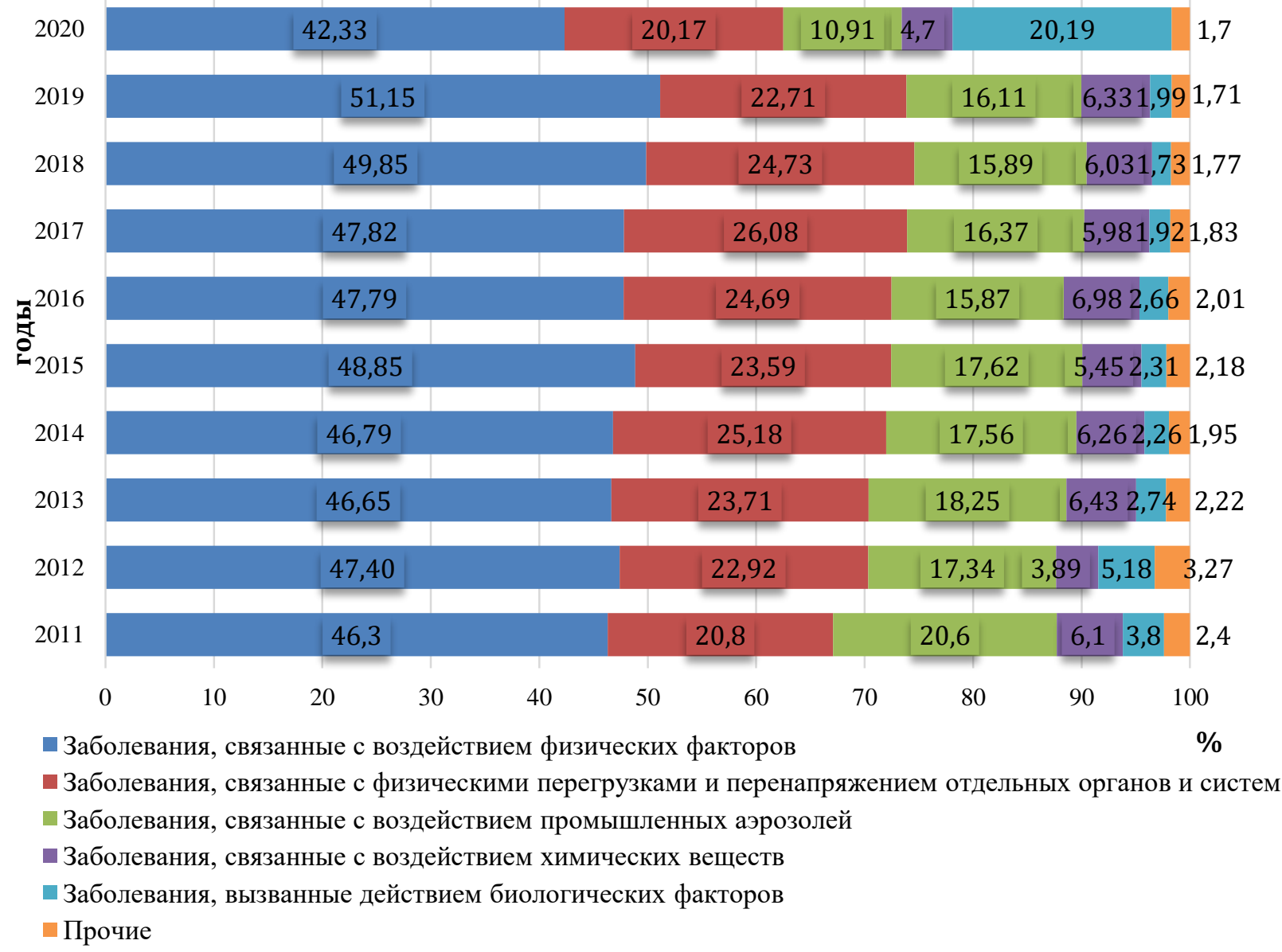

Рис. 102. Структура профессиональной патологии в зависимости от воздействующих факторов трудового процесса, 2011-2020 гг., \% 
Распределение по основным нозологическим формам в группе профессиональных заболеваний, обусловленных воздействием физических факторов трудового процесса, в 2020 г. не претерпело значительных изменений: превалирует нейросенсорная тугоухость - 70,56\% от количества всех заболеваний в группе, второе ранговое место занимает вибрационная болезнь - 29,43\%. На долю прочей патологии в рассматриваемой группе приходится $0,01 \%$ (рис. 103).

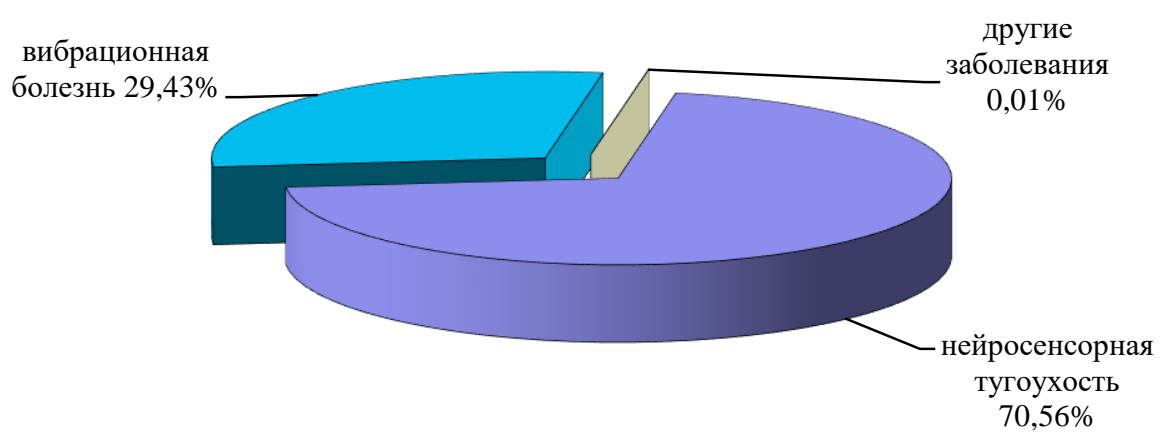

Рис. 103. Структура основных нозологических форм профессиональной патологии вследствие воздействия физических факторов производственного процесса, 2020 г., \%

В группе профессиональных заболеваний, обусловленных воздействием биологических факторов, в 2020 г. первое ранговое место занимают заболевания, вызванные новой короновирусной инфекцией, на их долю приходится 92,7\% от количества всех заболеваний в данной группе, второе ранговое место занимает туберкулез - 6,1\%, третье место и четвертое место - бруцеллёз и клещевой энцефалит (1,1\% и $0,2 \%$ соответственно) (рис. 104).

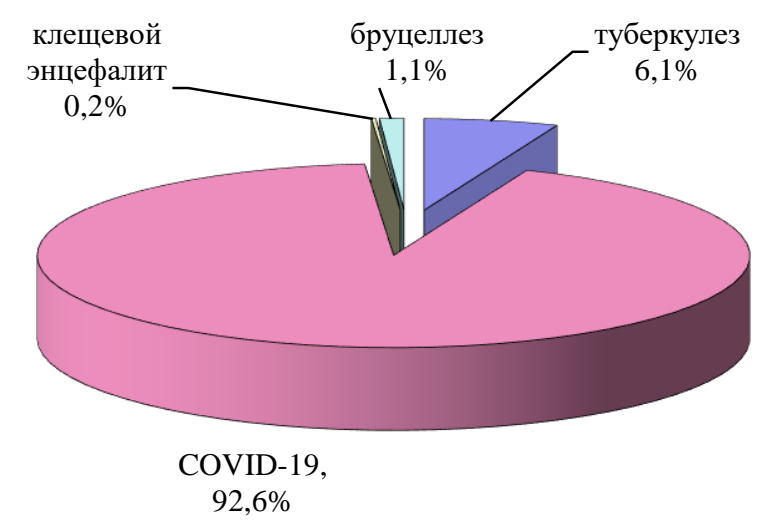

Рис. 104. Структура основных нозологических форм профессиональной патологии вследствие воздействия биологических факторов производственного процесса, 2020 г., \%

Основная доля профессиональной патологии вследствие физических перегрузок и перенапряжения отдельных органов и систем в 2020 г. принадлежит моно-, полинейропатиям - 57,0 \%. На долю радикулопатий различной локализации (поясничнокрестцовые, шейно-плечевые и др.) приходится $26,1 \%$ от общего числа заболеваний в данной группе, периартрозов и деформирующих остеоартрозов - 16,6\%, прочих заболеваний в группе $-0,3 \%$ (рис. 105). 


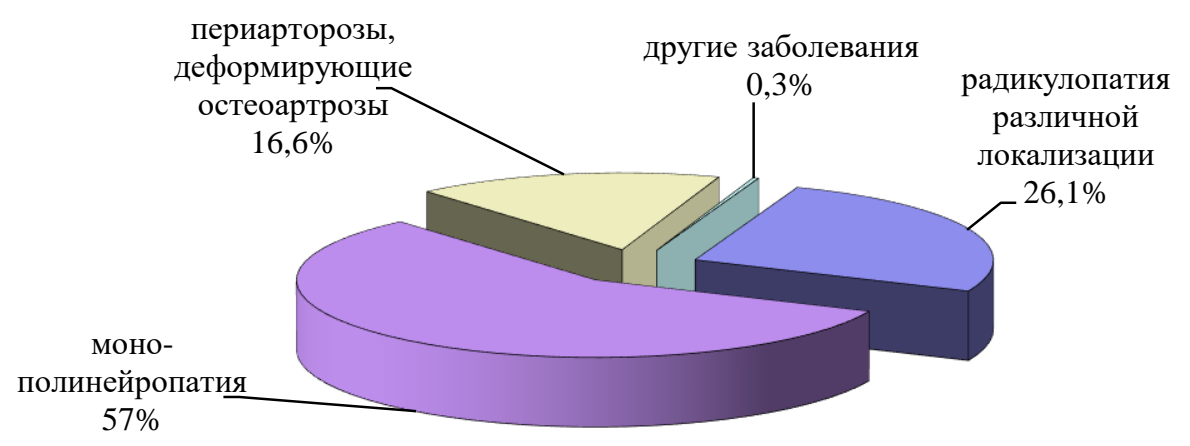

Рис. 105. Структура основных нозологических форм профессиональной патологии вследствие физических перегрузок и перенапряжения отдельных органов и систем, 2020 г., \%

Хронические пылевые бронхиты в группе профессиональных заболеваний, вызванных воздействием на организм работников промышленных аэрозолей, составляют 63,6\%. На долю пневмокониоза (силикоз) вследствие воздействия пыли, содержащей кремний, приходится 23,3\%, а хронических обструктивных (астматических) бронхитов - 12,6\%. Удельный вес других заболеваний в группе $-0,5 \%$ (рис. 106).

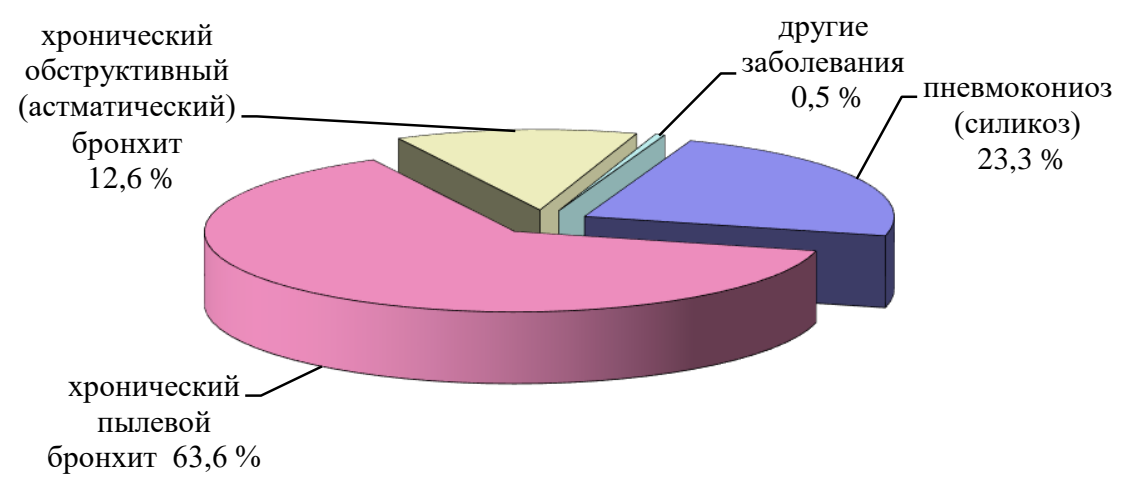

Рис. 106. Структура основных нозологических форм профессиональной патологии вследствие воздействия промышленных аэрозолей, 2020 г., \%

Из обширного перечня профессиональной патологии вследствие воздействия вредных химических факторов производства на долю флюороза приходится 55,7 \% от всех заболеваний в данной группе, хронических респираторных состояний $-37,1 \%$, хронического обструктивного (астматического) бронхита $-7,1 \%$, других заболеваний $0,1 \%$ (рис. 107).

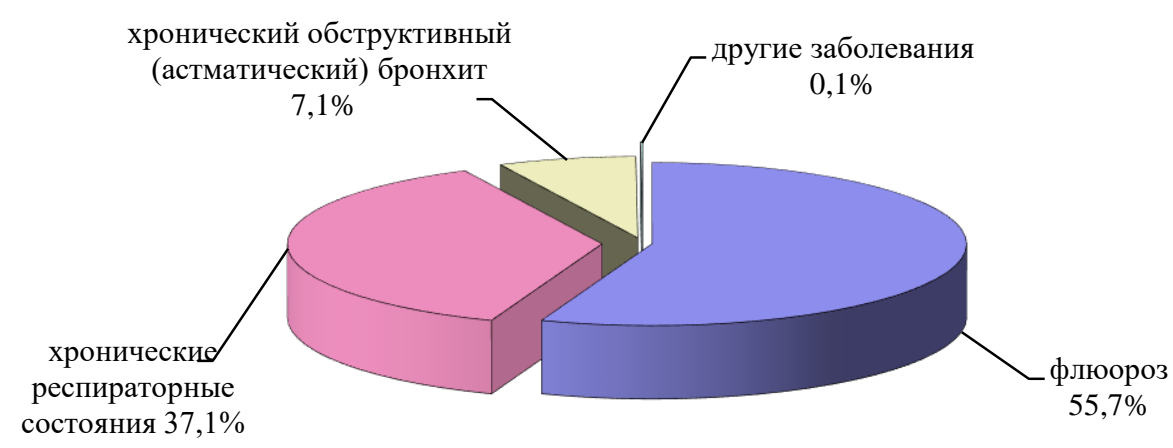

Рис. 107. Структура основных нозологических форм профессиональной патологии вследствие воздействия химических веществ, 2020 г., \% 
Показатели профессиональной заболеваемости по видам экономической деятельности в соответствии с ОКВЭД ОК 029-2001 (КДЕС Ред.1), который использовался для распределения профессиональной заболеваемости с 2006 по 2016 год, не могут быть сопоставлены с показателями профзаболеваемости по видам экономической деятельности в соответствии с новой редакцией ОКВЭД ОК 029-2014 (КДЕС Ред.2), что не позволяет провести углубленную ретроспективную оценку профессиональной заболеваемости как по отдельным видам экономической деятельности, так и в целом по Российской Федерации.

В 2020 году у работников предприятий по добыче полезных ископаемых отмечен наибольший удельный вес впервые зарегистрированной профессиональной патологии $46,93 \%$, на долю профессиональных заболеваний среди работников обрабатывающих производств приходится 29,99\% от всех впервые зарегистрированных. Третье ранговое место приходится на долю работников предприятий транспортировки и хранения $10,75 \%$. Четвертое и пятое ранговые места принадлежат соответственно уровням профессиональной заболеваемости среди работников предприятий строительства $3,64 \%$ и предприятий сельского, лесного хозяйства, охоты, рыболовства и рыбоводства $-3,46 \%$. На долю профессиональной патологии работников предприятий и организаций остальных видов экономической деятельности приходится 5,23 \% (рис. 108).

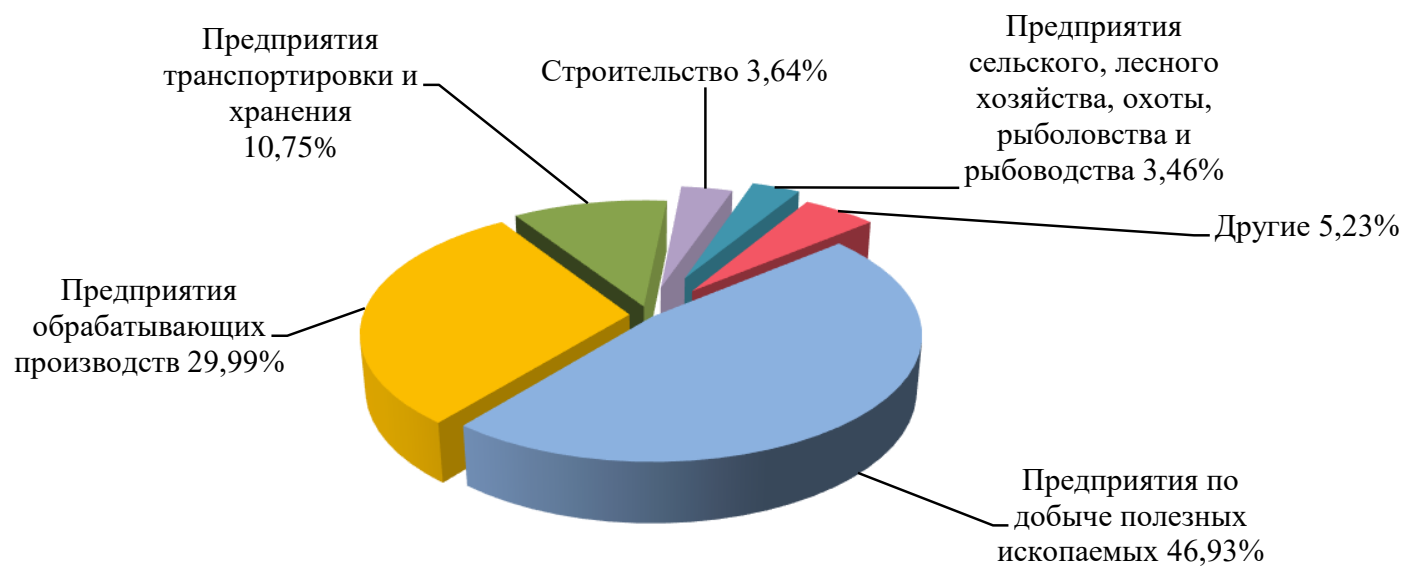

Рис. 108. Структура профессиональной заболеваемости по основным видам экономической деятельности, 2020 г., \%

Первое ранговое место среди показателей профессиональной заболеваемости на 10 тыс. работающих по видам экономической деятельности в 2019 г. занимают предприятия по добыче полезных ископаемых - 21,15, второе - обрабатывающие производства - 2,18, третье - предприятия транспортировки и хранения, четвертое предприятия сельского, лесного хозяйства, охоты, рыболовства и рыбоводства - 1,66 и 1,09 соответственно.

Показатели профессиональной заболеваемости, превышающие показатель по Российской Федерации в 2020 г. (0,78 на 10000 работающих), как и в предыдущие годы, отмечены в Республике Хакасия (7,21 на 10000 работающих), Кемеровской области (6,75 на 10000 работающих), Республике Коми (4,51 на 10000 работающих), Мурманской области (2,96 на 10000 работающих), Чукотском автономном округе (2,78 на 10000 работающих), Иркутской области (2,11 на 10000 работающих) и ряде других территорий.

Не регистрировались в 2020 г. профессиональные заболевания (отравления) в республиках Кабардино-Балкарская, Карачаево-Черкесская и Еврейской автономной области. 
По результатам расследований случаев профессиональных заболеваний в 2020 г. установлено, что основными причинами развития острых профессиональных заболеваний (отравлений) являются профессиональный контакт с инфекционным агентом (76,08 \%), несовершенство СИЗ (11,96 \%), несовершенство технологического процесса $(3,14 \%)$.

Хроническая профессиональная патология в 2020 г. чаще всего возникала вследствие конструктивных недостатков средств труда $(45,17 \%)$, несовершенства технологических процессов $(45,04 \%$ случаев), несовершенства рабочих мест $(2,04 \%)$ и санитарно-технических установок $(1,69 \%)$ (рис. 109).

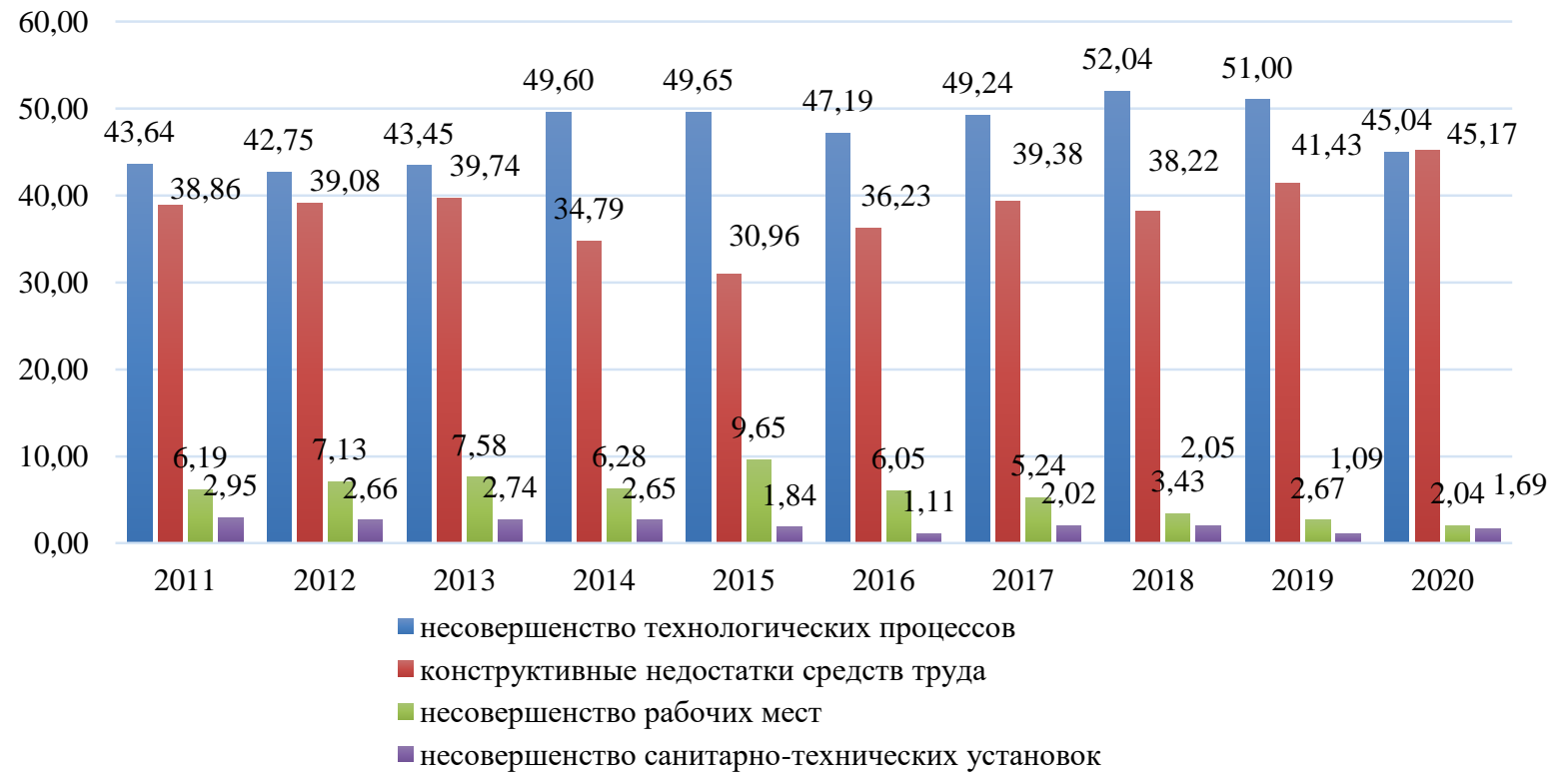

Рис. 109. Структура основных обстоятельств и условий возникновения хронических профессиональных заболеваний, 2020 г., \%

В 2020 г. структура впервые выявленной хронической профессиональной патологии у работников в период проведения периодических медицинских осмотров (ПМО) и при обращении сохраняется на протяжении трех последних лет. В 2020 году доля впервые установленных профессиональных заболеваний составила 59,31\% в период проведения ПМО составила $58,91 \%$, при активном обращении - 41,09\% (рис. 110).

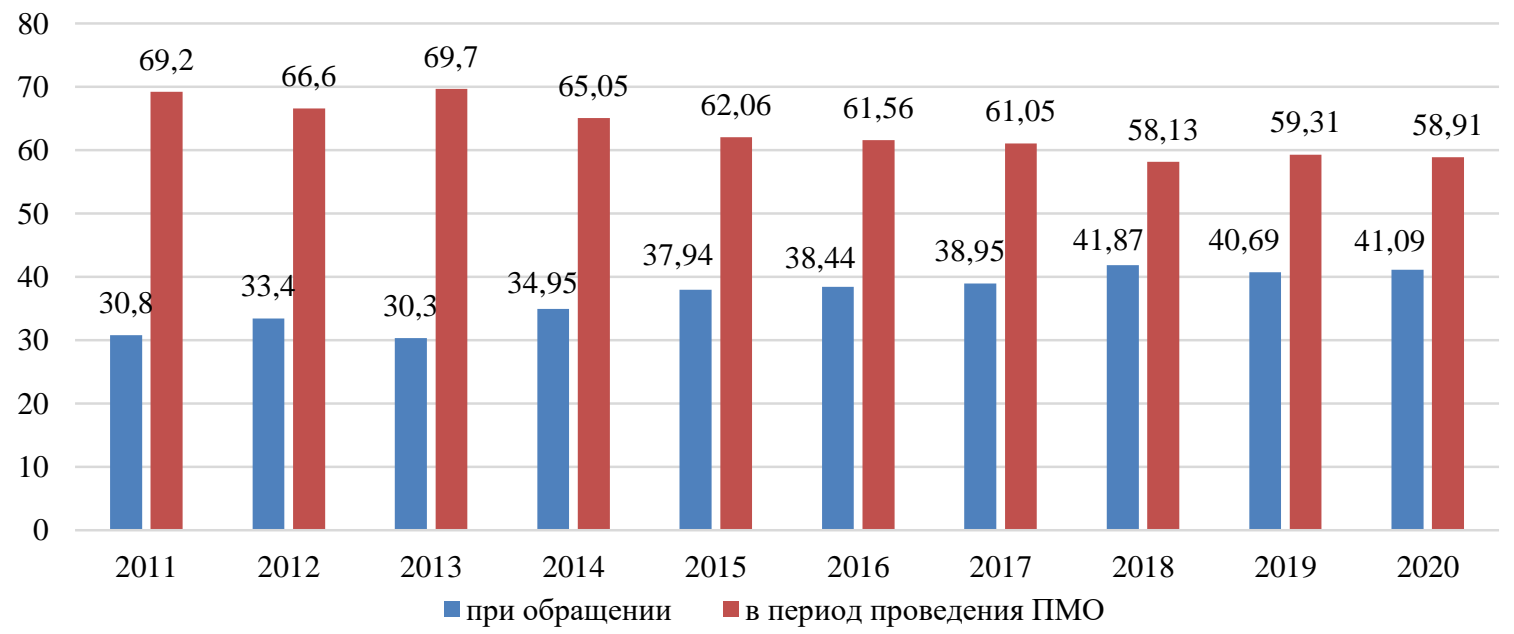

Рис. 110. Удельный вес хронической профессиональной патологии по условиям выявления, $2011-2020$ г., \% 
Уровень выявляемости хронической профессиональной патологии в зависимости от типа медицинских учреждений и их специализации в 2020 году изменился. В сравнении с 2011 г. увеличилась доля впервые выявленных профзаболеваний в ЛПУ на 4,44 \%, в НИИ - на 7,35 \%, уменьшилась доля впервые выявленных профзаболеваний в центрах профпатологии на $11,79 \%$ (рис. 111).

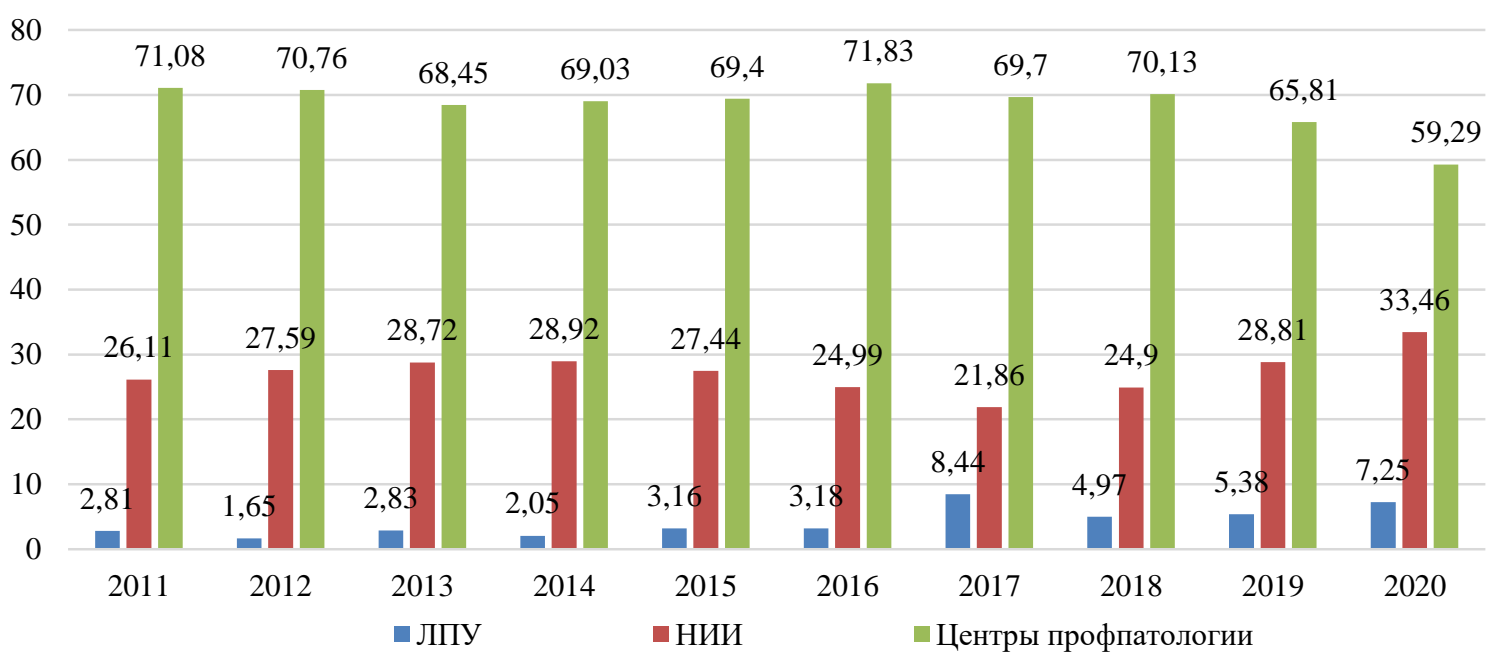

Рис. 111. Удельный вес хронической профессиональной патологии по месту выявления, $2011-2020$ г., \%

Максимальный риск возникновения профессионального заболевания проявлялся у работников-мужчин и у работниц-женщин при стаже в контакте с вредным производственным фактором от 20 до 34 лет и выше. В указанных стажевых группах доля зарегистрированных профессиональных заболеваний среди работников-мужчин составляет $40,30 \%$, среди работниц-женщин - 31,16\% от всех профессиональных заболеваний, распределенных по гендерному принципу.

В 2020 г. среди всех возрастных групп работников с впервые зарегистрированной профессиональной патологией наибольшему риску ее возникновения подвержены как работники-мужчины, так и работницы-женщины в возрасте 55-59 лет: уровень профессиональных заболеваний у мужчин в указанной возрастной категории составляет 24,66 \%, (2019 г. - 26,26\%), у женщин - 24,76\%, (2019 г. - 29,5 \%) от всех профессиональных заболеваний в распределении по половому признаку.

Наибольшему риску приобретения профессиональной патологии в зависимости от профессий подвержены мужчины, работающие горнорабочими, водителями автомобиля, машинистами экскаватора, электрослесарями подземными, машинистами горных выемочных машин. Среди женщин такому риску наиболее подвержены машинисты крана (крановщики), медицинские сестры, маляры, животноводы, шихтовщики, врачи. Доля профессиональных заболеваний работников указанных профессий от всех впервые зарегистрированных в 2012-2020 гг. в среднем составляет $40,30 \%$ и $60,73 \%$ среди мужчин и женщин соответственно.

\section{Заболеваемость с временной утратой трудоспособности}

Заболеваемость с временной утратой трудоспособности (далее - ЗВУТ) является значимым показателем качества трудового потенциала страны. Общий объем прямых и косвенных потерь валового внутреннего продукта от ЗВУТ сопоставим с общим объемом государственного финансирования национального здравоохранения. Анализ ЗВУТ проведен в период до 2019 года, поскольку значения показателя в 2020 году, определяются прежде всего COVID-19 и не могут быть сравнимы в ретроспективе. 
Отмечается снижение ЗВУТ в 2019 году (данные доступны по состоянию на 2019 год) по количеству случаев на 100 работающих, оно составило 28,7 \% к уровню 2010 года и 16,2 \% к среднемноголетнему уровню за 2010-2018 гг. Снижение ЗВУТ по количеству дней на 100 работающих составило в 2019 году 26,7 \% к уровню 2010 года и 14,5\% к среднемноголетнему уровню за 2010-2018 гг.

Средняя длительность 1 случая временной нетрудоспособности в 2019 году выросла на 3,1 \% к уровню 2018 года и на 2,2 \% к среднемноголетнему уровню за 2010 2018 гг. (рис. 112).

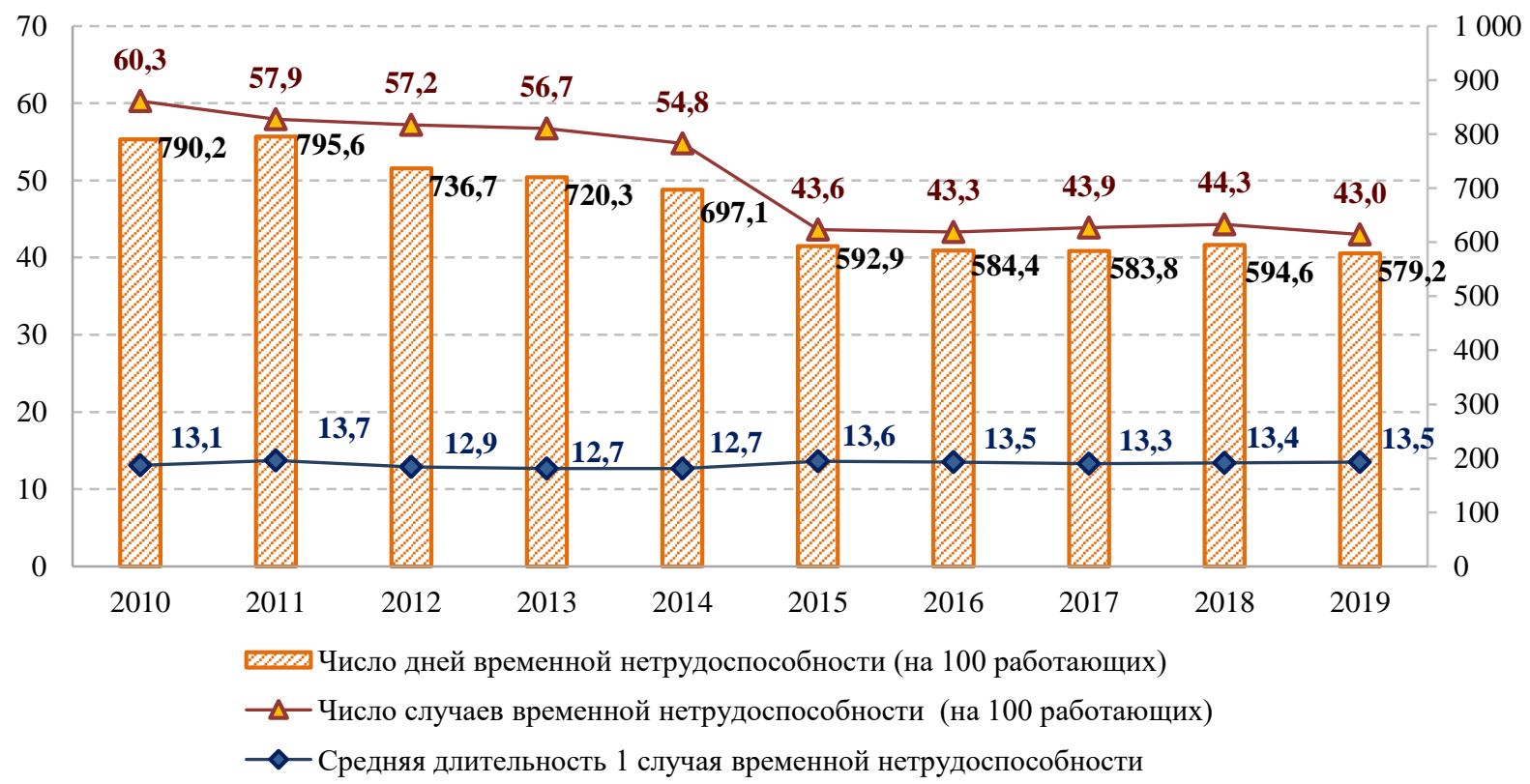

Рис. 112. Динамика изменения показателей, характеризующих заболеваемость с временной утратой трудоспособности в Российской Федерации (на 100 работающих)

Ведущая причина временной нетрудоспособности в 2019 году - болезни органов дыхания (40,0 \% случаев, 26,0 \% дней). На втором месте - болезни костно-мышечной системы (15,3\% случаев, 17,2 \% дней). На третьем - травмы, отравления и некоторые другие последствия воздействия внешних причин (9,5\% случаев, $16,6 \%$ дней) (рис. 113 и 114).

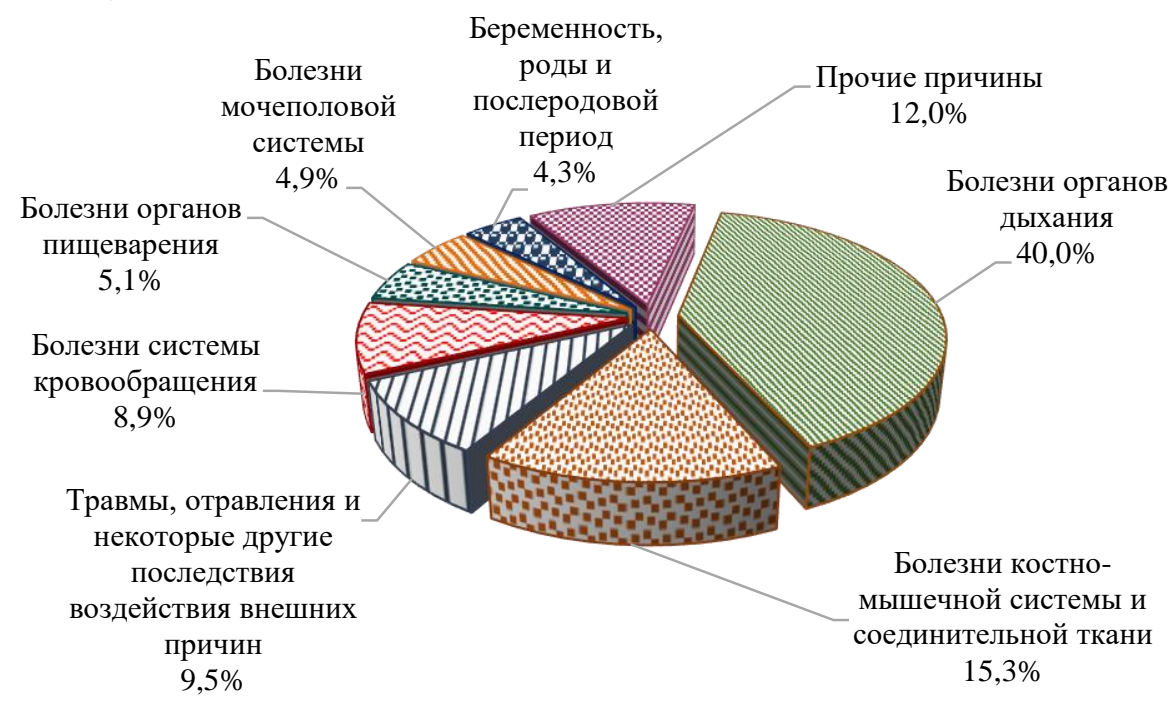

Рис. 113. Структура причин временной нетрудоспособности в 2019 году (по количеству случаев временной нетрудоспособности) 
Государственный доклад «О состоянии санитарно-эпидемиологического благополучия населения в Российской Федерации в 2020 году»

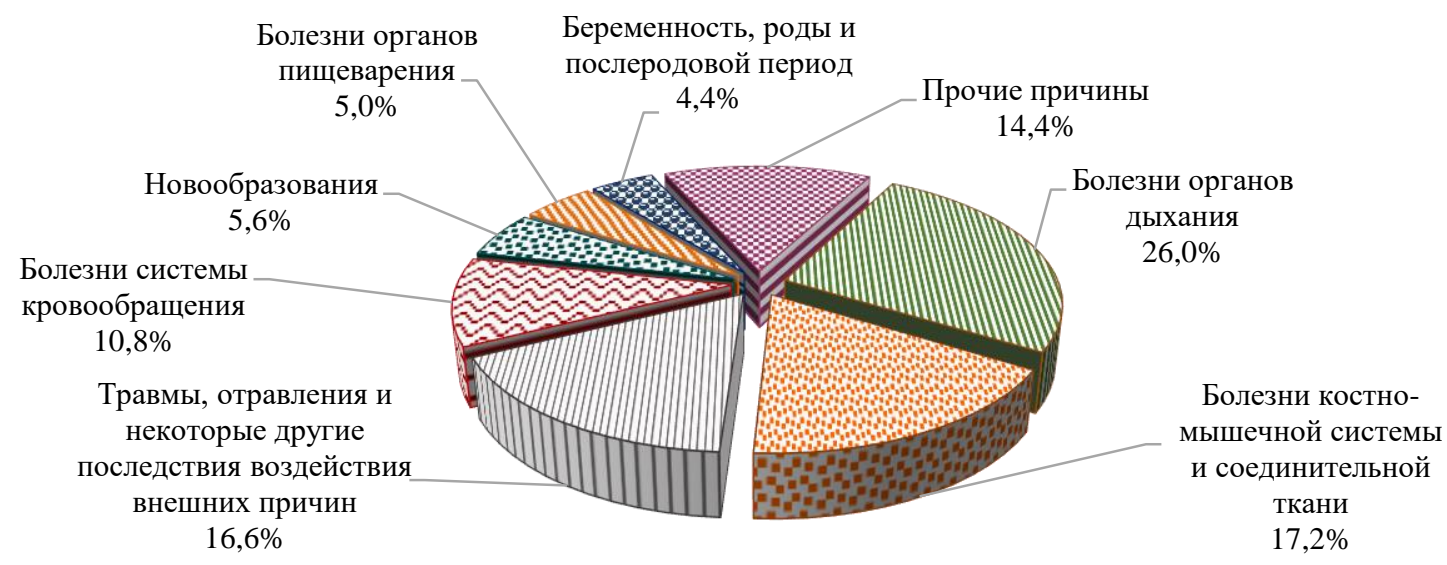

Рис. 114. Структура причин временной нетрудоспособности в 2019 году (по количеству дней ВН)

Самые высокие показатели средней длительности 1 случая временной нетрудоспособности отмечаются при новообразованиях (26,3 дня), травмах, отравлениях и некоторых других последствиях воздействия внешних причин (23,5 дня) и психических расстройствах и расстройствах поведения. Самые низкие показатели средней длительности 1 случая отмечаются при болезнях органов дыхания (8,8 дня), болезнях уха и сосцевидного отростка (10,3 дня) и болезнях мочеполовой системы (10,8 дня).

ЗВУТ от болезней органов дыхания характеризуется самой высокой долей случаев временной нетрудоспособности $(40,0 \%)$ и самыми низкими показателями средней длительности 1 случая $(8,8$ дня), что снижает долю этого класса болезней в структуре причин временной нетрудоспособности по количеству дней до 26,0\%. И напротив, травмы, отравления и некоторые другие последствия воздействия внешних причин при $9,5 \%$ от всех случаев временной нетрудоспособности дают 16,6\% всех дней потерь.

Показатели по числу случаев временной нетрудоспособности на 100 работающих в 2019 году в субъектах Российской Федерации представлены в табл. 40.

Таблица 40

\section{Перечень субъектов Российской Федерации с минимальными и максимальными значениями показателя «Число случаев временной нетрудоспособности (на 100 работающих)», 2019 год}

\begin{tabular}{|c|l|c|c|l|c|}
\hline \multicolumn{2}{|c|}{ Минимальные показатели } & \multicolumn{3}{c|}{ Максимальные показатели } \\
\hline $\begin{array}{c}\text { № } \\
\text { п/п }\end{array}$ & \multicolumn{1}{|c|}{ Субъект } & $\begin{array}{c}\text { Значение } \\
\text { показателя }\end{array}$ & $\begin{array}{c}\text { № } \\
\text { п/п }\end{array}$ & \multicolumn{1}{|c|}{ Субъект } & $\begin{array}{c}\text { 3начение } \\
\text { показателя }\end{array}$ \\
\hline 1 & Чеченская Республика & 14,8 & 1 & Новгородская область & 64,3 \\
\hline 2 & г. Севастополь & 19,2 & 2 & Курганская область & 63,5 \\
\hline 3 & Республика Дагестан & 28,3 & 3 & Вологодская область & 62,2 \\
\hline 4 & Ненецкий автономный округ & 29,2 & 4 & Ярославская область & 60,5 \\
\hline 5 & Приморский край & 29,4 & 5 & Республика Марий Эл & 60,2 \\
\hline 6 & Г. Москва & 29,5 & 6 & Республика Башкортостан & 57,7 \\
\hline 7 & Республика Крым & 30,3 & 7 & Тверская область & 57,4 \\
\hline 8 & Чукотский автономный округ & 31,2 & 8 & Московская область & 55,7 \\
\hline 9 & Амурская область & 32,9 & 9 & $\begin{array}{l}\text { Еврейская автономная } \\
\text { область }\end{array}$ \\
\hline 10 & Республика Тыва & 33,3 & 10 & Республика Карелия & 55 \\
\hline \multicolumn{2}{|l|}{ Российская Федерация } & & & 54,5 \\
\hline
\end{tabular}

Показатели по числу дней временной нетрудоспособности на 100 работающих в 2019 году представлены в табл. 41. 


\section{Перечень субъектов Российской Федерации с минимальными и максимальными значениями показателя «Число дней временной нетрудоспособности (на 100 работающих)», 2019 год}

\begin{tabular}{|c|c|c|c|c|c|}
\hline \multicolumn{3}{|c|}{ Минимальные показатели } & \multicolumn{3}{|c|}{ Максимальные показатели } \\
\hline $\begin{array}{l}\text { № } \\
\Pi / \Pi\end{array}$ & Субъект & $\begin{array}{c}\text { Значение } \\
\text { показателя }\end{array}$ & $\begin{array}{l}\text { № } \\
\Pi / \Pi\end{array}$ & Субъект & $\begin{array}{l}\text { Значение } \\
\text { показателя }\end{array}$ \\
\hline 1 & Чеченская Республика & 244,7 & 1 & Новгородская область & 1014,4 \\
\hline 2 & г. Севастополь & 283,7 & 2 & Вологодская область & 888,0 \\
\hline 3 & г. Москва & 333,5 & 3 & Курганская область & 874,0 \\
\hline 4 & Республика Дагестан & 365,0 & 4 & $\begin{array}{l}\text { Еврейская автономная } \\
\text { область }\end{array}$ & 867,5 \\
\hline 5 & Республика Крым & 372,2 & 5 & Республика Марий Эл & 833,6 \\
\hline 6 & Ненецкий автономный округ & 396,2 & 6 & Тверская область & 819,8 \\
\hline 7 & Чукотский автономный округ & 403,5 & 7 & Республика Башкортостан & 799,0 \\
\hline 8 & Калининградская область & 434,2 & 8 & $\begin{array}{l}\text { Карачаево-Черкесская } \\
\text { Республика }\end{array}$ & 771,8 \\
\hline 9 & Воронежская область & 478,7 & 9 & Ярославская область & 769,4 \\
\hline 10 & Республика Тыва & 481,9 & 10 & Орловская область & 768,8 \\
\hline & \multicolumn{3}{|l|}{ Российская Федерация } & \multicolumn{2}{|l|}{579,2} \\
\hline
\end{tabular}

В долгосрочном периоде средний возраст трудоспособного населения будет расти. Повышение среднего возраста работающего населения неминуемо будет сопровождаться увеличением времени болезни. Увеличатся риски трудовых и экономических потерь от ЗВУТ.

\section{3. Анализ инфекционной и паразитарной заболеваемости}

\subsection{1. Инфекционные заболевания}

В многолетней динамике, в том числе и за последние десять лет (2010-2020 гг.), отмечена тенденция к снижению заболеваемости для 61 инфекционных и 18 паразитарных болезней. В отношении 29 инфекционных болезней и 6 паразитарных инвазий напротив выявлен рост заболеваемости.

В 2020 году по сравнению с 2019 годом отмечено снижение заболеваемости по 77 формам инфекционных и 23 формам паразитарных болезней (в 2019 по сравнению с 2018 г. - снижение по 23 и 11 болезням соответственно). Данная ситуация обусловлена введением комплекса ограничительных мероприятий, связанных с пандемией новой коронавирусной инфекции (COVID-19), снижением интенсивности формирования очагов инфекционных болезней.

Наиболее существенное снижение отмечено по следующим инфекционным нозологиям: энтеровирусные инфекции - в 15,6 раза (в том числе энтеровирусный менингит - в 24 раза), корь - в 3,7 раза, коклюш - в 2,3 раза, эпидемический паротит - в 2,3 раза, впервые выявленный бруцеллез - в 3,4 раза, геморрагическая лихорадка с почечным синдромом (ГЛПС) - в 3,6 раза, лихорадка Западного Нила - в 24 раза, лихорадка Ку - в 19 раз, астраханская пятнистая лихорадка (АПЛ) - в 8,5 раз, бактериальная дизентерия - в 2,3 раза (в том числе вызванная шигеллами Зонне - в 3,9 раза).

Наиболее значительный рост заболеваемости в 2020 г. зарегистрирован по внебольничным пневмониям - в 3,6 раза (1856,18 на 100 тыс. населения), в том числе по вирусной пневмонии - в 109 раз (783,08 на 100 тыс. населения). 
В 2020 году в Российской Федерации зарегистрировано 37 млн 507 тыс. 161 случай инфекционных и паразитарных заболеваний, что на $13 \%$ выше суммы заболеваний по данным 2019 года (33 млн 086 тыс. 203 случая). Прослеживается слабо выраженная тенденция роста заболеваемости инфекционными болезнями (рис. 115).

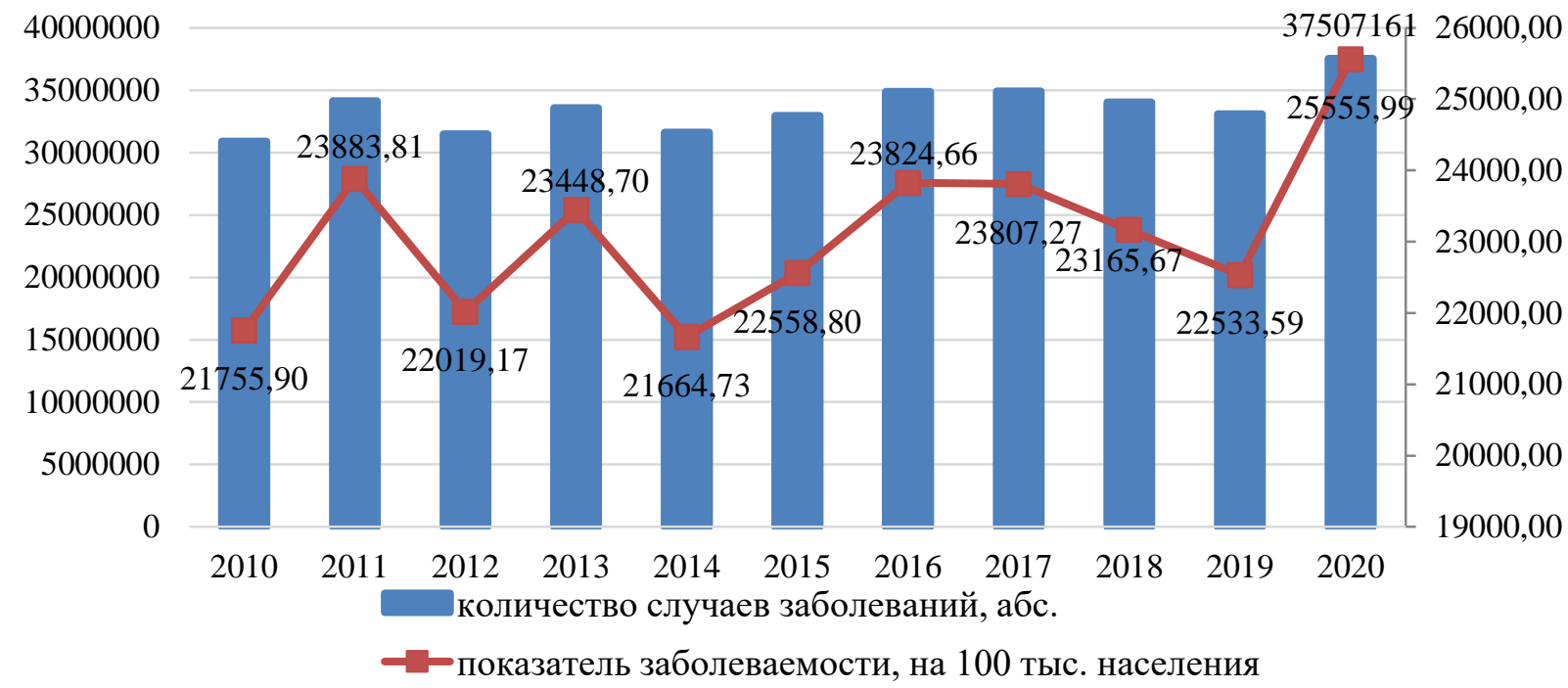

Рис. 115. Динамика заболеваемости инфекционными болезням, абс.

По ориентировочным расчетам, экономический ущерб только от 35 впервые выявленных в 2020 году случаев инфекционных заболеваний составил почти 695 млрд рублей (табл. 42), экономический ущерб с учетом прямых потерь от ранее диагностированных хронических инфекций, имеющих важное социальное значение, составил 828,6 млрд руб., а с учетом прямых и косвенных экономических затрат - более 996,3 млрд руб.

В целом абсолютные стоимостные показатели экономического ущерба, нанесенного инфекционной патологией, в 2020 году по сравнению с предыдущим годом с учетом инфляции возросли на 2,57\%.

Таблица 42

\section{Экономическая значимость инфекционных заболеваний в Российской Федерации} в 2020 году

\begin{tabular}{|c|l|c|}
\hline № п/п & \multicolumn{1}{|c|}{ Наименование заболеваний } & Ущерб (тыс. руб.) \\
\hline 1. & $\begin{array}{l}\text { Острые инфекции верхних дыхательных путей множественной и } \\
\text { неуточненной локализации }\end{array}$ & 606505442,0 \\
\hline 2. & Туберкулез (впервые выявленный), активные формы & 26654372,3 \\
\hline 3. & Ветряная оспа & 18158645,2 \\
\hline 4. & $\begin{array}{l}\text { Болезнь, вызванная вирусом иммунодефицита человека (ВИЧ), и } \\
\text { бессимптомный инфекционный статус, вызванный ВИЧ (впервые } \\
\text { выявленные и летальные случаи в 2020 году) }\end{array}$ & 12091161,8 \\
\hline 5. & $\begin{array}{l}\text { Острые кишечные инфекции, вызванные неустановленными инфекционными } \\
\text { возбудителями, пищевые токсикоинфекции неустановленной этиологии }\end{array}$ & 9637213,3 \\
\hline 6. & Ротавирусный гастроэнтерит & 4271046,6 \\
\hline 7. & Укусы, ослюнения, оцарапывания животными & 3715542,3 \\
\hline 8. & $\begin{array}{l}\text { Острые кишечные инфекции, вызванные установленными бактериальными, } \\
\text { вирусными возбудителями, а также пищевые токсикоинфекции } \\
\text { установленной этиологии }\end{array}$ & 2301468,2 \\
\hline 9. & Инфекционный мононуклеоз & 2299817,4 \\
\hline 10. & Педикулез & 1897499,4 \\
\hline 11. & Сальмонеллезные инфекции & 1593376,7 \\
\hline
\end{tabular}


Государственный доклад «О состоянии санитарно-эпидемиологического благополучия населения в Российской Федерации в 2020 году»

Продолжение табл. 42

\begin{tabular}{|c|c|c|}
\hline № ח/п & Наименование заболеваний & Ущерб (тыс. руб.) \\
\hline 12. & Грипп & 1577740,0 \\
\hline 13. & Хронический вирусный гепатит С & 1015736,1 \\
\hline 14. & Клещевой боррелиоз (болезнь Лайма) & 598601,6 \\
\hline 15. & $\begin{array}{l}\text { Вирусные лихорадки, передаваемые членистоногими, и вирусные } \\
\text { геморрагические лихорадки }\end{array}$ & 516315,8 \\
\hline 16. & Скарлатина & 436969,0 \\
\hline 17. & Острый гепатит А & 395448,4 \\
\hline 18. & Коклюш & 379952,8 \\
\hline 19. & Бактериальная дизентерия (шигеллез) & 212698,5 \\
\hline 20. & Острый гепатит C & 175601,8 \\
\hline 21. & Менингококковая инфекция (генерализованные формы) & 136793,7 \\
\hline 22. & Острый гепатит В & 127476,3 \\
\hline 23. & Корь & 80616,5 \\
\hline 24. & Иерсиниозы & 62998,1 \\
\hline 25. & Бруцеллез впервые выявленный & 40354,3 \\
\hline 26. & Псевдотуберкулез & 17852,2 \\
\hline 27. & Паротит эпидемический & 14661,7 \\
\hline 28. & Туляремия & 8493,9 \\
\hline 29. & Лептоспироз & 7503,8 \\
\hline 30. & Бактерионосительство брюшного тифа, паратифов & 2766,6 \\
\hline 31. & Столбняк & 1298,3 \\
\hline 32. & Паратифы А, В, С и неуточненный & 691,7 \\
\hline 33. & Брюшной тиф & 345,8 \\
\hline 34. & Дифтерия & 268,0 \\
\hline 35. & Краснуха & 118,5 \\
\hline & Итого & 694936888,5 \\
\hline
\end{tabular}

Согласно результатам рейтингового анализа величин экономического ущерба, нанесенного отдельными инфекционными болезнями в 2010-2020 гг. (табл. 43), наиболее значимое снижение экономического ущерба за десятилетие достигнуто по краснухе и вирусному гепатиту А и В.

Таблица 43

Рейтинговая оценка инфекционных болезней (без туберкулеза и ВИЧ-инфекции) по величине экономического ущерба в 2010-2020 гг. в Российской Федерации *

\begin{tabular}{|c|c|c|c|c|c|c|c|c|c|c|c|c|}
\hline \multirow{2}{*}{$\begin{array}{l}\mathrm{N} \\
\Pi / \Pi .\end{array}$} & \multirow[t]{2}{*}{ Нозологические формы } & \multicolumn{11}{|c|}{$\begin{array}{c}\text { Рейтинг по годам } \\
\text { (максимальный показатель ущерба }=1, \text { минимальный }=33 \text { ) }\end{array}$} \\
\hline & & 2010 & 2011 & 2012 & 2013 & 2014 & 2015 & 2016 & 2017 & 2018 & 2019 & 2020 \\
\hline 1 & 2 & 3 & 4 & 5 & 6 & 7 & 8 & 9 & 10 & 11 & 12 & 13 \\
\hline 1 & $\begin{array}{l}\text { Острые инфекции верхних } \\
\text { дыхательных путей } \\
\text { множественной и } \\
\text { неуточненной локализации }\end{array}$ & 1 & 1 & 1 & 1 & 1 & 1 & 1 & 1 & 1 & 1 & 1 \\
\hline 2 & Ветряная оспа & 3 & 3 & 3 & 3 & 3 & 3 & 3 & 3 & 2 & 2 & 2 \\
\hline 3 & $\begin{array}{l}\text { Острые кишечные } \\
\text { инфекции, вызванные } \\
\text { неустановленными } \\
\text { инфекционными } \\
\text { возбудителями, пищевые } \\
\text { токсикоинфекции } \\
\text { неустановленной } \\
\text { этиологии }\end{array}$ & 2 & 2 & 2 & 2 & 2 & 2 & 2 & 2 & 3 & 3 & 3 \\
\hline 4 & \begin{tabular}{|l|} 
Укусы, ослюнения, \\
оцарапывания животными
\end{tabular} & 5 & 6 & 5 & 5 & 5 & 5 & 5 & 5 & 6 & 5 & 4 \\
\hline
\end{tabular}


Продолжение табл. 43

\begin{tabular}{|c|c|c|c|c|c|c|c|c|c|c|c|c|}
\hline 1 & 2 & 3 & 4 & 5 & 6 & 7 & 8 & 9 & 10 & 11 & 12 & 13 \\
\hline 5 & $\begin{array}{l}\text { Острые кишечные } \\
\text { инфекции, вызванные } \\
\text { установленными бактери- } \\
\text { альными, вирусными } \\
\text { возбудителями, а также } \\
\text { пищевые токсикоинфекции } \\
\text { установленной этиологии }\end{array}$ & 4 & 5 & 4 & 4 & 4 & 4 & 4 & 4 & 4 & 4 & 5 \\
\hline 6 & $\begin{array}{l}\text { Инфекционный } \\
\text { мононуклеоз }\end{array}$ & 8 & 8 & 7 & 7 & 6 & 6 & 6 & 6 & 5 & 6 & 6 \\
\hline 7 & Педикулез & 9 & 9 & 8 & 9 & 8 & 8 & 9 & 9 & 9 & 8 & 7 \\
\hline 8 & $\begin{array}{l}\text { Другие сальмонеллезные } \\
\text { инфекции }\end{array}$ & 6 & 7 & 6 & 6 & 7 & 7 & 8 & 7 & 7 & 7 & 8 \\
\hline 9 & Грипп & 7 & 4 & 16 & 8 & 18 & 10 & 7 & 10 & 10 & 11 & 9 \\
\hline 10 & $\begin{array}{l}\text { Хронический вирусный } \\
\text { гепатит C }\end{array}$ & 10 & 10 & 9 & 10 & 9 & 9 & 10 & 8 & 8 & 10 & 10 \\
\hline 11 & $\begin{array}{l}\text { Клещевой боррелиоз } \\
\text { (болезнь Лайма) }\end{array}$ & 15 & 11 & 10 & 14 & 14 & 12 & 13 & 13 & 11 & 12 & 11 \\
\hline 12 & Носительство ВГВ & 13 & 12 & 11 & 16 & 13 & 14 & 15 & 15 & 17 & 17 & $32 *$ \\
\hline 13 & $\begin{array}{l}\text { Вирусные лихорадки, } \\
\text { передаваемые } \\
\text { членистоногими, и } \\
\text { вирусные геморрагические } \\
\text { лихорадки }\end{array}$ & 17 & 16 & 15 & 11 & 11 & 11 & 12 & 12 & 12 & 9 & 12 \\
\hline 14 & Скарлатина & 14 & 13 & 14 & 15 & 12 & 15 & 16 & 14 & 13 & 14 & 13 \\
\hline 15 & Острый вирусный гепатит A & 11 & 15 & 12 & 12 & 10 & 13 & 11 & 11 & 15 & 15 & 14 \\
\hline 16 & Коклюш, паракоклюш & 21 & 20 & 20 & 21 & 21 & 20 & 19 & 20 & 14 & 13 & 15 \\
\hline 17 & Дизентерия (шигеллезы) & 12 & 14 & 13 & 13 & 15 & 16 & 14 & 16 & 16 & 16 & 16 \\
\hline 18 & Острый вирусный гепатит C & 19 & 19 & 19 & 19 & 17 & 18 & 18 & 17 & 19 & 20 & 17 \\
\hline 19 & $\begin{array}{l}\text { Менингококковая } \\
\text { инфекция - } \\
\text { генерализованные формы }\end{array}$ & 18 & 18 & 18 & 18 & 19 & 21 & 20 & 19 & 18 & 18 & 18 \\
\hline 20 & Острый вирусный гепатит В & 16 & 17 & 17 & 17 & 16 & 17 & 17 & 18 & 20 & 21 & 19 \\
\hline 21 & Корь & 29 & 24 & 22 & 22 & 20 & 24 & 27 & 24 & 21 & 19 & 20 \\
\hline 22 & Иерсиниозы & 20 & 21 & 21 & 23 & 22 & 21 & 21 & 23 & 23 & 22 & 21 \\
\hline 23 & Бруцеллез & 23 & 22 & 23 & 24 & 23 & 22 & 22 & 22 & 22 & 23 & 22 \\
\hline 24 & Псевдотуберкулез & 22 & 23 & 24 & 25 & 24 & 23 & 23 & 25 & 25 & 25 & 23 \\
\hline 25 & Эпидемический паротит & 28 & 28 & 28 & 28 & 27 & 28 & 24 & 21 & 24 & 24 & 24 \\
\hline 26 & Туляремия & 25 & 29 & 27 & 20 & 26 & 25 & 25 & 26 & 26 & 27 & 25 \\
\hline 27 & Лептоспироз & 24 & 25 & 26 & 27 & 25 & 26 & 26 & 27 & 27 & 26 & 26 \\
\hline 28 & $\begin{array}{l}\text { Тифопаратифозные } \\
\text { заболевания }\end{array}$ & 27 & 26 & 29 & 26 & 28 & 27 & 28 & 28 & 28 & 28 & 27 \\
\hline 29 & Столбняк & 30 & 32 & 30 & 30 & 30 & 29 & 29 & 29 & 29 & 29 & 28 \\
\hline 30 & Дифтерия & 32 & 31 & 32 & 32 & 32 & 32 & 32 & 32 & 30 & 31 & 29 \\
\hline 31 & Краснуха & 26 & 27 & 25 & 29 & 29 & 30 & 30 & 31 & 32 & 30 & 30 \\
\hline 32 & $\begin{array}{l}\text { Носительство возбудителя } \\
\text { дифтерии }\end{array}$ & 31 & 30 & 31 & 31 & 31 & 31 & 31 & 30 & 31 & 32 & 31 \\
\hline
\end{tabular}

* В 2020 году нозологическая форма «Носительство ВГВ» исключена из статистической отчетности

**Цветом обозначены рейтинги:
$1-5$
$6-10-$
$115-$
$16-20-\square$
$21-33-\square$ 
Как и в предыдущие годы, в 2020 г. наибольшую экономическую значимость представляли острые инфекции верхних дыхательных путей множественной и неуточненной локализации, туберкулез, острые кишечные инфекции, ветряная оспа, ВИЧ-инфекция (впервые выявленные и летальные случаи в 2020 году), ротавирусный гастроэнтерит, укусы и ослюнения животными, инфекционный мононуклеоз, педикулез и сальмонеллезы.

В 2020 году снизился рейтинг экономического ущерба от вирусных лихорадок, передаваемых членистоногими, и вирусных геморрагических лихорадок (на 3 пункта), псевдотуберкулеза и туляремии (на 2 пункта), острых кишечных инфекций, вызванных установленными бактериальными, вирусными возбудителями, а также пищевых токсикоинфекций установленной этиологии, сальмонеллезов, иерсиниозов (на 1 пункт).

Отмечен рост рейтинга экономического ущерба от острыго вирусного гепатита С (на 3 пункта), дифтерии, гриппа, коклюша и острого вирусного гепатита В (на 2 пункта), бруцеллеза (впервые выявленным), боррелиоза, кори, педикулеза, скарлатины, острого вирусного гепатита А, а также от укусов, ослюнения, оцарапывания животными (на 1 пункт).

Экономический ущерб от хронических инфекционных заболеваний.

В 2020 году была произведена оценка экономического ущерба, наносимого бюджету Российской Федерации тремя наиболее распространенными и имеющими высокую социальную значимость хроническими инфекционными болезнями: туберкулезом, ВИЧ-инфекцией и вирусным гепатитом С, с которыми связана и основная смертность от инфекционных заболеваний.

При проведении оценки были учтены прямые затраты на организацию профилактических мероприятий и медицинской помощи всем россиянам, страдающим туберкулезом, ВИЧ-инфекцией и вирусным гепатитом $\mathrm{C}$, а не только больным, впервые выявленным в течение отчетного года. Прямые затраты бюджета на борьбу с этими тремя хроническими инфекционными болезнями составили в 2020 г. 173,4 млрд руб., что в 4 раза больше, чем ущерб от новых случаев указанных заболеваний (табл. 44). При этом наибольший объем прямых медицинских затрат приходился на туберкулез (102,0 млрд руб., по данным ФГБНУ ЦНИИТ, 2021 г.), причем существенная часть этих затрат связана с содержанием диспансеров и стационаров для лечения больных туберкулезом. На противодействие эпидемии ВИЧ-инфекции (по данным Аналитического центра при Правительстве Российской Федерации, 2021 г.), израсходовано 63,4 млрд руб.

Таблица 44

\section{Прямые затраты бюджета на борьбу с хроническими инфекционными болезнями (туберкулез, ВИЧ-инфекция, вирусный гепатит С) в Российской Федерации в 2020 году}

\begin{tabular}{|l|l|c|}
\hline $\begin{array}{c}\text { № } \\
\text { п/п }\end{array}$ & \multicolumn{1}{|c|}{ Наименование заболеваний } & Ущерб (млрд руб.) \\
\hline 1. & Туберкулез & 102,0 \\
\hline 2. & $\begin{array}{l}\text { Болезнь, вызванная вирусом иммунодефицита человека (ВИЧ), и } \\
\text { бессимптомный инфекционный статус, вызванный ВИЧ }\end{array}$ & 63,4 \\
\hline 3. & Хронический вирусный гепатит С & 8,0 \\
\hline & Итого & 173,4 \\
\hline
\end{tabular}

Все три перечисленные инфекционные болезни даже при использовании современных методов лечения приводят к длительной потере трудоспособности, а часто и к преждевременной смерти зараженных лиц. Макроэкономический ущерб от 
преждевременной гибели и сокращения численности трудоспособного населения России, выплат по нетрудоспособности и инвалидности может существенно превышать прямые медицинские затраты. По данным НИФИ Минфина России, основную часть экономического бремени в связи с ВИЧ-инфекцией составляют косвенные экономические затраты, определенные как потери ВВП от инвалидизации и преждевременной смертности населения вследствие ВИЧ, в 2019 г. они составили 149,5 млрд руб. Кроме того, значительными были и прямые немедицинские затраты (расходы на выплату пенсий по инвалидности), которые составили 12,6 млрд руб. Таким образом, суммарно экономический ущерб от ВИЧ-инфекции можно оценить в 225,5 млрд руб. в год. НИФИ Минфина России оценил косвенные экономические потери от преждевременной смертности трудоспособного населения вследствие распространения вирусного гепатита $\mathrm{C}$ как минимум в 5,6 млрд руб. в год, следовательно, общий ущерб от этого заболевания составил 13,6 млрд руб. в год. Косвенные экономические затраты, связанные с туберкулезом, не оценивались в 2020 г., эта работа запланирована на ближайшую перспективу. Суммарно экономический ущерб, нанесенный только тремя хроническими инфекционными болезнями (туберкулезом, ВИЧ-инфекцией и вирусным гепатитом С) в 2020 году составил более 341,1 млрд руб., что определяет исключительную значимость противодействия распространению этих заболеваний для экономики страны.

Оценка экономического ущерба, нанесенного COVID-19 в 2020 г., сопряжена с большими трудностями, поскольку большая часть бюджетных затрат пришлась на меры по поддержке экономики страны в связи с беспрецедентными ограничениями мобильности и самоизоляцией граждан в условиях эпидемического распространения новой коронавирусной инфекции. Только некоторые прямые выплаты из федерального бюджета на борьбу с COVID-19 (поддержка населения и предприятий) составили в сумме не менее 515,95 млрд руб.

Целевые ассигнования в сферу здравоохранения были предназначены для строительства инфекционных стационаров, перепрофилирования действующих больниц в инфекционные, разработки, производства и распределения оборудования и препаратов для диагностики, выявления, профилактики и лечения COVID-19, производства средств индивидуальной защиты, работы лабораторий и мобильных бригад и т.п. Только некоторые из выделенных из бюджета страны средств, направленные непосредственно на организацию и оказание медицинской помощи больным COVID-19, составили в сумме не менее 189,452 млрд руб.

Таким образом, только прямые выплаты из бюджета для борьбы с коронавирусной инфекцией составили в сумме не менее 705,402 млрд руб.

Исходя из опубликованных результатов расчета стоимости лечения госпитализированных больных COVID-19, с учетом данных Роспотребнадзора о распределении по тяжести течения случаев заболевания, потребовавших госпитализации, только прямые затраты на лечение в стационаре составили в 2020 г. около 183,06 млрд руб. За отчетный год было проведено более 90 млн тестов на COVID19, при средней стоимости лабораторного исследования 1200 руб. итоговые затраты на тестирование превысили 108,6 млрд руб. Суммируя перечисленные бюджетные траты вследствие распространения COVID-19, можно сделать вывод о том, что даже без учета потерь непроизведенного валового национального продукта вследствие летальных исходов, стойкой и временной нетрудоспособности ущерб экономике от новой инфекции в 2020 г. в стоимостных показателях составил более 997,06 млрд руб., что в 1,4 раза больше суммарного ущерба от остальных инфекционных болезней.

Новая коронавирусная инфекция впервые была выявлена в конце декабря 2019 г. в городе Ухань (Китайская Народная Республика). Генеральный директор ВО3 
Государственный доклад «О состоянии санитарно-эпидемиологического благополучия населения в Российской Федерации в 2020 году»

30.01.2020 объявил вспышку заболевания, вызванного новым коронавирусом 2019-nCoV, чрезвычайной ситуацией общественного здравоохранения, имеющей международное значение.

COVID-19 в 2020 г. оказал огромное воздействие на социальную, экономическую, политическую и культурную сферы деятельности, и данное влияние продолжает наблюдаться и по настоящее время.

Всего в Российской Федерации в 2020 г. выявлено более 3159 млн случаев коронавирусной инфекции в 85 регионах, показатель заболеваемости на 100 тыс. населения составил 2152,63.

Динамика числа заболевших COVID-19 в 2020 г. характеризовалась двумя подъёмами заболеваемости и снижением в летний период (рис. 116).

Динамика числа заболевших и госпитализированных с COVID-19 в 2020 г. характеризовалась в период первого подъёма заболеваемости большей долей госпитализированных пациентов из общего числа заболевших, в то время как в период повторного подъёма заболеваемости в осенне-зимний период 2020 года доля госпитализированных от общего числа зарегистрированных больных уменьшилась, что связано с оптимизацией терапевтических подходов.

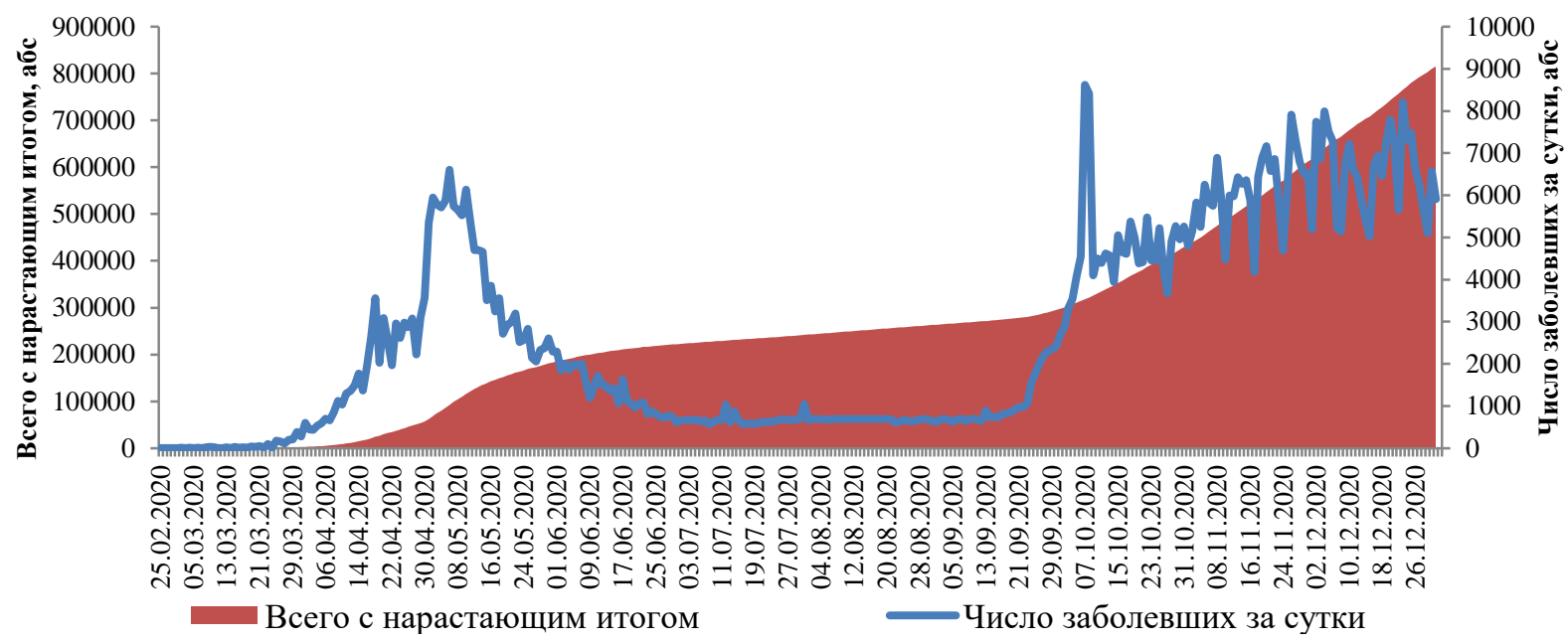

Pис.116. Динамика числа заболевших COVID-19, в том числе с нарастающим итогом в 2020 г.

В возрастной структуре заболевших COVID-19 отмечено, что преимущественно поражаемым контингентом были лица в возрасте от 30 до 64 лет (рис. 117). Доля детей на протяжении всего периода наблюдения в общей возрастной структуре не менялась. Начиная с 13 недели года доля лиц старше 65 лет также значимо не менялась в общей возрастной структуре заболевших.

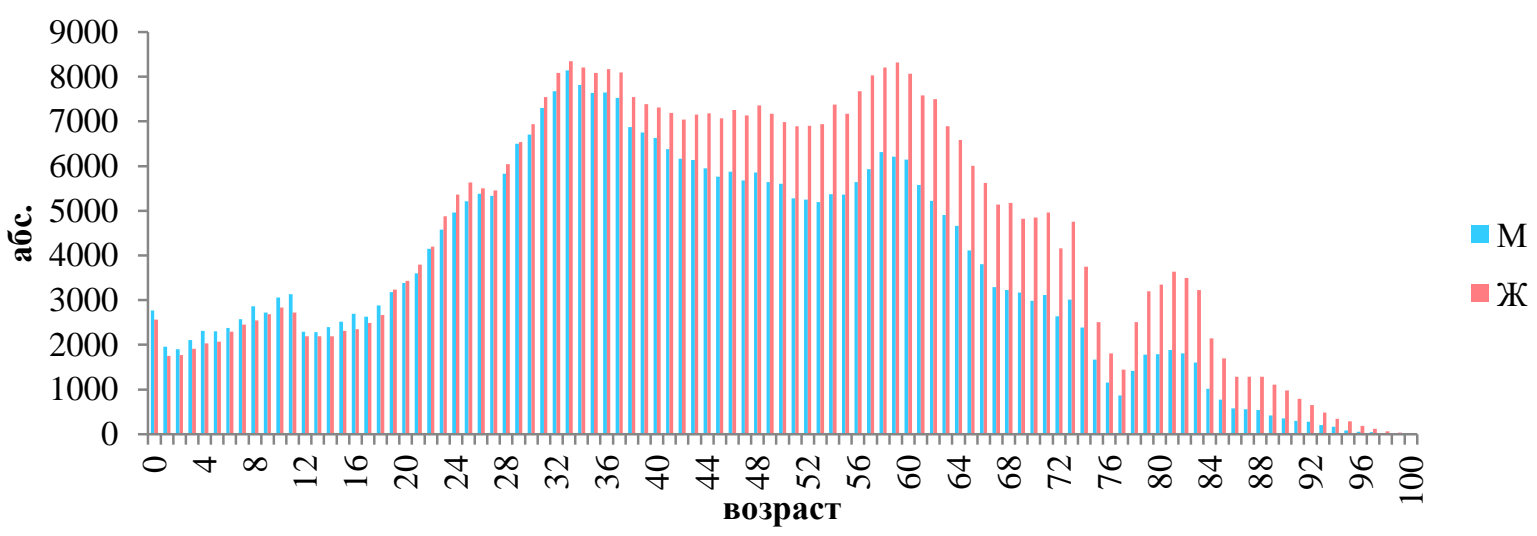

Рис. 117. Характеристика заболевших COVID-19 в 2020 г по полу и возрасту 
Преимущественно тяжелые формы инфекции отмечались в возрастной группе старше 55 лет $(77,6 \%)$.

В структуре заболевших COVID-19 по социальному статусу преобладали работающие лица $(40,9 \%)$, среди которых на долю медицинских работников приходилось 9,8\% (рис. 118). Среди учащихся на долю школьников приходилось 5,1\%, студентов $-1,8 \%$, а дети дошкольного возраста в общей структуре больных COVID-19 составили $3,3 \%$.

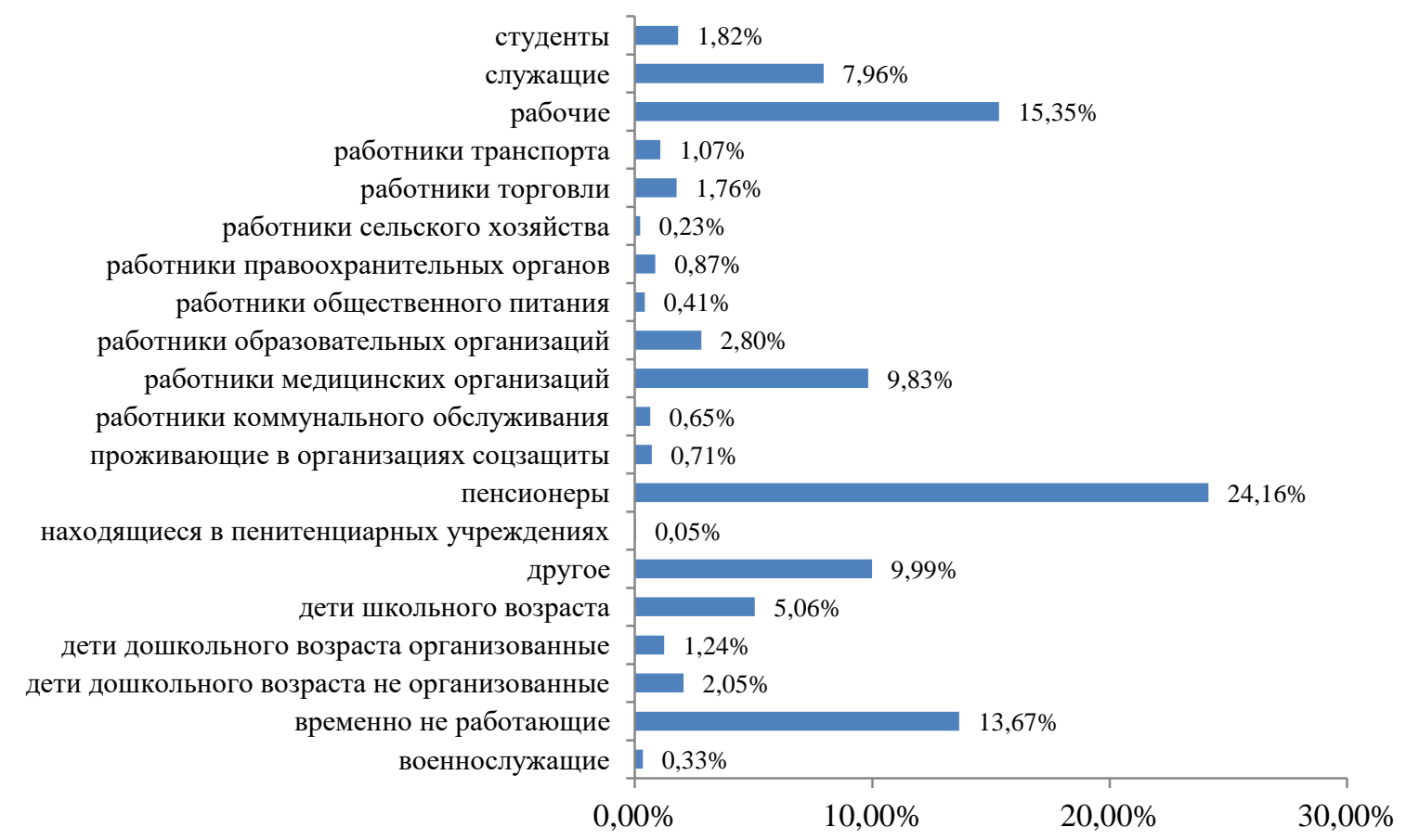

Рис. 118. Структура заболевших COVID-19 по социальному статусу

В связи с неблагополучной ситуацией по COVID-19 в мире Роспотребнадзором был организован и проводился комплекс противоэпидемических и профилактических мероприятий по недопущению ввоза и распространения на территории Российской Федерации новой коронавирусной инфекции.

Реализация комплекса мероприятий Роспотребнадзором проводилась в рамках Национального плана по предупреждению завоза и распространения новой коронавирусной инфекции на территории Российской Федерации, утвержденного Председателем Правительства Российской Федерации, постановлений Главного государственного санитарного врача Российской Федерации от 24.01 .2020 № 2 «О мероприятиях по недопущению распространения новой коронавирусной инфекции, вызванной 2019-nCoV», от 31.01.2020 № 3 «О проведении дополнительных санитарнопротивоэпидемических (профилактических) мероприятий по недопущению завоза и распространения новой коронавирусной инфекции, вызванной 2019-nCoV» и от 02.03.2020 № 5 «О дополнительных мерах по снижению рисков завоза и распространения COVID-2019», от 13.03.2020 № 6 «О дополнительных мерах по снижению рисков распространения COVID-2019», от 18.03.2020 № 7 «Об обеспечении режима изоляции в целях предотвращения распространения COVID-2019», от 30.01.2020 № 9 «О дополнительных мерах по недопущению распространения COVID-2019».

C 30 марта 2020 г. прекращено транспортное сообщение с иностранными государствами, изданы соответствующие распоряжения Правительства Российской Федерации, в соответствии с которыми ограничены въезд в Российскую Федерацию 
иностранным гражданам и движение через наземные пункты пропуска через государственную границу Российской Федерации.

Были приняты дополнительные меры по усилению санитарно-карантинного контроля в пунктах пропуска через государственную границу Российской Федерации. По данным формы отраслевого статистического наблюдения № 25-16 «Сведения об осуществлении санитарно-карантинного контроля на российском участке внешней границы Таможенного союза», в пунктах пропуска досмотрено более 15,8 млн человек, выявлено с признаками инфекционных заболеваний свыше 1,9 тыс. человек.

Первые тест-системы для диагностики COVID-19 в Российской Федерации были разработаны и зарегистрированы в установленном порядке в ГНЦ ВБ «Вектор» Роспотребнадзора (11.02.2020). В кратчайшие сроки налажено массовое производство тест-систем и снабжение лабораторий, осуществляющих диагностику новой коронавирусной инфекции, что позволило в максимально короткие сроки начать работу по выявлению больных.

Организовано поэтапное включение лабораторий в исследования на COVID-19. На начальном этапе лабораторная диагностика COVID-19 была организована на базе 15 научно-исследовательских организаций и центров гигиены и эпидемиологии. Со второй декады февраля (13.02.2020) в лабораторном тестировании были задействованы 84 центра гигиены и эпидемиологии во всех субъектах страны с последующей верификацией результатов исследований в 15 ПЦР-центрах. В соответствии с постановлением Главного государственного санитарного врача Российской Федерации от 13.03.2020 № 6 «О дополнительных мерах по снижению рисков распространения COVID-19», лабораторное исследование материала (без накопления возбудителя) организуется на базе лабораторий медицинских организаций, имеющих санитарноэпидемиологическое заключение на работу с возбудителями III-IV групп патогенности.

Результатом проведенных мероприятий по повышению доступности тестирования на COVID-19 в Российской Федерации стало увеличение мощности лабораторной базы и количества исследований на новую коронавирусную инфекцию (рис. 119).

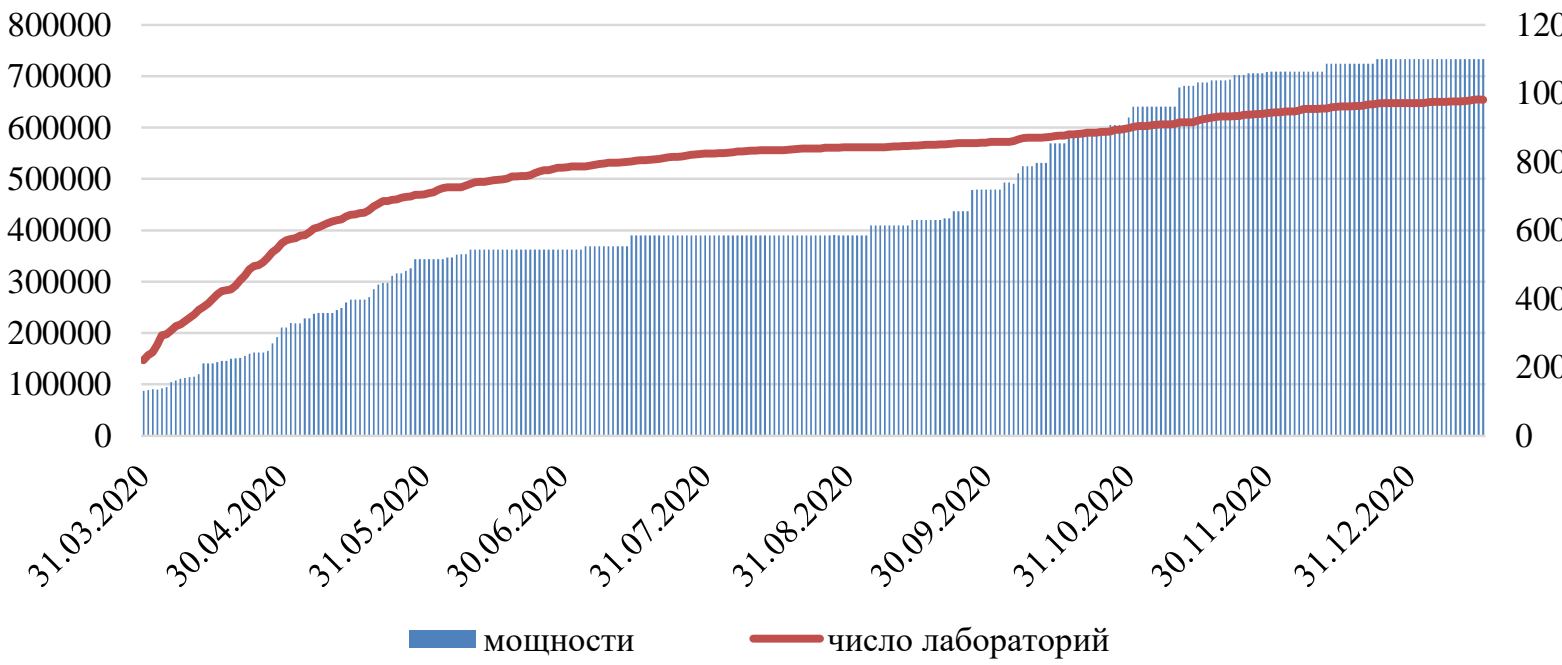

Рис. 119. Динамика числа лабораторий, проводящих исследований на COVID-19, и суммарная максимальная мощность (исследований в сутки)

По состоянию на 31.03.2020 исследования проводились в 221 лаборатории с максимальной суммарной мощностью более 86 тыс. исследований в сутки, из них $60 \%$ (52,4 тыс. исследований) - мощности лабораторий Роспотребнадзора: на 31.12.2020 исследования проводились более чем в 970 лабораториях, в том числе 111 лабораториях 
системы Роспотребнадзора, максимальная суммарная мощность всех лабораторий, задействованных в тестировании на COVID-19, составила 732,9 тыс. исследований, из них мощность лабораторий Роспотребнадзора - 88,1 тыс. исследований.

В рамках реализации постановления Правительства РФ от 15 апреля 2020 года № 507 «О временном порядке распределения в Российской Федерации тест-систем для диагностики новой коронавирусной инфекции» Федеральная служба по надзору в сфере защиты прав потребителей и благополучия человека определена уполномоченным федеральным органом исполнительной власти по учету и распределению в соответствии с временным порядком, утвержденным настоящим постановлением, произведенных (изготовленных) на территории Российской Федерации организациями, подведомственными федеральным органам исполнительной власти (за исключением организаций, подведомственных Министерству обороны Российской Федерации), тестсистем для диагностики новой коронавирусной инфекции, а также по учету информации о проведенных в Российской Федерации исследованиях на диагностику COVID-19 и об их результатах. Распределение диагностических наборов осуществляется путем еженедельного формирования планов-графиков, составленных исходя из потребностей всех организаций, осуществляющих диагностические исследования в регионе, независимо от их организационно-правовых форм. Оценка потребности субъекта Российской Федерации в тест-системах для диагностики COVID-19 основывалась на анализе количества проводимых исследований, анализе текущей потребности с учетом остатков, а также с учетом эпидемиологической ситуации в регионе.

До 20.07.2020 для безвозмездного распределения были доступны тест-системы «Вектор-ПЦРрв-2019-nCoV-RG» производства ФБУН «ГНЦ ВБ «Вектор» Роспотребнадзора. С 20 июля 2020 г. становится возможной передача на безвозмездной основе тест-систем «АмплиСенс ${ }^{\circledR}$ Cov-Bat-FL» производства ФБУН «ЦНИИ эпидемиологии» Роспотребнадзора, а с 27 июля - набора реагентов «COVID-19 Amp» ФБУН «НИИ эпидемиологии и микробиологии им. Пастера» Роспотребнадзора. Кроме того, с 24.08.2020 для безвозмездного распределения в рамках реализации постановления Правительства № 507 стали доступны наборы реагентов для анализа сыворотки или плазмы крови человека на наличие специфических иммуноглобулинов класса G к вирусу SARS-CoV-2 производства ФБУН «Государственный научный центр прикладной микробиологии и биотехнологии» Роспотребнадзора («ИФА анти-SARSCov-2 IgG» и «Экспресс-тест антитела COVID-19»).

Всего за период действия постановления Правительства РФ № 507 до 31.12.2020 распределено более 276,9 тыс. наборов реагентов (более 32 млн определений) для ПЦРдиагностики COVID-19, произведенных учреждениями Роспотребнадзора (рис. 120).

Кроме этого, при поддержке Правительства Российской Федерации стало возможным осуществлять поставки диагностикумов за пределы России в качестве безвозмездной помощи иностранным государствам. Всего в рамках реализации распоряжений Правительства Российской Федерации № 863-р от 03.04.2020 и № 1280-р от 15.05.2020 зарубежным партнерам было передано 15000 наборов средств диагностики.

В ноябре - декабре 2020 г. дан старт массовой вакцинации против COVID-19 зарегистрированной в установленном порядке пептидной вакциной «ЭпиВакКорона», разработанной ГНЦ ВБ «Вектор» Роспотребнадзора, проведены пострегистрационные исследования.

Организован сбор и молекулярно-генетическое исследование вирусов SARSCoV-2, циркулирующих на территории России, ведется мониторинг наличия антител к вирусу SARS-CoV-2 у граждан, проживающих в Российской Федерации, выборочно исследуются сыворотки крови от реконвалесцентов на наличие вирус-нейтрализующей активности. 
Государственный доклад «О состоянии санитарно-эпидемиологического благополучия населения в Российской Федерации в 2020 году»

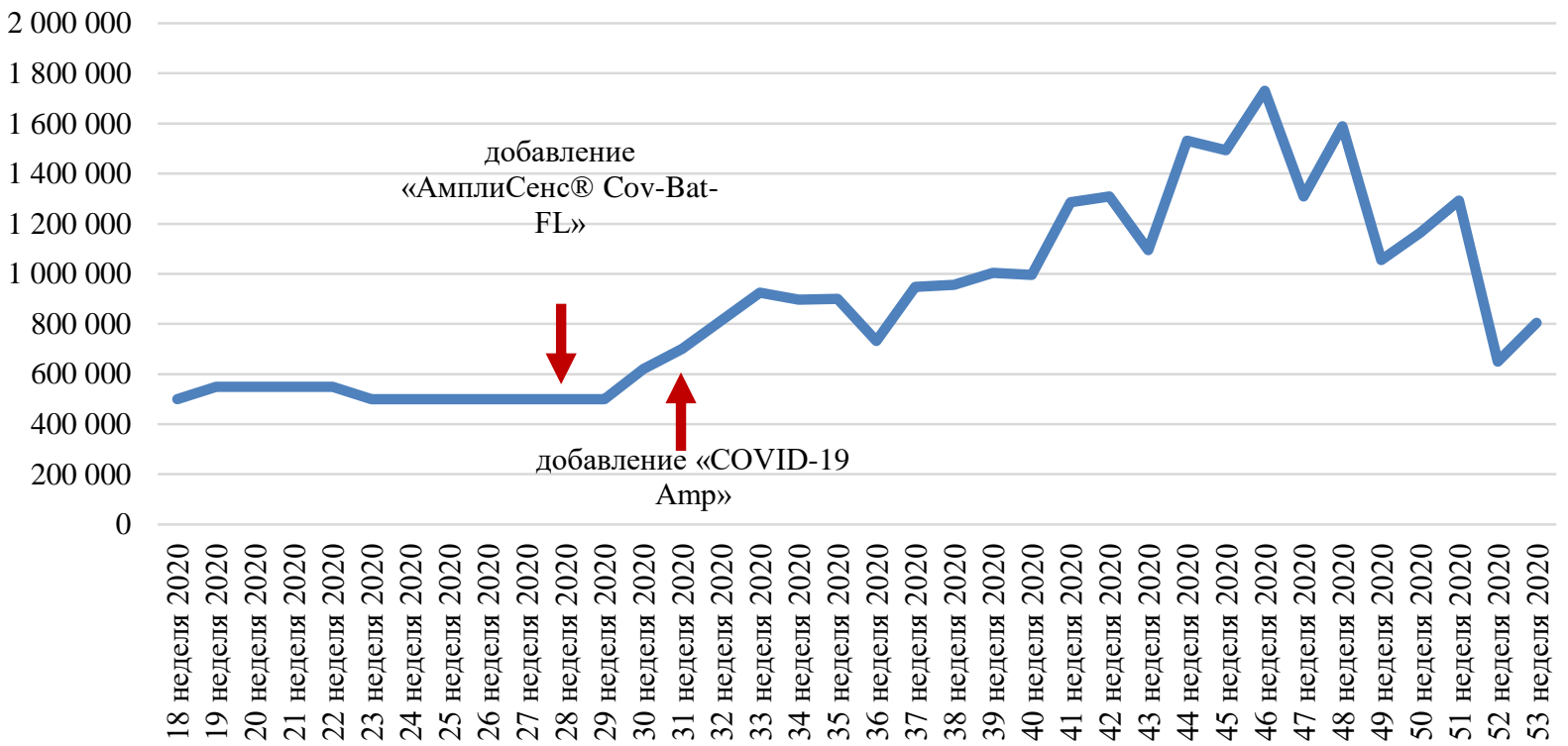

Рис. 120. Распределенное количество реагентов для ПЦР-диагностики новой коронавирусной инфекции с начала действия постановления Правительства РФ № 507 от 15.04.2020

Научно-исследовательские организации Роспотребнадзора участвовали совместно с управлениями Роспотребнадзора и центрами гигиены и эпидемиологии в субъектах Российской Федерации в организованном Роспотребнадзором и НИИ эпидемиологии и микробиологии им. Пастера пилотном проекте по проведению сероэпидемиологического исследования (определение в динамике антител класса IgG к вирусу SARS-CoV-2) населения Российской Федерации.

C начала пандемии Роспотребнадзором в целях организации и проведения противоэпидемических мер суммарно издано более 500 нормативных, методических и рекомендательных документов. 22 мая 2020 года постановлением Главного государственного санитарного врача Российской Федерации № 15 утверждены новые санитарно-эпидемиологические правила СП 3.1.3597-20 «Профилактика новой коронавирусной инфекции (COVID-19)». Кроме того, для организаций различных отраслей (агропромышленный комплекс, предприятия торговли и общепита, транспорта и транспортных предприятий, строительная отрасль) разработаны рекомендации по организации работы в условиях сохранения рисков распространения COVID-19.

Организована и проводилась широкомасштабная информационнопросветительская работа с населением по вопросам профилактики COVID-19: горячие линии, разделы на сайтах Роспотребнадзора, публикации в СМИ, информирование в транспорте и общественных местах, печатная продукция, баннеры и многое другое.

Открыт российский портал препринтов по COVID-19 - COVID-19 PREPRINTS в целях повышения открытости и доступности результатов исследований по COVID-19, расширения сотрудничества между учёными, информирования о результатах исследований.

В 2020 году острые инфекции верхних дыхательных путей множественной и неуточненной локализации (ОРВИ) составляли более $88 \%$ от числа всех инфекционных и паразитарных болезней, что сопоставимо с данными за последние 10 лет. Среднемноголетняя заболеваемость ОРВИ в Российской Федерации за период с 2011 по 2019 г. составила 20813 на 100 тыс. населения (рис. 121). 


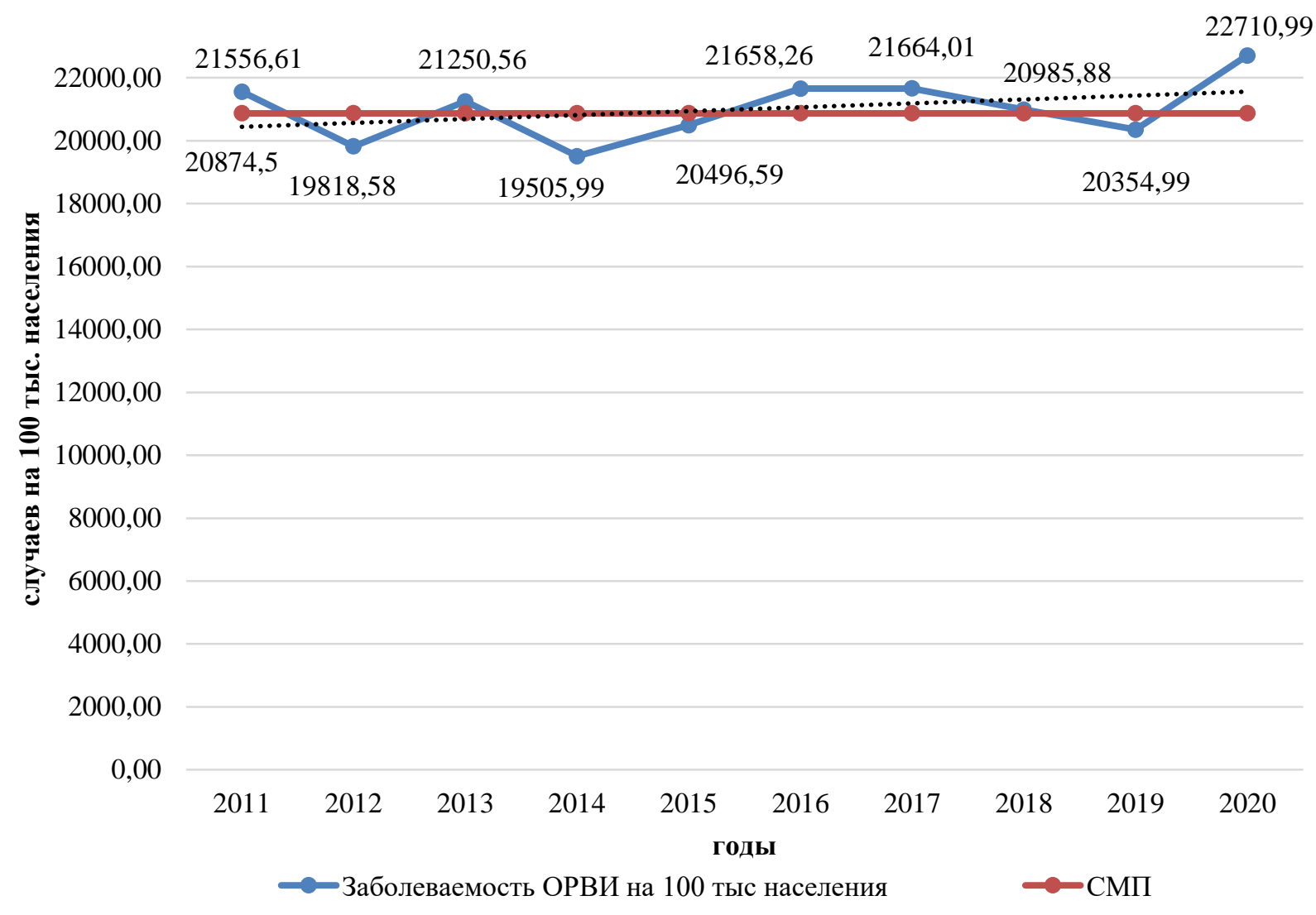

Рис. 121. Динамика заболеваемости ОРВИ (на 100 тыс. населения)

В 2020 году отмечался значительный рост заболеваемости ОРВИ в сравнении с предыдущим годом (на 11,5\%) и среднемноголетним значением - на 8,8 \% (2019 г. 20354,99 на 100 тыс. населения), показатель заболеваемости составил 22710,99 на 100 тыс. населения. Переболело 22,7 \% населения страны (зарегистрировано 33,3 млн случаев).

Данный выраженный рост заболеваемости ОРВИ связан с тем, что в 2020 году случаи COVID-19 с клинической формой ОРВИ в форме государственного статистического наблюдения учитывались совместно с OPВИ. Учет COVID-19 отдельно проводится с 2021 г. Кроме того, в начале первого зимне-весеннего эпидемического подъема заболеваемости, когда еще не были разработаны методы лабораторной диагностики и не налажено производство диагностических тест-систем, значительная часть не подтвержденных лабораторно заболеваний COVID-19 регистрировалась как ОРВИ и внебольничные пневмонии.

В 2020 году, как и в предшествующий период, заболеваемость детского населения была в 2,8 раза выше заболеваемости совокупного населения. Наибольшее количество случаев заболеваний ОРВИ в течение последних 10 лет (2011-2020 гг.) приходится на детей в возрасте до 17 лет в 2020 году их доля составила 53,6\%. В структуре заболеваемости детского населения преобладают дети в возрасте 1-2 года - 80492,03 на 100 тыс. населения и до 1 года - 79 051,36 на 100 тыс. населения.

Уровень заболеваемости ОРВИ по территориям страны имеет значительные различия, от наименьших показателей 598,16 на 100 тыс. населения в Чеченской Республике, 1674,14 на 100 тыс. населения в Республике Ингушетия и 2 189,39 в Краснодарском крае до 38790,56 на 100 тыс. населения в Архангельской области, 42 315,54 на 100 тыс. населения в Республике Коми и 50 770,68 на 100 тыс. населения в Ямало-Ненецком автономном округе. 
Государственный доклад «О состоянии санитарно-эпидемиологического благополучия населения в Российской Федерации в 2020 году»

Наиболее высокая заболеваемость среди детского населения регистрировалась в Ямало-Ненецком автономном округе, Республике Коми, Архангельской области, а также в Республике Карелия, г. Санкт-Петербурге и Костромской области (выше 93 963,12 на 100 тыс. населения).

Широкомасштабная прививочная кампания и комплексные мероприятия по информированию населения и формированию приверженности вакцинации способствуют росту охвата населения профилактическими прививками против гриппа. В результате подготовки к эпидемическому сезону 2020-2021 гг. против гриппа привито более 85,89 млн человек, что составило $59 \%$ от численности населения страны, в том числе привито более 19,62 млн детей.

В 36 субъектах Российской Федерации достигнуты охваты прививками против гриппа $60 \%$ населения и выше (табл. 45). Наименьший охват прививками населения $(50 \%)$ отмечен в Ивановской области и Республике Адыгея.

Таблица 45

\section{Субъекты Российской Федерации с наиболее высоким уровнем охвата вакцинацией против гриппа в 2020 году}

\begin{tabular}{|c|l|c|}
\hline & Российская Федерация & $59 \%$ \\
\hline 1 & Республика Мордовия & 64,5 \\
\hline 2 & Брянская область & 64,4 \\
\hline 3 & Республика Крым & 63,2 \\
\hline 4 & Калужская область & 63,1 \\
\hline 5 & Московская область & 63,0 \\
\hline 6 & Ленинградская область & 62,5 \\
\hline 7 & Республика Саха (Якутия) & 62,5 \\
\hline 8 & г. Севастополь & 62,0 \\
\hline 9 & Санкт-Петербург & 61,8 \\
\hline 10 & Свердловская область & 61,7 \\
\hline 11 & Пензенская область & 61,7 \\
\hline 12 & Республика Хакасия & 61,6 \\
\hline 13 & Ненецкий автономный округ & 61,2 \\
\hline 14 & Тульская область & 61,0 \\
\hline 15 & Мурманская область & 60,7 \\
\hline 16 & Республика Татарстан & 60,7 \\
\hline 17 & Чеченская Республика & 60,7 \\
\hline 18 & Саратовская область & 60,5 \\
\hline 19 & Ростовская область & 60,5 \\
\hline 20 & Республика Ингушетия & 60,5 \\
\hline 21 & Республика Коми & 60,4 \\
\hline 22 & Тамбовская область & 60,3 \\
\hline 23 & Республика Калмыкия & 60,2 \\
\hline 24 & Тюменская область & 60,2 \\
\hline 25 & Рязанская область & 60,1 \\
\hline 26 & Липецкая область & 60,1 \\
\hline 27 & Владимирская область & 60,1 \\
\hline 28 & Иркутская область & 60,1 \\
\hline 29 & Калининградская область & 60,0 \\
\hline 30 & Волгоградская область & 60,0 \\
\hline 31 & Амурская область & 60,0 \\
\hline 32 & Магаданская область & 60,0 \\
\hline 33 & Республика Башкортостан & 60,0 \\
\hline 34 & Сахалинская область & 60,0 \\
\hline 35 & Курганская область & 60,0 \\
\hline 36 & Томская область & 60,0 \\
\hline & & \\
\hline
\end{tabular}


Принимаемые меры по увеличению охвата вакцинацией способствовали устойчивому снижению заболеваемости гриппом в последние годы (рис. 122).

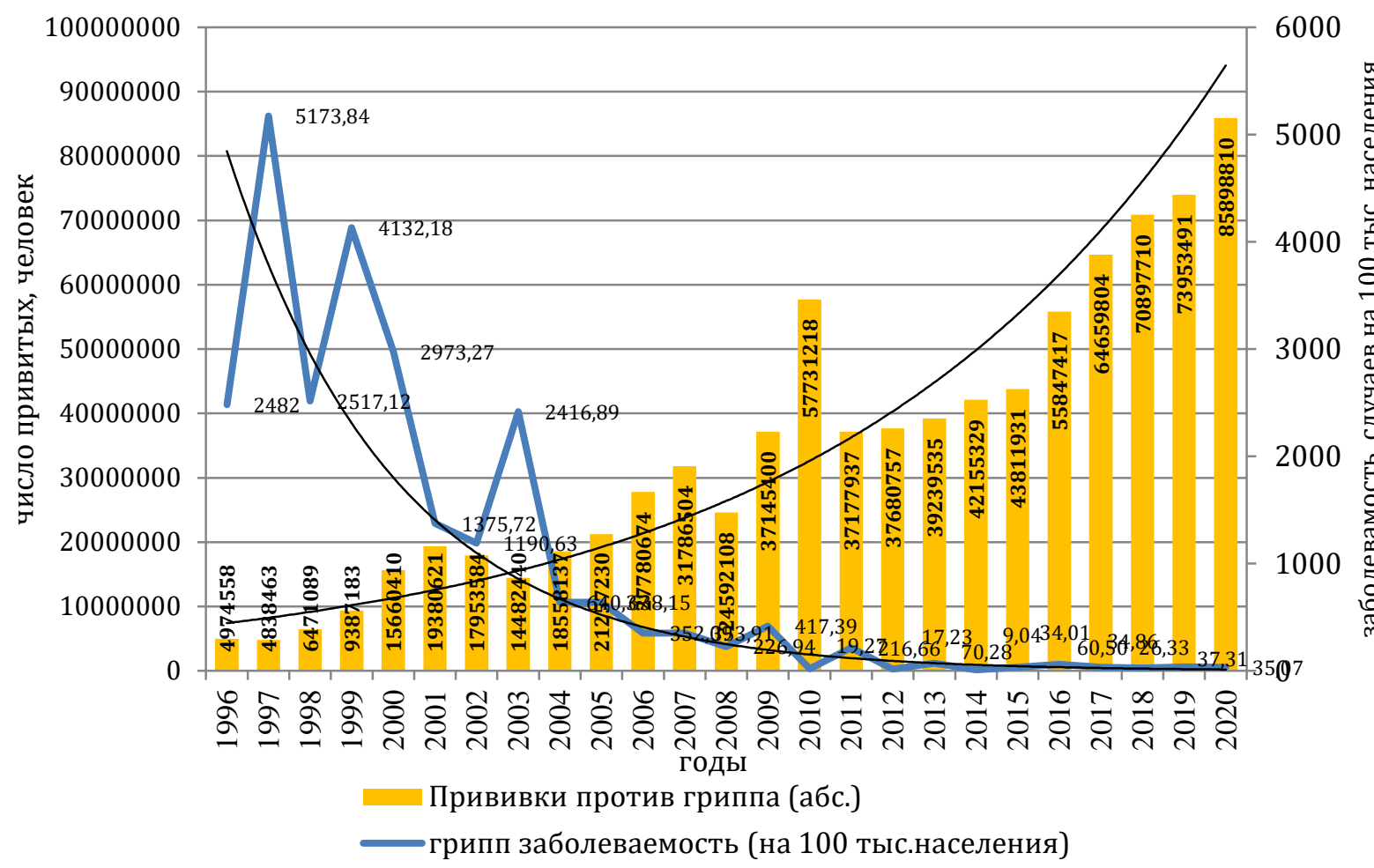

Рис. 122. Динамика заболеваемости гриппом (на 100 тыс. населения) и числа привитых против гриппа, абс.

Заболеваемость гриппом в 2020 году составила 35,07 на 100 тыс. населения, что ниже показателя прошлого года на 6 \%, среднего многолетнего показателя (СМП) (2010 2019 гг.) 52,55 на 100 тыс. населения на 33,3\%. Заболеваемость гриппом детского населения составила 92,97 на 100 тыс. населения, у возрастной группы 1-2 года - 144,08 на 100 тыс. населения, у детей 3-6 лет - 113,43 на 100 тыс. населения.

Заболеваемость гриппом, превышающая среднероссийское значение, была регистрирована среди населения 39 субъектов страны, наиболее высокая заболеваемость была отмечена в Магаданской области (169,16 на 100 тыс. населения), Ямало-Ненецком $(164,28)$, Ханты-Мансийском $(156,59)$, Чукотском $(154,1)$ автономных округах.

Доля положительных результатов, полученных молекулярно-биологическим методом, среди лиц, обследованных на грипп, в 2020 году составила 7,8 \%. Заболевания гриппом в 2020 г. были обусловлены вирусами гриппа A(H1N1)pdm09 (47 \%) и вирусами гриппа В (42 \%), в меньшей степени - вирусами гриппа А(H3N2) (12 \%).

В 2020 г. зарегистрировано 80 случаев летального исхода при гриппе, из них 13 случаев - среди детей до 17 лет.

В 2020 г. заболеваемость внебольничными пневмониями (ВП) возросла по сравнению с предыдущим годом более чем в 3,5 раза, показатель составил 1856,2 на 100 тыс. населения при среднемноголетней заболеваемости 397,4 (2011-2020 гг.) (рис. 123). При этом более чем в 100 раз относительно прошлого года увеличилась заболеваемость пневмонией вирусной этиологии, показатель составил 783,08 на 100 тыс. населения против 7,2 на 100 тыс. населения в 2019 г. 


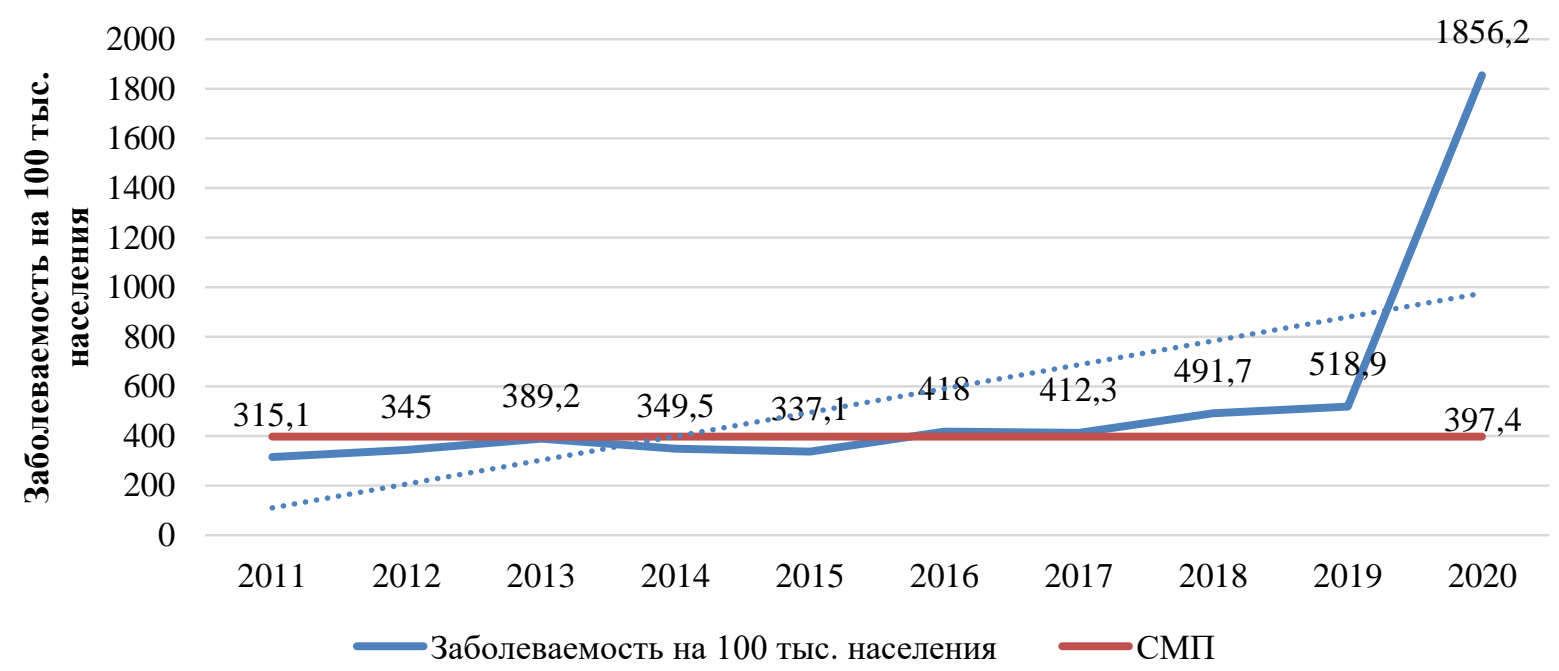

Рис. 123. Динамика заболеваемости внебольничными пневмониями (на 100 тыс. населения)

Данная ситуация объясняется тем, что в 2020 г. случаи внебольничных пневмоний, обусловленные новой коронавирусной инфекцией, учитывались в форме федерального статистического наблюдения № 2 «Сведения об инфекционных и паразитарных заболеваниях» совместно с внебольничными пневмониями вирусной этиологии. С 2021 г. случаи пневмонии, вызванные новым коронавирусом, регистрируются отдельно.

Зарегистрированное число летальных случаев от внебольничной пневмонии в 2020 году увеличилось почти в 12 раз по сравнению с предыдущим годом (65 232 и 5484 случая среди всего населения соответственно), что составило 44,45 на 100 тыс. населения, что также обусловлено в значительной мере новой коронавирусной инфекцией.

Вместе с тем доля детского населения в заболеваемости внебольничными пневмониями по сравнению с прошлым годом снизилась более чем в 5 раз и составила 6,6 \%, при этом заболеваемость детского населения снизилась по сравнению с 2019 г. на 38 \% и составила 595,2 на 100 тыс. населения. Максимальный показатель заболеваемости ВП наблюдался в возрастной группе до года (1 075,83 на 100 тыс.).

Отмечается неравномерная заболеваемость ВП в различных субъектах Российской Федерации (от 379,87 до 3965,99 на 100 тыс. населения) с тенденцией к росту в ряде регионов страны (табл. 46).

Таблица 46

\section{Субъекты Российской Федерации с более высоким уровнем заболеваемости внебольничными пневмониями}

\begin{tabular}{|l|c|c|c|}
\hline \multicolumn{1}{|c|}{ Российской Федерации } & $\begin{array}{c}\text { Заболеваемость } \\
\text { на } 100 \text { тыс. населения } \\
2019 \text { г. }\end{array}$ & $\begin{array}{c}\text { Заболеваемость } \\
\text { на } 100 \text { тыс. населения } \\
2020 \text { г. }\end{array}$ & $\begin{array}{c}\text { СМП (2011- } \\
2020 \text { гг.) }\end{array}$ \\
\hline Российская Федерация & 518,90 & 1856,18 & 397,4 \\
\hline Тверская область & 710,24 & 3965,99 & 523,6 \\
\hline Смоленская область & 571,23 & 3453,35 & 365,2 \\
\hline Удмуртская Республика & 1003,30 & 3445,95 & 590,3 \\
\hline Самарская область & 590,45 & 3149,32 & 491,9 \\
\hline Республика Калмыкия & 422,93 & 3074,39 & 378,3 \\
\hline Хабаровский край & 1168,69 & 3043,48 & 528,2 \\
\hline
\end{tabular}


В 2020 году зарегистрировано 12 очагов групповой заболеваемости внебольничными пневмониями с 127 пострадавшими, из которых 99 \% составили дети до 17 лет. Вспышки зарегистрированы в 5 субъектах страны. Наиболее часто вспышки регистрировались в общеобразовательных учреждениях (11 вспышек), где и было зарегистрировано наибольшее количество пострадавших (122 человека). При обследовании очагов в 11 из них изолирована Mycoplasma pneumoniae, в 1 - сочетание возбудителей Mycoplasma pneumonia и Streptococcus pneumonia. В Российской Федерации на протяжении 13-летнего периода продолжается неуклонное снижение заболеваемости туберкулезом. В 2020 г. зарегистрировано 47063 новых случая заболевания, показатель заболеваемости составил 32,07 на 100 тыс. населения, среднемноголетний показатель заболеваемости составил 60,07. По сравнению с 2019 г. заболеваемость снизилась на 21,93\% (рис. 124).

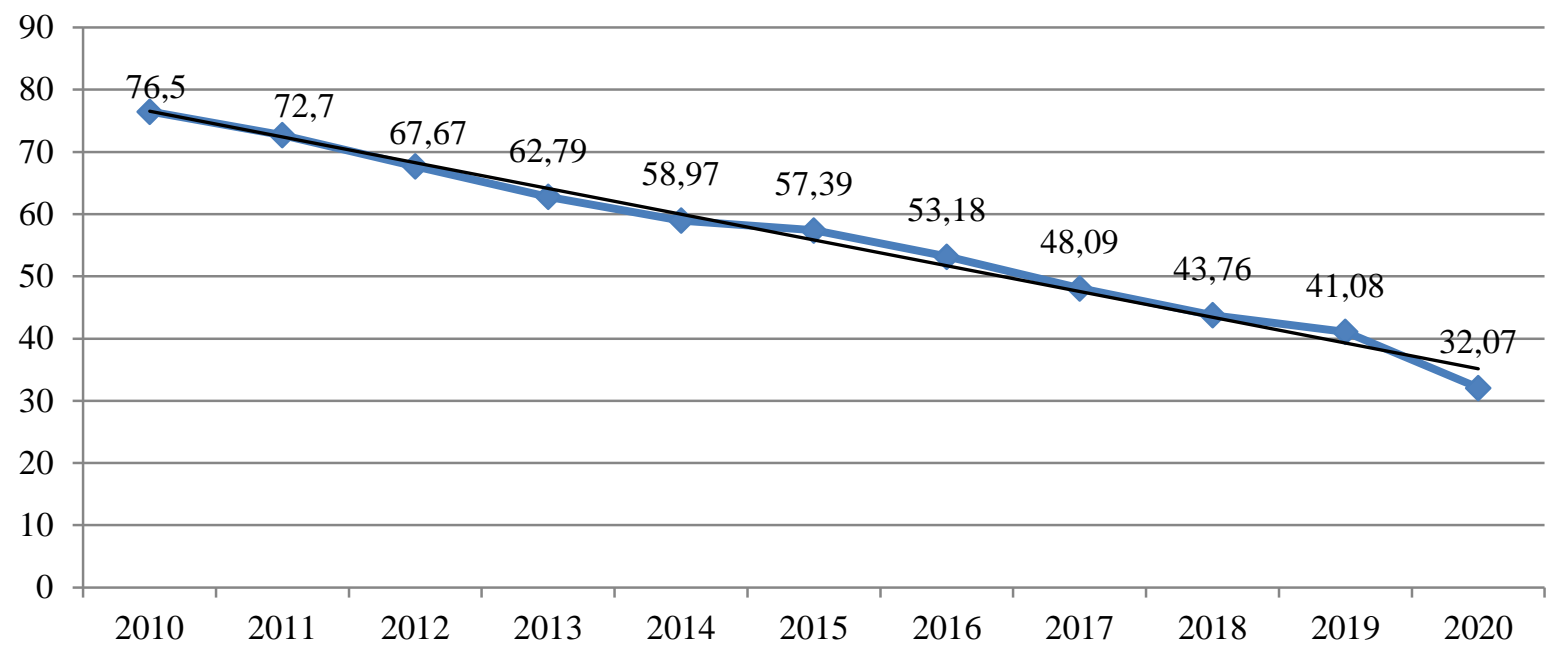

Рис. 124. Динамика заболеваемости туберкулёзом в Российской Федерации в 2010-2020 гг. (на 100 тыс. населения)

В 2020 г., как и в течение 13-летнего периода, наиболее высокая заболеваемость активным туберкулезом на территории Российской Федерации продолжает регистрироваться в Сибирском, Дальневосточном и Уральском федеральных округах: $57,58,53,47$ и 43,56 на 100 тыс. населения соответственно, хотя в них также отмечается уменьшение показателя заболеваемости на $22,25 \%, 19,34 \%$ и 22,3 \% соответственно по сравнению в 2019 годом.

Лидерами среди регионов с высокой заболеваемостью туберкулезом всего населения в 2020 г. продолжают оставаться Чукотский автономный округ, где заболеваемость составила 126,06 на 100 тыс. населения, Республика Тыва - 86,53, Приморский край - 74,71, Кемеровская область - Кузбасс - 72,28, Новосибирская область - 71,5 и Хабаровский край - 66,59, Еврейская автономная область - 60,96, Иркутская область - 60,72, Астраханская область - 59,61, Курганская область - 56,80. Во всех этих регионах наблюдается тенденция к снижению заболеваемости.

Заболеваемость детей от 0 до 17 лет впервые выявленным активным туберкулезом в период с 2009 по 2020 гг. также имеет общую тенденцию к снижению. Медленнее всего снижение наблюдается в возрастной категории детей от 0 до 1 года.

Среди регионов с наибольшей заболеваемостью детей до 17 лет продолжают лидировать Чукотский автономный округ - 55,18 и Республика Тыва - 32,86 на 100 тыс. детского населения. Далее в рейтинге с 3 по 10 места следуют Еврейская автономная область - 21,67, Астраханская область - 20,65, Магаданская область - 20,29, Приморский край - 19,92, Новосибирская область - 17,68, Хабаровский край - 16,23, Алтайский край 
Государственный доклад «О состоянии санитарно-эпидемиологического благополучия населения в Российской Федерации в 2020 году»

- 15,87 и Республика Саха (Якутия) - 15,14. Во всех этих регионах наблюдается тенденция к уменьшению заболеваемости детей, за исключением Магаданской области. Заболеваемость детей служит индикатором распространенности туберкулеза среди взрослых, но в ряде субъектов Российской Федерации отмечается несоответствие показателей заболеваемости детей и взрослых (табл. 47).

Таблица 47

\section{Субъекты Российской Федерации с наиболее высокой заболеваемостью туберкулезом среди населения (на 100 тыс. населения)}

\begin{tabular}{|c|c|c|c|c|c|c|c|c|}
\hline \multirow[b]{2}{*}{$\begin{array}{l}\text { Субъекты } \\
\text { Российской } \\
\text { Федерации }\end{array}$} & \multicolumn{4}{|c|}{ Все население } & \multicolumn{4}{|c|}{ Детское население } \\
\hline & 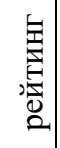 & $\begin{array}{c}\text { заболеваем } \\
\text { ость }\end{array}$ & $\begin{array}{c}\text { тенденция } \\
2011-2020 \\
\text { гг. }\end{array}$ & $\begin{array}{c}\text { СМП } \\
\text { (2010-2019 } \\
\text { гг.) }\end{array}$ & 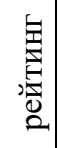 & $\begin{array}{c}\text { заболеваем } \\
\text { ость }\end{array}$ & $\begin{array}{c}\text { тенденция } \\
2011-2020 \\
\text { гг. }\end{array}$ & $\begin{array}{c}\text { СМП } \\
(2010- \\
2019 \text { гг.) }\end{array}$ \\
\hline $\begin{array}{l}\text { Российская } \\
\text { Федерация }\end{array}$ & - & 32,07 & $\downarrow$ & 60,07 & - & 7,19 & $\downarrow$ & 14,72 \\
\hline $\begin{array}{l}\text { Чукотский } \\
\text { автономный округ }\end{array}$ & 1 & 126,06 & $\downarrow$ & 145,07 & 1 & 55,18 & $\downarrow$ & 64,86 \\
\hline Республика Тыва & 2 & 86,53 & $\downarrow$ & 177,13 & 2 & 32,86 & $\downarrow$ & 54,72 \\
\hline Приморский край & 3 & 74,71 & $\downarrow$ & 139,65 & 6 & 19,92 & $\downarrow$ & 43,05 \\
\hline $\begin{array}{l}\text { Кемеровская } \\
\text { область - Кузбасс }\end{array}$ & 4 & 72,28 & $\downarrow$ & 109,51 & 17 & 11,42 & $\downarrow$ & 32,59 \\
\hline $\begin{array}{l}\text { Новосибирская } \\
\text { область }\end{array}$ & 5 & 71,50 & $\downarrow$ & 106,88 & 7 & 17,68 & $\downarrow$ & 25,36 \\
\hline Хабаровский край & 6 & 66,59 & $\downarrow$ & 106,88 & 8 & 16,23 & $\downarrow$ & 26,37 \\
\hline $\begin{array}{l}\text { Еврейская } \\
\text { автономная } \\
\text { область }\end{array}$ & 7 & 60,96 & $\downarrow$ & 138,32 & 3 & 21,67 & $\downarrow$ & 30,79 \\
\hline Иркутская область & 8 & 60,72 & $\downarrow$ & 116,65 & 35 & 7,77 & $\downarrow$ & 27,85 \\
\hline \begin{tabular}{|l} 
Астраханская \\
область
\end{tabular} & 9 & 59,61 & $\downarrow$ & 92,28 & 4 & 20,65 & $\downarrow$ & 40,62 \\
\hline Курганская область & 10 & 56,80 & $\downarrow$ & 103,42 & 52 & 5,04 & $\downarrow$ & 15,35 \\
\hline \begin{tabular}{|l|} 
Магаданская \\
область
\end{tabular} & 43 & 27,72 & $\downarrow$ & 60,13 & 5 & 20,29 & $\uparrow$ & 43,40 \\
\hline Алтайский край & 11 & 56,17 & $\downarrow$ & 103,26 & 9 & 15,87 & $\downarrow$ & 28,65 \\
\hline $\begin{array}{l}\text { Республика Саха } \\
\text { (Якутия) }\end{array}$ & 35 & 31,46 & $\downarrow$ & 68,65 & 10 & 15,14 & $\downarrow$ & 24,67 \\
\hline
\end{tabular}

Так, в Республике Саха (Якутия) заболеваемость детей занимает 10-е место в рейтинге регионов с наибольшей заболеваемостью среди этой категории населения, тогда как заболеваемость всего населения находится на 35 месте. В Магаданской области заболеваемость детей находится на 5 месте, а заболеваемость всего населения на 43 месте. Эти данные свидетельствуют о недовыявлении или о несвоевременном выявлении больных туберкулезом взрослых. К субъектам, где наблюдается обратная тенденция, относятся Кемеровская, Иркутская и Курганская области - при высокой заболеваемости взрослых (4, 8 и 10 места в рейтинге) заболеваемость детей находится на 17, 35 и 52 местах, что говорит о необходимости усилить профилактические осмотры среди детей. Учитывая разрыв в сроках между началом заболевания и диагностикой туберкулеза даже при активном выявлении в процессе профилактических осмотров, необходимо исключить инфицирование детей.

Несмотря на снижение заболеваемости туберкулезом, как у жителей города, так и у жителей села, удельный вес числа больных туберкулезом среди этих категорий на 
Государственный доклад «О состоянии санитарно-эпидемиологического благополучия населения в Российской Федерации в 2020 году»

протяжении 11 лет остается практически неизменным (рис. 125), что на фоне снижения общего количества больных свидетельствует об отсутствии усилий по обеспечению раннего обращения и доступности медицинской помощи и, следовательно, по нижению количества выявляемых очагов заболевания у жителей сельской местности.

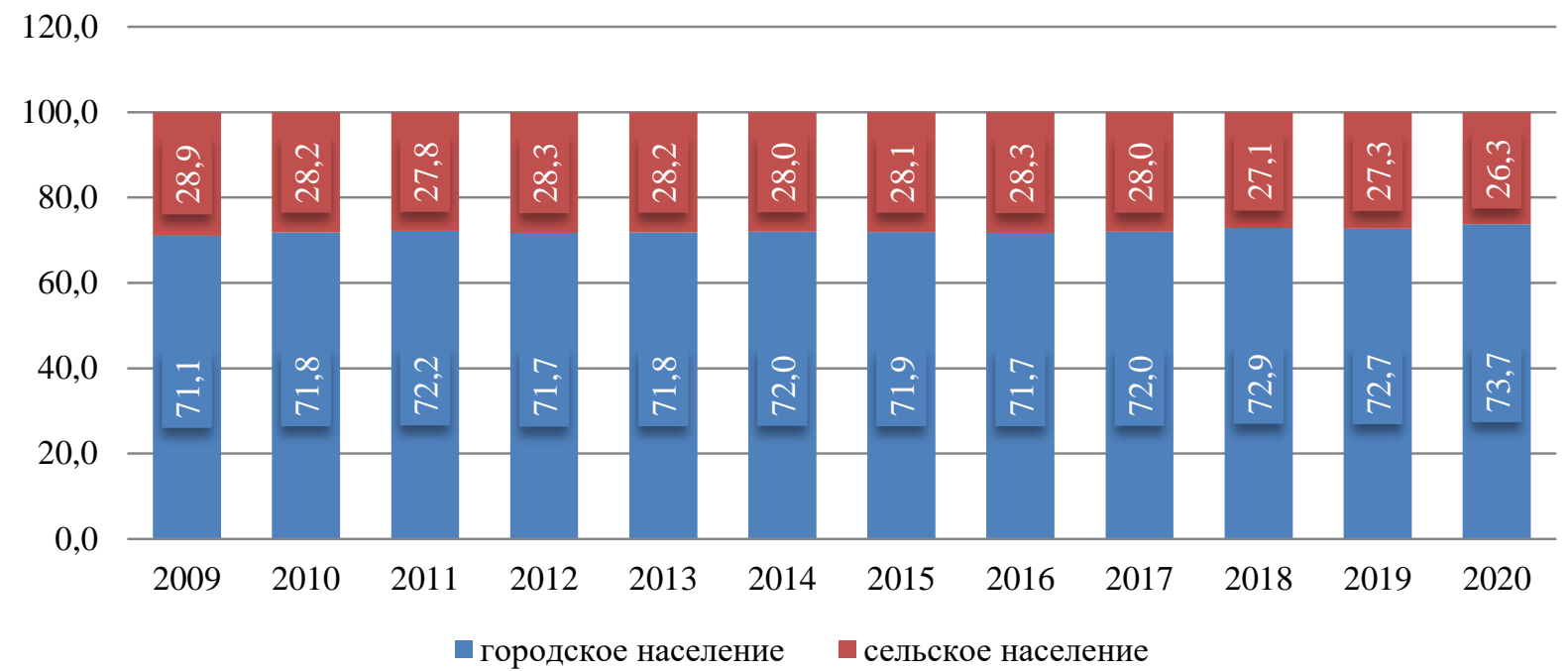

Рис. 125. Удельный вес числа больных впервые выявленным активным туберкулезом в Российской Федерации среди городских и сельских жителей в 2009-2020 гг., \%

Среди городского населения заболеваемость ниже, чем в среднем по стране, и за 11 -летний период среднемноголетний показатель заболеваемости составил 54,44 $\pm 13,47$ на 100 тыс. населения городов. В то же время заболеваемость туберкулезом среди жителей сельской местности выше - 59,78 \pm 14,74 на 100 тыс. населения жителей села (табл. 48).

Таблица 48

Субъекты Российской Федерации с наиболее высокой заболеваемостью туберкулезом среди населения, в том числе жителей сельской местности (на 100 тыс. населения)

\begin{tabular}{|c|c|c|c|c|c|c|c|}
\hline \multirow[b]{2}{*}{$\begin{array}{l}\text { № } \\
\Pi / \Pi\end{array}$} & \multirow[b]{2}{*}{$\begin{array}{c}\text { Субъекты } \\
\text { Российской Федерации }\end{array}$} & \multicolumn{3}{|c|}{ Все население } & \multicolumn{3}{|c|}{ Сельское население } \\
\hline & & $\begin{array}{l}\text { Заболевае- } \\
\text { мость }\end{array}$ & $\begin{array}{c}\text { Тенденция } \\
2011-2020 \\
\text { гг. }\end{array}$ & $\begin{array}{c}\text { СМП } \\
(2010- \\
2019 \text { гг.) }\end{array}$ & $\begin{array}{l}\text { Заболевае- } \\
\text { мость }\end{array}$ & $\begin{array}{c}\text { Тенденция } \\
2011-2020 \\
\text { гг. }\end{array}$ & $\begin{array}{c}\text { СМП } \\
(2010- \\
2019 \text { гг.) }\end{array}$ \\
\hline 1 & Российская Федерация & 32,07 & $\downarrow$ & 60,07 & 33,21 & $\downarrow$ & 59,78 \\
\hline 1 & $\begin{array}{l}\text { Чукотский автономный } \\
\text { округ }\end{array}$ & 126,06 & $\uparrow$ & 148,95 & 298,78 & $\uparrow$ & 275,32 \\
\hline 2 & Республика Тыва & 86,53 & $\downarrow$ & 170,76 & 62,97 & $\downarrow$ & 176,65 \\
\hline 3 & Приморский край & 74,71 & $\downarrow$ & 132,93 & 85,41 & $\downarrow$ & 158,81 \\
\hline 4 & Кемеровская область & 72,28 & $\downarrow$ & 107,23 & 69,36 & $\downarrow$ & 101,05 \\
\hline 5 & Новосибирская область & 71,5 & $\downarrow$ & 104,19 & 73,13 & $\downarrow$ & 113,08 \\
\hline 6 & Хабаровский край & 66,59 & $\downarrow$ & 105,03 & 76,97 & $\downarrow$ & 133,84 \\
\hline 7 & $\begin{array}{l}\text { Еврейская автономная } \\
\text { область }\end{array}$ & 60,96 & $\downarrow$ & 134,25 & 60,32 & $\downarrow$ & 147,85 \\
\hline 8 & Иркутская область & 60,72 & $\downarrow$ & 113,26 & 76,4 & $\downarrow$ & 94,17 \\
\hline 9 & Астраханская область & 59,61 & $\downarrow$ & 92,11 & 68,17 & $\downarrow$ & 94,37 \\
\hline 10 & Алтайский край & 56,17 & $\downarrow$ & 100,81 & 56,68 & $\downarrow$ & 91,47 \\
\hline 11 & Магаданская область & 27,72 & $\downarrow$ & 58,46 & 72,39 & $\uparrow$ & 52,7 \\
\hline
\end{tabular}


Государственный доклад «О состоянии санитарно-эпидемиологического благополучия населения в Российской Федерации в 2020 году»

В число случаев впервые выявленного туберкулеза включаются и случаи завоза этой инфекции из различных стран, что встречается ежегодно и практически повсеместно - в 2020 г. завоз был осуществлён на территорию 55 субъектов Российской Федерации. В подавляющем большинстве случаев такие больные туберкулёзом въезжают из стран СНГ (табл. 49).

Таблица 49

\section{Распределение завозных случаев туберкулёза в Российской Федерации} по странам возможного заражения в 2012-2020 гг.

\begin{tabular}{|c|l|c|c|c|c|c|c|c|c|c|c|}
\hline $\begin{array}{c}\text { № } \\
\text { п/п }\end{array}$ & $\begin{array}{c}\text { произошлона, где } \\
\text { заражениежное }\end{array}$ & 2012 & 2013 & 2014 & 2015 & 2016 & 2017 & 2018 & 2019 & 2020 & Итого \\
\hline 1 & Узбекистан & 780 & 759 & 748 & 1008 & 833 & 745 & 580 & 732 & 307 & 6492 \\
\hline 2 & Таджикистан & 367 & 407 & 395 & 619 & 557 & 641 & 428 & 565 & 305 & 4284 \\
\hline 3 & Украина & 161 & 193 & 660 & 586 & 341 & 247 & 189 & 149 & 64 & 2590 \\
\hline 4 & Кыргызстан & 169 & 203 & 205 & 229 & 232 & 203 & 211 & 273 & 225 & 1950 \\
\hline 5 & Азербайджан & 190 & 189 & 144 & 191 & 168 & 163 & 118 & 112 & 37 & 1312 \\
\hline 6 & Молдова & 88 & 83 & 150 & 131 & 94 & 91 & 64 & 41 & 27 & 769 \\
\hline 7 & Армения & 88 & 91 & 108 & 57 & 49 & 41 & 41 & 19 & 19 & 513 \\
\hline 8 & Казахстан & 92 & 74 & 84 & 79 & 39 & 50 & 42 & 30 & 17 & 507 \\
\hline 9 & Вьетнам & 26 & 23 & 31 & 25 & 32 & 32 & 33 & 40 & 19 & 261 \\
\hline 10 & Китай & 21 & 31 & 32 & 34 & 31 & 19 & 29 & 33 & 3 & 233 \\
\hline 11 & Туркменистан & 9 & 23 & 17 & 10 & 14 & 8 & 12 & 24 & 10 & 131 \\
\hline 12 & Беларусь & 10 & 26 & 11 & 17 & 15 & 9 & 8 & 4 & 3 & 103 \\
\hline 13 & Грузия & 2101 & 2226 & 2678 & 3066 & 2549 & 2359 & 1832 & 2118 & 1107 & 20036 \\
\hline $\begin{array}{l}\text { Завезено случаев } \\
\text { туберкулеза в Российскую } \\
\text { Федерацию, всего }\end{array}$ & & & & & & 9 & 14 & 24 & 16 & 16 & 120 \\
\hline
\end{tabular}

С 2003 по 2019 г. ежегодный охват своевременной вакцинацией против туберкулеза в целом по стране составляет более $95 \%$. В 2020 г. данный показатель составил 94,69 \%, к субъектам Россйиской Федерации, где данный показатель в 2020 г. достигнут не был, относятся Московская, Курганская, Ярославская, Новгородская, Самарская области, Забайкальский, Приморский и Хабаровский края, республики Карелия, Дагестан, Чеченская, Ханты-Мансийский автономный округ, г. Москва.

Эпидемиологическая ситуация по ВИЧ-инфекции в Российской Федерации продолжает оставаться напряженной. В 2020 г. было зарегистрировано 61232 новых случая болезни, вызванной вирусом иммунодефицита человека (ВИЧ). Показатель заболеваемости ВИЧ-инфекцией в 2020 г. составил 41,72 на 100 тыс. населения, что на $25,0 \%$ меньше, чем в 2019 г. (2019 г. - 55,65).

Превышение среднероссийского показателя заболеваемости ВИЧ-инфекцией в 2020 г. отмечено в 32 субъектах Российской Федерации: Кемеровская область (зарегистрировано 129,70 новых случаев ВИЧ-инфекции на 100 тыс. населения), Пермский край $(95,47)$, Иркутская область $(87,74)$, Красноярский край $(83,93)$, Оренбургская $(85,46)$, Тюменская $(77,88)$, Томская $(74,56)$, Челябинская $(71,25)$, Новосибирская $(69,75)$, Самарская $(69,41)$, Курганская $(68,72)$, Омская $(64,07)$ области, Алтайский край $(61,85)$, Удмуртская Республика $(57,57)$, Свердловская $(59,58)$, Ульяновская $(55,83)$ области, Чукотский автономный округ $(52,03)$, Ивановская область $(51,27)$, Ханты-Мансийский автономный округ $(49,00)$, Мурманская область $(47,53)$, Республика Коми $(47,25)$, Тульская область $(46,93)$, Республика Хакасия $(46,52)$, 
Нижегородская область $(45,87)$, г. Севастополь $(45,72)$, Тверская область $(44,82)$, Приморский край $(44,44)$, Московская $(43,79)$, Новгородская $(43,45)$, Ярославская $(42,74)$ области, республики Бурятия $(43,06)$ и Башкортостан $(41,86)$. В вышеперечисленных регионах было зарегистрировано 66,2 \% всех новых случаев ВИЧ-инфекции в 2020 г.

На протяжении всего периода распространения ВИЧ-инфекции в России обеспечивался высокий охват населения тестированием на ВИЧ. В 2020 г. в условиях активного распространения новой коронавирусной инфекции в России прошли медицинское освидетельствование на ВИЧ-инфекцию около 35,5 млн россиян $(24,2 \%$ от общей численности населения), что на 12,4\% меньше, чем в 2019 г. (рис. 125). За последние 10 лет охват тестированием на ВИЧ вырос на 43,7\% (в 2011 г. было обследовано 24,7 млн россиян).

Доля представителей ключевых и уязвимых групп населения среди обследованных на ВИЧ-инфекцию остается низкой. При этом наиболее высокий уровень пораженности ВИЧ-инфекцией в России регистрируется именно среди ключевых и уязвимых контингентов населения. При тестировании на ВИЧ в уязвимых группах населения ВИЧ-инфекция выявляется в среднем в 7 раз чаще, чем в основной популяции, поэтому задача тестирования на ВИЧ и привлечения к диспансерному наблюдению именно уязвимых групп (особенно наркопотребителей) остается очень актуальной.

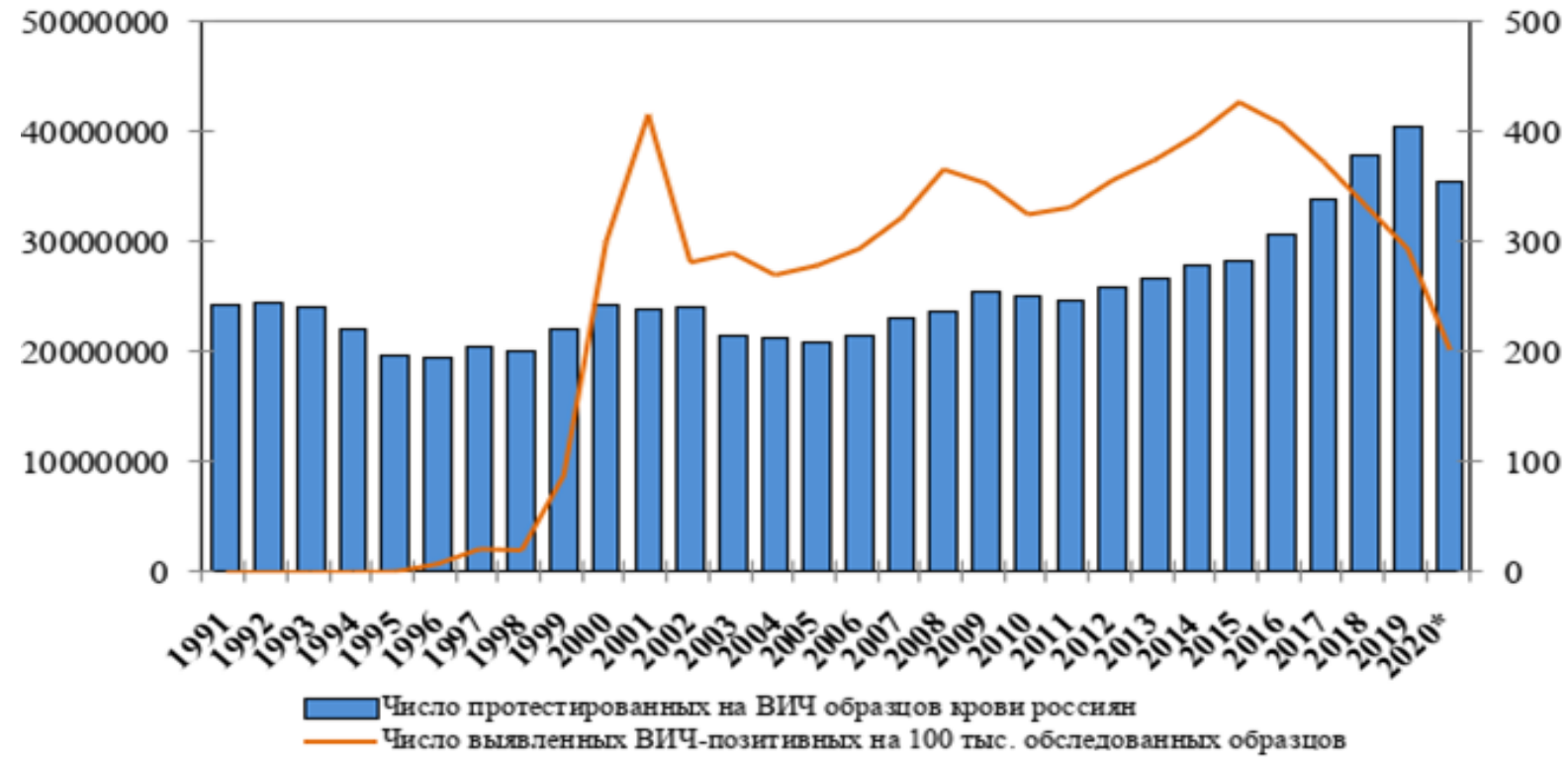

Рис. 126. Частота выявления новых случаев ВИЧ-инфекции в иммуноблоте среди граждан Российской Федерации, протестированных на ВИЧ, в 1991-2020 гг., абс.

В 2020 году умерло 32208 инфицированных ВИЧ, что на 4,3 \% меньше, чем за тот же период 2019 года. Умирают инфицированные ВИЧ в молодом возрасте - в среднем в 41 год. Ведущей причиной летальных исходов среди инфицированных ВИЧ остается туберкулез. Количество летальных исходов среди инфицированных ВИЧ ежегодно увеличивалось с 1987 по 2018 г. В 2019-2020 гг. благодаря значительному увеличению числа больных, получающих АРТ, было отмечено снижение заболеваемости и смертности от ВИЧ-инфекции.

Показатель пораженности ВИЧ-инфекцией составил 728,2 на 100 тыс. населения. Случаи ВИЧ-инфекции зарегистрированы во всех субъектах Российской Федерации (табл. 50). 
Субъекты Российской Федерации с наиболее высокой заболеваемостью и пораженностью ВИЧ-инфекцией в 2020 г.

\begin{tabular}{|c|c|c|c|c|}
\hline № $\Pi / \Pi$ & $\begin{array}{c}\text { Субъекты } \\
\text { Российской Федерации }\end{array}$ & $\begin{array}{c}\text { Показатель } \\
\text { заболеваемости } \\
\text { ВИЧ-инфекцией }\end{array}$ & $\begin{array}{c}\text { Тенденция } \\
\text { 2011-2020 гг. }\end{array}$ & $\begin{array}{c}\text { Показатель } \\
\text { пораженности ВИЧ- } \\
\text { инфекцией }\end{array}$ \\
\hline & Российская Федерация & 41,72 & $\uparrow$ & 728,2 \\
\hline 1 & Кемеровская область - Кузбасс & 129,7 & $\uparrow$ & 1998,6 \\
\hline 2 & Пермский край & 95,47 & $\uparrow$ & 1231,2 \\
\hline 3 & Иркутская область & 87,74 & $\uparrow$ & 1953,5 \\
\hline 4 & Оренбургская область & 85,46 & $\uparrow$ & 1520,0 \\
\hline 5 & Красноярский край & 83,93 & $\uparrow$ & 1142,5 \\
\hline 6 & Тюменская область & 77,88 & $\uparrow$ & 1284,1 \\
\hline 7 & Томская область & 74,56 & $\uparrow$ & 1066,5 \\
\hline 8 & Челябинская область & 71,25 & $\uparrow$ & 1365,1 \\
\hline 9 & Новосибирская область & 69,75 & $\downarrow$ & 1323,3 \\
\hline 10 & Самарская область & 69,41 & $\uparrow$ & 1496,9 \\
\hline 11 & Курганская область & 68,72 & $\uparrow$ & 1067,3 \\
\hline 12 & Омская область & 64,07 & $\uparrow$ & 938,3 \\
\hline 13 & Алтайский край & 61,85 & $\uparrow$ & 1058,7 \\
\hline 14 & Свердловская область & 59,58 & $\uparrow$ & 1854,9 \\
\hline 15 & Ульяновская область & 55,83 & $\uparrow$ & 1084,3 \\
\hline 16 & Ивановская область & 51,27 & $\uparrow$ & 927,7 \\
\hline 17 & $\begin{array}{l}\text { Ханты-Мансийский автономный } \\
\text { округ - Югра }\end{array}$ & 49,0 & $\downarrow$ & 1350,2 \\
\hline 18 & Мурманская область & 47,53 & $\uparrow$ & 801,9 \\
\hline 19 & Тверская область & 44,82 & $\uparrow$ & 900,6 \\
\hline 20 & Республика Крым & 41,21 & $\downarrow$ & 1184,2 \\
\hline 21 & Санкт-Петербург & 40,49 & $\downarrow$ & 973,4 \\
\hline 22 & Ленинградская область & 37,81 & $\downarrow$ & 1273,1 \\
\hline
\end{tabular}

Регистрируется рост числа регионов с высокой пораженностью ВИЧ-инфекцией (более $0,5 \%$ от численности общей популяции): с 22 (2014 г.) до 38 (2020 г.). В этих регионах проживало подавляющее большинство $(83,8 \%)$ всех инфицированных ВИЧ.

В настоящее время в России наблюдаются тенденции распространения ВИЧинфекции среди населения наиболее трудоспособного возраста, увеличения возраста людей, живущих с ВИЧ, и уменьшения доли новых случаев ВИЧ у лиц моложе 30 лет (рис. 127).

В 2000 г. 86,7 \% ВИЧ-инфицированных получили диагноз в возрасте 15-29 лет, к 2010 г. их доля снизилась до 44,3 \%. В 2020 г. 85,3 \% больных были впервые выявлены в возрасте старше 30 лет. Преимущественно в 2020 г. ВИЧ-инфекция диагностировалась у россиян в возрасте $30-49$ лет (71,4 \% новых случаев). Доля подростков и молодежи в возрасте 15-20 лет снизилась в 2020 г. до 0,8 \%; в 2000 г. на их долю приходилось $24,7 \%$ новых случаев ВИЧ-инфекции, а в 2010 г. $-2,2 \%$. 


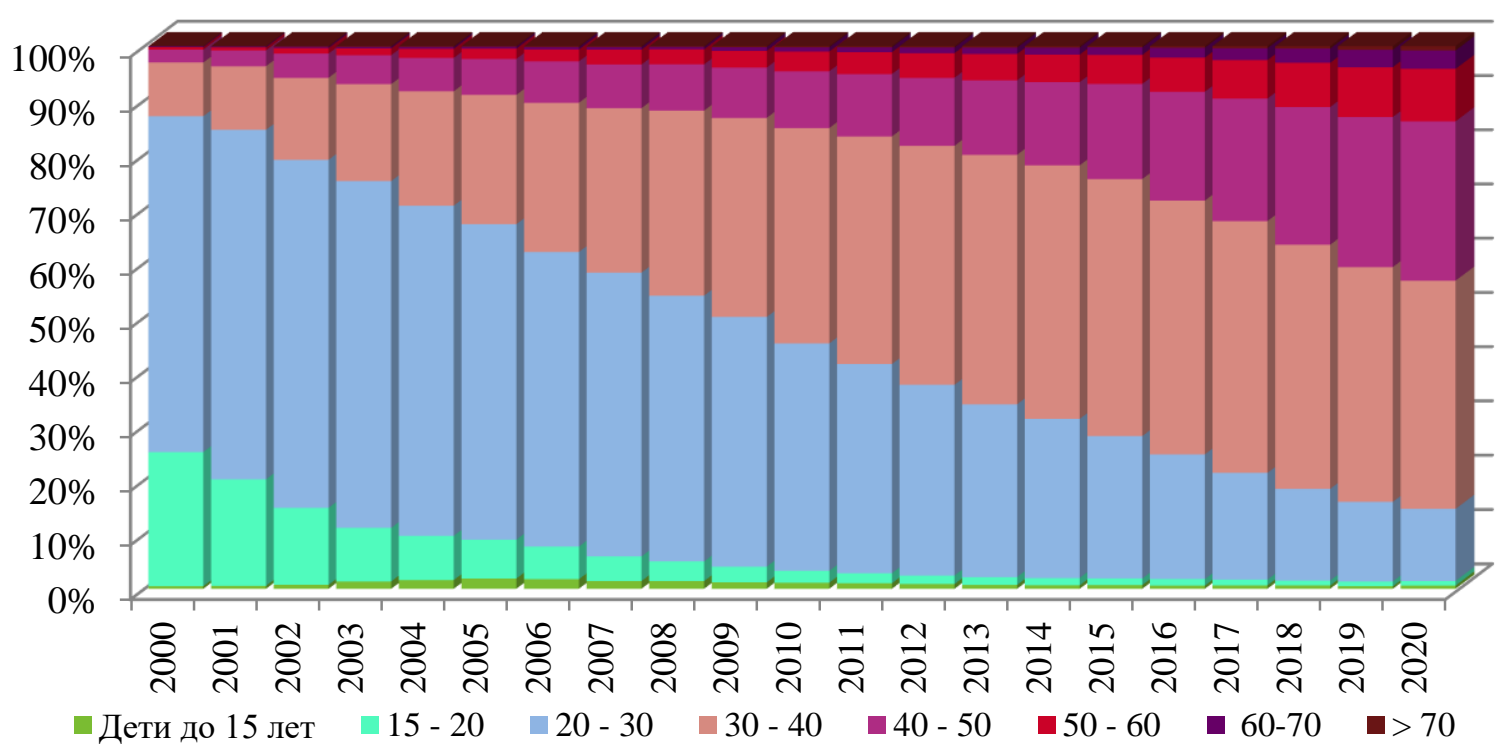

Рис. 127. Распределение ВИЧ-инфицированных в России среди новых случаев ВИЧ-инфекции по возрасту на момент выявления в 2000-2020 гг., \%

Среди больных ВИЧ-инфекцией в стране доминировали мужчины $(62,6 \%)$ среди всех зарегистрированных случаев заболевания и 60,8 \% от впервые выявленных в 2020 г. россиян. Наиболее поражены ВИЧ-инфекцией в 2019 г. были мужчины в возрасте 35-44 года (более 3 \% инфицированных ВИЧ) и женщины в возрасте 35-39 лет $(2,1 \%)$. Среди населения в возрасте 15-49 лет 1,4 \% были инфицированы ВИЧ.

В течение последних пяти лет в России ВИЧ-инфекция вышла за пределы уязвимых групп населения и активно распространяется в общей популяции. Большинство больных, впервые выявленных в 2020 г., заразились при гетеросексуальных контактах $(64,9 \%)$, доля инфицированных ВИЧ при употреблении наркотиков снизилась до $31,1 \%$ (рис. 128).

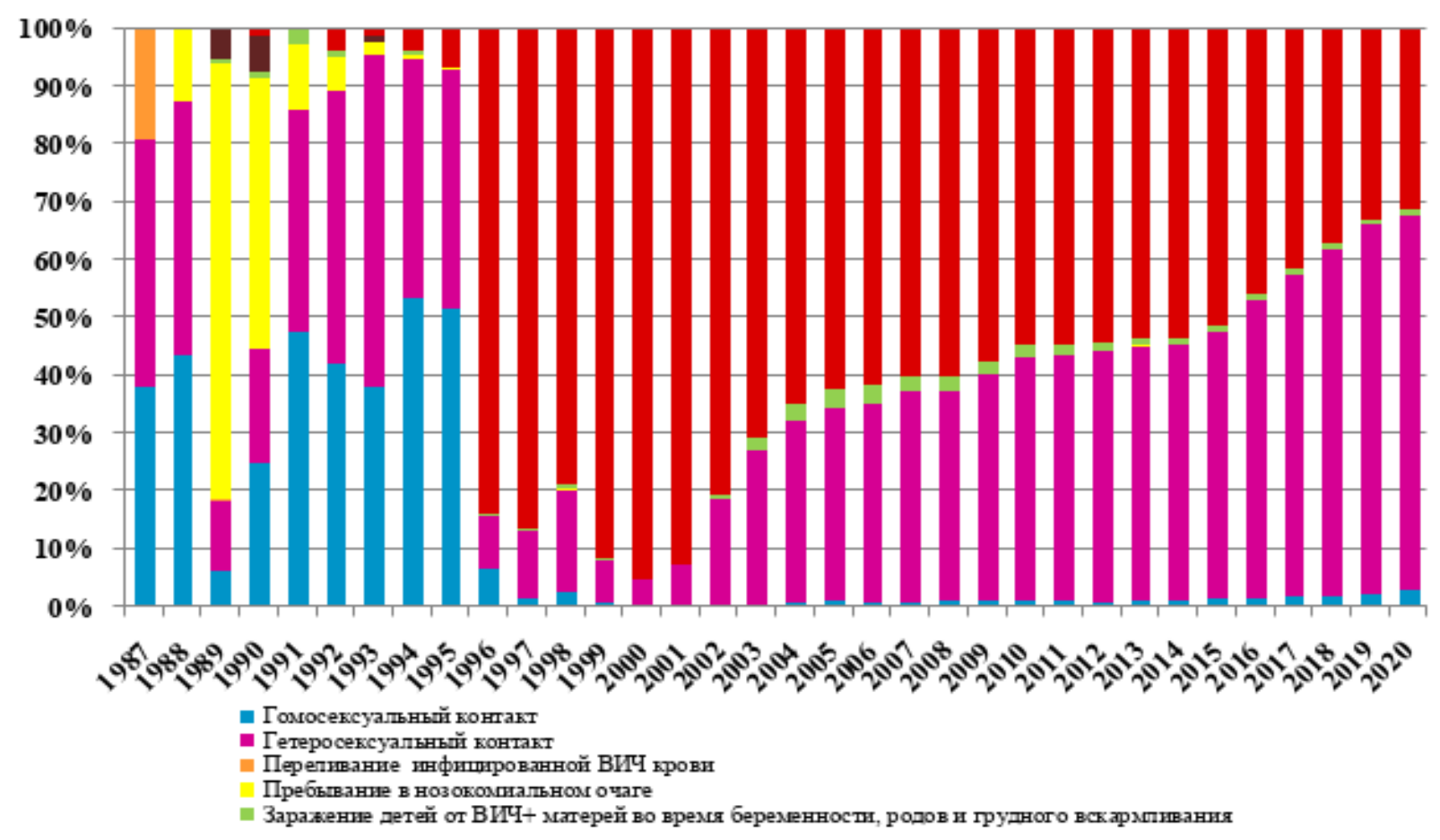

Рис. 128. Распределение инфицированных ВИЧ в России по основным известным факторам риска заражения, \% 
В 2020 г. в России родилось 13186 детей от ВИЧ-инфицированных матерей, из которых у 165 детей (1,3\%) подтверждена ВИЧ-инфекция.

На диспансерном учете в 2020 г. состояло 788938 инфицированных ВИЧ россиян, получали антиретровирусную терапию 604999 пациентов. Впервые были взяты на антиретровирусную терапию в 2020 г. 106106 инфицированных ВИЧ. Охват лечением составил 76,7 \% от числа состоявших на диспансерном наблюдении. В 2020 г. у 75,1 \% получавших АРТ была подавлена вирусная нагрузка.

Предупреждение распространения ВИЧ-инфекции продолжает оставаться одной из важнейших задач, что было закреплено в «Государственной стратегии по противодействию распространению ВИЧ в Российской Федерации до 2020 г. и дальнейшую перспективу», утвержденной распоряжением Правительства Российской Федерации от 20.10.2016 № 2203-р, и нашло продолжение в новой Государственной стратегии противодействия распространению ВИЧ-инфекции в Российской Федерации на период до 2030 года (утверждена распоряжением Правительства Российской Федерации от 21 декабря 2020 г. № 3468-p).

Ветряная оспа в 2020 г. по величине экономического ущерба по-прежнему занимала одно из лидирующих мест. Зарегистрировано более 490 тыс. случаев заболевания, показатель заболеваемости составил 333,91 на 100 тыс. населения при среднемноголетней заболеваемости 517,0. Случаи ветряной оспы с летальным исходом зарегистрированы не были.

Показатель заболеваемости ветряной оспой снизился на 40,3 \% по сравнению с 2019 годом (559,1 на 100 тыс. населения), что обусловлено длительным разобщением детей в организованных коллективах из-за ограничительных мероприятий в период эпидемического подъема заболеваемости новой коронавирусной инфекцией (рис. 129).

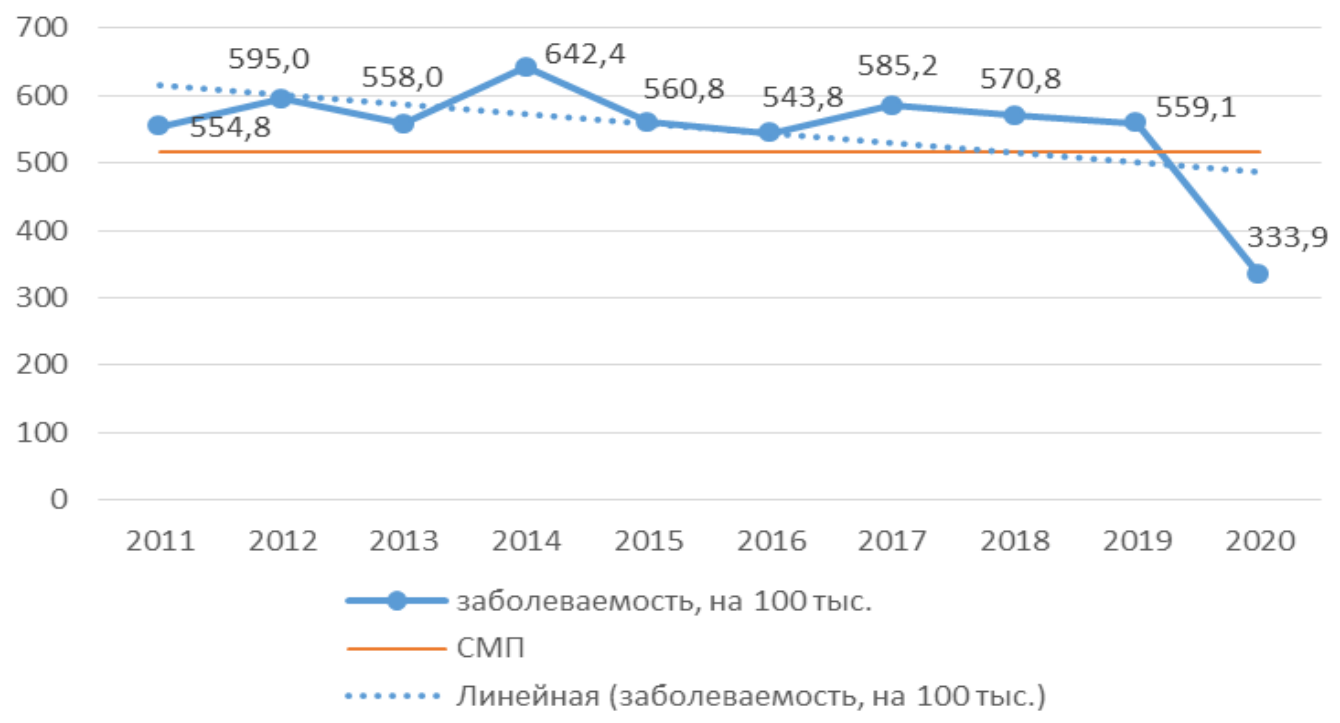

Рис. 129. Заболеваемость ветряной оспой в Российской Федерации в 2011-2020 гг. (на 100 тыс. населения)

Ветряная оспа регистрировалась на территориях всех субъектов Российской Федерации, а в 50 из них показатели заболеваемости превысили средний уровень по стране. Наиболее высокие показатели отмечены в субъектах Российской Федерации, приведенных в табл. 51. 


\section{Субъекты Российской Федерации с максимальными показателями заболеваемости ветряной оспой}

\begin{tabular}{|c|l|c|}
\hline \multicolumn{1}{|c|}{ Субъект РФ } & $\begin{array}{c}\text { Заболеваемость в 2020 г., } \\
\text { на 100 тыс. населения }\end{array}$ \\
\hline & Российская Федерация & $\mathbf{3 3 3 , 9 1}$ \\
\hline 1 & Республика Карелия & 857,38 \\
\hline 2 & Ненецкий автономный округ & 764,16 \\
\hline 3 & Камчатский край & 668,75 \\
\hline 4 & Чукотский автономный округ & 656,33 \\
\hline 5 & Ханты-Мансийский автономный округ - Югра & 621,66 \\
\hline 6 & Вологодская область & 618,94 \\
\hline 7 & Красноярский край & 544,57 \\
\hline 8 & Республика Коми & 532,62 \\
\hline 9 & Костромская область & 528,39 \\
\hline 10 & Еврейская автономная область & 513,48 \\
\hline
\end{tabular}

Основное число заболевших ветряной оспой составили дети (2020 г. - 94,9\%), большинство случаев заболевания (75\%) зарегистрировано среди детей в возрасте от 1 года до 6 лет, в том числе более половины $(60 \%)$ заболеваний - у детей в возрасте 3-6 лет, но при этом в 2020 г. продолжилась тенденция снижения заболеваемости в данной возрастной группе - в 1,7 раз по сравнению с предыдущим годом (рис. 130).

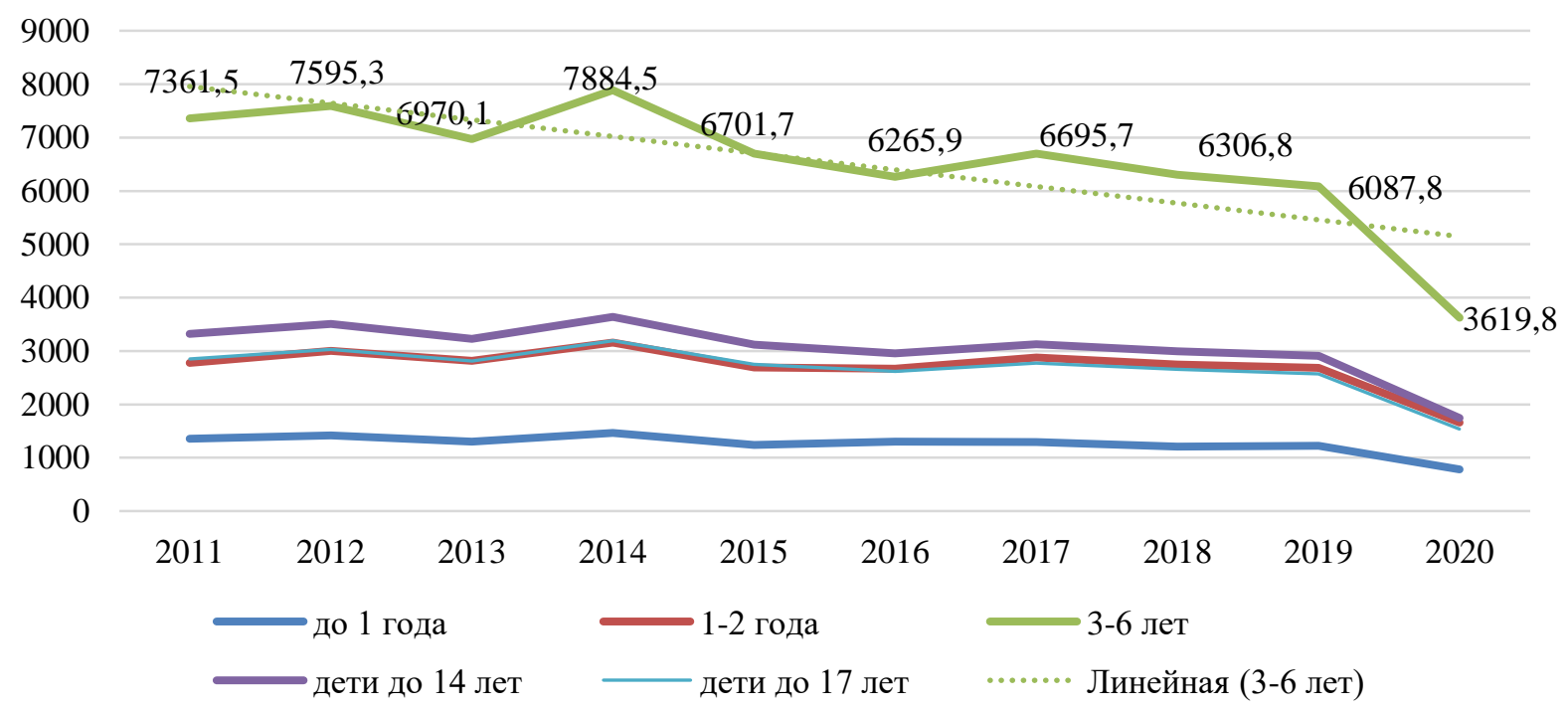

Рис. 130. Заболеваемость ветряной оспой детей различных возрастных групп в Российской Федерации в 2011-2020 гг. (на 100 тыс. населения соответствующего возраста)

В 2020 году по сравнению с 2019 годом на $30 \%$ увеличились объемы профилактической иммунизации против ветряной оспы: вакцинировано 143444 человек (в 2019 г. - около 110 тыс. человек), из них 93905 детей (65\%) и около 50 тыс. взрослого населения $(35 \%)$. Однако объемы иммунизации продолжают оставаться недостаточными для существенного влияния на эпидемический процесс данной инфекции в масштабах не только страны, но и отдельных регионов.

В субъектах России количество привитого населения распределилось неравномерно. В 8 субъектах Российской Федерации вакцинация против ветряной оспы 
не проводится (Ненецкий автономный округ, Еврейская автономная область, Кировская область, Республика Калмыкия, Республика Дагестан, Республика Адыгея, КарачаевоЧеркесская Республика, Республика Северная Осетия - Алания), в 13 не превышает 100 человек. При этом Ненецкий автономный округ и Еврейская автономная область являются регионами с максимальными показателями заболеваемости ветряной оспой. По-прежнему максимальное число прививок проводят в г. Москве, где вакцинация против ветряной оспы введена в региональный календарь профилактических прививок. В 2020 году в г. Москве привито $23 \%$ от всех иммунизированных в стране (в 2019 г. $27 \%)$.

В то же время необходимо отметить, что некоторые субъекты страны наращивают объемы иммунизации. Так, в Республике Бурятия и Курской области число привитых по сравнению с 2019 годом увеличилось в 9 раз; в г. Севастополе, Брянской и Тульской областях - более чем в 4 раза, в Свердловской, Иркутской, Новосибирской и Омской областях, в Алтайском крае, Республике Алтай, Удмуртской Республике, Камчатском крае и Ханты-Мансийском $\mathrm{AO}$ - более чем в 2 раза.

Несмотря на то, что иммунизация против ветряной оспы в России включена в календарь профилактических прививок по эпидемическим показаниям, вакцинация контактных лиц в очагах групповой заболеваемости ветряной оспой проводится в недостаточных объемах, о чем свидетельствуют высокие показатели вспышечной заболеваемости. При своевременном проведении иммунизации показатель вспышечной заболеваемости возможно было бы снизить по меньшей мере в 2 раза.

С 2019 г. в государственное статистическое наблюдение введена регистрация случаев опоясывающего лишая. В 2020 г. зарегистрировано 15168 случаев заболевания опоясывающим лишаем, показатель заболеваемости составил 10,33 на 100 тыс. населения, что ниже на 21 \% уровня заболеваемости в 2019 г. (13,09 на 100 тыс. населения), 3 случая опоясывающего лишая закончились летальным исходом.

В 28 субъектах показатели заболеваемости превышают средний уровень по стране, что в большей мере отражает качество регистрации данной нозологии. Наиболее высокие показатели отмечены в субъектах, приведенных в табл. 57.

Таблица 57

\section{Субъекты Российской Федерации с максимальными показателями заболеваемости опоясывающим лишаем, 2020 год}

\begin{tabular}{|c|l|c|}
\hline & \multicolumn{1}{|c|}{ Субъект Российской Федерации } & Заболеваемость, на 100 тыс. населения \\
\hline & Российская Федерация & $\mathbf{1 0 , 3 3}$ \\
\hline 1 & Курская область & 43,33 \\
\hline 2 & Челябинская область & 42,52 \\
\hline 3 & г. Севастополь & 42,36 \\
\hline 4 & Смоленская область & 36,44 \\
\hline 5 & Кемеровская область & 31,84 \\
\hline 6 & Сахалинская область & 29,86 \\
\hline 7 & Новосибирская область & 29,37 \\
\hline 8 & Ульяновская область & 29,33 \\
\hline 9 & Удмуртская Республика & 28,52 \\
\hline 10 & Вологодская область & 26,80 \\
\hline
\end{tabular}

В 11 субъектах Российской Федерации статистический учет случаев опоясывающего лишая в настоящее время не проводится, из них в 6 это заболевание не регистрировалось и в 2019 г. (Республика Калмыкия, Республика Дагестан, Республика 
Северная Осетия - Алания, Чеченская Республика, Республика Тыва, Еврейская автономная область).

В возрастной структуре заболевших опоясывающим лишаем $91 \%$ составляют взрослые, 9 \% дети. Регистрация случаев опоясывающего лишая у детей до 1 года (в 2020 г. - 11 случаев), а также значительного числа случаев заболевания ветряной оспой в данной возрастной группе (в 2020 г. - более 12 тыс. случаев) указывают на наличие риска развития врожденных форм инфекции вирусом Varicella Zoster.

На фоне противоэпидемических мер в отношении COVID-19 в 2020 г. по большинству инфекций с фекально-оральным механизмом передачи наблюдалось снижение показателей заболеваемости по сравнению с 2019 г. и среднемноголетними показателями. Уменьшилось число очагов групповой заболеваемости, в т.ч. в детских организованных коллективах.

Заболеваемость ОКИ, вызванными неустановленными инфекционными возбудителями, пищевыми токсикоинфекциями неустановленной этиологии (ОКИ неустановленной этиологии) в 2020 г. снизилась в 1,7 раза по сравнению с 2019 г. и составила 193,63 на 100 тыс. населения (СМП - 336,11). Наибольший показатель заболеваемости зарегистрирован в Сахалинской области $(632,17$, СМП - 863,07), Ненецком АО (550,38, СМП - 931,26), Томской области $(523,67$, СМП - 562,53), Приморском крае $(447,75$, СМП - 678,31), Хабаровском крае $(438,13$, СМП - 572,33), Чувашской Республике $(428,8$, СМП - 532,45), г. Санкт-Петербурге $(418,05$, СМП - 574,26), г. Севастополе (403,65, СМП - 296,39).

Несмотря на общее снижение заболеваемости в 2020 г., наиболее высокий (> $90 \%$ ) удельный вес ОКИ неустановленной этиологии в структуре заболеваемости кишечными инфекциями отмечен в Чеченской Республике (100\%), КарачаевоЧеркесской Республике (97 \%), Республике Ингушетия (93\%), Республике Северная Осетия - Алания (91\%), Рязанской области (90 \%).

Недостаточный уровень внедрения современных методов лабораторных исследований, сопровождающийся высокой долей диагнозов ОКИ, ассоциированных с условно-патогенной микрофлорой (>20\%), отмечался в 2020 г. в Республике Крым (41\%), Белгородской области $(25 \%)$, Республике Тыва (23\%), Республике Башкортостан $(21 \%)$.

Многолетняя динамика заболеваемости норовирусной инфекцией (НВИ) характеризуется тенденцией к росту (рис. 131).

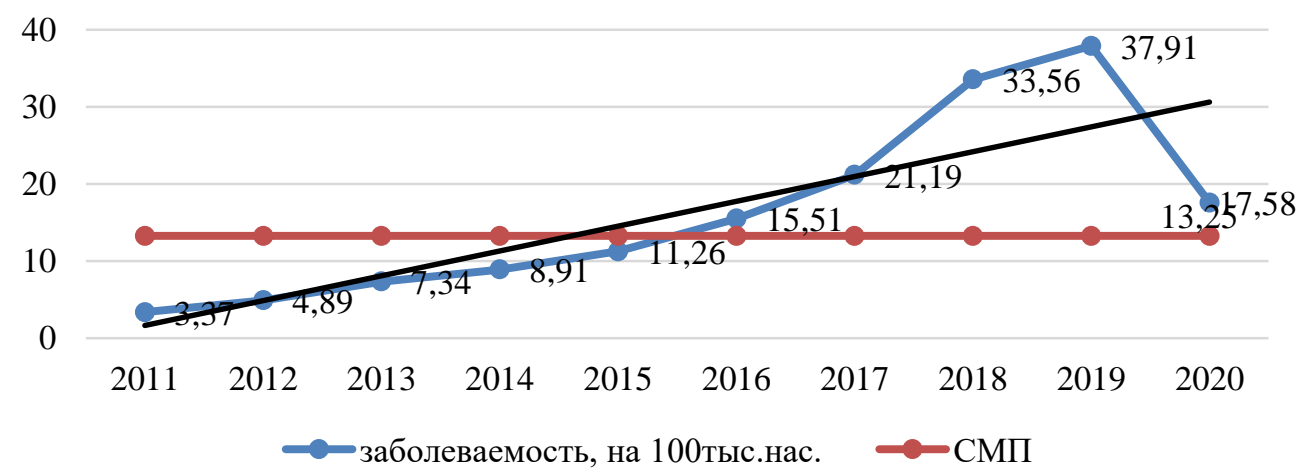

Рис. 131. Динамика заболеваемости норовирусной инфекцией в Российской Федерации, 2011-2020 гг. (на 100 тыс. населения)

В 2020 г. показатель заболеваемости НВИ в Российской Федерации (17,58 на 100 тыс. населения, СМП - 13,25) снизился в 2 раза по сравнению с 2019 г. 
Наиболее высокая заболеваемость отмечена в Ямало-Ненецком АО (92,09, СМП - 61,31), Еврейской АО (88,62, СМП - 91,07), Томской области $(75,49$, СМП - 47,70), Свердловской области (71,2, СМП - 25,4), Мурманской области (70,23, СМП - 39,42), Вологодской области (63,23, СМП - 42,93), Ханты-Мансийском АО (60,09, СМП - 75,00).

В ряде субъектов Российской Федерации показатель заболеваемости НВИ менее 1,0 на 100 тыс. населения, что может свидетельствовать о недостаточном охвате лабораторными исследованиями (Смоленская, Псковская, Тульская, Астраханская, Орловская области, Республика Адыгея). Не зарегистрированы случаи НВИ в Брянской, Рязанской областях, республиках Дагестан, Ингушетия, Кабардино-Балкарской, Карачаево-Черкесской, Чеченской.

В структуре очагов групповой заболеваемости с фекально-оральным механизмом передачи инфекции НВИ превалирует как по количеству очагов, так и по числу пострадавших. В 2020 г. в Российской Федерации зарегистрировано 103 очага групповой заболеваемости НВИ с общим числом пострадавших 1480 человек (в 2019 г. - 215 и 2705 соответственно). Наибольшее число вспышек зарегистрировано в дошкольных (58) и общеобразовательных (32) учреждениях.

По данным референс-центра по мониторингу ОКИ, несмотря на существенное снижение числа зарегистрированных вспышек НВИ в 2020 г., эффективная работа по выявлению очагов групповой заболеваемости была проведена в Ямало-Ненецком и Ханты-Мансийском автономных округах, Томской области, г. Москве, Хабаровском крае. Своевременное выявление очагов и проведение противоэпидемических мероприятий в этих субъектах позволило снизить среднее количество пострадавших в очаге до 10 человек при среднем по России - 14.

Наиболее крупные вспышки НВИ были зарегистрированы в Самарской, Сахалинской, Ростовской областях, г. Санкт-Петербурге. Наибольшее число вспышек (7 из 15) были вызваны доминировавшим в прошлом сезоне генотипом GII.P16_GII.2 (рис. 132).

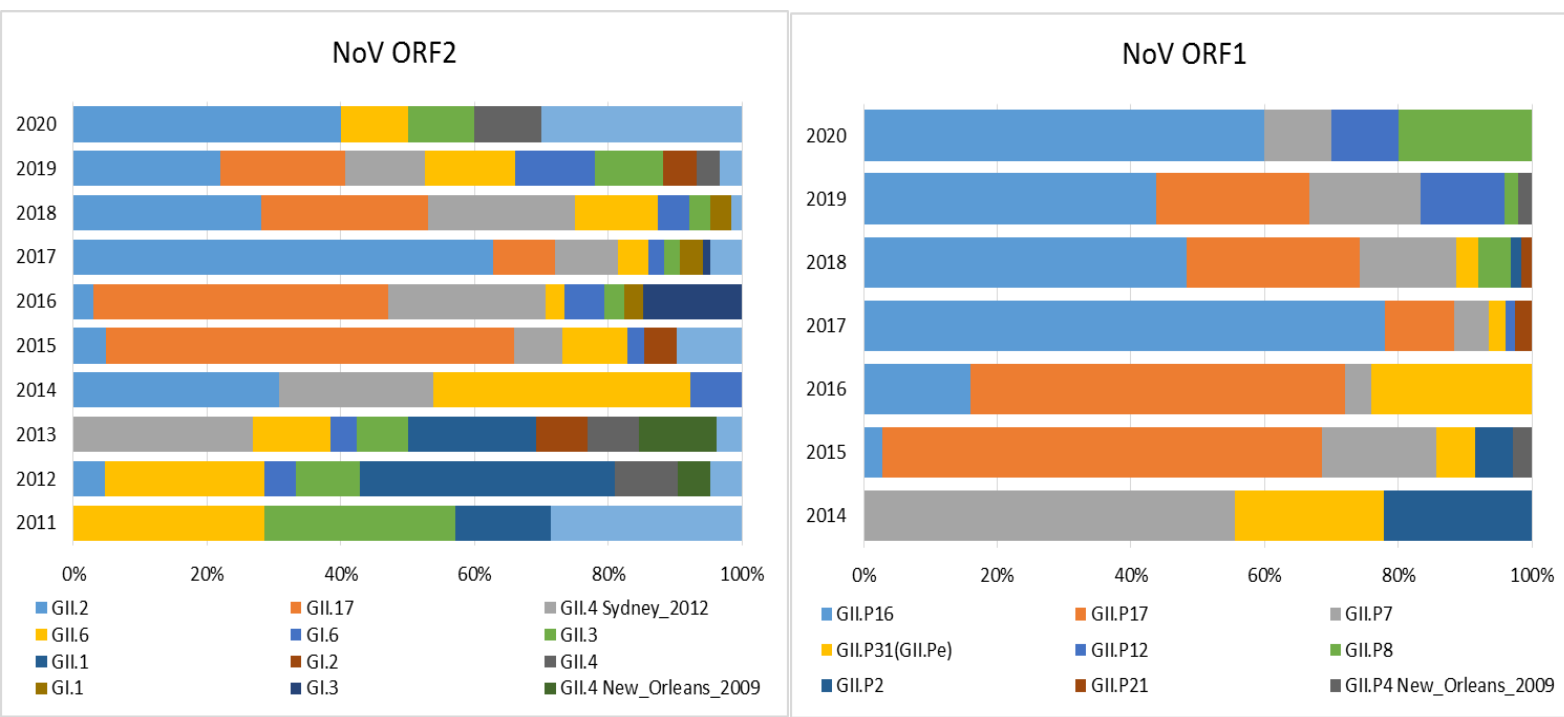

Рис. 132. Динамика превалирования различных генотипов норовирусов, ассоциированных со вспышечной заболеваемостью (по данным референс-центра по мониторингу ОКИ)

В 2020 г. референс-центром по мониторингу ОКИ проведено дополнительное изучение генотипов норовирусов, которые выявлены при спорадической заболеваемости на территории 10 субъектов Российской Федерации. Наибольшее распространение имел генотип GII.P12_GII.3 (48,8 \%) и GII.P16_GII.4 (30,2 \%). С генотипом GII.P16_GII.2, 
Государственный доклад «О состоянии санитарно-эпидемиологического благополучия населения в Российской Федерации в 2020 году» изолированном в очагах, было ассоциировано только $7 \%$ спорадической заболеваемости.

Заболеваемость ротавирусной инфекцией (РВИ) в 2020 г. снизилась в 2 раза по сравнению с 2019 г. и составила 33,94 на 100 тыс. населения (в 2019 г. - 70,26, СМП74,93) (рис. 133).

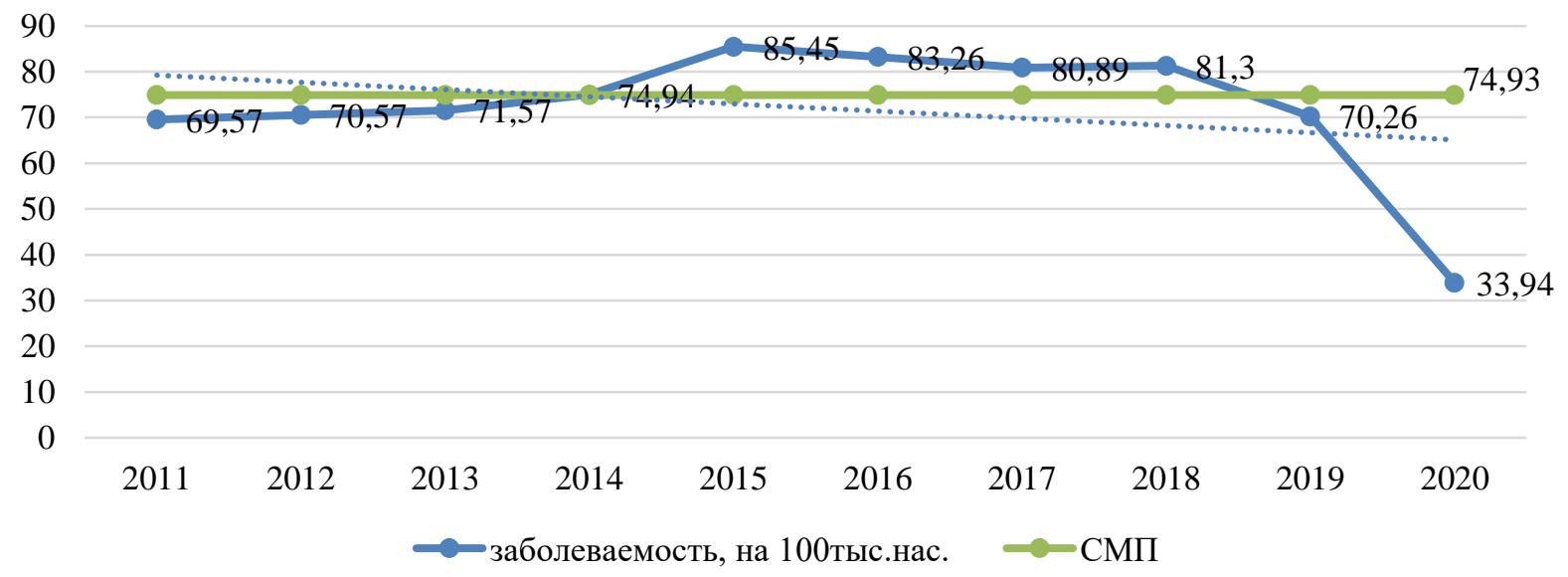

Рис. 133. Динамика заболеваемости ротавирусной инфекцией в Российской Федерации в 2011-2020 гг. (на 100 тыс. населения)

Наибольший показатель заболеваемости зарегистрирован в Ненецком АО (141,01, СМП - 48,08), Ямало-Ненецком АО (124,87, СМП - 247,43), Приморский край $(101,99$, СМП - 148,18), Республика Коми $(90,14$, СМП - 112,51), Вологодская область $(88,48$, СМП - 200,49), Ханты-Мансийском АО $(88,18$, СМП - 236,22). Низкое количество зарегистрированных случаев РВИ отмечалось в Республике Калмыкия, Республике Ингушетия, Чеченской Республике.

Наиболее высокие показатели заболеваемости в Российской Федерации зарегистрированы среди детей в возрасте 1-2 года (575,78 на 100 тыс. населения) и до 1 года $(466,47)$. Наиболее высокая интенсивность инфицирования детей первых месяцев жизни в 2020 г. наблюдалась в Республике Тыва, Республике Дагестан, КабардиноБалкарской Республике, Республике Бурятия, Забайкальском крае.

В 2020 г. против РВИ привито 53503 человека в 73 (в 2019 г. - 48584) субъектах Российской Федерации. Наибольшее число привито в г. Москве (27 573), Московской (4276), Сахалинской (3864), Тульской (3517) областях. По данным Всемирной организации здравоохранения, критерием адекватной вакцинации является охват не менее 80 \% целевой когорты населения при доле лиц с неполным курсом вакцинации не более $10 \%$. Достоверные популяционные эффекты проявляются при охвате иммунизацией против РВИ не менее $60 \%$.

Среди очагов групповой заболеваемости, вызванных возбудителями с фекальнооральным механизмом передачи, РВИ занимает 2-е место. В 2020 г. зарегистрировано 27 очагов (в 2019 г. - 83) групповой заболеваемости с общим количеством пострадавших 219 человека (в 2019 г. - 622), из них 26 очагов - в дошкольных образовательных учреждениях.

По данным референс-центра по мониторингу ОКИ, в зимне-весенний сезон 2020 г. в Российской Федерации превалировали изоляты ротавирусов группы А генотипа G9P[8] (рис. 134).

Для многолетней динамики заболеваемости сальмонеллезом (рис. 135) характерна общая тенденция к снижению показателя заболеваемости. В 2020 г. по сравнению с 2019 г. показатель уменьшился в 1,6 раза и составил 14,71 на 100 тыс. населения (СМП - 29,1). 
Государственный доклад «О состоянии санитарно-эпидемиологического благополучия населения в Российской Федерации в 2020 году»

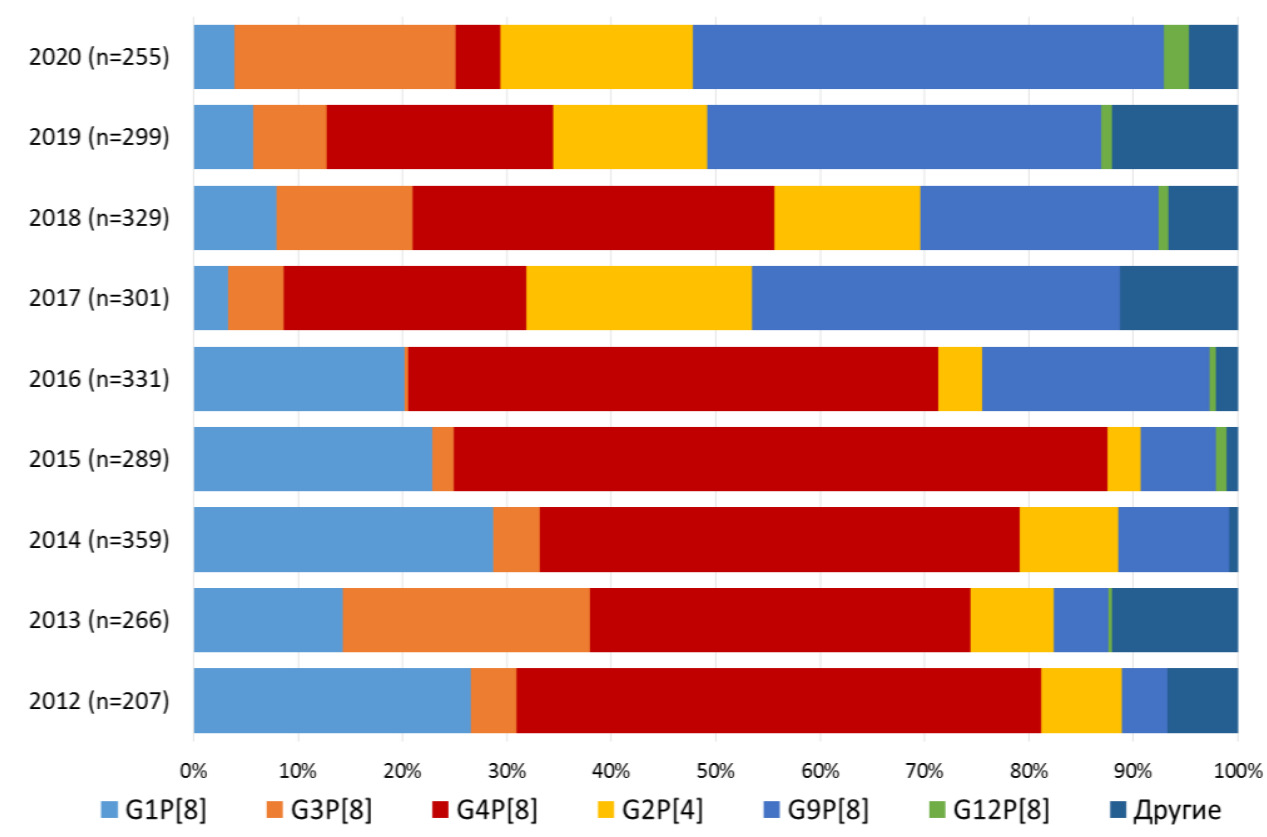

Рис. 134. Распределение генотипов ротавирусов в Российской Федерации в период 2012-2020 гг. (по данным по данным референс-центра по мониторингу ОКИ)

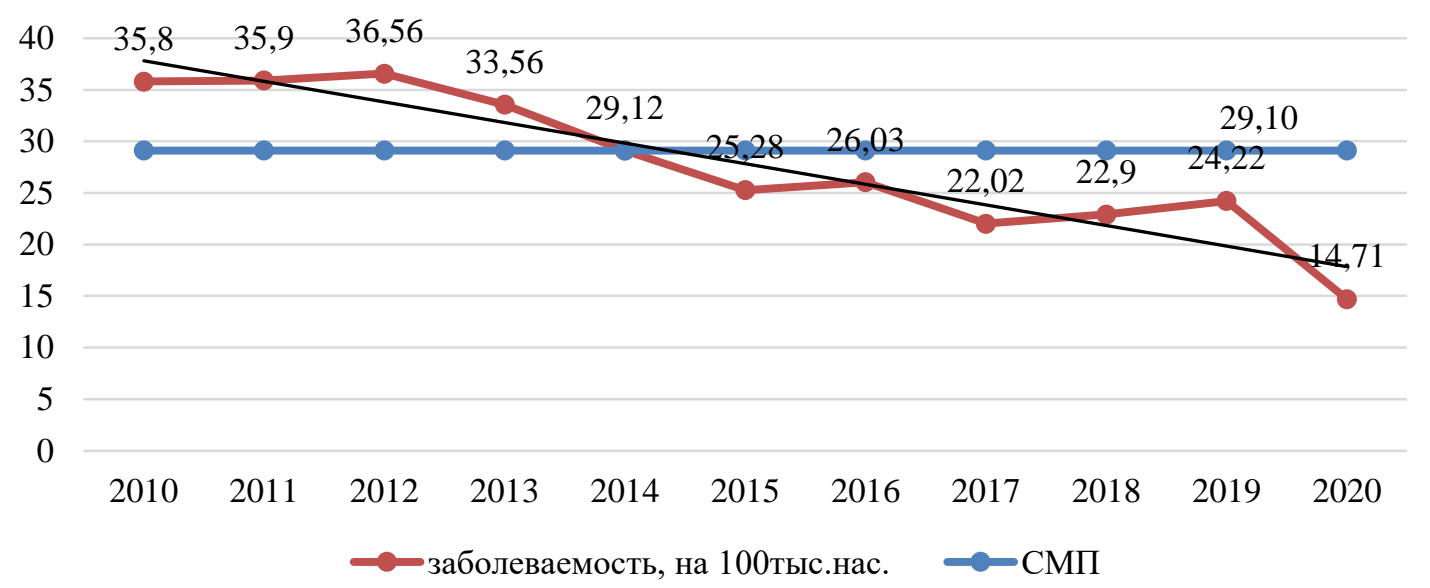

Рис. 135. Динамика заболеваемости сальмонеллезом в Российской Федерации в 2011-2020 гг. (на 100 тыс. населения)

Наибольший показатель заболеваемости зарегистрирован в Томской $(41,36$, СМП - 53,53), Иркутской $(34,91$, СМП - 38,43) областях, Республике Саха $(34,45$, СМП 51,70), Архангельской области (32,02, СМП - 29,87).

В этиологической структуре преобладают сальмонеллезы, вызванные сальмонеллами группы D $(77,4 \%)$.

Вместе с тем сальмонеллез сохраняет свою актуальность при формировании вспышечной заболеваемости и занимает третье место в структуре очагов групповой заболеваемости с фекально-оральным механизмом передачи инфекции. За 2020 г. было зарегистрировано 20 (в 2019 г. - 70) очагов групповой заболеваемости сальмонеллезом с общим количеством пострадавших 422 (в 2018 г. - 1829) человека. Наиболее крупные очаги групповой заболеваемости, с количеством пострадавших более 40 человек, были зарегистрированы в Иркутской и Волгоградской областях, Республике Дагестан.

По данным референс-центра по мониторингу сальмонеллезов, в 2020 г. в очагах групповой заболеваемости от пострадавших выделялись сальмонеллы 27 серотипов, из 
продовольственного сырья - 17, объектов окружающей среды - 16 . Как и в предыдущие годы, выделение сальмонелл наиболее часто наблюдалось из продукции птицеводства. Основные выделяемые возбудители - S. enteritidis и S. infantis. При исследованиях пищевых продуктов наиболее высокая доля образцов, содержавших сальмонеллы, выявлялась в Иркутской области и Красноярском крае.

В 2020 г. 58,7\% изолятов S. enteritidis характеризовались устойчивостью к колистину, $75 \%$ - к ципрофлоксацину. Множественная устойчивость (резистентность более чем к двум классам антибиотиков) обнаружена у 4,1\% изолятов. Для двух изолятов S. enteritidis установлена резистентность к полимиксинам, монобактамам, пеницилинам, цефалоспоринам II, III, IV поколения.

Изоляты S. infantis в $85 \%$ случаев проявляли резистентность более чем к трем классам антибиотикам. Вместе с тем все исследованные изоляты были чувствительны к гликоциклинам, полимиксинам, карбопенемам, цефалоспоринам I поколения и аминогликозидам III поколения.

Половина изолятов S. typhimurium была чувствительна к действию всех антибиотиков, в то время как у $30,0 \%$ резистентность наблюдалась к двум классам (пенициллины, тетрациклины).

В течение последних 10 лет отмечается тенденция к ежегодному снижению заболеваемости бактериальной дизентерией (шигеллезом). Показатель заболеваемости шигеллезом в 2020 г. составил 1,98 на 100 тыс. населения (рис. 136) при среднемноголетнем - 7,43.

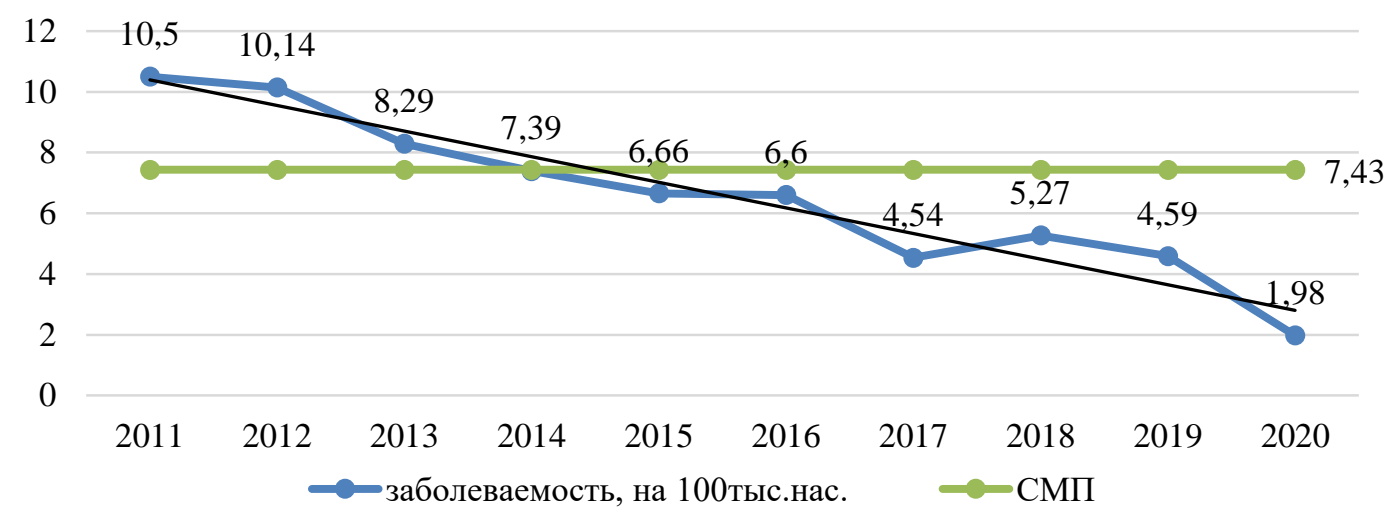

Рис. 136. Динамика заболеваемости шигеллезом в Российской Федерации в 2011-2020 гг. (на 100 тыс. населения)

Удельный вес бактериологически подтвержденного шигеллеза в Российской Федерации составил 82 \%, что не отличается от предыдущих лет. Наиболее высокая доля лабораторно подтвердженных случаев наблюдалась в Южном (97,6 \%), Центральном $(89,8 \%)$ и Приволжском (87 \%) федеральных округах.

На шигеллез Зонне приходилось 23,6 \% бактериологически подтвержденных заболеваний, на шигеллез Флекснера - 71,6 \%. Наибольший показатель заболеваемости зарегистрирован в Республике Дагестан $(46,67$, СМП - 54,90), Республике Тыва $(10,13$, СМП - 133,49).

В прошедшем году в стране было зарегистрировано 6 (в 2019 г. - 17) очагов групповой заболеваемости шигеллезом с 575 (в 2019 г. - 638) пострадавшими. Крупные вспышки отмечались в Республике Дагестан и Москве.

Заболеваемость кампилобактериозом на протяжении последних лет сохраняет тенденцию к умеренному росту, обусловленному внедрением более эффективных методов лабораторной диагностики данного заболевания. Показатель заболеваемости кампилобактериозом в 2020 г. в Российской Федерации составил 1,4 на 100 тыс. 
населения. Частота выявления кампилобактерий в пищевых продуктах в 2020 г. составила $0,48 \%$. Высокая эффективность диагностики кампилобактериоза в прошедшем году отмечалась в г. Санкт-Петербурге, г. Москве, Краснодарском крае, Свердловской области.

Многолетняя динамика заболеваемости гепатитом А (ГА) характеризуется тенденцией к снижению. В 2020 г. показатель составил 1,89 на 100 тыс. населения (в 2019 г. - 2,88, СМП-4,66) (рис. 137).

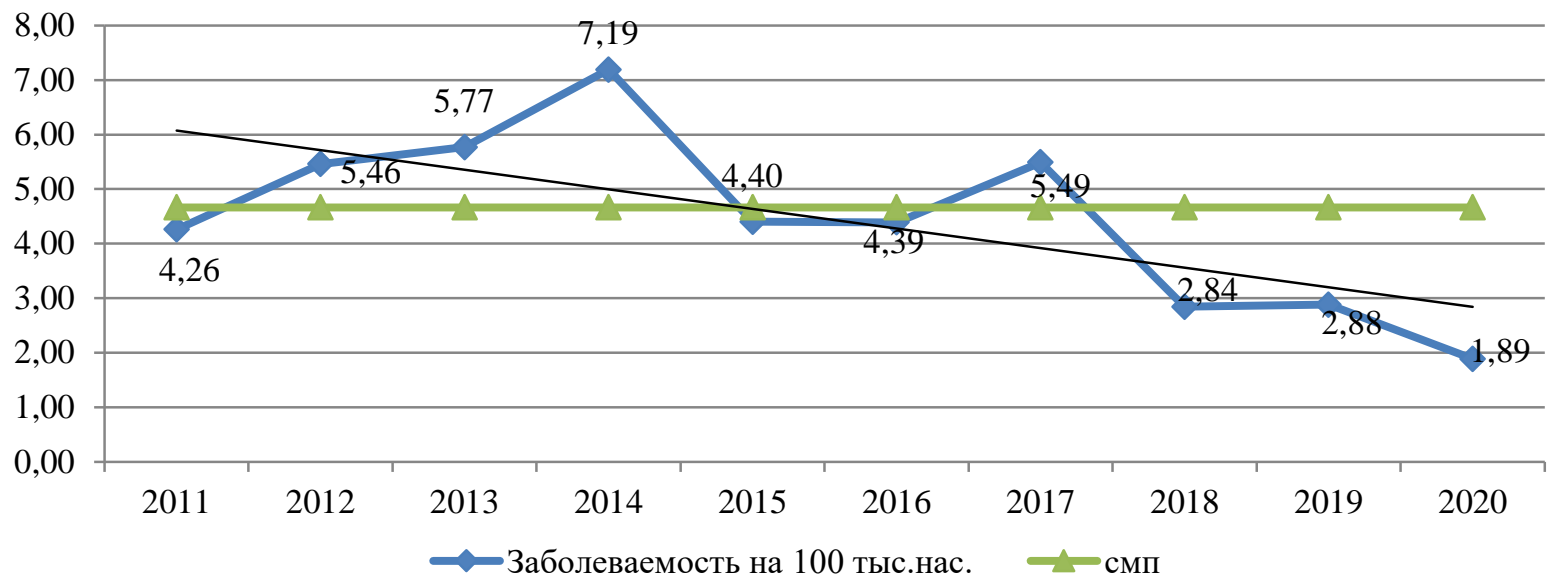

Рис. 137. Динамика заболеваемости гепатитом А в Российской Федерации в 2011-2020 гг. (на 100 тыс. населения)

Наибольший показатель заболеваемости зарегистрирован в Брянской $(34,69$, СМП - 2,07), Мурманской $(10,74$, СМП - 2,21) областях. В 2020 г. зарегистрировано 3 очага группой заболеваемости, число пострадавших -61 .

Основной мерой специфической профилактики ГА является вакцинопрофилактика, в первую очередь иммунизация групп высокого риска инфицирования, которые определены календарем профилактических прививок по эпидемическим показаниям. Вместе с тем ежегодные объемы иммунизации недостаточны, чтобы повлиять на эпидпроцесс. В 2020 г. в целом по стране привито более 349 тыс. человек (в 2019 г. - 504,1 тыс.), в том числе почти 130 тыс. детей в возрасте до 17 лет. Наибольшее число людей привито в субъектах страны, где действуют утвержденные региональные календари профилактических прививок (Свердловская область, г. Москва).

Учет случаев заболеваний гепатитом $\mathbf{E}(\boldsymbol{\Gamma E )}$ в формах государственного статистического наблюдения ведется с 2013 г. Существенную роль в частоте регистрации ГЕ играет настороженность врачей в отношении данной инфекции и качество лабораторной диагностики. В 2020 г. зарегистрировано 58 сл. ГЕ в 36 субъектах Российской Федерации (182 сл. - в 2019 г.), показатель заболеваемости составил 0,04 на 100 тыс. населения.

В 2020 г. продолжалась реализация мероприятий по поддержанию свободного от полиомиелита статуса Российской Федерации. Работа проводилась в соответствии с Планом действий по поддержанию свободного от полиомиелита статуса страны на 20192021 гг., утвержденным Роспотребнадзором и Министерством здравоохранения РФ, а также другими нормативно-методическими документами. Российская Федерация по итогам 2020 года сохраняет статус страны, свободной от полиомиелита, вызванного диким полиовирусом.

Всемирная организация здравоохранения (ВО3) объявила Африканский регион свободным от дикого полиовируса (ДПВ). Несмотря на то, что в мире осталось две страны, где продолжается эндемичная передача ДПВ типа 1 (Афганистан и Пакистан), значительно осложнилась эпидситуация в ряде стран, свободных от ДПВ, наблюдается 
увеличение масштабов циркуляции ДПВ типа 1 и полиовирусов вакцинного происхождения (ПВВП) типа 2. В прошедшем году в мире число случаев полиовирусной инфекции, вызванной цПВВП, увеличилось в 3 раза по сравнению с 2019 г. До тех пор, пока в мире остаются страны, где продолжается циркуляция ДПВ или ПВВП, риск их завоза на свободные территории будет сохранять актуальность.

Для свободных от ДПВ стран, по данным ВО3, в настоящее время сохраняются следующие риски:

- завоз ДПВ типа 1 из эндемичных стран;

- завоз/появление ПВВП;

- утечка полиовируса, в том числе вакциноподобного штамма Сэбина типа 2, с производства вакцин или из лабораторий, продолжающих работу с полиовирусом;

- выделение ПВВП лицами с первичными иммунодефицитами, связанными с В-клетками (иПВВП).

В Российской Федерации показатели охвата детей своевременной иммунизацией против полиомиелита в многолетней динамике находятся на уровне более $95 \%$ (рис. 138).

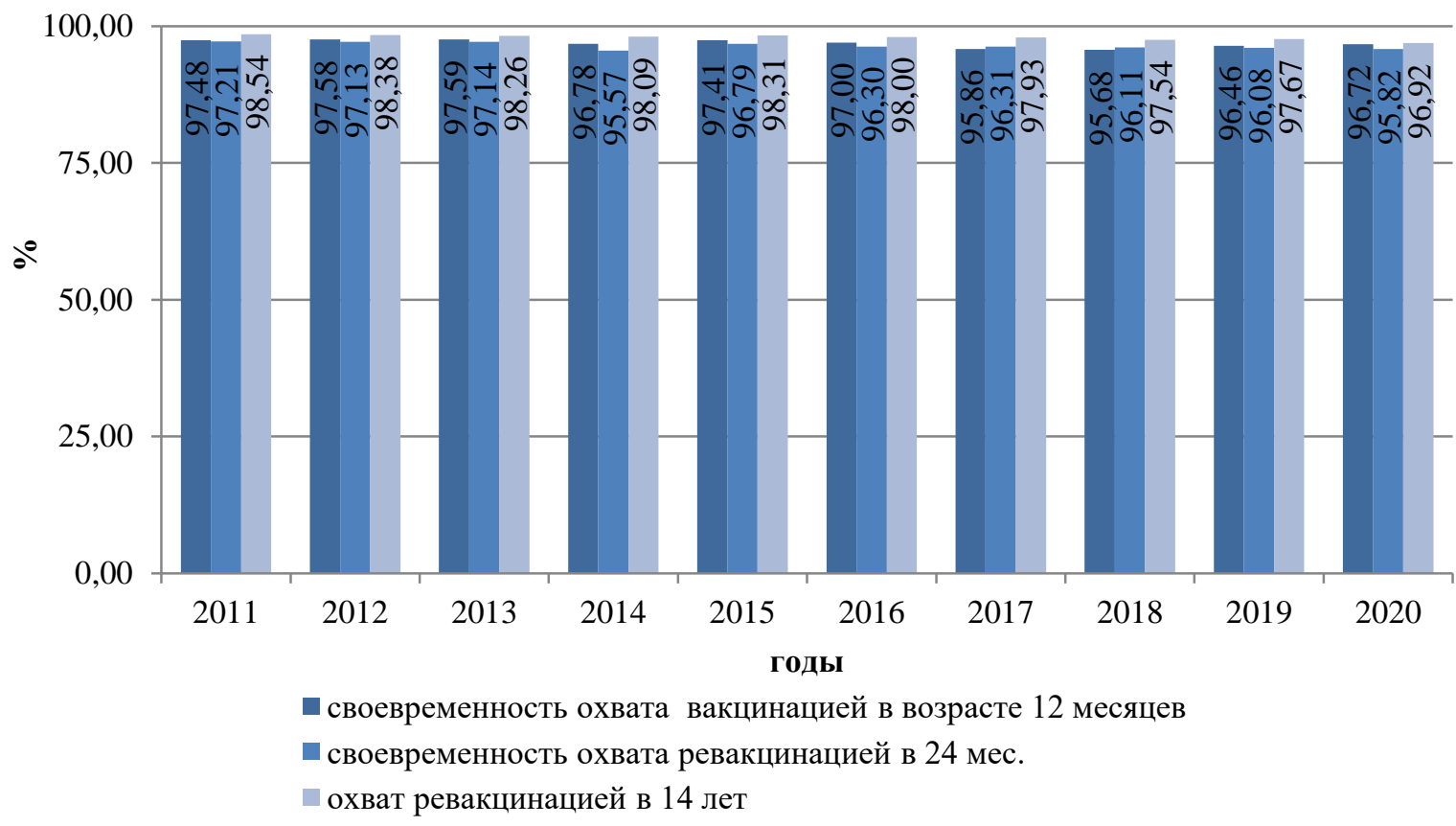

Рис. 138. Динамика показателей иммунизации против полиомиелита в Российской Федерации, 2011-2020 гг., \%

В 2020 г. показатель иммунизации в возрасте 12 мес. составил 96,72\%, в 24 мес. $-95,82 \%$, в 14 лет $-96,92 \%$.

На фоне противоэпидемических мероприятий в связи с пандемией COVID-19 по сравнению с 2019 г. увеличилось число субъектов Российской Федерации, где показатели иммунизации не достигли $95 \%$. В возрасте 12 месяцев не достигнут показатель в 9 (в 2019 г. - в 9) субъектах страны, в возрасте 24 месяцев - в 12 (в 2019 г. - в 9), охвата ревакцинацией в 14 лет - в 11 (в 2019 г. - в 2).

В целях оценки популяционного иммунитета к полиовирусам среди детей, привитых против полиомиелита до и после глобального перехода на бивалентную оральную полиовирусную вакцину, а также разработки тактики проведения серологического мониторинга популяционного иммунитета в условиях контейнмента полиовируса типа 2 в 2019-2020 гг. Роспотребнадзором реализуется пилотный проект по изучению популяционного иммунитета к полиовирусам у детей. В пилотный проект 
включены 7 регионов (г. Москва, Республика Адыгея, Чеченская Республика, Республика Ингушетия, Ставропольский край, Московская и Омская области). Проект реализуется совместно с Национальным центром по лабораторной диагностике полиомиелита (ФГБНУ «ФНЦИРИП им. М.П. Чумакова РАН»).

Несмотря на высокие уровни охвата профилактическими прививками, сохраняются проблемы в области организации безопасной иммунизации. Об этом свидетельствуют случаи ВАПП, которые регистрируются в стране ежегодно. Так в 2020 г. в 2 субъектах Российской Федерации зарегистрировано 2 случая ВАПП у детей, не получивших полный курс вакцинации против полиомиелита.

В 2020 г. в большинстве субъектов Российской Федерации отмечается снижение чувствительности эпидемиологического надзора за полиомиелитом по сравнению с предыдущими годами. Показатель заболеваемости ОВП неполиовирусной этиологии составил 0,91 на 100 тыс. детей до 15 лет при регламентируемом национальными нормативно-методическими документами и рекомендуемом ВОЗ - 1 на 100 тыс. детей до 15 лет и более. Данный факт может быть связан со снижением внимания медицинских работников к синдрому ОВП на фоне пандемии COVID-19. Не зарегистрированы случаи заболеваний с синдромом ОВП («молчащие» территории) в 13 субъектах (в 2019 г. - в 10), показатель менее 1 - в 24 (в 2019 г. - в 9). Вместе с тем стоит отметить, что тенденция к снижению показателя чувствительности относительно среднемноголетнего наметилась с 2017 г. При этом в ряде субъектов страны имеется «хроническая» проблема низкой чувствительности эпидемиологического надзора за ОВП: г. Севастополь (в 2015, $2017-$ 2020 гг.), Республика Крым (в 2014, 2015, 2017, 2018, 2020 гг.), Республика Карелия (в 2016-2020 гг.), Республика Коми (2018-2020 гг.), Архангельская область (20182020 гг.), Ленинградская область (в 2017-2020 гг.), Московская область (в 2014-2015, 2017-2020 гг.), Ивановская область (2019-2020 гг.), Тверская область (2019-2020 гг.), Ямало-Ненецкий автономный округ (в 2017-2020 гг.).

Ежегодно с целью выявления завоза ДПВ/цПВВП в субъектах Российской Федерации организуется обследование на полиовирус детей в возрасте до 5 лет среди потенциально неучтенного населения (прибывшие из эндемичных, неблагополучных по полиомиелиту стран, кочующие группы населения, мигранты и пр.). В 2020 году в связи с ограничениями на международные поездки значительно снизилось число обследованных детей. ДПВ/цВРПВ среди обследованных лиц не выделялись.

В учреждениях, сохраняющих ДПВ типа 1 , реализуются мероприятия в рамках программы контейнмента.

Таким образом, по итогам 2020 г. присутствуют следующие основные проблемы: нарушения в области организации иммунопрофилактики, приводящие к регистрации случаев ВАПП; снижение чувствительности эпиднадзора за ОВП; пропуск синдрома ОВП медицинскими работниками.

Достигнутые на сегодняшний день успехи программы ликвидации полиомиелита и сохраняющиеся для стран, свободных от полиомиелита, риски подчеркивают значимость качественной организации иммунопрофилактики полиомиелита и эпидемиологического надзора за ОВП и поддержание их на высоком уровне.

Работа по профилактике и эпидемиологическому надзору за энтеровирусной (неполио) инфекцией (ЭВИ) проводится в соответствии с ведомственной программой «Эпидемиологический надзор и профилактика энтеровирусной (неполио) инфекции на 2018-2022 гг.».

Многолетняя динамика заболеваемости ЭВИ (рис. 139) характеризуется общей тенденцией к росту и периодическими подъемами заболеваемости. 


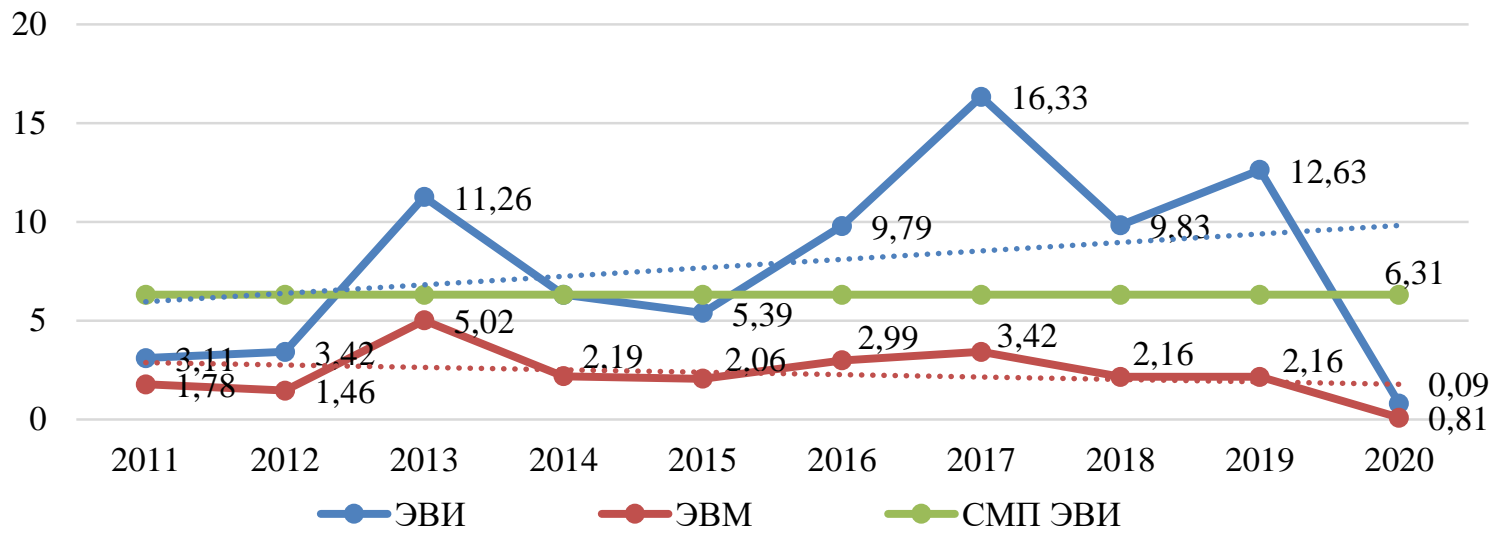

Рис. 139. Динамика заболеваемости ЭВИ, ЭВМ в Российской Федерации в 2011-2020 гг. (на 100 тыс. населения)

В 2020 г. в Российской Федерации произошло многократное снижение заболеваемости энтеровирусной (неполио) инфекцией (ЭВИ). По сравнению с 2019 г. показатель заболеваемости ЭВИ снизился в 15,5 раза и составил 0,81 на 100 тыс. населения, в 7,8 раза - по сравнению с СМП (6,31). Показатель заболеваемости энтеровирусным менингитом (ЭВМ) снизился в 24 раза $(2020$ г. - 0,09). На течение эпидпроцесса ЭВИ в 2020 г. кардинальным образом повлияли противоэпидемические мероприятия, введенные в связи с пандемией COVID-19: снижение миграционных процессов и разобщение людей. Радикальное снижение числа случаев ЭВИ/ЭВМ произошло во всех субъектах страны.

Значительно сократилось и число очагов групповой заболеваемости ЭВИ, традиционно актуальных в детских организованных коллективах и летних оздоровительных организациях. В 2020 г. в Российской Федерации зарегистрировано 3 (в 2019 г. - 60) очага групповой заболеваемости ЭВИ с числом пострадавших 34 (в 2019 г. - 925) человека, из них 33 - дети до 17 лет (в 2019 г. - 875).

По данным Референс-центра по мониторингу ЭВИ (ФБУН ННИИЭМ им. академика И.Н. Блохиной Роспотребнадзора), Урало-Сибирского (ФБУН «Екатеринбургский НИИ вирусных инфекций» Роспотребнадзора) и Дальневосточного (ФБУН «Хабаровский НИИЭМ» Роспотребнадзора) региональных центров по изучению ЭВИ на территории Российской Федерации в 2020 г. установлено значительное снижение разнообразия циркулирующий среди населения неполиомиелитных энтеровирусов (НПЭВ). В 2020 г. отмечена циркуляция 13 типов НПЭВ (в 2019 г. - 41). При этом не выявлено случаев ЭВМ, связанных с эпидемическими вариантами вируса ЕСНО30, который доминировал среди возбудителей этой формы ЭВИ в стране на протяжении многих предыдущих лет. Ни у пациентов с ЭВИ, ни в сточной воде не было выявлено вируса Коксаки А16, который в течение предыдущих двух лет входил в число энтеровирусов, широко циркулировавших в России и за рубежом.

В соответствии с прогнозом Референс-центра по мониторингу ЭВИ (ФБУН «ННИИЭМ им. академика И.Н. Блохиной» Роспотребнадзора) в 2021 г. маловероятна активизации циркуляции и распространения эпидемических вариантов НПЭВ. В связи с этим, заболеваемость ЭВИ/ЭВМ в 2021 г., даже в случае отмены ограничений во втором полугодии, по всей вероятности, будет значительно ниже среднемноголетних показателей.

Однако следует обратить внимание, что пропущен как минимум год «естественной иммунизации» населения в отношении ЭВИ. В сложившихся условиях можно предполагать, что после отмены всех ограничений по мере восстановления миграционной активности населения в 2022-2023 гг. будет расти риск эпидемического подъема заболеваемости ЭВИ в большинстве субъектов Российской Федерации, 
Государственный доклад «О состоянии санитарно-эпидемиологического благополучия населения в Российской Федерации в 2020 году»

связанный с возможным заносом из эндемичных регионов и распространением эпидемических вариантов НПЭВ: Коксаки А6, Энтеровируса А71, Коксаки А16, ЕСНО30, ЕСНО9 и др.

Заболеваемость острыми формами парентеральных вирусных гепатитов в Российской Федерации имеет устойчивую тенденцию к снижению (рис. 140). Так, в 2020 г. острый вирусный гепатит (как впервые установленный диагноз) выявлен у 4387 больных, что составило 2,99 случая на 100 тыс. населения (в 2019 г. - 6870 случаев, показатель составлял 4,68 на 100 тыс. населения). Среднемноголетний показатель заболеваемости (СМП) за 2011-2020 гг. составляет 7,55 на 100 тыс. населения.

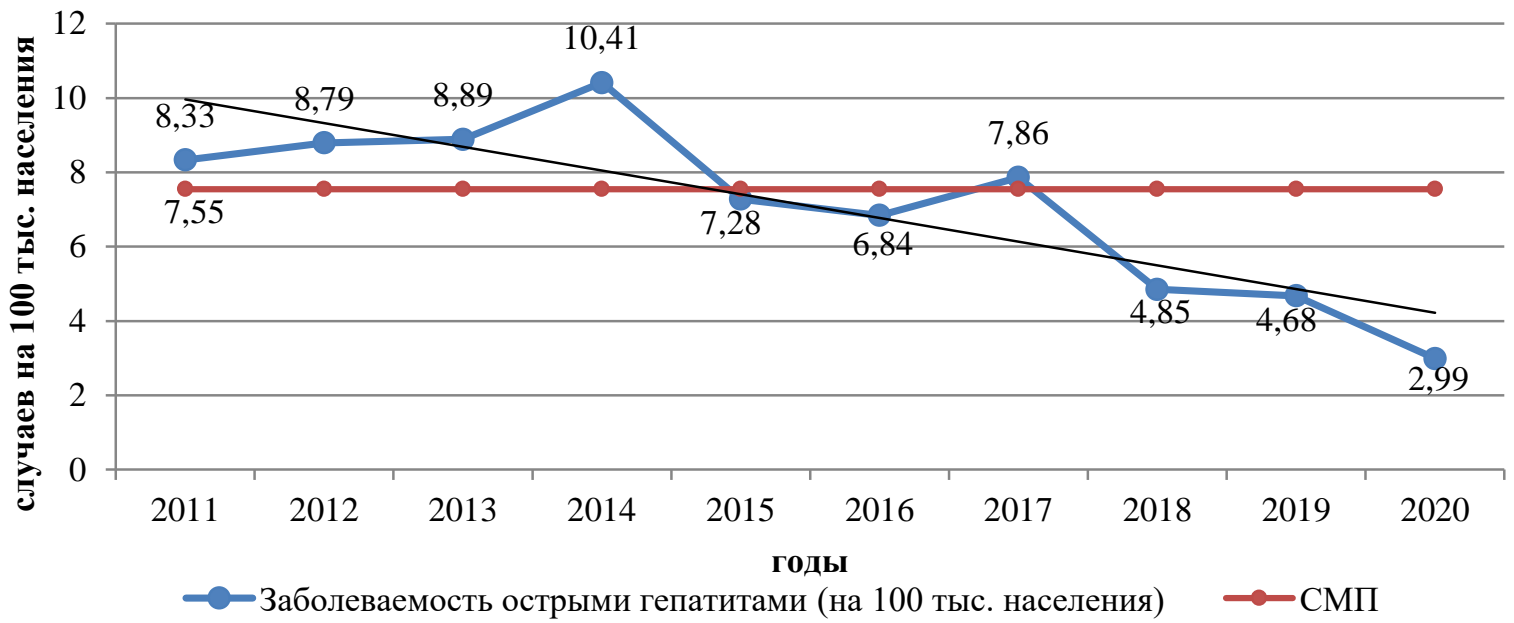

Рис. 140. Динамика заболеваемости острыми гепатитами в Российской Федерации в 2011-2020 гг. (на 100 тыс. населения)

Перечень субъектов Российской Федерации с наиболее высоким (4 субъекта) и низким (6 субъектов) уровнем заболеваемости острыми вирусными гепатитами приведен в табл. 52.

Таблица 52

\section{Субъекты Российской Федерации с наиболее высоким и низким уровнем заболеваемости острыми вирусными гепатитами}

\begin{tabular}{|c|l|c|c|}
\hline \multirow{2}{*}{$№$} & \multicolumn{1}{|c|}{ Субъекты Российской Федерации } & $\begin{array}{c}\text { Количество } \\
\text { случаев (абс. ч.) }\end{array}$ & $\begin{array}{c}\text { Заболеваемость } \\
\text { на 100 тыс. населения }\end{array}$ \\
\hline 1 & Российская Федерация & $\mathbf{4 3 8 7}$ & $\mathbf{2 , 9 9}$ \\
\hline 2 & Брянская область & 426 & 35,61 \\
\hline 3 & Мурманская область & 90 & $\mathbf{1 2 , 0 8}$ \\
\hline 4 & Смоленская область & 65 & 6,93 \\
\hline 5 & Чукотский автономный округ & 3 & 5,93 \\
\hline 6 & Иркутская область & 142 & 0,10 \\
\hline 7 & Республика Бурятия & 1 & 0,28 \\
\hline 8 & Забайкальский край & 3 & 0,37 \\
\hline 9 & Республика Калмыкия & 1 & 0,43 \\
\hline 10 & Карачаево-Черкесская Республика & 2 & 0,48 \\
\hline 11 & Псковская область & 3 & \\
\hline
\end{tabular}

В структуре заболеваемости острыми вирусными гепатитами (ОВГ) за 10 лет с 2011 г. удельный вес острого вирусного гепатита В (ОГВ) снизился на 8,8 \% (рис. 141) и составила в 2020 г. 11,7 \% от общего числа зарегистрированных ОВГ (12,2 \% - в 2019 г.). 

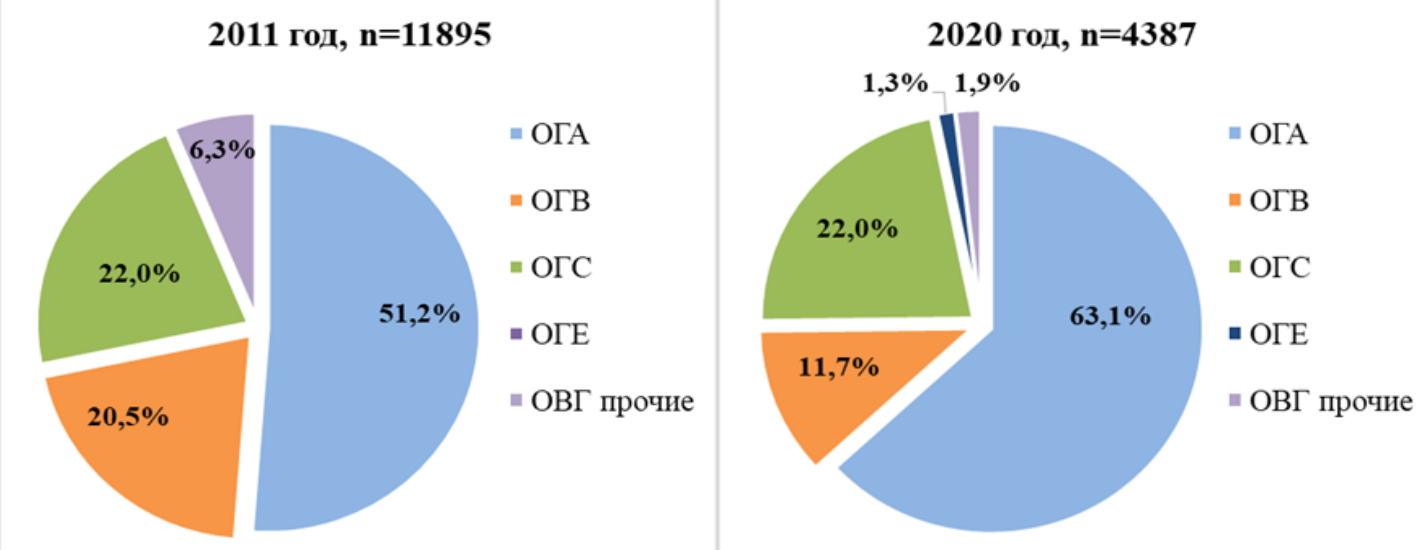

Рис. 141. Этиологическая структура острых вирусных гепатитов в Российской Федерации в 2011 г. и 2020 г., \%

Достижение таких значительных успехов в борьбе с данной инфекцией стало возможным благодаря реализации программы массовой иммунизации населения Российской Федерации против гепатита В.

За последнее десятилетие (с 2011 по 2020 г.) заболеваемость ОГВ снизилась в 4,9 раза с 1,71 сл. до 0,35 сл. на 100 тыс. населения (в 2019 г. - 0,57 сл.). СМП - 1,10 на 100 тыс. населения (рис. 142).

Среди детей до 17 лет в 2020 г. зарегистрировано 4 случая ОГВ $(0,01$ сл. на 100 тыс. детей) в 4 субъектах Российской Федерации - в Новосибирской области, Республике Татарстан, Республике Крым и г. Москве (в 2019 г. - 24 случая, 0,08 сл. на 100 тыс. детей).

В 2020 году в 26 субъектах Российской Федерации (в 2019 г. - в 18) не зарегистрировано случаев заболеваний ОГВ: Орловская, Смоленская, Тульская, Ленинградская, Мурманская, Псковская, Астраханская, Омская, Амурская и Магаданская области, Ненецкий и Чукотский автономные округа, республики Коми, Адыгея, Калмыкия, Ингушетия, Марий Эл, Тыва, Хакасия, Бурятия, Еврейская автономная область, Хабаровский, Забайкальский и Камчатский края, КарачаевоЧеркесская и Кабардино-Балкарская республики.

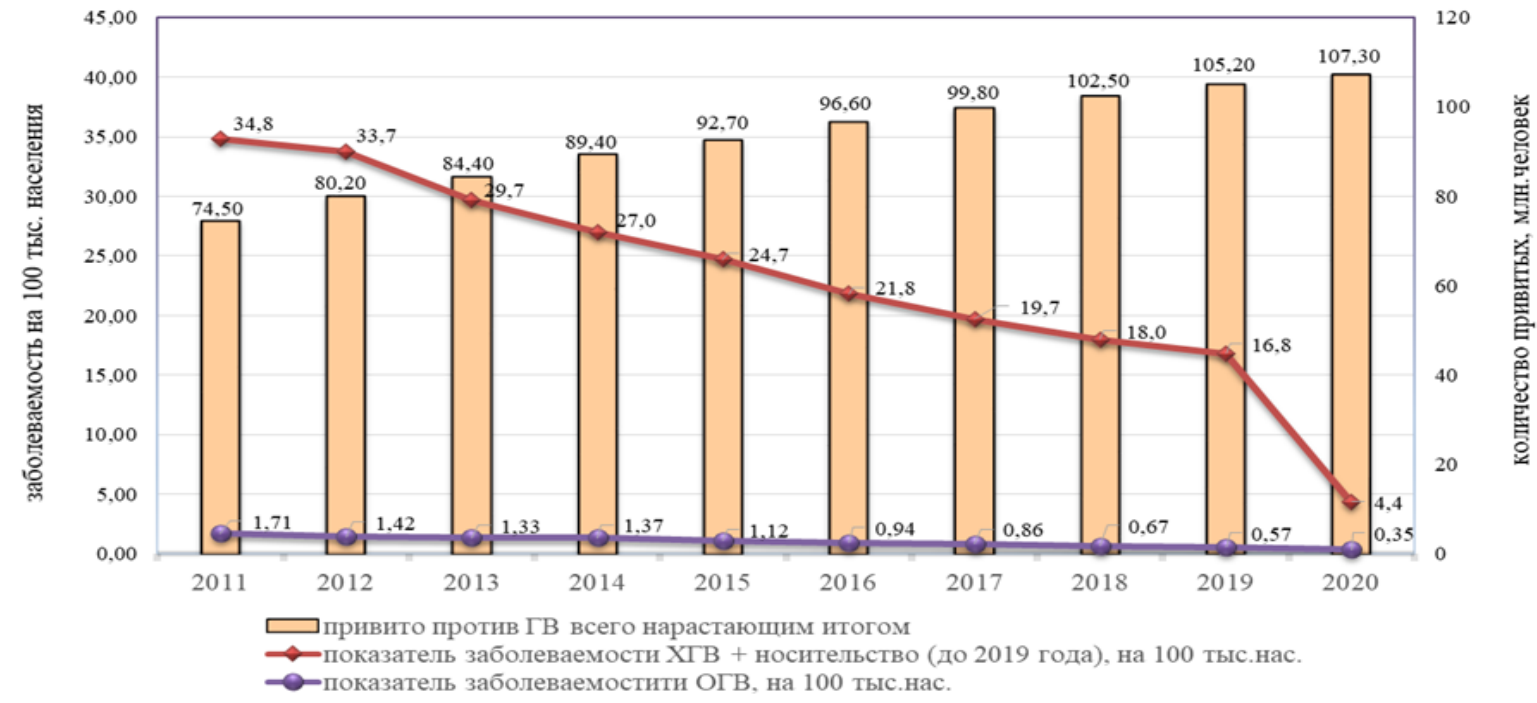

Рис. 142. Динамика заболеваемости ОГВ и частота регистрации хронической инфекции, вызванной вирусом гепатита В (хронический гепатит В и носительство (до 2019 года) вируса гепатита В), на 100 тыс. населения, и число привитых против гепатита В по нарастающей (млн чел.) с 2011 по 2020 г. 
Государственный доклад «О состоянии санитарно-эпидемиологического благополучия населения в Российской Федерации в 2020 году»

В 6 субъектах показатель заболеваемости ОГВ превышает среднероссийский в 2 раза и более (табл. 53).

Таблица 53

\section{Субъекты Российской Федерации с превышением среднероссийского показателя заболеваемости острым гепатитом В в 2,0-4,6 раза}

\begin{tabular}{|c|l|c|c|}
\hline \multicolumn{1}{|c|}{ Субъекты Российской Федерации } & $\begin{array}{c}\text { Количество } \\
\text { случаев, абс. }\end{array}$ & $\begin{array}{c}\text { Заболеваемость на } \\
100 \text { тыс. населения }\end{array}$ \\
\hline & Российская Федерация & 512 & 0,35 \\
\hline 1 & Республика Крым & 31 & 1,62 \\
\hline 2 & г. Москва & 171 & 1,35 \\
\hline 3 & Владимирская область & 14 & 1,03 \\
\hline 4 & Саратовская область & 24 & 0,99 \\
\hline 5 & Тюменская область & 14 & 0,92 \\
\hline 6 & Ивановская область & 7 & 0,70 \\
\hline
\end{tabular}

В 2020 г. в России зарегистрировано 6 случаев смерти от ОГВ, что в 0,6 раза ниже, чем число летальных случаев в 2019 г. (в 2019 г. - 10 сл.). Летальных исходов среди заболевших детей в 2020 г. зарегистрировано не было (в 2019 г. - 1 летальный случай).

Основной мерой профилактики гепатита В является проведение вакцинации населения в соответствии с национальным календарем профилактических прививок. В 2020 г. в Российской Федерации вакцинировано против гепатита В - 2,15 млн человек, в том числе 1,45 млн детей (в 2019 г. вакцинировано 2,66 млн чел., в 2018 г. 2,73 млн чел.), общее число вакцинированных с начала иммунизации составляет 107,37 млн человек (рис. 143).

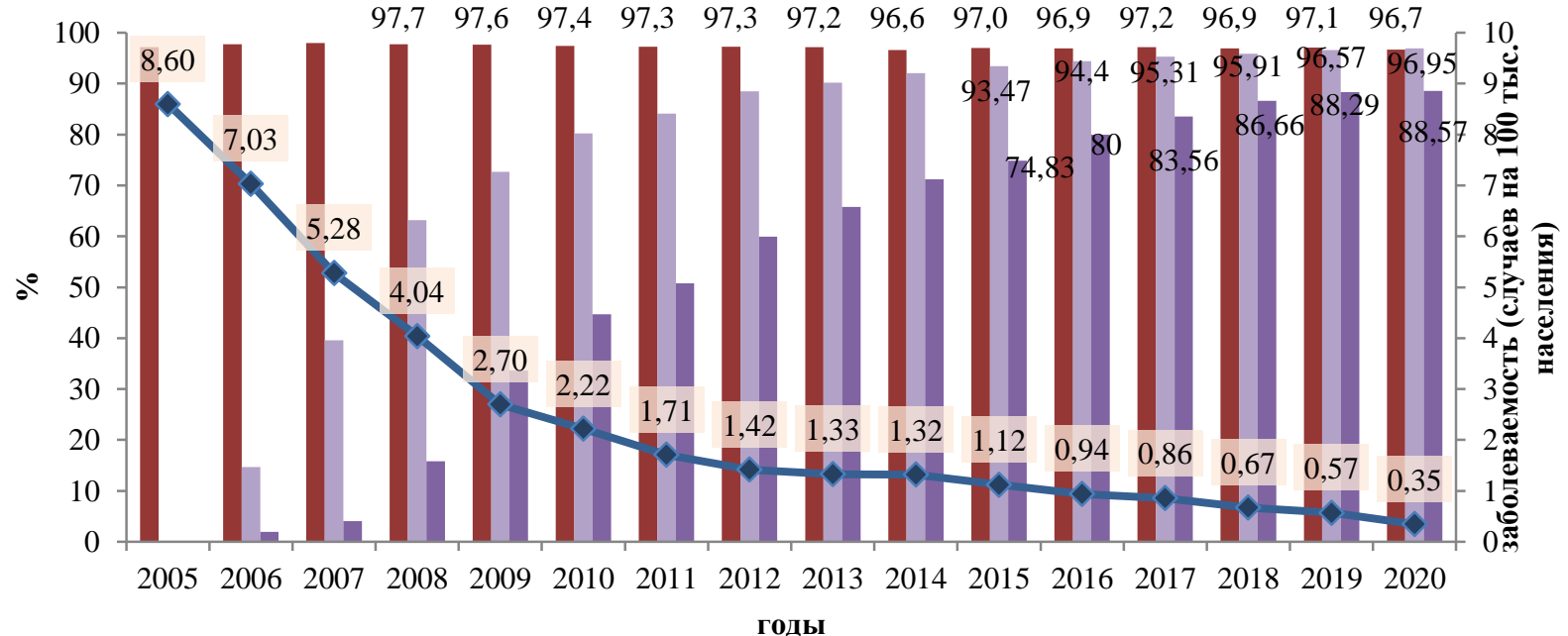

\footnotetext{
Своевременность охвата (\%) прививками против гепатита В в возрасте 12 месяцев

Охват иммунизацией взрослого населения 18-35 лет (\%)

охват иммунизацией взрослого населения 36-59 лет (\%)

— Заболеваемость на 100 тыс.населения
}

Рис. 143. Охват иммунизацией против гепатита В населения Российской Федерации, 2005-2020 гг., \%

Своевременный охват вакцинацией против гепатита В детей в возрасте 12 мес. в 2020 году составил 96,72\% (в 2019 г. - 97,06\%). Низкие показатели охвата своевременной вакцинацией детей в возрасте 12 мес. отмечаются в Ненецком $(91,86 \%)$, Чукотском $(92,52 \%)$ и Ханты-Мансийском $(92,87 \%)$ автономных округах, КарачаевоЧеркесской Республике $(93,53 \%)$. 
Охват иммунизацией взрослого населения увеличился за 2 года (2019-2020 гг.) среди лиц в возрасте 18-35 лет с 96,57 \% до 96,95 \%, в возрасте 36-59 лет - с 88,29 \% до $88,57 \%$, а старше 60 лет - с 28,85\% до 31,93\%.

В Российской Федерации с 2014 г. отмечается неуклонное ежегодное снижение заболеваемости острым гепатитом С (рис. 144).

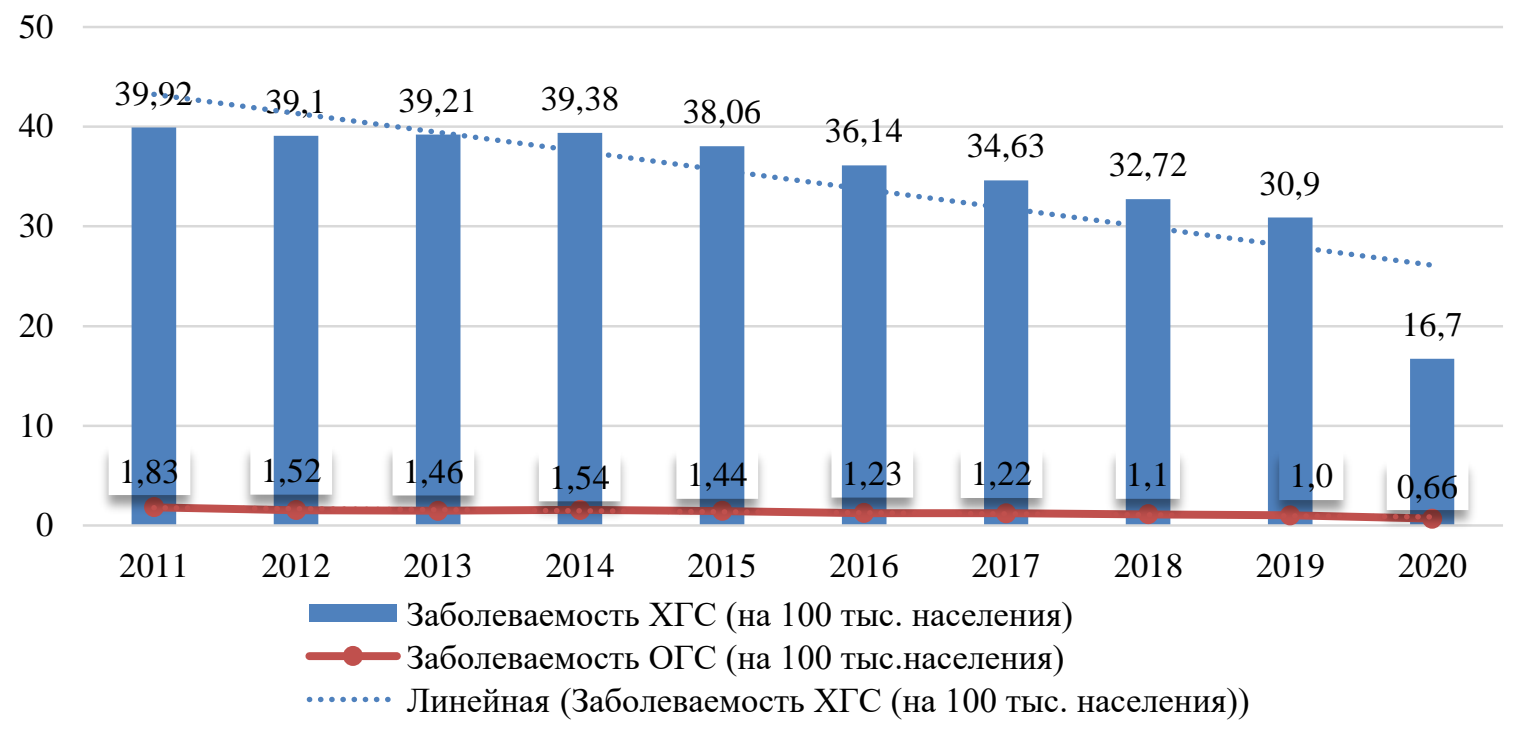

Рис. 144. Динамика заболеваемости острым и хроническим гепатитом $\mathrm{C}$ в Российской Федерации в 2011-2020 гг. (на 100 тыс. населения)

За период с 2011 г. по 2020 г. снижение наблюдается в 2,8 раза, заболеваемость ОГС составила 0,66 сл. на 100 тыс. населения (1,0 сл. - 2019 г.), СМП составляет 1,37 на 100 тыс. населения. Заболеваемость ОГС детей до 17 лет составила 0,10 сл. на 100 тыс. детского населения - показатель снизился в 2,2 раза по сравнению с 2011 г. (с 0,22 сл. до 0,10 сл. на 100 тыс. детей соответственно).

В 2020 г. всего зарегистрировано 964 случая ОГС. Удельный вес детей от общего числа заболевших составил $3,1 \%$ (в 2019 г. - 2,4\%). Доля детей до 1 года среди всех заболевших ОГС детей в 2020 г. составила 46,7 \% (14 сл.), а в 2019 г. - 54,3 \% (19 сл.).

В 10 субъектах заболеваемость ОГС превышала среднероссийский показатель от 2,0 до 3,4 раза: Камчатский край (2,23 сл. на 100 тыс. населения), Костромская область $(2,20)$, Владимирская область $(2,06)$, Чукотский автономный округ $(2,00)$, Новгородская область $(1,67)$, г. Санкт-Петербург $(1,63)$, Республика Коми $(1,45)$, Республика Крым $(1,41)$ и Мурманская область $(1,34)$, Саратовская область $(1,32)$.

ОГС в 2020 г. не регистрировали в 13 субъектах Российской Федерации: Орловской, Псковской, Магаданской и Сахалинской областях, Ненецком автономном округе, республиках Ингушетия, Алтай, Тыва и Бурятия, Забайкальском крае и Кабардино-Балкарской Республике, г. Севастополе, Еврейской автономной области (в 2019 г. - в 7 субъектах).

На территории Российской Федерации продолжают регистрироваться высокие уровни заболеваемости хроническими формами вирусных гепатитов (ХВГ). Всего в 2020 г. зарегистрировано более 31 тыс. случаев ХВГ (в 2019 г. - 58,3 тыс. случаев), снижение за год - 46,8 \%. Заболеваемость ХВГ в 2020 г. составила 21,15 сл. на 100 тыс. населения (СМП - 47,8 на 100 тыс. населения), среди детей до 17 лет - 0,74 сл. на 100 тыс. детей.

Показатели заболеваемости ХВГ резко отличаются по субъектам Российской Федерации (от 0,45 до 76,5 на 100 тыс. населения), что в определенной степени зависит от качества диагностики и полноты регистрации данной группы заболеваний (табл. 54). 


\section{Субъекты Российской Федерации с наиболее высоким и низким уровнем заболеваемости ХВГ}

\begin{tabular}{|c|l|c|c|}
\hline № & \multicolumn{1}{|c|}{ Субъекты Российской Федерации } & $\begin{array}{c}\text { Количество } \\
\text { случаев (абс.) }\end{array}$ & $\begin{array}{c}\text { Заболеваемость } \\
\text { на 100 тыс. населения }\end{array}$ \\
\hline & Российская Федерация & $\mathbf{3 1 0 3 9}$ & $\mathbf{2 1 , 1 5}$ \\
\hline 1 & г. Санкт-Петербург & 4124 & 76,50 \\
\hline 2 & г. Москва & 6200 & 49,02 \\
\hline 3 & Костромская область & 299 & 47,06 \\
\hline 4 & Ненецкий автономный округ & 19 & 43,21 \\
\hline 5 & Новосибирская область & 1149 & 41,10 \\
\hline 6 & Сахалинская область & 193 & 39,47 \\
\hline 7 & Чукотский автономный округ & 1 & 2,00 \\
\hline 8 & Республика Ингушетия & 10 & 1,99 \\
\hline 9 & Псковская область & 12 & 1,91 \\
\hline 10 & Астраханская область & 4 & 0,87 \\
\hline 11 & Республика Адыгея & 4 & 0,46 \\
\hline 12 & Кабардино-Балкарская Республика & 2 & 0,45 \\
\hline 13 & г. Севастополь & & \\
\hline
\end{tabular}

В этиологической структуре впервые зарегистрированных случаев ХВГ преобладает хронический гепатит С (ХГC), число случаев которого составило 24,5 тыс. случаев, из них детей до 17 лет - 205 случаев (0,84 \% от числа всех ХГС).

С начала регистрации (1999 г.) до 2020 г. доля ХГС увеличилась с 54,8 \% до 79,0 \%, при этом доля хронического гепатита В (ХГВ) снизилась с 38,0 \% в 1999 г. до $20,6 \%$ в 2020 году.

В 2020 году показатель заболеваемости ХГС составил 16,7 сл. на 100 тыс. населения (в 2019 г. - 30,9), при СМП - 36,7 на 100 тыс. населения и устойчивой тенденции к снижению. Показатель заболеваемости ХГС в 2020 г. превышал заболеваемость ХГВ в 3,8 раза.

Заболеваемость ХГВ снизилась в 2 раза и составила 4,36 сл. на 100 тыс. населения (в 2019 г. - 8,7 сл.), СМП - 10,8 на 100 тыс. населения.

Ежегодно регистрируется около 2 тыс. сочетанных форм вирусных гепатитов, до 70 \% которых представлены разными формами сочетания носительства ВГВ, ХГВ, ХГС. Активность эпидемического процесса парентеральных вирусных гепатитов поддерживается преимущественно регистрацией высоких уровней заболеваемости хроническими формами гепатитов при медленных темпах снижения заболеваемости ОВГ.

В целях значительного сокращения заболеваемости и распространенности ХВГ в Российской Федерации необходима разработка и реализация эффективных программ профилактики и лечения ХВГ современными препаратами прямого противовирусного действия (ПППД) согласно последним рекомендациям ВОЗ. С учетом стратегии ВОЗ по эрадикации ВГС к 2030 г. лечение вирусного гепатита С признается необходимой профилактической мерой, ведущей к значительному сокращению источников ВГС. При разработке программ и осуществлении контроля за качеством лабораторной диагностики, регистрации и учета случаев заболеваний ХВГ и охвата больных 
эффективным лечением целесообразно внедрение регистра больных всеми вирусными гепатитами на территории всех субъектов Российской Федерации.

В 2020 г. в рамках реализации программы «Элиминация кори и краснухи в Российской Федерации к 2020 году» и достижения целевых показателей Стратегии развития иммунопрофилактики инфекционных болезней на период до 2035 г. задачей Роспотребнадзора были достижение и поддержание устойчивой спорадической заболеваемости корью и краснухой во всех регионах Российской Федерации.

После подъема заболеваемости корью в Российской Федерации в 2019 г., наметился спад в 2020 г., частично обусловленный ограничительными мероприятиями, связанными с неблагополучной эпидемиологической ситуацией по COVID-19.

За 2020 году в России зарегистрировано 1212 случаев кори (в том числе 777 у детей в возрасте до 17 лет), показатель заболеваемости составил 0,83 на 100 тыс. населения, что в 3,6 раза ниже уровня прошлого года и меньше СМП на 36 \% (рис. 145). Летальных случаев от кори зарегистрировано не было.

Сохранилось неравномерное распределение случаев кори по территории Российской Федерации. Изменение количественных характеристик эпидемического процесса кори проявилось в снижении числа территорий (в 1,3 раза), где регистрировались случаи заболевания: с 69 в 2019 году до 38 территорий в 2020 г.

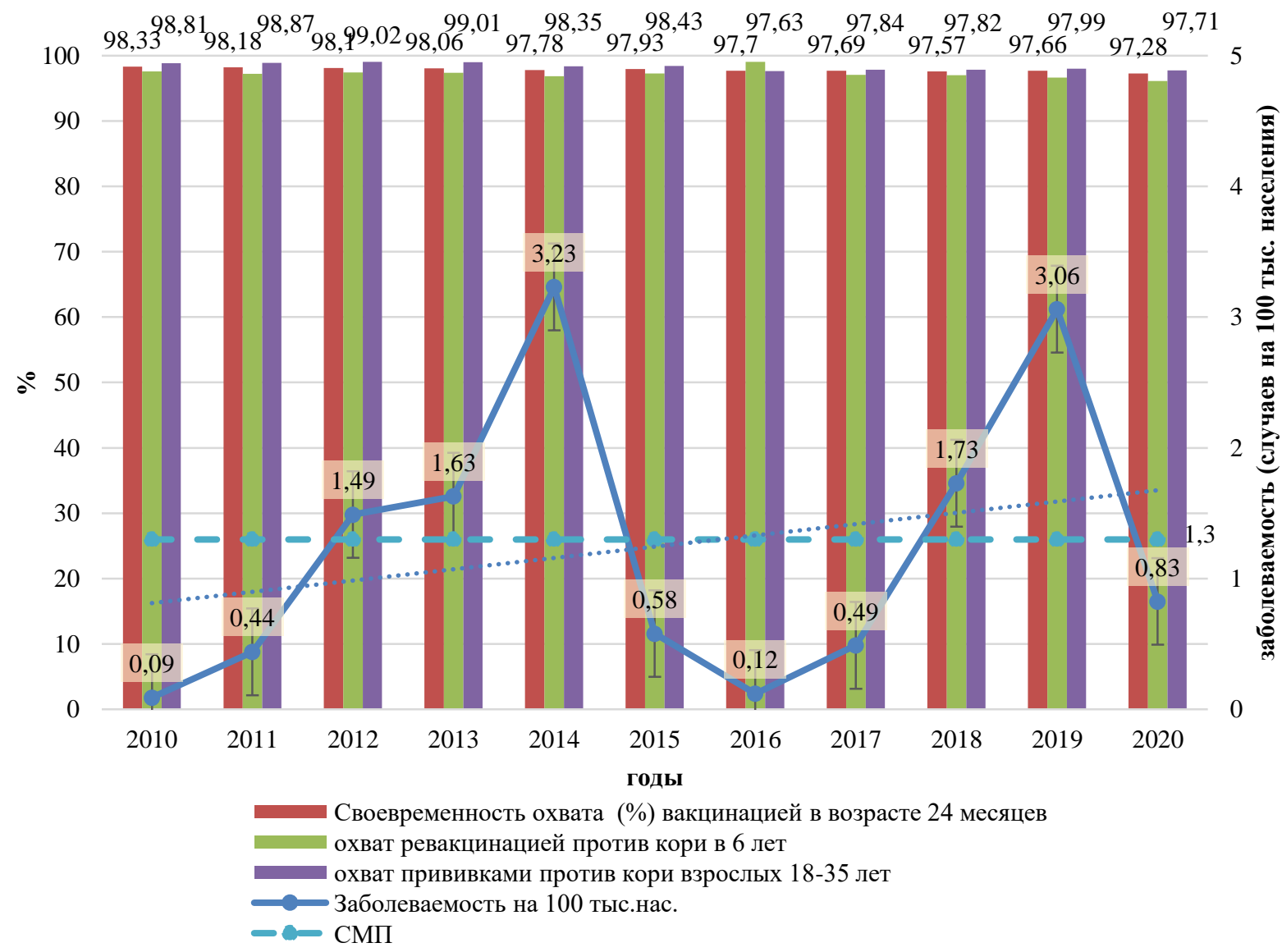

Рис. 145. Динамика показателей заболеваемости корью на 100 тыс. населения и охват вакцинацией в Российской Федерации в 2010-2020 гг., \%

В 47 субъектах страны случаи заболевания корью не регистрировались, в 18 регистрировались единичные случаи заболевания, в 17 - вторичное распространение не превышало второго поколения воспроизводства инфекции. Только в 12 субъектах России показатель заболеваемости в 2020 г. был в пределах показателя элиминации инфекции - 1,0 на млн жителей. 
В общее число заболевших вошли 29 случаев кори, выявленных при активном надзоре. Проводимые в стране масштабные противоэпидемические мероприятия, направленные на предупреждение распространения новой коронавирусной инфекции (разобщение, использование средств индивидуальной защиты, закрытие государственных границ), привели к тому, что случаи заболевания корью в 2020 году регистрировались только первые 6 месяцев. Несмотря на это, обследование пациентов с пятнисто-папулезной сыпью и лихорадкой и пациентов с подозрением на корь/краснуху не прекращалось, что подтверждает наличие чувствительного эпидемиологического надзора за корью и краснухой. С июля по декабрь 2020 г. ежемесячно количество обследованных пациентов с температурой и сыпью колебалось от 77 до 324 человек.

В 2020 году в структуре заболевших преобладали дети до 14 лет $(63,04 \%)$, на долю взрослого населения приходилось $35,81 \%$; подростков - $1,15 \%$ от всех зарегистрированных случаев кори. Анализ долевого участия в эпидемическом процессе лиц разного возраста показал, что наибольшая доля приходилась на детей 1-2 лет $24,5 \%$ и лиц в возрасте 30 лет и старше - 21,3\%, наименьшая - на возраст 18-19 лет $(1,8 \%)$ и подростков.

Сохранилась тенденция последних 10 лет - преобладание в структуре заболевших непривитых, как среди детей, так и взрослых. В 2020 г. доля непривитых составила 88,12\% против 84,28 \% в 2019 году. Удельный вес заболевших вакцинированных и ревакцинированных против кори остается небольшим - 5,33 \% и 6,52 \% соответственно, что свидетельствует об эффективности используемой тактики иммунизации против кори.

В 2020 г. показатели охвата своевременной иммунизацией против кори в декретированных возрастах в целом по стране достигли регламентируемого уровня (не менее $95 \%$ ). Не достигнут показатель в возрасте 24 мес. в трех субъектах Российской Федерации: Карачаево-Черкесской Республике, Чеченской Республике, Республике Карелия, в возрасте 6 лет - в Чеченской Республике, Республике Дагестан, Ненецком автономном округе, Республике Карелия, Ставропольском крае, Курганской области, Ханты-Мансийском автономном округе, Чукотском автономном округе, Красноярском крае, Приморском крае.

По-прежнему основной причиной отсутствия прививок против кори у детей и взрослых являются отказы от иммунизации, в том числе при проведении прививок в очагах групповой заболеваемости кори по эпидемическим показаниям.

Важным аспектом является вовлечение в эпидемический процесс социальнопрофессиональных групп риска, к которым относятся работники медицинских организаций, сферы образования, торговли, общественного питания и прочие (не более $2,1 \%$ от числа всех заболевших). Среди вышеуказанных групп высокого риска инфицирования в отчетном году лидировали работники медицинских организаций и студенты средних и высших учебных заведений. На втором месте по значимости (с одинаковыми показателями $0,8 \%$ ) стояли работники образовательных учреждений и работники торговли.

В 2020 г. зарегистрировано 755 очагов кори, из которых по-прежнему преобладали очаги без распространения инфекции - 601 очаг $(79,6 \%)$; в 20,4 \% очагов регистрировались два и более случаев, а среднее число случаев на один очаг составило 3,9 заболевших (против 4,9 в 2019 году).

Случаи внутрибольничного заражения регистрируются практически каждый год, при этом не имеют линейной тенденции и зависят от роста или спада общей заболеваемости. В 2020 году внутрибольничные очаги зарегистрированы в 15 субъектах Российской Федерации (г. Москва и г. Санкт-Петербург, Московская, Тамбовская, Оренбургская, Амурская, Астраханская, Орловская, Ленинградская области, республики Адыгея, Мордовия, Саха (Якутия), Дагестан, Краснодарский, Карачаево-Черкесская Республика). Всего было сформировано 30 очагов (70 заболевших), из них с единичными 
случаями - 16 очагов и 14 с распространением инфекции. В возрастной структуре заболевших в очагах превалировали дети - 78,6 \% (55). На долю взрослых приходилось всего $21,4 \%$ - 15 заболевших, из которых 5 человек являлись медицинскими работниками и 4 прочим персоналом медицинских организаций (младший медицинский персонал, рабочие и др.).

Риски завоза и связанного с этим распространения коревой инфекции на территории страны остаются высокими. В 2020 году, по данным ФБУН «МНИИЭМ им. Г.Н. Габричевского» Роспотребнадзора, на территории 16 субъектов Российской Федерации был импортировано 39 случаев кори (против 231 в 2019 году) из 11 стран. Наиболее часто корь завозилась из Узбекистана (19), Таиланда (8), Азербайджана (3), Казахстана (2), по 1 случаю импортировано из Украины, Грузии, Германии, Кыргызстана, ЮАР, Великобритании, Италии. Импортированные случаи кори наиболее часто регистрировались в Москве (11), Московской (5) и Оренбургской (4) областях.

В связи с закрытием границ из-за пандемии COVID-19 в 2020 году не сохранилась многолетняя тенденция роста числа импортированных случаев, однако по-прежнему преобладало импортирование случаев кори из сопредельных государств (в 2020 году около $70 \%$ от числа всех импортированных случаев).

В 2020 году было генотипировано 94 случая кори, в ходе изучения их генома для 14 штаммов определена принадлежность к генотипу D8, для 80 штаммов - к генотипу B3. Штаммы, относящиеся к генотипу В3, были представлены 1 генетической линией и 12 генетическими вариантами. 3 генетических линии (D8 MVs/Istanbul.TUR/28.18/, D8 MVs/Southern Finland.FIN/49.18/ и D8 MVs/Dagon Seikkan.MMR/5.18) и 2 генетических варианта вируса, выявленные в 2020 г., относились к генотипу D8. Результаты проведенного мониторинга циркуляции диких штаммов показали снижение генетического разнообразия вируса кори на территории России в 2020 г. в сравнении с 2019 г.

Следует отметить, что местная передача штаммов линии В3 MVs/Kabul.AFG/20.2014/3 длилась в период с 4 недели 2019 г. по 19 неделю 2020 г., затем отмечено прерывание эндемичной передачи вируса кори данной генетической линии. Однако обращает на себя внимание появление уникальных генетических вариантов вируса, изолированных от случаев заболевания в начале года, возможно, явившееся следствием активной местной циркуляции предковых штаммов генетической линии MVs/Kabul.AFG/20.2014/3. В то же время молекулярно-генетические данные о новых штаммах свидетельствуют об отсутствии у них новых антигенных свойств, которые могли бы отрицательно сказаться на эффективности вакцинопрофилактики.

Анализ данных показал, что при проведении на должном уровне работы по плановой и подчищающей иммунизации населения против кори, активному выявлению и иммунизации лиц, не привитых против этой инфекции, в том числе среди иностранных граждан, иммунизации по эпидемическим показаниям в очагах кори, широкомасштабной информационной работы с населением по пропаганде вакцинопрофилактики возможно дальнейшее снижение и стабилизация заболеваемости корью на спорадическом уровне.

В 2020 году число заболевших краснухой снизилось до 3 случаев $(0,002$ на 100 тыс. населения) против 34 в 2019 г. (0,02 на 100 тыс. населения). Среди заболевших 2 женщины и 1 мужчина. Все случаи были лабораторно подтверждены, зарегистрированы на территории двух субъектов страны: г. Москва и г. Санкт-Петербург. Летальных случаев и случаев синдрома врожденной краснухи не зарегистрировано.

Возрастная структура заболевших - лица 19-35 лет, не привитые против краснухи, что в очередной раз подтверждают значимость иммунопрофилактики населения против краснухи.

Анализ охвата прививками против краснухи показал, что в целом по России 97,29\% детей к 24 месяцам имеют прививки против краснухи. На 4 территориях показатель своевременности вакцинации был ниже 95,0 \%: Республика Карелия 
(94,69 \%), Карачаево-Черкесская Республика (93,15 \%), Ненецкий автономный округ $(93,48$ \%) и Чеченская Республика $(94,91 \%)$.

Вторую прививку против краснухи в 6 лет получили 96,02 \% детей этого возраста. К числу регионов, где охват детей ревакцинацией был ниже 95,0\%, относятся: республики Карелия $(77,67 \%)$ и Дагестан $(94,56)$, Чеченская Республика $(83,24)$ Курганская область $(92,82)$, Ставропольский $(91,35)$ и Приморский края $(94,22)$, Чукотский $(74,58)$, Ханты-Мансийский $(93,87)$ и Ненецкий $(91,68)$ автономные округа. Охват ревакцинирующими прививками против краснухи девушек в возрасте 18-25 лет в среднем по стране составил $57,37 \%$ против 56,05 \% в 2019 году.

В 2020 году заболеваемость эпидемическим паротитом после подъема в 2017 г. продолжила снижаться и составила 0,3 на 100 тыс. населения (рис. 146) при среднемноголетнем показателе 0,73 . Летальных случаев не зарегистрировано.

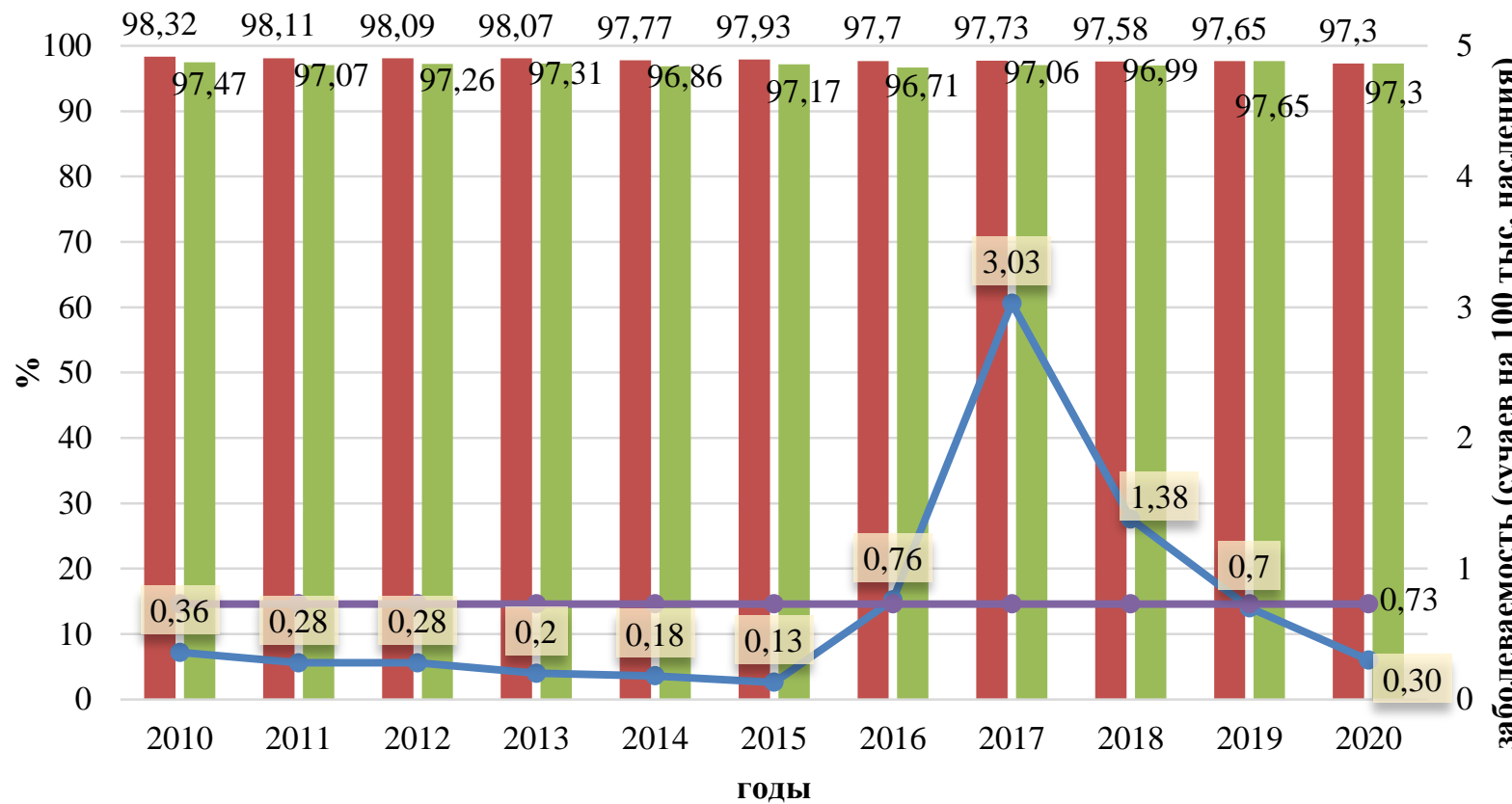

\footnotetext{
Своевременность охвата (\%) прививками в возрасте 24 месяцев

Охват ревакцинацией в возрасте 6 лет (\%)

- Заболеваемость

- СМП
}

Рис. 146. Динамика заболеваемости эпидемическим паротитом в Российской Федерации в 2010-2020 гг. (на 100 тыс. населения)

Заболеваемость эпидемическим паротитом характеризовалась неравномерным распределением по территориям страны. На более чем 90 \% территорий заболеваемость либо не регистрировалась, либо регистрировались единичные случаи. В последние годы наметилась тенденция к росту числа субъектов РФ, где случаи заболевания не регистрировались: с 39 (2018 г.) до 64 (2020 г.).

С 2016 года сохранилось преобладание заболеваемости эпидемическим паротитом в Северо-Кавказском федеральном округе по сравнению с другими федеральными округами. В 2020 году в СКФО зарегистрировано 375 случаев заболевания, показатель заболеваемости составил 3,79 на 100 тыс. населения. Наиболее высокий показатель отмечен в Республике Дагестан, где заболеваемость превысила среднероссийскую в 40 раз и составила 11,88 на 100 тыс. населения.

Дети и взрослые болели эпидемическим паротитом практически в равных долях - 51,03\% и 43,28 \% соответственно. Вклад в общую заболеваемость подростков был незначительным - всего 5,6\%. Среди заболевшего детского населения преобладали 
школьники, преимущественно не привитые против эпидемического паротита $(78,3 \%)$. Заболеваемость детей в 2020 году снизилась по сравнению с 2019 годом в 2,2 раза и составила 0,83 на 100 тыс. детей до 17 лет $(2019$ г. - 1,85). Снижение заболеваемости наблюдалось во всех возрастных группах детей, что также может быть связано с ограничительными мероприятиями в течение всего 2020 г.

В структуре заболевших преобладают непривитые дети и взрослые, на долю которых приходилось $80,87 \%$, показатель заболевших вакцинированных 7,06 \%, ревакцинированных - $12,07 \%$. Все это свидетельствует об эффективности вакцинопрофилактики как массового мероприятия.

Регламентированный уровень охвата своевременной вакцинацией против эпидемического паротита детей в возрасте 24 месяца (не менее 95,0\%) в 2020 году достигнут $(97,3 \%)$ и поддерживается во всех субъектах Российской Федерации, за исключением Карачаево-Черкесской Республики $(93,15 \%)$, Республики Карелия (94,61 \%), Чеченской Республики $(94,89 \%)$.

Ревакцинацию против эпидемического паротита в 6 лет в среднем по стране получили 96,05\% детей, однако на некоторых территориях (9 субъектов) регламентированный уровень охвата не достигнут: в Республике Карелия $(77,62$ \%), Ненецком автономном округе (91,68 \%), Республике Дагестан $(94,63 \%)$, Чеченской Республике $(83,28 \%)$, Ставропольском крае $(92,41 \%)$, Курганской области $(93,05 \%)$, Ханты-Мансийском автономном округе $(93,91 \%)$, Приморском крае $(94,17 \%)$ и Чукотском автономном округе $(87,36 \%)$.

В динамике заболеваемости коклюшем за последние 10 лет на территории России отмечены колебания показателя заболеваемости от 3,15 на 100 тысяч населения в 2013 году до 9,8 на 100 тысяч населения в 2019 году. В 2020 году завершился циклический эпидемический подъем заболеваемости коклюшем, который начался в 2018 году (рис. 147). Наиболее вероятно уменьшение количества заболевших более чем в два раза связано с ограничительными мероприятиями и разобщением организованных коллективов на протяжении 2020 года вследствие роста заболеваемости COVID-19.

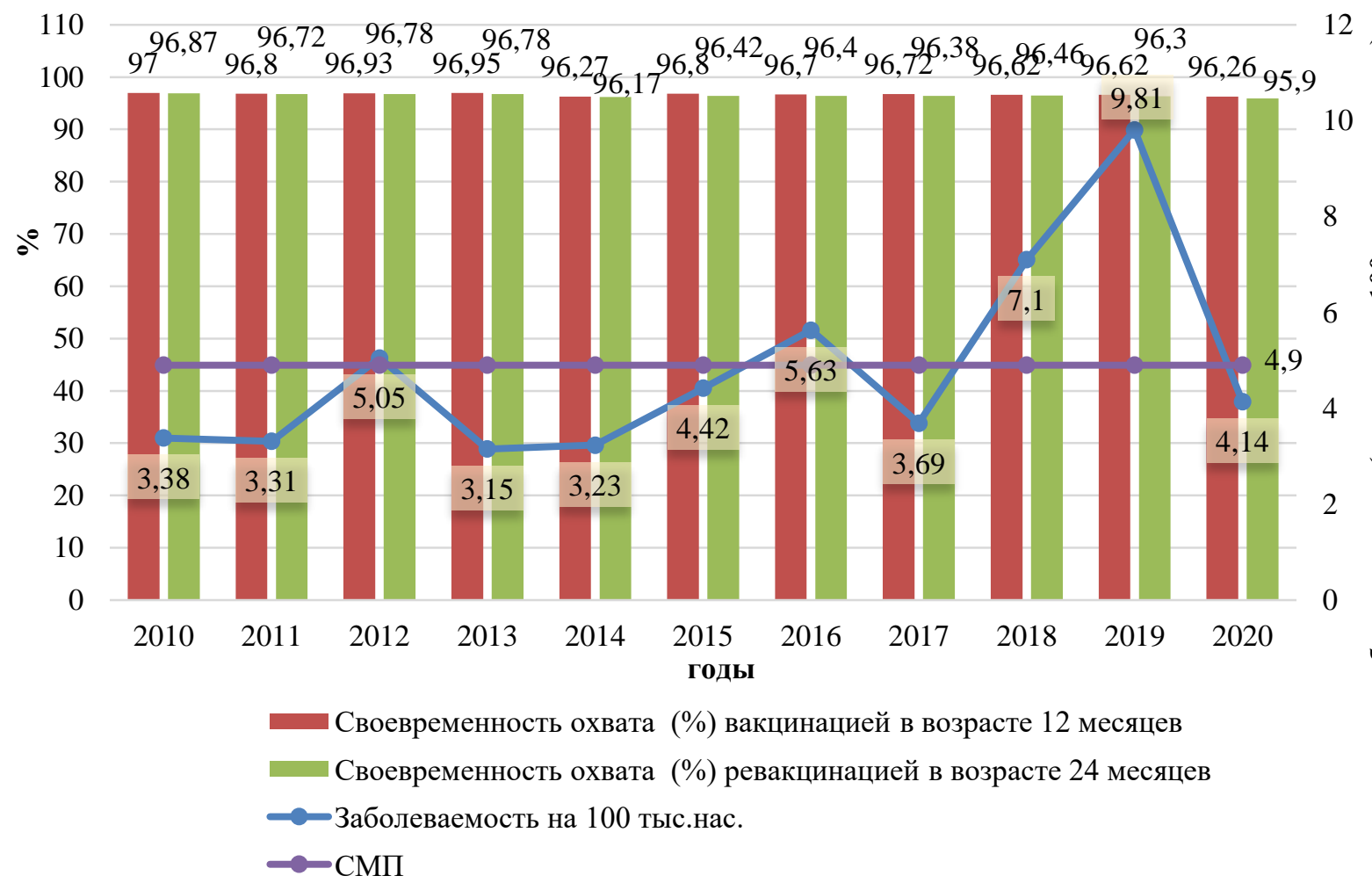

Рис. 147. Динамика заболеваемости коклюшем в Российской Федерации в 2010-2020 гг. 
В 2020 году зарегистрировано 6069 случаев коклюша, показатель заболеваемости составил 4,14 на 100 тысяч населения (СМП 4,9), что на 58,2 \% ниже показателя за 2019 год. Зарегистрировано два летальных случая (непривитые дети в возрасте до 1 года и 1,5 лет).

Как и в прошлые годы заболеваемость коклюшем регистрируется практически во всех субъектах страны, но распределена неравномерно. Так, в 68 субъектах отмечается низкий уровень заболеваемости коклюшем - не более 5,0 на 100 тысяч населения (что на 36 субъектов больше, чем в 2019 году). Не зарегистрировано ни одного случая данного заболевания в Ненецком и Чукотском автономных округах, Карачаево-Черкесской Республике, Магаданской области.

В 3 субъектах Российской Федерации заболеваемость коклюшем превышает среднероссийский показатель более чем в 2 раза: г. Москва (11,7 на 100 тыс. населения), Республика Карелия $(14,7)$, Кировская область $(22,4)$.

Более 10 лет в структуре заболевших коклюшем около 90 \% составляют дети до 14 лет. Анализ возрастной заболеваемости коклюшем в 2020 году показал сохранение данных тенденций: удельный вес детей до 14 лет составил 87,9 \%, подростков 15-17 лет - 5,9\%, взрослого населения - 6,2\% от всех заболевших. При этом максимальная заболеваемость, как и ранее, приходится на детей в возрасте до одного года - 52,3 на 100 тыс. детей данного возраста (в 2018 г. - 113,8 на 100 тысяч детей данного возраста, в 2019 г. - 148,9), что в очередной раз указывает на детей первого года жизни как на группу высокого риска в отношении заболеваемости коклюшем и подчеркивает важность их своевременной иммунизации.

За последние 10 лет показатель охвата прививками населения в декретированных возрастах составлял значения, превышающие регламентированные $95 \%$. В 2020 г. своевременно вакцинированы против коклюша в возрасте 12 месяцев 96,3 \% детей, своевременно ревакцинированы в возрасте 24 месяцев 95,9\%. Однако регламентированный показатель своевременности охвата вакцинацией детей в возрасте 12 месяцев не достигнут в 10 субъектах Российской Федерации: в Чувашской $(94,83$ \%), Карачаево-Черкесской $(93,47 \%)$ и Чеченской $(94,39 \%)$ республиках, республиках Карелия (89,31\%) и Саха (Якутия) (92\%), Приморском крае $(94,84 \%)$, Ненецком $(91,1 \%)$, Ханты-Мансийском $(93,17 \%)$, Чукотском $(93,36 \%)$ автономных округах, Еврейской автономной области (94,98 \%). В Ненецком автономном округе и Чувашской Республике аналогичная картина наблюдалась в 2019 г. $\quad(88,2 \%$ и $94,9 \%$ соответственно). Целевой показатель своевременности охвата ревакцинацией детей в 24 месяца не достигнут в 11 субъектах страны: Брянской области $(94,7 \%)$, Республике Карелия $(85,2 \%)$, Ненецком автономном округе $(87,0)$, Кабардино-Балкарской Республике (94,3 \%), Карачаево-Черкесской Республике $(92,3$ \%), Чеченской Республике $(91,5 \%)$, Чувашской Республике $(94,9 \%)$, Ханты-Мансийском автономном округе $(93,7 \%)$, Красноярском крае $(94,9 \%)$, Приморском крае $(94,4 \%)$, Чукотском автономном округе $(82,4 \%)$.

Заболеваемость дифтерией и носительство токсигенных коринебактерий в Российской Федерации более 10 лет находится на стабильно низком уровне. Показатель заболеваемости колебался от 0,001 на 100 тысяч населения $(2013,2014,2016,2020$ гг.) до 0,003 на 100 тысяч населения (2011, 2012, 2018, 2019 гг.), в 2017 году случаи дифтерии не регистрировались. Показатель носительства токсигенных коринебактерий из расчета на 100 тыс. населения регистрировался в пределах от 0,001 (2016, 2017, 2019 гг.) до 0,008 (2012 год), в 2020 году ни одного носителя не выявлено.

В 2020 году дифтерией заболел один человек (ребенок 7 лет).

Единичная заболеваемость дифтерией в нашей стране обеспечена многолетним широким охватом декретированных возрастных групп специфическими прививками против этой инфекции. В связи с этим возрастает значимость своевременной вакцинации и первой ревакцинации против дифтерии, формирующих грунт-иммунитет. В 2020 году своевременно первый вакцинный комплекс в возрасте 12 месяцев получили 96,5\% 
подлежащего вакцинации населения. Регламентируемое значение показателя охвата не было достигнуто на 8 территориях: Республика Карелия (89,5 \%), Ненецкий автономный округ (91,1\%), Карачаево-Черкесская Республика (93,7 \%), Чеченская Республика $(94,7 \%)$, Ханты-Мансийский автономный округ $(93,4 \%)$, Республика Саха (Якутия) $(92,06 \%)$, Приморский край $(94,9 \%)$, Чукотский автономный округ $(91,7 \%)$.

Целевой показатель своевременной первой ревакцинации против дифтерии в 24 месяца $(95 \%)$ в целом по стране составил $96,1 \%$ и не был достигнут в 9 субъектах Российской Федерации: Республика Карелия (85,4\%), Ненецкий автономный округ $(87,0$ \%), Кабардино-Балкарская Республика $(94,8$ \%), Карачаево-Черкесская Республика (92,3\%), Чеченская Республика (92,3\%), Чувашская Республика $(94,9 \%)$, ХантыМансийский автономный округ $(93,9 \%)$, Приморский край $(94,4 \%)$, Чукотский автономный округ $(82,4 \%)$.

Заболеваемость менингококковой инфекцией в Российской Федерации имеет многолетнюю тенденцию к снижению. За период 2016-2019 гг. отмечен рост показателя заболеваемости на $33 \%$.

С 2020 г. в форме федерального статистического наблюдения № 2 «Сведения об инфекционных и паразитарных заболеваниях» учитываются только генерализованные формы менингококковой инфекции (ГФМИ). Заболеваемость ГФМИ в Российской Федерации также имеет многолетнюю тенденцию к снижению с периодом подъема в 2016-2019 гг., в 2020 г. было отмечено снижение показателя заболеваемости относительно предыдущего года на $56 \%$ до 0,26 на 100 тыс. населения $(2019$ г. - 0,59) и СМП на $62,3 \%$ (рис. 148).

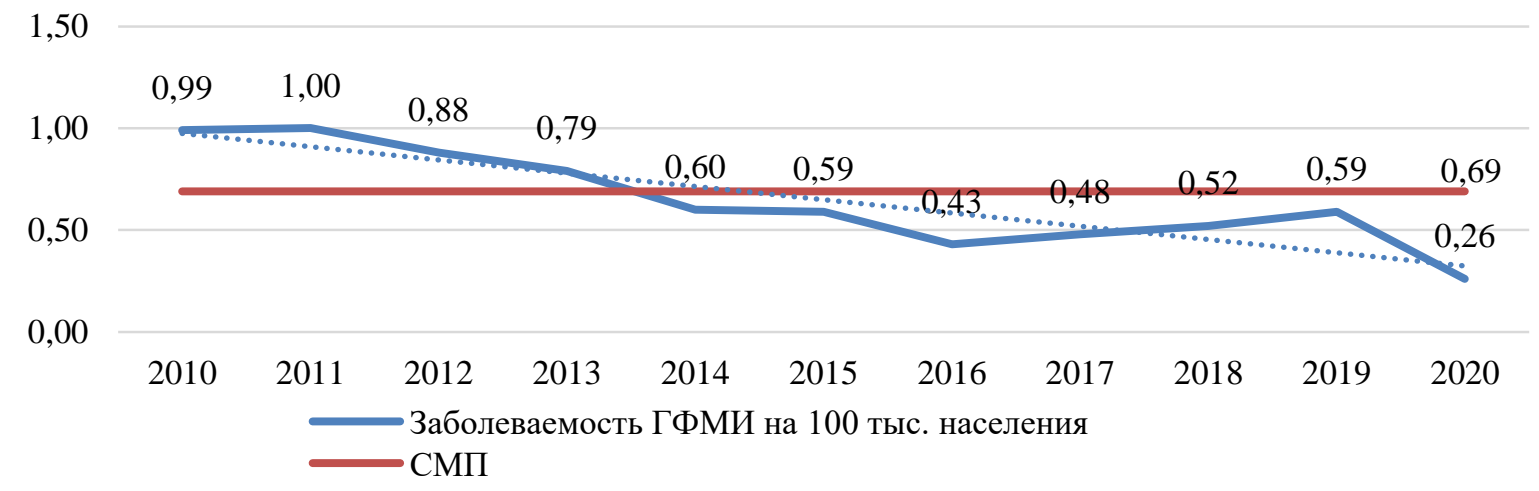

Рис. 148. Заболеваемость ГФМИ в Российской Федерации в 2010-2020 гг. (на 100 тыс. населения)

Несмотря на резкое снижение заболеваемости ГФМИ, остаются территории, где показатель заболеваемости в 2020 г. превышал среднероссийский в 2 и более раза: в Новгородской области $(1,17$ на 100 тыс. населения), г. Москве $(0,99)$, Хабаровском крае $(0,76)$, Республике Марий Эл $(0,59)$.

Результативность лабораторной диагностики определяет качество и достоверность аналитических показателей эпидемиологического надзора. Удельный вес лабораторного подтверждения диагноза генерализованной формы менингококковой инфекции (ГФМИ) ежегодно повышается и составляет в 2020 г. 81 \% (2019 г. - 78 \%).

По данным референс-центра по мониторингу за бактериальными менингитами, дети болели ГФМИ в 5 раз чаще, чем взрослые, а среди них группой наиболее высокого риска являются дети в возрасте 0-4 года. Самые высокие показатели заболеваемости ГФМИ среди подростков и взрослых отмечены в возрастной группе 15-19 лет.

Летальность от ГФМИ продолжает оставаться на высоком уровне, и в 2020 г. этот показатель составил $12 \%$. Отмечен значительный вклад в формирование летальности от ГФМИ наиболее уязвимых возрастных групп, а именно лиц до 1 года, 45-64 лет и лиц от 65 лет и старше (24\%, 19 \% и $27 \%$ соответственно). Показатель летальности подростков 15-19 лет составил $5 \%$. 
В серогрупповой характеристике инвазивных штаммов выявлено преобладание Neisseria meningitidis серогруппы А (30\%). Далее по частоте выделения следовали штаммы серогруппы В (18\%), C (16\%) и W (5\%). Менингококк серогруппы Y выделен в 3 случаях ГФМИ. В $29 \%$ случаев серогрупповую характеристику определить не удалось. У детей (0-4 года) чаще выделяли серогруппу В, у лиц от 15 лет и старше серогруппу А.

Число привитых против менингококковой инфекции в 2020 г. по сравнению с 2019 г. увеличилось в 1,3 раза (привито 374786 человек), при этом в 1,8 раза увеличилось число вакцинированных детей, их доля от общего числа вакцинированных составила $58 \%$.

Несмотря на снижение показателя заболеваемости в 2020 г., сохраняются признаки начала периодического подъема заболеваемости менингококковой инфекцией в Российской Федерации, что указывает на актуальность на необходимость расширения вакцинации лиц из групп риска с использованием современных конъюгированных вакцин.

На территории Российской Федерации в 2020 г. зарегистрировано 10,9 тыс. случаев заболеваний природно-очаговыми инфекциями (далее - ПОИ), что почти в 2,6 раза меньше по сравнению с 2019 г. (28,1 тыс. случаев). Снижение заболеваемости связано с введенными ограничительными мерами, направленными на недопущение распространения новой коронавирусной инфекции. Уменьшение числа случаев заболеваний ПОИ в 2020 г. наблюдалось практически по всем нозологиям (табл. 55), за исключением туляремии (по 41 случаю в 2020 г. и 2019 г.) и бешенства.

В структуре заболеваемости ПОИ основную долю составляют иксодовые клещевые боррелиозы (ИКБ) - 38,5\% от всех случаев, 35,2\% - геморрагическая лихорадка с почечным синдромом (ГЛПС), 10,5\% - риккетсиозы группы клещевой пятнистой лихорадки (КПЛ), по суммарным данным учета случаев заболевания сыпным клещевым тифом Северной Азии (сибирским клещевым тифом, далее - СКТ) и Астраханской пятнистой лихорадкой (АПЛ), 8,9\% - клещевой вирусный энцефалит (КВЭ). Среди прочих ПОИ (6,9\%) зарегистрирован псевдотуберкулез (263 случая - 2,4 \%), лихорадка денге (121 случай - 1,1 \%), бруцеллез (119 случаев - 1,1 \%), лептоспироз (94 - 0,9 \%).

Таблица 55

\section{Распространенные в Российской Федерации природно-очаговые,} зоонозные и зооантропонозные инфекции

\begin{tabular}{|c|c|c|c|c|c|c|c|}
\hline \multirow[b]{2}{*}{$\begin{array}{l}\text { № } \\
\text { П/П }\end{array}$} & \multirow[b]{2}{*}{$\begin{array}{c}\text { Нозологические } \\
\text { формы }\end{array}$} & \multicolumn{3}{|c|}{ Все население } & \multicolumn{3}{|c|}{ Сельское население } \\
\hline & & $\begin{array}{c}\text { Заболевае- } \\
\text { мость в } \\
2020 \text { г. }\end{array}$ & \begin{tabular}{|c|} 
Тенденция \\
$2010-$ \\
2020 гг.
\end{tabular} & $\begin{array}{c}\text { СМП } \\
(2010- \\
2019 \text { гг.) }\end{array}$ & $\begin{array}{c}\text { Заболевае- } \\
\text { мость в } \\
2020 \text { г. }\end{array}$ & \begin{tabular}{|c|} 
Тенденция \\
$2010-$ \\
2020 гг.
\end{tabular} & $\begin{array}{c}\text { СМП } \\
(2010- \\
2019 \text { гг.) }\end{array}$ \\
\hline 1 & ГЛПС & 2,62 & $\uparrow$ & 5,02 & 4,46 & $\uparrow$ & 6,97 \\
\hline 2 & ИКБ & 2,86 & $\downarrow$ & 4,8 & 1,7 & $\downarrow$ & 3,4 \\
\hline 3 & КВЭ & 0,66 & $\downarrow$ & 1,56 & 0,86 & $\downarrow$ & 2,01 \\
\hline 4 & CKT & 0,76 & $\downarrow$ & 1,06 & 2,06 & $\downarrow$ & 2,61 \\
\hline 5 & Лептоспирозы & 0,06 & $\downarrow$ & 0,14 & 0,08 & $\downarrow$ & 0,17 \\
\hline 6 & КГЛ & 0,02 & отсутствует & 0,07 & 0,06 & отсутствует & 0,21 \\
\hline 7 & Сибирская язва & 5 сл. & $\downarrow$ & - & 5 сл. & $\downarrow$ & - \\
\hline 8 & Бруцеллез & 0,08 & $\downarrow$ & 0,26 & 0,25 & $\downarrow$ & 0,8 \\
\hline 9 & Туляремия & 0,03 & $\downarrow$ & 0,07 & 0,04 & отсутствует & 0,08 \\
\hline 10 & Псевдотуберкулез & 0,18 & $\downarrow$ & 0,81 & 0,13 & $\downarrow$ & 0,62 \\
\hline 11 & Бешенство (гидрофобия) & 7 сл. & $\downarrow$ & - & 6 сл. & $\downarrow$ & - \\
\hline 12 & Лихорадка Ку & 8 сл. & $\downarrow$ & 0,09 & 8 сл. & $\downarrow$ & 0,15 \\
\hline 13 & ЛЗН & 0,01 & $\downarrow$ & 0,12 & 0,01 & $\downarrow$ & 0,11 \\
\hline 14 & АПЛ & 0,02 & $\downarrow$ & 0,18 & 0,05 & $\downarrow$ & 0,43 \\
\hline
\end{tabular}


Государственный доклад «О состоянии санитарно-эпидемиологического благополучия населения в Российской Федерации в 2020 году»

Инфекции, передающиеся клещами (ИПК). Среднее количество обращений за медицинской помощью в Российской Федерации по поводу укусов клещей за 20142020 гг. составило $347 \pm 33$ тыс. на 100 тыс. населения. Относительно 2019 г., когда был зарегистрирован максимальный показатель за весь период наблюдения, в 2020 г. этот показатель снизился на $19 \%$, однако относительно среднего показателя за 7-летний период - только на 7 \%. Более четверти пострадавших - дети.

Эпидемиологическое неблагополучие в отношении инфекций, передающихся клещами (ИПК), традиционно наблюдается в регионах Сибири, Приволжья, в ряде субъектов Северо-Западного и Центрального федеральных округов. Среди субъектов с максимальными показателями регистрации обращений в 2020 г. - Томская область, Республика Алтай и Тюменская область. Показатель обращаемости вырос в Новосибирской, Томской, Тюменской и Кемеровской областях (табл. 56).

На первом месте по распространенности и частоте регистрации в 2020 г. среди ИПК находятся иксодовые клещевые боррелиозы (ИКБ).

Таблица 56

\section{Субъекты Российской Федерации с наиболее высокой обращаемостью} по поводу укусов клещами и заболеваемостью КВЭ и ИКБ в 2020 году

\begin{tabular}{|c|c|c|c|c|c|c|c|c|}
\hline \multirow[b]{2}{*}{$\begin{array}{c}\text { № } \\
\Pi / \Pi\end{array}$} & \multirow[b]{2}{*}{$\begin{array}{c}\text { Субъекты } \\
\text { Российской } \\
\text { Федерации }\end{array}$} & \multirow[b]{2}{*}{$\begin{array}{l}\text { Обращае- } \\
\text { мость }\end{array}$} & \multicolumn{3}{|c|}{ КВЭ } & \multicolumn{3}{|c|}{ ИКБ } \\
\hline & & & $\begin{array}{c}\text { Заболе- } \\
\text { ваемость }\end{array}$ & $\begin{array}{c}\text { СМП } \\
(2010- \\
2019 \text { гг.) } \\
\end{array}$ & $\begin{array}{c}\text { Тренд } \\
2010- \\
2020 \text { гг. }\end{array}$ & $\begin{array}{c}\text { Заболева- } \\
\text { емость }\end{array}$ & $\begin{array}{c}\text { СМП } \\
(2010- \\
2019 \text { гг.) } \\
\end{array}$ & $\begin{array}{c}\text { Тренд } \\
2010- \\
2020 \text { гг. }\end{array}$ \\
\hline & $\begin{array}{l}\text { Российская } \\
\text { Федерация }\end{array}$ & 321,35 & 0,66 & 1,56 & $\downarrow$ & 2,86 & 4,8 & $\downarrow$ \\
\hline 1 & Томская область & 2392,16 & 2,97 & 9,84 & $\downarrow$ & 10,29 & 13,9 & $\downarrow$ \\
\hline 2 & Республика Алтай & 1756,07 & 5,92 & 9,69 & $\downarrow$ & 7,74 & 8,44 & $\downarrow$ \\
\hline 3 & Тюменская область & 1250,87 & 2,55 & 5,05 & $\downarrow$ & 3,47 & 5,19 & $\uparrow$ \\
\hline 4 & Костромская область & 1195,29 & 2,2 & 4,78 & $\downarrow$ & 6,77 & 14,21 & $\downarrow$ \\
\hline 5 & Кемеровская область & 1183,88 & 4,05 & 4,79 & $\downarrow$ & 5,51 & 8,96 & $\uparrow$ \\
\hline 6 & Кировская область & 1000,67 & 3,55 & 7,78 & $\downarrow$ & 6,31 & 21,83 & $\downarrow$ \\
\hline 7 & \begin{tabular}{|} 
Удмуртская \\
Республика
\end{tabular} & 878,56 & 1,06 & 4,31 & $\downarrow$ & 0,93 & 9,77 & $\downarrow$ \\
\hline 8 & Вологодская область & 788,69 & 2,15 & 5,47 & $\downarrow$ & 4,64 & 23,61 & $\downarrow$ \\
\hline 9 & $\begin{array}{l}\text { Новосибирская } \\
\text { область }\end{array}$ & 768,84 & 3,51 & 5,71 & $\downarrow$ & 4,36 & 9,39 & $\downarrow$ \\
\hline 10 & Свердловская область & 724,54 & 1,0 & 2,84 & $\downarrow$ & 7,19 & 16,2 & $\downarrow$ \\
\hline 11 & Иркутская область & 587,98 & 1,59 & 4,47 & $\downarrow$ & 1,71 & 5,04 & $\downarrow$ \\
\hline 12 & Пермский край & 544,72 & 0,84 & 6,71 & $\downarrow$ & 2,03 & 12,89 & $\downarrow$ \\
\hline 13 & Республика Хакасия & 527,45 & 1,12 & 7,24 & $\downarrow$ & 1,31 & 11,37 & $\downarrow$ \\
\hline 14 & Красноярский край & 526,84 & 5,54 & 13,43 & $\downarrow$ & 5,47 & 10,29 & $\downarrow$ \\
\hline 15 & Челябинская область & 491,58 & 1,61 & 2,43 & $\downarrow$ & 1,5 & 3,26 & $\downarrow$ \\
\hline 16 & Ярославская область & 302,75 & 0,32 & 0,81 & $\downarrow$ & 3,9 & 10,34 & $\downarrow$ \\
\hline 17 & Калужская область & 184,0 & 0 & 0 & - & 8,85 & 8,3 & $\uparrow$ \\
\hline 18 & г. Москва & 109,74 & 0,02 & 0,09 & - & 10,21 & 7,81 & $\uparrow$ \\
\hline 19 & Воронежская область & 97,63 & 0 & 0 & - & 6,19 & 2,72 & $\uparrow$ \\
\hline 20 & Брянская область & 88,19 & 0 & 0 & - & 4,43 & 2,59 & $\uparrow$ \\
\hline
\end{tabular}


С учетом 2020 г. динамику показателя среднемноголетней заболеваемости ИКБ в Российской Федерации за 10-летний период можно охарактеризовать как снижение (рис. 149).

Второй по распространенности инфекцией является клещевой вирусный энцефалит (КВЭ). В 2020 г. зарегистрировано 967 случаев КВЭ в 38 субъектах страны (0,66 на 100 тыс. населения, что в 2 раза ниже, чем в 2019 г.), 18 - с летальным исходом, связанные с поздним обращением населения за медицинской помощью, несвоевременной постановкой диагноза, отсутствием вакцинации в анамнезе.

Показатель заболеваемости ИКБ в среднем за 2011-2020 гг. составил 4,8 $\pm 1,1$ на 100 тыс. населения. По сравнению с 2019 г. произошло уменьшение показателей заболеваемости в 2 раза. Значительное снижение числа случаев ИКБ в 2020 г. в регионах с привычно высоким уровнем заболеваемости зарегистрировано в Вологодской, Кировской, Свердловской областях и Красноярском крае.

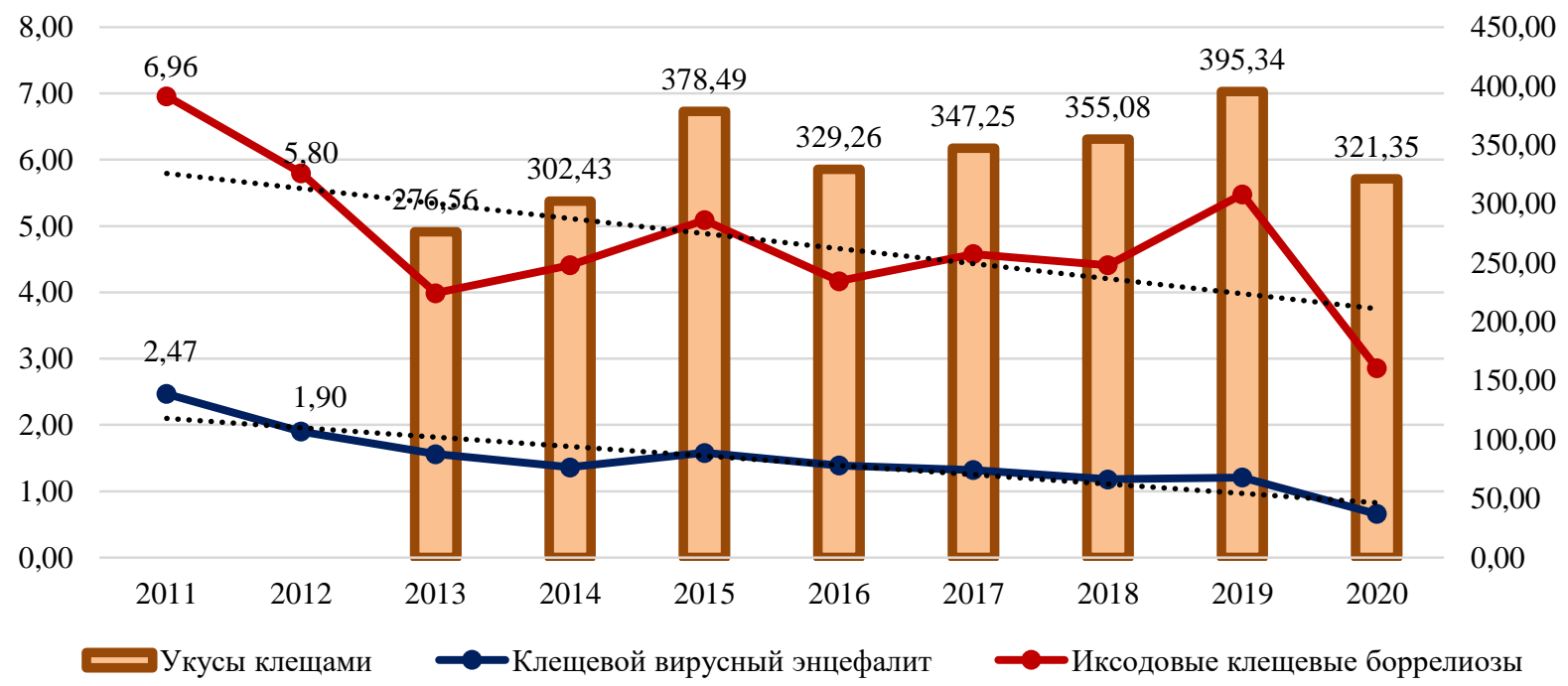

Рис. 149. Динамика заболеваемости ИКБ, КВЭ и частоты укусов клещами в Российской Федерации в 2011-2020 гг. (на 100 тыс. населения)

По сравнению с 2019 г. заболеваемость ИКБ в 2020 г. во всех 16 представленных в таблице регионах снизилась на $39 \%$ (от минимальных $8 \%$ в Томской области до $75 \%$ в Вологодской области). В ряде субъектов в 2020 г. выявлен рост заболеваемости по сравнению со средним за 10-летний период: Воронежская область - 77 \%, Брянская область - 38 \%, г. Москва - $19 \%$, Рязанская область - $17 \%$.

В 2020 году значительнее всего снизилось количество регионов, где показатель присасывания был выше 527 на 100 тыс. населения. В группе со «средним уровнем» присасываний клещей изменение в составе было незначительным. Группа регионов с низким уровнем присасывания в 2020 году увеличилась на 14 \% (табл. 57).

Таблица 57

\section{Распределение регионов РФ по рангам, отражающим показатель присасывания клещей на 100 тыс. населения}

\begin{tabular}{|l|c|c|c|}
\hline $\begin{array}{c}\text { Ранг регионов по показателю } \\
\text { присасывания }\end{array}$ & $\begin{array}{c}\text { Диапазон } \\
\text { показателя на } \\
100 \text { тыс. населения }\end{array}$ & $\begin{array}{c}\text { Количество регионов } \\
\text { в 2014-2020 гг. } \\
(\mathrm{n}=85)\end{array}$ & $\begin{array}{c}\text { Количество } \\
\text { регионов в 2020 г. } \\
(\mathrm{n}=83)\end{array}$ \\
\hline Низкий уровень & $0.3-264.1$ & 42 & 48 \\
\hline Средний уровень & $264.2-526.9$ & 21 & 19 \\
\hline Высокий уровень & выше 527 & 22 & 16 \\
\hline
\end{tabular}


Государственный доклад «О состоянии санитарно-эпидемиологического благополучия населения в Российской Федерации в 2020 году»

ИКБ регистрировали в 2020 году в меньшем числе регионов, чем в среднем за 10 лет. Сократилось число регионов со средним и высоким уровнем заболеваемости (табл. 58).

Таблица 58

\section{Ранжирование регионов РФ по среднему показателю заболеваемости ИКБ на 100 тыс. населения}

\begin{tabular}{|c|c|c|c|}
\hline \multirow[t]{2}{*}{$\begin{array}{c}\text { Ранг (по уровню } \\
\text { заболеваемости ИКБ) }\end{array}$} & \multirow{2}{*}{$\begin{array}{c}\text { Диапазон для } \\
\text { показателя } \\
\text { заболеваемости }\end{array}$} & \multicolumn{2}{|c|}{$\begin{array}{c}\text { Количество регионов с разным рангом } \\
\text { заболеваемости ИКБ }\end{array}$} \\
\hline & & в 2011-2020 гг. $(\mathrm{n}=76)$ & в 2020 год $(\mathrm{n}=68)$ \\
\hline Низкий уровень & $0.01-3.7$ & 38 & 49 \\
\hline Средний уровень & $3.71-7.0$ & 19 & 13 \\
\hline Высокий уровень & выше 7.1 & 19 & 6 \\
\hline
\end{tabular}

зарегистрированы в Республике Алтай, Красноярском крае, Кемеровской области. В 2020 г. в Российской Федерации вакцинированы и ревакцинированы против КВЭ 2766288 человек.

Прогнозируемые значения КВЭ в 2021 г. $(0,68 \pm 0,276)$ реализуются при отсутствии существенных изменений от многолетних норм в действии абиотических (температуры, высоты снежного покрова, количества осадков и т. д.), биотических (обилия прокормителей клещей - переносчиков вируса), антропогенных (поллютанты, процессы урбанизации, изменение ландшафтов и т. п.) и социально-экономических факторов (продление действия ограничений, связанных с COVID-19). Изменение объемов профилактических мер в субъектах страны также отразится на инцидентности КВЭ. Усиление действия факторов направленного снижения заболеваемости, особенно в субъектах с высокой инцидентностью КВЭ, позволит обеспечить дальнейшее улучшение эпидемической обстановки как в отдельных федеральных округах, так и на территории Российской Федерации в целом.

Заболеваемость острыми риккетсиозами группы КПЛ, в частности СКТ, попрежнему высока в Республике Алтай (101,13 на 100 тыс. населения), Алтайском крае (20,39 на 100 тыс. населения), Новосибирской области (4,83 на 100 тыс. населения). Клещевой риккетсиоз группы КПЛ выявлен в Приморском (4,05 на 100 тыс. населения) и Хабаровском (5,23 на 100 тыс. населения) краях. В Российской Федерации в 7 раз снизилось число зарегистрированных случаев АПЛ (всего - 35 случаев, из них 34 в Астраханской области).

Заболеваемость моноцитарным эрлихиозом человека и гранулоцитарным анаплазмозом человека в 2020 году отмечена на уровне единичных случаев.

Геморрагическая лихорадка с почечным синдромом (ГЛПС) нетрансмиссивный зооноз, который занимает ведущее место среди природно-очаговых вирусных инфекций в Российской Федерации. Показатель заболеваемости ГЛПС в 2020 г. в Российской Федерации (2,62 на 100 тыс. населения) - самый низкий за последние 10 лет. На рис. 150 приведена динамика показателей заболеваемости ГЛПС за последние 10 лет с максимальным подъемом в 2019 г. и наименьшим в 2020 г. Всего в 2020 г. зарегистрировано 3845 случаев ГЛПС, из них 13 летальных. Максимальный уровень заболеваемости по-прежнему отмечался в Приволжском федеральном округе. 
Государственный доклад «О состоянии санитарно-эпидемиологического благополучия населения в Российской Федерации в 2020 году»

12,00

10,00

8,00

6,00

4,00

2,00

0,00

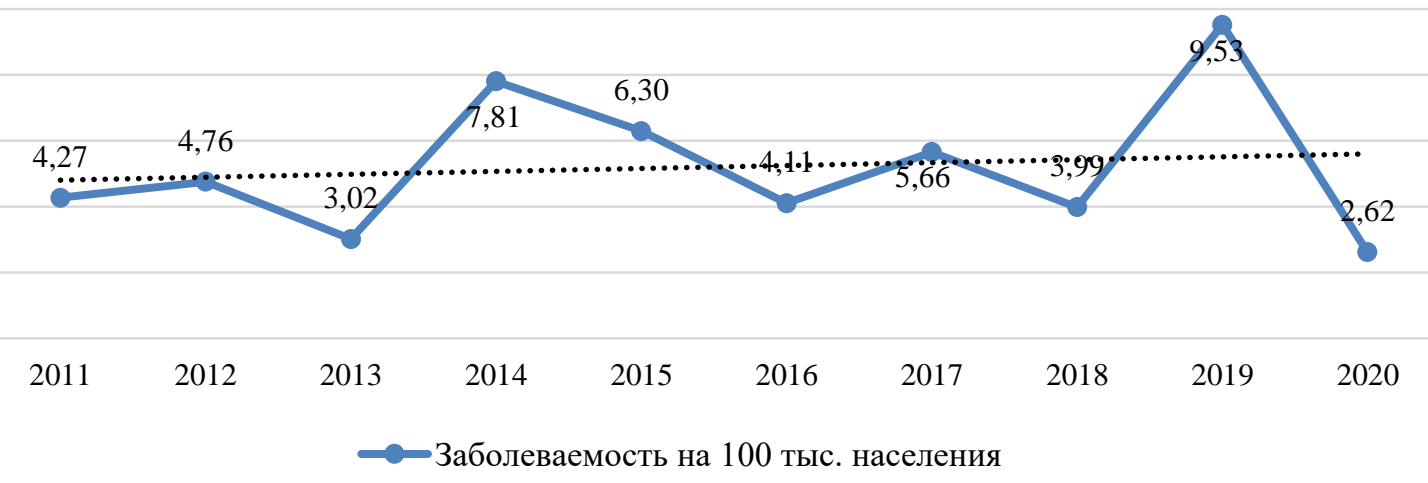

Рис. 150. Динамика заболеваемости геморрагической лихорадкой с почечным синдромом в Российской Федерации в 2010-2020 гг. (на 100 тыс. населения)

Наиболее сложная эпидемиологическая ситуация с заболеваемостью ГЛПС наблюдалась в Удмуртской Республике (25,46 на 100 тыс. населения), Пензенской области (19,13 на 100 тыс. населения) и Республике Марий Эл (16,03 на 100 тыс. населения) (табл. 59).

Таблица 59

\section{Субъекты Российской Федерации с наиболее высокой заболеваемостью ГЛПС в 2020 году}

\begin{tabular}{|c|c|c|c|c|c|c|c|c|}
\hline \multirow{3}{*}{$\begin{array}{l}\text { № } \\
\Pi / \Pi\end{array}$} & \multirow{3}{*}{$\begin{array}{l}\text { Субъект } \\
\text { кая Федерация }\end{array}$} & \multicolumn{3}{|c|}{$\begin{array}{c}\text { Показатель заболеваемости } \\
\text { ГЛПС } \\
\text { на } 100 \text { тысяч населения }\end{array}$} & \multirow{2}{*}{\multicolumn{2}{|c|}{$\begin{array}{c}\text { Динамика } \\
\text { заболеваемости } \\
\text { ГЛПС } \\
\text { по сравнению } \\
\text { с } 2019 \text { г. }\end{array}$}} & \multirow{2}{*}{\multicolumn{2}{|c|}{$\begin{array}{c}\text { Динамика } \\
\text { относительно } \\
\text { среднего значения } \\
\text { показателя } \\
\text { за } 10 \text { лет }\end{array}$}} \\
\hline & & 2020 г. & 2019 г. & $\begin{array}{c}2011- \\
2020 \text { гг. }\end{array}$ & & & & \\
\hline & & 2,62 & $\mathbf{9 , 5 3}$ & 5,21 & $\downarrow$ & в 3,6 раза & $\downarrow$ & в 2 раза \\
\hline 1 & Удмуртская Республика & 25,46 & 76,94 & 68,7 & $\downarrow$ & в 3 раза & $\downarrow$ & в 2,7 раза \\
\hline 2 & Пензенская область & 19,13 & 64,99 & 25,22 & $\downarrow$ & в 3,4 раза & $\downarrow$ & в 1,3 раза \\
\hline 3 & Республика Марий Эл & 16,03 & 40,36 & 24,58 & $\downarrow$ & в 3 раза & $\downarrow$ & в 1,5 раза \\
\hline 4 & Костромская область & 14,17 & 34,83 & 12,54 & $\downarrow$ & в 2,5 раза & $\uparrow$ & в 1,1 раза \\
\hline 5 & Чувашская Республика & 13,52 & 22,98 & 11,69 & $\downarrow$ & в 1,7 раза & $\uparrow$ & в 1,2 раза \\
\hline 6 & Кировская область & 13,49 & 20,51 & 13,06 & $\downarrow$ & в 1,5 раза & $=$ & \\
\hline 7 & Республика Татарстан & 11,54 & 28,41 & 18,32 & $\downarrow$ & в 2,5 раза & $\downarrow$ & в 1,6 раза \\
\hline 8 & $\begin{array}{l}\text { Республика } \\
\text { Башкортостан }\end{array}$ & 11,50 & 39,34 & 35,43 & $\downarrow$ & в 3,4 раза & $\downarrow$ & в 3 раза \\
\hline 9 & Республика Мордовия & 10,97 & 39,24 & 25,02 & $\downarrow$ & в 3,6 раза & $\downarrow$ & в 2,3 раза \\
\hline 10 & Ульяновская область & 10,37 & 16,58 & 12,62 & $\downarrow$ & в 1,5 раза & $\downarrow$ & в 1,2 раза \\
\hline 11 & Нижегородская область & 8,91 & 32,1 & 13,5 & $\downarrow$ & в 1,6 раза & $\downarrow$ & в 1,5 раза \\
\hline 12 & Самарская область & 8,77 & 27,32 & 14,14 & $\downarrow$ & в 3,1 раза & $\downarrow$ & в 1,5 раза \\
\hline 13 & Ярославская область & 8,04 & 31,92 & 11,48 & $\downarrow$ & в 1,4 раза & $\downarrow$ & в 1,6 раза \\
\hline 14 & Рязанская область & 7,20 & 18,16 & 6,95 & $\downarrow$ & в 2,5 раза & $=$ & \\
\hline 15 & $\begin{array}{l}\text { Еврейская автономная } \\
\text { область }\end{array}$ & 6,28 & 8,08 & 6,89 & $\downarrow$ & в 1,3 раза & $=$ & \\
\hline 16 & Саратовская область & 6,17 & 110,2 & 7,97 & $\downarrow$ & в 17,9 раза & $\downarrow$ & в 1,3 раза \\
\hline
\end{tabular}

В Дальневосточном регионе ГЛПС чаще регистрируется в Еврейской автономной области (6,28 на 100 тыс. населения), что сопоставимо со среднемноголетним 
показателем заболеваемости в этом регионе. Возбудителями ГЛПС на Европейской территории являются хантавирусы Пуумала и Добрава/Белград, на азиатской территории Сеул, Хантаан и его геновариант Амур. При проведении эпизоотологического мониторинга в большинстве территорий Российской Федерации в 2020 году численность мелких млекопитающих в природных биотопах была ниже или на уровне среднемноголетних значений. Снижение показателей заболеваемости ГЛПС произошло на фоне низкой эпизоотической активности природных очагов на большинстве территорий России, осуществления неспецифических профилактических мероприятий и введенных ограничительных мер по предотвращению распространения новой коронавирусной инфекции. Инфицированные мелкие млекопитающие выявлены во всех федеральных округах Российской Федерации кроме СКФО, на большей территории которого исследования не проводились или объемы исследуемого материала были крайне малы. В структуре инфицированных хантавирусами мелких млекопитающих основную долю занимала рыжая полевка $(54,7 \%)$ - резервуарный хозяин хантавируса Пуумала.

В 2020 г. отмечено рекордное снижение регистрации случаев лихорадки Западного Нила (ЛЗН), выявленной только в 3 субъектах (в 2019 г. в 15 субъектах). Всего в 2020 г. зарегистрировано лишь 10 местных случаев ЛЗН (2019 г. - 352 случая). Такое значительное снижение заболеваемости связано как с ограничением передвижения граждан в связи с эпидемиологической ситуацией по COVID-19, так и с проведением несвоевременной этиологической диагностики на некоторых эндемичных территориях.

Показатель заболеваемости КГЛ в 2020 г. (32 случая в 6 субъектах Российской Федерации) характеризуется также значительным снижением по сравнению с 2019 г. (134 случая в 6 субъектах). Завозные случаи лихорадки денге, по причине снижения туристического потока в 2020 г, также регистрировались в 3,4 раза реже по сравнению с 2019 г. Всего выявлен 121 случай в крупных мегаполисах и их агломерациях: в Москве, Санкт-Петербурге, Новосибирской области, Красноярском крае.

В Российской Федерации сохраняется эпизоотическое неблагополучие по бешенству. В 2020 году бешенство животных зарегистрировано в 62 субъектах страны (65 - в 2019 году). Максимальное число случаев бешенства среди животных выявлено на территориях Центрального (607 случаев) и Приволжского (526 случаев) федеральных округов, так же, как и в 2019 г., - 514 и 317 случаев соответственно. По данным ФГБУ «Центр ветеринарии» Минсельхоза России, в 2020 году зарегистрировано 729 случаев бешенства среди собак и кошек (585 - в 2019 году), 660 случаев среди диких животных, преимущественно среди лисиц (587 - в 2019 году). Среди сельскохозяйственных животных в 2020 году выявлен 161 случай бешенства (в 2019 году - 99 случаев).

Случаи гидрофобии у людей в Российской Федерации регистрируются ежегодно. Следует отметить, что в 2020 г. зарегистрировано 7 случаев (в 2017-2019 гг. регистрировалось по 2 случая заболевания у людей). Бешенством заразились 5 взрослых и 2 ребенка. Заболевание у людей выявлено в Пензенской области (2 случая) и по 1 случаю в Калужской, Ярославской, Волгоградской областях, Ставропольском крае, Республике Марий Эл. В 2020 г. по поводу укусов, нанесенных животными, обратилось 337955 человек (в 2019 г. - 397248 человек).

В 2020 г. зарегистрированы 5 случаев сибирской язвы у людей в Республике Дагестан. Принимая во внимание большое количество стационарно неблагополучных по сибирской язве пунктов и сибиреязвенных захоронений на территории Российской Федерации, снижение охвата вакцинацией сельскохозяйственных животных и объемов плановой вакцинации контингентов риска, сохраняются эпидемиологические риски возникновения случаев сибирской язвы на спорадическом уровне. Наиболее высокие показатели иммунизации населения профилактическими прививками против сибирской язвы в 2020 г. отмечены в Республике Татарстан, Ямало-Ненецком автономном округе, Республике Алтай, Омской, Белгородской и Нижегородской областях, Краснодарском крае. В этих субъектах на учете числится большое количество сибиреязвенных 
захоронений (включая «моровые» поля, где ранее имел факт массового падежа животных). Следует отметить, что в Республике Дагестан, где на протяжении нескольких последних лет, в отличие от других регионов России, продолжает устойчиво проявляться эпизоотолого-эпидемиологическое неблагополучие по этой инфекции и регистрируются случаи заболевания сибирской язвой у людей, объем вакцинации/ревакцинации в 2020 г. отставал от субъектов, указанных выше (230 вакцинированы, ревакцинированы 115 человек).

В 2020 году зарегистрировано 119 случаев впервые выявленного бруцеллеза у людей (397 случаев в 2019 г.) За последние 10 лет эпидемиологическая ситуация по бруцеллезу в Российской Федерации характеризовалась как неблагополучная, но с тенденцией к снижению заболеваемости. По данным эпидемиологических расследований, большинство случаев бруцеллеза людей преимущественно связаны с эпизоотиями в хозяйствах индивидуального сектора. В условиях продолжения реализации региональных программ импортозамещения в животноводческой отрасли сельского хозяйства, усиления интереса к развитию молочного и мясного скотоводства среди индивидуальных предпринимателей сохраняется высокая вероятность заноса возбудителя бруцеллеза с больными животными из неблагополучных административных территорий СКФО, ЮФО, СФО в благополучные по бруцеллезу регионы. Сохраняется вероятность заражения населения возбудителем бруцеллеза в регионах, где постоянно регистрируются случаи неорганизованной торговли продукцией животноводства без соответствующих ветеринарно-сопроводительных документов.

Наибольшее число людей, заболевших бруцеллёзом, как и в предыдущие годы, регистрировалось в Республике Дагестан (81 случай). Напряженная эпидемиологическая ситуация наблюдалась в Республике Калмыкия и Ставропольском крае (11 и 10 заболевших соответственно). В этих территориях сложилось стойкое эпизоотическое неблагополучие по бруцеллёзу среди КРС и МРС. Несмотря на то, что в 2020 г. в вышеуказанных субъектах проводилась вакцинация и ревакцинация против бруцеллеза, ее охват, вероятно, не является достаточным.

Среди болезней, общих для человека и животных, следует отметить коксиеллез (Qлихорадка, лихорадка Ку), заболеваемость которым не имела тенденции к снижению вплоть до 2019 года. Однако в 2020 г. зарегистрировано низкое число заболевших - 8 случаев в Ставропольском крае (в 2019 г. - 286 случаев). Вероятной причиной уменьшения показателей заболеваемости в 2020 г. могло стать сокращение объемов специфических лабораторных исследований. Вместе с тем в 2020 г. в 16 субъектах избирательные исследования на маркеры Q-лихорадки проводились, в 10 регионах были определены антитела/антиген к возбудителю Coxiella burnetii. Больше всего серопозитивных пациентов с подозрением на коксиеллез выявлено в Воронежской, Курганской, Ленинградской, Вологодской и Волгоградской областях.

Заболеваемость туляремией у людей в 2020 г. осталась на уровне предыдущего года (по 41 случаю инфицирования в 2019 и 2020 гг.), что, скорее всего, явилось следствием эффективных профилактических мероприятий в регионах с проявлениями эпизоотий у животных - всего в Российской Федерации вакцинировано 242283 человека, ревакцинировано 643773 человека.

В 2020 г. также регистрировались случаи заболеваемости лептоспирозом (94 случая) и псевдотуберкулезом (263 случая), что меньше, чем в предыдущем году в 1,8 и 1,9 раза, соответственно. Клинический диагноз листериоза лабораторно подтвержден 42 заболевшим (6 смертей).

На территории Российской Федерации действуют 11 природных очагов чумы общей площадью 253 тыс. 590 км². Эпизоотии чумы выявляются ежегодно, в связи с этим эпидемиологический надзор за очагами чумы ведётся постоянно, в т. ч. за очагами с многолетним отсутствием эпизоотий чумы. Эпидемиологический надзор за чумой 
Государственный доклад «О состоянии санитарно-эпидемиологического благополучия населения в Российской Федерации в 2020 году»

включает эпизоотологическое обследование природных очагов, эпидемиологическое наблюдение за населением, проведение экстренных специфических и неспецифических профилактических мероприятий при возникновении реальной опасности заражения человека чумой. В 2020 году в природных очагах чумы под наблюдением ветеринарных работников и специалистов противочумных станций находилось 3452 голов верблюдов, из них 640 - в частном секторе. В течение года пало 11 верблюдов (Астраханская область - 10, Республика Калмыкия, в частном секторе, - 1). С целью исключения диагноза чумы у павших верблюдов специалистами Астраханской и Элистинской ПЧС было выполнено соответственно 10 и 1 выездов; произведён отбор проб от всех павших верблюдов для исследования на чуму, возбудитель не обнаружен.

\subsection{2 Санитарная охрана территории Российской Федерации}

Одним из основных направлений деятельности Роспотребнадзора является обеспечение санитарной охраны территории, что связано с возникающими угрозами и рисками в области общественного здравоохранения.

Неблагополучная эпидемиологическая ситуация в мире, а также наличие ряда природных очагов инфекционных болезней на территории Российской Федерации требуют принятия дополнительных мер по организации мероприятий по санитарной охране территории, в том числе усиления санитарно-карантинного контроля в пунктах пропуска через государственную границу Российской Федерации.

По состоянию на 2020 год на территории России имеется 241 санитарнокарантинный пункт (СКП) пропуска через государственную границу Российской Федерации, досмотрено 1,7 млн транспортных средств и прошли санитарнокарантинный контроль 15,7 млн человек. Из них наибольшее число - в пунктах пропуска Московской и Ростовской областей, г. Санкт-Петербурга и г. Москвы, Республики Крым, Краснодарского и Приморского краев. Из числа досмотренных выявлено 1924 человека с признаками инфекционных болезней, из них в автомобильных пунктах пропуска - 29,7 \%, воздушных - 50,9\%.

Из-за туристической активности населения и частой миграции граждан случаи завозных инфекций регистрируются ежегодно. Случаи малярии и лихорадки денге носят только завозной характер. Ввиду ограничения возможности передвижения российских граждан в связи пандемией новой коронавирусной инфекцией отмечается снижение общего числа случаев этих инфекций. Так, в 2020 г. было выявлено 57 случаев малярии, подавляющее большинство которых зарегистрировано у граждан, прибывших из стран Африки и Азии. Наибольшее число случаев малярии в 2020 г. зарегистрировано среди возвратившихся из Республики Танзания (по 2 случая заболевания выявлено в г. Москве, Московской области и Республике Татарстан, в Воронежской, Самарской областях, Удмуртской Республике и г. Санкт-Петербурге - по 1 случаю). Зарегистрированы завозы (табл. 60) из Новой Гвинеи (2 случая), Индии (1 случай), Венесуэлы (1 случай), Колумбии (1 случай) и стран Африки: республик Нигерия и Экваториальная Гвинея (5 случаев), Демократической Республики Конго (4 случая), Центральной Африканской Республики, республик Гвинея, Камерун, Судан (по 3 случая), республик Эфиопия, Сьерра-Леоне, Южный Судан (по 2 случая), республик Ангола, Габон, Уганда и Джибути (по 1 случаю). Все выявленные случаи малярии лабораторно подтверждены.

Число случаев лихорадки денге также сократилось с 415 в 2019 г. до 121 в 2020 г. (табл. 61). Наибольшее количество заболевших выявлено в г. Москве (в 2018 г. - 70 случаев, в 2019 г. - 126 случаев, в 2020 г. - 28 случаев), Новосибирской области (в 2018 г. - 20 случаев, в 2019 г. - 31 случай, в 2020 г. - 16 случаев). На протяжении 2012-2020 гг. наметилась тенденция к росту общего количества завозных случаев лихорадки денге на территорию России, в том числе и из определенных стран, что может быть связано с ростом интенсивности их посещения. 


\section{Распределение завозных случаев малярии в Российской Федерации} по странам возможного заражения в 2012-2020 гг., абс.

\begin{tabular}{|c|l|c|c|c|c|c|c|c|c|c|c|}
\hline $\begin{array}{c}\text { № } \\
\text { п/п }\end{array}$ & $\begin{array}{l}\text { Страна, где произошло } \\
\text { возможное заражение }\end{array}$ & 2012 & 2013 & 2014 & 2015 & 2016 & 2017 & 2018 & 2019 & 2020 & Итого \\
\hline 1 & Индия & 6 & 22 & 32 & 14 & 18 & 13 & 9 & 5 & 1 & 120 \\
\hline 2 & Нигерия & 5 & 3 & 12 & 7 & 7 & 9 & 19 & 15 & 5 & 82 \\
\hline 3 & Камерун & 1 & 3 & 4 & 8 & 4 & 5 & 6 & 4 & 3 & 38 \\
\hline 4 & Конго & 2 & 2 & 3 & 2 & 11 & 5 & 8 & 3 & 4 & 40 \\
\hline 5 & Ангола & 3 & 2 & 3 & 6 & 6 & 5 & 3 & 4 & 1 & 33 \\
\hline 6 & Судан & 1 & 3 & 3 & 4 & 3 & 2 & 8 & 2 & 3 & 34 \\
\hline 7 & Гвинея & 3 & 2 & 4 & 2 & 4 & 6 & 5 & 8 & 0 & 34 \\
\hline 8 & Кот-д'Ивуар & 2 & 0 & 1 & 2 & 2 & 5 & 2 & 2 & 0 & 16 \\
\hline 9 & Афганистан & 0 & 0 & 0 & 4 & 2 & 2 & 32 & 5 & 3 & 48 \\
\hline 10 & $\begin{array}{l}\text { Центральная } \\
\text { Африканская Республика }\end{array}$ & 0 & 0 & 0 & 4 & 3 & 3 & 2 & 6 & 0 & 18 \\
\hline 11 & Республика Чад & 90 & 97 & 101 & 93 & 98 & 89 & 132 & 103 & 57 & 860 \\
\hline Завезено случаев малярии в \\
Российскую Федерацию, всего
\end{tabular}

Таблица 61

Распределение завозных случаев лихорадки денге в Российской Федерации по странам возможного заражения в 2012-2020 гг. (абс. числа)

\begin{tabular}{|c|l|c|c|c|c|c|c|c|c|c|c|}
\hline $\begin{array}{c}\text { № } \\
\text { п/п }\end{array}$ & $\begin{array}{l}\text { Страна, где произошло } \\
\text { возможное заражение }\end{array}$ & 2012 & 2013 & 2014 & 2015 & 2016 & 2017 & 2018 & 2019 & 2020 & Итого \\
\hline 1 & Таиланд & 52 & 127 & 54 & 65 & 45 & 100 & 179 & 260 & 88 & 970 \\
\hline 2 & Вьетнам & 2 & 9 & 17 & 23 & 32 & 34 & 25 & 64 & 5 & 211 \\
\hline 3 & Индонезия & 12 & 12 & 12 & 19 & 26 & 6 & 1 & 16 & 3 & 107 \\
\hline 4 & Индия & 2 & 6 & 4 & 3 & 4 & 10 & 4 & 10 & 1 & 44 \\
\hline 5 & Филиппины & 1 & 4 & 4 & 3 & 9 & 6 & 0 & 8 & 3 & 38 \\
\hline 6 & Мальдивы & 1 & 1 & 2 & 4 & 2 & 3 & 8 & 16 & 1 & 38 \\
\hline 7 & Шри-Ланка & 0 & 1 & 3 & 3 & 4 & 1 & 14 & 2 & 28 \\
\hline $\begin{array}{l}\text { Завезено случаев лихорадки } \\
\text { денге в Российскую } \\
\text { Федерацию, всего }\end{array}$ & 72 & 169 & 105 & 136 & 145 & 196 & 259 & 415 & 121 & 1618 \\
\hline
\end{tabular}

В связи с неблагополучной ситуацией, связанной с новым коронавирусом Российская Федерация начала проведение комплекса противоэпидемических мер сразу после появления первой информации о ситуации в Китае, что позволило не допустить завозов в течение 2 месяцев и выиграть время для полноценной подготовки к противодействию инфекции, включая формирование запасов и готовность медицинских организаций.

Правительством Российской Федерации с 30 марта 2020 года прекращено транспортное сообщение с иностранными государствами, изданы соответствующие распоряжения, в соответствии с которыми ограничен въезд в Российскую Федерацию иностранным гражданам, а также ограничено движение через наземные пункты пропуска через государственную границу Российской Федерации, за исключением определенных категорий граждан. 


\subsection{3. Инфекции, связанные с оказанием медицинской помощи (ИСМП)}

Тенденции эпидемического процесса инфекций, связанных с оказанием медицинской помощи (ИСМП), за 2020 год характеризуются, прежде всего, значительным ростом регистрируемых случаев (130803 сл.) по сравнению с 2019 годом (25463 сл.). Подобное 5-кратное увеличение число случаев ИСМП обусловлено пандемией COVID-19, большинство случаев которой вошли в группу других инфекционных заболеваний (2020 г. - 100814 сл.; 2019 г. - 2341 сл.) и в группу инфекций нижних дыхательных путей (2020 г. - 15919 сл.; 2019 г. - 7909 сл.). У персонала медицинских организаций в 2020 году зарегистрировано 81144 случая ИСМП, что составляет 62 \% от всех зарегистрированных случаев ИСМП (рис. 151).

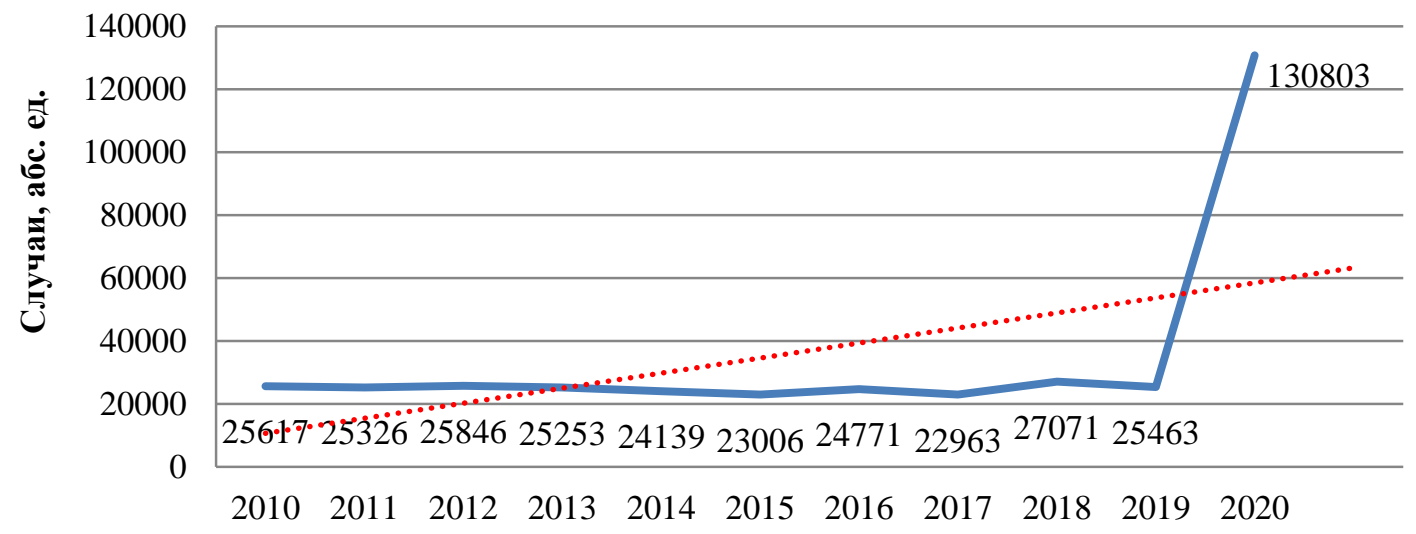

Рис. 151. Число случаев ИСМП в медицинских организациях, абс.

Кроме того, в 2020 году были внесены изменения в форму № 2 федерального статистического наблюдения: изменены нозологические формы регистрируемых ИСМП, выделены учреждения стационарного социального обслуживания и инфекционные стационары (отделения) для регистрации случаев ИСМП.

На протяжении последних 10 лет основная доля в общей заболеваемости ИСМП принадлежала хирургическим и прочим стационарам. При этом в 2020 г. значимость хирургических стационаров в заболеваемости ИСМП значительно снизилась, в них зарегистрировано всего 24,3 \% от всех случаев ИСМП (при 42 \% в 2019 г.). Увеличилась доля ИСМП, выявленных в прочих стационарах, до 42,4 \% от общего количества случаев (в 2010 - 15,04 \%). Доля ИСМП, зарегистрированных в учреждениях стационарного социального обслуживания, составила $15,5 \%$, в инфекционных стационарах и отделениях $-3,4 \%$ (рис. 152 ).

В структуре ИСМП на протяжении 2016-2019 гг. наибольшую долю занимали внутрибольничные пневмонии (в 2012-2015 гг. первое место принадлежало послеоперационным инфекциям). В 2020 году наибольшую долю составила группа других инфекционных заболеваний $-77,1 \%$, на втором месте - внутрибольничные пневмонии - 12,2 \%. Воздушно-капельные инфекции составляют 3,7 \% от общего числа зарегистрированных случаев ИСМП. На гнойно-септические инфекции (ГСИ) новорождённых в 2020 г. приходится 1,6 \% (2019 г. - 10,0 \%) и 1,3 \% приходится на ГСИ родильниц (2019 г. - 8,9 \%).

Доли инфекций в области хирургического вмешательства и инфекций мочевыводящих путей в структуре ИСМП в 2020 году снизились более чем в 10 раз и составили 2,3 \% и 0,8 \% соответственно (в 2019 г. - 23,6 \% и 5,9\%). Доля инфекций, связанных с инфузией, трансфузией и лечебной инъекцией, иммунизацией составила 0,6 \% (2019 г. - 6,7 \%), острых кишечных инфекций - 0,4 \% (2019 г. - 4,6 \%), туберкулез впервые выявленный, активные формы - 0,01 \% (рис. 153). 


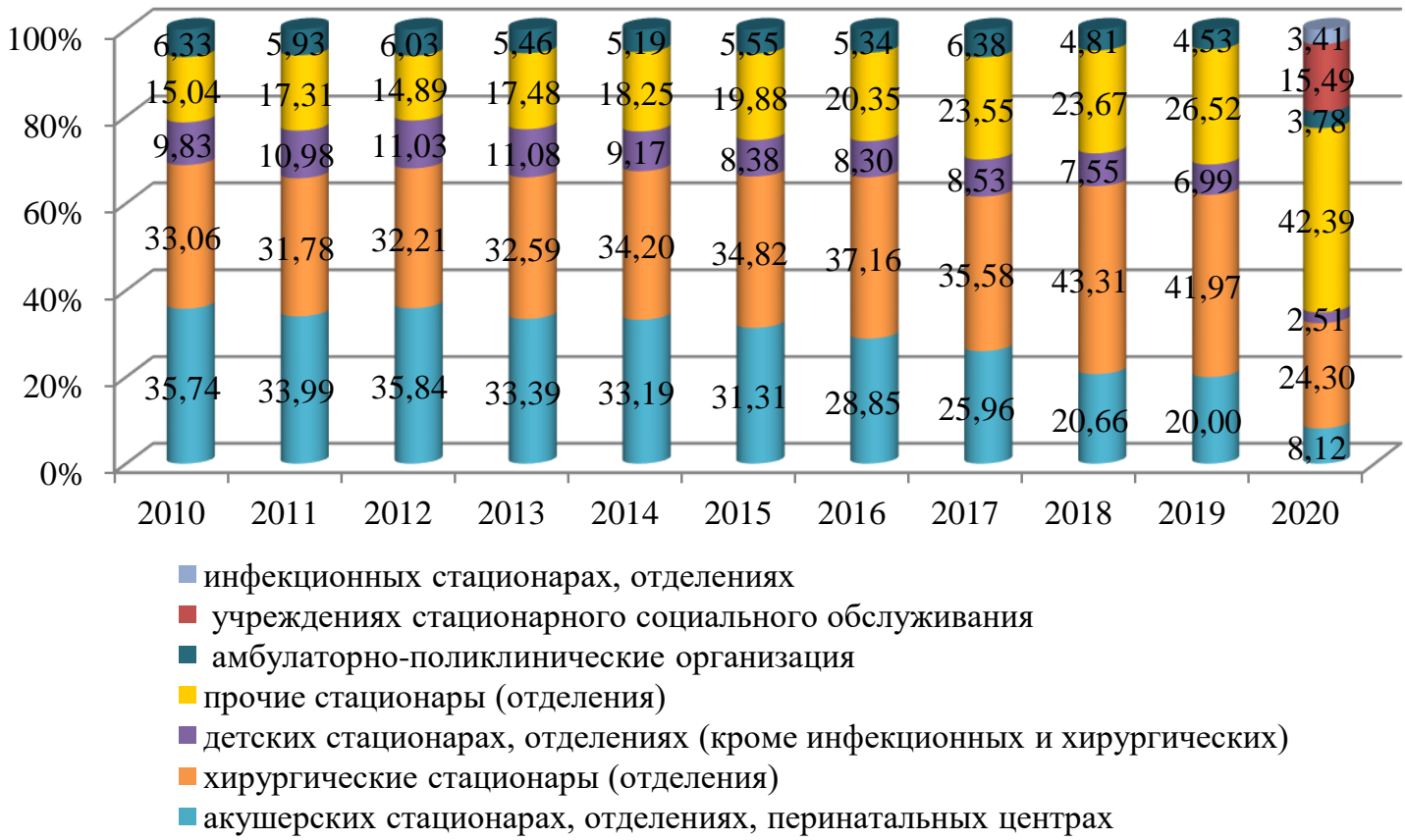

Рис. 152. Распределение случаев ИСМП по видам медицинских организаций, \%

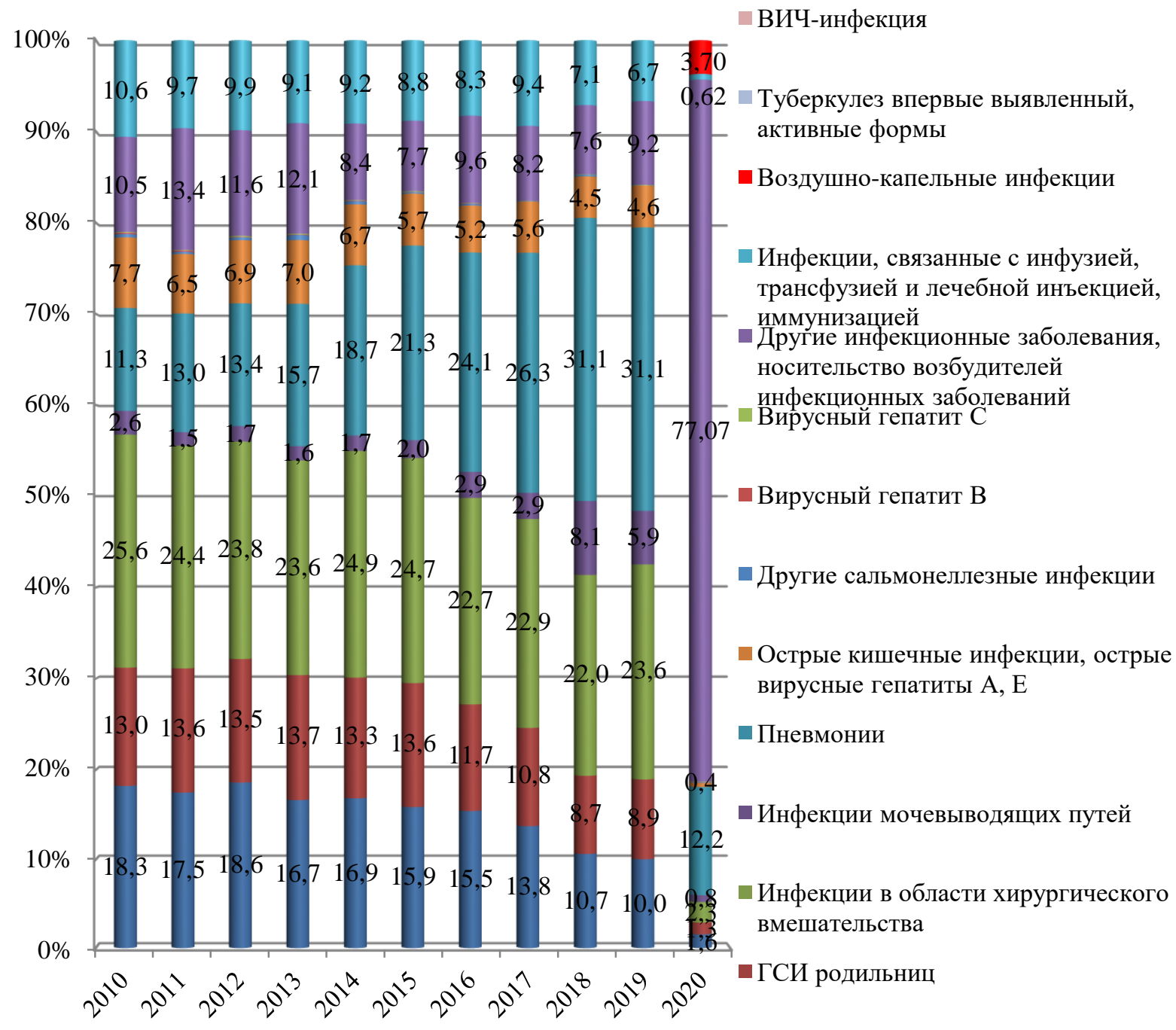

Рис. 153. Динамика нозологической структуры заболеваемости ИСМП в РФ с 2010 по 2020 г., \% 
Изменения в нозологической структуре заболеваемости ИСМП обусловлены пандемией новой коронавирусной инфекции и изменениями в регистрируемых формах. Случаи заболевания COVID-19 вошли в группу других инфекционных заболеваний, в группу инфекций нижних дыхательных путей и воздушно-капельных инфекций. В группе других инфекционных заболеваний зарегистрировано 100814 случаев (в 2019 г. - 2341 сл.), из них 81118 случаев у персонала медицинских организаций. Наибольшая часть случаев зарегистрирована в прочих стационарах и отделениях (10 011 случаев) и в учреждениях стационарного социального обслуживания (5234 случая). В 2020 году было зарегистрировано 15919 случаев инфекций нижних дыхательных путей (в 2019 г. - 7909 случаев), из них наибольшая доля зарегистрирована в прочих стационарах и в хирургических стационарах (отделениях): 8388 и 4046 случаев соответственно. Зарегистрирован 4831 случай воздушно-капельных инфекций, из них 2229 случаев в прочих стационарах и отделениях, 1528 случаев в хирургических стационарах и отделениях. За год количество гнойно-септических инфекций (ГСИ) родильниц уменьшилось на $23 \%$ и составило 1752 случая (в 2019 г. - 2268 случаев).

Количество ГСИ среди новорождённых снизилось по сравнению с 2019 годом на $26 \%$ (в 2020 году зарегистрировано 2028 случаев ГСИ новорождённых, в 2019 г. - 2555). Вместе с тем в нозологической структуре заболеваемости новорождённых снизилась значимость генерализованных форм (сепсиса, остеомиелита и бактериального менингита), на долю которых в 2020 году пришлось 8,3 \% (в 2019 г. - 9,5 \%), при этом летальность при этих формах за последний год повысилась до 7,1 \% (в 2019 г. - 3,7 \%). Наибольшую долю среди ГСИ новорожденных составили пиодермия, импетиго, панариций, паранихий и мастит - 28,9\% (в 2019 г. - 24,3\%), на втором месте конъюнктивит и дакриоцистит у новорожденных - 21,9\% (в 2019 г. - $25 \%$ ), на третьем - пневмонии - 14,1\% (в 2019 - 15,0\%). В последние годы все большее значение приобретают внутриутробные инфекции новорождённых (ВУИ), число которых многократно превышает количество ГСИ новорождённых, что может свидетельствовать о возможном сокрытии случаев внутрибольничной инфекции у новорождённых под диагнозом «внутриутробная инфекция» или о гипердиагностике ВУИ вследствие отсутствия утвержденных критериев постановки диагноза ВУИ, проблем в организации микробиологического обследования пары «мать - дитя». Соотношение внутрибольничных ГСИ новорождённых к ВУИ новорождённых в 2010 году по Российской Федерации составляло 1:4,7, в 2020 году - 1:12,7. В 39 субъектах число зарегистрированных случаев ВУИ в 10 и более раз превышает число ГСИ новорождённых, наиболее высокие показатели соотношения зарегистрированы в Республике Татарстан, Тамбовской области, Амурской области, Саратовской области, Курской области и г. Москве (табл. 62).

Таблица 62

\section{Субъекты Российской Федерации с наиболее высоким соотношением ВУИ новорождённых к внутрибольничным ГСИ новорождённых в 2020 г.}

\begin{tabular}{|l|c|}
\hline \multicolumn{1}{|c|}{ Субъекты Российской Федерации } & $\begin{array}{c}\text { Соотношение внутрибольничных ГСИ } \\
\text { новорождённых к ВУИ новорождённых }\end{array}$ \\
\hline Республика Татарстан & $1: 248$ \\
\hline Тамбовская область & $1: 204$ \\
\hline Амурская область & $1: 167$ \\
\hline Саратовская область & $1: 124$ \\
\hline Курская область & $1: 123$ \\
\hline г. Москва & $1: 95$ \\
\hline
\end{tabular}


При отсутствии ГСИ новорождённых регистрируются только внутриутробные инфекции во Владимирской области (99 случаев), Калужской области (497 случаев), Костромской области (1 сл.), Республике Адыгея (60 сл.), Республике Крым (6 сл.), Республике Марий Эл (1 сл.), Красноярском крае (413 сл.). Отсутствует регистрация как ГСИ новорождённых, так и ВУИ в г. Севастополе, Карачаево-Черкесской Республике, Чеченской Республике, Республике Тыва и Чукотском автономном округе, что свидетельствует об отсутствии налаженной в этих субъектах работы по выявлению и учету этих инфекций.

В период 2010-2020 гг., как результат работы по массовой вакцинации населения, отмечается уверенная тенденция к снижению числа случаев внутрибольничного инфицирования вирусом гепатита В (регистрируются единичные случаи). В 2020 году зарегистрирован 1 случай внутрибольничного инфицирования вирусом гепатита В (ВГВ) в медицинской организации (МО) (в 2010 г. - 34 случая). В 2020 году зарегистрировано 4 случая внутрибольничного инфицирования вирусом гепатита С (ВГС) (в 2010 г. 13 случаев). Учет заболеваемости данными инфекциями может иметь недостатки. В 2020 году зарегистрирован 1 случай внутрибольничного инфицирования ВИЧ-инфекцией.

С целью профилактики внутрибольничного инфицирования ВГВ и ВГС необходимо не снижать контроль за соблюдением дезинфекционно-стерилизационного режима, поддерживать охват вакцинацией против гепатита В на высоком уровне, обеспечить контроль за соблюдением требований санитарного законодательства по обеспечению инфекционной безопасности в МО.

В 2020 году отмечено значительное увеличение общего числа вспышек инфекционных заболеваний, зарегистрированных в медицинских организациях (с 32 до 953 , т. е. в 29,8 раза по сравнению с 2019 г.). Общее число пострадавших в таких очагах значительно увеличилось по сравнению с 2019 годом - с 526 чел. до 28405, при этом доля детей до 17 лет уменьшилась и составила 0,8 \% (в 2019 году - 68,8 \%). Наибольшая доля вспышек была зарегистрирована в прочих стационарах (791 вспышка), на втором месте хирургические стационары (109 вспышек), на третьем - детские стационары (27 очагов), в родильных домах зарегистрировано 9 вспышек.

В 2020 году вспышки в МО были преимущественно связаны с воздушнокапельным путем передачи инфекций $(97,9 \%)$, контактно-бытовой путь передачи составил $1,4 \%$, прочие пути - 0,7\%. Значимая доля в структуре вспышечной заболеваемости принадлежит прочим воздушно-капельным инфекциям, так как в эту группу вошли вспышки, обусловленные COVID-19 (зарегистрирован 941 очаг).

В 2020 году по-прежнему сохраняют актуальность вопросы выявления и учета ИСМП в МО. Так, в отчетном году в 63 субъектах Российской Федерации не регистрировались внутрибольничные инфекции мочевыводящих путей, в 10 субъектах инфекции нижних дыхательных путей и пневмонии, в 14 субъектах - ГСИ родильниц, в 20 субъектах - инфекции в области хирургического вмешательства, в 19 субъектах инфекции, связанные с инфузией, трансфузией и лечебной инъекцией, иммунизацией.

В рамках пилотного проекта «Обеспечение эпидемиологической безопасности медицинской помощи» в динамике изменились показатели полноты выявления случаев ИСМП, в том числе такие нозологические формы заболеваний родильниц, как лохиометра и гематометра стали регистрировать впервые.

Разрабатываемая в рамках пилотного проекта автоматизированная система сбора данных об ИСМП позволит упростить и сократить время ввода данных из компьютера или любого мобильного устройства, при этом проверка и корректировка вводимых данных предусмотрены на начальном этапе ввода информации. Данная система позволяет проводить сложный анализ (корреляционный, факторный и кластерный), что позволит обеспечить формирование реестра ИСМП в целом по России. 
Государственный доклад «О состоянии санитарно-эпидемиологического благополучия населения в Российской Федерации в 2020 году»

\subsection{4. Паразитарные заболевания}

2020 г. зарегистрировано 173,43 тыс. случаев паразитарных заболеваний, показатель заболеваемости составил 118,17 на 100 тыс. населения, что на 41,53 \% ниже показателя 2019 г. и 2,3 раза меньше показателя 2011 года. На детей до 17 лет приходится $86,7 \%$ всех случаев паразитарных заболеваний. Превышение среднероссийского показателя заболеваемости паразитарными болезнями зарегистрировано в 34 субъектах Российской Федерации, из них в 4 субъектах - более чем в 3 раза (табл. 63).

Таблица 63

\section{Субъекты Российской Федерации с наиболее высокими показателями суммарной заболеваемости паразитарными болезнями}

\begin{tabular}{|c|c|c|c|}
\hline $\begin{array}{l}\text { № } \\
\Pi / \Pi\end{array}$ & $\begin{array}{c}\text { Субъекты } \\
\text { Российской Федерации }\end{array}$ & $\begin{array}{c}\text { Суммарное количество } \\
\text { паразитарных } \\
\text { заболеваний }\end{array}$ & $\begin{array}{r}\text { Показатель } \\
\text { на } 100 \text { тыс. } \\
\text { населения }\end{array}$ \\
\hline & Российская Федерация & 173430 & 118,17 \\
\hline 1 & Республика Коми & 4093 & 495,91 \\
\hline 2 & Курганская область & 3492 & 420,25 \\
\hline 3 & Вологодская область & 4531 & 389,23 \\
\hline 4 & Архангельская область & 3871 & 353,08 \\
\hline 5 & Ненецкий автономный округ & 153 & 347,96 \\
\hline 6 & Томская область & 3461 & 320,95 \\
\hline 7 & Республика Саха (Якутия) & 2998 & 309,23 \\
\hline 8 & Ханты-Мансийский автономный округ & 4923 & 294,93 \\
\hline 9 & Новосибирская область & 7997 & 286,04 \\
\hline 10 & Республика Карелия & 1690 & 274,32 \\
\hline 11 & Кемеровская область - Кузбасс & 6823 & 255,92 \\
\hline 12 & Пермский край & 6652 & 255,35 \\
\hline 13 & Ямало-Ненецкий автономный округ & 1371 & 252,50 \\
\hline 14 & Еврейская автономная область & 401 & 252,03 \\
\hline 15 & Тюменская область & 3807 & 249,14 \\
\hline 16 & Республика Хакасия & 1265 & 236,35 \\
\hline 17 & Удмуртская Республика & 3401 & 226,10 \\
\hline 18 & Чувашская Республика & 2561 & 209,81 \\
\hline 19 & Красноярский край & 5806 & 202,29 \\
\hline
\end{tabular}

В общей структуре паразитарной заболеваемости доля гельминтозов в 2020 г. составила 87,5\%, протозоозов - 12,5\%. В сравнении с показателями 2011 г. этиологическая структура заболеваемости паразитозами изменилась - доля гельминтозов увеличилась на 10,3 \%, а доля протозоозов снизилась на 39,3 \%.

В 2020 г. в Российской Федерации продолжается снижение количества заболевших малярией. Всего зарегистрировано 58 случаев $(0,04$ на 100 тыс. населения) в 24 субъектах Российской Федерации против 108 случаев малярии (0,07 на 100 тыс. населения) в 33 субъектах Российской Федерации в 2019 г.

В 2020 году, в связи с поздней диагностикой, зарегистрировано 9 летальных случаев от малярии (2019 г. - 5), в т.ч. 1 летальный случай среди детей до 17 лет.

Продолжается снижение заболеваемости населения страны лямблиозом, в 2020 г. по сравнению с 2019 г. показатели заболеваемости снизились в 1,8 раза и составила 13,06 на 100 тыс. населения (рис. 154), СМП - 43,8 на 100 тыс. населения. 


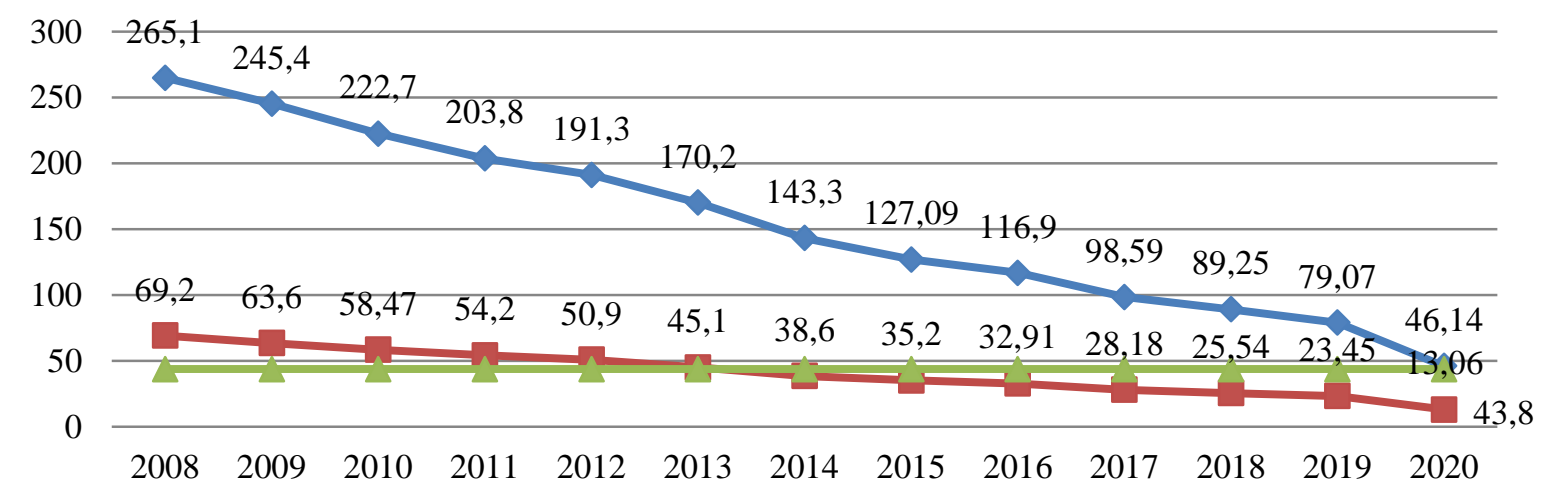

$\sim$ дети - Заболеваемость на 100 тыс. населения $\_$СМП заболеваемость на 100 тыс. населения

Рис. 154. Динамика заболеваемости лямблиозом в Российской Федерации в 2008-2020 гг. (на 100 тыс. населения)

Удельный вес заболеваемости детей до 17 лет лямблиозом составляет $73 \%$ от всех случаев, показатель заболеваемости данной возрастной группы в 2020 г. составил 46,14 на 100 тыс., что на 41,65\% ниже уровня 2019 г. и в 4,4 раза ниже 2011 г. Максимальная заболеваемость лямблиозом приходится на детей в возрасте от 3 до 6 лет (59,50 на 100 тыс. возрастной группы), у детей до 1 года зарегистрировано 210 случаев 13,66 на 100 тыс. населения.

Заболеваемость лямблиозом на территории Российской Федерации распределяется неравномерно - от 0,1 до 167,16 на 100 тыс. населения при среднем показателе по стране 13,06 на 100 тыс. населения. Превышение среднероссийского показателя наблюдается в 27 территориях.

С целью мониторинга за объектами внешней среды проводились санитарнопаразитологические исследования воды централизованного водоснабжения и воды плавательных бассейнов, цисты лямблий были обнаружены в воде централизованного водоснабжения в 0,02\% проб (2019 г. - 0,04\%, 2011 г. - 0,07\%), в воде плавательных бассейнов - 0,004 \% (в 2019 г. - 0,02 \%, 2011 г. - 0,02 \%). Обнаружение цист лямблий в воде централизованного питьевого водоснабжения, плавательных бассейнов, аквапарков определяет риски заражения.

Среди протозойных болезней на территории Российской Федерации продолжается регистрироваться токсоплазмоз, который имеет повсеместное распространение среди людей и животных. Регистрируется как врожденный, так и приобретенный токсоплазмоз. Врожденный токсоплазмоз является серьезной проблемой, несмотря на то, что встречается менее чем в 1 \% случаев от всех случаев токсоплазмоза.

За 2020 г. зарегистрировано 318 случаев токсоплазмоза в 28 субъектах $(0,22$ на 100 тыс. населения), что ниже показателя прошлого года на 24,14 \% и в 1,8 раза ниже показателя 2011 г., при этом 15 случаев выявлены среди детей.

В структуре заболеваемости гельминтозами энтеробиоз продолжает оставаться доминирующей инвазией $(74,3 \%)$, определяющей уровень детской заболеваемости паразитозами. Тем не менее заболеваемость энтеробиозом в последние 10 лет имеет устойчивую тенденцию к снижению. В 2020 г. зарегистрировано более 128,9 тыс. случаев энтеробиоза (87,78 на 100 тыс. населения), что ниже показателя прошлого года в 1,6 раза, а по сравнению с 2011 г. - ниже в 1,8 раза. Среди детей до 17 лет показатель заболеваемости энтеробиозом составил 417,2 случая на 100 тыс., по сравнению с 2019 г. наблюдается снижение заболеваемости на 40,06 \%, а с 2011 г. - в 1,9 раза. 
В 2020 г. доля инвазированных детей до 17 лет составила 98,1\% от всех случаев энтеробиоза. Максимальная заболеваемость энтеробиозом приходится на возрастную группу от 3 до 6 лет (741,86 на 100 тыс. детей данного возраста). Энтеробиоз выявлен также среди детей до 1 года, показатель заболеваемости составил 25,3 на 100 тыс. детей, по сравнению с $2011(69,32)$ он снизился почти в 2,7 раза.

Превышение среднероссийского показателя в 2020 г. отмечено в 39 субъектах Российской Федерации, при этом разброс показателей заболеваемости колебался от 2,66 до 361,06 на 100 тыс. населения.

Обнаружение в смывах в детских образовательных организациях, плавательных бассейнах, аквапарках и прочих местах, яиц гельминтов может свидетельствовать о нарушении санитарно-эпидемиологического режима в данных организациях. Удельный вес выявления яиц гельминтов в смывах в 2020 г. составил 0,06 \% (в 2019 г. - 0,06 \%, в 2011 г. $-0,1 \%)$.

В 2020 г. выявлено 9516 случаев аскаридоза (6,48 на 100 тыс. населения), это в 1,8 раза ниже показателя 2019 г. (11,57 на 100 тыс. населения) и в 4,1 раза ниже чем в 2011 году (26,57 на 100 тыс. населения). Среди детского населения выявлено 7032 (23,21 на 100 тыс. детей данного возраста), показатель заболеваемости детей этой группы снизился на 42,1 \% по сравнению с 2019 г., а по сравнению с 2011 г. - в 4,5 раза.

Превышение среднероссийского показателя заболеваемости зарегистрировано в 32 субъектах Российской Федерации. Показатели заболеваемости аскаридозом варьировали от 0,12 до 31,86 на 100 тыс. населения.

Удельный вес городского населения среди заболевших в 2020 г. составил 71,9 \%, что отражает тенденцию последних лет и объясняется заражением городского населения в основном на дачных участках при употреблении в пищу загрязненных яйцами гельминтов ягод и столовой зелени.

По результатам лабораторных исследований обсемененность яйцами гельминтов овощей и столовой зелени в 2020 г. составила $0,26 \%$ (в 2019 г. - 0,21\%, в 2011 г. 0,5\%), из них импортируемых - 0,11\% (в 2019 г. - 0,10\%, в 2011 г. - 0,2\%); плодов и ягод $-0,07 \%$ (в 2019 г. - 0,10\%, в 2011 г. - 0,3\%), из них импортируемых - 0,04 \% (в 2019 г. $-0,03 \%$, в 2011 г. $-0,3 \%)$.

Серьезной проблемой последних лет является заболеваемость населения токсокарозом, в особенности населения крупных городов. В 2020 г. зарегистрирован 871 случай заболевания (0,59 на 100 тыс. населения), по сравнению с 2019 годом заболеваемость снизилась 2,25 раза, а с 2011 г. - в 3,9 раза. Среди детей до 17 лет выявлено 353 случая токсокароза (1,17 на 100 тыс. данного возраста), это в 1,9 раза меньше, чем в 2019 году, а по сравнению с 2011 г. заболеваемость уменьшилась в 4,9 раза (рис. 155).

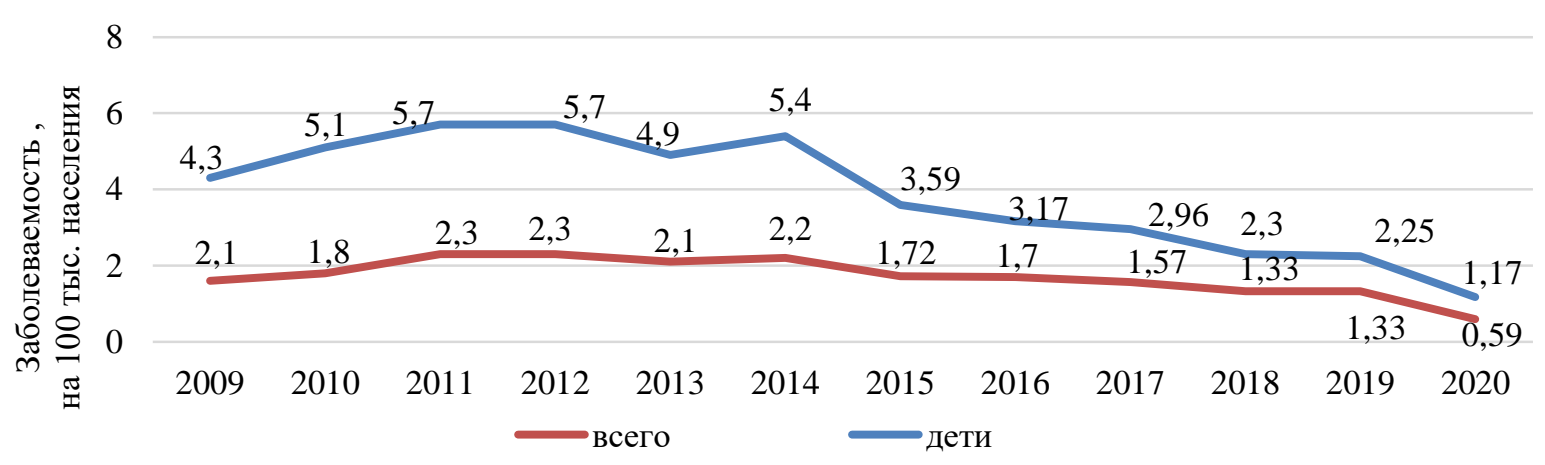

Рис. 155. Заболеваемость токсокарозом в Российской Федерации в 2009-2020 гг. (на 100 тыс. населения) 
В 2020 г. возбудители паразитозов были обнаружены в почве территорий животноводческих комплексов - 0,8\% (в 2019 г. - 1,71\%, в 2011 г. - 4,5\%), растениеводческих хозяйств $-1,9 \%$ (в 2019 г. - 0,77\%, в 2011 г. - 2,0 \%), в селитебной зоне $-0,81 \%$ (в 2019 г. $-0,88 \%$, в 2011 г. - 1,5\%), в том числе на территориях детских организаций и детских площадок - 0,52\% (в 2019 г. - 0,57\%, в 2011 г. - 1,1\%), в зоне санитарной охраны источников водоснабжения - 1,3\% (в 2019 г. - 1,04\%, в 2011 г. $1,4 \%)$.

Высокая численность собак в городских поселениях при несоблюдении правил их содержания, отсутствии мер дезинвазии экскрементов приводит к широкой циркуляции возбудителя токсокароза в окружающей среде (почве) и возрастанию риска заражения. В большинстве субъектов при выявлении яиц гельминтов в почве дезинвазия ее овицидными препаратами не проводится, профилактические мероприятия ограничиваются заменой песка, закрытием песочниц крышками.

Описторхоз, дифиллоботриоз, эхинококкоз, трихинеллез и другие биогельминтозы наносят немалый ущерб здоровью населения, течение болезни при данных нозологиях нередко сопровождается хронизацией процесса и необратимыми осложнениями, приводящими к инвалидности, а в ряде случаев заканчивается летальными исходами. В структуре биогельминтозов в 2020 году на долю описторхоза приходилось $79,98 \%$, дифиллоботриоза $-16,7 \%$, дирофиляриоза $-0,47 \%$, эхинококкоза $-1,87 \%$, альвеококкоза $-0,26 \%$, тениоза $-0,09 \%$, тениаринхоза $-0,09 \%$, клонорхоза $0,38 \%$, трихинеллеза $-0,16 \%$.

Важной проблемой остаются паразитозы, передающиеся через рыбу, ракообразных, моллюсков, земноводных, пресмыкающихся и продукты их переработки. Наиболее распространенными паразитозами среди населения Российской Федерации являются описторхоз, клонорхоз, дифиллоботриозы, кроме того, существует риск заражения другими менее распространенными паразитозами.

Описторхоз - самый распространенный гельминтоз, передающийся через зараженную пресноводную рыбу. В 2020 г. зарегистрировано 9932 случая описторхоза (6,77 на 100 тыс. населения), что ниже показателя 2019 г. в 2 раза $(13,35)$, а по сравнению с 2011 г. - ниже в 3,3 раза (22,37). Удельный вес городского населения составляет 76,3 \% случаев заболевания (7579 случаев), на долю сельского населения приходится 23,7\% (2353 случаев). Описторхоз зарегистрирован во всех возрастных группах. Доля детей до 17 лет, заболевших описторхозом, составила 10,7 \% (1068 случаев, 3,53 на 100 тыс. населения данной возрастной группы).

Отмечено превышение среднероссийского показателя в 2020 г. так же, как и в 2019 г., в 13 субъектах Российской Федерации. Показатель заболеваемости описторхозом в субъектах страны варьировал от 0,04 до 112,15 на 100 тыс. населения. Неблагополучными по описторхозу являются практически все территории, примыкающие к бассейнам рек Оби, Иртыша, Томи и их притокам.

Удельный вес обнаружения личинок гельминтов в рыбе в 2020 г. составил $0,8 \%$ (в 2019 г. $-1,6 \%$, в 2011 г. - 3,7\%).

Несмотря на проводимую разъяснительную работу среди населения о мерах личной и общественной профилактики биогельминтозов, по-прежнему не удается преодолеть привычки жителей неблагополучных по данным паразитозам территорий употреблять в пищу сырую рыбу.

В 2020 г. зарегистрировано 20 случаев трихинеллеза $(0,01$ на 100 тыс. населения), в 2019 г. - 51 случай (0,03 на 100 тыс. населения), заболеваемость снизилась в 3 раза. Трихинеллез зарегистрирован в 7 субъектах Российской Федерации, в 2019 г. в 19. Среди детей до 17 лет зарегистрировано 3 случая (2019 г. - 10 случаев). 
Причиной заражения людей трихинеллезом послужило мясо домашних и диких животных, не прошедшее ветеринарно-санитарную экспертизу: добытое на охоте, приобретенное в местах несанкционированной продажи, из личного подворья, купленное на рынках. Мясные блюда, послужившие причиной заражения возбудителем трихинеллеза, по способам кулинарной обработки были следующими: копченое мясо, шашлыки, мясо соленое, сырой фарш и котлеты.

Заболеваемость населения эхинококкозом в 2020 г. по сравнению с 2019 г. снизилась в 1,9 раза. Всего в 2020 г. зарегистрировано 233 случая (0,16 на 100 тыс. населения) против 451 случаев (0,31 на 100 тыс. населения) в 2019 г. Заболеваемость среди детей до 17 лет снизилась на 26,67 \% по сравнению с 2019 г. - выявлено 32 случая (0,11 на 100 тыс. детей данного возраста), в 2019 г. - 44 случая (0,15 на 100 тыс. населения детей данного возраста).

Наиболее высокая заболеваемость эхинококкозом и альвеококкозом регистрируется в субъектах Российской Федерации, где население занимается охотничьим промыслом и отгонным животноводством.

Заболеваемость альвеококкозом в 2020 г. снизилась в 2 раза по сравнению с 2019 г., выявлено 32 случаев альвеококкоза (0,02 на 100 тыс. населения) против 65 случаев (0,04 на 100 тыс. населения) в 2019 году. По сравнению с 2013 годом (год введения регистрации на федеральном уровне) заболеваемость снизилась в 1,5 раза - 47 случаев (0,03 на 100 тыс. населения).

Летальные случаи от эхинококкоза и альвеококкоза регистрируются ежегодно, в 2020 г. - 2 летальных случая от альвеококкоза (2019 г. - 7 летальных случаев от эхинококкоза, в том числе 1 ребенок до 17 лет, и 4 случая от альвеококкоза).

Основными причинами неблагополучия по эхинококкозам традиционно являются нарушение правил убоя сельскохозяйственных животных, неэффективные мероприятия по дезинвазии объектов окружающей среды и отсутствие действенных мер по регулированию численности и дегельминтизации бродячих собак, что приводит к выявлению в крупных городах детей, больных эхинококкозами.

Клонорхоз распространен в основном в Дальневосточном федеральном округе, где в 2020 г. зарегистрировано 45 случаев в Приморском крае и территориях в бассейне реки Амур и его притоках, по 1 случаю - в Сибирском и Центральном федеральных округах. Всего в 2020 г. зарегистрировано 47 больных клонорхозом, показатель заболеваемости составил 0,03 на 100 тыс. населения (в 2019 г. - 77 случаев $(0,05)$. В многолетней динамике заболеваемость клонорхозом характеризуется общей тенденцией к снижению, по сравнению с 2019 г. она снизилась в 1,7 раз. Среди заболевших в 2020 г. 13 случаев $(0,03$ на 100 тыс. населения) приходится на сельских жителей (2019 г. - 32 случая). Среди детей до 17 лет зарегистрировано 3 случая, показатель заболеваемости составил 0,03 на 100 тыс. детей данного возраста, это на 7 случаев меньше, чем в 2019 г. (10 случаев - 0,02 на 100 тыс. детей). 


\section{Раздел 2. Основные результаты научных исследований в области гигиены, эпидемиологии, профилактической медицины}

\section{1. Основные результаты научных исследований в области гигиены}

В 2020 году в соответствии с отраслевой научно-исследовательской программой Роспотребнадзора на 2016-2020 гг. «Гигиеническое научное обоснование минимизации рисков здоровью населения России» выполнялись научные исследования, направленные на определение причинно-следственных связей состояния здоровья населения, разработку и научное обоснование методических подходов к оценке, мониторингу и управлению рисками для здоровья различных категорий населения, включая риски развития профессиональной и профессионально обусловленной патологии в условиях комбинированного и сочетанного воздействия факторов производственной среды, разработку высокочувствительных селективных методов определения химических веществ в объектах окружающей и производственной среды и в биологических средах для обоснования маркеров экспозиции, применяемых при формировании доказательной базы негативного воздействия факторов.

Научные исследования позволили создать потенциал для развития и совершенствования деятельности по обеспечению санитарно-эпидемиологического благополучия населения Российской Федерации по следующим направлениям: анализ состояния качества атмосферного воздуха, питьевой воды, почвы населенных мест и ее влияния на здоровье населения; мониторинг безопасности продовольственного сырья и пищевых продуктов; оценка влияния потребления алкоголя и табакокурения на здоровье населения; мониторинг условий обучения и воспитания детей и подростков, мониторинг физических факторов среды обитания, воздействующих на здоровье, мониторинг радиационной обстановки, анализ состояния здоровья работающего населения и профессиональной заболеваемости.

Результатом работы научных организаций гигиенического профиля явилось выполнение более 150 НИР. Получено 162 патента на изобретения.

Проведенный научными организациями системный анализ обязательных санитарно-эпидемиологических требований и гигиенических нормативов обеспечил возможность обосновать, сформировать и обеспечить утверждение научно обоснованных гармонизированных санитарно-эпидемиологических правил, касающихся условий оказания услуг населению, условий проживания, планировки, застройки и содержания территорий населенных мест; условий труда и производственных процессов, пищевых производств, условий отдыха и оздоровления детей, их воспитания и обучения; радиационной гигиены, отдельных видов транспорта, а также единого актуализированного свода гигиенических нормативов по всем факторам среды обитания.

\section{Научное обоснование комплексного анализа факторов риска, обеспечения гигиенической безопасности и разработка системы мероприятий по управлению риском воздействия неблагоприятных факторов среды обитания на состояние здоровья населения России}

Обоснована организационно-функциональная и информационно-аналитическая перспективная модель государственной системы социально-гигиенического мониторинга, отражающая современные тенденции развития управления риском для здоровья населения на основе сопряжения подходов гигиенического нормирования и методологии оценки формируемого промышленными предприятиями риска для здоровья населения и обеспечивающая адекватную оценку санитарноэпидемиологического благополучия населения, работающих и потребителей, (рис. 156). 
Государственный доклад «О состоянии санитарно-эпидемиологического благополучия населения в Российской Федерации в 2020 году»

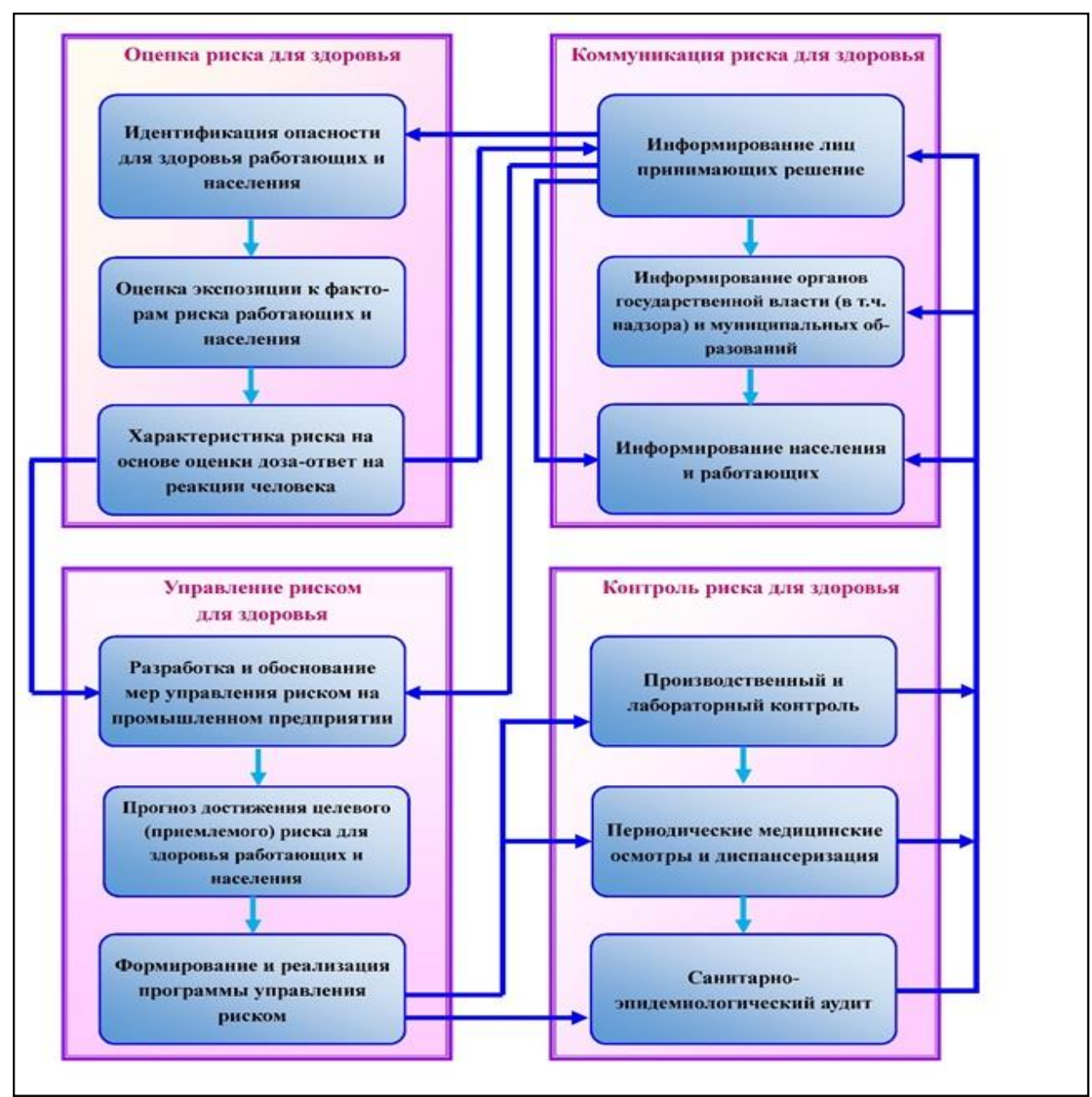

Рис. 156. Схема управления риском для здоровья работающих и населения в связи с хозяйственной деятельностью промышленных предприятий

Оценено математическое ожидание вариативности потерь ожидаемой продолжительности жизни (ОПЖ) в субъектах РФ, полученное на основе 85 сценариев погодно-климатических условий, что составило от $-4,2$ дней до $-348,7$ дней. В целом по РФ средневзвешенное по численности населения значение климатоассоциированных потерь ОПЖ составило 191,7 дня. Установлено, что в случае сохранения наблюдающихся тенденций в изменении ряда социально-экономических, санитарноэпидемиологических и других показателей (на фоне реальных погодно-климатических условий регионов страны), а также достижения целевых значений данных показателей согласно национальным проектам к 2024 году, ОПЖ всего населения РФ увеличится на 1325 дней (3,6 года). Выявлено, что несбалансированность рациона питания и несоблюдение обязательных требований к безопасности и качеству пищевой продукции формирует вероятностно порядка 150-200 тыс. смертей ежегодно (8-11\% от общей смертности населения) и более 3 млн 400 тыс. заболеваний разных классов.

Установлено, что в условиях комплексного воздействия факторов окружающей среды, современного образовательного процесса, питания и образа жизни у обучающихся увеличивается вероятность развития болезней костно-мышечной системы и соединительной ткани в 4,6-15,0 раза; болезней глаза и его придаточного аппарата за различные периоды - в 3,9-9,0 раза; расстройств вегетативной нервной системы - 4,27,4 раза; болезней органов пищеварения в 5,5-41,05 раза. Риск развития патологий эндокринной системы, расстройств питания и нарушений обмена веществ у гимназистов к окончанию начальной школы возрастает в 3,1 раза $(\mathrm{OR}=3,11$, ДИ $2,22-8,15)$. При 
анализе множественных моделей, отражающих зависимость «фактор - вероятность ответа», показано, что максимальный вклад в формирование расстройств вносят негативные факторы образовательного процесса (до 49,8\%), образа жизни и химического загрязнения окружающей среды.

При реализации намеченных федеральным проектом «Чистая вода» национального проекта «Экология» мероприятий, проведены исследования, результатом которых стала интерактивная карта контроля за качеством воды централизованных систем питьевого водоснабжения на территории России, позволяющая информировать население в режиме онлайн о качестве питьевой воды по каждому заданному конкретному адресу, проводить совершенствование работы специалистов органов и учреждений Роспотребнадзора по ведению СГМ и установлению причинноследственных связей в области «вода - здоровье», ведению контроля и управления за реализацией целевых показателей федерального проекта «Чистая вода». Результатом исследований стали разработанные и утвержденные методические рекомендации МР 2.1.4.0173-20 «Организация мониторинга обеспечения населения качественной питьевой водой из систем централизованного водоснабжения».

Принимая во внимание бурный рост производства и потребления бутилированной питьевой воды в России, изучен опыт нормирования содержания диэтилгексилфталата; ди-n-бутилфталата, диизобутилфтлата, бисфенола А в таре для питьевой воды и бутилированной воде и проведены исследования их содержания в отечественной таре и возможности миграции в питьевую воду. Разработаны предложения по включению этих показателей в программы производственного контроля и социально-гигиенического мониторинга качества питьевой воды, зарегистрирована база данных «Результаты содержания диэтилгексилфталата; ди-n-бутилфталата; диизобутилфтлата; бисфенола А в таре для питьевой воды и бутилированной воде (свидетельство № 2020622808 от 24.12.2020). В результате исследований программа производственного контроля за качеством воды, упакованной в тару, увеличена на несколько показателей, что обеспечит социальный эффект в виде снижения риска здоровью потребителей.

Показано, что в условиях российского климата и уровней заболеваемости инфекциями, передающимися комарами, штатного режима применения препаратов в соответствии с инструкцией достаточно. Установлено, что риск заражения инфекциями, переносчиками которых являются комары, составляет $0,1 \times 10^{-8}-0,1 \times 10^{-6}$, превышает риск воздействия репеллентов и инсектицидов. Применение репеллентов и инсектицидов в соответствии с инструкциями по применению снижает риск до уровня $0,3 \times 10^{-10}-0,9 \times 10^{-10}$.

В хроническом 12-месячном эксперименте на беспородных белых крысах-самцах установлено воздействие (поступление объекта испытания с кормом в дозах 2,0 и 10 мг/кг массы тела) технического продукта фунгицида - дженерика эпоксиконазола Китайского производства на систему антиоксидантной системы защиты организма теплокровных: повышение активности каталазы через месяц воздействия, а также повышение активности глутатионпероксидазы через 3 месяца воздействия, в дозе 10,0 мг/кг м.т. - повышение активности глутатионпероксидазы через 6 месяцев, снижение активности каталазы через 12 месяцев. Поступление объекта испытания в организм опытных животных в дозе 0,4 мг/кг м.т. не вызывало изменений изученных показателей. Доза 0,4 мг/кг м.т. была признана недействующей.

Выявлено генотоксическое действие смеси каптан+флудиоксонил на эритроциты костного мозга мышей, обусловленное эффектом синергизма. Смесь вызывала разрывы ДНК, приводящие к увеличению частоты образования микроядер (кластогенный эффект). Анализ ТБК-активных продуктов в сыворотке позволяет предположить, что повреждения ДНК обусловлены взаимодействием продуктов перекисного окисления липидов с ДНК. 
Смесь карбендазим+тирам оказывала мутагенное действие на штаммы бактерий S. typhimurium TA100, ТА102 и ТА97. В условиях in vivo каждый из пестицидов проявлял генотоксичность, но эффект смеси был выше аддитивного. Сопоставление результатов микроядерного теста и анализа ДНК-комет показало, что генотоксичность может быть опосредована не повреждением ДНК, а влиянием на сегрегацию хромосом (анеугенное действие).

Смесь карбендазим+флутриафол в низких дозах вызывала статистически значимое повышение частоты образования микроядер в эритроцитах мышей. При высоких дозах наблюдали снижение эффекта, что было связано с ингибированием эритропоэза флутриафолом. Эффект подавления эритропоэза флутриафолом обнаружен впервые (рис. 157).

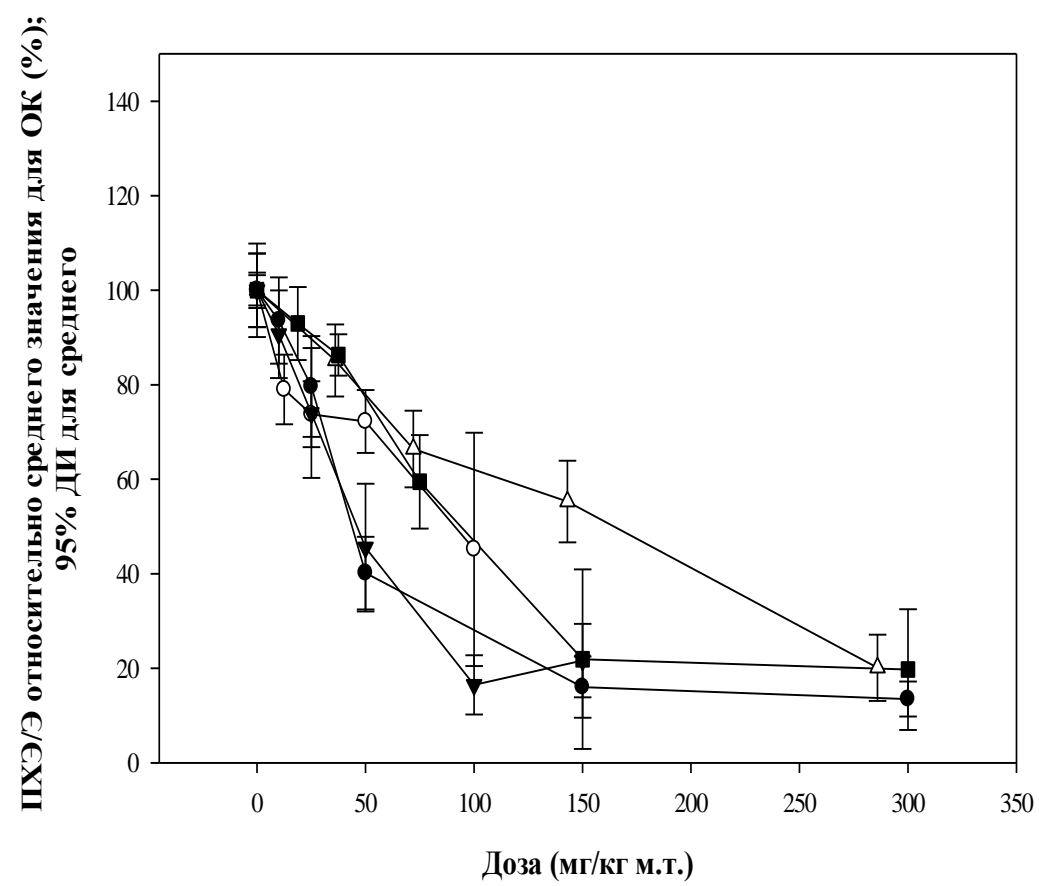

Рис. 157. Влияние технических продуктов флутриафола на эритропоэз в костном мозге мышей (ОК - отрицательный контроль, ДИ - доверительный интервал)

Препаративная форма на основе тирама и карбоксина индуцировала мутации у бактерий. Препарат вызывал зависимое от дозы повышение частоты формирования микроядер у самок мышей.

Таким образом, комбинации пестицидов, используемые в составе одного препарата или применяемые совместно (в баковой смеси), могут оказывать генотоксическое действие на нецелевые организмы. В качестве важного показателя опасности пестицидов предложено использовать результаты оценки генотоксичности не только отдельных действующих веществ, но и их комбинаций, а также препаративных форм, содержащих два и более действующих вещества.

Показано, что токсическое действие тетрахлорметана (ТХМ) на фоне измененного гормонального статуса усиливается: увеличивается содержание билирубина на $55 \%$ и цитолиз гепатоцитов (повышение до $35 \%$ выхода в кровь гепатоспецифических ферментов - аланинаминотрансферазы, аспартатаминотрансферазы. Установлено увеличение содержания гидроперекисей (на $29 \%$ ) на фоне значимого понижения активности внутриклеточной каталазы, которое в 3 раза выраженнее проявлялось в зимний период, что может привести к пониженной защите организма от негативного влияния свободных радикалов. 
Государственный доклад «О состоянии санитарно-эпидемиологического благополучия населения в Российской Федерации в 2020 году»

Показано, что длительный контакт с изопропиламинной солью глифосата приводит к истощению возможностей организма противостоять окислительному стрессу, что выражается в значительным нарастании показателей окислительного карбонилирования белков (в 2 раза), преимущественно за счет вторичных маркеров (кетон-динитрофенилгидразонов).

Разработаны подходы, совмещающие комплекс натурных, модельных и вычислительных методов, которые позволили расширить уровень понимания процессов, связанных с абиогенной и биогенной компонентами миграции загрязнений в экосистеме p. Енисей, а также указать на равномерность поступления техногенных загрязнителей в пространственном континууме.

Исследуемые водные растения обладают значительными адаптационными свойствами к потенциальному негативному воздействию антропогенных загрязнений, поступающих в водную среду. Водные растения могут служить перспективными фитосорбентами, использоваться в качестве биоиндикаторов токсичности воды различного происхождения.

Данные исследований были положены в основу расчетов интегральных рисков для здоровья населения как потенциального потребителя воды р. Енисей (табл. 64).

Таблица 64

\section{Расчет интегральных рисков для населения, как потенциального потребителя воды р. Енисей}

\begin{tabular}{|l|c|c|c|}
\hline \multicolumn{1}{|c|}{ Вид риска } & $\begin{array}{c}\text { Значения, по суммарной } \\
\text { оценке }\end{array}$ & $\begin{array}{c}\text { Величина } \\
\text { приемлемого } \\
\text { значения }\end{array}$ & $\begin{array}{c}\text { Отношение риска в } \\
\text { приемлемом значении }\end{array}$ \\
\hline \multicolumn{4}{|c|}{ Вода реки Енисей } \\
\hline Неканцерогенный риск & 0,012804 & 0,05 & 0,256 \\
\hline Канцерогенный риск & 0,0023 & 0,029 & 0,079 \\
\hline \multicolumn{4}{|c|}{ Питьевая вода г. Красноярска } \\
\hline $\begin{array}{l}\text { Риск появления рефлекторно- } \\
\text { ольфакторных эффектов }\end{array}$ & 0,001 & 0,1 & 0,336 \\
\hline Неканцерогенный риск & 0,017 & 0,05 & 0,34 \\
\hline Канцерогенный риск & 0,000 & 0,00 \\
\hline
\end{tabular}

В целом риски по всем анализируемым показателям не превышали приемлемых уровней и не требовали принятия дополнительных мер по регулированию качества воды.

В городах - участниках федерального проекта «Чистый воздух» проведены расчеты риска здоровью населения по результатам сводных расчетов загрязнения атмосферного воздуха на основе сводных расчетов загрязнения атмосферного воздуха на базовый 2017 г. Определены приоритетные химические вещества, оказывающие наибольшее неблагоприятное воздействие на здоровье и содержащиеся в выбросах предприятий, автотранспорта и автономных источников теплоснабжения (АИТ). Определено количество населения, подверженного воздействию атмосферных загрязнений на неприемлемых для здоровья уровнях (превышение приемлемого (допустимого) канцерогенного и неканцерогенного воздействия. Пример зонирования аэрогенных рисков для г. Красноярска приведен на рис. 158. 


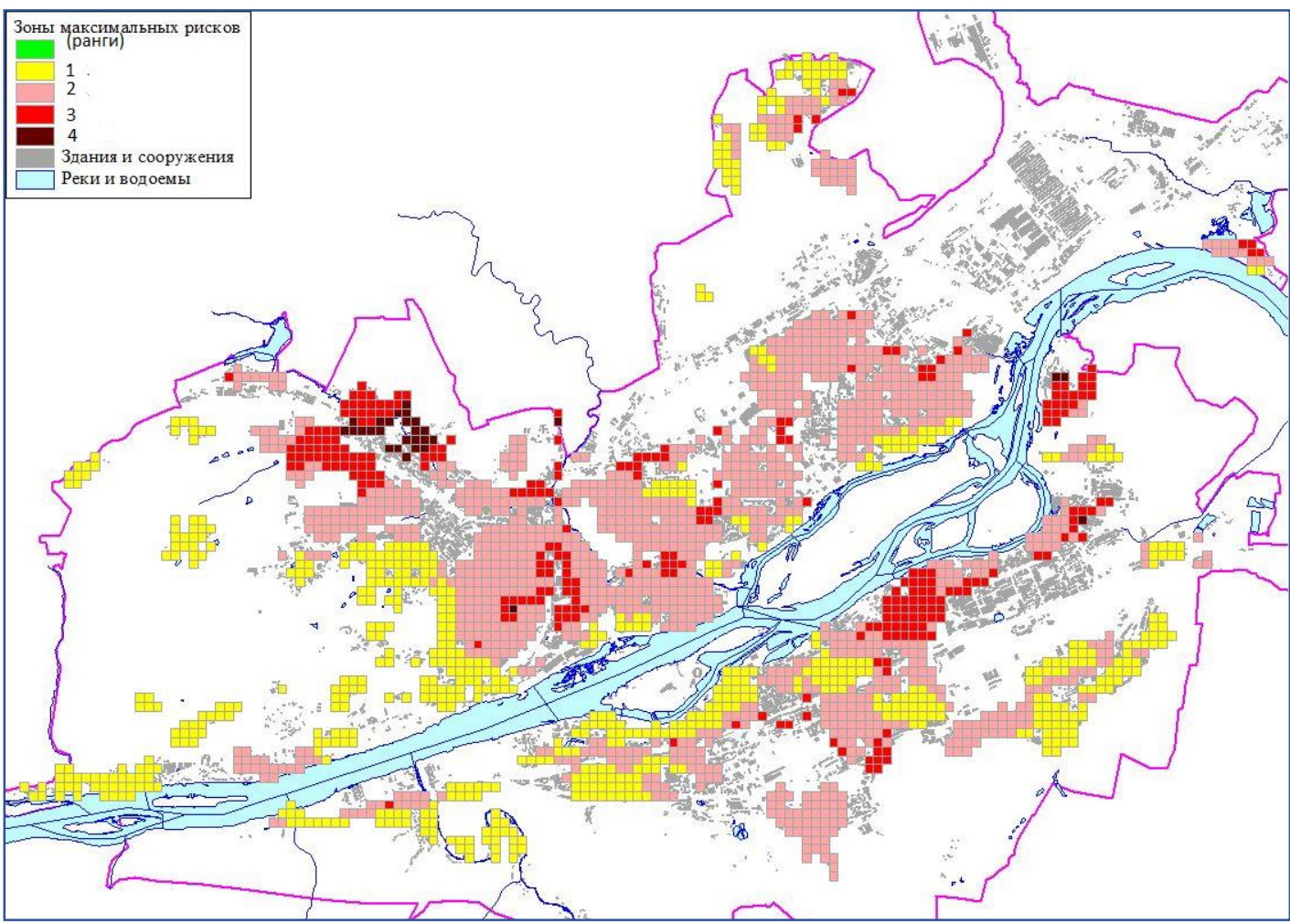

Рис. 158. Пространственное распределение аэрогенного риска на территории г. Красноярска (сопряжение зон разного вида и уровней риска)

Установлены вещества и их стационарные источники, которые следует учесть при квотировании выбросов, учитывая их потенциальное канцерогенное и неканцерогенное острое и хроническое воздействие на здоровье в городах - участниках ФП «Чистый воздух».

Интенсивность дорожного движения более 2000 машин в час характеризуется самой большой величиной суммарного загрязнения (НI) воздуха поллютантами как непосредственно вблизи автодороги, так и на придомовых территориях. В зоне влияния улично-дорожной сети на прилегающей к домам территории в период максимальной интенсивности транспортных потоков объективно регистрируются уровни шума, превышающие ПДУ до 18 дБА, которые обусловливают опасный и вызывающий опасение уровни риска развития неспецифических эффектов. Ранними маркерами неудовлетворительной адаптации инспекторов ДПС, работающих в зоне воздействия повышенного уровня шума, проявляющимися при стаже 2-4 года, являются дизрегуляторные нарушения сердечного ритма, а также снижение активированных Тлимфоцитов в иммунограмме и дефицит Se в крови. Разработана и зарегистрирована программа для ЭВМ «Оценка потенциального риска здоровью населения от воздействия транспортного шума» (номер государственной регистрации программы для ЭВМ 20200661425, дата государственной регистрации в Реестре программ для ЭВМ 23.09.2020).

\section{Научное обоснование комплексных мер по оценке и управлению риском для здоровья работающего населения в ведущих отраслях экономики на основе совериенствования персонифицированной системы мониторинга вредных производственных факторов и состояния здоровья}

По итогам изучения клинико-гигиенических аспектов сохранения трудоспособности стажированных работников в условиях воздействия опасных и вредных факторов труда получен патент на изобретение «Способ определения направленности течения хронического профессионального бронхита» (№ 2733866, дата 
государственной регистрации в Государственном реестре изобретений Российской Федерации 07.10.2020).

Для использования на современных химических производствах разработаны МУК «Атомно-адсорбционное определение ртути в моче методом холодного пара с использованием ртутно-гидридной приставки» (направлен в Роспотребнадзор 03.07.2020, исх. № 52-50/327/2020/02).

Зарегистрирована база данных «Результаты содержания диэтилгексилфталата; ди-n-бутилфталата; диизобутилфтлата; бисфенола А в таре для питьевой воды и бутилированной воде (свидетельство № 2020622808 от 24.12.2020). Обоснованно увеличена на несколько показателей программа производственного контроля за качеством воды, упакованной в тару.

Зарегистрирована база данных «Данные медицинского обследования работающих во вредных условиях труда металлургического производства Нижегородской области» (свидетельство № 2020620196 от 04.02.2020).

Разработаны и апробированы методические указания «Методика проведения измерений электрических и магнитных полей промышленной частоты 50 Гц в жилых и общественных зданиях», «Методика проведения измерений инфразвука на территории жилой застройки и в помещениях жилых и общественных зданий», «Методика проведения измерения воздушного ультразвука на рабочих местах и в жилых помещениях», «Оценка профессионального риска здоровью работающих в условиях шума выше 80 дБА» и методических рекомендаций «Методика измерения электромагнитных полей промышленной частоты 50 Гц на селитебной территории».

В качестве основных причин хронических заболеваний сменных работников установлены продолжительность, частота и степень нарушения суточного ритма, стаж работы, количество ночных смен за месяц, возможности кратковременного сна в ночной смене. Выходными параметрами разработанной модели является ГПРі - годовой прирост риска заболевания і-й нозологии (синдром хронической усталости, ожирение, метаболический синдром, диабет; психические расстройства; желудочно-кишечные расстройства; сердечно-сосудистые заболевания, онкология; нарушения репродуктивной функции у женщин).

Обоснованы экспресс-, упрощённые и углубленные методы физиологогигиенической оценки режимов работы при повышенной продолжительности рабочей смены, а также алгоритмы оценки параметров режима сменного труда. По результатам этих работ зарегистрированы базы данных «Результаты исследований риска здоровью работников при нарушениях суточного ритма сна и бодрствования (свидетельство № 2020621444 от 17 августа 2020 г.) и «Результаты медицинского осмотра и субъективной оценки утомления, состояния здоровья преподавателей высшей школы (свидетельство № 2020621514 от 24 августа 2020 г.).

Установлено, что на формирование кардиоваскулярного риска оказывают влияние производственные факторы (химический, шум, напряженность труда, физические нагрузки) в сочетании с психоэмоциональным стрессом, вызванным пожароили взрывоопасностью производства, работой в ночную смену. У работников основных профессий химического комплекса выявлена высокая распространенность таких факторов кардиоваскулярного риска, как артериальная гипертензия - 35,0\%, метаболические нарушения (абдоминальное ожирение - 40,1\%), гиперхолестеринемия - 49,5\%, поведенческие факторы (низкая физическая активность - 55,0\%, нерациональное питание - 38,0 \%, курение - 36,7 \%), психоэмоциональный стресс по Reeder $(39,6 \%)$.

Профессиональная потеря слуха выявлена в 37,8 \% случаев у горнорабочих при добыче медно-цинковых руд и $16,5 \%$ у работников нефтедобычи, что соответствует уровню риска «выше среднего». Результаты импедансометрии свидетельствуют о 
наличии нарушений функции слуховой трубы, снижении объема рефлекторной деятельности внутриушных мышц. Выявлены значимые сосудистые изменения конъюнктивы глаза у работников шумовых производств.

У операторов по добыче нефти и газа установлена связь сенсорной нагрузки с атеросклерозом $(\mathrm{RR}=2.9)$, язвенной болезнью желудка и двенадцатиперстной кишки $(\mathrm{RR}=5.8)$, а также связь режима работы с атеросклерозом $(\mathrm{RR}=4.8)$. Риск, связанный с развитием язвенной болезни желудка и двенадцатиперстной кишки, обусловлены сенсорной нагрузкой, классифицируется как средний. Риск, связанный с развитием атеросклероза в результате воздействия сенсорной нагрузки и режима работы, относится к высокой категории риска.

Установлено, что нарушения сперматогенеза ассоциированы с избыточной экспрессией ключевого рецептора процесса апоптоза - CD95, а также маркера ранней активации клеток - CD25, что отражает запуск активности апоптотических сценариев в мужской репродуктивной системе. Доказано, что что ряд ароматических углеводородов реализует репротоксичность, используя механизм избыточной индукции мембранной сигнализации рецептора клеточной гибели, ускоряет естественную программу клеточной гибели оринтировочно на 20 \% по сравнению с состоянием репродуктивных клеток, не подвергшихся стимуляции. Выявлено, что возрастание экспрессии маркера апоптоза CD95+ на сперматозоидах является фактором, ассоциированным с угнетением фертильности спермы в условиях экспозиции бензолом. Идентифицированные полиморфные варианты генов-кандидатов и их встречаемость позволят на последующих этапах исследований уточнить роль генетического фактора в формировании индивидуальных рисков возникновения репродуктивных нарушений.

У овощеводов защищенного грунта установлена высокая степень причинноследственной связи с работой гипертонической болезни $(\mathrm{RR}=2,805 ; \mathrm{EF}=64,35 ; \mathrm{CI}=1,498-$ $5,253)$, дорсопатии пояснично-крестцового отдела позвоночника $(\mathrm{RR}=2,290$; $\mathrm{EF}=56$; $\mathrm{CI}=1,140-4,599)$ и средняя степень связи миомы матки $(\mathrm{RR}=1,969 ; \mathrm{EF}=49 ; \mathrm{CI}=0,988-$ $3,926)$ и хронического бронхита $(\mathrm{RR}=1,532 ; \mathrm{EF}=34,7 ; \mathrm{CI}=0,682-3,442)$. У работников молокоперерабатывающего производства установлена очень высокая степень причинноследственной связи с работой болезней уха и сосцевидного отростка $(\mathrm{RR}=4,3$; $\mathrm{EF}=76,7 \% ; \mathrm{CI}=1,6-3,9)$ и высокая степень связи заболеваний костно-мышечной системы и соединительной ткани $(\mathrm{RR}=2,22 ; \mathrm{EF}=55,1 \% ; \mathrm{CI}=1,17-2,5)$.

Обоснован перечень приоритетных химических соединений (бутанон-2, бутанол2, метилмеркаптан, изопропанол, ацетон, толуол, фенолы, ацетальдегид, сероводород, аммиак), подлежащих контролю на границе санитарно-защитной зоны полигонов складирования осадков сточных вод.

Зарегистрирована база данных «Технологии обработки осадков очистных сооружений канализации» (свидетельство № 2020621908 от 02.10.2020).

Зарегистрирована база данных «Взаимосвязь обращаемости населения за медицинской помощью с факторами земной и космической погоды» (свидетельство № 2020622028 от 20.10.2020), программа прогнозирования уровней заболеваемости от климатических условий и антропогенного загрязнения атмосферы для ЭВМ № 2020666244 от 8 декабря 2020 г.

Разработаны методы и критерии определения биоиндикаторов токсикологического риска, связанного с трансграничным переносом в Арктику опасных загрязняющих веществ промысловыми мигрирующими видами (ПМВ) диких рыб, птиц и животных. Показано, что эти риски, наряду с известными феноменами биоаккумуляции и биомагнификации химических загрязнений в пищевом сырье, определяются также некоторыми социально-экономическими, биологическими и эндемическими факторами, оказывающими модифицирующее действие на экспозицию, канцерогенные и неканцерогенные эффекты стойких загрязняющих веществ. Мировая 
новизна разработанного метода детоксикации подтверждена патентом на изобретение RU 2676929 C1 («Способ снижения содержания ДДТ и его метаболитов в пищевом сырье из промысловых животных»).

Для оценки влияния информационной нагрузки на уровень профессионального риска разработаны и зарегистрированы: программа для ЭВМ «Экспресс-оценка индивидуального профессионального риска, связанного с информационной нагрузкой у офисных работников» (№ государственной регистрации программы для ЭВМ 2020616862, дата государственной регистрации в Реестре программ для ЭВМ 25.06.2020); программа для ЭВМ «Совершенствование регистрации в системе ДПМО для снижения информационной нагрузки на операторов ПК» (номер государственной регистрации программы для ЭВМ 2020612883, дата государственной регистрации в Реестре программ для ЭВМ 05.03.2020); база данных «Электронный учет в системе дополнительного профессионального медицинского образования (ДПМО)» (номер государственной регистрации базы данных 2019622496, дата государственной регистрации в Реестре баз данных 26.12.2019), а также Методические рекомендации «Использование методов здоровьесбережения для профилактики профессионального выгорания» (направлены в Роспотребнадзор 09.12.2020, исх. № 52-50/540/2020/02).

\section{Оценка комбинированного и комплексного воздействия вредных факторов среды на организм}

Научно обоснован комплекс медико-профилактических мероприятий по управлению риском для здоровья населения в связи с повышенной химической нагрузкой для здоровья населения на примере территорий Свердловской (14 городов) и Оренбургской областей (2 города). Системой биологической профилактики риска развития заболеваний, обусловленных химическим загрязнением среды обитания, охвачено в 2020 году более 4715 детей, посещающих дошкольные образовательные организации, и около 100 беременных женщин. Экономическая эффективность реализации комплекса медико-профилактических мероприятий достигла 11 рублей предотвращенного ущерба для здоровья на каждый рубль затрат.

В субхроническом эксперименте при интраназальном введении металлосодержащих наночастиц $\left(\mathrm{CuO}, \mathrm{PbO}, \mathrm{CdO}, \mathrm{Fe}_{2} \mathrm{O}_{3}\right)$ одинакового размерного диапазона, образующихся при различных технологических процессах металлургических производств, установлены изменения поведенческих реакций у крыс (рис. 159, 160).

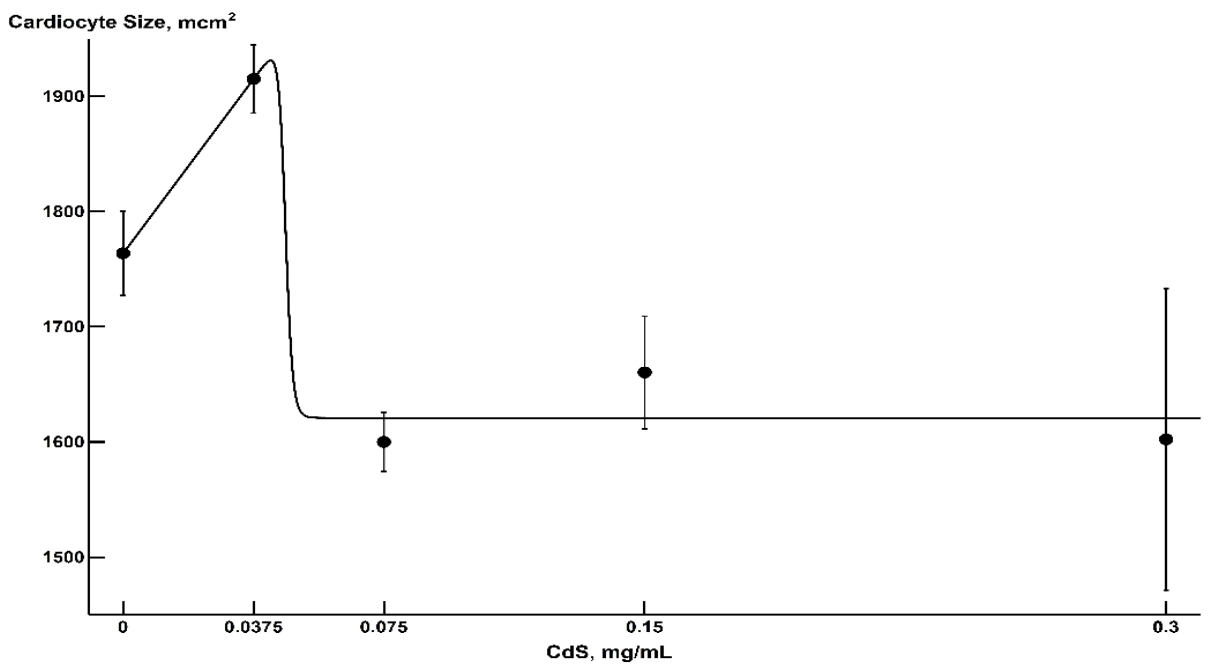

Рис. 159. Зависимость изменения средней п кардиомиоцитов линии HL-1 (мкм²) от концентрации наночастиц $\mathrm{CdS}$ в среде инкубации 


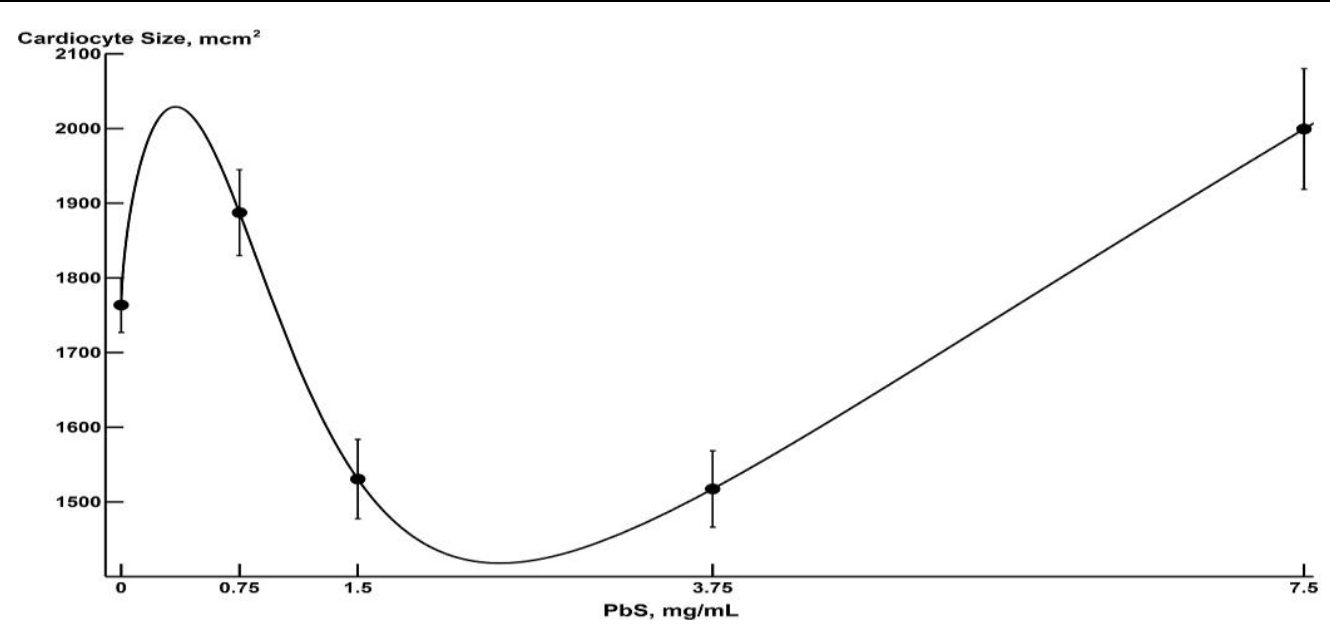

Рис. 160. Зависимость изменения средней площади ( \pm стандартная ошибка) кардиомиоцитов линии HL-1 (мкм²) от концентрации наночастиц PbS в среде инкубации.

Показан стимулирующий эффект не только при минимальных концентрациях, но и после промежуточного диапазона, в котором имело место угнетение

Впервые показан немонотонный характер зависимости от дозы наночастиц $\mathrm{CdS}$ и $\mathrm{PbS}$ при воздействии на культуру кардиомиоцитов линии HL-1 (полифазность гормезиса). Получен патент на промышленный образец № 122110 «Схема «Новая дефиниция понятия «гормезис», обобщающая различные варианты немонотонной зависимости «доза - ответ»»».

Оценка эффективности ограничительных мероприятий на использование личных устройств мобильной связи школьниками в общеобразовательных организациях показала, что, по мнению обучающихся, у них после введения ограничительных мероприятий повышаются: внимательность во время уроков (у 73,1 \% респондентов); умственная работоспособность (у 70,3 \%); вербальные коммуникации между детьми и педагогами (у 51,4 \%); уровень двигательной активности во время перемен (у 59,0 \%). Отмечено снижение тревожности детей, обусловленной потерей телефона у 69,6\% респондентов, ожиданием звонка или смс (у 79,7 \%). При использовании сотовых телефонов во время перемен установлена выраженная причинно-следственная связь между сниженным резервом аккомодации у детей и формированием к окончанию учебного дня патологических рефракций $(\mathrm{r}=0,77 ; \mathrm{p} \leq 0,05)$.

Объективная оценка двигательной активности обучающихся в течение учебного дня выявила значимые различия в показателях энерготрат детей: суммарно в группе наблюдения они на 9,8\% выше аналогичных показателей в контрольной группе. Различия в показателях были обусловлены более высокой двигательной активностью детей во время перемен. Получен патент на изобретение «Способ определения энергозатрат организма человека» (№ 2728262).

Исследованиями была подтверждена у большинства детей привычка засыпания $(78,2 \%)$ с сотовым телефоном (независимо от принимаемых ограничений на их использование во время нахождения в общеобразовательной организации).

Разработано специализированное кросс-платформенное программное средство «Мониторинг питания и здоровья детей».

На основании результатов исследования пероральной и ингаляционной токсичности, определения выраженности раздражающих свойств и расчета нормативных величин в соответствии с действующими методическими указаниями, в качестве ориентировочного безопасного уровня воздействия (ОБУВ) в атмосферном воздухе городских и сельских поселений аэрозоля сульфата цинка гептагидрата обоснована концентрация $0,01 \mathrm{~m} / \mathrm{m}^{3}$.

Формируется геопортал «Санитарно-эпидемиологическое благополучие населения Арктической зоны Российской Федерации» (геопортал АЗРФ) - единая 
многоуровневая цифровая платформа по сбору, систематизации и анализу медикодемографических, социально-экономических и санитарно-эпидемиологических данных о состоянии здоровья населения и факторов среды обитания.

Проведена идентификация генетических маркеров ГМО в мясной продукции (колбасы), сформирован перечень маркерных показателей для задач проведения санитарно-гигиенической экспертизы и других видов оценок.

Разработаны новые методы идентификации и количественного определения генетически модифицированных организмов (ГМО), которые позволяют выявлять генетически модифицированные линии кукурузы, сои и рапса, запрещенные для применения в продуктах питания и кормах на территории Российской Федерации. Создан алгоритм лабораторного исследования образцов пищевой продукции, полученной с использованием сырья растительного происхождения, на наличие универсальных элементов растительного генома, содержащихся в ГМО. Разработаны и утверждены методы идентификации и количественного определения генетически модифицированных кукурузы, сои, рапса (МР 4.2.0163-20, МР 4.2.0217-20).

В исследуемых 34 образцах колбасных изделий 11 производителей из регионов России выявлено присутствие трансформационных событий - промотора $35 \mathrm{~S} \mathrm{CaMV}$, целевого гена агробактерии cp4 EPSPS, маркерного гена неомицин-фосфотрансферазы nptII, терминатора NOS. Проведенный полуколичественный анализ образцов определил присутствие данных линий в пределах $0,1 \%$, что соответствует допустимому порогу при маркировке продукта согласно ТР ТС 022/2011. Рекомендовано в рамках проведения мониторинга и выборочного контроля качества колбасных изделий массового производства на наличие ГМ-трансформационных событий использовать в качестве наиболее патогномоничных генетических маркеров ДНК сои, ДНК кукурузы, ДНК картофеля, ДНК рапса, промотор 35s CaMV, целевой ген сp4 EPSPS, маркерный ген nptII, терминатор NOS как наиболее часто встречающиеся в ГМ-культурах.

Оценка риска для здоровья населения при поступлении 11 элементов с основными группами пищевых продуктов позволила установить, что общий индекс опасности не превышает допустимого значения $(\mathrm{HI}=0,74)$. При одновременном поступлении в организм с пищевыми продуктами мышьяка, меди, цинка, хрома и кадмия критическими, подверженными наибольшему токсическому воздействию, являются иммунная система, желудочно-кишечный тракт, центральная нервная система, гормональная система и кровь. Индивидуальный канцерогенный риск от воздействия свинца, кадмия и мышьяка находится на предельно допустимом уровне $\left(8,0 \times 10^{-5}\right)$. Проведенные исследования свидетельствуют о необходимости введения контроля содержания химических элементов (алюминий, хром, никель) в пищевых продуктах, составляющих основу пищевого рациона (рис. 161).

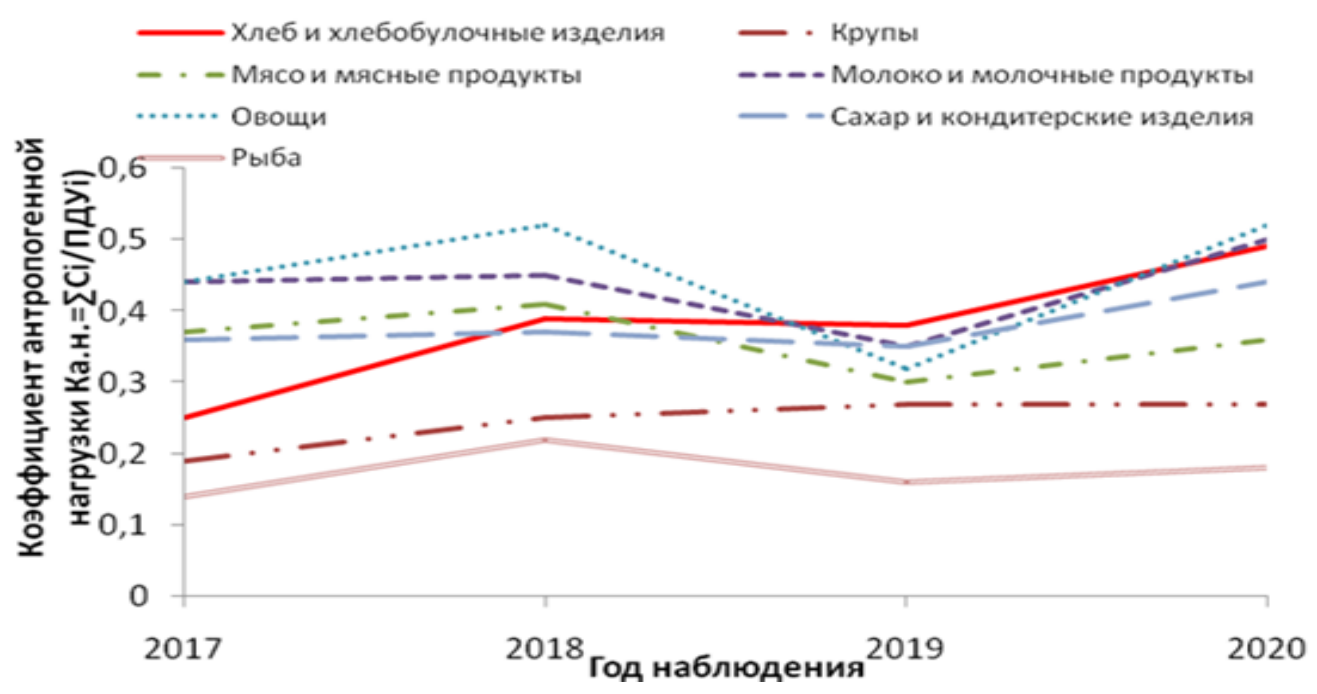

Рис. 161. Вклад основных товарных групп в коэффициент антропогенной нагрузки 
В отдельных образцах фруктов были идентифицированы остаточные количества ряда действующих веществ пестицидов: имазалил $(0,015-0,42$ мг/кг), пириметанил $(0,073-2,1$ мг/кг), тиабендазол $(0,18-1,4$ мг/кг), обнаружены минорные содержания азоксистробина, дифеноконазола, имидаклоприда, прохлораза, клотианидина и пирипроксифена. Все выявленные остаточные количества пестицидов не превышали МДУ/ВМДУ для импортируемой продукции.

Выполнено 1092 экспериментальных исследования по определению остаточных количеств пестицидов в сельхозпродукции, в воздухе и других средах с применением разработанных высокоселективных аналитических методов; оценке риска для лиц, работающих с пестицидами, и населения; токсичности пестицидов, в том числе мутагенности.

Опубликованы два справочника, содержащие значимую информацию для практических учреждений: «Методы контроля остаточных количеств пестицидов в пищевых продуктах и сельскохозяйственном сырье» (более 2 тысяч официальных методов) и «Токсиколого-гигиеническая характеристика пестицидов и первая помощь при отравлении» (информация о 267 новых пестицидах).

Предложен приоритетный способ определения массовых концентраций примесей в атмосферном воздухе при помощи масс-спектрометрии с индуктивно-связанной плазмой, который оформлен в виде государственной заявки на изобретение с получением патента (приоритет от 03.08.2020).

\section{Научное обеспечение радиацинной безопасности населения России}

Разработаны проекты постановлений Правительства Российской Федерации «О порядке проведения радиационно-гигиенической паспортизации организаций и территорий Российской Федерации», «О функционировании единой государственной системы контроля и учета индивидуальных доз облучения граждан», «О лицензировании деятельности в области использования источников ионизирующего излучения (генерирующих)».

Разработка нормативных документов обусловлена необходимостью учета опыта их функционирования в Российской Федерации и приведения в соответствие с изменениями нормативных документов и структуры органов исполнительной власти. В проекте постановления Правительства Российской Федерации «О лицензировании деятельности в области использования источников ионизирующего излучения (генерирующих)» внесены важные положения и изменения, основное - добавление ряда позиций в перечень лицензируемых видов деятельности («реализация ИИИ», «монтаж и наладка ИИИ») и исключение из лицензируемых видов деятельности позиции «эксплуатация средств радиационной защиты ИИИ».

Проведен анализ существующего программного обеспечения радиационногигиенической паспортизации, осуществлена его модернизация и получены свидетельства на их государственную регистрацию в Роспатенте (7 компьютерных программ и 3 базы данных).

Разработаны и усовершенствованы методы радиационного контроля питьевой воды, пищевых продуктов, включая расчеты допустимых уровней содержания радионуклидов в пищевых продуктах при их аварийном загрязнении. Полученные научные результаты вошли в ряд методических документов в этой области: МР 2.6.1.0214-20 «Радиационный контроль питьевой воды методами радиохимического анализа», МР 2.6.1/2.3.7.0216-20 «Определение удельной активности природных радионуклидов в пробах пищевой продукции, почвы, других объектов окружающей среды и биопробах». 
Научный анализ современных подходов к риск-коммуникации с населением при кризисных ситуациях по вопросам радиационной безопасности позволил разработать MP «Ведение кризисной риск-коммуникации на разных этапах радиационных аварий».

Разработаны алгоритмы анализа и обобщения информации, собираемой в рамках ЕСКИД, для внедрения автоматизированной справочной геоинформационной системы анализа доз облучения населения Российской Федерации по результатам работы «Единой государственной системы контроля и учета индивидуальных доз облучения граждан». С этой целью разработаны и зарегистрированы в Роспатенте две компьютерные программы. $\mathrm{C}$ использованием этих компьютерных программ сформирован и опубликован сборник «Дозы облучения населения Российской Федерации в 2019 году».

В связи необходимостью учета современного состояния отечественной лучевой диагностики в 2020 г. была выполнена переработка формы федерального государственного статистического наблюдения № 3-ДОЗ «Сведения о дозах облучения пациентов при проведении медицинских рентгенорадиологических исследований», направленная на расширение номенклатуры учитываемых рентгенорадиологических исследований и раздельного учета доз медицинского облучения взрослых и детей, кардинально переработан раздел по радионуклидной диагностике.

Для обеспечения максимальной эффективности КТ-диагностики в 2020 г. были разработаны и утверждены МУК 2.6.7.3652-20 «Методы контроля в КТ- диагностике для оптимизации радиационной защиты» с целью оптимизации проведения КТ исследований. Разработаны и утверждены МР 2.6.1.0215-20 «Оценка радиационного риска у пациентов при проведении рентгенорадиологических исследований», включающие в себя методики расчета радиационных рисков при проведении лучевой диагностики для пациентов различного пола и возраста.

Проведенные исследования позволили дать научное обоснование и разработать радиационно-гигиенические требования к охранным зонам мирных ядерных взрывов при переводе их в стадию консервации. Результаты исследований легли в основу предложений по обустройству охранных зон и радиационному контролю; разработаны предложения в проект СанПиН по обустройству охранных зон мирных ядерных взрывов на стадии их консервации. Получены два свидетельства о государственной регистрации двух компьютерных программ в Роспатенте.

Разработаны методические документы:

- MP 2.6.1.0214-20 «Радиационный контроль питьевой воды методами радиохимического анализа»;

- MP 2.6.1/2.3.7.0216-20 «Определение удельной активности природных радионуклидов в пробах пищевой продукции, почвы, других объектов окружающей среды и биопробах»;

- МУК 2.6.7.3652-20 «Методы контроля в КТ-диагностике для оптимизации радиационной защиты»;

- МР 2.6.1.0215-20 «Оценка радиационного риска у пациентов при проведении рентгенорадиологических исследований».

\section{Совериенствование методов количественного определения и контроля загрязнений окружающей среды}

Обоснованы условия атомно-абсорбционного анализа электротермической атомизацией с инновационным способом пробоподготовки почвы, сочетающим предварительную гомогенизацию образцов методом криоизмельчения и последующую микроволновую минерализацию, что обеспечивает точность и воспроизводимость результатов анализа ряда токсичных тяжелых металлов в образцах почвы различного гранулометрического состава, с варьированием содержания органического вещества и 
кислотности $(\mathrm{pH})$. Разработанная методика определения тяжелых металлов в почве утверждена в качестве официального документа МУК 4.1.3658-20 «Определение содержания тяжелых металлов в почве методом безпламенного атомно-абсорбционного анализа с микроволновой минерализацией».

Создан метод многокомпонентного определения остаточных количеств пестицидов в плодах цитрусовых культур.

Разработана методика многокомпонентного определения остаточных количеств пестицидов различных химических классов в цитрусовых, утвержденная в виде официального документа (МУК 4.1.3657-20) апробирована при исследовании плодов цитрусовых (мандарины, апельсины, грейпфруты, лимоны), импортированных из Абхазии, Турции и Египта.

В связи с массовым загрязнением подземных вод, используемых для питьевых целей, разработана методика выполнения измерений массовой концентрации кремния, содержащегося в его растворенных и нерастворенных формах, в воде методом молекулярной спектроскопии и атомно-эмиссионной спектрометрии.

Отработаны методические подходы и разработаны методические рекомендации «Порядок выявления и идентификации потенциально опасных незаявленных и непреднамеренно присутствующих химических веществ в пищевой продукции».

Экспериментальными исследованиями воздействия наночастиц оксида меди (II), используемого при острой ингаляционной экспозиции, установлен 5-й класс опасности; при остром пероральном воздействии - 3-й класс опасности. Выявлено, что наночастицы оксида меди (II) кумулируют в лёгких, печени, желудке, почках, кишечнике и головном мозге при ингаляционной экспозиции; в лёгких, печени, желудке, кишечнике, почках и крови при пероральной экспозиции. При ингаляционной и пероральной экспозиции наночастицы оксида меди (II) обладают более выраженной, чем микрочастицы этого вещества, степенью бионакопления, вызывают более выраженные изменения показателей гомеостаза и стрессовые реакции, имеют более выраженный характер патоморфологических изменений в тканях лёгких, печени, желудке, толстом кишечнике экспериментальных животных относительно частиц микроразмерного химического аналога (рис. 162).

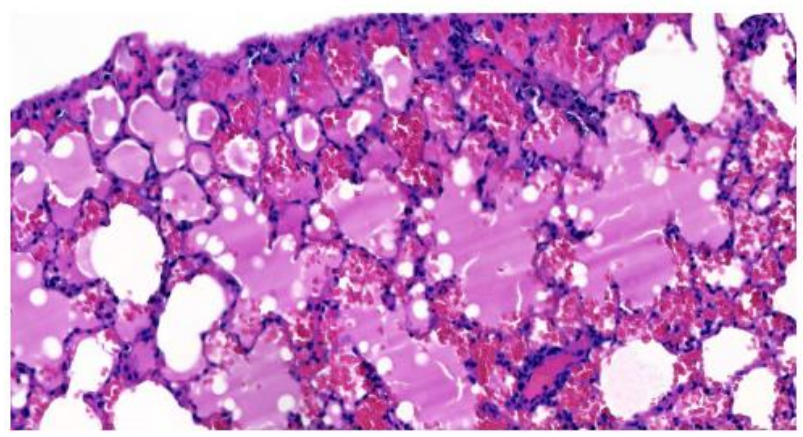

a)

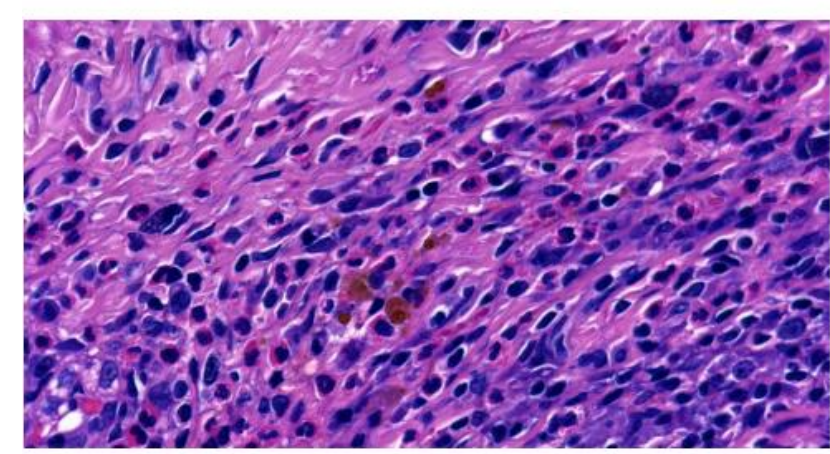

б)

Рис. 162. Препараты, свидетельствующие о воздействии наноразмерных частиц оксида меди. Фактическая концентрация наноразмерного $\mathrm{CuO}$ в ингаляционной камере $1,17 \pm 0,18 \mathrm{Mг} / \mathrm{M}^{3}$ (г-э, 200:1). а) альвеолярный отёк лёгкого крысы б) воспалительная инфильтрация стенки бронха лёгкого крысы

При пероральной экспозиции дополнительно выявлены более выраженные изменения (центролобулярные некрозы, гиалиново-капельные дистрофии, скопления коричневого пигмента) в печени и почках.

Получены 2 свидетельства об аттестации методики (метода) измерений (№ 8816207-006-RA.RU.310657-2020 «Методика измерений массовой концентрации 
4-гидрокси-2,2,6,6-тетраметилпипередин-1-оксила (4-гидрокси-ТЕМПО) в воздухе рабочей зоны методом хромато-масс-спектрометрии», № 88-16207-009-RA.RU.3106572020 «Методика измерений массовой концентрации смеси н-алканов, изоалканов, циклоалканов С15-С20 в воздухе рабочей зоны методом хромато-масс-спектрометрии»); 1 свидетельство о государственной регистрации программы для ЭВМ (№ 2020615135 «Анкетирование школьников, родителей, учителей и директоров общеобразовательных организаций по вопросам порядка использования мобильных телефонов»); 24 свидетельства о государственной регистрации баз данных.

Разработана методика измерения массовых концентраций рифампицина в молоке методом высокоэффективной жидкостной хроматографии в сочетании со спектрофотометрическим детектированием, чувствительность которой на уровне и ниже максимально допустимого уровня остаточного количества антибиотика. Степень экстракции рифампицина из молока $99 \%$. Относительная погрешность измерения не превышает $31 \%$.

Разработана методика для селективного определения содержания нормируемых токсичных элементов (кадмий, свинец, мышьяк, ртуть) в плодоовощной продукции (свежие и свежезамороженные овощи, картофель, бахчевые, фрукты, ягоды, грибы) методом масс-спектрометрии с индуктивно связанной плазмой. Методика позволяет определять данные элементы из одной пробы в диапазоне концентраций от сотых долей ПДК с приемлемыми метрологическими характеристиками точности, правильности и воспроизводимости.

Разработана высокочувствительная методика контроля содержания потенциально опасных летучих органических соединений (трихлорэтилен и тетрахлорэтилен) в атмосферном воздухе с низкими пределами обнаружения на базе высокотехнологичного аналитического оборудования. Методика характеризуется высокой эффективностью и позволяет реализовать предел обнаружения на уровне для тетрахлорэтилена

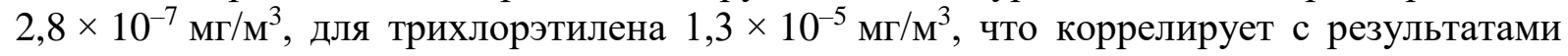
международных исследований.

Разработаны рекомендации по применению методов биоиндикации в системах оценки, мониторинга, прогнозирования и предотвращения рисков нарушений здоровья населения, связанных с переносом в арктические районы опасных экотоксикантов дикими промысловыми видами рыб, птиц и животных.

Научно обоснованы и гармонизированы с международными требованиями санитарно микробиологические показатели безопасности питьевой воды централизованного водоснабжения: обобщенные колиформные бактерии, E. coli и энтерококки.

Обоснованы микробиологические показатели и нормативы в СанПиН 1.2.3685-21 «Гигиенические нормативы и требования к обеспечению безопасности и (или) безвредности для человека факторов среды обитания», в раздел III «Нормативы качества и безопасности воды».

Обоснованы положения по безопасности, введены микробиологические показатели и нормативы в МР 2.1.4.0176-20 «Организация мониторинга обеспечения населения качественной питьевой водой из централизованного водоснабжения» за качеством питьевой водой из систем централизованного водоснабжения».

Научно обоснован методический подход к оценке достаточности и эффективности планируемых мероприятий по снижению выбросов загрязняющих веществ в атмосферный воздух для митигации рисков и вреда здоровью населения, в том числе с применением метода нечетких множеств. Отработан механизм оценки остаточного риска здоровью и оценки эффективности мероприятий по критериям риска и вреда здоровью. 


\section{2. Основные результаты научных исследований в области эпидемиологии и профилактической медицины}

В соответствии с отраслевой научно-исследовательской программой на 20162020 гг. «Проблемно-ориентированные научные исследования в области эпидемиологического надзора за инфекционными и паразитарными болезнями» продолжены изучение современных тенденций развития эпидемического процесса, наблюдение за возбудителями инфекций, совершенствование лабораторной диагностики, определение особенностей иммунного статуса человека при инфекциях и вакцинации, создание диагностических, профилактических и лечебных препаратов; осуществлялось научное и методическое обеспечение функций Роспотребнадзора, связанных с профилактикой и снижением заболеваемости инфекционными и паразитарными болезнями в Российской Федерации.

Научными организациями проведена широкомасштабная работа по изучению нового коронавируса человека SARS-CoV-2 и вызываемого им заболевания. Созданы коллекции штаммов, изучены биологические свойства SARS-CoV-2, разработаны методы его индикации и идентификации. Разработаны и зарегистрированы медицинские иммунобиологические препараты для диагностики, лечения и профилактики новой коронавирусной инфекции COVID-19. Налажен выпуск отечественных наборов для обеспечения практической потребности учреждений здравоохранения и госсанэпиднадзора в диагностических препаратах, адаптированных для применения в сферах клинической лабораторной диагностики и эпидемиологических исследований. Создана пептидная вакцина «ЭпиВакКорона» для профилактики COVID-19, которая успешно прошла доклинические и клинические исследования, зарегистрирована для использования в России.

Получено 65 патентов на изобретения, подано 36 заявок на получение патентов на изобретения, получены регистрационные удостоверения на 16 иммунобиологических препаратов, зарегистрировано 5 программных продуктов и 47 баз данных. Получены справки о депонировании 322 штаммов микроорганизмов в коллекциях микроорганизмов, проведено депонирование в международные базы данных 2320 нуклеотидных последовательностей возбудителей инфекций, в том числе их полных геномов.

\section{Научно-методическое обеспечение эпидемиологического надзора за инфекционными заболеваниями, управляемыми средствами специфической профилактики}

1. Корь, краснуха, парвовирусная инфекиии. Отменён гендерный подход при вакцинации против краснухи взрослых 18-25 лет в рамках Национального календаря профилактических прививок; ревакцинацию по эпидемическим показаниям однократно привитых против кори рекомендовано проводить только среди лиц старше 6 лет. Наблюдение за специфическим иммунитетом позволило выявить возрастные группы риска повышенного инфицирования корью и краснухой, установлены причины возникновения локальных вспышек кори, в том числе в медицинских учреждениях.

Исследования штаммов вируса кори, выделенных в 2020 г., показали уменьшение генетического разнообразия вируса кори по сравнению с 2019 г., отмечено появление штаммов, не изолировавшихся в мире ранее, что, вероятно, явилось следствием активной местной циркуляции вирусов кори. В 2020 г. циркулируют штаммы генотипов B3 и D8 и доминируют штаммы генетической линии B3 MVs/Kabul.AFG/20.2014/3, циркуляция которой в странах СНГ началась в 2019 г. Штаммы генотипа D8 изолировались реже, большинство из них - от импортированных случаев из разных стран. 
Впервые разработана система процедур использования контрольных препаратов «ВЛК Корь-IgM сер.2» для проведения внутреннего контроля качества исследований на корь, выполняемых методом ИФА при диагностике кори, которая позволит определять достоверность результатов и корректно анализировать данные, полученные в разное время в разных лабораториях на тест-системах разного формата (рис. 163).

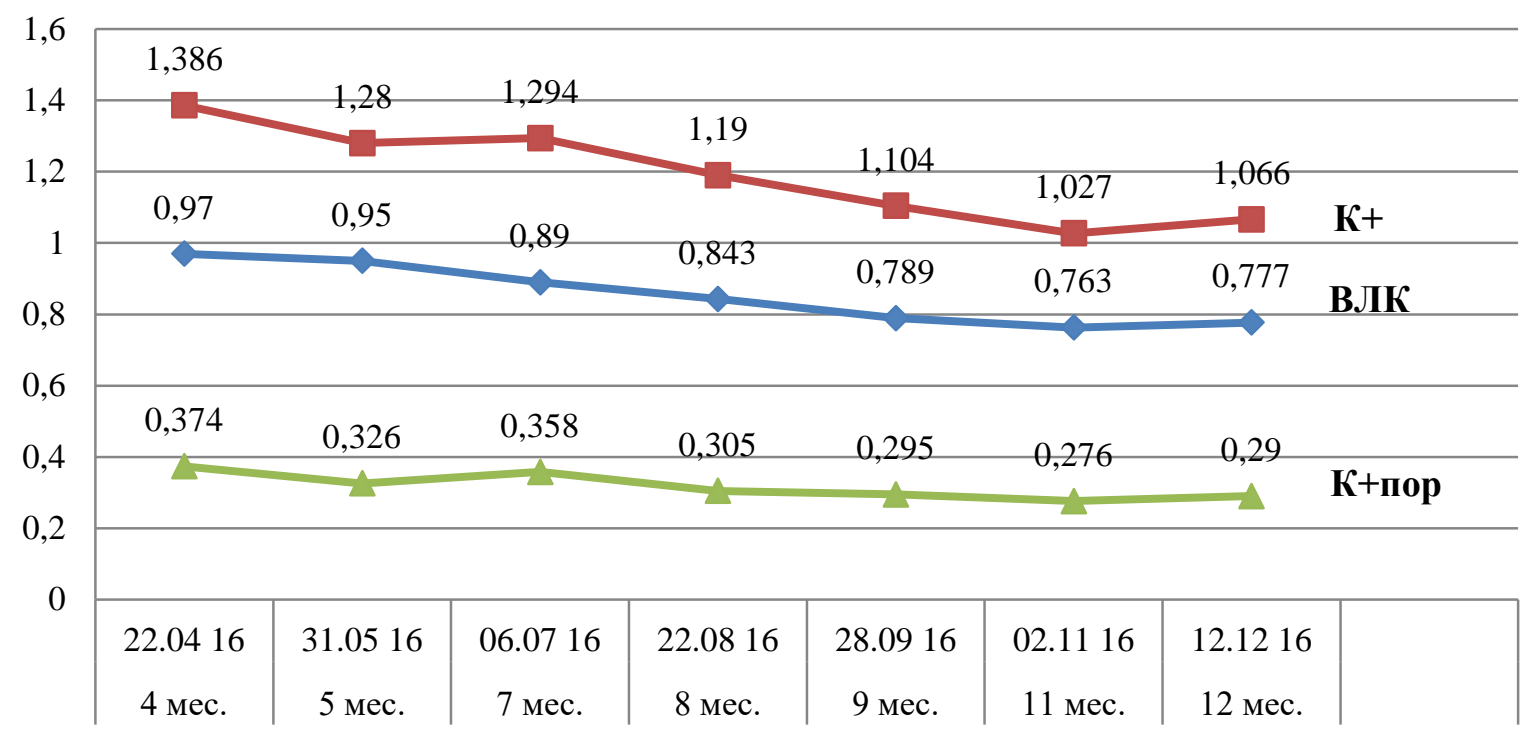

Рис. 163. Оперативный контроль ВЛК на протяжении срока годности тест-системы (1 год) в сравнении с активностью контролей, прилагаемых к коммерческой тест-системе.

Впервые сопоставлены особенности гуморального иммунного ответа привитых и больных корью взрослых. Более половины больных корью и привитых от кори здоровых серонегативных взрослых ответили на контакт с вирусом кори вторичным иммунным ответом, что подтверждает спектр субклассов и авидности специфических антител (преобладание высокоавидных антител $\mathrm{G}$ класса (>80\%) в высокой концентрации (>2,0 ME/мл) с преобладанием специфических антител субкласса $\mathrm{IgG}_{1}$ над $\mathrm{IgG}_{3}$ ). Это может свидетельствовать о потере привитыми в детстве лицами защитных уровней антител, но сохранении у них В-клеток памяти, которые сформировались при вакцинации в детстве.

2. Парвовирусная инфекция. Установлено широкое распространение в СевероЗападном федеральном округе парвовирусной инфекции, которая постоянно выявлялась на 10 из 11 территорий округа. Выделенные в СЗФО изоляты РVВ19 принадлежат к генотипу 1A, преимущественно, подтипу 1А2. Они тесно связаны между собой и с изолятами, обнаруженными ранее в России, Европе, США, Японии, что свидетельствует о продолжающейся циркуляции PVB19. Некоторый уровень кластеризации вирусов по годам может указывать на импортитрование штаммов вируса из других регионов.

3. Дифтерия, коклюш. Установлено, что на фоне низкой заболеваемости дифтерией возрастает роль её серологического мониторинга. Подтверждена эффективность ревакцинации против дифтерии лиц 60 лет и старше.

Апробирована новая изотермическая полимеразная цепная реакция (LAMP-ПЦР), позволяющая проводить скрининг штаммов и биоматериала от пациентов на наличие токсигенных штаммов Corynebacterium diphtheriae.

Изучена длительность поствакцинального иммунитета при коклюше и серопревалентности к Bordetella pertussis детей и подростков в Санкт-Петербурге, свидетельствующая о широкой циркуляции B.pertussis среди детей и подростков 
среднего и старшего школьного возраста и необходимости ревакцинации детей в возрасте 6-7 лет.

Разработана методика мультиплексной ПЦР в реальном времени (ПЦР-РВ), позволяющая выявлять в биологическом материале больных ДНК B.pertussis, B. parapertussis, B. holmesii.

4. Инфекции, вызываемые менингококком (Neisseria meningitidis), пневмококком (Streptococcus pneumoniae), гемофильной палочкой (Haemophilus influenzae). В г. Москве, несмотря на период спорадической заболеваемости менингококковой инфекцией (МИ), продолжающийся в течение 30 лет, уровень заболеваемости последовательно увеличивается с 2016 г. Среди больных генерализованными формами МИ возрастает интенсивность циркуляции менингококка эпидемически значимой серогруппы А (до 76,5 \%) сиквенс-типа ST-75 клонального комплекса 1. Более половины здорового населения не имеет антител к менингококку серогруппы А и подавляющее большинство - к менингококку серогруппы C.

В г. Москве среди трудовых мигрантов выделены штаммы менингококка сиквенстипа 175 (NmNG cc175), входящие в клональный комплекс 175 и не зарегистрированные ранее в России, которые вследствие мутаций не способны синтезировать полисахаридную капсулу, что в целом характерно для носительских штаммов, так как позволяет им персистировать в организме человека, не нанося ему особого вреда. Установленный высокий уровень генетической изменчивости и потенциальная способность к приобретению генов, обеспечивающих возможность синтеза капсулы, характерной для штаммов серогрупп $\mathrm{W}$ и $\mathrm{Y}$, не позволяют исключить возможности возникновения генерализованных форм инфекции, обусловленных штаммами этого клонального комплекса с изменёнными в результате рекомбинационных процессов свойствами.

Впервые установлено, что комменсальные бактерии, в частности лактобациллы и коринебактерии, в том числе полученные из них бактериеподобные частицы, способны подавлять рост и вирулентность назальных патогенов, что определяет перспективу их использования для создания интраназальных пробиотиков для защиты носоглотки от колонизации патогенными бактериями, в том числе менингококком и пневмококком.

5. Ветряная оспа. Впервые в России теоретически обоснован выбор наиболее эффективной тактики проведения вакцинопрофилактики ветряной оспы - плановая (когортная) двукратная вакцинация детей в рамках календаря профилактических прививок. Оценены риски внутрибольничной заболеваемости ветряной оспой.

Разработаны рекомендации по совершенствованию и оптимизации эпидемиологического надзора за ветряной оспой и опоясывающим лишаем, за вакцинопрофилактикой ветряной оспы.

\section{Научно-методическое обеспечение эпидемиологического надзора за гриппом и другими острыми респираторными вирусными инфекциями}

6. Грипn. В эпидсезоне 2019-2020 гг. превалировали вирусы гриппа $\mathrm{A}\left(\mathrm{H}_{1} \mathrm{~N}_{1}\right) \mathrm{pdm} 09$ и $\mathrm{B}$, в меньшей степени вирусы гриппа $\mathrm{A}\left(\mathrm{H}_{3} \mathrm{~N}_{2}\right)$. Циркулирующие вирусы $\mathrm{A}\left(\mathrm{H}_{1} \mathrm{~N}_{1}\right) \mathrm{pdm} 09$ относятся к клайду 6В.1А, субклайду 6В.1А5 подгруппе 6В.1A5A, к субклайду 6В.1А7, к субклайду 6В.1А1, как и вакцинный штамм A/Brisbane/02/2018 с гомологией по гену НА - 97,9-99,0 \%, по гену NA - 98,3-99,8 \%. Среди вирусов гриппа $\mathrm{A}\left(\mathrm{H}_{3} \mathrm{~N}_{2}\right)$ преобладает подгруппа 3C.2a1b, кластер 3C.2alb+T131K и 3C.2alb+T135K-B, c гомологией с вакцинным штаммом A/Kansas/14/2017 по гену НА - 95,8-96,4 \%, по гену NA $-98,2-98,4 \%$. 
Успешно тестирована шифр-панель по внешней оценке качества диагностики субтипов вируса гриппа, полученная из Референс-лаборатории ВОЗ по диагностике гриппа Н5-подтипа.

Разработан и внедрён в производство набор реагентов «Influenza virus B-тип-FL» для быстрой идентификации антигенных вариантов вируса гриппа В (Yamagata и Victoria) в клиническом материале.

Вирусы гриппа чувствительны к ингибиторам нейраминидазы, но имеют мутации, снижающие чувствительность к ремантадину.

7. Новая коронавирусная инфекция COVID-19. Организован сбор и молекулярногенетическое исследование вирусов SARS-CoV-2, циркулирующих на территории России, определены последовательности 447 изолятов SARS-CoV-2 из 74 регионов, количество исследованных образцов постоянно увеличивается.

Проводится диагностика новой коронавирусной инфекции и мониторинг наличия антител к вирусу SARS-CoV-2 у граждан России. Выборочно сыворотки крови от реконвалесцентов тестируются на наличие вирус-нейтрализующей активности.

Определены серопревалентность и особенности изменения титров антител класса IgG к вирусу SARS-CoV-2 в динамике наблюдения у 74,2 тыс. волонтеров разных возрастных групп и социального статуса в 26 регионах России. Исследования продолжаются на фоне проведения массовой вакцинации против COVID-19.

Создана программа, позволяющая на основе анализа динамики развития эпидемиологической ситуации с COVID-19 в регионах России автоматизировать расчёт ряда аналитических показателей и визуализировать их в виде графиков, диаграмм, карт. Разработана методика краткосрочного прогнозирования развития эпидемиологической обстановки. Разработаны детерминированные компартментные (SIR, SEIR) математические модели развития эпидемии COVID-19 в городах и субъектах России с учётом влияния ограничительных мер (карантин, социальное дистанцирование и т. п.).

Установлено, что в Омской области в структуре вариантов SARS-CoV-2, наряду с вирусами европейского кластера (GR-клайд), выявляемыми в ходе пандемии на территории России, Европы, американского континента, присутствуют вирусы Оклайда, циркулирующие Юго-Восточной Азии, Индонезии, Австралии. Разработан алгоритм краткосрочного прогнозирования (1-2 недели вперед) новых случаев COVID19 в Омской области, показавший высокую точность.

Предложена интерактивная модель SEIR (Susceptible - восприимчивый, Exposed - находящийся в инкубационном периоде, Infectious - инфицированный, Recovered выздоровевший), на базе которой обработаны данные и проанализированы материалы по случаям заражения, тяжести течения заболевания у больных, случаям смерти от COVID19 в Ростовской области с целью прогноза развития эпидемиологической ситуации.

Установлена особенность внебольничных пневмоний у пациентов с лабораторно подтверждённым COVID-19 - высокая частота микст-инфекций вирусной и бактериальной этиологии, преобладающим этиологическим агентом является Streptococcus spp.

Установлено, что наличие ВИЧ-инфекции не является предиктором тяжёлого течения COVID-19 и высокой летальности, лицам с ВИЧ необходимо следовать стандартным мерам профилактики COVID-19.

Исследован гуморальный иммунитет к SARS-CoV-2 у больных с подтверждённой инфекцией COVID-19. Антитела IgG определяли с помощью отечественных коммерческих ИФА тест-систем, детектирующих антитела к антигенам SARS-CoV-2: цельновирионному, белку нуклеокапсида (N-белку), белку шипа (S-белок), к рецепторсвязывающему домену S-белка (RBDs). Антитела IgM определяли к N-белку или RBDs. До 5-го дня болезни в сыворотке крови пациентов не выявляются IgM- и IgG-антитела 
ко всем антигенам. Сероконверсия IgM- и IgG-антител наблюдается в первую неделю заболевания. Динамика IgM-антител к N-белку и RBDs сходна, отличается уровень антител. IgM-антитела к RBDs обнаруживаются на 1-й неделе болезни, но не достигают высоких значений. Уровень IgM-антител к N-белку увеличивается от нулевых до высоких значений к 3-й неделе болезни и снижается к 8-й неделе. Динамика IgG-антител к цельновирионному антигену, S-белку, RBDs сходна с максимальными значениями показателей на 4-5 неделе наблюдения. Для IgG-антител к N-белку характерен незначительный рост титра к 1-й неделе и невысокий уровень в течение всего срока наблюдения. Для антител к $\mathrm{N}$-белку характерно резкое увеличение и высокий уровень $\operatorname{IgM-антител,~уровень~IgG-антител~к~N-белку~нарастает~плавно~и~не~достигает~высоких~}$ значений. Для антител к RBDs наблюдается обратная картина. Динамика уровня IgGантител к S-белку и RBDs позволяет предположить продолжительность заболевания.

\section{Научно-методическое обеспечение профилактики вирусных гепатитов}

8. Выявлена необходимость ревакцинации при гепатите В (ГВ), сформулированы предложения по оптимизации эпидемиологического надзора и контроля за эпидемическим процессом вирусных гепатитов на региональном уровне. Для своевременного принятия решений о необходимости и сроках проведения бустериммунизации среди взрослых лиц актуальным является подбор индикаторных групп населения, состояние специфического иммунитета которых позволит экстраполировать полученные результаты на популяцию конкретной территории. Сроки ревакцинации у лиц высокого риска инфицирования (медицинские работники) необходимо рассматривать индивидуально по результатам ежегодного серомониторинга уровня и напряжённости специфического иммунитета, который необходимо включить в стандарты оказания медицинской помощи (рис. 164).

Оптимизирована вакцинопрофилактика ГВ в центрах гемодиализа. Разработан алгоритм вакцинопрофилактики ГВ у больных на гемодиализе на основе оценки предикторов ослабленного, слабого, отрицательного ответа на вакцину (концентрация в крови IgM, ИЛ-2). В зависимости от прогноза алгоритм предполагает использование увеличенной дозы вакцины по усиленной схеме, при необходимости назначаются специфический иммуноглобулин и иммуномодулятор. Предложены оптимальные сроки ревакцинации, что позволяет отказаться от дорогостоящего мониторинга титра суммарных анти-HBs антител в течение первых 3 лет после вакцинации.

Продемонстрирована важность мониторинга напряжённости поствакцинального иммунитета против ГВ с целью совершенствования вакцинопрофилактики на территории Санкт-Петербурга. Установлено, что 5,7\% добровольцев имели незаконченный курс вакцинации, у 18,5 \% выявлен отрицательный показатель анти-HBs, у $60,8 \%$ - низкий и средний уровень анти-HBs, у 20,7 \% - высокий уровень анти-HBs.

Разработан и внедрён метод диагностики ГВ на основе количественной оценки кольцевой ковалентно-замкнутой ДНК вируса ГВ в тканях печени; показана его значимость при HBsAg-негативном ГВ. Разработан и внедрён метод выявления вируса ГВ при низкой вирусной нагрузке в плазме крови с использованием двухстадийной ПЦР, что позволяет выявлять и анализировать распространённые геноварианты вируса ГВ. 


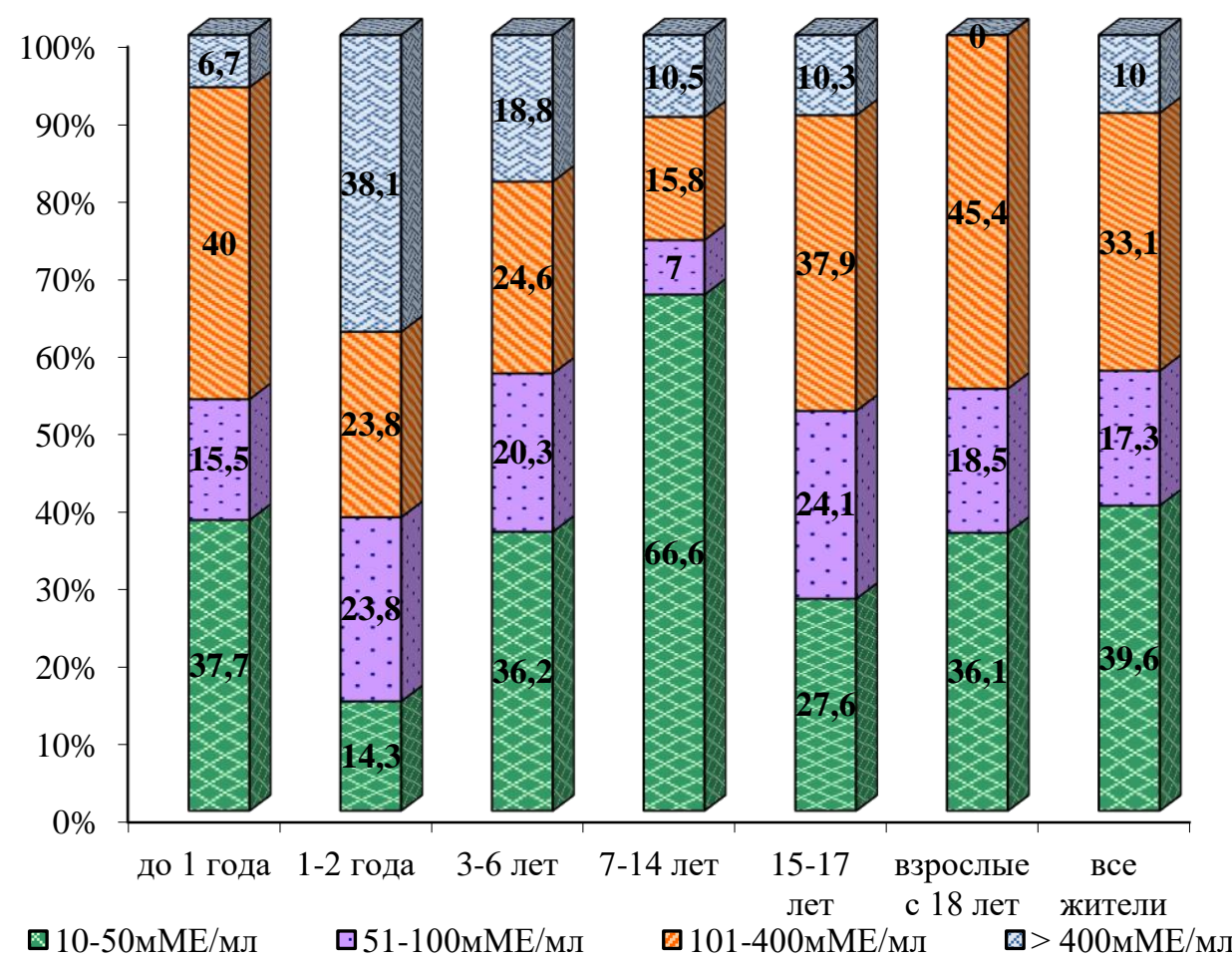

Рис. 164. Напряжённость поствакцинального иммунитета к вирусу гепатита В населения г. Нижнего Новгорода в 2019 г. (на 100 исследований)

\section{Научно-методическое обеспечение профилактики инфекций, связанных с оказанием медицинской помощи (ИСМП)}

9. Разработан стандарт определения случаев гнойно-септических инфекций (ГСИ) ожоговой раны, что упрощает выявление этой нозологии и позволяет управлять процессом её распространения.

Разработаны рекомендации по работе эндоскопических подразделений в стационарах, принимающих больных COVID-19, и неинфекционных стационарах, по профилактике заноса коронавируса в эндоскопические стационары, ограничению и порядку выполнения генерирующих аэрозоль процедур, защите здоровья пациентов и медицинского персонала. Разработаны меры профилактики инфицирования эндоскопической бригады коронавирусом при проведении бронхоскопии. Даны рекомендации по видам эндоскопических исследований, которые в условиях пандемии должны выполняться при плановых, экстренных и неотложных вмешательствах.

10. Описаны новые клональные генетические линии Klebsiella pneumoniae, несущие гены карбапенемаз ST395 ${ }^{\text {NDM-1 }}$, ST13 ${ }^{\text {OXA-48 }}$, ST3346 OXA-48/CTX-M-14, ST3551 OXA-48, и генетическая линия, несущая ген цефалоспориназы ST39СТХ-М-14. Штаммы имеют фенотип экстремальной или множественной лекарственной устойчивости (МЛУ). Появление в России новых клональных групп K. pneumoniae, продуцентов карбапенемаз, подтверждает наличие генетических процессов, обеспечивающих неблагоприятную глобальную тенденцию распространения мультирезистентности в лечебных учреждениях.

В геномах штаммов K. pneumoniae идентифицированы гены $\beta$-лактамаз blashv, bla $a_{\mathrm{CTX}-\mathrm{M}}$, bla $a_{\mathrm{TEM}}$, bla $a_{\mathrm{OXA}-48}$, bla $a_{\mathrm{NDM}-1}$, интегроны класса 1 , несущие наборы генных кассет: aacA4 (n=2), dfrA1-orfC, aadB-aadA1, dfrA15-aadA1, dfrA112-orfF-aadA2. Все штаммы имели наборы из четырёх генов вирулентности: wabG, fimH, uge, allS, два штамма дополнительно - ген $k f u$. 
Государственный доклад «О состоянии санитарно-эпидемиологического благополучия населения в Российской Федерации в 2020 году»

Выявлена циркуляция нового для России высокопатогенного сиквенс-типа

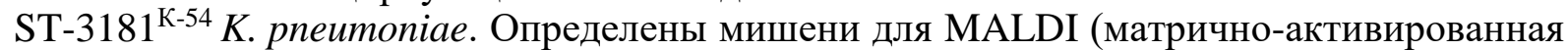
лпзерная десорбция/ионизация), минисеквенирования, доказана целесообразность их использования для быстрой дифференциации эпидемически значимых штаммов K. pneumoniae.

11. Зафиксировано перекрёстное инфицирование пациентов отделений реанимации и интенсивной терапии (ОРИТ) госпитальным патогеном с высокой резистентностью к антимикробным препаратам (АМП) Acinetobacter baumannii, принадлежащим к нескольким генетическим линиям, чувствительным только к полимиксину и тетрациклинам.

Запатентован мультирезистентный штамм A. baumanii для стандартизации оценки эффективности разрабатываемых АМП и дезинфицирующих средств.

12. Впервые в России использована биологическая модель личинок большой восковой моли Galleria mellonella для оценки вирулентности клинических штаммов бактерий и тестирования АМП. Штаммы уропатогенных Escherichia coli и Staphylococcus aureus по их способности вызывать гибель модели разделены на высокои слабовирулентные.

В геномах штаммов уропатогенных E. coli (UPEC) выявлены различные генетические детерминанты вирулентности: адгезинов, сидерофоров, токсинов и других, профили генов вирулентности в полных геномах штаммов UPEC у высоковирулентных и слабовирулентных штаммов различны. Большинство штаммов UPEC относятся к категории МЛУ ( $\beta$-лактамы, фторхинолоны, нитрофураны, аминогликозиды, полимиксины). Фенотипы МЛУ коррелируют с наличием генетических детерминант антибиотикорезистентности.

13. Исследована толерантность к дезинфектантам $S$. aureus клональных комплексов СС 8, СС 15, СС 30, отличающихся способностью к биоплёнкообразованию. Показано, что самую плотную биоплёнку образуют штаммы $S$. aureus клональной группы CC8, самую слабую - CC 15. Чувствительность штаммов $S$. aureus к дезинфектантам разных функциональных классов варьирует в зависимости от состояния бактериальной культуры (планктонные клетки, биоплёнки разной степени выраженности). Создана панель штаммов $S$. aureus для тестирования антибиоплёночной активности АМП (рис. 165).

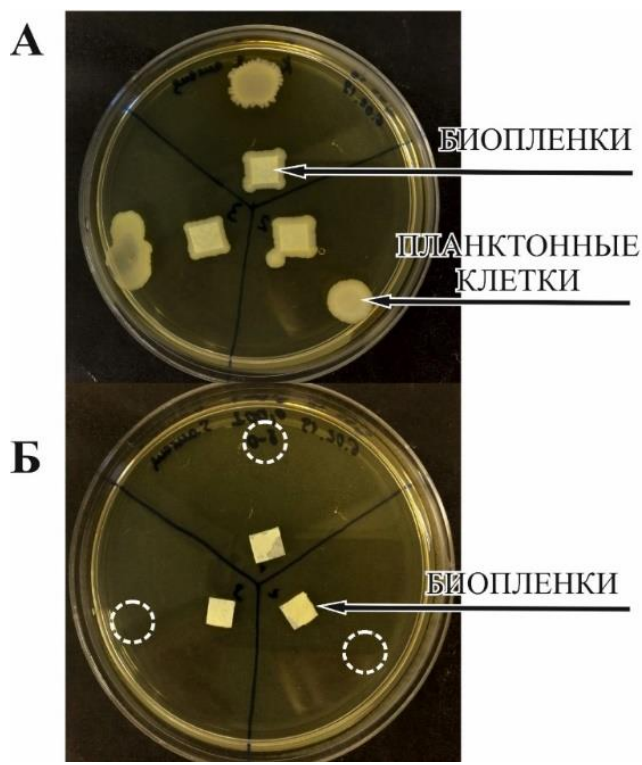

Рис. 165. Оценка методом аппликаторов и микрокапель роста $S$. aureus на питательной среде, содержащей различные концентрации дезсредства на основе четвертичных аммониевых соединений (ЧАС) в микрокаплях (планктонные клетки) и на аппликаторах (биоплёнки) 
14. Проведено электрофоретипирование по спектрам внеклеточных белков и изучена антибиотикорезистентность штаммов коагулазонегативных стафилококков (КОС), изолированных от больных и с объектов окружающей среды детского стационара. Установлено, что в детском стационаре более интенсивное распространение имеют культуры Staphylococcus haemolyticus, чем S. epidermidis. Полученные данные ставят задачу постоянного мониторинга циркуляции в стационарах S. epidermidis и S. haemolyticus как возможных возбудителей ИСМП.

15. Изучены фенотипические свойства 100 штаммов бактерий группы ESKAPE (Enterococcus faecium, Staphylococcus aureus, Klebsiella pneumoniae, Acinetobacter baumannii, Pseudomonas aeruginosa, Enterobacter) наиболее опасных в плане развития ИСМП, выделенных в медицинских учреждениях Санкт-Петербурга. Наибольшей устойчивостью к АМП характеризуются штаммы Klebsiella spp.

16. Показано усиление патогенности микроорганизмов, вызывающих ИСМП и ОКИ, при их ассоциациях в опытах in vivo, in vitro и при ведении пациентов на примере изучения способности к биоплёнкообразованию и антибиотикорезистентности.

Определено, что биоплёнкообразование представителей микробиоты толстой кишки человека связано с выраженностью их патогенности и повышением устойчивости к АМП и дезинфицирующим средствам. Установлено, что биоплёнкообразование бактерий снижается при использовании препарата лактоглобулина при лечении ОКИ в эксперименте на лабораторных животных, что определяет перспективу использования данного препарата в терапии и профилактике ИСМП и ОКИ. Отработаны режимы получения препарата лактоглобулина против условно-патогенных бактерий и сальмонелл.

17. Предложен вариант использования данных масс-спектрометрического анализа микроорганизмов MALDI-ToF с применением дополнительно программного обеспечения MALDI Quant и среды R для определения маркёров антибиотикорезистентности.

\section{Научно-методическое обеспечение эпидемиологического надзора за энтеровируснымии инфекциями}

18. Доказано, что все территории Санкт-Петербургского регионального центра по эпидемиологическому надзору за полиомиелитом в 2016-2020 гг. сохранили свободный от полиомиелита статус.

Установлены нарастание разнообразия доминирующих в циркуляции в Северозападном федеральном округе серотипов энтеровирусов (ЭВ) ЕCHO $, \mathrm{ECHO}_{18}, \mathrm{ECHO}_{25}$, $\mathrm{ECHO}_{30}$, Коксаки B4, B5, Коксаки A6, А9 и корреляция между выделением ЭВ ЕСНО, $\mathrm{ECHO}_{30}$, Коксаки В1-6 от больных энтеровирусной инфекцией (ЭВИ) и из объектов окружающей среды, что подтверждает их широкую циркуляцию среди населения.

Установлено родство российских штаммов ЭВ с изолятами, выделенными в разных странах; зарегистрирована смена в 2017-2019 гг. доминировавших генотипов ЭВ

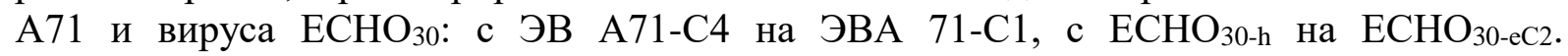
Зафиксировано увеличение типового и генетического разнообразия ЭВ в России в период интенсивной миграции населения в 2018-2019 гг. Получены данные, свидетельствующие о множественных заносах эпидемических вариантов ЭВ на территорию страны из разных географических зон. Отмечено снижение активности циркуляции ЭВ и заболеваемости ЭВИ на фоне ограничительных мероприятий в период пандемии новой коронавирусной инфекции.

Разработан набор синтетических олигонуклеотидных праймеров для получения нуклеотидной последовательности гена $\mathrm{VP}_{1}$ ЭВ Коксаки А10, что может быть использовано в молекулярно-эпидемиологических исследованиях ЭВИ. 


\section{Научно-методическое обеспечение профилактики инфекций желудочно-кишечного тракта}

19. Установлено, что спектр генотипов ротавирусов группы А с превалированием генотипа G9P[8] не претерпел существенных изменений. Превалировавший в период 2012-2016 гг. генотип G4P[8] характеризуется самой низкой частотой выявления. Данные молекулярного типирования позволяют прогнозировать эффективность использования ротавтрусных вакцин и совершенствовать программы вакцинопрофилактики.

Установлено превалирование генотипа GII.2GII.P16 норовирусов, что свидетельствует о стабильности популяции возбудителя и эпидемиологической ситуации по норовирусной инфекции.

20. Установлена структура и сероварный пейзаж возбудителей сальмонеллёзов на территории России в период 2015-2020 гг. Доминируют серотипы S. enteritidis $(64,7$ \%), S. typhimurium $(4,8 \%)$, S. infantis (3,2\%). S. infantis наиболее широко представлены в мясе кур, S. kentucky - в мясе индеек, S. typhimurium - в объектах внешней среды и свинине. Штаммы серовара S. enteritidis, характеризуются устойчивостью к ципрофлоксацину (39,6 \%). МЛУ у $S$. enteritidis обнаружена реже $(0,8 \%)$, чем у $S$. infantis $(6,3 \%)$ и S. typhimurium (6,5\%). Данные об ассоциации сальмонелл с различными источниками и оценка их чувствительности к АМП позволяют достичь точных представлений об отраслях животноводства, в которых наблюдается формирование резистентности к АМП.

Более 60 \% штаммов Salmonella, выделенных в России, устойчивы к АМП. Отмечен рост резистентности в 10 раз к хинолонам и цефалоспоринам расширенного спектра, используемым для лечения сальмонеллёзов.

21. Брюшной тиф в России обусловлен штаммами Salmonella typhi международного клона высокого риска - субклады 4.3.1 (гаплотипа Н58), резистентного к хинолонам, препаратам выбора для лечения брюшного тифа, что отражает тенденции развития устойчивости в эндемичных странах Юго-Восточной Азии.

Выявлены штаммы международных полирезистентных клонов высокого риска пандемического распространения, имеющие глобальное распространение в мире: Salmonella kentucky ST198, Salmonella newport AmpC-MDR/CMY-2, Salmonella typhi субклады 4.3.1 (гаплотипа H58), Escherichia coli $\mathrm{O}_{26}: \mathrm{H}_{11} \mathrm{ST} 21$, E. coli $\mathrm{O}_{25}: \mathrm{H}_{4}-\mathrm{B} 2-\mathrm{ST} 131$.

22. Впервые в России выявлены штаммы S. enteritidis и S. bovismorbificans, несущие на IncX4 и IncI2 конъюгативных плазмидах гены $m c r-1.1$ резистентности к колистину. Продолжено широкомасштабное секвенирование изолятов S. enteritidis и анализ структуры популяции в целях расшифровки случаев групповой заболеваемости сальмонеллёзом и определением связей между очагами при выявлении скрытой вспышечной заболеваемости.

23. Генотипически охарактеризованы штаммы Yersinia pseudotuberculosis по наличию факторов патогенности, обусловливающих многообразие клинических форм псевдотуберкулёза. Выявлено отличие российских и зарубежных штаммов. Большинство российских штаммов (82 \%) обладает хромосомным геном суперантигена, не содержит генов «острова высокой патогенности» HPI, относится к геногруппе G3 $\left(\mathrm{HPI}^{-} \mathrm{YPM}^{+}\right)$, вызывают псевдотуберкулёз с симптомами дальневосточной скарлатиноподобной лихорадки, которая характеризуется наиболее полным проявлением псевдотуберкулёза. Выявлены штаммы геногруппы G2, характерные для зарубежных территорий, не вызывающие проявлений ДСЛ, у которых отсутствует ген суперантигена, но содержатся гены «острова высокой патогенности» $\mathrm{HPI}\left(\mathrm{HPI}^{+} \mathrm{YPM}^{-}\right)$, вызывающие заболевание с симптомами гастроэнтерита, лихорадкой, мезентериальным лимфаденитом, симптомами острого аппендицита, что обосновывает необходимость 
обследования на псевдотуберкулёз больных с проявлениями ОКИ неустановленной этиологии и пациентов хирургического стационара с диагнозом «острый аппендицит».

24. Выделен новый вариант гибридного EAHЕC штамма серотипа $\mathrm{O}_{181}: \mathrm{H}_{4}$ диареегенной Escherichia coli, генетически родственного штаммам EAHEC $\mathrm{O}_{104}: \mathrm{H}_{4}$, выделенными в Германии и Грузии, и ЕAgЕС О $181: \mathrm{H}_{4}$, выделенным в Англии.

25. Впервые у штамма Salmonella enterica серотипа Enteritidis, устойчивого к ампициллину, амоксициллину/клавуланату, ципрофлоксацину, выделенному от пациентов с ОКИ и из пищевых продуктов, идентифицирован ген $\beta$-лактамазы $b l a$ тЕм-32.

26. Получены лабораторные образцы высокоочищенных препаратов бактериоцинов: энтероцина Е28 из штамма Enterococcus faecalis E28 и паеницина из штамма Paenibacillus polymyxa B-112.

27. Выявлена корреляция между статусом $\operatorname{cag} A^{+}$(цитотоксичний антиген) и аллельным вариантом $s 1$ гена vacA H. pylori. Показана взаимосвязь между клиническими формами $H$. pylori-инфекции и cagA-статусом штаммов H. pylori генотипа vacAsl.

Установлено, что среди $H$. pylori штаммов $30 \%$ резистентны к кларитромицину, 23,3 \% - к левофлоксацину, 4,5 \% - к амоксициллину, 0,8 \% - к тетрациклину. Выявлены точечные мутации гена 23S rRNA, мутация T2244C обнаружена у всех резистентных к кларитромицину штаммов H.pylori. Резистентность H.pylori к кларитромицину и левофлоксацину свидетельствует о необходимости тестирования их чувствительности перед назначением схемы эрадикации.

Предложен способ первичного анализа географического происхождения российских штаммов H.pylori методом INDEL-типирования. В России впервые выявлены штаммы популяций hspEAsia и hspWAfrica, ранее обнаружены только штаммы hpEurope.

\section{Научно-методическое обеспечение эпидемиологического надзора за социально значимыми инфекциями}

28. ВИЧ-инфекция. Оценено влияние ВИЧ-инфекции на смертность трудоспособного населения и детей, исследованы эпидемиологические связи между распространением ВИЧ и эпидемией коронавирусной инфекции.

ВИЧ-инфекция стала одной из основных причин преждевременной смертности молодежи, в том числе женщин детородного возраста. Все показатели, характеризующие смертность детей раннего возраста, рождённых ВИЧ-позитивными женщинами, выше общепопуляционных, что связано с большим числом новых случаев заражения ВИЧ и недостатками организации медицинской помощи ВИЧ-позитивному населению, ведущим к неполному охвату диспансерным наблюдением и лечением. Снижение выявления новых случаев ВИЧ-инфекции связано с сокращением объёма обследований на ВИЧ и снижением обращаемости пациентов в центры по профилактике и борьбе со СПИД в период осуществления противоэпидемических мероприятий по коронавирусной инфекции COVID-19. Актуально тестирование на ВИЧ и диспансерное наблюдение за ключевыми уязвимыми группами. Установлено, что увеличение количества обследований населения на антитела к ВИЧ автоматически не ведёт к увеличению выявляемости источников ВИЧ.

Лица, инфицированные ВИЧ, являющиеся источниками ВИЧ-инфекции, не получающие медицинской помощи или получающие её в недостаточном объёме, ведут к распространению резистентных к лечению форм ВИЧ и представляют угрозу дальнейшего распространения инфекции. Фактором, осложняющим эпидемиологическую ситуацию по ВИЧ-инфекции, стала пандемия COVID-19. ВИЧпозитивные лица больше подвержены инфицированию COVID-19, но реже обращаются за медицинской помощью. 
Создана национальная база данных и разработано программное обеспечение, позволяющее в автоматическом режиме анализировать лекарственную устойчивость изолятов ВИЧ, осуществлять мониторинг её распространения, разрабатывать стратегии повышения эффективности лечения ВИЧ-инфекции (рис. 166).

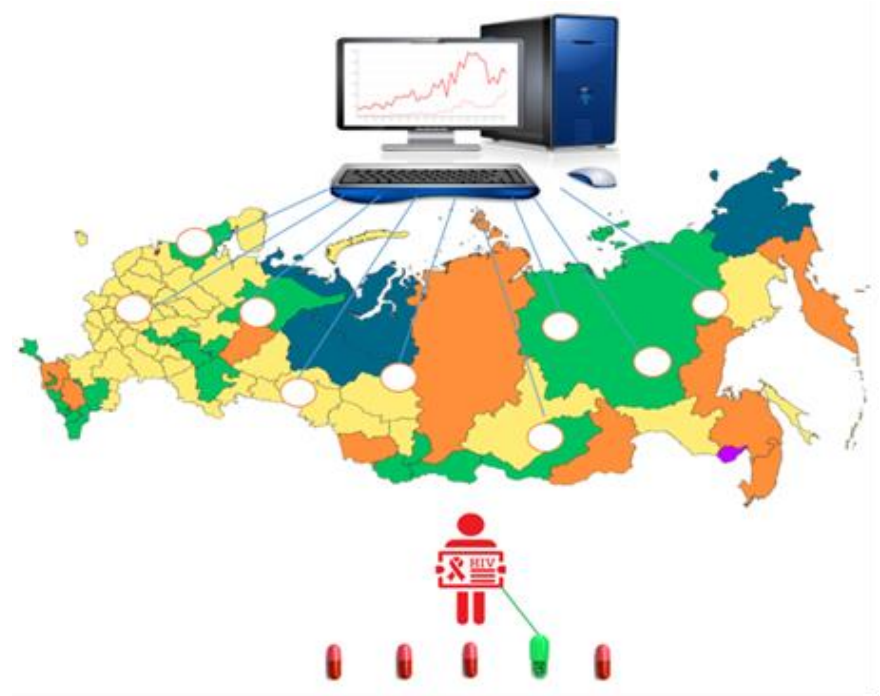

Рис. 166. Национальная база данных устойчивости ВИЧ к антиретровирусным препаратам

На территории Приволжского федерального округа увеличивается встречаемость штаммов ВИЧ с множественной лекарственной устойчивостью к нуклеозидным и ненуклеозидным ингибиторам обратной транскриптазы (НИОТ, ННИОТ), ингибиторам протеазы (ИП), что свидетельствует о неблагоприятном развитии эпидемического процесса ВИЧ-инфекции. Распространены мутации, обусловливающие лекарственную устойчивость: M184V - к НИОТ; G190S - к ННИОТ; M46I - к ИП ВИЧ. В популяции генетических вариантов ВИЧ, циркулирующих в ПФО, доминирует подтип А (A6) $95,8 \%$.

Выявлены закономерности распространения в Сибирском федеральном округе субтипов и мутаций резистентности ВИЧ среди пациентов групп риска, получающих AРВТ, обоснованы алгоритмы молекулярно-генетического мониторинга ВИЧ.

Установлена устойчивая циркуляция новых рекомбинантных форм ВИЧ (В, CRF03_AB, CRF01_AE, CRF02_AG) на юге России, выделены штаммы, резистентные к АРВП, в том числе штаммы с мутацией первичной резистентности ВИЧ-1 у недавно инфицированных пациентов, не получавших ранее АРВТ.

Определены частоты однонуклеотидных полиморфных вариантов генов CCR5del32 и CCR2 у жителей Санкт-Петербурга методом пиросеквенирования для оценки предрасположенности к ВИЧ-инфекции и прогнозирования динамики развития СПИД у ВИЧ-инфицированных.

29. Туберкулёз. Установлено, что популяция Mycobacterium tuberculosis представлена штаммами глобально распространённых генетических групп: Т (14,5\%), LAM (12,2 \%), Ural (6,9\%), Haarlem (3,8 \%), доминирующей Beijing (56,5\%); 50 \% штаммов резистентны к АМП, МЛУ выявлена у трети штаммов.

Впервые в России проведено полногеномное секвенирование ДНК 2 клинических изолятов Mусobacterium avium subsp. hominissuis (MAH), выделенных от больных микобактериозом лёгких, обнаружено 64 мутации со сдвигом рамки считывания, свидетельствующие о высокой изменчивости генома клинических изолятов МАН.

Проведены международные сравнительные испытания по выявлению и идентификации возбудителя туберкулёза и определению атибиотикорезистентности 
панелей микроорганизмов; проведён международный контроль качества работы всех противотуберкулёзных учреждений России с использованием полученных из международного центра в Антверпене (Бельгия) тест-панелей микроорганизмов.

30. Папилломавирусная инфекция. Изучена распространённость генотипов вируса папилломы человека высокого канцерогенного риска (ВПЧ ВКР) и цитомегаловируса в Нижегородском регионе, что позволило оценить целесообразность применения разработанных за рубежом вакцин.

Для ВИЧ-инфицированных пациентов рекомендовано внедрение алгоритмов скрининга предраковых заболеваний, поскольку у них увеличен риск персистенции ВПЧ ВКР, что ухудшает прогноз и способствует развитию онкологических заболеваний.

\section{Научно-методическое обеспечение эпидемиологического надзора за природно-очаговыми, зооантропонозными, особо опасными инфекциями. Санитарная охрана территории}

31. Разработаны документы о сотрудничестве по предупреждению и реагированию на чрезвычайные ситуации санитарно-эпидемиологического характера; о базовой организации государств СНГ по мониторингу, оперативному оповещению и совместному реагированию на чрезвычайные ситуации санитарно-эпидемиологического характера.

32. Доработана автоматизированная информационная система оценки рисков, связанных с завозом опасных инфекционных болезней и санитарного контроля пассажиров в пунктах пропуска через государственную границу России (АИС СКП).

33. Разработан геоинформационный программный комплекс «Электронный эпидемиологический атлас Российской Федерации. Территория федерального округа», позволяющий создать базу данных по России. Сформированы 15 баз данных по Приволжскому федеральному округу. Проведён анализ инфекционной заболеваемости населения ПФО за 2019 г. Проведён картографический учёт в геоинформационной системе инфицированных COVID-19 лиц по месту жительства в оперативном режиме.

34. Инфекции, передающиеся клещами. Представлен прогноз заболеваемости на 2021 г. и значений 95\%-го доверительного интервала возможных колебаний показателя заболеваемости с учётом наличия или отсутствия трендов её изменения на территории федеральных округов и субъектов России в 2011-2020 гг. Показано, что риск заболеваемости клещевым вирусным энцефалитом (КВЭ) наиболее высок для населения, проживающего в приграничных субъектах на юге Сибири, меньше - на Южном Урале и на северо-западе европейской части страны.

С целью совершенствования эпидемиологического надзора и профилактики клещевых трансмиссивных инфекций (КТИ) разработан комплексный рискориентированный подход, включающий мониторинг паразитарных систем, слежение за интенсивностью эпидпроцесса, прогнозирование неблагоприятных тенденций, оптимизацию мер профилактики с учётом различной степени риска заражения населения.

Дифференцированы очаговые территории России с выделением зон низкого, среднего, выше среднего, высокого, очень высокого риска заражения населения. Разработаны рекомендации по проведению эпидемиологических наблюдений для дифференцированной оценки защитной способности лекарственных средств, противоэпидемической эффективности, экономической результативности различных стратегий их применения для профилактики КТИ. Конкретизированы подходы к определению показаний к превентивной постконтактной терапии пациентов с учётом индивидуального риска инфицирования возбудителями КТИ по данным современных методов микроанализа. 
Разработан интегральный подход, основанный на выявлении тенденций динамики относительной инцидентности клещевых риккетсиозов (КР) - сибирского клещевого тифа, астраханской пятнистой лихорадкой, средиземноморской лихорадки при оценке 10-летней динамики и прогнозирования численности мелких млекопитающих и иксодовых клещей, что способствует объективному составлению общего прогноза заболеваемости КР на эндемичных территориях России. Оценено состояние лабораторной диагностики официально регистрируемых КР, рекомендован алгоритм применения зарегистрированных тест-систем для серологической и молекулярно-биологической диагностики КР. Разработан комплекс мероприятий по профилактике КР, включающий мероприятия неспецифической профилактики и экстренной антибиотикопрофилактики.

Для повышения эффективности лабораторной диагностики риккетсиозов группы клещевой пятнистой лихорадки (КПЛ) показана диагностическая значимость выявления антител IgA к группоспецифическому антигену риккетсий группы КПЛ, позволяющая снизить число неподтверждённых лабораторно риккетсиозов группы КПЛ. Определение авидности антител класса IgG полезно для дифференцировки диагностических и анамнестических антител, что важно на эндемичных территориях.

Установлено единовременное сосуществование нескольких патогенов (бактерий, простейших, вирусов, в том числе патогенных для человека Borrelia miyamotoi, B. burdorferi s.l., Babesia microti, вируса клещевого энцефалита) в организме теплокровных - прокормителей иксодовых клещей. Показана возможность длительной (в случае отдельных видов возбудителей КТИ - пожизненной) персистенции в организме представителей отряда грызунов, в том числе при микст-инфицировании несколькими близкородственными или неродственными возбудителями. В отношении возбудителей иксодовых клещевых боррелиозов (ИКБ) продемонстрированы независимая циркуляция в условиях микст-инфицирования, без взаимного влияния на уровни бактериемии. Установлена возможная роль луговых клещей Dermacentor reticulatus в циркуляции боррелий различных геновидов в природных очагах на территории России.

Разработана ПЦР тест-система в формате реального времени для выявления Coxiella burnetii в биологическом материале, которая выпускается и внедрена в практику. Впервые в России разработана нормативная документация для производства и использования ИФА тест-системы для выявления IgG-антител к C. burnetii.

36. Инфекции, передающиеся комарами. Проведено ОТ-ПЦР генотипирование РНК вируса Западного Нила (ВЗН), выделенного в Астраханской, Волгоградской, Ростовской областях, Республике Калмыкия в 2020 году. Установлена циркуляция 2 и 4 генотипов ВЗН, ряд однонуклеотидных полиморфизмов (SNP), характерных для штаммов ВЗН волгоградской клады. Филогенетический анализ штаммов свидетельствует в пользу правомерности гипотезы о том, что циркуляция ВЗН генетической линии 2 на эндемичных по лихорадке Западного Нила территориях юга Европейской части России поддерживается за счёт местной популяции вируса, существующей продолжительное время.

37. Особо опасные инфекции и зооантропонозные инфекции. Чума. Разработаны и внедрены в практику прогнозы эпизоотической активности природных очагов чумы на территории России на 2020 г.

Предложен рациональный вариант приведения внутривидовой классификации Yersinia pestis в соответствие с правилами Международного кодекса номенклатуры бактерий и эволюционной таксономии, на основе данных молекулярно-генетического анализа, эпидемиологической значимости, географического распространения.

Определены коммерческие иммуномодуляторы для направленной модуляции специфического противочумного иммунного ответа у людей. Сконструированы 
оригинальные продуценты иммуногенных химерных белков, перспективных для включения в состав кандидатных химических вакцин для профилактики чумы. Получены новые данные о формировании и роли нейтрофильных ловушек, осуществляющих захват патогенных микроорганизмов, в иммуно- и патогенезе чумы. Исследовано влияние иммуномодуляторов на вакцинный штамм $Y$. pestis EV НИИЭГ с целью повышения его иммуногенных свойств и предложен эффективный способ повышения иммуногенности вакцины чумной живой.

Для совершенствования оценки иммунитета у лиц, привитых вакциной чумной живой, предложен высокопроизводительный и эффективный экспресс-метод определения фагоцитарной активности лейкоцитов крови по отношению к инактивированным клеткам $Y$. pestis in vitro в образцах периферической крови методом проточной цитометрии.

Разработана технология получения «бактериальных теней» (клеточных стенок) Y.pestis, показана перспективность их включения в состав чумных вакцин в качестве компонента, расширяющего спектр эффективно иммунизируемых лиц (рис. 167).
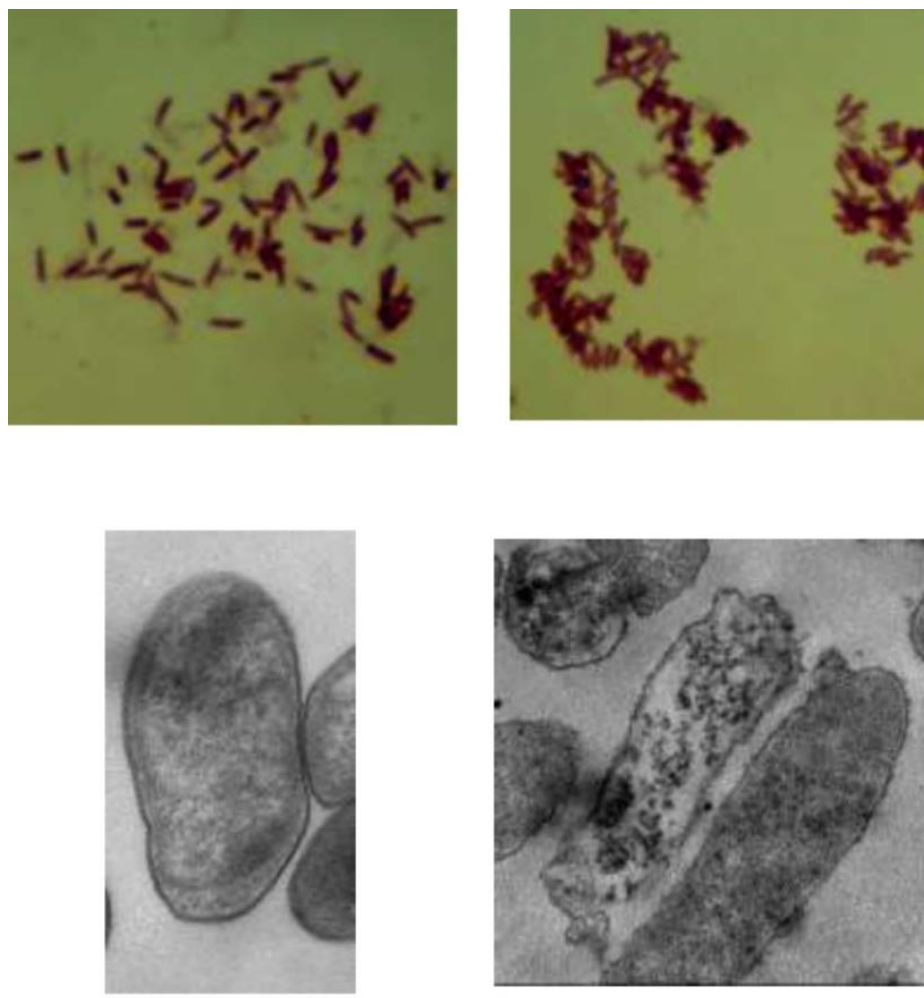

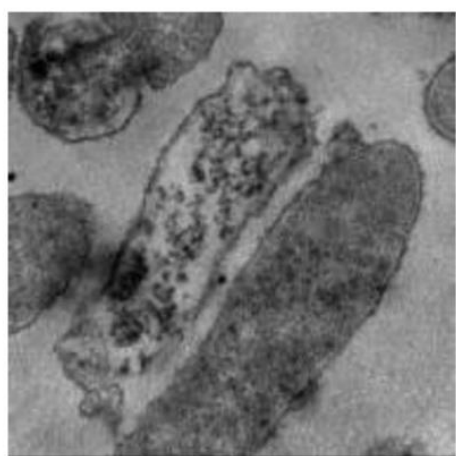

Бактериальные тени

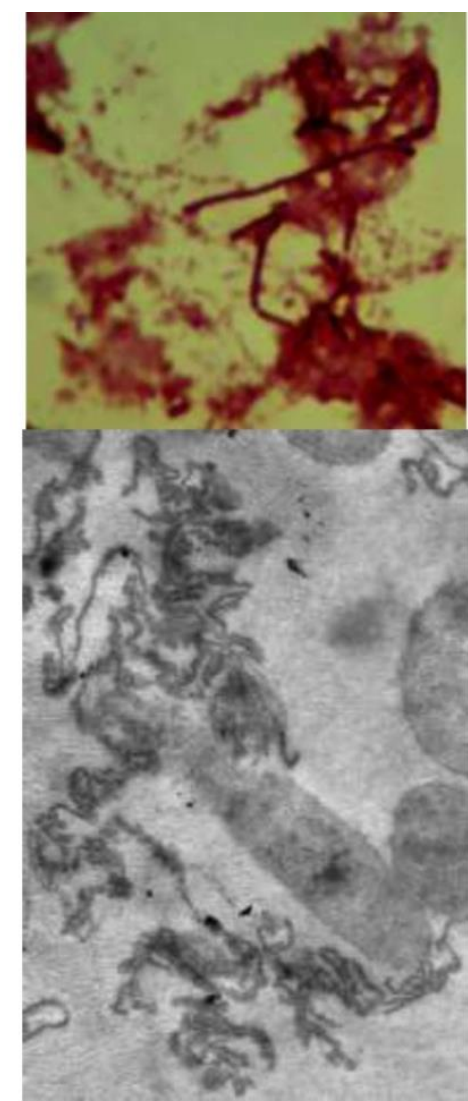

Бактериальные лоскутки

Интактные бактерии

Рис. 167. Интактные бактерии, «бактериальные тени», «бактериальные лоскутки»

Сконструирован набор аттенуированных мутантов $Y$. pestis-продуцентов везикул внешних мембран - перспективных самоадъювантных полиантигенных компонентов чумных вакцин.

38. Сибирская язва. Сформировано современное представление о генетическом разнообразии штаммов Bacillus anthracis, циркулирующих в Сибири, на Дальнем Востоке, в Республике Дагестан, на основе данных полногеномного анализа. Установлена филогенетическая связь изолятов B. anthracis, выделенных в Республике Дагестан, со штаммами, изолированными в Западной Сибири, позволяющая предположить существование в прошлом общего предка; разработана методика 
многофакторного анализа, проведено ранжирование территорий СКФО, ЮФО, УФО по степени риска осложнения эпизоотолого-эпидемиологической ситуации по сибирской язве.

Разработан прототип мультиплексной ОТ-ПЦР для индикации B. anthracis (в том числе бесплазмидных штаммов) и дифференциации её от близкородственных бацилл.

Получены два штамма E. coli - продуцента иммуногенных сибиреязвенных белков PA-63 и LF1-PA4. Показано, что двукратная иммунизация этими белками защищает морских свинок и золотистых хомячков от гибели при заражении вирулентным штаммом B. anthracis.

Получен генноинженерный вариант токсиногенного капсулообразующего аттенуированного штамма $B$. anthracis PasteurII, несущий плазмиду с геном pNCMO2 и геном BCSP31. Штамм характеризуется сниженной вирулентностью, гиперпродукцией внеклеточного белка (17-70 кДа) и перспективен в качестве живой вакцины или как продуцент вакцинного препарата. Получено химерное моноклональное антитело (МКА) xi1E10, способное нейтрализовать летальный токсин $B$. anthracis, что подтверждено в экспериментах in vitro и in vivo, перспективное для разработки препарата, способного нейтрализовать сибиреязвенный токсин.

39. Холера. Получены новые данные об эпидемической значимости биоплёнкообразования Vibrio cholerae, влиянии экологических факторов на адаптацию токсигенных и нетоксигенных $V$. cholerae, их способности персистировать в виде монои мультивидовых биоплёнок на биотических поверхностях при конкурентных взаимоотношениях с аутохтонной микрофлорой. В сложной биоплёнке V. cholerae преодолевают межродовой, межвидовой антагонизм аутохтонной микрофлоры, продуцируют специфические жирные кислоты, сохраняют фенотипические свойства. На эпидемическую значимость биоплёнкообразования указывает сохранение патогенных свойств V. cholerae в 30-суточных биоплёнках, широкого спектра ферментативной активности, устойчивости к фагоцитозу простейшими. Данные о нарастании антибиотикорезистентности V.cholerae в биоплёнках будут востребованы при совершенствовании тактики профилактики и лечения холеры.

Разработана схема полногеномного сиквенс-типирования (cgMLST) V. cholerae на основе анализа корового генома, позволяющая проводить оценку филогенетических взаимоотношений разных групп штаммов V. cholerae и идентифицировать специфичные для каждой группы геномные маркёры для коррекции тактики и объёма профилактических и противоэпидемических мероприятий. Своевременно проведённый комплекс мероприятий в случае обнаружения штаммов группы USGulf-подобной филогенетической линии позволит предотвратить дальнейшее распространение клона на территории и снизить риски инфицирования населения.

40. Туляремия. Обобщены и систематизированы данные о передаче Francisella tularensis комарами. Показано, что в условиях разлитых эпизоотий существует вероятность трансмиссивной передачи $F$. tularensis кровососущими комарами и развития вспышек туляремии, что требует усиления предупредительных мероприятий.

Впервые в мире получена информация о полногеномной нуклеотидной последовательности представителя новой филогенетической группы штаммов в составе Francisella tularensis subsp. mediasiatica, выделенных на территории Алтайского края, занимающих промежуточное положение по вирулентности между subspp. tularensis и holarctica.

Разработана ИФА тест-система на основе МКА и иммуномагнитных частиц для детекции $F$. tularensis, обеспечивающая высокую специфичность выявления $F$. tularensis в образцах и стандартность основных её компонентов, простая в применении и не требующая дорогостоящего оборудования. 
Разработан способ получения аттенуированных штаммов F. tularensis без дополнительных генов антибиотикоустойчивости, синтезирующих гетерогенные протективные антигены, для создания перспективных рекомбинантных вакцин для защиты организма человека и животных от возбудителей внутриклеточных инфекций.

Адаптирован метод 2D-электрофореза для двухмерного разделения мембранных белков клеточных стенок $F$. tularensis разных подвидов в изоэлектрическом поле с целью идентификации протективных и специфических антигенов, которые могут быть использованы при конструировании диагностических и профилактических препаратов.

41. Бешенство. Впервые с помощью ГИС-технологий выполнен картографический анализ зон распространения бешенства в России и представлен в виде теплокарты. Риск заражения бешенством сохраняется почти во всех регионах России, наряду с неблагоприятной эпизоотической обстановкой по бешенству в сопредельных странах.

Получены новые данные о генетическом разнообразии вируса бешенства, о распространении «степного» бешенства в направлении запад - восток, возникновении эпизоотий на территории Восточной Сибири и Дальнего Востока. Высказано предположение, что в Республике Бурятия в степях формируется очаг лисьего бешенства.

Определено распространение групп вируса бешенства (по особенностям гена $N$ ) на территории Сибири. В группу 1 вошли изоляты, выделенные на территориях Монголии, Китая и пограничных регионов России (Республика Тыва, Республика Бурятия, Забайкальский край). Группа 2 представлена изолятами из Минусинской котловины, расположенной в пределах Красноярского края и Республики Хакасия. Группа 3 представлена изолятами, выделенными на территориях Казахстана, Омской области и Назаровской котловины, расположенной в западной части Красноярского края.

Показано, что вероятным путём заноса вируса бешенства в Бурятию, в Республику Хакасия, в южную часть Красноярского края является его проникновение с территории Монголии.

42. Мелиоидоз. Изучены ландшафтно-географические особенности распространения мелиоидоза во Вьетнаме, территория которого эндемична по данной инфекции. Установлена генетическая гетерогенность Burkholderia pseudomallei внутри одного и между разными регионами страны, показан высокий уровень внутривидового полиморфизма консервативных генов, входящих в стандартную схему мультилокусного сиквенс-типирования (MLST) B.pseudomallei. Выявлено 8 новых сиквенс-типов B.pseudomallei, ранее не представленных в международной базе данных PubMLST. Обнаружены атипичные штаммы B. pseudomallei с изменёнными фенотипическими признаками, имеющими диагностическое значение.

Впервые выделены из внешней среды во Вьетнаме патогенные для человека и животных вариантные штаммы B.thailandensis, экспрессирующие B.pseudomalleiподобный капсульный полисахарид и относящиеся к отдельной филогенетической кладе.

Разработана, испытана, подтверждена высокая эффективность новой мультиплексной тест-системы для идентификации и дифференциации Burkholderia pseudomalle, B. mallei, B. thailandensis, обнаруженных во Вьетнаме.

43. Геморрагическая лихорадка с почечным синдромом (ГЛПС). Установлено, что в природных очагах ГЛПС Республики Башкортостан и Челябинской области циркулирует вирус Puumala. Впервые проведены исследования по идентификации рекомбинантных и реассортантных геномов ортохантавируса Puиmala у больных ГЛПС и переносчиков хантавирусной инфекции в Республике Татарстан. Проанализированы 
участки S, M, L сегментов генома штаммов Puumala orthohantavirus, циркулирующих в ряде популяций рыжей полёвки на территории Предкамья в Республике Татарстан. Установлено, что все штаммы принадлежат к российской генетической линии, однако генетическое расстояние между линиями не коррелирует напрямую с географическим расстоянием между популяциями рыжей полевки. Выявленная картина распространённости штаммов вируса Puumala PUUV является следствием ряда последовательных разнонаправленных миграционных потоков рыжей полёвки на территорию Предкамья.

Разработана экспериментальная тест-система для оценки индивидуальной генетической предрасположенности и для прогнозирования тяжести ГЛПС у больного.

44. Бруцеллёз. Лептоспироз. Лихорадка Ку. При обследовании работников предприятий мясной промышленности г. Омска и Омской области выявлены лица, серопозитивные к бруцеллам и коксиеллам Бернета (возбудителю Ку-лихорадки), что свидетельствует о реализации профессионального риска заражения и является основанием для проведения эпидемиологического расследования в отношении этих инфекций на предприятии.

У пациентов с хроническим бруцеллёзом регистрируются противоорганные аутоантитела в повышенном титре, что позволяет судить о полиорганности поражений. Выявлено, что величина антиген-индуцированной продукции интерферона $\gamma$ может использоваться как показатель напряжённости специфического клеточного иммунного ответа в группах невакцинированных и вакцинированных ранее от бруцеллёза лиц.

Сконструирован набор реагентов для выявления возбудителей лептоспироза в биологическом материале методом ПЦР-РВ.

\section{Научно-методическое обеспечение диагностики инфекционных болезней Регистрация иммунобиологических препаратов для диагностики инфекционных болезней}

45. Разработаны и зарегистрированы:

наборы ПЦР реагентов с гибридизационно-флуоресцентной детекцией результатов для индикации коронавирусов, вызывающих тяжёлые инфекции дыхательных путей (SARS, MERS, COVID-19); набор для количественного определения PHK SARS-CoV-2. В регионы России и страны СНГ поставлены реагенты для проведения более 14 млн исследований;

тест-система для диагностики COVID-19 на основе петлевой изотермической амплификации для выявления мутации коронавируса N501Y («британского» штамма SARS-CoV-2), что позволяет сократить время исследования в 3-4 раза;

наборы реагентов для детекции PHK SARS-CoV-2 методом ПЦР и одновременной детекции PHK SARS и SARS-CoV-2 методом одностадийной ПЦР с гибридизационнофлуоресцентной детекцией результатов; наборы реагентов для ИФА выявления иммуноглобулинов класса G к SARS-CoV-2 и к белкам SARS-CoV-2;

иммунохроматографический (ИХ) экспресс-тест на антитела к возбудителю (изготовлено 125 тыс. тестов); набор ИФА для выявления антител к возбудителю COVID-19 (изготовлено 67 тыс. тестов);

набор реагентов для идентификации методом мультилокусной аллельспецифической ПЦР с гибридизационно-флуоресцентной детекцией Vibrio cholerae и $V$. parahaemolyticus на основе детекции генов seqY, hlyA, vppC, что позволяет дифференцировать $V$. cholerae и V.parahaemolyticus, выделенные из клинических образцов путём культивирования; 
девять наборов реагентов для молекулярной диагностики острых кишечных инфекций, риккетсиозов, особо опасных инфекций, урогенитальных инфекций, для определения генетических полиформизмов при соматических заболеваниях;

питательная среда для культур клеток бессывороточная жидкая «ВекторВак-ПС2»; питательная среда для бактериологических исследований колумбийский агар сухой и дифференциально-элективная питательная среда для выделения клебсиелл сухая;

плотная питательная среда аргинин-железо-сахарозный агар для дифференцирования $V$. cholerae от других микроорганизмов, готовая к использованию после переплавки.

46. Иммунобиологические препараты на различных стадиях испьтаний. Подготовлен комплект документов для проведения технических испытаний набора реагентов для генотипирования штаммов Burkholderia mallei методом амплификации дифференцирующих регионов генома (DFR) методом ПЦР с флуоресцентной детекцией.

Разработана нормативная документация на производство и применение питательной среды для определения лизиндекарбоксилазы (среда с лизином) и питательной среды для контроля стерильности (Тиогликолевая среда с резазурином).

Наработаны и паспортизированы экспериментальные серии набора реагентов для проведения ПЦР-ОТ с гибридизационно-флуоресцентной детекцией для выявления и дифференциации генотипов 1/2/4 вируса Западного Нила, подготовлена техническая и эксплуатационная документация, контрольная панель стандартных образцов предприятия.

Утверждена документация для производства диагностического фаг-тест-набора «ЭК-О 157 », для быстрой идентификации E. coli серогруппы $\mathrm{O}_{157}$, выделенных из биологического материала, продуктов питания, объектов окружающей среды.

Проведены контрольные испытания диагностикума эритроцитарного сапного и мелиоидозного антигенного сухого и диагностикума эритроцитарного гистоплазмозного и кокцидиоидомикозного антигенного сухого.

Утверждён пакет научно-технической документации на производство и применение набора реагентов жидкого для быстрой идентификации Clostridium difficile в реакции латекс-агглютинации.

47. Разработка препаратов для диагностики инфекиий. Разработаны: метод определения полных последовательностей геномов SARS-CoV-2; способ определения количества генетических вариантов вируса в биологическом образце; программный продукт для обработки данных секвенирования, определения генотипов SARS-CoV-2 и количества генетических вариантов вируса в биологическом образце; праймерная панель; методика амплификации и определения последовательности геномов SARSCoV-2 с помощью высокопроизводительного секвенирования (Illumina).

Разработана технология использования элементов генетического редактирования системы CRISPR/Cas для получения диагностических препаратов нового поколения.

Созданы продуценты и реакторная масштабируемая технология наработки рекомбинантного нуклеокапсидного протеина SARS CoV-2 в граммовых количествах.

Разработана ПЦР-РТ тест-система для детекции генов антибиотикорезистентности грамотрицательных бактерий и оценки возможностей этих бактерий проявлять резистентность на фенотипическом уровне. Рекомендована к использованию при расследовании вспышек ИСМП и изучении эпидемиологических и генетических свойств штаммов-возбудителей, выделяемых из окружающей среды и клинического материала.

48. Сконструирован набор ПЦР реагентов для внутривидового типирования Legionella pneumophila. Разработан способ внутривидовой дифференциации Yersinia pseudotuberculosis с помощью молекулярно-генетических методов. 
Для внешнего контроля качества исследований по холере подобрана коллекция вибрионов основных циркулирующих генотипов. Подобраны панель V. Cholera, устойчивых к АМП, и коллекция штаммов рода Vibrio для определения диагностически значимых масс-спектров патогенных вибрионов.

Разработаны набор ПЦР-реагентов для выявления штаммов Vibrio cholerae $\mathrm{O}_{1}$ «гаитянской делеции» и программное обеспечение INDEL Finder для типирования нуклеотидных последовательностей $V$. cholerae; программное обеспечение для пакетной обработки результатов газовой хроматографии-масс-спектрометрии спектра жирных кислот $V$. cholerae $\mathrm{O}_{1}, \mathrm{O}_{139}$ и non $\mathrm{O}_{1} /$ non $\mathrm{O}_{139}$ серогрупп с идентификацией и анализом значимых пиков.

49. Разработан диагностический фаговый препарат для идентификации $V$. cholerae $\mathrm{O}_{1}$ серогруппы биоваров classical и El Tor. Разработана питательная среда для выделения и идентификации парагемолитических вибрионов.

Предложены новые способы внутривидовой дифференциации Yersinia pseudotuberculosis по выявлению INDEL-маркёров в генах биосинтеза сидерофоров, сконструированы праймеры, которые использованы для генотипирования штаммов Y. pseudotuberculosis с помощью ПЦР.

Разработана сыворотка листериозная агглютинирующая сухая для реакции агглютинации. Сконструирована тест-система для обнаружения Yersinia pseudotuberculosis методом дот-иммуноанализа с использованием специфических антител, меченных наночастицами серебра.

50. Получены экспериментальные сибиреязвенные споровые магноиммуносорбенты для концентрирования спор в пробах почвы; разработан экспериментальный препарат для ИФА-детекции противосибиреязвенных антител; сконструирован набор реагентов для генотипирования штаммов Brucella melitensis и B. abortus методом фрагментного анализа; разработан подход для экстракции тотального протеома споровой и вегетативной форм B. anthracis, обеспечивающий соблюдение режима биологической безопасности; разработана технология стабилизации эритроцитарных диагностикумов при лиофильном высушивании препарата.

\section{Научно-методическое обеспечение диагностики и профилактики паразитарных заболеваний}

51. Наработаны и экспериментально проверены в условиях Республики Гвинея иммунохроматографические (ИХ) экспресс-тесты на выявление возбудителя малярии в перифиреческой крови.

Впервые в мире получена визуализация взаимодействия наноигл наночастиц нитрида (BN) бора с бактериями с МЛУ. Острые (5 нм) нанообразования (наноиглы) на поверхности BN прокалывают клеточную мембрану и проникают внутрь клеток. Поврежденные участки клеток имеют характерный яркий контраст на тёмном фоне (рис. 168). (https://doi.org/10.1021/acsami.0c10169).

52. Спроектированы и секвенированы праймеры для выявления методом ПЦР Dirofilaria immitis и D. repens.

Масc-спектрометрия с использованием программного обеспечения Flex analysis MALDI-ToF MS при анализе белковых экстрактов D. immitis и D. repens, Ascaris suum и A. lumbricoides выявляет видовые различия возбудителей дирофиляриоза и аскаридоза, что ускоряет верификацию и диагностику паразитарных инвазий. Показана перспективность иммунного блоттинга при серодиагностике эхинококкозов возможность дифференцировать однокамерный и многокамерный эхинококкозы, выявлять ложноположительные результаты ИФА при аллергических заболеваниях и других гельминтозах, что повышает точность постановки клинического диагноза. 
Государственный доклад «О состоянии санитарно-эпидемиологического благополучия населения в Российской Федерации в 2020 году»
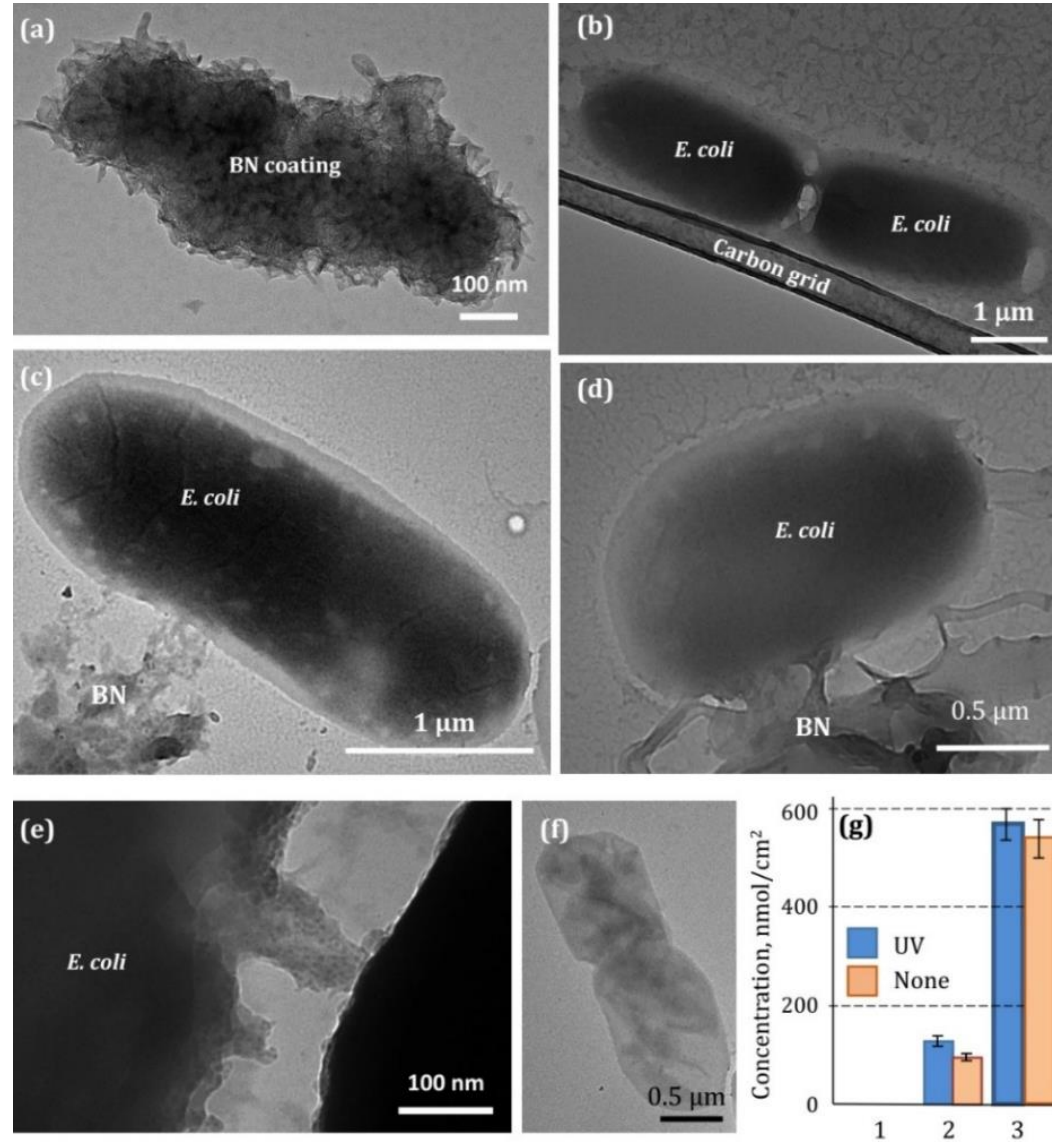

Рис. 168. Фрагмент BN-покрытия (a), контрольных клеток E. coli (b) и клеток E. coli после контакта с покрытием BN (c-f), электронная микроскопия

\section{Разработка препаратов для специфической профилактики и лечения инфекционных болезней}

53. Создана пептидная вакцина «ЭпиВакКорона» для профилактики COVID-19, которая успешно прошла доклинические и клинические исследования, зарегистрирована для использования в России 13 октября 2020 г. (РУ № ЛП-006504). Произведено 50 тыс. доз вакцины, в гражданский оборот введено 6 серий вакцины, общим количеством 43300 доз.

Продолжено двойное слепое сравнительное рандомизированное плацебоконтролируемое исследование иммуногенности, реактогенности, безопасности живой культуральной вакцины (Вакцина VAC $\Delta 6$ ) против натуральной оспы и других ортопоксвирусных инфекций на основе вируса осповакцины на добровольцах в 18-60 лет.

54. Начата I фаза клинического исследования препарата НИОХ-14 для лечения натуральной оспы и поствакцинальных осложнений: открытое, простое рандомизированное исследование безопасности, переносимости, фармакокинетики ГЛФ препарата на добровольцах в возрасте 18-50 лет в параллельных группах.

55. Адаптированы модели с использованием госпитальных штаммов острого стафилококкового сепсиса, клебсиеллёзного сепсиса, хронической туберкулёзной инфекции для исследования терапевтической эффективности АМП совместно с иммуностимуляторами.

56. Клинические испытания комплексного иммуноглобулинового препарата «КИП назальный» продемонстрировали его положительный эффект при включении в комплексную терапию различных форм ринитов, отягощённых бактериальной инфекцией.

57. Разработана технология получения очищенного липополисахарида Haemophilus influenzae типа b для применения в комплексных вакцинах. Усовершенствована технология создания отечественных конъюгированных субстанций 
H. influenzae тип b, что позволит совершенствовать вакцинопрофилактику гемофильной инфекции и перейти к вакцинации всего детского населения России в соответствии с национальным календарем профилактических прививок.

58. Созданы препараты из инактивированного ротавируса человека, обладающие иммуногенными свойствами по отношению к лабораторным животным. Изучена возможность их использования для создания вакцины против ротавирусной инфекции, определены способы введения препарата, формирующего уровень антител у животных. Составлена программа доклинического исследования вакцинных инактивированных штаммов ротавируса.

Впервые апробирована конъюгационная технология при разработке отечественной инактивированной ротавирусной вакцины для парентерального и энтерального применения с положительным эффектом по антигенности. Проведены исследования по связыванию экзогенного NSP пептида ротавируса с оболочечными белковыми антигенами ротавируса человека с целью повышения иммуногенности комплекса.

59. Установлено, что по ряду свойств Bacillus cereus является наиболее перспективным кандидатом на роль бактериального вектора для пероральных вакцин.

Получен и охарактеризован растворимый рекомбинантный белок $\mathrm{VP}_{1}$ норовируса, способный выступать в качестве антигена при выработке антител к большому структурному белку $\mathrm{VP}_{1}$ норовируса, что обосновывает возможность его использования для создания отечественной вакцины для профилактики норовирусной инфекции.

60. Создана и пополняется коллекция фагов, активных против возбудителей пищевых и госпитальных инфекций (Escherichia coli, в том числе шига-токсин продуцирующие, Salmonella enterica серотипов Enteritidis, Typhimurium, Infantis, Staphylococcus aureus, Pseudomonas aeruginosa, Klebsiella pneumoniae, Acinetobacter baumannii и др.).

Созданы фаговые коктейли, активные против E. coli («Eco-1», «Eco-2»), Salmonella enterica серотипов Enteritidis, Typhimurium, Infantis («Salm-1», «Salm-2») для деконтаминации продуктов питания от патогенных эшерихий и сальмонелл.

61. Сконструированы человеческие моноклональные антитела (МКА), нейтрализующие летальный токсин $B$. anthracis. Исследована in vitro и in vivo токсиннейтрализующая активность наработанных серий МКА в отношении сибиреязвенного токсина.

62. Установлена противовирусная и антиоксидантная активность сульфатированных полисахаридов из бурых и красных водорослей, нафтохинонов и спинохромов морских ежей, их стандартизованных фрагментов и синтетических аналогов в отношении вирусов герпеса ВПГ-1, ВПГ-2, энтеровируса ЕСНО-1, ВИЧ-1. Показано прямое вирулицидное действие соединений на ВПГ-1; ингибирование адсорбции ВПГ-1 к клеткам Vero, снижение индуцированной ВПГ-1 внутриклеточной продукции активных форм кислорода.

Показана перспективность использования биологически активных веществ из морских гидробионтов для разработки противовирусных средств широкого спектра действия и иммунных адъювантов для различных вакцин.

63.Разработана питательная среда жидкая на основе экстракта кукурузной патоки для глубинного выращивания вакцинного штамма Yersinia pestis EV, обеспечивающая высокий процент живых микробных клеток в биомассе.

\section{Разработка методов и средств неспецифической профилактики инфекционных и паразитарных заболеваний}

64. Разработана методика расчёта потребности медицинских организаций (МО) в спиртовых кожных антисептиках для обработки рук и локтевых, бесконтактных, сенсорных дозаторах для спиртовых кожных антисептиков. Зарегистрировано 3 
программы ЭВМ по расчёту потребности дезинфицирующих средств и кожных антисептиков в МО. Разработан способ контроля обработки рук кожными антисептиками.

Разработаны 6 методов анализа дезинфекционных средств, на которые получены свидетельства об аккредитации.

65. Разработаны методы исследования эффективности новых дератизационных средств ультразвукового характера действия. Отработаны режимы и способы их применения для борьбы с серыми крысами и домовыми мышами на городских объектах.

Установлена резистентность популяции головных и платяных вшей к перметрину, определён её молекулярный механизм (по типу гена).

С помощью разработанного впервые в России метода показано участие гена $k d r$ в механизме резистентности к пиретроидам (особенно к циперметрину) у обыкновенного постельного клопа Cimex lectularius.

66. Создана методическая база оценки дезинвазионной эффективности дезинфицирующих веществ, включающая многофункциональную микрокамеру и способ экспериментального отбора овицидных химических соединений. Разработано устройство для отбора дезинфектантов для дезинвазии грунта, заражённого яйцами гельминтов, цистами и ооцистами простейших.

Впервые в России разработано дезинфицирующее средство на основе сальмонеллёзных бактериофагов, предназначенное для обработки объектов ветеринарного надзора и профилактики инфекционных болезней животных «БиоСальм», на которое получена Декларация о соответствии. Разработано и подготовлено досье на лекарственный препарат на основе сальмонеллёзных бактериофагов для ветеринарного применения.

67. Разработано дезинфицирующее средство для ветеринарного применения на основе листериозных бактериофагов «Био-Листер».

Биодезинфектанты и лекарственный препарат на основе бактериофагов для ветеринарного применения после регистрации будут внедрены в ветеринарную практику промышленных птицеводческих предприятий как безвредные и высокоэффективные средства профилактики желудочно-кишечных инфекций птицы и предупреждения контаминации пищевых полуфабрикатов.

\section{Биологическая безопасность и противодействие биотерроризму}

68. Разработано 11 современных высокоэффектвных препаратов для индикации и идентификации возбудителей опасных инфекционных заболеваний методами мультилокусной ПЦР, ПЦР-РВ, фрагментарного анализа; 2 диагностических набора для выявления антител к $F$. tularensis методом ИХ, к возбудителям вирусных заболеваний III групп патогенности методом мультиплексных иммуночипов.

69. Подтверждена компетенция российских лабораторий для работы с патогенными биологическими агентами (ПБА) II-IV групп патогенности по результатам выездных проверок состояния биологической безопасности.

70. Актуализирован алгоритм учёта, хранения, передачи, транспортировки ПБА I-IV групп опасности внутри учреждения.

Разработан порядок патологоанатомического вскрытия лабораторных животных и забора материала для гистологических исследований при работе с особо опасными инфекциями (чума, сибирская язва, туляремия, бруцеллёз).

Определены методы контроля обеззараживания (стерилизации) материалов, содержащих бактерии I-IV групп патогенности. 
Государственный доклад «О состоянии санитарно-эпидемиологического благополучия населения в Российской Федерации в 2020 году»

Раздел 3. Результаты деятельности органов и учреждений Российской Федерации, входящих в систему федерального государственного санитарно-эпидемиологического надзора

\section{1. Основные результаты деятельности структурных подразделений Федерального медико-биологического агентства Российской Федерации}

Федеральный государственный санитарно-эпидемиологический надзор осуществляется Федеральным медико-биологическим агентством Российской Федерации (ФМБА России) и его территориальными органами в целях обеспечения санитарно-эпидемиологического благополучия работников организаций отдельных отраслей промышленности с особо опасными условиями труда и населения отдельных территорий по перечню, утверждаемому Правительством Российской Федерации.

ФМБА России осуществляет федеральный государственный санитарноэпидемиологический надзор в отношении химически опасных объектов: объектов по уничтожению химического оружия, бывших объектов по производству и разработке химического оружия, предприятий, включая космодромы, на которых осуществляется производство, использование, транспортировка, хранение, испытание и утилизация компонентов ракетных топлив, а также изделий с компонентами ракетных топлив.

В 2020 году в отношении юридических лиц, осуществляющих свою деятельность на химически опасных объектах, территориальными органами ФМБА России проведено 37 проверок (2019 г. - 77) и 1 административное расследование (2019 г. - 2).

При проведении проверок выявлено 97 правонарушений. В структуре правонарушений преобладают нарушения обязательных требований санитарного законодательства $(98 \%)$ и невыполнение предписаний органов государственного контроля (надзора) (2\%). По результатам проверок привлечено к административной ответственности 16 лиц (в 2019 г. - 95), из них 15 - по результатам плановых проверок, 1 - внеплановых.

По результатам проверок и административных расследований вынесено 20 постановлений о наложении административных штрафов на общую сумму 188,1 тыс. рублей. Из них на должностное лицо - 8 на общую сумму 7,1 тыс. рублей, на юридическое лицо - 12 на общую сумму 181 тыс. рублей. Всего по результатам проверок выдано 16 предписаний должностных лиц.

В 2020 году территориальными органами ФМБА России было продолжено осуществление федерального государственного санитарно-эпидемиологического надзора за объектами по уничтожению химического оружия.

В 2020 году выполнено 329831 исследование объектов производственной и окружающей среды объектов по уничтожению химического оружия. Случаев превышения гигиенических нормативов отравляющих веществ и продуктов их деструкции в окружающей среде не зарегистрировано. В 2020 гг. профессиональная заболеваемость персонала объектов по уничтожению химического оружия не регистрировалась.

ФМБА России в 2020 году было продолжено ведение единой системы медицинского мониторинга (далее - ЕСММ) при хранении, перевозке и уничтожении химического оружия, созданной для динамического наблюдения за состоянием здоровья как отдельных групп населения, так и индивидуально каждого человека, а также за объектами среды обитания, с целью выявления причинно-следственных связей между состоянием здоровья населения и воздействием факторов среды обитания, в том числе и химического фактора.

\section{2. Основные результаты деятельности структурных подразделений Управления делами Президента Российской Федерации}

Федеральный государственный санитарно-эпидемиологический надзор в целях сохранения и обеспечения санитарно-эпидемиологического благополучия на объектах, подведомственных Управлению делами Президента Российской Федерации, в 2020 году 
Государственный доклад «О состоянии санитарно-эпидемиологического благополучия населения в Российской Федерации в 2020 году»

был направлен на контроль безопасности питания и водоснабжения на подведомственных объектах; мониторинг условий труда работников учреждений Управления делами; обеспечение проведение социально-гигиенического мониторинга; контроль радиационной безопасности на подведомственных объектах; учет и анализ инфекционной и паразитарной заболеваемости контингентов, прикрепленных к медицинским организациям Управления делами Президента Российской Федерации; подготовку рекомендаций по проведению профилактических и противоэпидемических мероприятий и контроль их выполнения.

Комплекс организационных, практических и санитарно-противоэпидемических мероприятий позволил обеспечить выполнение мероприятий по основным направлениям деятельности, добиться снижения по отдельным параметрам вредного воздействия факторов среды обитания на здоровье человека, не допустить возникновения массовых неинфекционных заболеваний и сохранить благополучную санитарно-эпидемиологическую обстановку на объектах, подведомственных Управлению делами Президента Российской Федерации.

Особое внимание уделялось обеспечению объектов безопасной питьевой водой. Основной причиной несоответствия источников питьевого водоснабжения санитарноэпидемиологическим требованиям является повышенное природное содержание железа и фтора. Состояние питьевой воды в распределительной сети сохраняется на уровне предыдущих лет. Лабораторные исследования питьевой воды из водоисточников, водопроводных сетей на объектах Управления делами Президента Российской Федерации по микробиологическим и паразитологическим показателям, как и в 2019 году, подтверждают высокую степень ее безопасности.

В 2020 году исследование почвы по санитарно-химическим, микробиологическим, паразитологическим показателям проводилось, в основном (95\%) на территории детских учреждений. По санитарно-химическим, паразитологическим показателям, содержанию радиоактивных веществ превышений гигиенических нормативов не зарегистрировано.

Как и в предыдущие годы, отмечается стабильно благополучная ситуация на объектах питания медицинских организаций. Отмечается улучшение качества пищевых продуктов и готовых блюд по микробиологическим показателям в медицинских организациях, оздоровительных комплексах по сравнению с аналогичными показателями прошлых лет.

В 2020 году проводилась оценка соответствия параметров производственной среды постоянных рабочих мест работников различных учреждений требованиям, установленным нормативными правовыми актами. Содержание загрязняющих химических веществ в воздухе рабочей зоны не превышало гигиенических нормативов.

Позитивными итогами проведения в 2020 году организационно-методических, профилактических и противоэпидемических мероприятий стало снижение уровня инфекционной заболеваемости контингента, прикрепленного к медицинским организациям Управления делами Президента, в основном за счет уменьшения уровня заболеваемости кишечными инфекциями - в 2 раза, воздушно-капельными инфекциями (ветряная оспа, коклюш, корь) - в 2,2 раза, вирусных гепатитов - в 2,8 раза (за счет заболеваемости хроническим гепатитом С), социально обусловленными инфекциями - в 2,3 раза. В 2020 году по сравнению с 2019 годом отмечается увеличение в 1,7 раза заболеваемости внебольничными пневмониями за счет вирусных пневмоний.

Охват профилактическими прививками в рамках национального календаря взрослого и детского населения по медицинским учреждениям, подведомственным Управлению делами Президента Российской Федерации, соответствует регламентированным показателям.

Работа по профилактике новой коронавирусной инфекции (COVID-19) среди основного контингента на подведомственных объектах проводилась в соответствии с нормативными и распорядительными документами ВО3, Роспотребнадзора, Минздрава 
России, а также организационно-распорядительными документами Управления делами Президента Российской Федерации.

В соответствии с поручениями Управления делами Президента Российской Федерации и постановлением Главного государственного санитарного врача по объектам Управления делами Президента Российской Федерации от 13.03.2020 № 1 осуществлялись:

- ежедневный мониторинг заболеваемости гриппом, ОРВИ, внебольничными пневмониями, новой коронавирусной инфекцией;

- ежедневный сбор и обобщение сведений об отборе проб у пациентов (контактных), обследованных на COVID-19, в подведомственных медицинских организациях, контроль получения результатов обследования из лабораторий, проводящих исследование на COVID-19;

- ежедневный сбор информации о случаях самоизоляции сотрудников по установленной форме;

- ежедневное информирование Главного медицинского управления Управления делами Президента Российской Федерации о результатах мониторинга за выявлением случаев заболевания, вызванного COVID-19, результатах мониторинга проведенных исследований клинического материала.

Осуществлялась разработка профилактических мероприятий, направленных на профилактику и предупреждение распространения случаев новой коронавирусной инфекции.

\section{3. Основные результаты деятельности структурных подразделений Министерства внутренних дел Российской Федерации}

Одним из приоритетных направлений деятельности подразделений, уполномоченных осуществлять федеральный государственный санитарноэпидемиологический надзор на объектах МВД России, в 2020 году являлось обеспечение санитарно-эпидемиологической безопасности сотрудников органов внутренних дел Российской Федерации в условиях складывающегося неблагополучия по новой коронавирусной инфекции на территории Российской Федерации.

C 1 марта 2020 г. осуществлялся ежедневный мониторинг случаев заболеваний COVID-19. В целях профилактики возникновения и распространения COVID-19 изданы нормативные правовые и распорядительные акты МВД России.

Негативными последствиями эпидемического неблагополучия по COVID-19 явилось снижение охвата личного состава иммунизацией по национальному календарю профилактических прививок, а также недостаточный охват профилактическими медицинскими осмотрами персонала, занятого на работах с вредными условиями труда и на работах, при выполнении которых проводятся обязательные периодические медицинские осмотры. Соответствующие меры по достижению необходимого охвата прививками и осмотрами предстоит принять в 2021 году (с учетом эпидемиологической обстановки в субъектах Российской Федерации).

Осуществлялся мониторинг за объектами среды обитания, и по результатам показано, что в течение последних пяти лет санитарно-эпидемиологическая обстановка на объектах контроля имеет тенденции к улучшению: снижается удельный вес исследованных проб воды объектов хозяйственно-питьевого водоснабжения, не отвечающих гигиеническим нормативам по санитарно-химическим показателям; удельный вес результатов исследований продовольственного сырья и пищевых продуктов, не соответствующих гигиеническим нормативам по санитарно-химическим показателям; удельный вес результатов исследований продовольственного сырья и пищевых продуктов, не соответствующих гигиеническим нормативам по микробиологическим показателям. Радиационная обстановка в системе МВД России не менялась и оставалась удовлетворительной. Радиационных происшествий и аварий в 
подразделениях и организациях МВД России, использующих источники ионизирующего излучения, не зарегистрировано.

В 2020 году проводились контрольно-надзорные мероприятия на объектах надзора и за последние 10 лет на 14,6 \% увеличилось число объектов, находящихся на контроле подразделений МВД. По результатам надзорных мероприятий в 1,5 раза снизился удельный вес объектов, не соответствующих санитарно-эпидемиологическим требованиям. Доля выполненных предписаний по приведению объектов надзора в соответствие с санитарно-эпидемиологическими требованиями, вынесенных в процессе осуществления надзора, в течение последних 10 лет увеличилась в 1,2 раза.

Определены приоритетные направления деятельности службы на 2021 год, направленные на достижение ключевых показателей обеспечения санитарноэпидемиологического благополучия населения.

\section{4. Основные результаты деятельности структурных подразделений Федеральной службы безопасности Российской Федерации}

Федеральный государственный санитарно-эпидемиологический надзор (далее госсанэпиднадзор) в органах Федеральной службы безопасности (далее - органы безопасности) осуществляется специалистами медико-профилактического дела Военномедицинского управления ФСБ России, федерального государственного казенного учреждения «Центр государственного санитарно-эпидемиологического надзора ФСБ России» и центров государственного санитарно-эпидемиологического надзора медикосанитарных частей (военно-медицинских служб) территориальных органов безопасности.

С целью обеспечения санитарно-эпидемиологического благополучия сотрудников органов безопасности основная работа проводилась по следующим направлениям:

- контроль исполнения требований санитарного законодательства, нормативных правовых актов ФСБ России, регламентирующих охрану здоровья и санитарноэпидемиологическое благополучие сотрудников органов безопасности;

- развитие профилактической направленности в системе медицинского обеспечения;

- профилактика инфекционных болезней, управляемых средствами специфической профилактики;

- проведение социально-гигиенического мониторинга инфекционной заболеваемости, иммунопрофилактики и санитарно-технического состояния объектов органов безопасности с использованием современных информационных технологий и лабораторных методов исследования.

Проведена оценка качества состояния объектов среды обитания, осуществлялся эпидемиологический мониторинг за инфекционной заболеваемостью. Благодаря реализации мероприятий по иммунопрофилактике в 2020 году не зарегистрировано случаев заболеваний дифтерией, вирусным гепатитом А, бешенством, брюшным тифом и иных.

В связи с развитием пандемии новой коронавирусной инфекции COVID-19 санитарно-эпидемиологическая обстановка в 2020 году характеризовалась как неустойчивая, иные критические обстоятельства в области обеспечения санитарноэпидемиологического благополучия отсутствовали.

\section{5. Основные результаты деятельности структурных подразделений учреждений Федеральной службы исполнения наказаний Российской Федерации}

Государственной санитарно-эпидемиологической службой Федеральной службы исполнения наказаний в 2020 году осуществлялся государственный санитарноэпидемиологический надзор на объектах учреждений уголовно-исполнительной 
системы (УИС). С каждым годом снижается доля объектов учреждений УИС, несоответствующих санитарно-эпидемиологическим требованиям. К приоритетным санитарно-эпидемиологическим и социальным факторам, оказывающим влияние на состояние здоровья подозреваемых, обвиняемых и осужденных, относятся соответствие питьевого водоснабжения, состояние питания и условий проживания санитарным требованиям.

Сравнительный анализ проведенных лабораторных исследований по микробиологическим показателям показал, что в период 2011-2020 гг. отмечалось ежегодное планомерное снижение процента нестандартных проб воздуха в 9,5 раза, воды - в 5,7 раза, продовольственного сырья и пищевых продуктов - в 8 раз. По результатам выполненных оценок отмечается постепенное ежегодное снижение процента проб, не отвечающих гигиеническим нормативам по санитарно-химическим показателям: продовольственного сырья и пищевых продуктов - в 5,6 раза, воды - в 6,3 раза, воздуха закрытых помещений и рабочей зоны - в 4 раза. Снизился процент измерений физических факторов окружающей среды, не соответствовавших нормативным требованиям, - в 3,4 раза. Проводится эпидемиологический мониторинг инфекционной и социально-значимой заболеваемости.

По результатам оценки санитарно-эпидемиологической обстановки определяются задачи для планирования контрольно-надзорных мероприятий и разработки мер по предупреждению и снижению заболеваемости. В рамках реализации мер по обеспечению санитарно-эпидемиологического благополучия на объектах УИС во всех территориальных органах ФСИН России организовано взаимодействие с органами и учреждениями Роспотребнадзора, региональными службами и центрами.

\section{6. Основные результаты деятельности структурных подразделений Федеральной службы войск национальной гвардии Российской Федерации}

Выполнен анализ состояния среды обитания в период с 2011 по 2020 год, и выделены приоритетные факторы среды обитания, формирующие негативные тенденции в состоянии здоровья подведомственного контингента, показал следующее.

За анализируемый период в результате проведённых мероприятий на объектах хозяйственно-питьевого водоснабжения удельный вес неудовлетворительных проб воды по санитарно-химическим и микробиологическим показателям снизился. Удельный вес исследованных проб воды объектов хозяйственно-питьевого водоснабжения, не отвечающих гигиеническим нормативам по микробиологическим показателям, снизился в 4,5 раза.

В подразделениях и организациях, использующих источники ионизирующего излучения, аварийных ситуаций не отмечено. Случаев превышения основных пределов доз для персонала в организациях не зарегистрировано. Проведена радиационногигиеническая паспортизация всех организаций, эксплуатирующих медицинские источники ионизирующего излучения.

Среди личного состава войск национальной гвардии Российской Федерации за анализируемый период случаев массовых неинфекционных заболеваний (отравлений) и профессиональных заболеваний не зарегистрировано.

Немаловажную роль в положительной динамике в заболеваемости личного состава имеет охват военнослужащих и сотрудников сезонной вакцинацией против гриппа, военнослужащих по призыву - против гриппа и пневмококковой инфекции, проведение в организованных коллективах неспецифической профилактики противовирусными препаратами в период санитарно-эпидемиологического неблагополучия.

В целях раннего и своевременного выявления случаев заболевания новой коронавирусной инфекцией и проведения санитарно-профилактических (противоэпидемических) мероприятий были развернуты лаборатории, на базе которых проводились ПЦР-исследования биологического материала. 
В войсках национальной гвардии Российской Федерации в период с 2011 по 2020 год издано 47 документов нормативно-правового характера, по организации федерального государственного санитарно-эпидемиологического надзора, проведения санитарно-противоэпидемических (профилактических) мероприятий.

\section{7. Основные результаты деятельности структурных подразделений Министерства обороны Российской Федерации}

Федеральный государственный санитарно-эпидемиологический надзор в Вооруженных Силах Российской Федерации (далее - Вооружённые Силы) осуществляют федеральные государственные казённые учреждения - центры государственного санитарно-эпидемиологического надзора Министерства обороны Российской Федерации (далее - ЦГСЭН МО РФ), входящие в единую систему федерального государственного санитарно-эпидемиологического надзора Российской Федерации.

ЦГСЭН МО РФ активно работают в системе медицинского обеспечения войск по территориальному принципу, реализуя следующие основные направления деятельности: информационно-аналитическое и организационно-методическое обеспечение, осуществление федерального государственного санитарно-эпидемиологического надзора, проведение санитарно-противоэпидемических (профилактических) мероприятий, лабораторно-экспертное обеспечение.

В целях поддержания санитарно-эпидемиологического благополучия личного состава Вооружённых Сил Российской Федерации, а также воздействия на должностных лиц, грубо и систематически нарушающих требования санитарного законодательства, специалистами ЦГСЭН МО РФ в тесной взаимосвязи с работниками военной прокуратуры применялись меры административного воздействия; количество дел, переданных в военную прокуратуру, уменьшилось на $18 \%$.

Анализ результатов федерального государственного санитарноэпидемиологического надзора в 2020 году показал, что меры, принимаемые командованием воинских частей и организаций, а также выполняемые ими рекомендации специалистов ЦГСЭН МО РФ способствовали улучшению материальной базы и санитарного состояния объектов войсковой инфраструктуры, обеспечивающих санитарно-эпидемиологическое благополучие личного состава Вооруженных Сил Российской Федерации. Однако в отдельных воинских частях и организациях имеются проблемные вопросы в обеспечении удовлетворительного санитарного состояния объектов войсковой инфраструктуры.

Случаев массовых неинфекционных заболеваний (отравлений), а также случаев профессиональной заболеваемости личного состава Вооруженных Сил Российской Федерации в 2020 году не зарегистрировано.

Уровень заболеваемости инфекционными и паразитарными заболеваниями показал, что санитарно-эпидемиологическая обстановка в Вооруженных Силах в 2020 году оценивалась в целом, как неустойчивая (неблагополучная по новой коронавирусной инфекции и неустойчивая по болезням органов дыхания).

Стабилизация санитарно-эпидемиологической обстановки по большинству показателей явилась результатом последовательной реализации командованием, должностными лицами мер, направленных на снижение инфекционной и массовой неинфекционной заболеваемости, соблюдения санитарного законодательства Российской Федерации и оптимизации контрольно-надзорной деятельности.

Научно-методическое обеспечение деятельности федерального государственного санитарно-эпидемиологического надзора в Вооруженных Силах Российской Федерации в 2020 году в основном было направлено на недопущение возникновения и распространения среди личного состава новой коронавирусной инфекции (COVID-19); и были разработаны методические рекомендации «Диагностика, лечение и профилактика новой коронавирусной инфекции (COVID-19)», а также продолжена работа по внедрению риск-ориентированной модели при организации и проведении государственного санитарно-эпидемиологического надзора в воинских коллективах. 
Раздел 4. Достигнутые результаты улучшения санитарноэпидемиологической обстановки, имеющиеся проблемные вопросы при обеспечении санитарно-эпидемиологического благополучия и намечаемые меры по их решению

\section{1. Достигнутые результаты и прогноз улучшения качества среды обитания и состояния здоровья населения, оценка предотвращенных экономических потерь валового внутреннего продукта, связанных с неблагоприятным воздействием факторов среды обитания}

В 2020 году Федеральная служба по надзору в сфере защиты прав потребителей и благополучия человека продолжала осуществлять свои полномочия по надзору и контролю за исполнением обязательных требований законодательства Российской Федерации в области обеспечения санитарно-эпидемиологического благополучия населения с применением риск-ориентированных подходов. Внедрение рискориентированной модели в контрольно-надзорную деятельность Роспотребнадзора позволило применить дифференцированные подходы к проведению надзорных мероприятий. При этом внимание было сосредоточено на объектах, формирующих наибольший потенциальный риск причинения вреда здоровью населения, а административные ограничения для бизнеса, проявляющего социальную ответственность, - минимизированы.

Технологии и методы управления риском для здоровья населения в связи с влиянием социально-экономических и санитарно-гигиенических факторов, а также факторов образа жизни, реализуемые на основе системного подхода и оценки риска, являются одной из наиболее результативных и эффективных управленческих методологий, реализуемых в Российской Федерации на всех уровнях управления рисками, включая субъекты Российской Федерации, муниципальные образования и хозяйствующие субъекты, и позволяют обосновать принятие и реализовать наиболее адекватные современным угрозам и вызовам управленческие решения по снижению рисков для здоровья населения и, прежде всего, обоснования распределения и оптимизации материальных и иных ресурсов, необходимых для обеспечения санитарноэпидемиологического благополучия населения.

Информационно-аналитической основой создания и внедрения методологии оценки, мониторинга, управления и информирования о рисках для здоровья населения является действующая система социально-гигиенического мониторинга, реализуемая на всех уровнях от муниципального до федерального. Оценка достигнутых результатов управления риском для здоровья и обеспечения санитарно-эпидемиологического благополучия населения в первую очередь базируется на достижения ключевых индикативных показателей федеральных и национальных проектов, принятых в соответствии с Указом Президента Российской Федерации от 7 мая 2018 г. № 204 «О национальных целях и стратегических задачах развития Российской Федерации на период до 2024 года» и от 21 июля 2020 г. № 474 «О национальных целях развития Российской Федерации на период до 2030 года», целей и задач стратегического развития Российской Федерации.

По результатам оценки санитарно-эпидемиологической обстановки ежегодно определяются приоритетные направления деятельности и стратегические задачи для разработки, обоснования и обеспечения реализации мероприятий по обеспечению санитарно-эпидемиологического благополучия и управления рисками для здоровья населения на среднесрочную перспективу. 
В системе управления рисками и обеспечения санитарно-эпидемиологического благополучия населения наряду с контрольно-надзорными мероприятиями реализуются государственные региональные программы. В 2020 году органами и организациями Роспотребнадзора проводилась работа по разработке и реализации региональных программ. Число утвержденных региональных программ по обеспечению санитарноэпидемиологического благополучия населения Российской Федерации составило 5704 и 5315 соответственно (рис. 169).

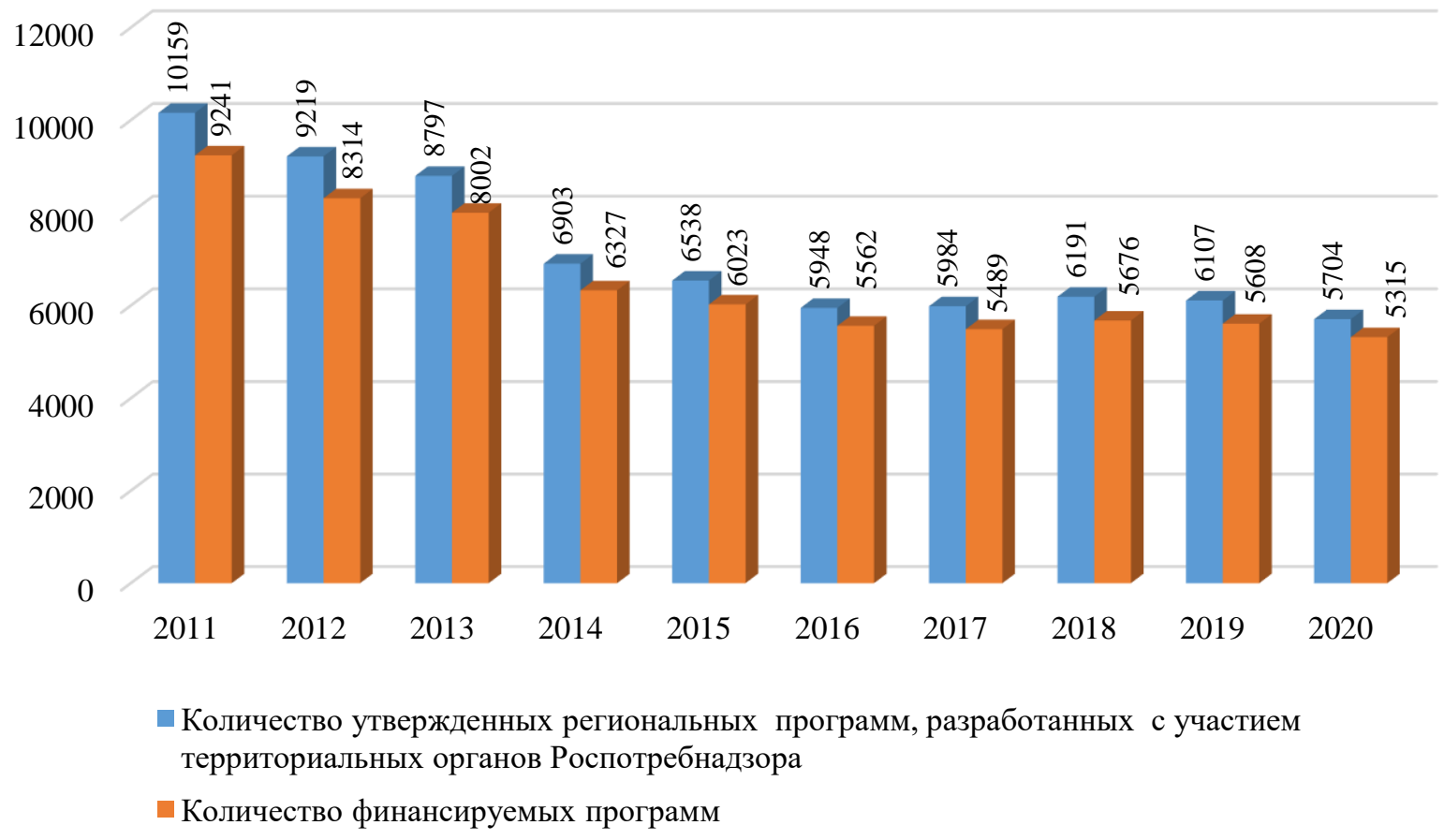

Рис. 169. Реализация региональных программ по вопросам обеспечения санитарноэпидемиологического благополучия и управления рисками в Российской Федерации

Учитывая сложившиеся тенденции в состоянии санитарно-эпидемиологического благополучия населения в субъектах Российской Федерации, в последние годы направленность государственных региональных программ все в большей степени обеспечивает решение приоритетных направлений обеспечения санитарноэпидемиологической обстановки и управления рисками для здоровья населения. Структура реализованных управленческих решений по приоритетным направлениям обеспечения санитарно-эпидемиологического благополучия населения в 2020 году приведена на рис. 170.

Основная доля всех принимаемых управленческих решений в 2020 году, направленных на обеспечение качества среды обитания и снижения влияния факторов риска, ориентирована на улучшение качества питьевого водоснабжения (31\%) и включает меры по охране водоемов, обеспечению систем водоснабжения на всех этапах водоподготовки, замене труб в распределительной сети и в целом на обеспечение населения качественной питьевой водой. 
Государственный доклад «О состоянии санитарно-эпидемиологического благополучия населения в Российской Федерации в 2020 году»

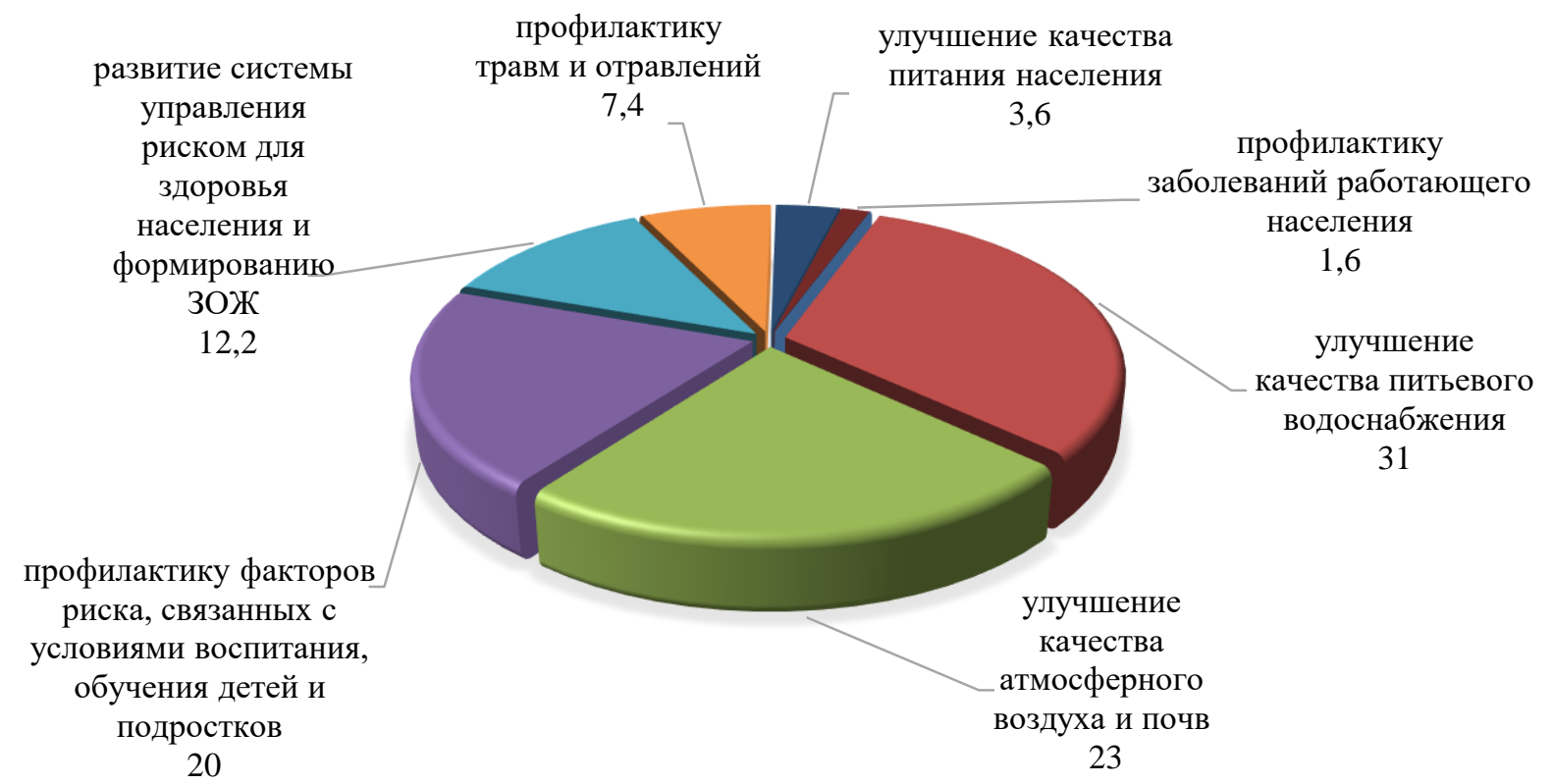

Рис. 170. Структура реализованных управленческих решений по приоритетным направлениям обеспечения санитарно-эпидемиологического благополучия населения Российской Федерации в 2020 году, \%

На втором месте по доле реализуемых управленческих решений находятся меры по снижению загрязнения и улучшению качества атмосферного воздуха, и снижению загрязнения почв (23 \%), которые включают комплекс мероприятий, направленных на снижение выбросов от промышленных источников, автотранспорта, благоустройство территорий, вывод транзитных автомагистралей за пределы городов, снижение почвенного пыления и ландшафтные решения в городах.

Доля управленческих решений, направленных на профилактику и снижение влияния факторов риска, связанных с условиями воспитания и обучения детей и подростков, составила $20 \%$. Реализованы решения по развитию материальнотехнического состояния действующих и строительству новых образовательных учреждений, расширению обеспечения детей местами в образовательных учреждениях, созданию благоприятных условий по параметрам микроклимата, обеспечению детей горячим питанием, сбалансированным и адекватным физиологическим потребностям организма, развитию физкультуры и спорта для детей и подростков, проведению оздоровительной кампании в течение года.

Доля реализованных мероприятий по управлению рисками для здоровья населения от влияния поведенческих факторов риска составила 12,2\%. Преимущественно на территориях реализованы мероприятия по реабилитации здоровья населения, подвергающегося воздействию факторов среды обитания, по профилактике табакокурения, употребления алкоголя и наркотических препаратов, в первую очередь среди молодежи, информированию и обучению целевых аудиторий по приоритетным направлениям сохранения здоровья различных групп населения, проведению массовых акций, спортивных мероприятий для населения, расширению приверженности здоровому образу жизни.

Реализовано 7,4\% мероприятий от общего числа принятых и реализованных управленческих решений, включающих профилактику дорожно-транспортного травматизма, школьных и спортивных травм, благоустройство территорий и ремонт автомагистралей. Для предупреждения и снижения числа острых отравлений населения в быту реализованы меры по ограничению продажи алкоголя, контролю за реализацией 
медикаментов и сильнодействующих препаратов, работа с молодежью по профилактике зависимостей и обеспечение занятости молодежи и досуга.

Доля мероприятий, направленных на улучшение питания населения, снижение риска для здоровья от употребления некачественной пищевой продукции составила 3,6\%. Реализованы мероприятия по мониторингу качества и безопасности пищевой продукции, обеспечению населения доступными продуктами питания, особенно в сельских территориях. Развитие индустрии по выпуску продукции, обогащенной витаминами и микроэлементами, здорового питания, ярмарки правильного питания.

В 2020 году реализация мероприятий по профилактике заболеваемости работающего населения от влияния факторов риска производственной среды и трудового процесса в субъектах Российской Федерации составила 1,6 \% в структуре всех управленческих решений. Преимущественно мероприятия были направлены на проведение периодических медицинских осмотров, раннюю диагностику и профилактику рака в условиях канцерогеноопасных производств, обеспечение работающих средствами индивидуальной защиты.

Доля мероприятий по снижению влияния физических факторов (шум, ЭМИ, радиационный фактор) на состояние здоровья населения составила 1,2\%, и основные реализованные решения направлены на защиту населения от транспортного и производственного шума, радиационную паспортизацию.

В 2020 году органами и организациями Роспотребнадзора было предложено и вынесено на рассмотрение в органы государственной власти, местного самоуправления 59983 вопроса по обеспечению санитарно-эпидемиологического благополучия в Российской Федерации, предотвращению распространения новой коронавирусной инфекции, предотвращению современных угроз и вызов для здоровья населения (рис. 171).

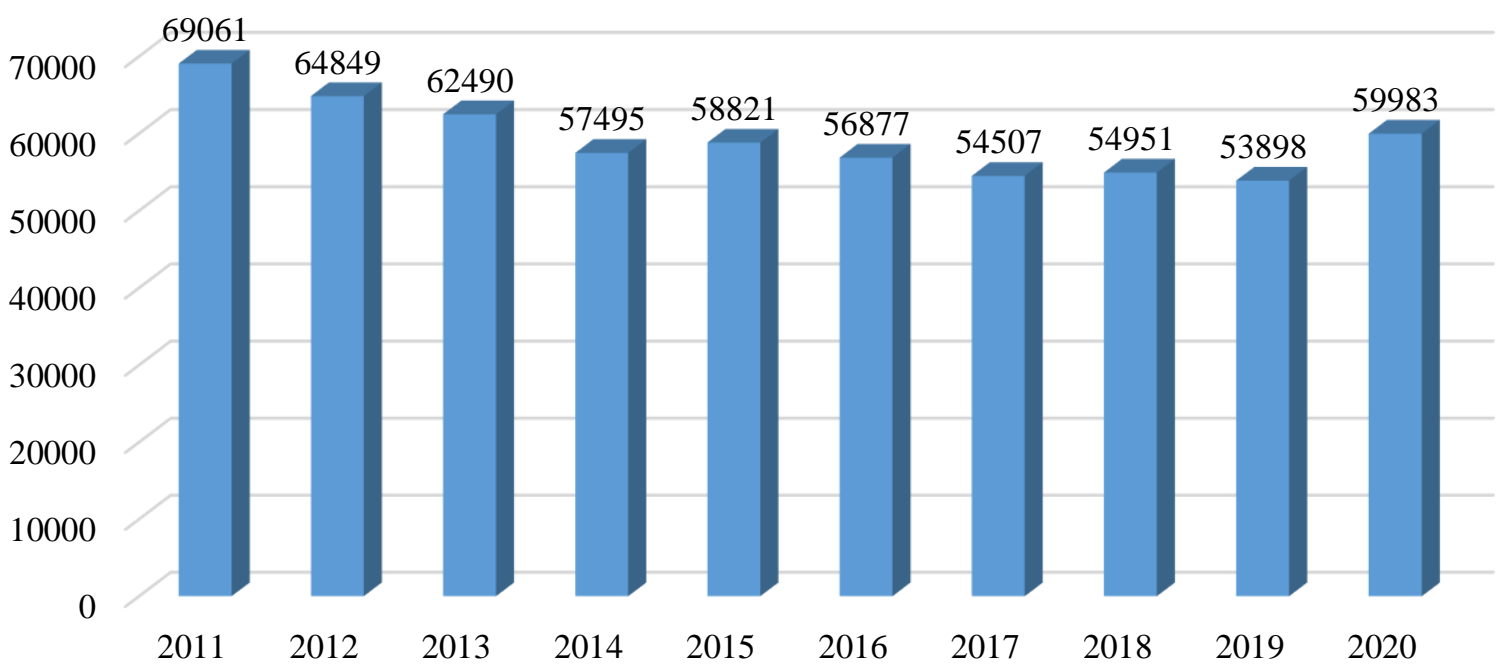

Рис. 171. Число вынесенных на рассмотрение органов власти вопросов по обеспечению санитарно-эпидемиологического благополучия в Российской Федерации в 2011-2020 гг.

Полномасштабная реализация полномочий органов и учреждений Роспотребнадзора по обоснованию и инициированию управления санитарноэпидемиологической обстановкой позволили в сложных эпидемических условиях 2020 года стабилизировать негативное влияние факторов среды обитания на здоровье населения.

Снизились показатели загрязнения среды обитания вследствие предупреждения возможных нарушений обязательных санитарно-эпидемиологических требований 
Государственный доклад «О состоянии санитарно-эпидемиологического благополучия населения в Российской Федерации в 2020 году»

хозяйствующими субъектами. При отсутствии управляющих действий Роспотребнадзора («нулевой вариант») уровень воздействия на среду обитания химических, биологических и физических факторов мог быть значительно выше.

Анализ результативности деятельности органов и учреждений Роспотребнадзора в отношении качества среды обитания населения показал, что в 2020 году действиями службы было предотвращено возникновение более 5,22 \% проб питьевой воды из систем централизованного водоснабжения, не соответствующих гигиеническим нормативам по санитарно-химическим, и 1,01 \% - по микробиологическим показателям (табл. 65).

Таблица 65

\section{Результативность деятельности органов и учреждений Роспотребнадзора в 2020 году по улучшению качества среды обитания населения}

\begin{tabular}{|c|c|c|c|}
\hline Показатели & $\begin{array}{l}\text { Фактический } \\
\text { уровень } \\
\text { показателя }\end{array}$ & $\begin{array}{c}\text { Предотвращено } \\
\text { действиями } \\
\text { Роспотребнадзора }\end{array}$ & $\begin{array}{c}\text { Вероятный уровень } \\
\text { показателя, } \\
\text { «нулевой вариант» } \\
\text { (отсутствие действий } \\
\text { Роспотребнадзора) }\end{array}$ \\
\hline 1 & 2 & 3 & 4 \\
\hline $\begin{array}{l}\text { Доля проб питьевой воды систем } \\
\text { централизованного водоснабжения, } \\
\text { превышающих гигиенические нормативы } \\
\text { по санитарно-химическим показателям (\%) }\end{array}$ & 17,11 & 5,22 & 22,33 \\
\hline $\begin{array}{l}\text { Доля проб питьевой воды систем } \\
\text { централизованного водоснабжения, } \\
\text { превышающих гигиенические нормативы } \\
\text { по микробиологическим показателям (\%) }\end{array}$ & 2,02 & 1,01 & 3,03 \\
\hline \multicolumn{4}{|c|}{ Доля проб питьевой воды с превыщением ПДК (\%) по содержанию: } \\
\hline натрия & 6,26 & 12,46 & 18,72 \\
\hline сульфатов (по $\left.\mathrm{SO}_{4}\right)$ & 1,49 & 10,04 & 11,53 \\
\hline магния & 5,22 & 9,53 & 14,75 \\
\hline бора & 13,13 & 7,96 & 21,09 \\
\hline хлоридов (по Сl) & 2,95 & 7,52 & 10,46 \\
\hline железа (включая хлорное железо) по Fе & 14,03 & 6,02 & 20,05 \\
\hline нитратов (по $\left.\mathrm{NO}_{3}\right)$ & 1,75 & 4,52 & 6,27 \\
\hline стронция & 3,61 & 3,72 & 7,33 \\
\hline фтора для климатических районов I-II & 2,36 & 3,43 & 5,79 \\
\hline алюминия & 1,17 & 2,34 & 3,51 \\
\hline аммиака и аммоний-иона (по азоту) & 1,82 & 2,27 & 4,09 \\
\hline марганца & 5,69 & 1,56 & 7,26 \\
\hline \multicolumn{4}{|c|}{ Доля проб атмосферного воздуха в городских и сельских поселениях с превышением ПДК ( \%): } \\
\hline $\begin{array}{l}\text { Всего проб с превышением ПДК (\%), в том } \\
\text { числе по содержанию: }\end{array}$ & 0,77 & 7,43 & 8,20 \\
\hline гидроксибензола и его производных & 1,25 & 21,33 & 22,57 \\
\hline углерода оксида & 0,47 & 12,38 & 12,85 \\
\hline формальдегида & 0,29 & 9,98 & 10,27 \\
\hline углеводородов & 1,49 & 7,63 & 9,12 \\
\hline дигидросульфида & 0,68 & 6,87 & 7,56 \\
\hline
\end{tabular}


Государственный доклад «О состоянии санитарно-эпидемиологического благополучия населения в Российской Федерации в 2020 году»

Продолжение табл. 65

\begin{tabular}{|l|c|c|c|}
\hline \multicolumn{1}{|c|}{1} & 2 & 3 & 4 \\
\hline азота диоксида & 0,42 & 6,44 & 6,87 \\
\hline ксилола & 2,82 & 5,58 & 8,40 \\
\hline свинца & 0,09 & 5,48 & 5,57 \\
\hline ароматических углеводородов & 2,19 & 4,81 & 7,00 \\
\hline бенз(а)пирена & 8,16 & 4,74 & 12,90 \\
\hline серной кислоты & 0,06 & 3,51 & 3,57 \\
\hline хлористого водорода & 1,00 & 3,03 & 4,03 \\
\hline ртути & 0,00 & 2,23 & 2,23 \\
\hline фтористого водорода & 0,52 & 2,01 & 2,53 \\
\hline хлора & 0,63 & 1,87 & 2,50 \\
\hline бензола & 0,74 & 1,76 & 2,50 \\
\hline $\begin{array}{l}\text { алифатических предельных } \\
\text { углеводородов }\end{array}$ & 0,13 & 1,49 & 1,62 \\
\hline $\begin{array}{l}\text { фтора и его соединений (в пересчете на } \\
\text { фтор) }\end{array}$ & 0,40 & 1,18 & 1,58 \\
\hline толуола & 1,67 & 0,62 & 2,28 \\
\hline $\begin{array}{l}\text { алифатических непредельных } \\
\text { углеводородов }\end{array}$ & 0,00 & 0,02 & 0,02 \\
\hline \multicolumn{2}{|c|}{ Доля проб почв в селитебной зоне с превыщением ПДК (\%): } \\
\hline по паразитологическим показателям & 0,82 & 25,09 & 25,90 \\
\hline по микробиологическим показателям & 5,52 & 10,86 & 16,38 \\
\hline по санитарно-химическим показателям & 0,05 & 1,58 & 1,63 \\
\hline по содержанию радиоактивных веществ & 0,04 & 1,82 & 1,85 \\
\hline $\begin{array}{l}\text { Доля точек измерений, в которых уровень } \\
\text { нми не соответствовал гигиеническим } \\
\text { нормативам (\%) }\end{array}$ & 1,37 & 0,85 & 2,22 \\
\hline
\end{tabular}

В результате эффективной деятельности Роспотребнадзора, реализации комплекса мер по снижению риска для здоровья населения, улучшению качества среды обитания было предотвращено появление более $12,46 \%$ проб питьевой воды с превышением предельно допустимого содержания натрия, более 10,04 \% проб сульфатов, более 9,53\% - нестандартных проб питьевой воды по содержанию магния, более 7,96 \% проб - бора, 7,52 \% - хлоридов и пр.

Последовательная реализация комплекса плановых и внеплановых контрольнонадзорных мероприятий, системы управления рисками на всех уровнях управления санитарно-эпидемиологической обстановкой в субъектах Российской Федерации позволили снизить уровень загрязнения атмосферного воздуха городских и сельских поселений Российской Федерации в 2020 году, предотвратить возникновение более 7,43 \% проб атмосферного воздуха с превышением ПДК, в том числе по содержанию гидроксибензола и его производных - 21,33 \% проб с превышениями, углерода оксида 12,38 \% проб, формальдегида - 9,98 \% проб с превышениями ПДК и др. В 2020 году предотвращено возникновение 25,09 \% проб почв селитебной зоны, не соответствующих гигиеническим нормативам по паразитологическим показателям, 10,86 \% проб - по микробиологическим, 1,58 \% проб - по санитарно-химическим показателям.

Достигнутые результаты позволили в 2020 году вероятностно предотвратить возникновение более 0,23 дополнительных случая смерти на 1 тыс. населения и более 3,603 тыс. дополнительных случаев заболеваний на 100 тыс. населения Российской 
Федерации, в том числе в результате улучшения качества воздуха вероятностно предотвращено более 0,12 дополнительных случая смерти на 1 тыс. населения, снижения загрязнения почв - более 0,06 случаев на 1 тыс. населения, улучшения качества питьевой воды - более 0,04 дополнительных случая смерти на 1 тыс. населения России. В структуре предотвращенных смертей взрослого населения трудоспособного возраста преобладали случаи по причине инфекционных и паразитарных болезней $(57,5 \%)$, болезней системы кровообращения $(22,0 \%)$, болезней органов пищеварения $(9,3 \%)$ и органов дыхания $(6,1 \%)$, а также злокачественных новообразований $(5,1 \%)$. Эти заболевания вероятностно обусловлены микробиологическим и химическим загрязнением питьевой воды, загрязнением почв свинцом и радиоактивными веществами, микробным и паразитарным загрязнением почв, загрязнением атмосферного воздуха диоксидом азота, оксидом азота, аммиаком, бенз(а)пиреном, взвешенными веществами, фенолом, ароматическими углеводородами, ксилолом, свинцом, формальдегидом, фтором и его соединениями.

Наряду с предотвращением случаев смерти в 2020 году предотвращено более 2,069 тыс. дополнительных случаев заболеваний на 100 тыс. населения, вероятностно обусловленных загрязнением атмосферного воздуха; вероятностно предотвращено 1,008 тыс. случаев на 100 тыс. населения в связи с качеством почв селитебных территорий, более 509,87 случаев на 100 тыс. населения - в связи с качеством питьевой воды. В структуре предотвращенной заболеваемости взрослого трудоспособного населения в 2020 году преобладали болезни органов дыхания $(31,3 \%$ от общего количества предотвращенных заболеваний у взрослого населения трудоспособного возраста), некоторые инфекционные и паразитарные болезни $(26,8 \%)$, болезни органов пищеварения $(11,3 \%)$ и костно-мышечной системы $(11,3 \%)$, болезни мочеполовой системы $(5,6 \%)$, болезни кожи и подкожной клетчатки $(5,3 \%)$, а также болезни нервной системы $(4,6 \%)$.

Среди детского населения в структуре предотвращенных случаев заболеваний преобладали болезни органов дыхания $(51,6 \%$ от общего количества случаев заболеваний), некоторые инфекционные и паразитарные болезни $(30,6$ \%), болезни кожи и подкожной клетчатки (6,0 \%), а также болезни органов пищеварения $(5,6 \%)$.

В 2020 году продолжена работа по оптимизации обязательных санитарноэпидемиологических требований, позволяющих концентрировать возможности и потенциал Роспотребнадзора на приоритетных проблемах обеспечения санитарноэпидемиологического благополучия населения. Роспотребнадзором с привлечением научного и практического звена проведена работа по систематизации, кодификации и сокращению числа санитарных правил и гигиенических нормативов с более чем 400 документов до 10, что позволило уйти от фрагментарности разрозненных актов по узким вопросам, а также сформировать научно обоснованные, гармонизированные с международным опытом санитарно-эпидемиологические требования, разработать к ним методические рекомендации и иллюстрированные пособия. Шесть нормативных документов вступили в силу с 1 января 2021 года. Это санитарные правила по:

- организации общественного питания населения;

- условиям деятельности торговых объектов и рынков, реализующих пищевую продукцию;

- воспитанию и обучению, отдыху и оздоровлению детей;

- отдельным видам транспорта и объектам транспортной инфраструктуры;

- условиям труда;

- условиям деятельности хозяйствующих субъектов, осуществляющих отдельные работы и услуги, включая гостиничные, медицинские, бытовые, социальные услуги, а также продажу непродовольственных товаров для личных и бытовых нужд. 
Еще два акта - санитарные правила по содержанию территорий городских и сельских поселений и условиям проживания, а также гигиенические нормативы факторов среды обитания - вступили в силу с 1 марта 2021 года, и с 1 сентября 2021 года вступают в силу санитарные правила по профилактике инфекционных болезней. При этом в период с 1 марта по 1 сентября 2021 года продолжат действовать 58 санитарноэпидемиологических правил по профилактике инфекционных болезней, включенных в постановление Правительства Российской Федерации от 31 декабря 2020 года № 2467 (так называемый «белый список»).

Таким образом, обеспечено не только принятие новых санитарных правил и гигиенических нормативов, но и синхронизация вступления их в силу с ранее действовавшими актами.

При этом Роспотребнадзором во взаимодействии с Федеральной службой по аккредитации проведена работа по подтверждению эквивалентности применения новых санитарных правил и гигиенических нормативов, что позволит осуществлять работы по оценке соответствия без дополнительного оснащения испытательным оборудованием и средствами измерений, без внесения изменений в процедуры и без расширения области аккредитации.

В 2020 году Роспотребнадзором приняты и продолжают действовать до 1 января 2022 года санитарные правила (3), направленные на выявление и предупреждение распространения новой коронавирусной инфекции COVID-19:

- CП 3.1.3597-20 «Профилактика новой коронавирусной инфекции (COVID-19)»;

- СП 3.1/2.4.3598-20 «Санитарно-эпидемиологические требования к устройству, содержанию и организации работы образовательных организаций и других объектов социальной инфраструктуры для детей и молодежи в условиях распространения новой коронавирусной инфекции (COVID-19)»;

- СП 3.1.3671-20 «Условия транспортирования и хранения вакцины для профилактики новой коронавирусной инфекции (COVID-19) Гам-Ковид-Вак».

Одним из ключевых показателей, характеризующих социально значимые результаты деятельности органов и учреждений Роспотребнадзора, является предотвращенный экономический ущерб для здоровья населения, оцениваемый как сумма потерь валового внутреннего продукта, предотвращенных за счет снижения дополнительных случаев преждевременной смерти и заболеваний, обусловленных факторами среды обитания.

В 2020 году сумма предотвращенного ущерба для здоровья населения оценена по двум составляющим деятельности Роспотребнадзора:

- принятие мер ограничительного характера для снижения распространения новой коронавирусной инфекции COVID - 19;

- деятельность по управлению риском для здоровья населения и обеспечению выполнения обязательных санитарно-эпидемиологических требований (без деятельности по противодействию коронавирусной инфекции).

Первая составляющая, связанная с экономической оценкой потерь от мер ограничительного характера, реализованных в Российской Федерации для снижения распространения новой коронавирусной инфекции (COVID-19), основана на обеспечении решения двух взаимосвязанных задач:

задача 1. Снизить пиковые нагрузки на систему здравоохранения, связанные с повышенным числом заболеваний новой коронавирусной инфекцией (COVID-19), обеспечивающие возможность лечения больных с учетом расширения возможности диагностики и увеличения коечного фонда в лечебно-профилактических учреждениях;

задача 2. Снизить скорость и увеличить сроки распространения новой коронавирусной инфекции (COVID-19) на период, достаточный для обеспечения 
возможности разработки, внедрения вакцины и широкой вакцинации, прежде всего в группах риска населения.

При этих условиях оценка возможной суммы потерь валового внутреннего продукта (далее - ВВП) в результате случаев заболеваний и смерти от новой коронавирусной инфекции в случае отказа от принятия ограничительных мер могла составить 3073,1 млрд рублей $(3,6 \%$ от ВВП) при замедлении скорости распространения инфекции в пять раз (на основе сравнительных оценок с процессами распространения новой коронавирусной инфекции (COVID-19) в иных странах). Потери от реализации ограничительных мер предварительно оцениваются в сумме 2 668,5 млрд рублей $(3,1 \%$ от ВВП). Относительная экономическая эффективность своевременного введения ограничительных мер может быть оценена как 1,15 руб. предотвращенного экономического ущерба для здоровья на 1 руб. потерь от введения ограничительных мер.

Вторая составляющая основана на результатах надзорной деятельности органов и учреждений Роспотребнадзора по инициации, созданию и развитию систем управления риском для здоровья населения в субъектах Российской Федерации, которые обеспечили стабилизацию санитарно-эпидемиологической ситуации и, соответственно, высокую экономическую эффективность обеспечения санитарно-эпидемиологического благополучия. Несмотря на то, что не была достигнута положительная динамика изменения суммы предотвращенного экономического ущерба для здоровья населения в результате снижения уровня смертности и заболеваемости населения, обусловленных влиянием санитарно-гигиенических факторов среды обитания, в отдельных субъектах Российской Федерации были достигнуты положительные результаты по снижению преждевременных случаев смерти и (или) заболеваний.

Прогноз развития санитарно-эпидемиологической ситуации и состояния здоровья населения основан на вероятности того, что в период до 2024 года и далее до 2030 года сохранятся базовые прогнозные параметры вклада влияния на состояние здоровья групп факторов среды обитания (при оценке суммарного влияния - $100 \%$ ): социальноэкономические факторы - в пределах от 42,0 \% до 46,0\%, санитарно-гигиенические факторы - в пределах от 25,0 \% до 29,0 \%, факторы образа жизни - от 27 \% до 31,0 \%. При этом восстановятся и сохранятся начиная с 2021-2022 гг. уровень стабилизации санитарно-эпидемиологической ситуации в субъектах Российской Федерации и достигнутые в период до 2019 года положительные тенденции по улучшению состояния санитарно-эпидемиологического благополучия населения. Эти тенденции будут характеризоваться улучшением качества среды обитания по комплексу санитарногигиенических показателей и показателей образа жизни и стабилизации уровня воздействия на состояние здоровья комплекса социальных и экономических показателей.

На рис. 172 приведены оценочные фактические на период до 2020 года и целевые на период до 2022 года данные по уровню предотвращенного экономического ущерба для здоровья населения в результате деятельности органов и учреждений Роспотребнадзора по обеспечению санитарно-эпидемиологического благополучия населения. 


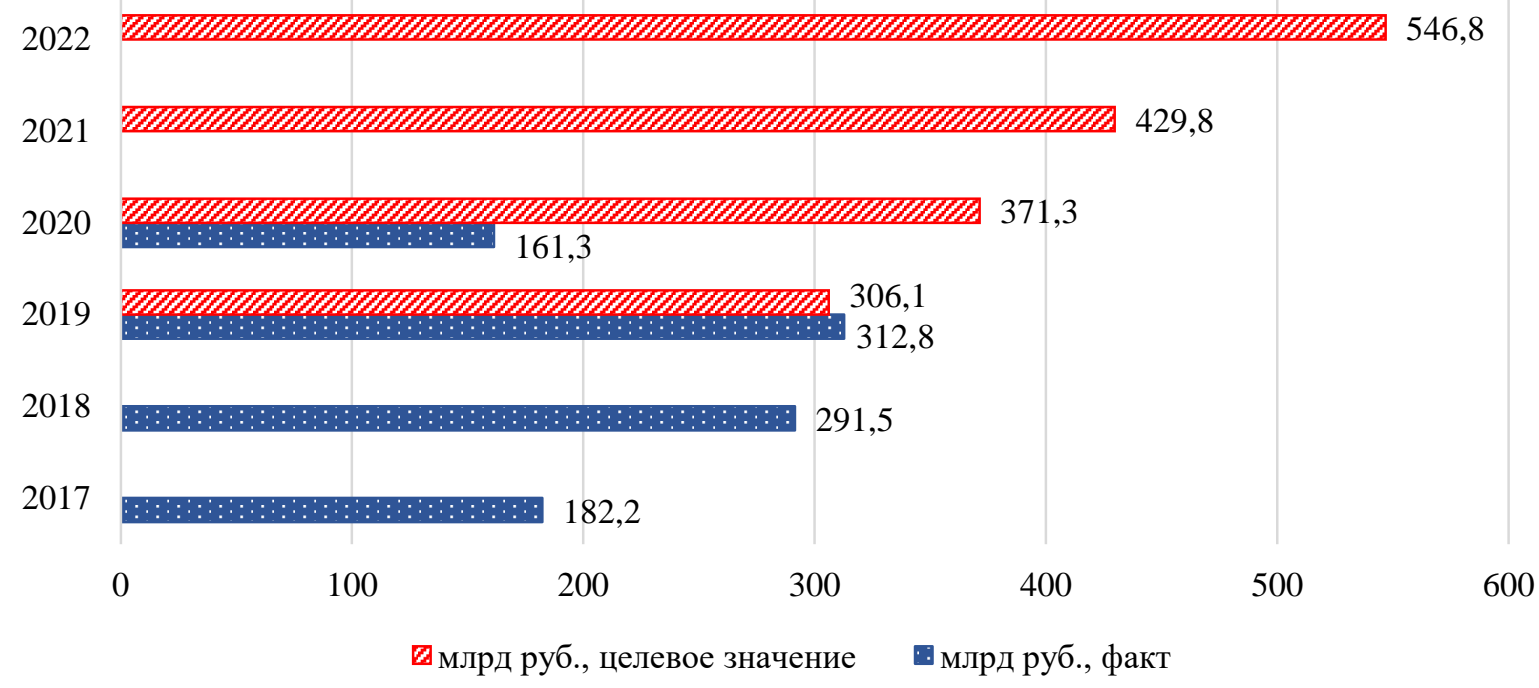

Рис. 172. Целевые и фактические уровни предотвращаемого экономического ущерба для здоровья в результате реализации мер и действий органов и учреждений Роспотребнадзора по управлению риском для здоровья населения, 2017-2022 гг.

В 2020 году сумма предотвращенных в результате деятельности Роспотребнадзора экономических потерь ВВП составила более 161,3 млрд руб., в том числе от смертности - свыше 10,9 млрд руб., от заболеваемости - более 150,4 млрд руб., вероятностно обусловленных воздействием факторов среды обитания.

При этом экономическая эффективность деятельности Федеральной службы в сфере защиты прав потребителей и благополучия человека за десятилетний период по сравнению с 2012 годом возросла на 20 \% и составила (по критерию предотвращенных потерь ВВП Российской Федерации) в 2020 году около 20,23 руб. на 1 руб. затрат.

Прогнозируется, что по результатам антикризисных мер, принятых в 2020 году и планируемых на 2021 год, включая меры по поддержке экономики Российской Федерации в связи с ограничительными мерами по новой коронавирусной инфекции (COVID-19), уровень предотвращенного экономического ущерба для здоровья населения в результате действий и мер по управлению риском для здоровья населения и обеспечению санитарно-эпидемиологического благополучия населения, реализуемых при участии органов и учреждений Роспотребнадзора в субъектах Российской Федерации, увеличится к 2022 году почти в 3,4 раза и составит около 546,8 млрд руб. в сопоставимых ценах.

Суммарно уровень предотвращенного экономического ущерба в результате принятия мер по управлению эпидемической ситуацией по управлению новой коронавирусной инфекцией и надзорной деятельности органов и учреждений Роспотребнадзора по управлению риском для здоровья населения в результате воздействия комплекса факторов среды обитания в 2020 году в субъектах Российской Федерации составил 3 234,4 млрд руб., или 3,6 \% ВВП страны.

Развитие и совершенствование организационно-функциональной структуры Федеральной службы по надзору в сфере защиты прав потребителей и благополучия человека на основе стабилизации эпидемической ситуации, развития рискориентированной модели надзорной деятельности, проектного адресного управления риском для здоровья населения, оптимизации нормирования качества и уровня влияния факторов среды обитания на состояние здоровья населения, усиления надзора за функционированием и развитием субъектов хозяйствования, формирующих угрозы, риски и наносящих значительный вред здоровью, использования информационноаналитических возможностей системы социально-гигиенического мониторинга и 
развития проблемно ориентированных референс-центров, а также иных мер позволяют прогнозировать общее повышение эффективности и результативности деятельности органов и учреждений Роспотребнадзора по показателю предотвращенного экономического ущерба для здоровья населения на уровне не ниже 3,5\% ВВП Российской Федерации.

\section{2. Выполнение мер по реализации международных актов и нормативных правовых актов Российской Федерации, принятых в целях обеспечения санитарно-эпидемиологического благополучия населения Российской Федерации}

Важным аспектом работы Роспотребнадзора в 2020 году стало укрепление и расширение международного взаимодействия по реагированию на пандемию новой коронавирусной инфекции COVID-19, прежде всего со странами Евразийского экономического союза (ЕАЭС) и Содружества Независимых Государств (СНГ), а также Китаем, государствами Юго-Восточной Азии и Африки. Кроме того, была продолжена реализация других проектов в сфере содействия международному развитию.

Зарубежным партнёрам оказано безвозмездное материально-техническое содействие, научно-методическая помощь на двусторонней и многосторонней основе. Во Всемирную организацию здравоохранения (ВО3) на борьбу с инфекциями, включая COVID-19, внесено 5,7 млн долл. США.

В общей сложности в 50 стран мира передано более 1,5 млн тестов производства ФБУН «ГНЦ ВБ «Вектор», причём около 2/3 направлены в страны СНГ. Именно при помощи российских тестов были выявлены первые случаи коронавирусной инфекции в Армении, Белоруссии, Таджикистане и Узбекистане.

Эффективность и точность тест-систем «Вектора» была подтверждена в ходе визита 4-7 февраля в Китай. Это до сих пор первая и единственная группа зарубежных специалистов, представляющих одну страну, принятая КНР.

Специалисты и учёные Роспотребнадзора провели 13 научно-консультативных миссий в странах ближнего и дальнего зарубежья, оказав необходимую поддержку в наиболее сложные периоды пандемии в Киргизии, Казахстане, Таджикистане, Узбекистане, Молдове, Туркменистане, Италии, Ливане, Абхазии, Южной Осетии.

При этом продолжалась работа созданных Роспотребнадзором лабораторий в Гвинее и Вьетнаме. В Гвинее российская лаборатория одной из первых в стране начала проводить исследования на COVID-19, и сегодня совместно с гвинейскими специалистами проведено уже более 10 тыс. исследований. Во Вьетнаме на базе Российско-Вьетнамского Тропического центра специалисты Роспотребнадзора провели свыше 2 тыс. исследований на новую коронавирусную инфекцию с использованием мобильной лаборатории.

В целом пандемия новой коронавирусной инфекции (COVID-19) выявила несостоятельность западных подходов по децентрализации служб санитарноэпидемиологического благополучия, сворачивания лабораторной сети, внедрения «общественного здравоохранения». В результате в Казахстане, Узбекистане, Киргизии и Таджикистане приняты меры по укреплению санитарно-эпидемиологических служб и возврату к ранее действовавшим подходам с использованием российских методик.

В настоящее время разрабатывается проект по развитию международного научного взаимодействия, в рамках которого планируется провести популяционные исследования иммунитета к новой коронавирусной инфекции (COVID-19) в ряде приграничных стран и провести полногеномное секвинирование около 1000 образцов, полученных на территориях соседних стран.

В рамках единого эпидемиологического пространства стран Евразийского экономического союза Роспотребнадзор активизировал работу Совета руководителей 
уполномоченных органов в области санитарно-эпидемиологического благополучия населения. С февраля 2020 года было проведено уже 19 заседаний Совета.

Состоялись консультации со странами СНГ и Шанхайской организации сотрудничества и 10 онлайн-семинаров для более чем 400 специалистов из стран СНГ и дальнего зарубежья по вопросам диагностики, профилактики и лечения новой коронавирусной инфекции.

По инициативе Российской Федерации главами правительств одобрен Комплексный план мероприятий в области здравоохранения и санитарноэпидемиологического благополучия населения по предотвращению распространения новой коронавирусной инфекции COVID-19 и иных инфекционных заболеваний. Подобный план, разработанный Роспотребнадзором, был также принят лидерами стран ШОС.

В рамках СНГ разработан проект Плана совместных действий государств участников СНГ по противодействию распространению инфекционных болезней, который предполагается принять в 2021 году и 2 основополагающих соглашения: о санитарной охране территории государств - участников СНГ и о реагировании на чрезвычайные ситуации санитарно-эпидемиологического характера.

ФБУН «Государственный научный центр вирусологии и биотехнологии «Вектор» Роспотребнадзора включён ВО3 в реестр лабораторий, оказывающих содействие этой организации в диагностике нового коронавируса. Сегодня в Центре исследуются образцы, получаемые не только из регионов России, но и из-за рубежа.

8 декабря 2020 года ГНЦ ВБ «Вектор» направил документы в ВОЗ для внесения «ЭпиВакКороны» в список вакцин для международного использования, в том числе при чрезвычайных ситуациях санитарно-эпидемиологического характера.

Учёные и эксперты Роспотребнадзора регулярно участвуют в брифингах и консультациях, а также в экспертных обсуждениях, проводимых ВОЗ.

Российские эксперты вошли в состав Чрезвычайного комитета ВОЗ по новой коронавирусной инфекции, возглавляемого Генеральным директором Организации, с момента его создания. Специалисты Роспотребнадзора входят в состав рабочих групп ВОЗ по лабораторной диагностике, иммунизации, инфекционному контролю, а также по исследованиям и разработкам в области средств диагностики, лекарственных препаратов и вакцин.

В 2020 году в Киргизию и Беларусь передано по 50000 доз российской вакцины против кори. Кроме того, передано 7 мобильных лабораторий, а также 1 мобильная клиника (Узбекистану в рамках помощи по борьбе с ВИЧ/СПИД).

Роспотребнадзор при поддержке Правительства Российской Федерации оказывает помощь 11 приграничным государствам по 7 проектам. За последние 5 лет в 10 стран передана 21 мобильная лаборатория, обучено более 3000 иностранных специалистов, переданы сотни единиц лабораторного оборудования, сотни тысяч диагностикумов российского производства, проведено 5 международных учений по реагированию на опасные инфекции, воссозданы российские лаборатории во Вьетнаме и Гвинее.

Развитие и укрепление двустороннего и многостороннего международного сотрудничества с области санитарно-эпидемиологического благополучия населения, реализации обязательств Российской Федерации в рамках членства России в международных организациях по вопросам борьбы с инфекционными, неинфекционными и паразитарными болезнями, обеспечения безопасности продукции и среды обитания человека с учетом ограничительных мер, связанных с коронавирусной инфекцией. 
Государственный доклад «О состоянии санитарно-эпидемиологического благополучия населения в Российской Федерации в 2020 году»

\section{3. Приоритетные задачи обеспечения санитарно-эпидемиологического благополучия населения}

Достижение национальных целей и решение стратегических задач развития Российской Федерации, предусмотренных указами Президента Российской Федерации от 7 мая 2018 года № 204 «О национальных целях и стратегических задачах развития Российской Федерации на период до 2024 года» и от 21 июня 2020 года № 474 «О национальных целях развития Российской Федерации на период до 2030 года», реализация национальных и федеральных проектов по обеспечению его выполнения на период до 2030 года определяют приоритетные задачи органов и учреждений Роспотребнадзора, их роль в достижении ключевых социально значимых результатов, таких как повышение ожидаемой продолжительности жизни к 2030 году - до 78 лет, ожидаемой продолжительности здоровой жизни до 67 лет, снижение показателей смертности населения трудоспособного возраста (до 350 случаев на 100 тыс. населения), снижение заболеваемости по управляемым заболеваниям инфекционной и неинфекционной природы, обусловленным качеством среды обитания человека.

Имеющийся опыт и внедрение методов проектного и целевого управления, применение новых подходов к организации деятельности по обеспечению санитарноэпидемиологического благополучия на всех уровнях государственного и муниципального управления и управления на уровне субъектов хозяйствования, прежде всего переход к модели управления рисками для здоровья населения, оптимизация системы нормирования и установления санитарно-эпидемиологических требований при осуществлении экономической деятельности субъектов хозяйствования, эффективное планирование контрольно-надзорной деятельности обеспечивают создание необходимого потенциала, включая информационно-аналитическое обеспечение органов и учреждений Роспотребнадзора для их результативного участия в реализации национальных проектов.

В этих условиях и при складывающихся тенденциях развития ситуации по обеспечению санитарно-эпидемиологического благополучия населения (с учетом обеспечения реализации всего комплекса национальных проектов Российской Федерации) проведенные оценки дают основания для осторожного оптимистичного прогноза целевых уровней социально значимых результатов, в достижении которых непосредственно участвуют органы и учреждения Роспотребнадзора.

На решение проблем санитарно-эпидемиологического благополучия населения по результатам оценки 2020 года должны быть направлены максимальные ресурсы, прежде всего в субъектах Российской Федерации, для которых эти проблемы являются наиболее приоритетными (табл. 66).

Таблица 66

\section{Приоритетные субъекты Российской Федерации по обеспечению управления риском для здоровья по проблемам санитарно-эпидемиологического благополучия населения}

\begin{tabular}{|c|c|l|}
\hline \multirow{2}{*}{ № п/п } & $\begin{array}{c}\text { Проблемы обеспечения } \\
\text { санитарно-эпидемиологического } \\
\text { благополучия населения }\end{array}$ & \multicolumn{1}{|c|}{$\begin{array}{c}\text { Приоритетные субъекты } \\
\text { Российской Федерации }\end{array}$} \\
\hline 1 & 2 & \multicolumn{1}{|c|}{3} \\
\hline 1. & $\begin{array}{l}\text { Улучшение качества атмосферного } \\
\text { воздуха и почв }\end{array}$ & $\begin{array}{l}\text { Красноярский край } \\
\text { Свердловская область } \\
\text { Челябинская область } \\
\text { Иркутская область } \\
\text { Забайкальский край } \\
\text { Кемеровская область }\end{array}$ \\
\hline
\end{tabular}


Государственный доклад «О состоянии санитарно-эпидемиологического благополучия населения в Российской Федерации в 2020 году»

Продолжение табл. 66

\begin{tabular}{|c|c|c|}
\hline 1 & 2 & 3 \\
\hline & & $\begin{array}{l}\text { Вологодская область } \\
\text { Липецкая область } \\
\text { Омская область } \\
\text { Республика Хакасия } \\
\text { Республика Бурятия } \\
\text { Республика Тыва } \\
\text { Республика Дагестан } \\
\text { Алтайский край } \\
\text { Приморский край } \\
\text { Хабаровский край } \\
\text { Новосибирская область } \\
\text { Сахалинская область } \\
\text { Оренбургская область }\end{array}$ \\
\hline 2. & $\begin{array}{c}\text { Стабильное обеспечение и улучшение } \\
\text { качества питьевого водоснабжения }\end{array}$ & $\begin{array}{l}\text { Республика Калмыкия } \\
\text { Республика Тыва } \\
\text { Забайкальский край } \\
\text { Республика Бурятия } \\
\text { Вологодская область } \\
\text { Ненецкий автономный округ } \\
\text { Республика Саха (Якутия) } \\
\text { Еврейская автономная область } \\
\text { Курганская область } \\
\text { Республика Дагестан } \\
\text { Смоленская область } \\
\text { Архангельская область } \\
\text { Республика Карелия } \\
\text { Республика Крым } \\
\text { Томская область } \\
\text { Республика Хакасия } \\
\text { Чеченская Республика } \\
\text { Ханты-Мансийский автономный округ } \\
\text { Ростовская область } \\
\text { Новгородская область } \\
\text { Кабардино-Балкарская Республика } \\
\text { Республика Ингушетия } \\
\text { Свердловская область }\end{array}$ \\
\hline 3. & $\begin{array}{c}\text { Снижение влияния физических } \\
\text { факторов риска на здоровье населения }\end{array}$ & \begin{tabular}{|l} 
Брянская область \\
Костромская область \\
Тверская область \\
Республика Коми \\
Республика Дагестан \\
Республика Марий Эл \\
Пермский край \\
Ханты-Мансийский автономный округ \\
Томская область \\
Магаданская область \\
Республика Северная Осетия - Алания \\
Новосибирская область \\
Нижегородская область \\
Республика Дагестан \\
Иркутская область \\
Калужская область
\end{tabular} \\
\hline
\end{tabular}


Продолжение табл. 66

\begin{tabular}{|c|c|c|}
\hline 1 & 2 & 3 \\
\hline & & $\begin{array}{l}\text { Магаданская область } \\
\text { Ивановская область } \\
\text { Республика Башкортостан } \\
\text { Вологодская область } \\
\text { Тамбовская область } \\
\text { Владимирская область } \\
\text { Челябинская область } \\
\text { Новгородская область } \\
\text { Республика Татарстан } \\
\text { г. Москва } \\
\text { Республика Крым } \\
\text { Краснодарский край }\end{array}$ \\
\hline 4. & $\begin{array}{c}\text { Обеспечение безопасности, } \\
\text { сбалансированности и качества питания } \\
\text { населения }\end{array}$ & $\begin{array}{l}\text { Республика Калмыкия } \\
\text { Республика Алтай } \\
\text { Республика Дагестан } \\
\text { Республика Мордовия } \\
\text { Кабардино-Балкарская Республика } \\
\text { Республика Марий Эл } \\
\text { Магаданская область } \\
\text { Чукотский автономный округ } \\
\text { Республика Тыва } \\
\text { Республика Ингушетия } \\
\text { Республика Саха (Якутия) } \\
\text { Новгородская область } \\
\text { Псковская область } \\
\text { Владимирская область } \\
\text { Республика Карелия } \\
\text { Сахалинская область } \\
\text { Московская область } \\
\text { Приморский край } \\
\text { г. Москва } \\
\text { Калужская область }\end{array}$ \\
\hline 5. & $\begin{array}{c}\text { Профилактика факторов риска, } \\
\text { связанных с условиями воспитания, } \\
\text { обучения и отдыха детей и подростков }\end{array}$ & $\begin{array}{l}\text { Ненецкий автономный округ } \\
\text { Новгородская область } \\
\text { Ханты-Мансийский автономный округ } \\
\text { Республика Тыва } \\
\text { Республика Хакасия } \\
\text { Приморский край } \\
\text { Магаданская область } \\
\text { Еврейский автономный округ } \\
\text { Чукотский автономный округ } \\
\text { Архангельская область } \\
\text { Республика Калмыкия } \\
\text { Республика Дагестан } \\
\text { Чеченская Республика } \\
\text { Республика Саха (Якутия) } \\
\text { Забайкальский край } \\
\text { Хабаровский край } \\
\text { Республика Карелия } \\
\text { Карачаево-Черкесская Республика } \\
\text { Иркутская область } \\
\text { Республика Северная Осетия - Алания } \\
\text { Республика Ингушетия } \\
\text { Владимирская область }\end{array}$ \\
\hline
\end{tabular}


Государственный доклад «О состоянии санитарно-эпидемиологического благополучия населения в Российской Федерации в 2020 году»

Продолжение табл. 66

\begin{tabular}{|c|c|c|}
\hline 1 & 2 & 3 \\
\hline & & $\begin{array}{l}\text { Костромская область } \\
\text { Смоленская область } \\
\text { Республика Коми } \\
\text { Курганская область } \\
\text { Республика Хакасия } \\
\text { Красноярский край } \\
\text { Омская область } \\
\text { Сахалинская область } \\
\text { Чукотский автономный округ }\end{array}$ \\
\hline 6. & $\begin{array}{c}\text { Условия труда и профилактика } \\
\text { заболеваний работающего населения }\end{array}$ & 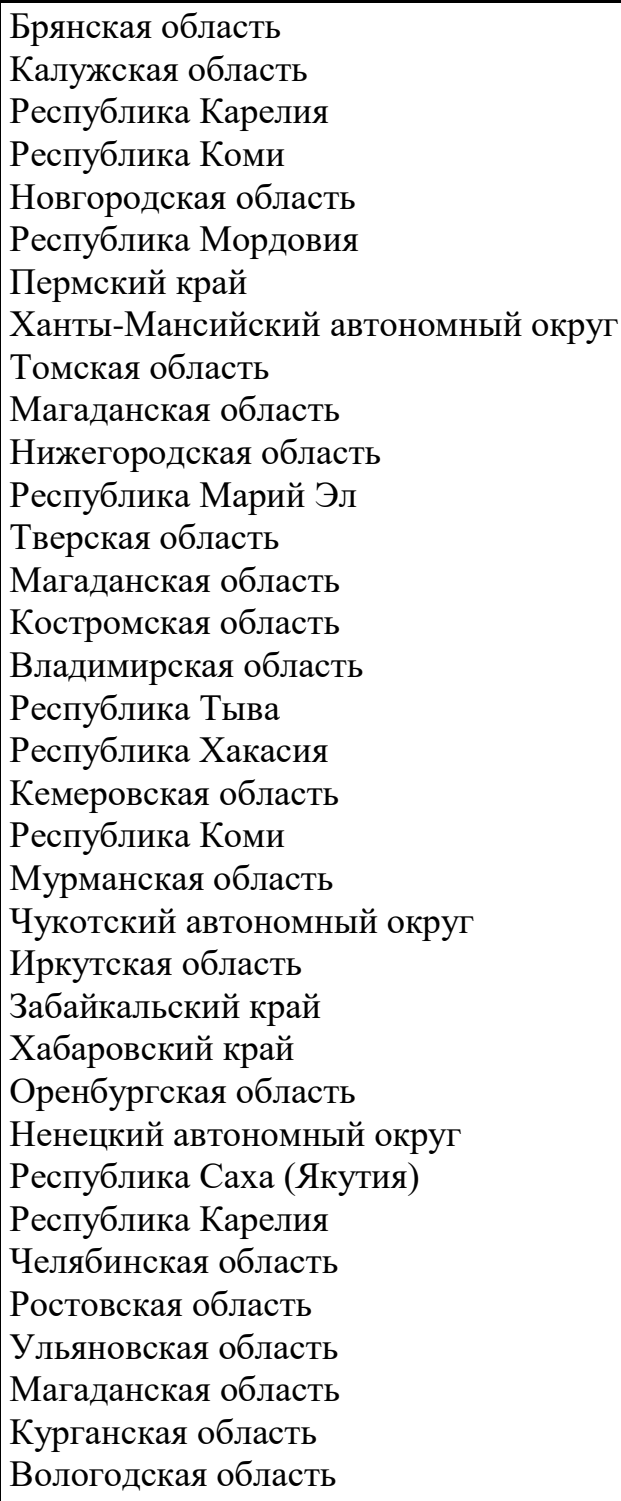 \\
\hline 7. & $\begin{array}{c}\text { Профилактика инфекционных и } \\
\text { паразитарных заболеваний }\end{array}$ & $\begin{array}{l}\text { город Москва, город Санкт-Петербург } \\
\text { Московская область } \\
\text { Нижегородская область } \\
\text { Свердловская область } \\
\text { Ростовская область } \\
\text { Воронежская область } \\
\text { Красноярский край } \\
\text { Иркутская область } \\
\text { Архангельская область } \\
\text { Ханты-Мансийский автономный округ }\end{array}$ \\
\hline
\end{tabular}


Продолжение табл. 66

\begin{tabular}{|c|c|c|}
\hline 1 & 2 & 3 \\
\hline & & $\begin{array}{l}\text { Хабаровский край } \\
\text { Ульяновская область } \\
\text { Мурманская область } \\
\text { Республика Карелия } \\
\text { Вологодская область } \\
\text { Республика Коми } \\
\text { Ямало-Ненецкий автономный округ } \\
\text { Псковская область } \\
\text { Томская область } \\
\text { Курганская область } \\
\text { Сахалинская область } \\
\text { Республика Башкортостан } \\
\text { Магаданская область } \\
\text { Амурская область } \\
\text { Волгоградская область } \\
\text { Калининградская область } \\
\text { Тверская область } \\
\text { Смоленская область } \\
\text { Удмуртская Республика } \\
\text { Самарская область } \\
\text { Республика Калмыкия } \\
\text { Хабаровский край }\end{array}$ \\
\hline 8. & $\begin{array}{c}\text { Формирование и профилактика } \\
\text { здорового образа жизни }\end{array}$ & $\begin{array}{l}\text { Воронежская область } \\
\text { Ненецкий автономный округ } \\
\text { Ленинградская область } \\
\text { Удмуртская Республика } \\
\text { Свердловская область } \\
\text { Ямало-Ненецкий автономный округ } \\
\text { Республика Хакасия } \\
\text { Амурская область } \\
\text { Еврейский автономный округ } \\
\text { Республика Крым } \\
\text { г. Санкт-Петербург } \\
\text { Самарская область } \\
\text { Красноярский край } \\
\text { Алтайский край } \\
\text { Республика Тыва } \\
\text { Калужская область } \\
\text { Московская область } \\
\text { г. Москва } \\
\text { Республика Коми } \\
\text { Калининградская область } \\
\text { Мурманская область } \\
\text { Республика Татарстан } \\
\text { Тюменская область } \\
\text { Ханты-Мансийский автономный округ } \\
\text { Республика Саха (Якутия) } \\
\text { Хабаровский край } \\
\text { Камчатский край } \\
\text { Магаданская область } \\
\text { Сахалинская область } \\
\text { Чукотский автономный округ }\end{array}$ \\
\hline
\end{tabular}


Проблемы санитарно-эпидемиологического благополучия объединены в 8 групп, характеризующих основные направления деятельности по управлению риском для здоровья населения в результате воздействия факторов среды обитания. При этом перечень задач, которые необходимо решить в рамках управления риском для здоровья населения, формируются для каждого субъекта Российской Федерации индивидуально в зависимости от характерных факторов среды обитания, формирующих здоровье населения.

Основные направления деятельности Федеральной службы по надзору в сфере защиты прав потребителей и благополучия и человека предусматривают решение следующих задач:

На федеральном уровне обеспечить:

- осуществление нормативной, научно-методической и информационной поддержки и участие в реализации нормативных правовых документов, государственных программ, национальных и федеральных проектов, отраслевых документов стратегического планирования, включая:

- Указ Президента Российской Федерации от 07.05.2018 № 204 «О национальных целях и стратегических задачах развития Российской Федерации на период до 2024 года»;

- Указ Президента Российской Федерации от 21.07.2020 № 474 «О национальных целях развития Российской Федерации на период до 2030 года»;

- Указ Президента Российской Федерации от 31.12.2015 № 683 «О Стратегии национальной безопасности Российской Федерации»;

- Указ Президента Российской Федерации от 01.12.2016 № 642 «О Стратегии научно-технологического развития Российской Федерации»;

- Указ Президента Российской Федерации от 29.05.2017 № 240 «Об объявлении в Российской Федерации Десятилетия детства»;

- Указ Президента Российской Федерации от 13.10.2018 № 585 «Основы государственной политики в области обеспечения ядерной и радиационной безопасности Российской Федерации на период до 2025 года и дальнейшую перспективу»;

- Указ Президента Российской Федерации от 28.11.2018 № 680 «О развитии генетических технологий в Российской Федерации»;

- Указ Президента Российской Федерации от 11.03.2019 № 97 «Об Основах государственной политики Российской Федерации в области обеспечения химической и биологической безопасности на период до 2025 года и дальнейшую перспективу»;

- Указ Президента Российской Федерации от 06.06.2019 № 254 «О Стратегии развития здравоохранения в Российской Федерации на период до 2025 года»;

- Указ Президента Российской Федерации от 21.01.2020 № 20 «Об утверждении доктрины продовольственной безопасности Российской Федерации»;

- Указ Президента Российской Федерации от 25.12.2020 № 812 «О проведении в Российской Федерации Года науки и технологии»;

- Указ Президента Российской Федерации от 04.01.2021 № 12 «Об утверждении Порядка действий органов публичной власти по предупреждению угрозы возникновения чрезвычайных ситуаций, связанных с заносом на территорию Российской Федерации и распространением на территории Российской Федерации опасных инфекционных заболеваний»;

- Федеральный закон от 31.07.2020 № 247-Ф3 «Об обязательных требованиях в Российской Федерации»;

- Федеральный закон от 31.07.2020 № 248-Ф3 «О государственном контроле (надзоре) и муниципальном контроле в Российской Федерации»;

- Федеральный закон от 30.12.2020 № 492-Ф3 «О биологической безопасности в Российской Федерации»; 
- Федеральную научно-техническую программу развития генетических технологий на 2019-2027 годы, разработанную в соответствии с Указом Президента Российской Федерации от 28.11.2018 № 680 «О развитии генетических технологий в Российской Федерации» (утв. постановлением Правительства Российской Федерации от 22.04.2019 № 479);

- Программу фундаментальных научных исследований в Российской Федерации на долгосрочный период (2021-2030 годы) (утв. распоряжением Правительства Российской Федерации от 31.12.2020 № 3684-p);

- Государственную программу «Обеспечение химической и биологической безопасности Российской Федерации»;

- План мероприятий («дорожная карта») по развитию и укреплению системы федерального государственного санитарно-эпидемиологического надзора на 20212028 годы (утв. распоряжением Правительства Российской Федерации от 30.12.2020 № 3680-p);

- Приказ Роспотребнадзора от 26.08.2019 № 665 «Об утверждении концепции развития социально-гигиенического мониторинга»;

- Приказ Роспотребнадзора от 24.12.2020 № 869 «Об утверждении Концепции научного обеспечения органов и организаций Роспотребнадзора на период до 2025 года и отраслевых научно-исследовательских программ на 2021-2025 годы по актуальным вопросам обеспечения деятельности Роспотребнадзора»;

- Федеральные проекты «Чистая вода», «Чистый воздух» национального проекта «Экология»;

- Федеральные проекты «Формирование системы мотивации граждан к здоровому образу жизни, включая здоровое питание и отказ от вредных привычек», и «Старшее поколение» национального проекта «Демография»;

- Федеральный проект «Экспорт продукции АПК» национального проекта «Международная кооперация и экспорт»;

- Национальный проект «Наука»;

- ВЦП «Организация государственного санитарно-эпидемиологического надзора и обеспечение санитарно-эпидемиологического благополучия населения» Государственной программы «Развитие здравоохранения»;

- План мероприятий («дорожная карта») по реализации механизма «Регуляторная гильотина»;

- Стратегию повышения качества пищевой продукции в Российской Федерации до 2030 года;

- Стратегию предупреждения распространения антимикробной резистентности в Российской Федерации на период до 2030 г. (утв. распоряжением Правительства Российской Федерации от 25 сентября 2017 г. № 2045-p);

- Доктрину продовольственной безопасности Российской Федерации;

- Концепцию осуществления государственной политики противодействия потреблению табака и иной никотиносодержащей продукции в Российской Федерации на период до 2035 и дальнейшую перспективу;

- Основы государственной политики Российской Федерации в области здорового питания населения на период до 2020 года;

- Распоряжение Правительства Российской Федерации от 21.12.2019 № 3116-р по укреплению национальных лабораторий отдельных стран Восточной Европы, Закавказья и Центральной Азии по противодействию распространению устойчивости к противомикробным препаратам, оказанию научно-методической и материальнотехнической поддержки, включая поставку лабораторного оборудования, и обучению иностранных специалистов;

- План действий по поддержанию свободного от полиомиелита статуса Российской Федерации на 2019-2021 гг.; 
- Государственную стратегию противодействия распространению ВИЧинфекции в Российской Федерации на период до 2020 года и дальнейшую перспективу (утв. распоряжением Правительства Российской Федерации от 20.10.2016 № 2203-p);

- Национальный план по предупреждению завоза и распространения новой коронавирусной инфекции на территории Российской Федерации, утвержденный Председателем Правительства Российской Федерации;

- постановление Главного государственного санитарного врача Российской Федерации от 24.01.2020 № 2 «О мероприятиях по недопущению распространения новой коронавирусной инфекции, вызванной 2019-nCoV»;

- постановление Главного государственного санитарного врача Российской Федерации от 31.01.2020 № 3 «О проведении дополнительных санитарнопротивоэпидемических (профилактических) мероприятий по недопущению завоза и распространения новой коронавирусной инфекции, вызванной 2019-nCoV»;

- постановление Главного государственного санитарного врача Российской Федерации от 02.03.2020 № 5 «О дополнительных мерах по снижению рисков завоза и распространения COVID-2019»;

- постановление Главного государственного санитарного врача Российской Федерации от 13.03.2020 № 6 «О дополнительных мерах по снижению рисков распространения COVID-2019»;

- постановление Главного государственного санитарного врача Российской Федерации от 18.03.2020 № 7 «Об обеспечении режима изоляции в целях предотвращения распространения COVID-2019»;

- постановление Главного государственного санитарного врача Российской Федерации от 30.01.2021 № 9 «О дополнительных мерах по недопущению распространения COVID-2019»;

- создание в субъектах Российской Федерации комплексных межведомственных систем управления риском для здоровья населения в результате воздействия факторов среды обитания различной природы на основе социально-гигиенического мониторинга;

- развитие риск-ориентированной модели надзорной деятельности с усилением надзора за функционированием наиболее опасных, формирующих значительные потери здоровья населения субъектов хозяйствования на основе методов и технологий оценки, управления, мониторинга и информирования о рисках для здоровья населения;

- оптимизацию системы нормирования и адекватности установления санитарноэпидемиологических требований по приоритетным направлениям обеспечения санитарно-эпидемиологического благополучия населения с учетом результатов оценки риска для здоровья населения;

- создание референс-центров информационно-аналитической

поддержки управления риском для здоровья населения на основе развития социальногигиенического мониторинга в субъектах Российской Федерации и научнометодического обеспечения научных учреждений Роспотребнадзора.

- совершенствование законодательной и нормативно-методической базы обеспечения санитарно-эпидемиологического благополучия населения и защиты прав потребителей при одновременном сокращении административных барьеров для хозяйствующих субъектов и создание благоприятного климата для ведения бизнеса;

- повышение эффективности профилактики, выявления и предупреждения распространения инфекционных заболеваний, управляемых средствами вакцинопрофилактики, в том числе реализацию мер, направленных на поддержание низких уровней заболеваемости дифтерией, дальнейшее снижение заболеваемости корью, краснухой, острым гепатитом В, усиление информационного взаимодействия с населением по вопросам вакцинопрофилактики;

- предупреждение завоза и распространения полиомиелита, вызванного диким и вакцинородственным полиовирусом; достижение уровня охвата прививками против 
Государственный доклад «О состоянии санитарно-эпидемиологического благополучия населения в Российской Федерации в 2020 году»

гриппа в целом по стране не менее 40 \% от общей численности населения и не менее 80 \% - групп высокого риска инфицирования;

- продвижение в рамках полномочий Роспотребнадзора интересов Российской Федерации в сфере международной борьбы с инфекционными и паразитарными заболеваниями и обеспечения безопасности продукции;

- совершенствование деятельности специализированных отраслевых органов межгосударственного сотрудничества СНГ, ШОС, БРИКС, ВАС, АТЭС при лидирующей роли Российской Федерации;

- развитие модели риск-ориентированного надзора, санитарно-гигиенического мониторинга и системы управления рисками жизни и здоровью населения страны, включая совершенствование системы оценки результативности и эффективности деятельности Роспотребнадзора и его структурных подразделений;

- существенное расширение информационного взаимодействия органов и организаций Роспотребнадзора с представителями бизнес-сообщества, гражданского и экспертного сообществ, основанное на принципах открытости и взаимного доверия;

- содействие развитию сервисов, включая цифровые, в сфере здорового и безопасного питания населения, в том числе посредством сети научно-методических и образовательных центров;

- совершенствование федерального государственного санитарноэпидемиологического надзора за обеспечением населения качественной питьевой водой в рамках Национального проекта «Экология», направленное на достижение запланированных индикативных показателей деятельности по вопросам надзора за источниками негативного воздействия на водные объекты, используемые в питьевых и рекреационных целях, а также объектами водоснабжения и водоотведения;

- разработка и реализация системы мер по контролю за санитарногигиеническими аспектами условий труда с ориентацией на повышение периода здоровой жизни трудоспособного населения;

- развитие лабораторного дела в системе организаций Роспотребнадзора, совершенствование материально-технической, методической и кадровой базы испытательно-лабораторных центров на основе принципов и критериев лучших лабораторных практик, создание и развитие существующих профильных опорных баз и референсных центров по направлениям лабораторной деятельности;

- расширение практики использования современных информационных технологий, интеграцию информационных ресурсов Роспотребнадзора на единой централизованной платформе с использованием и наукоемких аналитических средств и инструментов;

- развитие двустороннего и многостороннего международного сотрудничества в целях снижения угроз здоровью и благополучию населения Российской Федерации и продвижение национальных интересов в области обеспечения санитарноэпидемиологического благополучия населения, биологической безопасности;

- разработку нормативных правовых актов в рамках новой структуры нормативного регулирования, содержащих актуализированные требования, разработанные с учетом риск-ориентированного подхода и современного уровня технологического развития, соблюдение которых подлежит проверке при осуществлении государственного контроля (надзора);

- научное обоснование включения в технические регламенты Евразийского экономического союза (Таможенного союза) максимально допустимых уровней содержания в пищевой продукции новых загрязняющих веществ, в том числе остаточных количеств лекарственных препаратов для ветеринарного применения, в целях гармонизации с международными требованиями характеристик и параметров качества и безопасности пищевой продукции на основе фундаментальных исследований в области гигиены и науки о питании; 
- организацию системы мониторинга качества и безопасности пищевых продуктов с разработкой нормативных правовых актов, регулирующих требования к нормируемым значениям, и формирование положений по созданию единой обязательной базы данных пищевой и энергетической ценности пищевой продукции, обращаемой на рынке ЕАЭС;

- разработку системы мер по развитию и реализации государственных стратегий и планов действий по сокращению угрозы устойчивости к противомикробным препаратам и организации системы мониторинга за остаточными количествами антибиотиков в пищевых продуктах, продовольственном сырье и антибиотикорезистентностью бактерий.

- развитие информационно-коммуникационных ресурсов, направленных на защиту потребителей от недостоверной информации о продукции, в том числе не соответствующей принципам здорового питания, с содержанием результатов оценки качества и безопасности пищевой продукции, проводимой Роспотребнадзором;

- совершенствование организационно-функциональной модели обеспечения развития системы СГМ на всех уровнях ее функционирования с учетом адаптации и гармонизации с международными требованиями научно-методического, лабораторного, технического, информационного, программно-аппаратного обеспечения;

- разработку АИС информирования о качестве атмосферного воздуха и питьевой воды на основе элементов анализа риска;

- развитие системы оценки результативности и экономической эффективности реализации федерального проекта «Чистый воздух» в пилотных территориях по критериям здоровья при реализации комплексных планов мероприятий по снижению на ключевых промышленных предприятиях городов, формирующих на $95 \%$ выбросы загрязняющих веществ в атмосферный воздух от стационарных источников;

- развитие системы предупреждения, раннего выявления, оперативного реагирования и ликвидации биологических угроз санитарно-эпидемиологического характера;

- оптимизацию государственного регулирования обеспечения радиационной безопасности населения в рамках реализации Основ государственной политики в области обеспечения ядерной и радиационной безопасности Российской Федерации на период до 2025 года и дальнейшую перспективу, утвержденных Указом Президента Российской Федерации от 13.10.2018 № 535;

- повышение эффективности деятельности научных организаций Роспотребнадзора в рамках национальных проектов и отраслевых научноисследовательских программ Роспотребнадзора, ориентированных на обеспечение санитарно-эпидемиологического благополучия и повышение качества жизни населения Российской Федерации;

- создание и развитие на базе научных и образовательных организаций лабораторий и центров, осуществляющих исследования в области генетических технологий, в том числе технологий генетического редактирования, и их техническую поддержку по направлениям реализации Программы или разработку и внедрение в практику генетических технологий для совершенствования диагностики, профилактики и лечения опасных инфекционных заболеваний с целью обеспечения биологической безопасности Российской Федерации;

- организацию взаимодействия с органами исполнительной и законодательной власти в субъектах Российской Федерации по вопросам реализации указов Президента Российской Федерации, национальных проектов «Образование», «Демография», а также региональных целевых программ, направленных на улучшение условий пребывания детей в организованных детских коллективах, в том числе с учетом климатогеографических и этнических особенностей детского населения; 
- совершенствование санитарного законодательства Российской Федерации в области охраны здоровья детей и подростков с учетом научных исследований в области состояния здоровья детей;

- организацию мониторинговых наблюдений за условиями воспитания и обучения, организацией питания, результативностью профилактической деятельности и контрольно-надзорных мероприятий;

- разработку и внедрение научных исследований в области оценки и обоснования современных факторов риска для здоровья детей в условиях изменяющейся системы образования.

\section{Задачи регионального уровня:}

- расширение взаимодействия с органами исполнительной и законодательной власти субъектов Российской Федерации по вопросам реализации указов Президента Российской Федерации от 7 мая 2018 года № 204 «О национальных целях и стратегических задачах развития Российской Федерации на период до 2024 года», от 29 мая 2017 № 240 «Об объявлении в Российской Федерации Десятилетия детства», национальных проектов;

- повсеместное внедрение в контрольно-надзорную деятельность контроля за оборотом на территории Российской Федерации товаров, в отношении которых принято решение об обязательном маркировании средствами идентификации (распоряжение Правительства Российской Федерации от 28.04.2018 № 792-р «Об утверждении перечня отдельных товаров, подлежащих обязательной маркировке средствами идентификации»);

- совершенствование практики контрольных закупок товаров (работ, услуг) в интересах защиты здоровья и имущественных прав потребителей;

- повсеместное внедрение риск-ориентированных подходов при осуществлении контрольно-надзорной деятельности с целью повышения эффективности и результативности деятельности органов и организаций Роспотребнадзора;

- расширение практики реализации положений Федерального закона от 27.12.2018 № 560-Ф3 «О внесении изменений в статьи 2 и 26 Федерального закона «О государственном регулировании производства и оборота этилового спирта, алкогольной и спиртосодержащей продукции и об ограничении потребления (распития) алкогольной продукции» в части запрета на производство и (или) оборот порошкообразной спиртосодержащей продукции;

- усиление контроля за обращением с отходами потребления, твердыми коммунальными отходами в соответствии с новыми требованиями, изложенными в Федеральном законе от 25.12.2018 № 483-Ф3;

- значительное усиление контроля за планированием, организацией и проведением иммунопрофилактики населения в рамках национального календаря профилактических прививок и календаря профилактических прививок по эпидемическим показаниям, за достижением и поддержанием достоверно высоких уровней охвата профилактическими прививками детей и взрослых в декретированных возрастах (не менее 95 \%) с расширением информирования населения о преимуществах вакцинопрофилактики, противодействие антипрививочным кампаниям, проведение комплекса мероприятий в рамках Всемирной недели иммунизации 2019 года;

- реализация мероприятий по поддержанию статуса субъекта Российской Федерации, свободного от полиомиелита, в том числе мероприятий в рамках программы «Эпидемиологический надзор и профилактика энтеровирусной (неполио) инфекции»;

- организация дополнительных профилактических и противоэпидемических мероприятий в целях стабилизации заболеваемости корью, достижения статуса субъекта Российской Федерации, свободного от эндемичной кори и краснухи, в рамках реализации программы «Элиминация кори и краснухи в Российской Федерации (20162020 гг.)»; 
- реализация мероприятий, направленных на борьбу с гриппом, в том числе достижение не менее $45 \%$ уровня охвата профилактическими прививками против гриппа населения субъекта Российской Федерации и не менее 75 \% охвата прививками против гриппа групп риска;

- научное обоснование совершенствования и реализация системы мероприятий по снижению интенсивности распространения и профилактике ВИЧ-инфекции;

- усиление взаимодействия с НКО - исполнителями общественно полезных услуг, занимающимися вопросами профилактики ВИЧ-инфекции, поддержки людей, живущих с ВИЧ;

- совершенствование организационного построения лабораторной сети, системы лабораторного обеспечения надзорной деятельности и социально-гигиенического мониторинга, укрепление материально-технической базы лабораторий, внедрение современного аналитического оборудования;

- совершенствование мер по медицинскому освидетельствованию иностранных граждан, прибывающих в Российскую Федерацию, а также контроль за своевременным и правильным оформлением материалов по принятию решения о нежелательности пребывания (проживания) иностранного гражданина или лица без гражданства в Российской Федерации;

- повышение оперативности и полноты получения и передачи информации в случае осложнения эпидситуации, регистрации групповых очагов инфекционных болезней, своевременное проведение эпидрасследований с организацией адекватных противоэпидемических мероприятий и контролем их исполнения;

- расширение межведомственного взаимодействия государственных контрольных органов в пунктах пропуска через государственную границу Российской Федерации в случае подозрения или выявления больных с признаками острых инфекционных болезней, ввоза потенциально опасной продукции на территорию страны;

- совершенствование системы взаимодействия органов Роспотребнадзора с органами исполнительной власти субъектов Российской Федерации по вопросам предложений по стабилизации ситуации с учетом проводимого анализа эпидситуации и актуальности санитарно-гигиенических проблем на конкретной территории;

- разработка и тестовая апробация элементов Единой информационноаналитической системы Роспотребнадзора на базе пилотных территорий;

- усиление контроля за оборотом на территории Российской Федерации табака и иной никотиносодержащей продукции (распоряжение Правительства Российской Федерации от 18.11.2019 № 2732-p);

- совершенствование системы оценки эффективности и результативности деятельности органов государственной власти, муниципальной исполнительной власти и хозяйствующих субъектов на основе учета критериев состояния среды обитания, здоровья населения, защиты прав потребителей, функционирования систем управления риском для здоровья населения;

- организационное построение регламентирования процедуры по рассмотрению комплексных экологических разрешений в рамках реализации полномочий Роспотребназдора при реализации положений Федерального закона от 27 декабря 2019 г. № 453-Ф3 «О внесении изменений в статьи 11 и 18 Федерального закона «Об экологической экспертизе» и Федеральный закон «Об охране окружающей среды»;

- реализация процедуры квотирования выбросов загрязняющих веществ, приоритетных для здоровья населения (Федеральный закон от 26.07.2019 № 195-Ф3 «О проведении эксперимента по квотированию выбросов загрязняющих веществ и внесении изменений в отдельные законодательные акты Российской Федерации в части снижения загрязнения атмосферного воздуха»);

- совершенствование контроля качества пищевой продукции, полученной с использованием биотехнологий, включая генно-инженерно-модифицированные 
Государственный доклад «О состоянии санитарно-эпидемиологического благополучия населения в Российской Федерации в 2020 году»

(трансгенные) организмы, в том числе генетически модифицированные микроорганизмы, и государственной регистрации пищевой продукции, полученной с использованием генно-инженерно-модифицированных (трансгенных) организмов, в том числе генетически модифицированных микроорганизмов;

- проведение исследований структуры питания различных групп населения в регионах Российской Федерации в целях выявления рисков здоровью, связанных со структурой питания, качеством и безопасностью пищевых продуктов, и обоснованием норм потребления основных групп пищевых продуктов;

- обеспечение реализации новых полномочий Роспотребнадзора (Федеральный закон от 27.12.2019 № 451-Ф3) в части выдачи представлений в связи с осуществлением мероприятий по государственному контролю (надзору) за соблюдением требований законодательства в области обеспечения санитарно-эпидемиологического благополучия населения об осуществлении экспертизы качества специальной оценки условий труда;

- усиление надзора за организацией и проведением производственного контроля, предварительных и периодических медицинских осмотров с контролем и верификацией данных со стороны работодателя в ходе надзорных мероприятий;

- организация взаимодействия с органами исполнительной власти субъектов Российской Федерации в сфере здравоохранения по вопросам практической реализации национальных проектов «Здравоохранение» и «Демография» в части снижения кардиологической и онкологической заболеваемости как наиболее частых причин смертности трудоспособного населения;

- обеспечение внедрения методических подходов в части обоснования и выбора загрязняющих веществ для установления квот и оценки результативности и эффективности компенсационных мероприятий для достижения установленных целевых результатов по критериям здоровья населения с включением этих мероприятий в комплексные планы мероприятий по снижению выбросов загрязняющих веществ в атмосферный воздух на период до 2024 года и дальнейшую перспективу (реализация Федерального закона от 26 июля 2019 г. № 195-Ф3 «О проведении эксперимента по квотированию выбросов загрязняющих веществ и внесении изменений в отдельные законодательные акты Российской Федерации в части снижения загрязнения атмосферного воздуха»);

- обеспечение исполнения требований постановления Правительства Российской Федерации от 28 января 2019 года № 50 «О внесении изменений в Правила продажи отдельных видов товаров, утвержденных постановлением Правительства Российской Федерации от 19 января 1998 года № 55, в части выкладки молочной продукции»;

- повсеместное внедрение основ формирования здорового образа жизни граждан Российской Федерации, включая популяризацию культуры здорового питания, профилактику алкоголизма и наркомании, противодействие потреблению табака и иной никотиносодержащей продукции;

• внедрение технологий Единой информационно-аналитической системы Роспотребнадзора в деятельность территориальных органов и учреждений Роспотребнадзора;

- обеспечение системного анализа и прогнозирования санитарноэпидемиологической обстановки, выработки управленческих решений, гарантирующих санитарно-эпидемиологическую безопасность граждан и устойчивое развитие стран в динамично изменяющихся социально-экономических условиях;

- совершенствование организации питания детей в организованных детских коллективах, условий воспитания и обучения, отдыха детей и их оздоровления.

Задачи на мунииипальном уровне:

- усиление контроля за внедрением Федерального закона от 29.07.2018 № 244-Ф3 «О внесении изменений в Федеральный закон «Об общих принципах организации местного самоуправления в Российской Федерации» в части установления правомочия 
органов местного самоуправления на реализацию функций в области защиты прав потребителей, определенных статьей 44 Закона Российской Федерации «О защите прав потребителей», за счет доходов местных бюджетов;

- совершенствование мер по контролю соблюдения санитарнопротивоэпидемического режима в медицинских организациях в целях недопущения формирования очагов инфекций, связанных с оказанием медицинской помощи (ИСМП);

- повышение интенсивности надзора за готовностью медицинских, детских образовательных и прочих организаций к эпидемическому подъему заболеваемости гриппом и ОРВИ, своевременностью введения ограничительных мероприятий в целях предупреждения распространения гриппа и ОРВИ в организациях;

- расширение системы мер по достижению уровня охвата прививками против гриппа населения, включая работающее, не менее $45 \%$, а групп риска - не менее $75 \%$;

- совершенствование контроля за проведением обучения медицинского персонала по вопросам организации, проведения и безопасности иммунопрофилактики населения;

- контроль чувствительности и качества эпидемиологического надзора за ПОЛИО/ОВП, реализация мероприятий по профилактике ВАПП;

- разработка и реализация дополнительных профилактических и противоэпидемических мероприятий с целью снижения заболеваемости корью, в том числе выявление непривитых, проведение подчищающей иммунизации против кори;

- поиск и реализация новых методов системной разъяснительной работы с населением, информирование в средствах массовой информации о преимуществах вакцинопрофилактики;

• оптимизация комплекса профилактических и противоэпидемических мероприятий по предупреждению завоза опасных инфекционных болезней, распространения природно-очаговых и зоонозных инфекций;

- усиление контроля за условиями размещения детей, температурным режимом в помещениях, немедленной изоляцией инфекционных больных, своевременной подачей экстренных извещений и проведением противоэпидемических мероприятий в связи с высокой эпидемиологической значимостью и актуальностью ОРВИ, внебольничных пневмоний, ветряной оспы и других инфекций;

- повышение противоэпидемической готовности органов и организаций Роспотребнадзора в целях оперативного реагирования на чрезвычайные ситуации санитарно-эпидемиологического характера;

• расширение консультативной, методической и информационной помощи органам местного самоуправления в целях совершенствования обеспечения санитарноэпидемиологического благополучия населения и защиты прав потребителей;

- организация и проведение на промышленных предприятиях и объектах комплекса мероприятий по устранению и снижению риска возникновения профессиональных заболеваний и отравлений;

- совершенствование системы мер по надзору за созданием безопасных для здоровья детей и подростков условий воспитания, обучения с учетом изменяющейся системы образования; за организацией отдыха и оздоровления детей;

- усиление контроля за источниками негативного воздействия на водные объекты, используемые в питьевых и рекреационных целях, а также объектами водоснабжения и водоотведения. 
1. В 2020 году санитарно-эпидемиологическая обстановка в Российской Федерации характеризовалась как напряженная, вместе с тем управляемая, позволившая с минимальными потерями пройти сложный период пиковых нагрузок в связи с распространением коронавирусной инфекции (COVID-19). Реализован комплекс последовательных, системных мер в рамках Национального плана по предупреждению завоза и распространения новой коронавирусной инфекции (COVID-19) на территории Российской Федерации.

2. Наиболее значимыми факторами среды обитания, формирующими состояние санитарно-эпидемиологического благополучия и здоровья населения Российской Федерации, в 2020 году являлись:

- социальные и экономические факторы, наиболее выраженному влиянию которых на здоровье подвержено около 94,3 млн человек в 53 субъектах Российской Федерации (64,6 \% населения Российской Федерации);

- санитарно-гигиенические факторы (химические, биологические, физические), которые оказывают выраженное влияние на состояние здоровья более чем 93,7 млн человек в 50 субъектах Российской Федерации (64,2 \% населения);

- факторы образа жизни (табакокурение, употребление алкоголя, несбалансированное питание), оказывающие выраженное влияние на состояние здоровья около 64,9 млн человек в 46 субъектах Российской Федерации $(44,5 \%$ населения).

3. Все больше проявляется тенденция снижения численности населения, подверженного влиянию санитарно-гигиенических факторов, в субъектах Российской Федерации. За последнее десятилетие снижение характеризуется как устойчиво стабильное.

Наиболее значимыми санитарно-гигиеническими факторами, определяющими уровень нагрузки и формирующими состояние здоровья населения, в 2020 году являлись:

- комплексная химическая нагрузка (химическое загрязнение продуктов питания, питьевой воды, атмосферного воздуха и почвы), воздействию которой подвержено население численностью 78,6 млн человек в 44 субъектах Российской Федерации (53,85 \% населения);

- комплексная биологическая нагрузка (биологическое загрязнение продуктов питания, питьевой воды и почвы), оказывающая воздействие на состояние здоровья около 61,8 млн человек в 37 субъектах Российской Федерации (42,3 \% населения);

- комплексная нагрузка, связанная с физическими факторами среды обитания (шум, электромагнитное излучение, вибрация, ультразвук и иные), с численностью подверженного воздействию населения 62,2 млн человек в 29 субъектах Российской Федерации (42,6 \% населения).

При стабильной положительной тенденции к снижению комплексной химической нагрузки на население продолжает оставаться стабильным и высоким уровень воздействия комплекса биологических факторов, а также развитие тенденции к увеличению воздействия физических факторов, в основном за счет увеличения шумового (от автотранспорта) и электромагнитного (от мобильных средств телефонной связи) воздействия.

4. Мониторинг качества среды обитания, контрольно-надзорная деятельность санитарно-эпидемиологической обстановки, оценка состояния санитарноэпидемиологического благополучия населения и его прогноз обеспечили разработку, 
Государственный доклад «О состоянии санитарно-эпидемиологического благополучия населения в Российской Федерации в 2020 году»

обоснование и принятие результативных и эффективных решений по управлению риском для здоровья населения, адекватных возникшим в 2020 году угрозам.

Система осуществляемых в Российской Федерации в течение ряда лет профилактических и превентивных мероприятий по улучшению качества среды обитания позволила снизить обусловленную влиянием загрязнения среды обитания дополнительную заболеваемость и смертность населения с учетом особенностей и приоритетов решения проблем санитарно-эпидемиологического благополучия населения в субъектах Российской Федерации.

5. В связи с напряженной эпидемиологической ситуацией, возникновением угроз санитарно-эпидемиологическому благополучию приняты дополнительные меры по санитарной охране территории, в том числе усилению санитарно-карантинного контроля в пунктах пропуска через государственную границу Российской Федерации. Правительством Российской Федерации был принят и реализован Национальный план по предупреждению завоза и распространения новой коронавирусной инфекции (COVID-19) на территории Российской Федерации.

Утверждены новые санитарно-эпидемиологические правила СП 3.1.3597-20 «Профилактика новой коронавирусной инфекции (COVID-19)».

Разработаны и зарегистрированы в установленном порядке тест-системы для диагностики новой коронавирусной инфекции (COVID-19). В конце 2020 г. начата вакцинация населения против новой коронавирусной инфекции (COVID-19) вакциной «ЭпиВакКорона», разработанной ГНЦ ВБ «Вектор» Роспотребнадзора. Организовано и проводится молекулярно-генетическое исследование вирусов SARS-CoV-2, циркулирующих на территории России. Проводится мониторинг наличия антител к вирусу SARS-CoV-2 у лиц, проживающих в Российской Федерации.

6. На фоне противоэпидемических мер в отношении новой коронавирусной инфекции (COVID-19) в 2020 г. по большинству инфекций наблюдалось снижение показателей заболеваемости по сравнению с 2019 г. и среднемноголетними показателями. Уменьшилось число очагов групповой заболеваемости, в том числе в детских организованных коллективах. По целевым индикаторам достигнуты утверждённые уровни: заболеваемость дифтерией регистрируется на уровне менее 0,01 на 100 тыс. населения, эпидемическим паротитом, гепатитом В - на уровне менее 1 на 100 тыс. населения, не регистрируется полиомиелит, вызванный диким полиовирусом.

С 2017 года Российская Федерация сохраняет статус страны, свободной от эндемичной краснухи. Обеспечено поддержание статуса Российской Федерации как территории, свободной от полиомиелита.

В результате подготовки к эпидемическому сезону 2020-2021 гг. привито против гриппа более 85,89 млн человек, что составило 59 \% от численности населения страны, в том числе привито более 19,62 млн детей. Результативность вакцинации подтверждается динамикой снижения заболеваемости гриппом, уровень которой уменьшился с 1997 года почти в 147 раз (с 5 173,8 на 100 тыс. населения (при охвате вакцинацией 4,9 млн человек в 1996 году) до 35,07 в 2020 году (при охвате вакцинацией 72 млн человек в 2019 году).

Ежегодно регистрируются только единичные случаи дифтерии.

В целом по стране достигнут охват прививками выше регламентированного 95\%-го уровня в отношении всех инфекций, управляемых средствами иммунопрофилактики, кроме туберкулеза $(94,69 \%)$.

7. В 2020 году благодаря реализации комплекса мер по управлению рисками отмечаются тенденции улучшения показателей среды обитания, в частности, улучшилось качество питьевой воды централизованных систем водоснабжения и каждая двадцатая проба воды соответствует гигиеническим нормативам по санитарно- 
химическим показателям; улучшилось качество атмосферного воздуха - доля проб с превышением предельно допустимых концентраций снижена на 7,43; снижены уровни загрязнения почв, и каждая четвертая проба, отобранная на территории селитебной зоны, соответствует гигиеническим нормативам по паразитологическим показателям, каждая десятая проба - по микробиологическим; также снижено воздействие физических факторов.

8. Снижение уровня загрязнения атмосферного воздуха, химического и микробиологического загрязнения питьевой воды, доли проб почв городских и сельских поселений, не соответствующих гигиеническим нормативам по микробиологическим и паразитологическим показателям, а также уменьшение воздействия физических факторов как результат деятельности органов и учреждений Роспотребнадзора позволило в 2020 году вероятностно предотвратить возникновение более 0,23 дополнительных случая смерти на 1000 населения и более 3,603 тыс. дополнительных случаев заболеваний на 100 тыс. населения Российской Федерации.

9. Предотвращенные случаи заболеваний, как у взрослого, так и детского населения, ассоциированы в основном с загрязнением атмосферного воздуха азота диоксидом, азота оксидом, углерода оксидом, бенз(а)пиреном, взвешенными веществами, гидроксибензолом и его производными, алифатическими предельными углеводородами, ароматическими углеводородами (ксилолом, толуолом, бензолом и пр.), формальдегидом, тяжелыми металлами (свинцом и прочими тяжелыми металлами), фтором и его соединениями, хлором и его соединениями, микробным и паразитарным загрязнением почвы, а также с загрязнением почвы радиоактивными веществами, с загрязнением питьевой воды микробными агентами и химическими веществами (железо, марганец, аммиак и аммоний-ион), с негативным воздействием электромагнитного излучения.

10. За десятилетний период сократился удельный вес рабочих мест на промышленных предприятиях, не соответствующих санитарным нормам по уровню воздействия на организм работников шума (с 24,63 \% в 2011 г. до 12,43 \% в 2020 г.), вибрации (с 14,83\% до 7,51\%), параметров микроклимата (с 5,99\% до 4,05\%), освещенности (с 16,73 \% до 12,43\%), паров и газов по веществам I и II классов опасности (с 3,8 \% до 1,42 \%), пыли и аэрозолей по веществам I и II классов опасности (с 7,9 \% до $0,94 \%$ ). Наиболее неблагоприятные условия труда характерны для предприятий по добыче полезных ископаемых, металлургии, машиностроения и судостроения, по производству строительных материалов, стройиндустрии, сельского хозяйства, транспорта.

11. Уровень профессиональной заболеваемости в Российской Федерации снизился с 1,9 случая на 10 тыс. работников в 2011 г. до 0,78 в 2020 г., и среди факторов и условий труда, формирующих профессиональную патологию, лидируют физические (44,03\%); биологические $(20,19 \%)$, вклад которых существенно возрос в связи с пандемией COVID-19; воздействие физических перегрузок и перенапряжения отдельных органов и систем $(20,17 \%)$; воздействие промышленных аэрозолей $(10,91 \%)$ и химических веществ $(4,7 \%)$.

12. За период с 2011 по 2020 г. снизилась доля проб пищевой продукции, не соответствующих санитарно-эпидемиологическим требованиям по санитарнохимическим показателям (с 2,95 \% до 0,4 \%) и микробиологическим (с 4,84 \% до 3,54 \%) показателям. Доля проб отечественной пищевой продукции, не соответствующих требованиям по санитарно-химическим показателям, с 3,0 \% до 0,29 \%, импортируемой продукции - с 2,07\% до 0,29\%. Доля проб импортируемой продукции, не соответствующих нормативам по микробиологическим показателям, возросла с 2,07 \% до $2,36 \%$. 
В 2020 году доля исследований по определению незаявленных веществ от общего количества исследований составила $1,24 \%$; в образцах выявлялись консерванты, подсластители, красители, микотоксины, никотин, кокцидиостатики, антигельментики, ингибиторы фосфодиэстеразы-5.

Установлена контаминация антимикробными препаратами в 4,55 \% образцов. Доля проб продукции с обнаруженными ГМО в целом по России в 2020 г. составила 0,005 \% (2019 г. - 0,04 \%), по импортируемой продукции - 0,07 \% (2019 г. - 0,22 \%). По результатам мониторинга качества и безопасности пищевой продукции, находившейся в 2020 году на потребительском рынке, в целом по Российской Федерации органами Роспотребнадзора забраковано 27980 партий продукции объемом 1 210,4 т.

13. В 2020 году сумма предотвращенных в результате деятельности Роспотребнадзора экономических потерь валового внутреннего продукта составила более 161,3 млрд руб., в том числе от смертности, ассоциированной с воздействием факторов окружающей среды, свыше 10,9 млрд руб., от ассоциированной заболеваемости - более 150,4 млрд руб. Экономическая эффективность деятельности Федеральной службы в сфере защиты прав потребителей и благополучия человека по сравнению с 2012 годом возросла на $20 \%$ и составила по критерию предотвращенных потерь ВВП Российской Федерации в 2020 году около 20,23 руб. на 1 рубль затрат.

14. Научно-исследовательские работы, выполненные в рамках отраслевых программ на 2016-2020 гг. «Проблемно-ориентированные научные исследования в области эпидемиологического надзора за инфекционными и паразитарными болезнями» и «Гигиеническое научное обоснование минимизации рисков здоровью населения России», обеспечили практическое применение и развитие научного потенциала, позволившего решить сложные санитарно-эпидемиологические проблемы 2020 года. Исследования проводятся с использованием современных, зачастую уникальных, методов и оборудования.

15. Необходимую поддержку в обеспечении санитарно-эпидемиологического благополучия населения оказали структурные подразделения федеральных органов исполнительной власти, входящие в систему федерального государственного санитарноэпидемиологического надзора. Санитарно-эпидемиологическая обстановка в подведомственных организациях и учреждениях характеризуется как стабильная.

16. В 2020 году получило развитие и укрепление двустороннее и многостороннее сотрудничество в области санитарно-эпидемиологического благополучия населения, реализация обязательств Российской Федерации в рамках членства в международных организациях по вопросам борьбы с инфекционными, неинфекционными и паразитарными болезнями, обеспечения безопасности продукции и среды обитания человека с учетом ограничительных мер, связанных с коронавирусной инфекцией.

17. В напряженной эпидемической ситуации Федеральной службой по надзору в сфере защиты прав потребителей и благополучия человека в 2020 году были проведены запланированные мероприятия по обеспечению санитарно-эпидемиологического благополучия населения, реализации национальных и федеральных проектов, предусмотренных к выполнению в соответствии с указами Президента Российской Федерации от 7 мая 2018 года № 204 «О национальных целях и стратегических задачах развития Российской Федерации на период до 2024 года» и от 21 июня 2020 года № 474 «О национальных целях развития Российской Федерации на период до 2030 года».

Установлены приоритетные направления деятельности Роспотребнадзора по обеспечению санитарно-эпидемиологического благополучия и управления риском для здоровья населения на уровне субъектов и в целом для Российской Федерации на среднесрочную перспективу. 